\author{
José Divino Lopes $\mathbf{F}^{\circ}$
}

\title{
A HISTÓRIA SOCIAL DE UMA DOENÇA: O BERIBÉRI NO CARAÇA
}

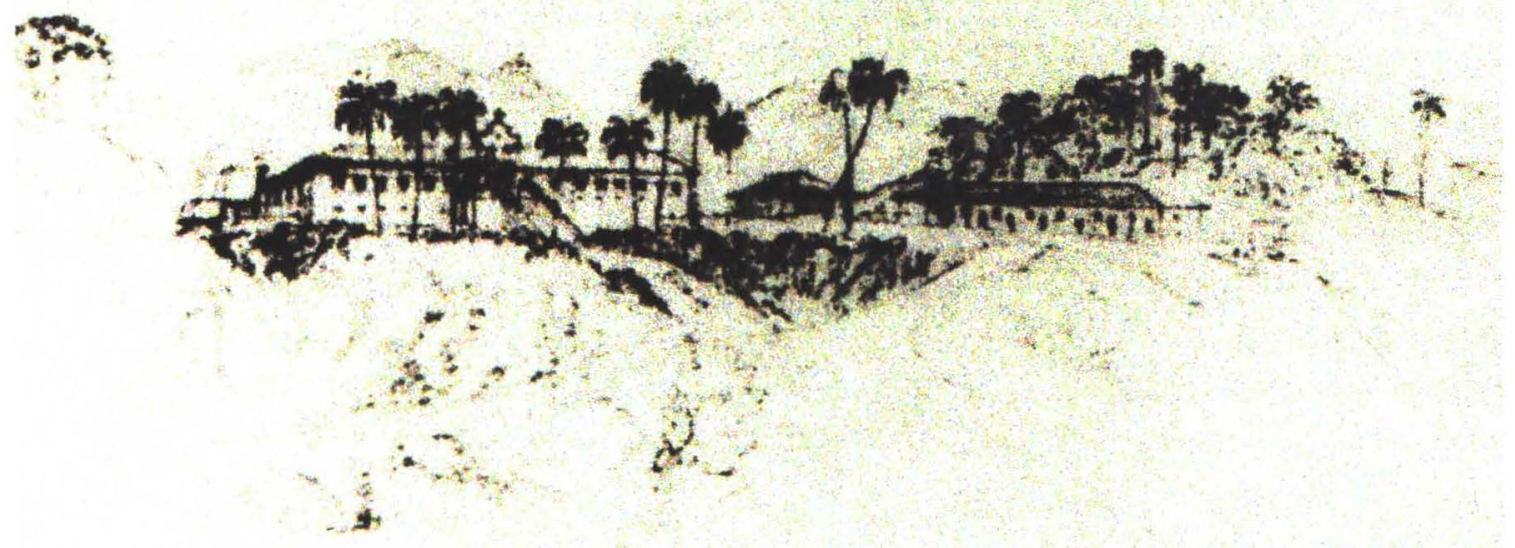

Tese apresentada à Faculdade de Saúde Pública da Universidade de São Paulo para obtenção do título de Doutor em Saúde Pública.

Orientador: Prof. Everardo Duarte Nunes.

São Paulo

1998 


\section{A HISTÓRIA SOCIAL DE UMA DOENÇA: O BERIBERI NO CARACA}
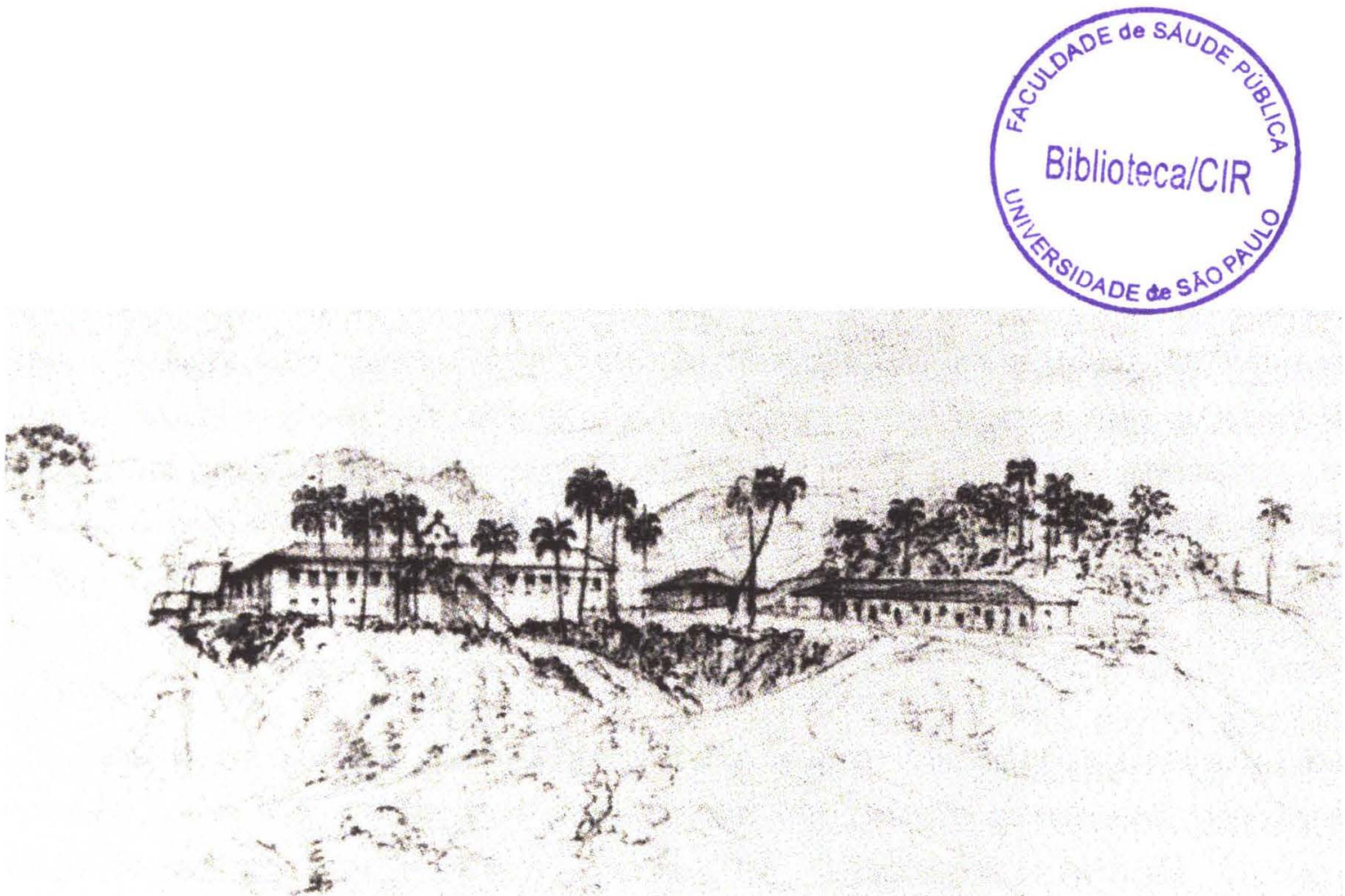

Josê Divino Lopes Fo 


\section{AGRADECIMENTOS}

Ao têrmino de um trabalho, não é fácil agradecer a todos aqueles que contribuiram para esta conclusão, sem correr o risco de esquecer alguém. Amigos próximos, conhecidos, profissionais diversos (bibliotecárias, arquivistas, pesquisadores, etc.) e, acreditem, até mesmo anônimos que, ouvindo-me falar do trabalho, insinuavam um ou outro comentário. Assim, a todos que se interessaram (perguntando, opinando, discutindo,... ) agradeço indistintamente.

Devo agradecer, em especial, a meu orientador, Prof. Everardo Duarte Nunes, que, com conhecimento, dedicação, habilidade e extremo respeito pelas idéias do orientando, forneceu-me todas as condições necessárias para a concretização do projeto;

Aos professores que participaram das etapas de "qualificação" e "pré-banca" (Rodolpho Telarolli Jr., Fernando Lefèvre, Jeanne M. Gagnebin, Paulo H. Gadelha e José Ricardo de C. M. Ayres) agradeço pelas sugestões, correçōes e estímulos que muito me encorajaram;

Pela generosidade com que me atenderam, colocando seus acervos documentais e bibliográficos à disposição, sou muito grato aos padres e irmãos coadjutores da Congregação da Missão, tanto no Caraça (especialmente através do Padre Zico), como também na Casa Central, no Rio de Janeiro;

A Ecilda Nunes, agradeço pela primorosa revisão e, mais ainda, pelo carinho, receptividade e estimulo recebido durante as etapas do trabalho;

Ao Prof. Ricardo Lafetá Novaes (in memoriam), que, nos nossos breves mas proficuos contatos, reconheceu e estimulou a viabilidade do então incipiente projeto.

Por fim, quero dizer que este trabalho expressa conhecimentos e experiências que adquiri em anos primordiais da minha vida na companhia das seguintes pessoas a quem, com este trabalho, gostaria de homenagear: Divino, Geralda, Joana, Donato, João, Rita e Pedro. 
Pela presença e compreensāo. dedico este trabalho, com muito afeto,

a

Ann, Dlogo

\author{
e
}

Martina 


\section{RESUMO}

Durante a segunda metade do século XIX e praticamente as três primeiras décadas deste século, o Colégio Caraça, tradicional educandário mineiro fundado em 1822, conviveu com o "fantasma do beribéri", doença provocada por uma deficiência nutricional (vitamina B1), mas que, na época, era de etiologia indefinida. Enquanto a ciência discutia as caracteristicas da doença, principalmente sua causa, o Colégio teve sua existenncia marcada por noticias cíclicas sobre a possivel ocorrência de beribéri. Este fato exigia, sucessivamente, medidas que atenuasse as repercussões das noticias, amparasse eventuais vitimas, e prevenisse, de acordo com os conhecimentos da época, novas ocorrências.

O presente trabalho, baseado em pesquisa histórica, narra a trajetória da instituição e da doença sob os olhos do conhecimento médico da enfermidade no periodo de sua prevalência. Foram utilizadas fontes primárias da instituição e uma ampla revisão da produção de conhecimentos sobre o beribéri no Brasil e no exterior, no periodo estudado. A partir de uma estrutura narrativa que funde realidade e ficção, foi reconstruido um possivel cenário que revela as circunstâncias culturais, sociais e políticas de produção não apenas dos textos científicos, mas também do cotidiano da instituição e, portanto, das circunstāncias que determinaram a "ocorrência" do beribéri no Caraça. Com este modelo também foi possivel reconstruir as circunstâncias de produção e os efeitos do conhecimento médico na trajetória da doença. Os resultados encontrados sugerem que a ocorrência do beribéri no Caraça não tenha tido a relevância explicitada nas crônicas, e que o seu desaparecimento não tenha tido relação com o conhecimento médico sobre o assunto. Neste sentido, a relevante repercussão social da doença pode ter sido produzida não apenas pela valorização médica da mesma, como também pelo significado social da instituição na época, visto que, a presença de um "mal" de origem desconhecida exercia delicado papel no imaginário social e político da época. 


\section{SUMMARY}

During the second half of the 19th century and, basically, the first three decades of this century, Colégio Caraça, founded in 1822 and a well-known school, lived with the "Beriberi Ghost". Beriberi is a disease caused by a nutritional deficiency of thiamine (vitamin B1), however, at that time, its etiology was unclear. While science discussed the characteristics of the disease and, especially its cause, the school's existence was marked by cyclical developments related to the possible occurrence of beriberi. This required measures to be taken in order to diminish the repercussions of the disease, give support to the victims and prevent, according to the knowledge of that time, new occurrences.

The present work, based on historical research, describes the course of the institution and the disease under the view of the medical knowledge of that period. The Institution's primary sources were used for the work, as well as a broad review of what was published about beriberi in Brazil and abroad during the period studied. With a narrative structure, mixing reality and fiction, a possible scenario was reconstructed, revealing cultural and social circumstances, as well as the policies regarding the production of scientific texts, and also the daily life of the institution and of the circumstances determining the "occurrence" of beriberi at Caraça. Through this model, it was also possible to reconstruct the circumstances of medical work and the effects of medical knowledge on the course of the disease. The results suggest that the occurrence of beriberi at Caraça might not have the importance displayed in the reports, and its disappearance may not have been connected to medical knowledge about the matter. Seen in this light, the relevant social repercussions of the disease may have been produced not only by the exaggerated medical value imputed to it, but also by the social meaning of the institution at the time, since the presence of an "evil" of unknown source provoked an intricate role in the social and political sphere of the time. 


\section{RESUME}

Pendant la deuxième moitié du XIXe siècle et, même, les trois premières décennies de celui-ci, le Collège Caraça, centre d'éducation traditionel de Minas Gerais, fondé en 1822, a connu le "fantôme du béribéri", maladie provoquée par une déficience alimentaire (vitamine $B$ 1), mais qui, à l'époque était d'étiologie indéfinie. Pendant que la science discutait sur les caracteristiques de la maladie, surtout sur a cause, le collège a eu son existence marquee par des notices cycliques concernant l'éventualité de cas de béribéri. Ce fait exigeait, successivement, des mesures qui atténuent les répercussions de ces bruits, apportent secours aux éventuels victimes et qui puissent prévenir, selon les connaissances de l'époque, de nouveaux cas de maladie.

L'oeuvre présentée, qui est fondée sur la recherche historique, raconte la trajectoire de l'institution et de la maladie du point de vue des connaissances médicales de la maladie dans la période des événements. Ont été utilisées: des sources primaires de l'institution et une ample revision de la production des connaissances sur le béribéri au Brésil et à l'étranger, de la période etudiée. Partant d'une structure de narration qui fond réalité et fiction, un scénario possible a été reconstruit. Il révèle les circonstances culturelles, sociales et politiques de production, pas seulement des textes scientifiques, mais aussi du quotidien de l'institution et donc des circonstances qui déterminaient "l'occurence" du béribéri au Caraça. Sur ce modèle, il a aussi été possible de reconstruire les circonstances de production et les effets de la connaissance médicale pendant la trajectoire de la maladie. Les résultats trouvés suggèrent que l'occurence du béribéri au Caraça n'a pas eu l'importance explicitée dans les chroniques, et que as disparition n'a pas eu de relation avec la connaissance médicale à ce sujet. Dans ce sens, la relevante répercussion sociale de la maladie peut avoir été produite, pas seulement par la valorisation médicale de celle-ci, comme aussi par limportance sociale de l'institution à l'époque, vu que, la présence d'un "mal" d'origine méconnue jouait un röle délicat dans l'imagination sociale et politique de l'époque. 


\section{ÍNDICE}

Introdução $\quad$ i

$\begin{array}{ll}\text { Primeira Parte } & 1\end{array}$

$\begin{array}{ll}\text { Segunda Parte } & 78\end{array}$

$\begin{array}{lr}\text { Terceira Parte } & 127\end{array}$

$\begin{array}{ll}\text { Quarta Parte } & 271\end{array}$

$\begin{array}{ll}\text { Bibliografia } & 363\end{array}$ 


\section{INTRODUÇÃO}

"Será que a narração de eventos passados, a qual, em nossa cultura desde o tempo dos gregos em diante, teve em geral que sujeitar-se à sanção da 'ciência' histórica, limitada pelo subjacente padrão do 'real, e justificada pelos princípios da exposição 'racional'será que essa forma de narração realmente difere, em algum traço especifico, em alguma caracteristica distintiva indubitável, da narração imaginária, tal como a encontramos no épico, no romance e no drama?"

\section{$R$. Barthes, "Le discours de l'histoire"1}

Em 1992, encontro-me com Alexandre Eulálio lendo, dele, "Uma educação mineira: Travessia de Joaquim de Salles"2 Evocativa leitura que se tornou prefácio de um livro ${ }^{3}$ que eu viria a ler no ano seguinte. "Uma educação..." expõe a relevância de um texto que resgata um dos eventos mineiros ainda aprisionado nas amarras do tempo: o exercicio institucional do antigo seminário e colégio Caraça. Mas fica claro no texto de Eulálio o significado de um cenário que se define no fundo de seus comentários, quer seja, o "mundo" que se esconde e surge, às vezes abruptamente, das entrecortantes montanhas de Minas. Textos esparsos

\footnotetext{
1 Transcrito de:

WHITE, H. A Questão da narrativa na teoria contemporànea da história. $\boldsymbol{R H}$ - Revista de história, (2-3) : 63-3. 1991.

2 EULÁlIO, A. Escritos, Ed. Unicamp, Campinas, 1992. p.295-311.

3 SALLES, J. de. Se não me falha a memória..., Instituto Moreira Salles : Ed. Giordano, São Paulo, 1993.
} 
presentes em Remate de Males ${ }^{4}$ alinham as curiosidades de Eulálio e convergem para aquele "mundo" que, enfim, parece ser a sua própria busca. Eulálio, mineiro nascido carioca, é de uma família que, como o colégio Caraça, encravou-se nos braços da serra do Espinhaço. Brilhos de diamantes e erudição demarcaram a curta distância entre o vale do Jequitinhonha e a serra do Caraça, distância esta que, na segunda metade do século XIX, exigia de 10 a 14 dias de resignada viagem a cavalo entre a cidade do Serro (antiga Vila do Principe, no Vale) e o Colégio. Então, de raizes e afinidades físicas e espirituais com Minas Gerais, Eulálio conhece de longe lugares e pessoas - e o fazer destas pessoas - daquela região:

"o avô da minha avó...[foi] assassinado na Serra do Mendanha nos idos de 1850 , ao se dirigir para a Diamantina com uma capanga recheada de pedras de boa água"s.

Conhecedor da topografia do Vale, sabe o ensaista que o Rio Jequitinhonha, desde sua nascente, percorre um árduo caminho que insiste em tentar impedir seu fluxo. Neste trajeto, uma sucessão de embates trava-se entre o relevo e as águas, insinuando que a única coisa impossivel de acontecer com elas - as águas - é chegar ao mar. E esta imagem de um rio estóico está próxima daquela que Eulálio usa para aludir à tarefa de Joaquim de Salles:

"Com os periodos de alta e baixa de inspiração de toda corrente espontânea, tais reminiscências estendiam-se livres, às vezes espalhando espuma nas margens com vivacidade corredeira; outra hora, apertadas em garganta de pedra, pareciam afundar sem saida num sumidouro; adiante espraiavam-se baças, lentas, embarradas em andadura trôpega; mais além retraiamse, bruscas, num salto claro, até, vencidos afinal serra e sertão,

- BOAVENTURA, M. E. \& CALIL, C. A. (Org.). Alexandre Eulálio Diletante Remate de Males, Departamento de Teoria Literária do Instituto de Estudos da linguagem - UNICAMP. Junho de 1993.

${ }^{3}$ BOAVENTURA, M. E. \& CALIL, C. A. (Org.). Op. cit., p. 365. 
desembocarem no descansado oceano da memória
reconstruida"6. Aqui, é impossivel não nos remeter à

"metáfora benjaminiana do rio que deve romper a barragem do sofrimento para chegar ao mar, pressupõe o longo e penoso caminhar da memória, esse trabalho paciente e árido do lembrar"7.

Quando, em 1993, leio Salles ${ }^{8}$, são várias as impressões que se impõem, oriundas de fontes e sentidos diversos e em direções muitas vezes diametralmente opostas: a tentativa de recompor um "mundo", muito menos na perspectiva de uma vã saudade, muito mais no cumprimento de uma obrigação com a qual o destino é implacável: a redenção de um mundo que, salvo, precisa descansar em paz. Estas impressões, então, são como uma rede que capta as incontáveis condições de possibilidade dadas pelas rememorações originais ou

"como a tecedura, para produzir um véu, se compõe dos movimentos ao mesmo tempo complementares e opostos dos fios da trama e da urdidura...9.

O "mundo" de Salles e o "mundo" de Eulálio são um único mundo, mediado, no máximo, por uma tênue $\mathrm{e}$ quase imperceptivel temporalidade. $\mathrm{O}$ autor e o crítico, ambos monarquistas, engalfinham-se nas brumas lânguidas da memória, num cenário que pode ser ilustrado pela bela

${ }^{6}$ EULÁlio, A. Escritos, op. cit. p. 297.

, GAGNEBIN, J. M. História e narração em W Benjamin. São Paulo: Perspectiva Fapesp; Campinas: Ed. Unicamp, 1994. p. 127-8.

- SAlLES, J., op. cit.

9 GAGNEEIN, J. M. Op. cit. p. 5-6. 
"imagem do labirinto, metáfora ao mesmo tempo das relações temporais entre presente, passado e futuro e das relações privilegiadas que o sujeito entretém consigo mesmo pelos descaminhos do amor, das viagens, da leitura e da escrita"10.

A intensidade do retorno do autor e suas narrativas sobre os procedimentos cotidianos do Caraça em particular,

"quebram a continuidade da cronologia tranqũila"11

com a propriedade de reconstruir os instantes vividos: o cotidiano nas suas atividades que o ornamentam. Nesta trajetória, o beribéri instaura uma ordem particular: um evento atípico, indesejável, numa instituição teleologicamente definida. $\mathrm{O}$ autor descreve $\mathrm{o}$ evento, procurando $\mathrm{o}$ melhor ângulo, descrever com os olhos da criança, cuja vida cheia de vicissitudes (é órfão de pai e mãe, na infância, e separado da familia por longos anos em função dos estudos religiosos) não diminui o fluxo poderoso destas reminiscências que, como pode ser visto, encurtam o tempo entre o passado e o presente, através de um jogo de buscas de um "futuro anterior" 12.

O beribéri no Caraça é, na narrativa do autor ${ }^{13}$, aquilo que, a um só tempo, interrompe e oculta a própria narrativa, mas, ao mesmo

$10 \quad$ Idem, p. 86

$11 \quad$ Idem, p. 112

12 Idem, p. 112.

Vale ressaltar que Gagnebin cita Peter Szondi como fonte desta "feliz expressào, num contexto benjaminiano onde

"O passado é salvo no presente porque nele o escritor descobre os rastros de um futuro que a criança pressentia sem conhecê-lo. Esta busca de um futuro anterior, ..., acarreta um olhar sobre o passado, e, em particular, sobre a infância, onde não há nada de idealizante ou de estetizante, mas que é, arrisquemos a palavra, profundamente político. Benjamim busca no passado os signos de uma promessa a respeito da qual ele hoje sabe se o futuro a cumpriu ou não, a respeito da qual ele se pergunta se cabe ainda ao presente realizá-la - ou se esta promessa está definitivamente perdida".

13 SALLES, J. de Op. cit. p. 269-447. 
tempo, renova-a e a recompõe. Não se trata aqui de evocar o desconhecimento cientifico da doença na época vivenciada. Esta situação de momento parece ter um papel precário nas lembranças do autor. $\dot{E}$ interessante atentar, mais uma vez, para a noção benjaminiana de que

\begin{abstract}
"a verdade de um discurso não se esgota nem no seu desenrolar harmonioso, nem na sua argumentação sem falhas, nem na sua coerència interna. Essas regras da enunciação racional que a Aufklärung erigiu em lei são preciosas por suas virtude de clarificação contra a onipotência do mito, por sua salutar irreverência para com as respeitáveis evidências do poder. Benjamim sempre ressaltou a importância desta tradição de autonomia e de irreverência que a Aufklärung nos legou"14.
\end{abstract}

A efervescência cientifica da segunda metade do século XIX, em especial no que se refere às novas descobertas sobre o processo saúdedoença, provavelmente geraram tensões inconciliâveis entre as formas representativas da doença, particularmente do beribéri em uma instituição de reconhecida tradição pedagógica e religiosa. Os novos conceitos de higiene e saúde, decorrentes das descobertas cientificas, produziram mudanças substanciais na representação sobre a morte e o morrer. Neste sentido, o que será mais tarde analisado por Foucault, conforme lembra Gagnebin ${ }^{15}$, é captado por Benjamin em "O Narrador", e deve ser citado:

"Desde há vários séculos pode-se acompanhar a perda em onipresença e força plástica que o pensamento de morte sofreu na consciência comum. Em suas ültimas fases este processo se desenrola em ritmo acelerado. E no decorrer do século XIX a sociedade burguesa produziu, com ritos higiênicos e sociais,

\footnotetext{
14 GAGNEBIN, J. M.. Op. cit, p. 115.

is GAGNEBIN, J. M.. Op. cit., p. 74.
} 
privados e públicos, um efeito secundário que talvez tenha sido seu objetivo principal, embora inconsciente: oferecer às pessoas a possibilidade de se furtarem à visão dos moribundos. Morrer, outrora um processo público e altamente exemplar (pensemos nas imagens da Idade Média, nas quais o leito de morte se metamorfoseava num trono, de encontro ao qual, através das portas escancaradas da casa mortuária o povo ia-se apinhando) - morrer, durante a Era Moderna, é cada vez mais repelido do mundo perceptivel dos vivos. Antigamente não havia uma casa, quase nem um quarto, em que alguém já não tivesse morrido"16.

Dado este campo de ocorrências metodológicas diversas (Saúde pública - na forma de uma doença de importância sanitária para a época, o beribéri -, pesquisa história, antropologia cultural e - "arrisquemos" em admitir - teoria literária) quais as possibilidades de

"descrever com minúcia e sobriedade não com a vã intenção de tudo compreender, de tudo explicar, de tudo erledigen (como se diz tão bem em alemão), mas em vista do passado no presente, isto é, em vista de um presente verdadeiro que acolhe o sofrimento irresolvido e o diz em sua irresolução mesma, em vez de aferrar-se a uma ilusória resolução"17.

quais são, então, as possibilidades de descrever a história do beribéri no Caraça?

Inicialmente, a efetivação do presente trabalho foi planejada tendo em vista que a abordagem do beribéri no Caraça assentava-se sobre duas proposições que se colocam como fundamentais nesta tese: como as

16 BENJAMIN, W. O Narrador. $2^{\mathrm{a}}$ ed. [vol. Benjamin, Adorno, Horkheimer, Habermas]. Col. Os Pensadores, Abril Cultural, São Paulo, 1983. p. 64

17 GAGNEBIN, J. M.. Op. cit. , p. 124. 
teorias cientificas ${ }^{18}$ difundem-se no meio social e, segundo, como grupos sociais distintos relacionam-se com estas teorias. Estas proposições foram abordadas pela filosofia e pela história da ciência, como nas importantes contribuições foucaldianas ${ }^{19}$. Porẻm, estas formas de abordar a questão não se mostravam suficientes; havia a necessidade de se "fazer a história"20, não somente da doença, mas daqueles que conviveram com a doença em questão.

Reconstruir um periodo de uma dada instituição, significa, em alguns momentos, irromper legitimos sentimentos que estarão preservados em, muitas vezes, procedimentos aparentemente banais: hábitos cotidianos, diálogos, intercâmbios, enfim, expressões de experiências vividas. Mas,

$$
\begin{aligned}
& \text { "um fenômeno histórico jamais se explica } \\
& \text { plenamente fora do estudo de seu momento" } 21
\end{aligned}
$$

18 No âmbito do presente estudo considerar-se-ão as teorias científicas relacionadas aos processos de saúde e enfermidade, especialmente aquelas desenvolvidas a partir da segunda metade do século XIX e que tem em Pasteur um de seus ícones. Nesta tradição,

"Para admitir o pasteurismo, foi preciso uma geração, o tempo para os "pasteurianos" se organizarem e proporem à sociedade um conjunto de medidas higiênicas" *.

* SAINT-ROMAIN, A. de. Pasteur: As verdadeiras razões de uma glória,

p. 89. In.: As doenças tem história, s.r.a., Terramar, s.r.d.

19 A Ao considerar a questão da história e da filosofia da ciència do ponto de vista de Foucault, é preciso primeiramente levar em consideração que seu interesse não diz respeito à ciência propriamente, mas ao saber; não à sua racionalidade imanente, mas às condições externas de possibilidades de sua existência" *.

* PORTOCARRERO, V. Foucault: A história do saber e das práticas. In. PORTOCARRERO, V (Org.). Filosofia, história e sociologia das ciências. Rio de Janeiro, Ed. Fiocruz, 1994, p.45.

20 Cito uma expressão de Jacques Le Goff, no prefácio de

BLOCH, M. Os Reis Taumaturgos: o caráter sobrenatural do poder régio, França e Inglaterra. Såo Paulo, Companhia das Letras, 1993. p. 16

21 BLOCH, M. Os Reis Taumaturgos:... Op. cit. , p. 17. 
Tomando-se como um princípio orientador que saúde e doença estabelecem um diálogo contínuo, o processo social de uma doença - o beribéri -, numa época em que novas regras de higiene e saúde 22 proliferavam na sociedade, está submetido a fatores como, no caso do Caraça, a ideologia religiosa, a inserção e origem cultural da instituição e seus componentes, no caso a cultura mineira de fins do século XIX e inicio do XX. Qual o papel da visão religiosa sobre a percepção e concepção da doença? Qual seria a percepção valorativa da saúde para as pessoas envolvidas com o beribéri ? Sob quais modelos a ciência abordou a doença naquele periodo? Como esta abordagem cientifica, produzida e mediada pelos homens em suas 'vontades', trafegava no meio médico e como era sua adoção pela sociedade?

Assim, o "movimento" que pretendesse descrever a história do beribéri no Caraça envolveria conhecer as idéias e a expressão dos individuos submetidos ao ambiente da enfermidade ${ }^{23}$. Esta investigação

22 É suficiente tomar o conceito de saúde como ausência de doença física ou mental Entretanto, é interessante atentar para o comentário de ROSEN ${ }^{*}$, quando este afirma que

"a função de proteger e promover a saúde e o bem-estar dos cidadãos é uma das mais importantes do Estado moderno, e representa a consubstanciação de uma série de considerações políticas, econòmicas, sociais e éticas".

Esta consideração reforça um aparente consenso político e social de que, de fato, a saúde é, em qualquer situação, um bem melhor do que a doença.

* ROSEN, G. Uma história da saúde pública. Hucitec: Unesp : São Paulo, Abrasco : Rio de Janeiro, 1994, p.25

23 Esta consideração significa admitir uma aproximação inerente à "história das mentalidade".

"A história das mentalidades, ramo recente e de certo modo mal definido, ainda, dos estudos históricos origina-se de uma mudança dupla de perspectiva por parte dos historiadores. Em primeiro lugar, refletindo a tendência geral da disciplina no sentido da totalidade, do social global, o interesse que tinham pelos elementos psicológicos de explicação - dantes limitado a visões impressionistas e quase sempre anacrònicos da 'psicologia dos grandes homens' passou a aplicar-se à problemátia da psicologia coletiva. Ao mesmo tempo, o referido interesse deixou de limitar-se, como antes, as denominadas 'expressões superiores do espírito humano' ( artes, teologias, filosofias, etc.) para estender-se a aspectos cotidianos e prosaicos da piedade popular, aos mecanismos da formaçåo educativa e da informação, à percepçåo diferencial dos va.ores pelos rarios grupos sociais. Em suma, as mentalidades coletivas, com todos os seus matizes e manifestaçðes, ingressaram no campo de 
sobre este mundo caracense, pelo próprio sentido metafórico desta expressão, exigiu uma flexibilidade tal, suficiente para

"transpor os limites e as barreiras, a ir além, mais longe, mais ao âmago dos fenômenos, dos homens e das sociedades históricas"24.

\section{Como realizar tal empreendimento?}

A historiografia brasileira na área de saúde e da doença tem recebido ultimamente valiosas contribuições de diversos autores ${ }^{25}$, com

trabalho da pesquisa histórica. Em segundo lugar, já não se considera a psicologia humana um dado invariável ou constante, reflexo do que às vezes é tido como uma abstrata e universal "natureza humana": os historiadores começaram a vê-la como um aos aspectos de um cambiante contexto histórico-social global" (*).

* CARDOSO, C. F. \& BRIGNOLI, H. P. Os métodos da história. Rio de Janeiro, Edições Graal, $3^{\text {a }}$. ed., 1983. p. 394-5.

24 BLOCH, M. Os Reis Taumaturgos:... Op. cit. , p. 29

25 Entre outras, cito as seguintes obras, todas elas com excelente contribuição bibliográfica:

LUZ, M. T. Medicina e ordem politica brasileira: Políticas e instituições de saúde (18501930). Rio de Janeiro, Ed. Graal, 1982.

MACHADO, R et al. Danação da norma - Medicina social e constituição da psiquiatria no Brasil. Rio de Janeiro, Ed. Graal, 1978.

NUNES, E. D. Revisión de estudios historiográficos sobre la salud pública brasileña. Rev. de la Sociedad Española de Historia de las Ciencias y de las Tecnicas, 19 (36) : 51-72, 1996.

TELAROLLI JR., R. PODER E SAÚDE: A república, a febre amarela e a formação dos serviços sanitários no estado de São Paulo. 2 v. [ Tese de doutoramento apresentada à Faculdade de medicina da UNICAMP ]. Campinas, 1993.

VIEIRA, P. E. G. História de doenças: ponto de encontros e de dispersöes. 2 v. [ Tese de doutoramento apresentada à Escola Nacional de Saúde Pública / Fundação Oswaldo Cruz ]. Rio de Janeiro, 1995. 
abordagens onde a evolução cronológica dos eventos é um dado histórico, e não a história. Isto porque, na historiografia mais antiga, os poucos registros nesta área referem-se, prioritariamente, a descrições cronológicas sobre a evolução de pesquisas científicas cujo centro é a trajetória pessoal de pesquisadores que desempenharam papéis importantes em suas áreas ${ }^{26}$.

Sobre o beribéri no Caraça, as investigaçōes mostraram que aquilo que se publicou a respeito pode ser sistematizado nos seguintes grupos temáticos:

1.: registros na imprensa e atas de reuniões politicas $(\mathrm{Na}$ imprensa da época, a doença não teve grande repercussão, mas foi objeto de discussão entre politicos do estado);

2o: registros (correspondēncias, livros de memórias, etc.) de diretores e ex-alunos sobre a ocorrência da doença;

3o: trabalhos acadêmicos onde é citada a ocorrência da doença no Caraça ${ }^{27}$.

Estes registros já são suficientes para sugerir a "materialidade" do episódio. São importantes, pois, como já foi discutido anteriormente, independentemente da dimensão epidemiológica da ocorrência da doença, ela esteve sendo vivida por pessoas desenvolvendo suas atividades, idéias e sob uma organização social especifica. Por conta, então, desta pluralidade de ações humanas que, mais recentemente, constituem-se no universo do historiador ${ }^{28}$, é importante atentar à questão e encaminhamento propostos por Corvisier ${ }^{29}$.

26 Ver, por exemplo,

BACELLAR, R. C. Brazil's contribuition to tropical medicine and malaria. Rio de Janeiro, 1963.

27 Estes trabalhos são, na sua maioria, as teses de conclusão do curso médico nas duas primeiras Faculdades de Medicina do país: a do Rio de Janeiro e a da Bahia.

28 REIS, J. J. A morte é uma festa: ritos fúnebres e revolta popular no Brasil do século XIX. São Paulo, Companhia das Letras, 1991

Este livro, nas palavras do autor, trata de um 


"Existem documentos próprios da história
social?"

E, segundo o autor, a resposta que se impõe é:

"Todos os documentos podem ser considerados

...como documentos de história social" ${ }^{30}$.

Mas, francamente, se na sua concepção inicial o presente trabalho pretendeu-se moldar por instrumentos conceituais e metodológicos da história social, o seu desenvolvimento exigiu um envolvimento e sustentação crescente com uma certa tendência metodológica já citada

\begin{abstract}
"Extraordinário acontecimento que teve lugar na Bahia do século passado: uma revolta contra um cemitério. O episódio, que ficou conhecido como Cemiterada, ocorreu em 25 de outubro de 1836 . No dia seguinte entraria em vigor uma lei proibindo o tradicional costume de enterros nas igrejas e concedendo a uma companhia privada o monopólio dos enterros em Salvador por trinta anos". (p.13).
\end{abstract}

Comentando aspectos metodológicos do seu trabalho, o autor, na página 22 , elabora o seguinte comentário:

"O historiador que hoje estuda um episódio como a Cemiterada tem a vantagem de pertencer a um tempo em que a historiografia nos permite formular, e talvez responder, questões mais complexas. Hoje já não há temas tabus para o historiador, que ajudado por outras disciplinas, como a antropologia, por exemplo, arrisca-se à investigação de aspectos muitas vezes obscuros do passado. $O$ historiador passou a estudar as atitudes em relação ao gosto culinário, o amor, a religiosidade popular, as mais diversas formas de sensibilidade fisica e espiritual".

29 CORVISIER, A. Sources et méthodes en histoire sociale. C.D.U. et SEDES. Paris, 1980. p. 127

30 Ao discutir as fontes escritas, o autor pondera sobre os cuidados que se deve ter ao se considerar, por exemplo, as fontes literárias e documentos subjetivos (Cf., p.ex., o capitulo VII, p. 127-12: Les documents écrits de h'istoire sociale, les documents ponctuels). 
anteriormente, mas agora reafirmada e reforçada na direção de uma identificação entre pesquisa histórica, antropologia cultural e teoria literária. Se a pista original para esta tendência já se fez presente através das significativas contribuiçōes de A. Eulálio e J. M. Gagnebin, a leitura de textos esparsos de $E$. V. de Decca constitui-se num momento oportuno de fortalecimento da referida tendência ${ }^{31}$. Em um de seus textos, Decca cita Ensensberger, a propósito de seus comentários sobre a história como ficção, no livro $O$ curto verão da anarquia. Parte do trecho citado afirma:

"A história è uma invenção e a realidade fornece os elementos desta invenção. Mas, não è uma invenção arbitrária. O interesse que suscita se baseia no interesse de quem a conta; quem a escuta pode reconhecer e definir com maior precisão seus próprios interesses e os seus inimigos. Muito devemos à investigação cientifica que se julga desinteressada; mas, sem dúvida, esta segue sendo para nós um produto artificial, um homem que perdeu a sua própria sombra. Só o verdadeiro ser da história projeta uma sombra. E projeta em forma de ficção coletiva ${ }^{32}$."

Esta história do beribéri no Caraça não è uma história de historiador. Os riscos de se lidar com um acervo bibliogräfico tão 'contaminado' de humanidade exigiriam uma certa indisciplina metodológica' que - penso, talvez ingenuamente - possa não ser tolerada pelos cânones da ciència historicizadora. Cada fonte bibliográfica agregada trazia em si um valoroso conteúdo humano que se alargou assustadoramente: registros que relatam os escusos e explicitos desejos de "expansão ilimitada" do homem moderno ${ }^{33}$. Se esses desejos são

31 Textos lidos por ocasião da disciplina "História, memória e historiografia", oferecida pelo Departamento de História/ IFICH - UNICAMP, sob a responsabilidade do prof. Edgar Salvatori de Decca, cursada no segundo semestre de 1994.

32 ENSENSBERGER, H. M. O curto verão da anarquia citado por:

DECCA, E. S. de. Não me historicize, por favor, ou a cura estória do evento rebelde. [ mimeo. ] p. 5 
vistos propositadamente através da aventura expansionista tão em moda no século XIX, eles também podem ser investigados nas aventuras imaginárias que utilizam, como instrumentos de manifestação, relatos diversos: correspondências pessoais e institucionais, artigos jornalisticos, comunicações científicas, etc. Neste sentido, a própria organização dos espaços urbanos - e rurais - , que têm na arquitetura a peculiar forma de expressão, constituí-se em momento para tentativas de efetivação de um certo imaginário. E no espaço urbano, em especial, a saúde pública ocupa lugar destacado. Afinal, o irresistivel apelo de viver "em ação e em fantasias" tem como palco uma realidade materialmente definida: a sociedade em sua época e espaços acessiveis. Apelo que impregna personagens reais, cidadãos dignos e inteligentes, que se aventuram honestamente - ou nem tanto - nos tentadores desejos que suas atividades suscitam:

"... Acredito que nunca um imbecil vendeu sua alma ao diabo: o imbecil é imbecil demais ou o diabo diabólico demais, sei lán. ${ }^{34}$

Ao optar por uma estrutura narrativa que funde ficção e realidade, o presente trabalho poderia requerer uma discussão introdutória que incorporasse discussões historiográficas mais abrangentes e aprofundadas. Mas, como já foi dito, este não é um trabalho de historiador. Este trabalho é, além de uma contribuição ao estudo histórico das doenças, um esforço que se apresenta para ampliar o entendimento da questão que já foi oportunamente colocada:

"Por que o ser humano se interessa em contar história?"

33 Esta abordagem deriva da leitura de Decca - sem que este autor tenha qualquer responsabilidade nas conseqüências desta derivação. Neste artigo, E. de Decca analisa

"a relação entre a literatura e a história... [através]... de um certo gênero literário produzido com maestria pelos ingleses, o romance de aventuras, que engendrou $e$ esmiuçou os personagens mais significativos do imperialismo" $(*$, p. 1).

DECCA, E. S. de. Literatura, modernidade e história. [ mimeo. ].

${ }^{34}$ Esta citação está, originalmente, presente em $O$ corução da treva, de Joseph Conrad DECCA, E. S. de Idem, p. 24 
É um esforço porque, mesmo não tendo sido realizado por um historiador, foi tomado como um desafio, que é o de

\section{"contar sem a tentação de explicar". ${ }^{35}$}

Em que medida isto foi possivel?

A opção feita para tornar exeqüivel tal possibilidade enveredou pela narrativa histórica e narrativa ficcional, já que ambas

"apenas se colocam em campos diferentes na maneira delas se referirem ao real"36.

Esta caracteristica do presente trabalho, já identificada preliminarmente ${ }^{37}$, ao contrário de acomodar a expectativa do fluxo narrativo, traz questões importantes para serem tratadas. Se, formalmente, esta opção se mostrou possivel, há, então, o encontro destes "problemas" que se colocaram no campo da convivência $e$ harmonia - da organização do contexto, enfim - entre os elementos da atividade historicizadora e ficcional. No primeiro campo, as exigências ocorrem em três planos fundamentais:

35 Em 23-11-1994, na disciplina "História, memória e historiografia" (cf. comentário anterior), a prof". Jeanne Marie Gagnebin iniciou sua exposição com a questão: "Por que o ser humano se interessa em contar história ?". Após discorrer sobre a natureza do 'contar' em autores como Heródoto, Tucídides, discutir a crise dos modelos de explicação e compreensão no século 20; sobre Ricouer - e por extensão, Freud, Nietzsche e Marx -, Primo Levi e a questão do extermínio dos judeus (“... o pior não são os carrascos, mas os homens ordinários”), etc., a professora encerra afirmando que o desafio para os historiadores é: "contar sem a tentação do explicar".

${ }^{36}$ DECCA, E. S. de. Narrativa e História. [mimeo.], 1994, p. 2.

${ }^{37}$ Em parecer emitido à Comissão de Pós-Graduação da FSP-USP (21/04/98), por ocasião da "pré-banca", a professora J. M. Gagnebin, sobre o presente trabalho, escreve que

“... o autor opta por uma apresentação ficcional-histórica. ... a mútua imbricação entre narra:iva histórica e narrativa ficcional - já que seu núcleo comum é, justamente, seu carater narrativo". 
"-Instalação de um plano descritivo;

"-Instauração de um plano explicativo ou interpretativo;

"-Elaboração de um plano narrativo ou discursivo"38.

Neste sentido, descortina-se um contexto histórico-social amplo e um "compromisso" cientifico imanente à própria exigência acadêmica, que é uma natureza do presente trabalho. No segundo campo (ficcional), o trabalho utiliza o artificio de "uma história de vida singular", através de um personagem central, elaborada conforme um modelo de criação caro à literatura. A esta junção de elementos históricos plurais com um personagem ficcional, como emulsificar a narrativa, dado que

"A personagem é um ser fictício - expressão que soa como paradoxo. De fato, como pode uma ficção ser? Como pode existir o que não existe? ${ }^{\text {n39 }}$.

Contudo, tomado numa existência concreta, i.é, o personagem e sua inserção no enredo, a criação se ancorará neste paradoxo:

${ }^{38}$ Aqui, utilizo a elaboração de DOMINGUES $\left(^{*}\right)$, que explica claramente os très planos citados:

“ 1) a instalação de um plano descritivo, [envolve] a) a enumeração dos agentes, processos, acontecimentos e ações que povoam o mundo dos homens, b) o estabelecimento das fontes que os atestam e dos relatos daqueles que os testemunharam, c) a descrição dos locais em que ocorreram, com vistas a figurar o quadro em que aparecem assim como a aquilatar o décor em que se situam e que se modifica bruscamente; 2) a instauração de um plano explicativo ou interpretativo, caracterizado pela interrogação dos móveis das açðes, bem como pela indagação das intençðes dos agentes ao deflagarem os acontecimentos, para fixar suas causas junto com seus desígnios; 3) a elaboração de um plano narrativo ou discursivo, a articular os niveis descritivo e explicativo, caracterizado pela arte de narrar as açðes, de registrar os feitos e de relatar os acontecimentos, dispondo-os em senes ordenadas, compondo a trama das intrigas que os enredam e expondo os nexos que os encadeiam".

* DOMINGUES, I. O fio e a trama: reflexões sobre o tempo e a história. São Paulo Iluminuras; Belo Horizonte : Editora UFMG, 1996. Cap. V: Verdade, tempo e história. p. 195

39 CÂNDIDO, A. A personugem de fiç̧ão. São Paulo, Perspectiva. p. 55. 
“... o problema da verossimilhança... depende desta possibilidade de um ser fictício, isto é, algo que, sendo uma criação da fantasia, comunica a impressão da mais lídima verdade existencial".

Neste processo de narrativa histórica e ficcional, o personagem teria que existir pessoal e socialmente, num espaço próprio sem, entretanto, alterar aquele fluxo dos acontecimentos documentalmente expostos. Constitucionalmente, a função deste personagem, mais do que interferir em acontecimentos historicizados, foi,

“... funcionando como uma sinédoque ... permitir uma agilidade e fecundidade na busca da multidemensionalidade histórico-social co fato sanitário..." ${ }^{\mathbf{4 0}}$.

Do fato sanitário entendido como fato eminentemente social, no qual os significantes revelam-se repletos de clareza e mistério que são, em última instância

"o mistério metafisico da própria existência"41.

O personagem assim instituido pode vir, então, com um lastro psicológico que não necessariamente esteja atrelado ao momento histórico em que se deu o episódio investigado (o beribéri no Caraça). Esta determinada filiação psicológica permitirá ao personagem "resistir" às lógicas de compreensão do processo saúde-doença da época, ao mesmo tempo que inrocará, para o exercicio cientifico, inquietações cuja vivência a realidade costuma ocultar. A este respeito, o personagem ficcional instituido no presente trabalho poderia muito bem incorporar, pelo menos fragmentariamente, um certo mito literário, numa caracterização comum aos "jovens poetas precursores do romantismo", onde o personagem deles é

to Comentário, sobre o presente trabalho, no parecer emitido a Comissão de PósGraduação da FSP-USP (三0/04/98), por ocasiåo da "pré-banca", pelo professor J. R. de C. M. Ayres.

"CÂNDIDO, A. Op. C: : p. 57. 
“... um individualista suficientemente audacioso para desafiar a moralidade, a sociedade, a religiāo, e para concluir uma aliança com o demônio"42.

Naturalmente, este trabalho não ambiciona elevar a personagem a objetivos tão caprichosos, quer seja pelo "desenho" metodológico do trabalho ou, principalmente, quer seja pela incapacidade do autor em fazê-lo. Mas esta mesma ambição é, de certa forma, utilizada como instrumento valioso para responder à seguinte questão:

"No processo de inventar a personagem, de que maneira o autor manipula a realidade para construir a ficção?"43.

Ou manipula a ficção para construir a realidade? É com este anseio de "contar sem a tentação de explicar" que o trabalho interessa-se não só em traçar um panorama de costumes, e neste caso

“... a personagem dependerá provavelmente mais da sua visão dos meios que conhece, e da observação de pessoas cujo comportamento the parece significativo. ...em conseqüência, menos aprofundado psicologicamente, menos imaginado nas camadas subjacentes do espírito..."44,

como também está interessado nos problemas humanos tal como são vivenciados pelas pessoas. $\mathrm{E}$, ai,

‘.. a personagem tenderá a avultar, complicar-se, destacando-se com a sua singularidade sobre o pano de fundo social ${ }^{45}$.

$\$ 2$ BRUNEL, P (org.). Dicionário de mitos literários. Rio de Janeiro, José Olympio, 1977. p. 336

${ }^{43}$ CÀNDIDO, A. Op. Cu. P. 66.

" Idem, p. 74

15 Idem, p. 74 
Durante o desenrolar do fluxo narrativo, é inegável o surgimento de tensōes de complicada elucidação, já que a própria presença de um "ser" - ainda que ficcional - que faz exigências ao autor - e aqui, exatamente por ser ficcional, pois assim exige e aceita caracteristicas e procedimentos de acordo com as possibilidades naturalmente dinâmicas do criador - revela-se polimorficamente a cada tipo de leitor. Assim, não há como fugir de armadilhas. Traçar panoramas de costumes ${ }^{46}$ é bem menos complexo do que "contar" sobre os seres, pois

"Os seres são, por sua natureza, misteriosos, inesperados. Dai a psicologia moderna ter ampliado $e$ investigado sistematicamente as noçōes de subconsciente e inconsciente, que explicariam o que há de insólito nas pessoas que reputamos conhecer, e no entanto nos surpreendem, como se uma outra pessoa entrasse nelas, invadindo inesperadamente a sua área de essência e de existência"47.

16 Aqui, a preferència pelo significado de "costumes" guarda semelhança com a elaboração do escritor Raduan Nassar( *) que, respondendo a uma questão sobre a espécie humana, afirma:

“Acho que seria um equivoco recorrer a usos e costumes como critério de avaliação de mudanças humanas. Que eu saiba, a espécie continua igualzinha ao que era antes, cada individuo fazendo de sempre, que vai de santo a capeta. O que acontece nesse percurso é o nosso patrimônio".

- CADERNOS de literatura brasileira. Instituto Moreira Salles, n. 2, set. 1996 : Raduan Nassar.

${ }^{47}$ C. ANDIDO, A. Op. ( " p. 56 


\section{PRIMEIRA PARTE}

Desde 1832 o Rio de Janeiro contava com um código de posturas elaborado pela câmara municipal ${ }^{1}$. Contemplando várias atividades que compunham a vida cotidiana dos habitantes da cidade, estas posturas trataram, na sua primeira seção, da saúde pública. Ai, instituía regras sobre cemitérios e enterros, dispondo normas de sepultamento que evitassem a exalação de gases oriundos das putrefações, cuidando, portanto, dos "miasmas cadavéricos"; sobre a venda de gêneros e remédios, enfatizava os deveres dos boticários e neste caso foi explícito quanto à proibição do popular pito do pango, erva que fazia delirar os escravos e já era experimentada por muitas pessoas que não estas. Consonante com as necessidades ambientais, as posturas regulavam categoricamente o esgotamento de pântanos e àguas infectadas, além de tapamentos de terrenos abertos, o que também baseava-se na prevenção de exalações fétidas. O código dispunha ainda sobre a economia e asseio dos currais, matadouros e açougues públicos, das exigências quanto aos hospitais, casas de saúde e moléstias contagiosas e, por último, disciplinava a instalação de curtumes, de fábricas e manufaturas que pudessem alterar e corromper a salubridade da atmosfera, e sobre depósitos de imundices.

Entre os titulos da seção dois deste código de postura, havia aquele que instituia a obrigatoriedade da vacina contra a variola e um outro que determinava que fiscais municipais deveriam, em sigilo, ajudar as parturientes, garantindo a estas o segredo do parto.

Estas posturas estabelecidas pela càmara eram uma resposta à

1 BARBOSA, P. \& REZENDE, C. B. (Org.). Os Serviços de saúde pública no Brasil: de 1808 a 1907 (Esboço e legislação). 2 v. Rio de Janeiro, Imprensa Nacional, 1909. p. $35-51$.

FONTENELLE, J. P. Hygiene e saúde pública. In. Diccionario historico, geographico e ethnographico do Brasil (commemorativo do primeiro centenário da independência) : primeiro volume, cap. $17^{\circ}$., Rio de Janeiro, Imprensa Nacional, 1922 
precariedade higiènica da capital do reino e foram elaboradas em conjunto com a Sociedade Nacional de Medicina. A qualidade de vida na cidade era, então, lastimável. $\mathrm{O}$ crescimento descontrolado e rápido acentuou este quadro. Apesar do avanço em termos de legislação sanitária, o código de postura não garantia as melhorias necessárias. Por exemplo, numerosas valas no meio das ruas continuavam expondo a céu aberto dejetos de toda natureza. Valas que extravasavam com as chuvas, transformando as ruas num lodo pestilento que, misturado com o lixo, permitia a proliferação de ratos por toda a parte. Em anos recentes estas valas tinham sido minimamente urbanizadas com a colocação de lajes, mas continuava a existir um desagradável odor fétido e um bom nicho de roedores.

Em algumas áreas da cidade as fezes eram recolhidas em barris os cabungos -, depositados nos quintais e periodicamente levados ao mar pelos escravos, carregadores incontestáveis de tudo, que os conduzia sobre as cabeças ${ }^{2}$. As moléstias infecciosas castigavam sem trégua

2 No dizer de CUNHA (i) uma das principais ocupações do 'negro de ganho' era carregar.

"Carregavam tudo nesse Brasil, onde um homem de qualidade recusava-se a levar o mais infimo pacote".

PEREGALLI (ii) afirma que

"os escravos transitavam... carregando os detritos orgânicos desde suas residências para serem despejados nos rios ou no mar".

Pode-se supor que, ao transportar os dejetos humanos, os escravos sofressem com o odor e prováveis vazamentos dos barris. segundo FONTENELLE (iii)

"as materias fecaes, eram depositadas em barris, nos fundos das casas e dos quintaes, a ahi ficavam tantos dias quantos os necessarios para o respectivo enchimento, depois do qual eram transportados para lançamento no mar. Durante o tempo em que ficavam depositados, como por ocasião do transporte, tinham as materias fecaes, assim, opportunidades de determinar contaminações, quando contagiantes, como também espalhavam no ar odores desagradáveis e incommodos...".

A prática de recolhimento dos dejetos humanos em barris e lançamento no mar é destacada por CHASSOT (iv), que descreve a rotina do trabalhador responsável por este transporte em Porto Alegre

i. CUNHA, M. C. Negros, estrangeiros. São Paulo, Brasiliense, 1985. p. 32-33.

ii. PEREGALLI, E Escravidão no Brasil São Paulo, Global, 1988. p. 67.

iii. FONTENELLE, J. P. Op. cit., p. 422 
naquela época: variola em 1834-35, numa epidemia terrivel, febre tifóide em 36, sarampo desde 1834, escarlatina em 35, febre amarela em 28 e 39 , e a freqüente tuberculose responsável por mais de um terço das mortes, entre outras.

Em consonância com as medidas do código de posturas, em 1833 o porto da cidade ganhou uma nova regulamentação para a inspeção de saúde pública. Posteriormente, em 1836, houvera pequenas modificaçōes que, no entanto, não alteravam a finalidade da inspeção: evitar que embarcações infectadas trouxessem moléstias contagiosas para o pais em geral e a capital em particular. Não era uma tarefa fácil. Grande número de embarcações aportavam na cidade. A imigração era, em muitos casos, favorecida pelos próprios paises de origem e havia ainda o tráfego de escravos, que incrementava uma rota de especial interesse econômico ${ }^{3}$.

$\mathrm{Na}$ inspeção sanitária do porto, a autoridade máxima, definida pelo regulamento, era um professor de saúde, que decidiria sobre as condiçōes em que se achavam as embarcações. Se já em condiçōes de operar livremente ou se quarentenaria. Nenhuma embarcação estava

iv. CHASSOT, A . I. Cubeiro - Um profissional que afortunadamente desapareceu. In: D'ANGELO, A . L. V. (Org.). Histórias de trabalho. Porto Alegre, EU/Porto Alegre, 1995.

3 Os escravos, além de serem, de fato, os trabalhadores exercendo as mais variadas funções no Rio de Janeiro, constituiam-se como capital e riqueza de seus proprietários (i). Riqueza que, como mercadoria, tinha seu valor realçado no lucrativo tráfico entre a África e o Brasil. Não é por acaso que

Numa lista feita, em 1799, das 36 maiores fortunas da província do Rio de Janeiro, sete são de traficantes. O lucro que eles obtinham em suas operações era, em média, de 19,2\% muito maior que o dos traficantes ingleses, quando estes atuavam $(9,5 \%)$, franceses $(10 \%)$ e holandeses $(5 \%)$, e maior que o de uma fazenda de café - $15 \%$, nos melhores anos... As mesmas pessoas que o comandavam [ o tráfego ] estavam envolvidas também na importação de tecidos... no setor financeiro, como prova o fato de que das dez companhias de seguro estabelecidas no Rio de Janeiro, em 1829, sete tinham traficantes entre seus diretores"(ii).

i. KARASCH, M. C. Slave life in Rio de Janeiro: 1808-1850. Princeton, Princeton University Pres, 1987. p. 185-213: Porters and property: The functions of slaves in Rio de Janeiro

ii. TOLEDO, R. P. de À sombra da escravidão. Veja, ano 29, n. 20: 52-65, 1996 
salva da inspeção. Quer mercantil ou militar, quer nacional ou estrangeira. Os navios inspecionáveis fundeavam no ancoradouro de Jurujuba, entre Santa Cruz e Boa Viagem, onde a policia marinha organizava as manobras.

A policia marinha seria, na verdade, um navio de guerra e funcionava fazendo cumprir as determinações da autoridade sanitária. Se o oficial de saúde determinasse o impedimento de certa embarcação, uma bandeira amarela era içada no mastro da proa e, por este sinal, a policia marinha providenciaria o seu isolamento. Estas medidas melhoravam a inspeção no porto, mas estavam longe de evitar a penetração de moléstias, ao mesmo tempo que não era regularmente respeitada por importantes segmentos da sociedade. No primeiro caso, além de poucos, a qualidade técnica do pessoal era questionável, o que era agudizado pelo volume intenso de embarcações a serem inspecionados. Isto aumentava não só a ineficácia do serviço, como também aumentava o risco de contato das tripulações não inspecionadas - ou inadequadamente inspecionadas - com a população terrestre. No segundo caso, a precariedade da inspeção freqüentemente arrastava por dias o desembarque de mercadorias, o que provocava confronto daquela com interesses comerciais explicitos. Grandes comerciantes, politicos, ou com férteis relações na esfera administrativa do governo, encontravam meios de apressarem, ou mesmo evitar indesejáveis inspeções que retardariam vantajosas operações comerciais.

No que se refere à atenção médica propriamente dita, a população ainda se encontrava complemente desprotegida. Na doença, a quase totalidade dos individuos lançavam-se às mãos de curandeiros, sangradores, benzedeiros e uma variedade imensa de profissionais não habilitados que, libertos de qualquer ação fiscalizadora, desempenhavam uma ação de "assistēncia médica", cuja eficácia era exatamente igual à própria capacidade do doente de se auto curar ${ }^{4}$.

- A assistência médica no periodo imperial era precária. É deste periodo o sucesso da homeopatia como terapêutica ao alcance de todos, invadindo os lares e ocupando

"lugar preponderante na terapèutica popular, caseira"(i).

Ainda neste período, 
O ensino médico incipiente, que havia iniciado com a chegada do

"A par da terapêutica científica, além dos glóbulos e tinturas homeopáticas, o mercado de drogas imundou-se de uma espantosa variedade de panacéias, elixires, remédios secretos e 'específicos', enfim. de medicações e prescrições de sentido nitidamente charlatanesco... A crendice e a ignorância populares, aliados à impotència da ciência oficial, favoreceram a terapêutica impostora" (i).

A popularização da arte de curar, quer seja através da homeopatia com os seus 'manuais de medicina ao alcance de todos', ou de outros livros como o famoso 'Dicionário de medicina popular", conhecido simplesmente como "Chernoviz" (referência a seu autor o médico francês Pedro Luís Napoleão Chernoviz) refletia a

"falta geral de médicos (homeopatas e alopatas)" (ii).

O cruzamento destas situações produziam, especialmente em regiões mais afastadas, a existência de curandeiros 'preparados' por estes manuais:

"No sertão cada qual é curandeiro e aplica drogas às cegas: os mais

adiantados lèem Chernovitz, decoram nele palavras que não compreendem, e

as pronunciam com certo prazer e ar de importância..." (iii).

$O$ fato é que

"o impacto da homeopatia parece ter sido realmente importante" (ii), tendo gerado grandes polèmicas na comunidade médica.

Em meio às diferentes práticas curativas, legislações sanitárias editaram leis que procuraram regular, fiscalizar e punir o exercicio ilegal da medicina (iv, v). No entanto, desconhece-se uma avaliação geral da eficácia destas medidas no século XIX.

i. HOLANDA, S. B. de. (Org.) História geral da civilização brasileira: II. O Brasil monárquico: 3. Reações e transações. São Paulo, Difel, 1967. p. 467 - 489: cap. VIII: Medicina no periodo imperial.

ii. NOVAES, R. L. O tempo e a ordem: sobre a homeopatia. São Paulo, Cortez/Abrasco, 1989. p. 209-259: Homeopatia no Brasil.

iii. FRANCO, V. M. M. Viagens pelo interior de Minas Geraes e Goyaz. Rio de Janeiro, Imprensa Nacional, 1888. p. 129.

iv. BARBOSA, P. \& REZENDE, C. B. Op. cit., p. 12-18 (Regimento para comissários delegados do Physico-mór do Reino de 22-1-1810): p. 37 (Posturas referindo ao exercicio ilegal de : facultativos, boticário, parteira ou sangrador, de janeiro 1832) , p. 63 (Art. $19^{\circ}$. sobre a fiscalizaçăo da pratica da medicina, cirurgia e farmácia de 14-2-1850); p.635 (sobre o exercício da farmácia, de 30-10-1882); p. 826-36 (Da fiscalização do exercício da medicina e da farmácia).

v. FONTENELLE, J. P. Op. cit., p. 421. 
governo português em 1808, não conseguia se instituir como um ato que viesse a refletir diretamente na assistência médica, quer seja pelo pequeno número de médicos que se formavam, quer seja pela direção profissional que estes tomavam. A maioria dos estudantes era oriunda de famílias privilegiadas da sociedade e, ao fim do curso, dedicava-se a assistir o seu grupo social, associado à carreira política. Não é raro, nesta primeira metade do século XIX, médicos e professores do curso médico afastarem-se da sua cadeira para assumir função legislativa ou administrativa por longo periodos.

As duas escolas médicas, criadas ainda pelo Principe Regente em Salvador e no Rio de Janeiro, reproduziam, no seu desenvolvimento, o modelo francês, deformado pelo irrisório meio social e cultural que caracteriza o periodo. Assim, caracteristica básica do ensino e desenvolvimento da medicina européia da época, a pesquisa e a experimentação eram desconhecidos nos primeiros cursos brasileiros. Nesta condição, tinha-se cursos essencialmente teóricos, baseados na literatura médica francesa e naturalmente casuistica.

$\mathrm{Na}$ mesma época do código de postura da câmara municipal e da inspetoria de saúde do porto, uma outra reforma procurou oxigenar o ensino médico. Membros da Sociedade de Medicina do Rio de Janeiro, que havia sido fundada em 1828 , por determinação da Regência, sugeriu estas reformas que foram acatadas pelos legisladores. De Academia passou-se para Faculdades (tanto a do Rio, como também Salvador) e o curso estruturado a partir do estatuto da Faculdade de Paris. Deve ser ressalvado que, apesar de constar nos regulamentos, não havia laboratórios ou equipamentos necessários às pesquisas. Para se matricular, o candidato deveria demonstrar conhecimentos de filosofia, Aritmetica, geometria e uma língua estrangeira (francès, preferencialmente, inglês ou latim). A idade mínima para ingresso era de 16 anos. A já Faculdade de Medicina do Rio de Janeiro funcionou até 1936 na Santa Casa de Misericórdia - em cujas enfermarias continuaram

${ }^{5}$ HOLANDA, S. B. Op. cit., p. 470.

NOVAES, R. L. Op. cit, p. 215-16. 
sendo dadas as aulas de clinica - e dai se transferiu para o antigo Colégio dos Jesuitas e, em seguida, para da rua de Santa Luzia.

Para as familias com recursos financeiros e dispostas a formarem seus filhos em medicina, uma opçāo natural era as escolas européias. França e Portugal em primeiro lugar, Inglaterra e Alemanha eram outras opções para o estudo.

O filho do Sr. Theremin, que substituira o pai nos negócios da família no Rio de Janeiro, e já conhecedor da cidade e suas instituições, aconselhou ao sócio brasileiro a enviar o seu filho para a Alemanha onde estudaria numa das conceituadas escolas médicas de lá. Hà alguns anos o filho do Sr. Magalhães freqüentava o curso, destinado aos filhos dos comerciantes alemães, na Sociedade Germânica. João Alphonso teria sido admitido no curso por cortesia e influência direta do Sr. Theremin, que prezava a distinção, caráter e abnegação do seu sócio. $\mathrm{O} \mathrm{Sr}$. Magalhães, um português que se instalara no Brasil na mesma época em que D. João VI, mantinha uma próspera atividade comercial atė a fusão de seus negócios, em 1823, com o Sr. Theremin, prussiano que se fixou na cidade anos atrás. Desta sociedade nasceu a $\mathrm{W}$. Theremin \& Co. $\mathrm{E}$ desta firma, uma sólida e conveniente amizade entre os dois homens. A firma funcionou inicialmente na Rua Direita, número 14 , endereço que dois anos mais tarde tornou-se o consulado da Prússia ${ }^{6}$.

O Sr. Magalhães era um eximio administrador.

${ }^{6}$ Karl Wihelm von Theremin (1784-1852), além da atividade comercial (fundou a firma Wm. Theremin \& Co), foi cônsul-geral da Prússia no Brasil em 1827. Como eximio pintor, retratou vistas do Rio de Janeiro entre os anos 1818-1835 (i, ii). Ele foi também um dos fundadores do clube Germânia, que congregava especialmente alemães, mas que, desde sua fundação, teve membros holandeses, suiços, dinamarqueses, etc. (ii).

1. OBERACKER Jr. , C. H. A contribuição teuta à formação da nação brasileira. $2^{a}$. ed. Rio de Janeiro, Presença, 1985, p. 230

ii. HINDEN, H. Deutsche und Deutscher Handel in Rio de Janeiro: Ein hundertjähriges Kulturbild. Zur Zentenar Feir der Gesellchaft "Germania". Rio de Janeiro, Hoepfiner \& Co, 1921 p. 44-7 : 145 -68. 
Seguro no controle contábil, organizado, alheio às relações politicas e discreto no estilo de vida e com um patrimônio considerável. Ele poderia pleitear na sociedade a condição de negociante de grosso trato, ainda mais com os negócios e fortuna em expansão. Entretanto, a sua discrição o mantinha alheio à elite social que gravitava em torno da coroa e às entidades assistenciais e religiosas, também local de demonstração de riqueza, através de doações de diversas natureza ${ }^{7}$. Era provável que contribuisse com alguma irmandade, mas isto seria muito discretamente. Por seu lado, o Sr. Theremin cumpria em parte o papel social do sócio. Não só pelo gosto, como também pela condição de primeiro cônsul prussiano, posto que veio a ocupar em 1824, e futuramente Cônsul Geral da Prússia no Brasil.

Aparentemente a fluência social do cônsul favorecia a performance comercial do seu sócio. O Sr. Theremin tinha sido presidente da Sociedade Germânica, tendo erguido uma igreja , a biblioteca e a escola em 1826. Ele costumava promover recepçōes em sua luxuosa residência no Flamengo, recebendo freqüentemente personalidades estrangeiras ilustres. Em 1835, o Sr. Theremin retornou a seu pais e o seu filho o substituiu.

A decisão do filho entrar para uma escola médica originou-se na confluência de duas certezas e uma incerteza. Uma das certezas: tratava-

7

"Na sociedade brasileira do início do século XIX, o lugar do negociante de grosso trato na sociedade carioca não era determinado exclusivamente pelo critério de fortuna e extensão de seus negócios. Era de suma importância o estilo de vida que levava e o grau de seu envolvimento com a Coroa e entidades religiosas e assistenciais do Rio de Janeiro. O seu prestígio pessoal era definido pelos títulos e honrarias recebidos e pela ocupação de altos postos na administração, nos corpos de milicias e nas irmandades religiosas" $(*)$.

* MARTINHO, L. M. \& GORENSTEIN, R. Negociantes e caixeiros na sociedade da independência. Rio de Janeiro Secretaria Municipal de Cultura, Turismo e Esportes; Departamento Geral de Documentação e Informação Cultural: Divisão de Editoração, 1993. p. 18.4-207, cap. 4: Os negociantes de grosso trato: Modus vivendi (Os mecanismos do processo de integração do negociante na elite dirigente) 
se de uma homenagem que o Sr. Magalhães prometera a si mesmo há muitos anos atrás. Ainda quando rapaz, em Portugal, tivera ele um primo próximo e querido que estudava medicina em Montpellier. Certa vez, de passeio em Portugal, este primo foi preso, acusado de conspiração, e morreu na prisão. Já naquela época o Sr. Magalhães prometera ao tio, que se transtornou profundamente, que, em nome da amizade dos dois, um dia um filho seu continuaria a estudar medicina, como forma de cumprir a vontade do tio. A outra certeza era do Sr. Theremin que, como o seu filho, se afeiçoara ao o filho caçula do sócio, que já dominava o idioma alemão com alguma fluência. Para os Theremin, já era tempo do Brasil investir na formação técnico-cientifica da sua juventude. Eles criticavam o atraso do pais nesta área, a indiferença e até mesmo o menosprezo da sociedade pela ciência e tecnologia e pela excessiva ênfase nos cursos de humanidades. O trajeto educacional livresco, formal, não atenderia às exigências do progresso em diversas áreas e até mesmo o extrativismo vegetal e mineral, requeriam a produção de conhecimentos ${ }^{8}$.

8 A gênese e o desenvolvimento da educação no Brasil liga-se à tradição dos estabelecimentos religiosos. Destes, os Jesuitas ocupam um lugar central pela sua importância e influência na sociedade brasileira. este ensino é, à luz da análise histórica, polêmico quanto as suas contribuiçð̃es ao desenvolvimento do país. Para WEREBE (i)

"A educação formal e anticientífica, a cargo dos jesuitas, influiu, sem dúvida, na péssima administração do país, no mau aproveitamento de nossas terras e riquezas".

As observaçð̃es de FREYRE (ii) mostram que a educação jesuitica cerceou o 'gosto de conhecer' do jovem brasıleiro com implicações na investigação científica da natureza Segundo este autor, para quem já no século XIX este quadro começaria a sofrer mudanças,

"Essa curiosidade, esse gosto, essa alegria nos foram comunicados nos fins do século XVIII, e através do XIX, pelos enciclopedistas e pelos revolucionários franceses e anglo-americanos. Através do século XIX, também por mestres franceses e ingleses que aqui estabeleceram colégios, para grande indignaçào dos padres".

Entretanto, AZEVEDO (iii) se mostra mais céptico quanto às alternativas jesuitica: "Do ponto de vista da estrutura, o nosso ensino médio, herdeiro e continuador dos colégios dos jesuitas, mantinha-se mais ou menos fiel às suas origens latinas e puramente literárias e guardava sem modificaçðes fundamentais, senão o plano tradicional de estudos, o mesmo espírito e o mesmo caráter que Ihe imprimiu o imperio". 
Citavam desde a insipiència e precariedade dos processos industriais, educacionais e sanitários, incluindo o deprimente estado geral da saúde da população. Todas estas coisas eram faladas com recheios de exemplos narrados pelos viajantes e cientistas, grande parte deles alemães, que incursionavam pelo Brasil a dentro e que necessariamente passavam pelo Rio. Assim, à promessa e desejo do sócio, os Theremin agregaram uma prática possivel.

Quanto à incerteza, esta era própria do espírito de João Alphonso. Aceitava as determinaçōes da familia por tê-las como atitudes triviais, prosaicas, decisões práticas do dia-a-dia, pelas quais não demonstrava nenhum interesse especial. No entanto, as suas inquietações interiores viviam encurraladas por um obscuro presente interior, encapsulado na segurança e conforto da vida doméstica e pela atividade na Sociedade Germânica. A idéia de ir estudar na Alemanha lhe era incerta, mas, ao mesmo tempo lhe colocava um desafio. Algo que lhe era estranho e que o cativara.

Para os estrangeiros no Brasil, a questão educacional era grave. Não lhes era possivel obter uma escola razoável para os filhos e a busca de soluções, como por exemplo no caso dos comerciantes alemães, acabava na criação de escolas especificas, na maioria das vezes com contratação de professores no pais de origem. Quando o Brasil se tornou independente de Portugal, acreditou-se no estabelecimento de uma prioridade decisiva para a educação. Esta crença redobrou quando a constituição imperial de 11 de dezembro de 1823 determinava:

i. WEREBE, M. J. G. A educação. In: HOLANDA, S. B. de (Org.). História geral da civilização brasileira. II: O Brasil monárquico; 4. Declínio e queda do Império. $4^{\text {a }}$. ed. São Paulo, Difel, 1985. p. 366-83.

ii. FREYRE, G. Sobrados e mucambos. 8 $^{a}$. ed. Rio de Janeiro, Record, 1990. p. 316.

iii. AZEVEDO, F A A cultura brasileira. São Paulo, Melhoramentos/Ed. UnB, 1963. p. 623-7. 
Artigo $1^{\circ}$. - criação de escolas de primeiras letras em todas as cidades, vilas e lugarejos;

Artigo $11^{\circ}$. - criação de escolas para meninas, nas cidades e vilas mais populosas;

Artigo $179^{\circ}$. - garantia de instrução primária gratuita a todos os cidadãos9.

Poucos anos após já se via que tais artigos não passavam de peças

9 WEREBE, M. J. G., Op. cit., p. 369.

Quanto à educação de filhos de emigrantes, era prática receberem instruções domiciliares. Natural também era os filhos dos emigrantes ricos serem enviados a seus paises para efetivarem seus estudos. CASTRO (i), narrando a vida do naturalista alemão Fritz Müller (1821-1897), que viveu em Santa Catarina, afirma que

"O que mais the desagradava era a possibilidade de as filhas perderem o conhecimento do alemão. No convívio com os brasileiros, a língua sofria uma deterioração inevitável... Criava-se uma espécie de dialeto, feito da adaptação de palavras ou de assimilação integral de expressões do português-brasileiro. No primeiro caso... : inkomodieren, visieren, namorieren,... No segundo, palavras sem tradução ...: die Roça, eine Balsa, die Pikade ... Ou se dizia naturalmente eine volta machen, por dar uma volta; hundert e tanto, por cento e tantos.

"Não queria entregar suas meninas à lamentável escola primária de Desterro, nem 'deixar que elas se tornassem brasileiras na linguagem e nas maneiras'. Era categórico: "Deutsch sollte ihre Hauptsprache bleiben"(o alemão devia continuar sendo a língua principal delas). ...Pedia ao irmão Hermann que the mandasse livros escolares e de leitura para as duas filhas mais velhas".

WILLEMS (ii) afirma que

"A colônia de Santa Cruz teve a sua primeira escola em 1851. Mas esta era particular. ... Anos depois, em 1867, havia no Município 13 escolas, mas destas, apenas uma gratuita, duas subvencionadas pela Provincia e as demais particulares, onde apenas se ensinava o alemão".

i. CASTRO, M. W. de O sábio e a floresta: a extraordinária aventura do alemão Fritz Müller no trópico brasileiro. Rio de Janeiro, Rocco, 1992. p. 64-5.

ii. WILLEMS, E. A aculturação dos alemães no Brasil São Paulo, Companhia Editora Nacional, 1946. p. 384. 
ilustrativas, sem nenhuma repercussão prática. Nada foi avante. $O$ número de analfabetos era incalculável e as alternativas de educação na capital do pais se limitavam a esforços particulares. Cursos básicos de alfabetização existiam em condições precárias e sem controle efetivo da qualidade. Anos mais tarde, em 1852, João Alphonso, lendo um dos suplementos semanais de "O Correio Mercantil", imaginaria o que lhe foi evitado por ter nascido Azevedo Magalhães:

"Foi o barbeiro recebido na sala, que era mobiliada por quatro ou cinco longos bancos de pinho, sujos já pelo uso, uma mesa pequena que pertencia ao mestre, e outra maior onde escreviam os discipulos, toda cheia de pequenos buracos para os tinteiros; nas paredes e no teto haviam penduradas uma porção enorme de gaiolas de todos os tamanhos e feitios, dentro das quais pulavam e cantavam passarinhos de diversas qualidades: era a paixão predileta do pedagogo.

Era este um homem todo em proporções infinitesimais, baixinho, magrinho, de carinha estreita e chupada, excessivamente calvo; usava de óculos, tinha pretensões de latinista, e dava bolos nos discipulos por dá cá aquela palha. Por isso era um dos mais acreditados na cidade. $O$ barbeiro entrou acompanhado pelo afilhado, que ficou um pouco escabriado à vista do aspecto da escola, que nunca tinha imaginado...chegaram os dous exatamente na hora da tabuada cantada...

As vozes dos meninos, juntas ao canto dos passarinhos, faziam uma algazarra de doer os ouvidos; o mestre, acostumado àquilo, escutava impassivel, com uma enorme palmatória na mão... "10.

O abandono completo da educação pelo estado, tanto do ensino primário como tambèm no secundário, fazia surgir um corpo docente desqualificado que mudava de profissão assim que surgia uma possibilidade de renda melhor. Os métodos de ensino, de coerção

10 JORNAL DO COMMERCIO, n. 227, 15:8:1852 
absoluta, levaram a câmara, em outubro de 1827, a promulgar uma lei que proibia castigos físicos. Esta lei também não foi cumprida, como também não se punia aqueles que continuavam castigando alunos nas escolas $^{11}$. Se o número de escolas e a qualidade da educação eram indesejáveis, a discriminação por sexo era maior. As meninas, exceto filhas de algumas familias instruidas que recebiam educação domiciliar, praticamente não recebiam nenhuma instrução. Neste quadro educacional, o governo imperial, em 1837, criou o Colégio Pedro II, que,

11 A tradição do castigo na escola perece só encontrar semelhança na péssima qualificação dos mestres. A educação primária, em especial, era a que mais sofria com a desatenção do estado.

"Os professores primários, escolhidos sem nenhum critério, leigos completamente sem preparo, eram pessimamente pagos, desconsiderados pelas autoridades e pela população ... Os poucos que permaneciam eram tão maus e brutais ... (i).

De fato, os castigos corporais se incorporaram à história do ensino no Brasil Experiências pessoais ou observacionais são descritas na literatura como, por exemplo, nas seguintes obras:

"O compadre expôs ... o objeto de sua visita, e apresentou o pequeno ao mestre.

“... não lhe há de dar muito trabalho, disse com orgulho.

"E se mo quiser dar, tenho o remédio; ... disse o mestre brandindo a palmatória"(ii).

“... ali está de joelhos o Franco. Assim atravessa as semanas... De joelhos como um penitente expiando a culpa de uma raça. o diretor chama-lhe cão.

O pai... mandou-o para aqui ..., pedindo severidade'(iii).

"O pior que ele podia ter, para nós, era a palmatória. E essa lá estava, pendurada do portal da janela, à direita, com os seus cinco olhos do diabo"(iv).

i. WEREBE, M. J. G. Op. cit., p. 370.

ii. ALMEIDA, M. A de Memórias de um sargento de milicias. $29^{\mathrm{a}}$. ed. Rio de Janeiro, Ediouro, 1995. p. 36.

iii. POMPÉIA, R. O Ateneu. São Paulo, Círculo do Livro, srd., p.30.

iv. ASSIS, M. de Contos. $2^{\text {d }}$ ed. São Paulo, Ática, 1973, p.31-38: Conto de escola 
durante muito tempo, seria o único curso secundário mantido pelo estado no pais, basicamente dirigido e freqüentado pela elite.

Assim, João Alphonso ingressou numa das primeiras turmas do colégio Pedro II para cursar o secundário, periodo no qual foi decidido que ele seguiria para a Alemanha, tão logo encerrasse o curso. Desta forma, a viagem já estava programada para o início de 1841 , procurando evitar o rigoroso inverno alemão. Os preparativos para a viagem deram-se no decorrer de vários meses, desde quando o Sr. Theremin escreveu ao Sr. Magalhães, afirmando que havia tomado as providências para a vida alemã de João Alphonso. Dizia que estaria em Berlim quando o rapaz chegasse para um periodo de adaptação. Neste periodo ele ficaria em sua casa e poderia aprimorar o idioma por alguns meses antes de iniciar o curso de medicina. Nesta correspondència, afirmava ainda o Sr. Theremin que

"... depois de aconselhar-me com alguns amigos, cheguei a conclusão de que seria melhor evitarmos o curso na Universidade de Berlim, como haviamos pensado. Os tempos estão tumultuados e há muitas discussões nesta universidade que, de certo, não interessariam ao nosso jovem e que até mesmo poderia prejudicar seu aprendizado médico. Assim sendo, optei por acertar o ingresso do rapaz na Universidade de Göttingen, onde será aceito na escola médica. O Sr. Wappäus, de quem já falamos outras vezes. e que reside na cidade, não só terá providenciado a moradia para João Alphonso como também aceitou ser o seu procurador. Ele se responsabilizará por todas as despesas e para tanto sugiro que lhe seja aberta uma linha de crédito numa das firmas de Hamburgo com as quais trabalhamos. O meu filho saberá lhe dar maiores informações sobre o Sr. Wappäus e sua próspera e honrada familia."

João Alphonso passou o natal de 1841 com a familia Theremin em Berlim. Nesta época tornou-se amigo e conversava bastante com um rapaz, parente proximo dos Theremin, que estudava na Universidade da cidade. Introspectivo e de imaginação bastante fértil, o magnetismo do rapaz produzia em Joào Alphonso uma vontade constante de conversar e 
ouvir suas idéias. Ele o havia presenteado com um livro de Holderlin e eles costumavam comentar os versos desta poesia em vários momentos ${ }^{12}$. Ademais, João Alphonso se mostrava fascinado com a efervescência intelectual da cidade que conhecia há pouco. Durante algumas semanas, e a convite do seu novo amigo, João Alphonso assistiu a algumas aulas do curso de filosofía. João Alphonso aceitara estes convites somente por muita motivação pessoal, porque não passava pelo sua cabeça retornar ao Brasil a não ser com o curso médico concluído, segundo o planejamento do pai.

A filosofia berlinense da época recebia influência de correntes distintas, e o amigo de João Alphonso estimava muito uma destas, representada pelo respeitado prof. Schelling ${ }^{13}$. Este, recém chegado a

12 J. C. Friedrich Holderin (1770-1843) está entre os maiores poetas líricos da Alemanha. Doente mental nas últimas quatro décadas de sua vida, nada mais criou. O livro que João Alphonso ganhara é uma edição de seus poemas publicados inicialmente em 1826. Diz-se que, naquele ano, ao receber um exemplar da edição, o poeta teria comentado:

"Os poemas são autênticos, são meus, mas o título é falso. Na vida, não me chamei Hölderlin, mas sim Scardanelli, ou algo assim". (i ; ii)

i. HÖLDERLIN, F. Poemas [trad. e introdução de José P. Paes]. São Paulo, Companhia das Letras, 1991.

ii. GROLIER MULTIMEDIA ENC. Danbury, CT, Grolier Eletronic Publishing, Inc, 1996: Hölderlin [CD-ROM].

13 Friedrich W. J. Schelling (1775-1854), filósofo alemão, "é geralmente apontado como a mais pura expressão da filosofia do romantismo" (i).

Especialmente durante a primeira metade do século XIX a filosofia de Schelling oporia, sem entretanto oferecer maiores resistências, à emergente filosofia materialista alemã. Para ele

"o pensamento filosófico nåo é suficiente para explicar a existência das coisas: ele deve ser complementado por conhecimentos de outra ordem, possiveis somente no mito e na revelação" (ii).

Para o filósofo húngaro, de expressão aleınã, G. Lukács (1885-1971) Schelling é o marco da

"ofensiva contra o racionalismo cartesiano ... uma das tendências importantes da filosofia burguesa reacionária" (iii).

i. SCHELling, F. W. J. Obras escolhidas. São Paulo, Abril Cultural, 1984. p. VIII 
Berlim por convite pessoal de Frederico Guilherme IV ${ }^{\mathbf{1 4}}$, oferecia um curso bastante procurado também por estudantes e filósofos, estetas, teólogos, que afluiam de diversos lugares da Europa para assistir a suas preleções.

Após a exposição do Filósofo, que culminava com o fim das aulas do dia, era comum os ouvintes se dispersarem pelas ruas da cidade à procura de algum bar. Ai, repassavam e discutiam conceitos e teorias assistidas. Em um destes dias, João Alphonso e seu amigo, já com outros dois estudantes, acomodaram-se num aconchegante bar onde se encontravam vários outros ouvintes do prof. Schelling. O grupo acomodou-se ao lado da mesa de um outro grupo, onde estava um dos

(Coleção "Os Pensadores").

ii. MONDIN, B. Curso de filosofia: os filósofos do ocidente. 3a. ed. São Paulo, Edições Paulinas, 1983. 3 V. p. 33

iii. LUKÁCS, G. El asalto a la razón. Barcelona, Ediciones Gritalbo S.A., 1978. p.24.

14 Frederico Guilherme IV (1795-1861) reinou a Prussia de 1840 a 1861 . Era considerado um romântico sendo um

"brilhante, notável orador, cheio de ardor e consciència e mesmo generosidade" (iii). Ele acreditava na origem divina de sua coroa (i). Foi em 1841 que trouxe Schelling de Munique para Berlim na tentativa de contrabalançar

"a crescente influència dos 'jovens hegelianos' - Marx (1818-1883), Feuerbach (1804-1872), Strauss (1808-1874) e outros -, que despertavam a oposição de elementos da igreja. A esquerda hegeliana, contudo, era muito forte e Schelling acabou por deixar suas funções docentes em Berlim" (iv).

Por conta de seus distúrbios mentais seu filho, Guilherme I, tornou-se regente a partir de 1858 e rei depois de 61 ( $i$; ii).

i. DROZ, J. História da Alemanha. Sintra Portugal, Publicą̧ðes Europa-América, 1985

p.29-57.

ii. GROLIER MULTIMEDIA ENC., Op. cit. : Frederick William IV, King of Prussia.

iii. BONNEFON, C. História da Alemanha. São Paulo, Companhia Editora nacional, 1945. p. 190-205.

iv. SCHELLING, F. W. J. Op. cit. p. viii - ix. 
discipulos e auxiliar de Schelling, conhecido do amigo de João Alphonso. Este discipulo, em fase final de seu doutoramento, encontrava-se em companhia de um moço de cabelos bem penteados, bem vestido, olhos grandes e brilhantes, com quem discursava fluentemente sobre $o$ conceito schelligiano de realidade. Após alguns comprimentos, enquanto seu amigo e o discipulo trocam informações bibliográficas acerca de tarefas de cursos, João Alphonso sente uma curiosidade pontual pelo moço que acompanha o discipulo. Meio hesitante, procura iniciar um diảlogo:

- E o senhor, também estuda com Schelling ?

- Não exatamente, sou apenas um ouvinte temporário, respondeu o moço, que também perguntou:

- O senhor é estudante na Universidade?

Inquieto, João Alphonso respondeu, evitando qualquer possibilidade de uma discussão filosófica:

- Não, não estudo filosofia.

- E também não é berlinense - afirmou o moço, perguntando sem convicção e sem maldade.

João Alphonso quis sentir vergonha do seu alemão, mas se recompôs ao reconhecer que não se saia tão mal entre a familia Theremin.

- De fato, sou sul-americano, do Brasil - disse João Alphonso.

- Do Brasil ? - Exclamou o moço com um olhar de agradável surpresa e algum espanto, dizendo:

- Não passo muito tempo sem pensar no Brasil. O cunhado das minhas irmãs já está na sua segunda viagem de estudos por lá e me parece que não tem pressa para voltar. Invejo o seu desprendimento. Mas, enfim, como o senhor se chama?

- João Alphonso Azevedo Magalhães, do Rio de Janeiro, e estou indo cursar medicina em Göttingen. E o senhor, como se chama?

- Soren. Soren Aabye Kiekergaard, de Copenhague. Meu parente, pois assim nos consideramos, que está no Brasil é o Dr. Lund. Peter Wilheim Lund. A última carta dele que li, nos chegou de Lagoa Santa, 
lembro-me bem, pois pretendo escrever-lhe em breve ${ }^{15}$.

15 Sören Aabye Kierkegaard, filósofo dinamarquês, viveu entre 5 de maio de 1813 e 11 de novembro de 1855. Era o último filho de pais já idosos, seu pai tinha 56 e sua mãe 44 anos quando nasceu. De familia abastarda, Kierkegaard foi um

"estudante inteligente mas indisciplinado e de trato dificil" (i), demonstrando talentos literário e oratório indiscutíveis. Estudou na Universidade de Copenhague onde se formou em 1840. Em 29 de setembro de 1841 defende sua tese "Le concept de l'ironie constamment rapporté à Socrate" (i). Após romper um noivado, embarca para Berlim em 25 de outubro de 1841 de onde retorna a 6 de março de 1842 . Durante o período berlinense freqüenta o curso de Schelling e sente-se estimulado pela intensa vida intelectual da cidade. Além da tese, escreveu várias obras a partir de 1843 , muitas delas sob 'curiosos pseudônimos'(ii).

A importância filosófica de Kierkegaard pode ser medida pelo seu enfrentamento a princípios fundamentais da filosofia do grande filósofo G. W. F. Hegel (1770-1831), morto durante uma epidemia de cólera. O filósofo francès J-P. Sartre (1905-1980) explicita a diferença entre os dois outros filósofos, demonstrando a tendência de suas respectivas filosofias:

“... o que opõe Kierkegaard a Hegel é que , para o último, o trágico de uma vida é sempre superado. O vivido se dissolve no saber: Hegel no fala do escravo e de seu medo da morte. Mas, este, que foi sentido, torna o simples objeto do conhecimento e o momento de uma transformação ela própria superada. Para Kierkegaard, pouco importa que Hegel fale de "liberdade para morrer" ou que descreva corretamente alguns aspectos da fé, o que ele critica no hegelianismo é o fato de negligenciar a insuperável opacidade da experiência vivida ..." (iii). [grifo do autor].

$\mathrm{Na}$ introdução de seu livro 'Existencialismo ou Marxismo", Lukács circunstancia politicamente as tendências filosóficas, achando-se aí o pensamento de Kierkegaard. Esta sistematização reflete a importância que se deu - e ainda hoje valorizadas - às correntes filosóficas e a capacidade destas refletirem corretamente ou não sobre a realidade Afirma, então, Lukács:

"De fato, o objeto do debate é um problema ideológico próprio do estágio do imperialismo, ... Num sentido mais geral, trata-se do choque de duas orientações do pensamento: de um lado, daquela que vai de Hegel a Marx, e de outro lado, daquela que liga Schelling ( a partir de 1804) a Kierkegaard" (iv).

i. MESNARD, P. Kierkegaard. Lisboa, Edições 70, 1986. p. 4 - 28.

ii. KIERKEGAARD, S.A. Obras escolhidas. São Paulo, Abril Cultural, 1984. p. vii - xiii (Coleção 'Os Pensadores').

iii. SARTRE, J-P. Obras escolhidas. São Paulo, Abril Cultural, 1984, p.109-185 Questão de método, p. 115. 
A chegada dos pedidos de ambas as mesas e o fim da conversa entre o amigo de João Alphonso e o discípulo de Schelling interrompeu, com um sorriso generoso de ambos, o diálogo entre o brasileiro e dinamarquês. Por algum momento, parece terem acreditado que se veriam novamente. Por João Alphonso nem passou a lembrança de que estaria viajando no dia seguinte para Göttingen.

Quando João Alphonso chegou a Göttingen, tudo já estava acertado para ele, da moradia à matrícula na Universidade. Contatos anteriores do $\mathrm{Sr}$ Theremin com o influente cidadão da cidade, o Sr. Wappäus, permitiram a João Alphonso alojar-se num agradâvel apartamento próximo à universidade onde estudaria. Da janela, contemplou parte da antiga cidade circunstanciado pela história que o Sr. Wappäus havia the contado rapidamente.

Göttingen, situada às margens do rio Leine, originou-se de uma vila, Gutingi, que já existia aí no ano 953. A cidade prosperou a partir do século 14, quando se juntou à Liga Hanseática. Tornou-se um importante centro comercial. Durante a reforma, a cidade assumiu o protestantismo, o que lhe causou graves prejuizos durante as guerras religiosas do século 16. A fundação da universidade, em 1737, contribuiu para uma nova fase de crescimento. Com os seus diversos prédios de arquitetura medieval, Göttingen produziu em João Alphonso uma sensação de volta no tempo, algo dificil de vivenciar na jovem cidade em que nascera. As igrejas logo chamaram a atenção de João Alphonso. Imponentes construçōes do século 14, aquelas davam um ar de religiosidade austera a toda a cidade. Muitas vezes ele andaria em torno delas, contemplando-as, numa inspeção misteriosa e carregada de respeito ${ }^{16}$.

iv. LUKÁCS, G. Existencialismo ou marxismo ?. São Paulo, Livraria Edıtora Ciências Humanas Ltda., 1979. p. 15-16.

${ }^{16}$ Sobre Göttingen, em:

BORG, H. Dierche Lexikon Deustschland. Westermann, 1985, p. 173 
Os meses passados em Berlim sob o teto da familia Theremin contribuiram para facilitar a adaptação em Göttingen. O Sr. Wappäus, de uma familia de comerciantes com negócios em todo o mundo a partir de Hamburgo, se oferecia às suas necessidades materiais. Mas João Alphonso teria dificuldades em constituir amizades que o satisfizessem. Suas inquietações faziam-no lembrar-se dos bons momentos vividos em Berlim na companhia do amigo dos Theremin. As comemorações, festas e jantares lhe interessavam pouco. Passava a maior parte do seu tempo estudando, lendo e escrevendo à familia, especialmente ao pai, que regulamentou, desde sua saída, a constância em suas correspondências. Nesta época ainda escrevia ao amigo berlinense e citava versos de Hölderlin. João Alphonso também gostava de passear pela ruas e observar, além das igrejas, outros detalhes que anunciavam o aspecto histórico da cidade que parecia lhe agradar. Não era raro visitar as antigas fortificações e prédios sustentados por madeiramento secular.

Em um destes passeios observou, enquanto andava próximo ao prédio da Câmara Municipal, construido entre o final do século 14 e a primeira metade do 15 , um colega de curso com quem não tinha nenhuma intimidade, apesar de, nas poucas vezes em que conversaram, ele houvesse se mostrado agradável. O colega estava sozinho e andava da

BROCKHAUS Enziklopådie. Mannheim, F. A Brockhaus Mannheim, 1989. 9a. B. p.20.

DER GROSSE Adac Städtführer. Stuttgard, VS Verlaghaus Stuttgard GmbH, 1993. p. 340 - 44. (???)

GEORG-AUGUST-UNIVERSITÄT GÖTTINGEN. Personal und Vorlesungsverzeichnis: Sommersemester 1995. Göttingen, Vandenhoeck \& Ruprecht, 1995.

GROLIER Multimedia Enc. Op. cit. : Göttingen

MEYERS Enziklopädisches Lexikon. Mannheim, Klambt-Druck GmbH, 1974. v.10, p. 635-6: Göttingen. 
direção da igreja de São João para a praça da Câmara. Fumava um curioso cachimbo curto de madeira e não tinha pressa. João Alphonso deteve-se a uma certa distância e, sem pressa ou curiosidade, observava o colega: era de uma altura mediana, magro, muito loiro e uma pele mais clara, impossivel. Os olhos azuis expressavam bondade e perscrutação. Depois de algum tempo, João Alphonso decidiu aproximar-se de Morten Schwarzkopf", que não notou a aproximação.

- Morten ? Descansando ? - Falou João Alphonso em voz suave.

Sem incómodos, o colega virou a cabeça e, levemente assustado, disse numa pronúncia carregada, dificil de distinguir de que alemão era oriunda:

- João ? Que surpresa! Sim, eu estou me preparando para voltar aos livros, temos um ponto dificil na próxima aula de anatomia.

João Alphonso concordou com a avaliação de Morten e continuaram a conversar sobre o curso. Como o frio aumentava, João Alphonso convidou Morten a irem beber alguma coisa antes de regressarem às suas casas. Enquanto chegavam a um bar, Morten perguntava e João Alphonso respondia sobre a vida num pais distante, longe dos amigos e familia. João Alphonso falou da viagem, da estada em Berlim e, observando o sotaque do colega, quis saber de Morten.

- Sou de Travemünde. Meu pai é capitão do porto; o velho Diederich - disse Morten, num doce sorriso de uma lembrança fraterna. Travemünde é também um balneário das familias ricas da região completou Morten.

Eles permaneceram conversando por mais algum tempo e, em seguida, sairam. Despediram-se a uma certa altura e seguiram seus caminhos.

A partir deste dia, João Alphonso e Morten Schwarzkopf freqüentemente estavam juntos. Falavam da vida universitária, da cidade, dos seus paises e continentes e estudavam juntos grande parte das matérias médicas. Ora na casa de um, ora na casa do outro. Em pouco tempo, discutiam idéias e principios que Joảo Alphonso aprendeu

"Este personagem, e algumas de seus aspectos aqui considerados, é originalmente descrito em "Os Buddenbrook", romance do escritor alemão Thomas Mann (18751955) 
a aceitar menos por convicção e mais por lealdade. Morten freqüentava uma sociedade de estudantes na Universidade, cujo apego às idéias liberais contestava a aristocracia além de clamar por liberdade $\mathrm{e}$ igualdade. João Alphonso não participava do grupo, mas o acompanhava passo a passo através do amigo que lhe pediu segredo desta sua atividade. Sua familia jamais poderia saber. Algumas vezes, os dois amigos, divergentes por principio quanto à teleologia da ação politica do individuo na sociedade, discutiam sobre a conjuntura politica e social da Alemanha e falavam da Europa em geral. Entretanto, o adorno ideológico não inviabilizava a relação entre ambos, que amiúde protegia a amizade destas divergências.

A amizade entre eles era interceptada quando Morten viajava para visitar os pais e João Alphonso aceitava um ou outro convite do Sr. Wappäus para passear na fazenda da familia ou ir a Hamburgo na casa de parentes deste. Uma ou outra vez o Sr. Theremin, vindo de Neuchâtel, na Suiça, onde tinha negócios, para Berlim, fazia questão de passar por Göttingen e visitar o filho do seu amigo e sócio brasileiro. Numa dessas passagens o Sr. Theremin presenteou João Alphonso com um âlbum rarissimo de gravuras belíssimas, intitulado Saudades do Rio de Janeiro, que ele mesmo havia pintado. Era uma habilidade reconhecida do Sr. Theremin ${ }^{17}$.

A Universidade de Göttingen se instalava no quadro de excelència das universidades alemãs, mundialmente reconhecidas. Não era uma das mais antigas. Outras, do século 14 e 15, já estavam solidamente constituidas ${ }^{18}$. Göttingen orgulhava-se da sua ascensão e se vangloriava

\footnotetext{
${ }^{17}$ Saudades do Rio de Janeiro“, litografados por L. Sachsse \& Comp., Berlim, é "um álbum rarissimo de seis quadros magnificamente coloridos dedicado a D. Pedro II" (*).

* OBERACKER JR. Op. cit., p. 230.

18 GEORG-AUGUST-UNIVERSITÄT GÖTTINGEN. $\boldsymbol{o p}$. cit.
} 
pelos personagens e fatos ligados a ela. A sua excelente biblioteca despertava interesse em todos que se dispunham a aprofundar os conhecimentos. A concorrência particular entre estas universidades era um dos fatores que repercutiam na qualidade dos cursos, sendo, neste caso, exigido dos alunos um esforço sem dispersão. A medicina, em particular, vinha cada vez mais recebendo informaçōes de outras ciências e novas disciplinas tinham que ser incorporadas ao curriculo. A evolução da prática experimental abria cada vez mais laboratórios qualificados, com a formação e incorporação de novas técnicas e formação de novos cientistas que evoluiam e produziam conhecimentos com mais freqüência. Era freqüente nesta época os melhores pesquisadores formarem seus discipulos, escolhidos, muitos deles, na graduação. Isto, de certa forma, garantia a continuidade de suas pesquisas e continuidade na produção de conhecimento. João Alphonso era um bom aluno, que assimilava bem as informações de todas as disciplinas, sem se sobressair pela excepcionalidade em alguma matéria. Por iniciativa própria ou por sugestão de algum professor, não se dedicou a nenhum projeto de investigaçāo experimental. Ele preferia ouvir e discutir algum tema novo com um dos colegas que o desenvolvesse, como era o caso de Morten. Este, atento à evolução da físiologia a partir das contribuição da química, somente não se aprofundou neste estudo por causa do seu entusiasmo com as idéias discutidas na Sociedade. Morten compreendia especialmente bem os conceitos que na época davam conta dos processos nutricionais e, sempre que lhe sobrava tempo, estava na biblioteca, revisando artigos sobre o assunto. E quando, na biblioteca, João Alphonso deparava com algum artigo nesta área, recomendava-o ao amigo.

A idéia de que nos alimentos há substâncias que, de fato, exercem determinadas funções no organismo humano foi construida basicamente a partir de fins do século XVIII e mais aperfeiçoadamente no decorrer do século XIX ${ }^{19}$. Nesta época em que João Alphonso estudou em Göttingen,

GROLIER Multimeia Enc. Op. cit. : European Universities, Germany.

19 Sobre a gènese e evolução da nutrição, é consenso adotar os estudos sobre a respiração, do quimico francès A. L. Lavoisier (174;-1794), como marco efetivo da 
duas ciências a química já constituída e a fisiologia em constituição uniam-se para oferecer uma explicação sobre o que ocorre com um alimento quando ele é ingerido. Na Alemanha, eram muitos os pesquisadores envolvidos com a questão, mas também na França e Inglaterra importantes pesquisas foram realizadas.

Alguns eventos promovidos pelas academias cientificas europeias procuravam elucidar dúvidas nas ciências e acabavam sendo fator estimulante para o empenho e desenvolvimento de ciências particulares. Por exemplo, em 1823 a Academia Francesa de Ciências instituiu um prêmio para $\circ$ trabalho que, através de experimentos químicos $\mathrm{e}$ fisiológicos, determinasse a seqüência dos fenômenos digestivos ${ }^{20}$. Ou seja, o trabalho deveria afirmar quais as etapas pelas quais passam os alimentos no organismo após serem ingeridos. Um quimico, L. Gmelin (1788-1853), e um fisiologista, F. Tiedemann (1781-1861), ambos alemães da Universidade de Heidelberg, ganharam o prêmio principalmente por demonstrarem que biologicamente ocorre aquilo que se observa quimicamente em laboratório: no organismo humano acontecem transformações quimicas de uma substância em outra, sendo inclusive o que explicaria a transformação dos alimentos. A este estudo,

investigação científica dos fenômenos nutricionais. Enunciados anteriores e isolados sobre estes fenômenos parecem não terem repercutido tão significativamente. Lavoisier principalmente, através de suas pesquisas, influência decisivamente o rumo das futuras investigações. Na bibliografia sobre o desenvolvimento da ciência da nutrição destacamse, entre outros:

SANTOS, K. M. O dos. O Desenvolvimento histórico da ciência da nutrição em relação ao de outras ciências. Campinas: UNICAMP, Centro de Lógica, Epistemologia e História da Ciência, 1989 (Coleção CLE, v.5).

McCOLLUM, E. $\mathrm{V}$ et al. Os novos conhecimentos da nutrição. Rio de Janeiro, Ed. Guanabara Waissman-Koogan Ltda., 1943.

IHDE, A. J. \& JANSSEN, J. F. Early american studies on respiration and calorimetry. Mol. Cell. Biochem., 5 (1-2): 11-6, 1974.

FLORKIN, M. A History of biochemistry. Amsterdam, Elsevier, 1972.

${ }^{20}$ SANTOS, K. M. O dos. Op. cit Seçð̄es 3.2 e 4.1 
que serviu como modelo básico, seguiram-se outros, entre eles os estudos do fisiologista Johannes Müller (1801-1850) e assistentes. O importante é que nesta época, primeira metade do século XIX, deslancharam na Alemanha pesquisas sobre os processos digestivos. A fisiologia conseguia excelentes resultados em suas pesquisas associadas à quimica.

Como produto de primeiras investigações ocorridas em fins do século XVIII e primeiras décadas do século XIX, ern 1828 um pesquisador inglês, William Prout (1785-1850), publicou um trabalho onde expunha sua conclusão sobre substāncias alimentares utilizadas pelo homem e outros animais. Disse que estas substâncias seriam de três tipos: carboidratos, gorduras e proteinas ${ }^{21}$. Era a primeira vez que um cientista estabelecia classificaçāo semelhante. Posteriormente, em 1834, este mesmo pesquisador detalhou suas conclusões anteriores, que foram acolhidas por toda comunidade cientifica da época. Assim, através deste estudo, já se podia, rusticamente, estipular uma dieta satisfatória em termos de substâncias quimicas. Na Alemanha, Johannes Müller era um dos que estimulavam e insistiam na necessidade de experimentação, particularmente na área de fisiologia, para se conhecer os processos metabólicos, entre eles a nutrição. Assim, o casamento entre estas duas ciências, a química já constituída e a fisiologia em constituição, permitia conhecer melhor os caminhos do alimento no organismo humano.

Morten não raras vezes chamava a atenção de João Alphonso para certas particularidades entre a alimentação, atividade fisica e meio ambiente. Exemplificava dizendo ao amigo que o ar do litoral, como na sua cidade, por exemplo, emagreceria as pessoas, pois acelerava o ciclo nutritivo. Por isso, dizia ele, a importância de uma alimentação substanciosa. Na verdade, o que Morten fazia era procurar aplicar os novos conhecimentos surgidos a observaçōes empiricas nada rigorosas.

Numa tarde em que folheava periódicos ingleses na biblioteca, João Alphonso notou um artigo na London Medical Gazette ${ }^{22}$. Nele, o autor, G.

"SANTOS, K. M. O dos Op. cir. Seção 2.2

22 BUDD, G. Disorders resulting from defective nutriment. Lond med gaz, ii: 632-36, 1842 
Budd (1808-1882), discute as alterações decorrentes da ausência de nutrientes. Conversando com Morten sobre o assunto, concordaram que era estranho admitir que a singularidade do alimento pudesse conter alguma substância tão potente a ponto de causar uma doença. Sabia-se que o escorbuto, doença que causava muitas mortes, principalmente nas tripulações de navios, era prevenido pelo uso de alimentos frescos, mas, explicavam, isto se devia à vitalização do organismo humano que se protegia contra a instalação da doença. Assim, entre os dispersos conhecimentos sobre o assunto que brotavam na época, a absorção inicial dos mesmos era, inicialmente, guiada pela desconfiança. As dificuldades do exercicio experimental recente e o conservadorismo das práticas no processo saúde e doença dificultaram a adesão a novos conceitos. Além disso, descobertas cientificas em outras áreas, e de respostas curativas mais imediatas, causariam maior interesse não só aos cientistas sanitaristas como também à população em geral e a governantes.

Nesta mesma época, a Saúde Pública ganhava força em paises europeus. As transformações econômicas e políticas da época criaram o meio ideal para que idéias sobre a qualidade de vida de trabalhadores urbanos, campesinato e, enfim, toda a massa de excluidos da sociedade, pudessem almejar melhorias nas condições de moradia, renda, saúde, etc. Este grande movimento em torno das questões da saúde pública foi decisivamente influênciado por concepções de natureza filosófica e

politica. As politicas de saúde foram impulsionadas na medida em que cada estado respondia às exigências das transformações econômicas, guardando, entretanto, a especificidade de cada contexto social. Estas ações de politica de saúde uniram em torno de si politicos e cientistas e, em muitos casos, cientistas com determinada ação politica. Assim, já na Alemanha da primeira metade do século XIX importantes nomes da medicina envolveram-se com questōes de saúde pública. Em geral, foram nomes oriundos da pequena burguesia que vieram a se alinhar 
ideologicamente com intelectuais comprometidos com o proletariado. No primeiro caso, as figuras de Virchow, Leubuscher e Neumann e no segundo, por exemplo, Marx e Engels ${ }^{23}$.

Neumann, em 1840, apresentou à Sociedade de Médicos e cirurgiōes de Berlim um projeto de lei de saúde pública que subsidiaria discussōes na área, especialmente nos anos que precederam a revolução de 1848. O projeto de Neumann tinha como objetivos da saúde pública os seguintes enunciados:

"O desenvolvimento sadio, mental e físico, do cidadão; a prevenção de todos os perigos para a saúde; o controle das doenças."

\section{Enunciava ainda que:}

"A saúde pública tem de cuidar da sociedade como um todo, levando em conta as condições gerais, físicas e sociais - como o solo, a indústria, os alimentos, a habitação - capazes de afetar adversamente a saúde; e tem de proteger cada indivíduo, levando em conta as condições que o impedem de cuidar de sua saúde, incluidas em duas categorias principais; condições como a pobreza e a enfermidade, nas quais o individuo tem o direito de requerer assistência do estado; e condições nas quais o estado tem o direito e a obrigação de interferir na liberdade pessoal do individuo - por exemplo no caso de doenças transmissiveis e doença mental".

23 Rudolf Virchow ( 1821-1902); Solomon Neumann; Rudolf Leubuscher; Karl Marx (1818-1883); Friderich Engels (1820-1895).

OLIVEIRA, C. R. Origem e desenvolvineinto das concepçðes da medicina social na Europa do séc. XIX . In: OLIVEIRA, C. R. Medicina e Estado: origem e desenvolvimento da medicina social no Brasil - Bahia: 1866 - 1896. Rio de Janeiro, 1982. [Dissertação de mestrado - Instituto de Medicina Social da UERJ]. p. $1-101$.

ROSEN, G. U'ma história da saúde pública. São Paulo, Ed. Unesp/Hucitec/Abrasco, 1994. p. 157 - 226: O industrialismo e o movimento sanitário. 
Por fim, o documento de Neumann concluia:

"A saúde pública pode cumprir estes deveres ao oferecer pessoal médico em número suficiente, e bem preparado, e ao estabelecer instituições destinadas a promover o bem da saúde pública"24.

Assim, alèm das discussões historicamente associadas às concepções políticas, a saúde pública requereria cada vez mais apropriação de conhecimentos científicos em áreas especificas como, por exemplo, na área das doenças transmissiveis.

A militância de Morten na Sociedade de Estudantes conduzia-o à discussão sobre as condições sanitárias da Alemanha, e o que mudaria nestas referidas condições dada uma nova estrutura política. João Alphonso não era interlocutor de Morten nestas questões: além de não freqüentar a sociedade estudantil, ele também se mostrava indiferente à questão. Morten provocava-o em alguns momentos, mas o respeito afetivo entre ambos costumava conter qualquer rispidez na discussão.

Certo dia, entretanto, eles se encontraram após mais uma das reuniões da Sociedade. Quando Morten chegou, João Alphonso lia Heine $^{25}$, livro emprestado pelo próprio amigo que considerava este poeta

\footnotetext{
${ }^{24}$ ROSEN, G. Op. cit, p. 200.
}

25 Heinrich Heine (1797-1856) é considerado um dos maiores e mais controvertidos escritores da Alemanha (i). Estudou direito em Bonn, Berlim e Göttingen, onde se doutorou em 1825. Entre 1826 e 31 publicou quatro volumes de "Quadros de Viagem" (Reisebilder). Antes, em 1824, iniciara um projeto ambicioso sobre a "grande dor judaica", obra que ficaria inacabada (ii). Após 1831, Heine passa a viver em Paris. Aproxima-se de intelectuais alemães exilados, entre eles Marx, de quem se tornou amigo (iii). Até perto da sua morte publicou várias obras em verso e em prosa com forte conotação politica, criticando as condições na Alemanha.

i GROLIER Mult. Enc Op. cit. : Heine 
superior a Hölderlin. Ao falar, Morten não conservava o seu jeito simpático e ingênuo. Estava exaltado. Trazia consigo livros, cadernos, impressos e jornais, distribuídos clandestinamente na Sociedade. João Alphonso fez menção de mostrar a correspondencia que havia recebido de Berlim: uma carta e um livro do filósofo Kierkegaard, que outro amigo havia lhe enviado. Mas Morten, indiferente, entregou-lhe os jornais, dizendo simplesmente:

- É para você lê-los.

João Alphonso colocou-os sobre uma mesa e, como não fazia freqüentemente, perguntou sobre a reunião do dia, no que o amigo the respondeu de forma critica e provocativa:

- Sabe, João, são coisas que talvez não te agradem muito. Estávamos falando dos desvalidos, da massa de miseráveis que passam fome, adoecem e morrem por causa da usura de uma aristocracia idiota.

João tentou reagir, canhestramente:

- E por causa da aristocracia idiota você esta nervoso e desperdiçado, enquanto os aristocratas se alimentam numa mesa farta, preparando-se para a fortuna do dia?

- Está vendo, está vendo! - Exclamou Morten ainda mais ferrenho - Eu disse que você não entenderia. É uma questão de princípio, João. Institucional. Queremos a igualdade e liberdade de todos os homens. Que um homem não seja propriedade de outro. Que a lei seja para todos. Sem privilégios - afirmou antes de encerrar - mas não creio que você seja, por completo, o culpado por sua cegueira. Sua familia no Brasil, creio, e seus amigos berlinenses, acredito, não contribuem para te fazer ver a perversidade de um estado discriminante, irracional.

João Alphonso suportou a contundência do discurso do amigo e achou que não respondê-lo poderia significar uma grave indiferença. Por isso, pensou em ser ameno e pouco provocativo, afirmando:

- Bom, acho tudo isto uma afirmativa genérica... ambiciosa sob

ii. HEINE, H. O Rabi de Bacherach. São Paulo, Hucitec, 1992.

iii. MARX, K \& ENGELS, F. Sobre literatura e arte. São Paulo, Edições Mandacaru Ltda., 1989. p.212-17: Henrique Heine. 
alguma perspectiva. Mas não creio que o estado seja uma instância com racionalidade para cumprir estes ideais.

Morten não esperava a resposta. E como um militante diante de um leigo inoportuno, procurou se conter e tentou ser didático através de um exemplo prático:

- João, as coisas não são assim. Bem ! Na nossa reunião de hoje discutimos algumas questōes relativas a moradia, renda, trabalho, etc. Há pessoas importantes, inclusive da nossa área, receptivos e com propostas para atuar nestas questões. Você deve se lembrar do projeto de saúde pública que lhe mostrei tempos atrás. Aquele projeto de Neumann apresentado à Sociedade de Médicos de Berlim. Lembra-se da introdução ? "A saúde pública tem como objetivos o desenvolvimento sadio, mental e fisico, do cidadão; a prevenção de todos os perigos para a saúde; o controle das doenças". Então ? Como podemos achar que o estado não comporta uma racionalidade ? João, o estado existe objetivamente. Podemos ou não podemos, temos ou não temos que lutar para que esta racionalidade seja canalizada a objetivos propostos à nossa realidade?

- Somente porque vocês pensam que é possivel compreender toda a realidade. Eu até acho...

Morten não deixou que João Alphonso completasse a frase $e$ afirmou:

- Como não ? É claro que o pensamento é capaz de apreender a realidade, as coisas. $E$ mais, ...

Agora, foi a vez de João Alphonso interceptá-lo, inquirindo-o:

- Então, é por conta disto que se deve acreditar que a saúde pública deve ter como objetivos, por exemplo, prevenir todos os perigos para a saúde?

- Como ideal, sim. Isto é humano, é político. E creio que em seu pais as ccisas são postas nestes termos, ou seja Alphonso, o pensamento reflete o real. E tem mais, João, com os trabalhadores, os proletários, há um grupo atuante de intelectuais, filósofos inclusive. E a filosofia do proletariado tem nos oferecido bons argumentos para compreender $\epsilon$ transformar a realidade - concluiu Morten.

- Ora, Morten - reagiu João Alphonso - pare com isso. Se é verdade que exista a filosofia e os proletários, é tolice acreditar que haja uma filosofia de proletariados e muito menos filósofos proletários. 
- Lamento não termos conhecimentos especificos para discutir o assunto. Mas você deve admitir que os intelectuais são os primeiros a ter consciência dos problemas e que, juntos, podem apontar a melhor maneira de enfrentá-los - respondeu Morten.

- Não creio que precisamos ser intelectuais para saber que qualquer faminto em qualquer lugar tem consciència da sua fome melhor do que ninguém. A questão é que determinadas "fomes" de alguns seres humanos alimentam-se das misérias de outros seres humanos argumentou João Alphonso.

- E onde você deseja chegar? Devo cruzar os braços com os pés atados? - perguntou Morten.

- Eu reconheço que não posso te oferecer uma alternativa tão dinâmica como a que tem. Pessoalmente, eu prefiro observar a ineficácia e desencantos do homem, a imaginar que a verdade está sempre ao meu lado, percorrendo comigo velhos e conhecidos caminhos - respondeu João Alphonso.

- Sabe, não adianta a gente discutir estes assuntos... Você tem as suas opiniões e eu as minhas. A discussão acaba se tornando redundante - afirmou Morten.

- Só tenho medo que esta sua generosidade coletiva, messiânica até, atropele sua felicidade pessoal de uma forma inconciliável - disse João Alphonso.

- Não se preocupe muito comigo, João. Eu e meus companheiros da Sociedade conhecemos as causas que defendemos. Cada coisa em seu tempo... até a liberdade, sabe ? a liberdade... - afirmou Morten, gesticulando acanhadamente.

- Olha, Morten, se eu não te conhecesse o bastante, eu acreditaria que você não leva a sério a existência individual de cada pessoa. Mas ainda bem, ainda bem que te conheço e por isto te respeito - respondeu João Alphonso, convidando o amigo a um passeio pela cidade.

O tempo passava e, numa época de férias em que João Alphonso aguardava a visita de um conhecido que estava chegando do Brasil com encomendas enviadas por sua familia, ele se deu conta do peso da 
ausência de Morten em sua companhia, jâ que fizera poucas amizades efetivas na cidade. Morten viajara para Travemünde e não voltaria nas próximas semanas. João Alphonso e Morten um dia pensaram em escrever juntos um relato sobre suas experiências em Göttingen. Mas este projeto não conseguia ir adiante por conta das exigências do curso de medicina, de outras atividades paralelas ou mesmo por conta das viagens que ambos, ocasionalmente, faziam separadamente. Nestes dias, João Alphonso imaginou avançar o projeto e sentou-se para escrever. Acabou escrevendo coisas que achou melhor enviar a Morten em Travemünde. Pôs o escrito num envelope, e antes que se preparasse para ir postar a correspondência, bateram à sua porta. Era o brasileiro que esperava. Depois de muito tempo descobrira que ainda falava fluentemente o português.

Morten retornou de Travemünde mais cedo do que o esperado. E João Alphonso só foi encontrá-lo, por acaso, alguns dias depois, quando encontrou-se com um terceiro colega que o informou tê-lo visto chegar de viagem. Imediatamente, João Alphonso dirigiu-se à moradia de Morten que, simpático, recebeu-o sem brilho. João Alphonso quis saber da viagem e, diante de respostas vagas e sociáveis, acomodou-se numa pequena poltrona, próximo à janela. Trocaram um olhar incerto e Morten ofereceu-lhe um trago de uma bebida levemente amarga, presente que seu pai ganhara de um marinheiro finlandês. João Alphonso não precisou perguntar a Morten, que falou com sua voz lerda:

- Meu pai mandou-me vir mais cedo.

João Alphonso já o conhecia o suficiente e sabia que nesta decisão havia alguma questão de principio. Inicialmente, pensou na secreta sociedade de estudantes, mas desconfiou de outros motivos para o retorno antecipado. Morten não precisava esperar que João Alphonso the perguntasse e continuou a falar:

- Recebemos em nossa casa um casal de jovens, filhos de uma familia da região, importante, mas amiga do meu pai. Foram descansar umas semanas em Travemünde. Fui contemporàneo de colégio do rapaz disse com paciência - e em seguida olhou fixamente para os olhos de João Alphonso, por poucos segundos, e, desviando o olhar, continuou:

- Envolvi-me com a jovem que já tinha um pretendente. Este ficou sabendo, veio a nossa casa, conversou com pai e... 
João Alphonso olhava para Morten, perscrutando informações e sentimentos. Sem saber o que dizer, perguntou:

- Como se chama ela?

- Antonie. Todos a tratam por "Tony".

- E o que você pretende fazer? - perguntou João Alphonso.

- Nada - respondeu Morten - Ela deverá se casar com o pretendente, que tem a concordância dos pais dela.

Foi a última vez que falaram do assunto. Nem mesmo quando, tempos depois, após alguns adiamentos, João Alphonso aceitou conhecer Travemünde. Seria uma descortesia, pensou ele, terminar os estudos na Alemanha sem conhecer a cidadezinha de Morten.

Durante esta viagem para Travemünde, eles conversaram bastante. Morten gostava de saber do Brasil e chamavam sua atenção as informaçōes que eram dadas pelos naturalistas que, incansáveis, iam e vinham de lá. João Alphonso relembrou-lhe o inusitado encontro no bar em Berlim há tempos atrás e ainda lembrou-se do último nome do cientista dinamarquês, de quem falara o filósofo de Copenhague. Morten interrompeu a conversa, exclamando:

- Veja o mar, estamos chegando!

Em breve, estavam passando pelas primeiras casas da cidadezinha e logo depois da igreja apearam do carro com a bagagem e percorreram a margem de um rio até uma simpática casa que causou ótima impressão a João Alphonso. A casa tinha uma agradável varanda tomada por uma trepadeira espessa que a cobria quase totalmente. Neste instante, apareceu nesta varanda o Sr. Schwarzkopf com um gorro de marinheiro e um familiar cachimbo de madeira, que manteve na boca mesmo quando falou:

- Ora, ora. Vejo que chegam dois “doutorzinhos” a minha casa.

Abraçou com felicidade o filho e cumprimentou cordialmente o amigo visitante. A mảe e a irmã apareceram e repetiram o gesto do pai. Esta recepção deixou João Alphonso muito à vontade e logo estavam conversando em torno de uma mesa com pratos variados, saudáveis, que 
aumentavam o apetite dos moços.

- Então, o Senhor vem de longe ? Os navios que viajam para aqueles lados partem e chegam, principalmente, por Hamburgo e Bremerhaven. Mas não é muito raro ouvir histórias sobre as novas terras do ocidente. - comentou o pai de Morten.

A mãe e a irmã perguntaram detalhes da natureza e dos animais e Morten falou-lhes dos naturalistas, especialmente os alemães, que muitos estudos realizavam no Brasil. Passada a expectativa inicial, João Alphonso quis saber da familia Schwarzkopf, e o pai, sem perda de tempo, arrolou várias informações. O pai narrava, e Morten, franzindo a testa e arregalando os olhos, pedia paciência à mãe e irmã. É que o pai começava a contar a história, que sua familia já ouvira incontáveis vezes, do nascimento do seu pai, que também se chamava Morten, a bordo de um navio que viajava para a Noruega. Quando tinha ouvintes, ele era um contador de histórias. $E$ as conhecia em quantidade. Para João Alphonso, o Sr. Schwarzkopf contou que, tempos atrás, encontrou aqui no seu porto um capitão de um navio norueguês que lhe contara a triste história de uma sobrinha, moradora de Kristiana, que teria sido abandonada, com très filhos, por um desenhista de sobrenome Brandt, que teria ido para a América do Sul. Espreguiçando-se, do apetite saciado, o "velho", com aquele conhecido sotaque do Morten, brincou:

- Então, rapaz, quando voltar para sua terra e encontrar com este moço fujão, embarque-o para cá que o enviaremos a Kristiana.

Diálogos amenos e uma hospitalidade espontânea, até então não encontrada na Alemanha, alegraram imensamente a estada de João Alphonso em Travemünde. Logo partiram de volta a Göttingen pois o fim do curso se aproximava.

João Alphonso recebeu uma longa carta de seus pais, dizendo que gostariam de ter vindo a Göttingen para a sua formatura, mas que a situação política e econômica do Brasil exigiam atenção nos negócios da familia, mas que os Srs. Theremin e Wappäus estariam presentes na ocasião. Além disso, aguardavam ansiosos o seu retorno, quando o 
comemorariam com uma grande festa. João Alphonso estava inquieto nos seus últimos dias de Göttingen. Dizia a todos que gostaria de estagiar em algum hospital de Berlim antes de retornar ao Brasil. Além disso, o Sr. Wappäus lhe comunicara, algumas semanas depois da sua formatura, que tudo já estava preparado para sua volta. Seguiria para Bremem, de lá para Bremerhaven, onde tomaria o navio para o Brasil, conforme já havia sido acertado com o seu pai.

Morten estudava algumas possibilidades de trabalho e desde já decidira que seria clínico em alguma cidade alemã. Pretendia estudá-las com calma, descansando uns dias em Travemünde. Ele esperou que João Alphonso partisse para Hamburgo, antes que ele fosse para Travemünde. No dia do embarque, enquanto o cocheiro arrumava a bagagem no carro do amigo, eles se afastaram do grupo que esperava pela viagem e se abraçaram afetuosamente. $\dot{E}$ difícil dizer a natureza de um choro quando sentimentos humanos acabam em lágrimas... mas ambos mantiveram os olhos cheios de lágrimas e prometeram que, além de se corresponderem, se visitariam dentro dos próximos anos. Com certeza, aquele não era o momento para acreditarem que jamais se veriam novamente. E partiram separadamente, rumo a seus destinos.

A viagem de volta demoraria em torno de dois meses. Em Bremem, pegaria a barcaça que, pelo rio Weser, conduziria os passageiros até Bremerhaven. Eram muitos os viajantes, mas João Alphonso quis se sentir só e evitou intentar diálogos. Em Bremerhaven, antes de tomar o navio, ele andou pelo porto e ficou admirado com o número de imigrantes que se alojavam no grande edificio que thes era destinado. Estariam todos saindo da Alemanha? perguntava-se. Homens, mulheres, crianças, sem sinais de tristeza, aguardavam ansiosos a hora do embarque. Caixas e malas de tamanhos diversos cruzavam-se nos ombros e mãos daquela gente sonhadora que partia. A vitalidade destas cenas acompanharam João Alphonso por muito tempo. Anos mais tarde, quando ganhou de amigos alemães um livro de um viajante alemão pelo Brasil, ele lembraria novamente estas cenas ao ler:

"Ininterruptamente chegavam embarcações apinhadas de passageiros e, enquanto uns desembarcavam com suas trouxas, outros carregavam, com grande esforço, caixas e malas...muitos entoavam canções alegres, enquanto outros 
riam e brincavam, sonhando com as imensas riquezas em busca das quais pensavam ir"26.

Quando João Alphonso embarcou de volta, deixou para trás um pais onde se encontravam vários focos de agitação social. Politicamente, os alemães contestavam a opressão burocrática de um estado absolutista. Do ponto de vista econômico, a Alemanha encontrava-se numa situação instável, provocada pela crise econômica de $45-47$, que gerou grande desemprego, com redução de salários. Além disso, havia a insatisfação dos artesãos, que se enfureceram com o advento de novas maquinarias. Por conta disto, ocorriam tumultos em várias localidades. A revolução de 1848 estava em marcha ${ }^{27}$.

Sem o mesmo significado das revoluções européias da época, no Brasil a revolução praieira surge, em Pernambuco, naquele ano de 1848 . Era orientada por um esforço de alguns intelectuais em compreender a realidade da provincia, oferecendo um programa onde surgia, por exemplo, a defesa do sufrágio universal para todos os brasileiros, expulsão dos portugueses, etc. Este acontecimento pernambucano sucedeu a outra tentativa de contestação do estado imperial: as revoltas liberais surgidas em maio e junho de 1842 em São Paulo e Minas Gerais, ramificando para o Rio de Janeiro. Assim, além de debelar insurreições, o governo imperial enfrentava um importante impasse no campo diplomático com a Inglaterra. Tratava-se da delicada questão da

${ }^{26}$ BURMEISTER, H. Viagem ao Brasil através das provincias do Rio de Janeiro e

Minas Gerais. Belo Horizonte: Ed. Itatiaia; São Paulo: Edusp, 1980. p. 17-49: plano de viagem - Partida de Halle e de Bremen - a esquadra alemã - O oceano

A edição original que teria sido lida pelo personagem é:

BURMEISTER, H. Reise nach Brasilien, durch die Provinzen von Rio de Janeiro und Minas Geraes, mit besonderer Rücksicht auf dir Naturgeschichte der Gold und

Diamantendistrickte. Berlin, Georg Reimer, 1853.

27 DEUTSCHE Geschichte - Epochen und Daten. Verlag Ploetz Freiburg-Würzburg, Freiburger Graphische Betrube, 1991 
escravatura. No Brasil, poderosos segmentos comerciais e politicos interessavam-se vivamente pela continuação do comércio negreiro e no escravismo em geral, enquanto a Inglaterra interessava-se em, ao menos, encerrar o träfico, o que viria a acontecer a partir de $1850^{28}$.

Ao aportar no Rio de Janeiro, o jovem médico encontrou uma cidade aparentemente desprovida de qualquer normatização higiênica e administração sanitária. Entre os cumprimentos de amigos e afagos familiares dos que foram esperá-lo no porto, João Alphonso ouvia relatos esparsos de uma ou outra pessoa sobre as moléstias na cidade. Naturalmente, esperavam que ele trouxesse da Alemanha uma fórmula médica que debelasse os perigos inesperados à saúde. De fato, as condições sanitárias da cidade não eram nada satisfatórias. Além das moléstias epidèmicas que a visitavam com frequeencia e sem inimigos, a imundice proliferava em qualquer canto e não eram respeitados os menores principios higiènicos. As praias mantinham-se como escoadouro de lixo e cadáveres de animais que ali eram jogados sem nenhum constrangimento. $\mathrm{O}$ escoamento das águas era precário, formando poças que dependiam do sol para evaporar ${ }^{29}$. João Alphonso recordou brevemente do código de postura que a câmara municipal aprovara anos atrás e que até mesmo o Sr. Theremin saudara como uma iniciativa necessária.

28 FAUSTO, B. História do Brasil 2. ed. São Paulo, Edusp: FDE, 1995. p. 175-236 : O segundo reinado (1840-1889)

29 A má condição higiênica da capital imperial neste periodo era convincentemente relatada (i ; ii).

“... Capistrano de Abreu, um famoso historiador brasileiro, dizia que no Rio de Janeiro do século XIX, quem cuidava da higiene pública eram as águas da chuva, os raios do sol e os urubus" (iii).

i. BARBOSA, P. \& REZENDE, C. B. Op. cit.

ii. FONTENELLE, J. P. Op. cit.

iii. TELAROLLI JR, R Epidemias no Brasil: uma abordagem biológica e social São Paulo, Ed. Modema, 1995 p 32. 
Durante o tempo em que permaneceu recebendo amigos, parentes e participando de várias recepções organizadas pela familia, João Alphonso foi se informando da administração sanitária municipal. Ficou sabendo da insatisfação da corte com a administração sanitária municipal e que, por isso, a desmunicipalização da saúde era eminente ${ }^{30}$.

O processo de reconhecimento de diplomas estrangeiros no Brasil, - que permitiria o exercicio legal da profissão, costumava ser demorado $^{31}$. Mas isto variava de acordo com a capacidade de influencia politica do interessado. No caso de João Alphonso, a tramitação do processo foi meramente preenchimento de formalidades. Seu pai, comerciante reconhecido, havia arranjado de tal forma o reconhecimento do diploma que as entrevistas realizadas por João Alphonso na Faculdade de Medicina eram apenas conversas entre velhos e novo médico. Os professores pediam informações sobre a medicina alemã, o curriculo, pesquisas... Um ou outro insinuava conhecer muito bem qualquer assunto que pudesse constituir novidade. Outros, aconselhavam o jovem médico, dizendo:

- Meu rapaz, esqueça muita coisa que aprendeu na Alemanha. Você está no Brasil, e aqui não temos tempo para pensar nos devaneios

\footnotetext{
30 Nesta época vigorava no pais a descentralização das açð̃es de saúde pública. Apenas o serviço de vacinação anti-variola continuava sob a direção do governo central. Mas a precariedade destas açð̃es, em especial na capital, onde as condiçðes sanitárias eram lastimáveis, geraram reclamos que pediam novamente a centralização das atividades de saúde. Isto viria a ocorrer com o aparecimento dos primeiros casos de febre amarela no Rio de Janeiro em 1849 (*).

* FONTENELlE, J. P. Op. cit., p. 422-23.

31 Esta é a experiência que teve, por exemplo, o médico Adolfo Lutz (1855-1940) que, retoando da Europa onde se formou e especializou, permaneceu oito meses no Rio de Janeiro submetendo-se às avaliçðes necessárias para validação do seu diploma:

"Sem estes exames, médicos diplomados no estrangeiro nåo poderiam clinicar no Brasil" (*)

* BeCEllar, R. C. Op. Cit.p. 91.
} 
de cientistas de laboratório.

João Alphonso não se animava com este tipo de conselho, nem com os incessantes pedidos de parentes e amigos para um aconselhamento ou mesmo consulta informal. Durante alguns meses, não conseguia pensar detidamente na sua instituição profissional. Passou a sair com amigos, mas se realizava mais desencaixotando livros, anotações, etc., que trouxera da viagem. Consumia tardes inteiras lendo e relendo anotações e os muitos livros. É desta data sua primeira carta a Morten, quando lhe narra as impressōes de retornar ao pais depois de tanto tempo. Visivelmente inquieto, apesar de não contestar e até absorver toda a expectativa que a familia criava em torno dele, João Alphonso afirmava, em um trecho da carta

... talvez agora eu entenda melhor o que é realidade para

Kierkegaard. Aqui, a minha existência tem sido a existência de um individuo em decisão ${ }^{32}$.

O pai de João Alphonso pretendia fazè-lo médico de familias do corpo diplomático, de comerciantes e demais pessoas importantes residentes no Rio de Janeiro. Era um mercado concorrido, inclusive com a presença de outros médicos formados na Europa. Assim, passaram a freqüentar reuniões sociais, coisa não muito comum anteriormente. Noutra situação, o próprio pai programava encontros para os quais a companhia do filho médico era imprescindivel. Em duas destas situações ocorreram fatos que viriam a interferir diretamente no futuro de João Alphonso. O seu pai, mesmo não sendo homem de freqüentar as concorridas irmandades, contribuiu, de maneira discreta e regularmente, para obras da irmandade do Santissimo Sacramento da Candelária. É bem verdade que isto só veio a ser sabido quando ele passou a freqüentar as reuniões com o filho ${ }^{33}$.

32 "Kierkegaard é um filósofo da realidade - isto é, da existència do indivíduo em decisåo" (*)

* MESNARD, P. Op. cit.

${ }^{33}$ No início do século XIX, 
Numa reunião beneficente, programada pela Irmandade, João Alphonso foi apresentado a uma moça que viria a ser sua esposa. Ela era filha de um alto funcionário da administração imperial e com amplas relações politicas e sociais. Era um tipo de associação desejável a ambas as familias. João Alphonso desconfiou da casualidade do momento e até mesmo da disponibilidade da família da moça. Até aquele momento, em que ainda se adaptava a uma nova vida social e cultural, João Alphonso não pensava e não foi despertado para nenhuma relação afetiva. Mas este contato com a moça que viria a ser sua esposa havia lhe causado uma agradável sensação. Discreta e utilizando muito adequadamente seus razoáveis recursos culturais, a moça se diferenciava de todos os interlocutores recentes que João Alphonso tivera até então na cidade. Não emitia opinião sobre o que desconhecia e muito menos dizia fazer ou conhecer o que nunca vira. Além disso, se interessou verdadeiramente por sua vida não acadêmica durante o periodo que esteve na Alemanha. Assim, naquele dia, pela primeira vez depois que chegara ao Brasil, ele não falava com alguém sobre matéria médica, oportunidade profissional, projeção de ganhos ou política. A agradável companhia da moça tornaria freqüentes suas visitas a sua casa. Ela se interessava e João Alphonso gostava de falar da história de Göttingen, de Berlim, suas amizades, principalmente da amizade com Morten. Sobre ele, João Alphonso falava dos projetos de escreverem juntos suas experiências na faculdade, viagens, a vida em Travemünde, os Schwarzkopf ... Assim, passou a ser com a sua nova amiga que João Alphonso confidenciava seus projetos pessoais e profissionais.

"havia no Rio de Janeiro, uma infinidade de Irmandades Religiosas, cujos 'irmãos' se congregavam como devotos de determinado santo. No entanto, não era somente a religiosidade que unia os homens em confrarias.

Outra afinidade ainda ligava os homens em irmandades, era a riqueza e o prestígio.

A irmandade do SS. da Candelária, uma das mais ricas do Rio de Janeiro, era constituida praticamente de negociante e comerciantes" (*).

* martinho, L. M. \& GORENSTEIN, R. Op. cit, p.19t 
Não sem razão, após várias visitas à casa de sua amiga João Alphonso se deu conta de que para suas familias aquelas visitas não eram apenas uma agradável amizade. Há anos sem a necessidade deste tipo de suspeita, ele se confundiu quando seu pai chamou-o e disse explicitamente que as respectivas familias aprovariam com muito bom gosto o casamento de ambos. Entretanto, salientava o pai, já se fazia necessário o rapaz assumir as ocupações de médico. O diploma já estava validado e uma clientela abonada aguardava o jovem doutor formado na Alemanha.

Foi na mesma época em que conheceu sua companheira, que João Alphonso viu coincidir alguns episódios que lhe ocorreram. Participava ele de um encontro, patrocinado pelo seu pai, de comerciantes com agentes financeiros que operavam na praça do Rio de Janeiro. O seu pai preocupava-se em apresentá-lo aos representantes de estabelecimentos europeus. Alguns deles preferiam falar em alemão com o jovem médico, que se tornava simpático a eles não apenas pela qualidade da sua pronúncia, como também pelo seu recato e inteligência atenta. Era assim que, encontrando-se e conversando com os representantes do estabelecimento comercial e financeiro Hammann \& Co. João Alphonso, falava dos avanços das ciências biológicas na Europa, a intensificação do uso de experimentos laboratoriais in vivo, etc. ${ }^{34}$. Um dos agentes quis

34 Na primeira metade do século XIX a fisiologia ganhou um grande impulso. Na Alemanha, um dos principais fisiologistas era Johannes Müller (cf. cap. vi) que, metodologicamente, incentivava os modelos preconizados pelo principal neurologista [área em que fez estudos pioneiros (i) ] e fisiologista francês da época, François Magendie (1783-1855). Magendie

"mostrou que, do ponto de vista físiológico, uma função era o resultado da ação conjunta de vários órgãos, rompendo a associação orgão-função que predominava em fisiologia como consequeencia de sua vinculação com a anatomia (...). Desse modo, estabeleceu o conceito fisiológico de funçåo, que passou a ser o ponto de partida das pesquisas em fisiologia, ao invés da estrutura anatòmica (...). (ii)

Em seu livro Prects clementure de phasologle (1825), faz uma ampla defesa dos experimentos em organismos v.vos: 
saber da repercussão cientifica na Europa dos trabalhos desenvolvidos pelos estudiosos que viajavam pelo Brasil. João Alphonso relatou alguns casos de alemães conhecidos no meio científico europeu, mas esta foi uma área, disse ele, que os estudos médicos não contemplavam prioritariamente. Ele quis saber se um agente financeiro teria interesse particular em algum destes estudiosos, ao que lhe foi respondido:

- Curiosidade apenas. Somos depositários de recursos que chegam para alguns destes estudiosos. $\mathrm{Na}$ maioria das vezes, por curto periodo de tempo. Outras vezes, nos surpreendemos pelo tempo em que estes naturalistas se dedicam com afinco aos seus estudos tão especificos.

- Interessante - disse João Alphonso. Custo a imaginar que um cientista europeu possa postergar por muito tempo as comodidades dos seus laboratórios, de seu ambiente cientifico e segurança profissional, para se embrenhar pelo interior do Brasil por tão longos periodos.

- Eu não me impressionaria com isto... - disse o agente, ao mesmo tempo que se inclinava levemente para um colega para completar a frase - ... veja o caso do irmão do Sr. Henrik Ferdinand Lund! Está há anos no Brasil, recebendo regularmente seu dinheiro da Dinamarca.

João Alphonso instantaneamente percebeu que, neste caso, havia informaçōes que não lhe eram estranhas e procurou confirmar:

- A quem o senhor está se referindo ?

- Ao Dr. Peter Wilhelm Lund. Dinamarquês, irmão do Sr. Henrik. respondeu o agente.

Com os olhos fixos nos do agente, João Alphonso se surpreendeu com a resposta e quis uma confirmação definitiva:

- Estaria o Dr. Lund em ..., em ... - não conseguia lembrar o nome da localidade e generalizou - na provincia de Minas Gerais ?

"Hoje em dia não há dúvida de que as investigações em animais são aplicáveis, e com precisão admirável, aos fenômenos da vida humana" (iii).

i. GROLIER MULT. ENC. Op. cit.: Magendie, Fránçois.

ii. SANTOS, K. M. O. dos. Op. cit., p. 33.

iii. MAGENDIE, F. Defensa del experimento fisiológico. In. PIÑERO, J. M. L.

Medicina, História, Sociedad. 3a ed. Barcelona, Editorial Arıel, 1973 p. 236-40. 
- Sim. Em Lagoa Santa - Confirmaram.

- É ele mesmo - alegrou-se João Alphonso com a coincidência, sob os olhos curiosos do grupo que não compreendia o motivo da pequena comemoração.

Em seguida, tratou João Alphonso de explicar a situação, momento em que rememorou as circunstâncias em que encontrara Sören Kierkegaard, parente do Dr. Lund, em Berlim, em 1842. Era um moço filósofo - disse João Alphonso - e demonstrou ter muito apreço pelo naturalista. E sem maiores comentários sobre este fato, o grupo foi se dispersando vagarosamente, formando novos grupos com novas conversas. Contudo, João Alphonso afastou-se sutilmente de todos e, em uma janela onde já podia observar as primeiras estrelas que despontavam no céu, começou a desejar um encontro com o Dr. Lund ${ }^{35}$.

A relação familiar entre os Lund e os Kierkegaard foram profundas. Os irmãos de Peter Wilheim Lund, Henrik e Christian, eram cunhados do caçula dos Kierkegaard, Sören (i , p. 88). P. W. Lund tem uma longa correspondência com Peter Christian, bispo de Aalborg e irmão mais velho do filósofo Kierkegaard (ii).

Nos registros biograficos do naturalista Peter W. Lund, não consta que ele tenha tido contato com algum livro de Kierkegaard. Os contatos daquele com os escritos deste teriam ocorrido através do jomal Faedrelandet ('A Pátria') e pelas cartas familiares, ambos enviadas da Dinamarca. Lund parece não ter se entusiasmado com os escritos do jovem Kierkegaard. Consta que, certa vez, Lund teria, numa carta, comentado com seu irmão Henrik sobre o filósofo:

"Talvez os deveres funcionais e as responsabilidades conjugais tivessem podido libertá-lo deste triste aprisionamento em seu próprio eu ..." (i, p. 255).

Por seu turno, Kierkegaard demonstrou respeito e afeto a Lund. Talvez por que tenha captado, ao contrário do outro, mais semelhanças do que diferenças entre ambos. Pelas referèncias, parece que nem todas as cartas escritas por Kierkegaard a Lund, teriam sido remetidas. Numa destas cartas:

“...chamava a atenção para a vantagem de sentir-se um tanto abandonado por parte dos amigos afirmando:

"O silêncio deles é nitidamente proveitoso para mim, porque me obriga a fixar a vista no meu eu; porque me estimula a aprender esse eu que é o meu; porque me obriga a manter-me fixo na infinita instabilidade da vida $e$ a voltar para mim o espelho côncavo com que dantes procurava abarcar a vida fora de mim mesmo. Esse silêncio agrada-me porque me sinto capaz desse esforço e com coragem para segurar o espelho, mostre-me ele o que mostrar, o meu ideal ou a minha caricatura'(iii) 
Um encontro que não ocorreria imediatamente. Através de um encarregado de negócios do governo dinamarquês, João Alphonso ficou sabendo que o Dr. Lund estava com a saúde precária e que nesta época se encontrava muito doente. Conforme relatos de estudiosos e viajantes que queriam encontrá-lo em Lagoa Santa, o encarregado disse a João Alphonso que o Dr. Lund só estava recebendo aqueles que comunicassem a visita com antecedência ${ }^{36}$. Sugeriu, então, que João

Numa outra carta, escreveria:

"Quão feliz não é o senhor, que no Brasil encontrou um enorme campo para as suas observaçòes. onde, a cada novo passo, se the oferecem reiteradas estranhezas, e onde os gritos do restante da república dos Sabios em nada lhe perturba o sossego... (i, p. 183).

i. STANGERUP, H. Lagoa Santa, vidas e ossadas. Rio de Janeiro, Nórdica Ltda., 1983.

ii. MATTOS, A O sábio Dr. Lund e os estudos sobre a pré-história brasileira. Belo Horizonte, edições Apollo, 1935. p. 297.

iii. KIERKEGAARD, S. A . Obras escolhidas. Op. cit., p. ix.

36 Praticamente nas últimas quatro décadas de sua vida, Lund não produziu mais nenhum trabalho cientifico de amplo reconhecimento como os anteriores, que o tornaram reconhecido por Darwin como

"um excelente observador"(i).

Os motivos desta letargia são ainda obscuros. A 'estrutura psicológica' do naturalista é difusa e carente de uma análise especializada. Entretanto, observa-se pelos relatos dos biógrafos e mesmo relatos de quem conviveu com ele (ii), uma personalidade marcada pelos confrontos de suas conviç̧ðes religiosas e científicas, como sugere, por exemplo, PROUS:

"Notando as semelhanças progressivamente maiores (falariamos hoje de 'evolução') entre as faunas sucessivas encontradas e a atual, Lund parece ter começado a duvidar da teoria catastrófica de Cuvier, intuindo uma teoria evolucionista que seria exposta pouco depois (em 1848) por Darwin e Wallace. Cristão convicto, correspondente e parente do bispo Kierkegaard, Lund podia temer que seu universo tradicional vacilasse. $O$ patriarca de Lagoa santa enclausurou-se no silèncio, evitando até receber visitas ilustres como a do naturalssta Richard Burton" (iii) 
Alphonso escrevesse a ele antes de iniciar a exigente viagem até a provincia mineira. Com menos freqüência do que antes, disse o agente, o Dr. Lund remetia a Copenhague caixas com o resultado de suas pesquisas paleontológicas. João Alphonso ficou sabendo da repercussão destas pesquisas e o respeito que o naturalista gozava no seu meio cientifico. Após inquirir, ficou sabendo ainda que os irmãos do Dr. Lund, Henrik e Christian, eram casados com duas irmãs, Petrea e Nicoline Kierkegaard, familia da qual o caçula era Sören. Uma outra informação do agente dinamarquês deixara João Alphonso surpreendido. O filho mais velho dos Kierkegaard, o teólogo Peter Christian, e com quem Dr. Lund em algumas épocas se comunicava freqüentemente, era bispo na cidade de Alborg e havia se doutorado em filosofia em Göttingen na década de 20. João Alphonso outras vezes encontrou-se com este agente dinamarquès e se tornou médico da sua pequena familia, mesmo havendo na cidade médico conterrâneo.

A modesta biblioteca do encarregado de negócios continha livros de um bom gosto literário, sendo dai um livro que João Alphonso ganhou de presente: uma edição, com poemas da mitologia escandinava, chamada $E d d a^{37}$. Descobriu também que este senhor, além de se envolver com a

i. TORT, P. Lund, Peter Wilhelm (1801 - 1888). In: TORT, P. (Org.). Dictionnaire du darwinisme et de l'evolution. 3 v. Paris, Presses Universitaires de France, 1996. v.2, p. 2717.

ii. SANTOS, N. C. O Naturalista. Belo Horizonte, Imprensa Oficial, 1923

iii. PROUS, A. Arqueologia brasileira. Brasília, Ed. UnB, 1992. p.6-7

${ }^{37}$ Edda, na definição do "Robert' é o

"titulo de duas coleções de poesia islandesa. A Grande Edda ou Edda Poética' e a 'A pequena Edda ou Edda Prosaica" (i).

"A diversidade de formas e virtuosidade das técnicas, variedade dos registros e dos tons, multiplicidade de gêneros, beleza selvagem da língua, esplendor refinado de innagens e figurinos" (ii),

torna os poemas do Edda as principais fontes para o conhecimento da mitologia escandinava (i).

i. LE ROBERT Dictionnaire Illustré des Noms Propres Paris, Le Robert, 1993 (1a ed. 197.10) 
burocracia diplomática, mantinha vivo seu interesse pela vida politica e social no seu país. Nesta época, a Dinamarca e a Alemanha encontravam-se em litigio pela posse das provincias de Schleswig e Holstein. A população, de origem alemã, não aceitava a imposição das leis dinamarquesas, ocorrendo, assim, sublevações. Tropas prussianas, então, teriam invadido a região ${ }^{38}$. Poucos meses após este relato do agente, João Alphonso fica sabendo que o dinamarquês não suportara ficar longe dos acontecimentos e voltara, com a pequena familia, para sua terra. Não ficou surpreso por esta ação, nem pela ausência de despedidas; enfim, nada lhe ficara devendo o agente. João Alphonso perdeu o seu olhar no vazio pensou nas trajetórias dos homens. Pensou no Dr. Lund e buscou na pequena estante do seu consultório o livro que ganhara de presente do dinamarquês. Abriu, ocasionalmente, no poema Völuspâ e leu

"Os irmãos farão a guerra uns aos outros e assassinarse-ão; e os filhos das irmãs romperão seus laços de parentesco"39.

ii. BOYER, R. Eddas. In: Encycloaedia Universalis. Paris, Encyclopedia Universalis France S.A, 1985. v. 6, p. 633 - 635

38 BONNEFON, C. Op. cit., p. $194-205$

DROZ, J. Op. cit., p. 49 - 57.

39 Völuspá é o primeiro poema de Edda poética (i). Em imagens fulgurantes e segundo um ritmo crescente em frenesi, ele descreve as origens, depois as lutas das divindades, fulmina as imprecauções contra a catástrofe para retornar, enfim, à serenidade magnifica do começo (ii). A frase utılizada no texto é citada por Engels (iii).

i. LE ROBERT, Op. cit., p. 1890.

ii. ENCYCLOPAEDIA Universalis, Op. cit., p. 635.

iii ENGELS, F. A Origem da familia, da propriedade privada e do estado. In: MARX, K \& ENGELS, F. Obras escolhidas. 3 v. São Paulo, Alfa-Omega Lida., srd. p. 110. 
Em pouco tempo o jovem médico adquiriu uma ótima clientela, sendo solicitado com freqüencia por familias de comerciantes, gente da esfera administrativa do governo e também já conseguia alguns clientes entre diplomatas europeus, especialmente aquelas de língua alemã, que estimavam contar com um médico formado numa universidade de méritos. Logo, tornou-se um dos médicos que assistiam a colônia teuta de Petrópolis. A colônia tinha perdido recentemente sua maior liderança, o Sr. Köler, que fora o responsável pelo planejamento inicial da vila; primeiras ruas e drenagem de áreas alagadas ${ }^{40}$. Os imigrantes desenvolviam vários ofícios e até mesmo uma incipiente pesquisa agrícola se iniciava com a tentativa de aclimatação de espécies vegetais européias (cereais, etc.) destinadas à alimentação. $O$ trajeto entre a capital e a cidade, que se tornou a residencia imperial de verão, era facilitada pela estrada engenhosamente construida sob o planejamento e supervisão inicial do próprio Sr. Köler ${ }^{41}$. Não raras vezes, enquanto estava em Petrópolis assistindo a colônia, João Alphonso se imaginava interiorizando a viagem, adentrando Minas Gerais e encontrando Dr. Lund, aquele que impressionava o filósofo dinamarquês.

A carta que recebeu de Morten encontrou-o retornando de Petrópolis. O envelope, junto com alguns periódicos assinados ainda quando na Alemanha, encontrava-se sobre a escrivaninha no seu escritório. Alegre, trancou a porta e leu atentamente. Era uma carta longa, em que Morten de tudo falava. Recordava momentos vividos em Göttingen, discorria sobre a situação política da Alemanha, e afirmava

\section{* OBERACKeR, C. H. Op. cit., p.263}

PREFEITURA MUNICIPAL DE PETRÓPOLIS. Centenário de Petrópolis. Petrópolis, 1943. v.3: Os fundadores.

4 PREFEITURA MUNICIPAL DE PETRÓPOLIS. Op. cit., p. 53 - 70: Major Júlio Frederico Koeler. 
ter optado por trabalhar em Breslau, onde formava um promissora clientela. Pedia a João Alphonso que relatasse a sua vida de médico no Brasil e que gostaria de receber informaçōes sobre "doenças tropicais". Também nesta primeira carta, Morten relatava que

"... tenho acompanhado os estudos e discussões sobre o metabolismo alimentar que tem gerado muitos trabalhos aqui na Alemanha, em especial os trabalhos do químico Dr. Liebig, caso você queira informações sobre o assunto, poderei enviar-lhe trabalhos que têm sido publicados..."42

Foi a primeira de uma série de cartas que ambos trocaram. E nelas, sempre quiseram cultivar a esperança de que se reencontrariam.

Os afazeres de médico já não eram poucos e nas vezes em que João Alphonso comentava com alguma pessoa mais próxima o projeto de seguir até Lagoa Santa, era desmotivado. Cobravam-lhe a necessária permanência na cidade para solidificar e aumentar os clientes, além do que a viagem não lhe traria nenhuma vantagem prática. Seria melhor, diziam, esperar a vinda do Dr. Lund ao Rio de Janeiro, fato que não demoraria a ocorrer, pois a capital é o porto natural dos sábios, especialmente para os estrangeiros que não rejeitariam o retorno aos seus paises. No inicio, sua amiga aprovara e incentivara a viagem de interesse tão particular para João Alphonso; após o casamento, ela disse que não se oporia, mas que se sentiria desprotegida diante da ausência

$\$ 2$ Os estudos do químico alemão Justus von Liebig (1803-1873) foram decisivos para o desenvolvimento da quimica orgànica. Durante vinte e oito anos o departamento de química da Universidade de Giessen, onde trabalhava ficou famoso em todo o mundo (i), através de suas pesquisas e formação de químicos que, alguns destes, tornaram-se conhecidos. As teorias de Liebig sobre o metabolismo animal baseavam-se basicamente na composição das substàncias orgânicas e suas reações químicas, mais do que em experimentos em organismos vivos. Os críticos consideravam sua teoria metabólica de natureza meramente especulativa. Entretanto, é consensual o valor de muitas de suas pesquisas e entre estas a que afirma

"que o metabolismo dos alimentos era a única fonte de energia para os animais" (ii).

i. GROLIER Multimedia Enc Op. cit. : Liebig

ii. SANTOS, K. M. O dos Op. cit, p. 68 
do marido.

No inicio de 1850, casa-se João Alphonso com Beatriz. Francamente um casamento que agradara as duas familias e diante do que é dificil especificar a natureza da aceitação do casal. Anos mais tarde, João Alphonso, conversando com o seu filho mais velho, diria que lhe era muito dificil compreender os motivos que o fizeram aceitar passivamente o acordo de casamento que seu pai havia feito com o pai de Beatriz. De fato, o casamento foi assumido por ambos como a extensão particular da amizade que tinham entre si. Beatriz exprimia uma certa vitalidade e disposiçāo de espirito claramente reprovadas na familia e sociedade ${ }^{43}$. Foi desta forma que se tornou uma amiga discreta e atraente para João Alphonso. Casada, passou a assumir cedo as tarefas domésticas, de forma que toda aquela vitalidade e disposição, que poderiam ser canalizadas para alguma atividade similar à dos homens, foi sendo, quotidianamente, dissipada pela rotina doméstica. Desde o seu inicio, o casamento se tornara para ambos um empecilho à continuidade daquela relação que usufruiam anteriormente. As tarefas reciprocas... $O$ primeiro filho, que chegaria já em fins do primeiro ano de casamento, alteraram a rotina de convivência sem, entretanto, destruir a ternura educada que existia entre ambos. Somente nesta época, quando Beatriz já estava nos últimos meses de gravidez, João Alphonso se dispôs a escrever ao amigo de Breslau, relatando-o as novidades do ano. Foi

\$3 Em "A mulher e o homem", Freyre interpreta aspectos das relações entre a mulher e o homem a partir de fins do século XVIII e durante o XIX. Diz o referido autor:

"Mas a beleza que se quer da mulher, dentro do sistema patriarcal, é uma beleza meio mórbida. A menina de tipo franzino, quase doente. Ou então a senhora gorda, mole, caseira, maternal, coxas e nádegas largas. Nada do tipo vigoroso e ágil de moça, aproximando-se da figura do rapaz. O máximo de diferenciação de tipo e de traje entre os dois sexos" $\left({ }^{*}\right)$.

* FREYRE, G. Sobrados e mocambos. 8a. ed. Rio de Janeiro, Record, 1990. p. 93 - 151: IV - A mulher e o homem. 
também uma carta longa na qual procurava explicar as opções que fizera até então e os seus planos. Solicitava textos técnicos e discorreu um pouco sobre as doenças tropicais.

Com o casamento, João Alphonso alterou pouco sua rotina social. Continuava com poucos amigos e introvertido com as suas preocupações. Às vezes, encontrava para conversas, os colegas do Hospital da Santa Casa da Misericórdia, encontrando ai um ou outro colega cuja companhia lhe aprazia. Um destes colegas era o médico alemão Robert Avé-Lallemant ${ }^{44}$. Amigo do Imperador, o dr. Lallemant gostava de

4 Robert C. B. Avé-Lallemant (1812-1884), fixou-se como médico no Rio de Janeiro a partir de 1837. Fez expedições pelo Brasil em 58 e 59, voltando-se, em seguida, a morar na Alemanha. Publicou livros decorrentes destas viagens e alguns outros. Consta da sua biografia que escreveu também ensaios médicos sobre a febre amarela (i).

Em seus livros de viagem pelo Brasil [Viagem pela província do Rio Grande do Sul (1858); Viagens pelas províncias de Santa Catarina, Paraná e São Paulo (1858) e Viagens pelas provincias da Bahia, Pernambuco, Alagoas e Sergipe (1859)] o autor demonstra atenção às condições de vida dos imigrantes alemães particularmente. Denuncia com ênfase a penúria da imigração no vale do Mucuri, MG ( ii, cap. IV e V). Entretanto, em uma 'nota do revisor', lê-se que:

"Avé-Lallemant fizera-se advogado de todos os alemães no Brasil. Para socorrê-los, recorria a amigos, a ministros de Estado e ao Imperador e prestava-lhes assistência também com os seus próprios recursos pessoais. Nobre missão, não há dúvida, mas, dado o seu temperamento exaltado e gênio metediço, criou inimigos, sobretudo entre fazendeiros e políticos. Muitos contemporâneos seus se referiram às suas calorosas denúncias como a “intrigas' do dr. Avé-lallemant" ( ii, p.255)

De fato, a natureza polêmica de Avé-lallemant despertou, no caso das denúncias contra a Cia. do Mucuri, protestos do fundador da companhia, Teófilo Ottoni. Um dos seus biógrafos (iii) afirma que Ottoni protestou energicamente contra as atitudes do médico alemão, relacionando-o ao então ministro da agricultura, conselheiro Manuel Felizardo de Souza e Melo, interessado em 'anarquizar a colonização do Mucuri':

"A verdade é que Lallemant não fora enviado pelo Governo Imperial ao Mucuri. Seguira para lá como agente confidencial do Sr. Manuel Felizardo, na época, ministro da Guerra. Em longos discursos, Ottoni prova o fato"(iii, p. 215)

i. FOUQUET, C. Origem da familia Avé-Lallemant e sua expansão no Brasil. Revista Genealogica Brasileira. Ano II, n.4, 1941. [Separata]. p. 460.

ii. AVÉ-LALLEMANT, R. Viagens pelas províncias da Bahia, Pernambuco, Alagoas e Sergipe Belo Horizonte : Itatiaia ; São Paulo : Edusp, 1980 
conversar longamente com João Alphonso sobre a Alemanha e os alemães no Brasil. O médico alemão era natural de Lübeck, cidade que João Alphonso conheceu quando, com Morten, foi a Travemünde. Lá, Morten estudara o ginasial e de lá também era a moça com quem ele, Morten, se envolvera numa certa época; episódio que João Alphonso não esquecera. Do ponto de vista médico, o dr. Lallemant motivou João Alphonso a se interessar mais vivamente pelas doenças tropicais e as condições do meio. $\mathrm{O}$ irmão do dr. Lallemant, Alexander, negociante e Cônsul da cidade livre e hanseática de Lübeck no Rio de Janeiro, contribuiu significativamente para que João Alphonso se tornasse um dos médicos da comunidade alemã, não só na capital, como também em Petrópolis ${ }^{45}$.

Contudo, enquanto se organizava profissionalmente, João Alphonso não esquecia o projeto de visitar o Dr. Lund em Lagoa Santa. A primeira carta que escreveu ao naturalista dinamarquês foi respondida polidamente, em nome do Dr. Lund, pelo Sr. Peter Andreas, de sobrenome ilegivel. Na carta, o Dr. Lund pedia que ele aguardasse um melhor momento para visitá-lo. Além da precariedade da sua saúde no momento, Dr. Lund dizia das atividades que o absorviam regularmente: alèm de acompanhar o trabalho desenvolvido por seu conterrâneo, o naturalista J. T. Reinhardt ${ }^{46}$, estava prestes a receber um estudioso

iii. CHAGAS, P. P. Teófilo Ottoni: Ministro do povo. Belo Horizonte : ed. Itatiaia ; Brasília : INL, 1978.

45 F. A. Alexander Avé-Lallemant (1815-1868), assim como seu irmão Robert, nasceu em Lübeck. Fixou-se no Brasil a partir de 1839 e foi membro ativo do clube Germânia (i). Faleceu em Petrópolis. A genealogia da família Avé-Lallemant e sua expansão no Brasil, do século XIX até as primeiras décadas do século XX, é minuciosamente descrita por FOUQUET (ii).

i. HINDEN, H. Op. cit., p. 168

ii. FOUQUET, C. Op. cit, p. 461.

+6 O naturalista J. T. Reinhardt (1816-1882) visitou Lund em Lagoa Santa por duas vezes e por ocasião da morte deste

"apresentou comunicação sobre a vida e a obra do naturalista dinamarquès 
alemão, H. Burmeister ${ }^{47}$, que lhe havia escrito há alguns meses atrás. No entanto, demonstrou interesse em recebè-lo e falar de alguém que lhe era tão próximo, o caçula dos Kierkegaard. Por fim, avisava que comunicaria a João Alphonso sobre a oportuna época de se encontrarem.

Enquanto João Alphonso desenvolvia uma bem sucedida clínica particular, já em 1849, em meio à precariedade sanitária na cidade do Rio de Janeiro e à ausência de qualquer diretriz que norteasse ações de saúde na capital e no país, era criada a Comissão Central de Saúde Pública, com diversas comissões sanitárias. Este ato antecedeu o de 1850, que criava a Junta de Higiene Pública e, assim, o gerenciamento dos serviços de saúde volvia à esfera federal. A decisão do governo de centralizar as ações de saúde foi precipitada pelo ressurgimento de casos de febre amarela ${ }^{48}$. Foi a comissão instalada que elaborou as

de Lagoa Santa" $\left({ }^{*}\right)$.

* STANGERUP, H. Op. cit, p. 294-5

47 H. Burmeister (1807-1892), naturalista alemão, visitou o Brasil entre setembro de 1850 a janeiro de 1852. Atraído pela fama de Lagoa Santa, passou alguns meses em companhia de Lund $\left({ }^{*}\right)$.

* MEYER, A. Nota bio-bibliográfica. In.: BURMEISTER, H. Op. cit., p. 13 -14.

8 "A primeira grande epidemia [de febre amarela] ocorrida na capital do império, em 1849-50" (i)

encontrou a cidade em condições desfavoráveis no dizer de REGO que escreveu:

"Surpreendida esta cidade em condiçðes tanto ou mais desfavoraveis, do que as provincias de que acabamos de fallar, como sejam; agglomeração subita da população pela chegada constante de emigrantes para a California, accumulação no interior da cidade de immigrantes estrangeiros, de africanos eivados de molestias graves de toda a especie, ..., total abandono da hygiene publica ... que, além do peso das condições summariamente expostas, gemia ainda sob a pressão de uma epidemia de escarlatina..." (ii).

É importante ressaltar que esta epidemia trouxe à tona variados argumentos sobre a causa da doença. Neste sentido, em um interessante estudo sobre os cortiços e epidemias no Rio de Janeiro. CHALHOUB afïrma que em função da epidemia de febre amarela,

"os defensores da explicaçào religiosa para o surgimento da peste e os 
"Providências para prevenir e atalhar o progresso da febre amarela", editadas em 14 de fevereiro de 1850. Ao que tudo indica, as providências tomadas não conseguiram deter o curso da epidemia daquele ano, que foi uma das mais graves jả ocorridas na cidade do Rio de Janeiro. A Junta de Higiene Pública, que veio a ser criada em setembro de 1850, passou a se encarregar de fixar normas necessárias à manutenção da saúde pública. Submetendo-se à direção da Junta, na capital do império, foram criadas em algumas províncias (Pará, Maranhão, Pernambuco, Bahia e Rio Grande do Sul) as "comissões de Higiene Pública" e, nas outras, os "Provedores de Saúde Pública". Devido a esta centralização de toda atividade sanitária no Império, a Junta passou a ser denominada "Junta Central de Higiene Pública".

Enfim, depois de alguns anos de desencontros de datas e disponibilidade, o encontro de João Alphonso com o Dr. Lund estava prestes a acontecer. Alem de episódios de doença e das ocupações do naturalista, outros fatos contribuiram para retardar a visita: o nascimento do primeiro filho, no primeiro ano de casamento, o estabelecimento profissional e a necessidade de não se ausentar do Rio de Janeiro, além da grave enfermidade do pai que colocou este entre a

chamados 'philosophos materialistas' - que eram, na realidade, os doutores médicos higienistas. Um temente a deus assim resumiu a posição dos philosophos: 'os homens da ciència' diziam 'que a epidemia é um fenômeno natural, é o resultado de várias combinações atmosféricas nocivas à vida animal; são os elementos da natureza na sua ação ordinária: Deus não entra nisto em nada, tudo é natural, nada aqui há de sobrenatural'."(iii).

i. BENCHIMOL, J. L. História da febre amarela no Brasil. Historia, Ciências, Saúde Manguinhos. I (1):121-24, 1994.

ii. REGO, J. P. Memoria historica das epidemias da febre amarella e cholera-morbo que têm reinado no Brasil . Rio de Janeiro, Typographia Nacional, 1873. p.34 - 5

iii. CHALHOUB, S. Cidade febril: cortiços e epidemias na corte imperial. Campinas, 1994. [Tese de livre docència - Departamento de História, IFCH, UNICAMP]. p. $82-3$ 
vida e a morte durante longos meses e só atenuada em meados de setembro de 1853. O naturalista escreveu-lhe e se mostrou em condições de recebê-lo. João Alphonso estava curiossísimo para conhecer o respeitado cientista dinamarquês e ouvir pessoalmente suas opiniōes sobre os escritos do seu parente filósofo. Neste sentido, na última carta que escreveu a João Alphonso, o naturalista, muito discretamente, insinuou alguma critica a estes escritos.

Já não era tanto pelas pessoas envolvidas que João Alphonso ainda se interessava muito por este encontro. Assim como para Kierkegaard o Dr. Lund despertava certa inveja por sua capacidade de afastar-se do mundo, dos amigos, também para João Alphonso a existência de um individuo, provavelmente tão sábio, que opta por submeter-se a uma vida de quase resignação longe dos confortos e da segurança familiar, embaralhava, num fascinio entremeado de incertezas, os seus pensamentos. Conhecer este homem tornou-se um desafio que ele, aliás, não dividiu com ninguém, nem mesmo com a sua esposa para quem a viagem tinha uma mistura de saudosismo e intercâmbio científico. Para esta viagem, João Alphonso encetou preparativos durante alguns meses. Precisava organizar o atendimento a seus pacientes, administrar questões familiares, etc. Beatriz e o filho, já com quase três anos, estariam seguramente assistidos pelas familias de ambos durante o periodo em que estivesse fora. Seu pai, homem prevenido, e o sogro deram-lhe cartas de apresentação para pessoas conhecidas na província mineira. Homens da administração imperial, por parte do sogro, e comerciantes, por parte do pai. A viagem até Lagoa Santa seria cansativa, já que não pretendia demorar por lá e, portanto, o tempo para se recompor da percurso de ida e volta seria pequeno.

A viagem se deu numa das caravanas que partiam da capital do império para a provincia de Minas Gerais. Era o final da estação de chuvas, e como estas escasseavam, os grupos de viajantes que partiam da capital aumentavam. Nesta época do ano, reiniciava-se com intensidade o träfego entre a provincia mineira e a capital imperial. A caravana com a qual João Alphonso viajou comportava autoridades administrativas, um pequeno grupo de imigrantes libaneses, um médico recém-formado pela Faculdade de medicina da capital e dois advogados, também recém-formados pela Faculdade de Direito de São Paulo e que 
passaram pelo Rio antes de viajarem a Minas. Os três jovens formandos seguiam para cidades no interior, de onde eram oriundos. Além deste grupo, tropeiros, pequenos comerciantes que alguns chamavam de "mascates" e "cometas" rumavam, a curta distância, para o interior ${ }^{49}$. A

49 Estes três personagens têm papel significante nos intercâmbios entre e dentro das províncias e entre eles, especialmente, os tropeiros. Segundo DORNAS FILHO

"o homem de hoje talvez não tenha idéia real do que seja uma 'tropa', no sentido econômico assumido no Brasil. Grandes lotes de muares, esfalfandose por centenas de léguas, estirando-se por todos os quadrantes para conduzir drogas do litoral e refluir à orla marítima com os produtos da terra - tal era a 'tropa', o primeiro meio de transportes e comércio que o Brasil possui, e seu maior elemento econòmico e social de colonização e fixação do homem"(i).

ALMEIDA diz que

"as tropas de mulas chucras cobriam todo o Brasil ... os tropeiros de tropas arreada percorriam todos estes rumos e caminhos, mais uma rede emaranhada de ramais em todas as direções" (ii).

Para se ter uma idéia da capacidade de carga de uma tropa, considera-se que cada muar pode carregar "uma carga de cento e vinte quilos" (iii)

Relata-se tropeiros com

"até dez lotes de burros [e, por exemplo] no oeste mineiro um lote era constituido de sete animais" (i).

Cometa, comitiva menor e mais ágil, designava os viajantes comerciais e financeiros. Praticava, enfim, algumas tarefas que a rede bancária passou a executar. O termo 'cometa' refere-se à periodicidade regular de suas viagens em torno de lugares prédeterminados. $\mathrm{O}$ mascate é um pequeno negociante ambulante, que vende e negocia desde miudezas de utilidades num lar a mercadorias da terra em pequeno volume. 'Mascate' é uma denominação que

"vem do topônimo árabe, a cidade de Mascate, porto da costa sul do golfo de

Oma, tomado pelos portugueses, em 1507. A denominação designava os

lusos que, de volta do oriente, traziam mercadorias trocadas em Mascate" (i).

Ligado a estes tipos, não se pode esquecer que em Minas Gerais o 'turco',

"nome dado, de modo geral, a todos os árabes, sírios e libaneses" (iv),

é uma figura sempre presente ou com uma casa comercial estabelecida ou com seu baú repleto de quinquilharias e novidades (i).

i. DORNAS FILHO, J. Tropas e tropeiros. In.: Seminário de estudos mineiros, 1o, Belo Horizonte, 1956. Conferências. Belo Horizonte, Universidade de Minas Gerais, 1957. p. $89-127$.

ii. ALMEIDA, A lida e morte do tropeiro. Såo Paulo, Martins Edusp, 1981 p. 112. 
cada dia o grupo diminuia, pela dispersão das pessoas. Os pontos de chegada eram os mais diversos: uns permaneciam em algum vilarejo, outros em fazendas, em uma vila mais movimentada. A atividade dos tropeiros, em particular, constituira um mundo repleto de ações e organização própria que detivera, na maior parte do tempo, a atenção de João Alphonso.

Com o passar dos dias, João Alphonso sentia-se cansado pelas exigências de um trajeto dificil e com o qual não estava acostumado. Primeiro, pensou em parar em Juiz de Fora. Uma das cartas do pai era para um certo Sr. Hirsch, que ali residia. Desistiu, por achar que o cansaço seria temporário. Mas, além do cansaço, passou a não conseguir dormir satisfatoriamente, apesar do tempo contribuir, em grande parte. Chovia cada vez menos $e$ as noites eram amenas. Os sonhos atormentavam-no, e despertava com a convicção de que estava doente e, por isso, vários dias se auto medicou. Por sorte, o humor e a disposição dos libaneses animavam a viagem. Eles contavam que haviam chegado ao Brasil há poucos meses sem pronunciar uma só palavra em português. Além de aprenderem o idioma, informaram-se sobre as possibilidades pelo interior e decidiram negociar em Minas, onde já moravam alguns patricios seus. Pronunciavam um português completamente compreensivel, apesar do sotaque ainda marcante. À primeira vista, era inacreditável que tivessem aprendido a lingua em tão pouco tempo. Narravam histórias fabulosas, ao mesmo tempo que confessavam o espanto com o mundo depois de Gibraltar, a imensidão do oceano e das terras que avistaram após intermináveis noites e dias ${ }^{50}$.

iii. MAIA, T \& MAIA, J. R. C. O folclore das tropas, tropeiros e cargueiros no Vale do Paraíba. Rio de Janeiro, MEC - SEC :FUNARTE: Instituto Nacional do Folclore ; São Paulo : Secretaria de Estado da Cultura : Universidade de Taubaté, 1981. p. 35 .

iv. BARBOSA, W. de A. Dicionário da terra e da gente de Minas. Belo Horizonte, Imprensa Oficial, 1985. p. 187.

so Assim como KNOWLTON (i), TRUZZI também anuncia a data em que sírios e libaneses chegaram ao Brasil:

"Os primeiros sírios e libaneses começaram a chegar ao Brasil ainda nos anos 
setenta do século passado" (ii)

É provável, que do ponto de vista quantitativo e de documentação estatística, esta seja uma afirmativa correta. No entanto, existem referências alusivas à presença destes imigrantes muito antes. DORNAS FILHO escreve que

"Foi o grande Pombal o único a perceber que a raça semítica, assim como os seus colaterais da orla oriental do Mediterrâneo, poderiam fecundar a terra virgem do seu império americano. E contra o parecer quase unânime dos homens que o cercavam, abriu a imigração aos muçulmanos e maometanos que quisessem se transferir para o Brasil, com a condição de não interferirem na organização religiosa da colônia.

"Foi então que vieram os primeiros sírios, libaneses, persas, egípcios - quase todos os nacionais do Mediterrâneo oriental, que o povo engloba sob o nome genérico de turco' "(iii).

Descrevendo as qualidades e os negócios do mascate no Brasil, o referido autor cita KOSTER (iv), que esteve no Brasil na segunda década do século XIX:

"O mascate sírio, geralmente probo e benquisto de todos, vai de povoação a povoação, de fazenda em fazenda, trocando suas mercadorias por gado, queijo, couro, peles. E que, como observou Henry Koster, no nordeste do Brasil, onde era pequeno o volume da moeda circulante, "raramente recebem dinheiro em trocas de suas vendas. Aceita o que lhes oferecem, alugam homens para ajudá-los a conduzir o gado ou o produto das barganhas até o mercado, onde é permutado por mercadorias, e regressam com elas ao interior. Um ano às vezes se passa numa dessas jornadas, mas os proveitos são enormes, duzentos ou trezentos por cento" (iii).

Também é provável que os registros oficiais de entrada de imigrantes tenham deixado de captar muitos. Mas mesmo nestes registros há a identificação de 'asiáticos' que teriam entrado no país. Num exame aleatório, notou-se, por exemplo, a entrada de 'Abdallah' e 'Samadã Alli', em 22-6-1836 (iv, v.3).

Apesar da reconhecida aptidão para o comércio, no Brasil a licença para 'mascatear' foi fornecida a muitos imigrantes inclusive, entre eles, chineses (iv, v.2).

i. KNOWLTON, C. S. Sírios e libaneses. Sào Paulo, Ed. Gráfica Piratininga, 1960. Cap. II: Imigração síria e libanesa para o Brasil.

ii. TRUZZI, O. M. S. Patrícios - Sírios e libaneses em São Paulo. [ Tese de doutoramento apresentada ao Instituto de Filosofia e Cièncias Humanas UNICAMP ].Campinas, 1993.

iii. DORNAS FILHO, J. Op. cit., p.124-7.

iv. KOSTER, H. Viagens ao nordeste do Brasil. 2a. ed. Recife, Secretaria de Educação e Cultura ;Governo do Estado de Pernambuco ;Departamento de Cultura, 1978. 
Entretanto, a companhia dos três jovens recém formados incomodara profundamente João Alphonso. O médico, especialmente, às vezes tornava-se impertinente. Tendo informações de João Alphonso, o rapaz tinha uma estratégia de conversa ao mesmo tempo inoportuna e inutilmente agressiva. Perguntava sobre o aprendizado da medicina na Alemanha e, a qualquer comentário de João Alphonso, interrompia, insinuando conhecimentos que não tinha, para afirmar a qualidade da sua formação. Em seguida, mudava de assunto bruscamente e discursava sobre o seu futuro como político. Neste campo custava ser aparteado pelos jovens advogados, que requeriam para si a primazia de pleitear a ascensão política em primeiro lugar. Como eram de lugares diferentes, acordavam quanto à simultaneidade das suas pretensões politicas e projetavam suas vidas, primeiro na provincia e depois na corte.

O longo percurso entre a capital e a provincia contava um pouco da vida das pessoas que compunham as cenas quotidianas do seu tempo. Fazendas imensas e bem cuidadas por dezenas e até centenas de escravos floresciam nos vales; outra vez, encontrava-se mendigos e doentes à beira da estrada, esmolando qualquer tipo de auxílio; À espreita, ladrões podiam atacar a qualquer momento, quando a caravana se mostrava vulnerável ou, então, malandros, alojados nas estalagens, aguardavam incautos para obter vantagem fácil; não raro podia-se encontrar uma ou outra milícia, protegendo um já escasso carregamento de ouro ou diamante; em outra situação, era possivel deparar com um séquito de algum personagem importante da cena política. Indo e vindo, exercitando cada um sua arte de qualquer significado, os homens viviam o seu tempo num jogo de movimentos múltiplos e só aparentemente descoordenados. João Alphonso tentava não perder as coisas nos seus momentos, mas o cansaço, as noites mal dormidas e os sonhos que o levavam a se auto medicar deixaram-no exausto ao chegar em Ouro

v. MINISTÉRIO DA JUSTIÇA E NEGÓCIOS INTERIORES Arquivo Nacional.

Registro de estrangeiros: 1808-1842. Rio de Janeiro, 1960-1964 + v. 
Preto. Inquirindo os tropeiros com quem viajava, foi informado de que encontraria facilmente caravanas que, saindo de Ouro Preto, iriam diretamente ou passariam por Lagoa Santa. Assim, resolveu descansar uns dois dias para que pudesse se encontrar com o Dr. Lund em melhores condições de diálogo.

Chegava-se a Ouro Preto por uma estrada larga, entrando pelo lado oeste da cidade, onde havia uma sólida ponte de pedra. João Alphonso adentrou a capital da província por uma rua que chegava à parte alta da cidade. Ele nunca imaginara um lugar igual. Nas ruas, ingremes, estreitas, tortuosas, as cavalgaduras pareciam sustentar-se apenas delicadamente. As casas apinhadas nos morros pareciam pequenos presépios velados pelas igrejas que, de diferentes tamanhos e riquezas, se espalhavam pela cidade. Naquela época, após o apogeu da época áurea, quando chegou a $30 \mathrm{mil}$, a cidade tinha em torno de 8 mil pessoas e, por isso, não era raro encontrar casa abandonadas e em ruínas. Não foi difícil João Alphonso concluir que só mesmo a fartura do ouro poderia ter gerado uma cidade naquela condição topográfica ${ }^{51}$.

De posse das cartas de apresentação, João Alphonso poderia usufruir de um conforto desejável na capital da provincia mineira. Ele próprio conhecera um importante comerciante da cidade, $\mathrm{Sr}$. Moretzsohn, que, quando no Rio de Janeiro, sempre encontrava seu pai. No entanto, optou por maior liberdade, alojando-se no hotel onde se encontravam viajantes e politicos de diversos pontos da província que

51 No início dos anos 50 do século XIX, BURMEISTER (i), em sua viagem por Minas Gerais, passou por Ouro Preto e registrou detalhadamente a situação da cidade e suas impressð̃es. Parte do relato é citado por LIMA JR. (ii) que reproduz também, entre outros, relato do naturalista francês Francis Castelnau que visitou Minas em 1843.

i. BURMEISTER, H. Op. cit., p. 221 - 35.

ii. LIMA JR., A. de. Vila Rica do Ouro Preto: Sintese histórica e descritiva. Belo Horizonte, Ediçåo do autor, 1957. p. 172 - 79. 
acorriam freqüentemente à capital. Tão logo chegou ao hotel, João Alphonso percebeu uma inquietação contida nos funcionários. Entretanto, procurou evitar qualquer conversa, preferindo ir para o quarto e descansar antes de uma refeição. Mais tarde, já no salão de refeiçōes do hotel, sentou-se à mesa, aguardando atendimento.

Não muito tempo depois, dois senhores se apresentaram a ele como funcionários administrativos do governo provincial52. Disseram que tinham sido informados da sua presença na cidade por um dos jovens advogados, sobrinho de um destes senhores, que também ficara em Ouro Preto. Os homens não só conheciam o sogro de João Alphonso, como teriam sido convidados para o casamento da filha Beatriz. Por isso, vieram oferecer hospedagem, bem como preencher qualquer necessidade do visitante. João Alphonso ponderou o convite, afirmando que sua estada em Vila Rica seria rápida, e dizendo dos seus objetivos.

- O Dr. Lund é muito visitado. É educado, mas também é muito sistemático. Mas o senhor, que esteve na Alemanha e conhece a natureza desta gente, haverá de se dar bem com ele - disse um dos homens.

- Aliás, se ele já se dispôs em recebê-lo, já é um bom sinal - disse o outro homem.

João Alphonso, aproveitando a inusitada presença dos dois homens da cidade, convidou-os a sentarem à mesa, para, em seguida, indagar-lhes:

- Tenho percebido alguma preocupação nas pessoas. Talvez seja impressão minha, mas estaria ocorrendo algum fato de importância na cidade que justifique esta atitude?

Os homens trocaram um olhar rápido entre si, e um deles, franzindo a testa sem muita discrição, disse:

- É, doutor Magalhães, de fato estamos preocupados com o número de pessoas que já morreram. Ninguém sabe quem será o próximo. $O$

52 Nesta época o presidente da provincia, empossado em outubro de 1853 , era o dr. Francisco Diogo Pereira de Vasconcellos.

"A sua administração, interrompida de 1 de maio a 6 de novembro de 1854 , termina a 2 de fevereiro de $1856 "\left({ }^{*}\right)$.

* VEIGA, J P. X da Ephemerides mineiras (1664-1897). Ouro Preto, Imprensa Oticial do Estado de Minas, 1897. v iv, p. 102 
senhor entende, isso traz insegurança e preocupação à população. Mas as medidas necessárias já estão sendo tomadas.

- Mas que doença tem provocado as mortes? - perguntou, preocupado João Alphonso.

- Então o senhor não sabe, doutor? Pelo menos isso poderiam ter dito ao senhor. É variola. A doença tem grassado aqui perto, em Mariana, e interferido em muitas atividades.

- Variola? E a vacinação? - perguntou, com alguma indignaçào, João Alphonso.

- O senhor sabe, doutor, isso aqui não funciona adequadamente. $O$ instituto Vacínico não funciona muito bem. Há falta de pessoal e de recursos, principalmente, e há muito tempo não temos recebido qualquer assistência do Rio de Janeiro. Deve haver razões, mas tem sido impossivel nossos médicos evitarem a eclosão de uma ou outra doença de vez em quando.

- $\mathrm{E}$ os doentes tèm recebido assistència?

- Na medida do possivel, sim - disse um dos homens - o senhor poderá informar-se melhor com o nosso médico, o comissário provincial, que lhe dará maiores informações ${ }^{53}$.

53 A figura do comissário vacinador nas capitais das províncias foi produto da organização do Instituto Vacínico - agosto de 1846 - em substituição à Junta da Instituição Vacínica, criada em 1811. Esta Junta,

"muito êxito não logrou a aplicação de tal medida imunizante, principalmente nas províncias"(i).

No entanto, estas mudanças administrativas não repercutiram significativamente na eficácia da imunização variólica. Problema antigo, desde $180+$ quando, na Europa, os "prefeitos recebem circulares convidando-os a usar a sua autoridade para garantirem a difusão maciça da vacina no quadro da sua circunscrição. Logo, promulgam decretos cujos artigos definem um certo numero de medidas com vista à concretizaçăo das vontades do governo" (ii).

Assim, desde a prescriçăo da vacina para o combate da varíola, diversos problemas relativos à aderència da população à ação, aliada à pouca ìnfase na saúde pública pelos governos, tem sido relatados (iii).

i. FONTENELLE, J. P. Op. cit. p.422.

ii. DARMON, P. A cruzada antivariólica. In.: As doenças tem história. Lisboa, 
João Alphonso sentiu-se, no emaranhado das circunstâncias sociais e profissional, sem uma alternativa - o que, na verdade, lhe seria mais conveniente - e procurou atenuar a sua possivel contribuição:

- Talvez amanhã de manhã eu possa tratar disto, apesar de achar que os cuidados que devem ser tomados já foram providenciados. Como permanecerei por aqui nos próximos dois dias, procurarei saber um pouco mais sobre esta ocorrência da variola.

Agradecidos, os homens despediram-se, prometendo encontrá-lo no hotel no dia seguinte. João Alphonso meditava sobre este encontro e o seu desenrolar. Envolvido estritamente na clinica privada, acompanhava esparsamente questōes politicas e administrativas da saúde pública. Sobre a variola, as ações do governo eram bem conhecidas na área médica. Além disso, era uma das poucas ações na área de saúde que contava com alguma boa vontade do governo. A variola estava também no centro das discussões teóricas da higiene: o caráter contagioso - da variola - em oposição à natureza infecciosa da malária, por exemplo. ${ }^{34}$

Terramar, srd. p. $305-21$.

iii. CHALHOUB, S. Op. cit., p. 154 - 293.

\$4 o século XIX a discussão sobre a maneira de propagação das doenças epidêmicas centravam-se basicamente em duas teorias: contagionista e infeccionista (ou miasmática)(i). CHALHOUB escreve que

"os contagionistas acreditavam que o surgimento de uma determinada doença sempre se explicava pela existência de um veneno específico que, uma vez produzido, podia se reproduzir no individuo doente a assim se propagar na comunidade" (ii).

A infeç̧ão, por sua vez,

"se devia à ação que substâncias animais e vegetais em putrefação exerciam no ar ambiente" (ii).

Esta discussão esta inserida no processo de

"formalização da ciência epidemiológica... [e] dá-se no contexto da consolidação instituicional da nova ordem social, conduzida sob a hegemonia político-ideológico da burguesia" (iii).

A condição básica da racionalidade epidemiologica, "saber (e procurar) as causas das doenças" (iv), deve ser compreendida dentro de "certas opçðes que caracterizam a ciència moderna...: a ciência como possibilidade de dominação da natureza. a verdade associada à utilidade; a 
Assim, João Alphonso experimentou algumas hipóteses e concluiu que a doença poderia mesmo estar provocando estragos significativos, disseminando o medo na população da região. Sem ter como avaliar com profundidade o intercámbio da saúde pública com a politica, ele admitiu que as autoridades da cidade não perderiam a chance de uma contribuição que pudesse assinalar alguma ação atenuante.

Logo de manhã, os dois homens que o visitaram na noite anterior esperavam-no na recepção do hotel. Solícitos, cumprimentaram João Alphonso e disseram-lhe que ele estava sendo aguardado no Instituto Vacinico, onde se daria uma reunião expositiva da epidemia. Percorreram algumas ruas da cidade para chegarem a um pequeno prédio de dois andares. Um corredor estreito, com portas de um lado e de outro, levava a uma escada que ia dar na ante-sala, com outras três grandes portas. Um dos homens bateu levemente na porta e, sem esperar resposta, entrou na sala ampla. À mesa, de madeira maciça e retangular, já se encontravam assentados duas outras pessoas. João Alphonso foi apresentado a eles: um médico, comissário vacinador provincial, e um padre, representante da igreja nas açōes de combate à epidemia de variola. Estes, com os dois homens do escalão administrativo da

perspectiva de apreensão objetiva dos fatos; a separação entre ciência e filosofia; a ciência considerada como forma superior de conhecimento"(v).

i. CHALHOUB, S. The politics of disease control: yellow fever and race in nineteenth century Rio de Janeiro. J. Lat. Amer. Stud. 25 : 441-63, 1993.

ii. CHALHOUB, S. Op. cit., $269 \cdot 70$.

iii. AYRES, J. R. de C. M. Elementos históricos e filosóficos para uma crítica da epidemiologia. Rev. Saúde Pública, 27 (2) :,135 - 44, 1993.

iv. NOVAES, R. L. A saúde e os conceitos. São Paulo, 1976. [Dissertação de mestrado apresentada à Faculdade de Medicina da USP]. p. 3.

v. CZERESNIA, D. Construção cientifica e inovação teórica: um desafio para a epidemiologia. Physis, 3 (1): 77-90, 1993 
provincia, começaram então a expor a João Alphonso os problemas que a região vinha enfrentando em decorrência da epidemia.

O comissário iniciou, com um relato sobre o Instituto, suas ações e dificuldades de atuação. Afirmou que a maior dificuldade era convencer as pessoas a procurarem o posto de vacinação que funcionava na sua própria casa. Além disso, em muitas povoações ainda não havia $o$ comissário paroquial, já que era dificil alguém assumir as obrigações do cargo sem que houvesse remuneração para isto5s. Neste instante, o Padre interveio, afirmando que a igreja se preocupava com o combate à variola e que desde 38 , por solicitação do presidente da provincia, era divulgado o "Compêndio sobre a Vacina"56. Contudo, continuou o Padre,

55

De fato, o regulamento do Instituto Vacínico instituía

"pessoal que se encarregasse da vacina sem perceber vencimentos" (i).

Esta parece ser apenas uma das situações de informalidade destas ações de vacinação.

Em São Paulo, por exemplo,

“a vacina progredia muito pouco. O Instituto Vacínico, ..., ainda estava sem o sem organização regular e por isso não havia prestado os bons serviços a que se destinava. Funcionava no domicílio (!) do dr. Comissário vacinador e inspetor da vacinação, sem que fosse auxiliado por indivíduos de competência profissional. Pelo diminuto número dos que são anualmente vacinados, pode a assembléia ajuizar da deficiência deste serviço" (ii).

A utilização do próprio domicílio do comissário vacinador como local de atendimento da população deve ter sido usual em outras províncias. Em Minas Gerais, o comissário anunciava nos jornais a sua disponibilidade para atender os interessados em se vacinarem (iii).

i. FONTENELLE, J. P. Op. cit., p. 422.

ii. NETTO, A. R. O caminho para formação do serviço sanitário de São Paulo de 1579 a 1891. Arquivos de Higiene e Saúde Pública, 7(14) : 7-34, 1943. p. 23.

iii. Conforme anúncio no jornal “Diário de Minas”, Anno I, n. 155-7 de 30-10-1873.

56 "Compèndio sobre a Vacina" é o título de uma memória escrita em 1838 pelo Sr. Hércules Octaviano Muzzi, "um dos inspectores da Junta da Instituição Vacínica, fundada no Rio de Janeiro em 1811 " $(*)$

O governo imperial imprimıu-a, distribuindo-a às provincias com recomendaçues para 
entre os próprios religiosos havia aqueles que resistiam à idéia da vacinação.

O médico, retomando a palavra, fez um discurso sobre a necessidade de meios que coagissem as pessoas a se vacinarem. Acreditava, porém, que a destinação de recursos para o Instituto seria o caminho mais fácil para melhorar as ações. Com isto concordaram os homens da administração provincial. Indagados sobre a situação em outras regiōes da província, pouco souberam informar. O médico contou suas viagens à corte, para tratar de assuntos da saúde provincial, e também seu trabalho, abnegado, na casa de saúde local, o impediam de deslocar às vilas do interior. Afirmou que não era raro ouvir relatos sobre a ocorrência da variola em uma ou outra localidade, reafirmando a baixa cobertura do procedimento de vacinação57. Mas, enfaticamente, garantiu que a ausência de recursos impedia qualquer ação mais consistente na área da saúde, que já era muito castigada pela ingerência de gente não capacitada para tratar das doenças do povo. Por último, os anfitriōes fizeram uma descrição de alguns aspectos da epidemia de variola na região. Tendo a cidade de Mariana como foco, convidaram João Alphonso para visitar um lazareto emergencial, para onde eram levados os doentes

sua divulgação.

* BARBOSA, P. \& REZENDE, C. B. Op. cit., p. 414.

57 De acordo com os dados de vacinações efetuadas nos estados do Brasil (i), as vacinações efetuadas em Minas Gerais (excetuando os anos de 1848, $1853,1859,1861,1866-73,1881-2,1884-5,1889$ sem registros) no período de 1848 a 1889 foram: 1849,$123 ; 1850,142 ; 1851,117 ; 1852,114 ; 1854,551 ; 1855,535 ; 1856,36$; 1857,$78 ; 1858,266 ; 1860,787 ; 1862,1719 ; 1863,8687 ; 1864,3231 ; 1865,5503 ; 1874$, $9506 ; 1875,437 ; 1878,1463 ; 1879,784 ; 1880,7 ; 1883,2107 ; 1886,194 ; 1887,777$; 1888,53 .

Considerando a população do estado (ii) em alguns estes anos (em 1854, 1300 000; em 1865,1600 000; em 1879, 2102689 ) tem-se que a cobertura vacinal, em relação a população total, seria de: em 1854, 0,04\%; em 1865, 0,19\%: em 1879, 0,15\%.

i. BARBOSA, P. \& REZENDE, C. B. Op. cit., p. 447

ii. FUNDAÇÃO IBGE. Séries estatísticas retrospectivas. Rio de Janeiro, 1986, v.3, 1986. p. 29 
em diferentes estados da doença. João Alphonso não esperava por esta atividade, mas também não soube como evitá-la.

Formando uma pequena comitiva, foram visitar o lazareto nas cercanias de Ouro Preto, mas já próximo de Mariana. As autoridades náo sabiam quantos estavam doentes, nem mesmo onde estavam recolhidos alguns infectados. Muitos deles eram isolados pela familia, outros se refugiavam, por conta própria, e, assim, tornava-se impossivel evitar a propagação do contágio. Enquanto a comitiva percorria os arredores de Ouro Preto, já na divisa com Mariana, João Alphonso pôde observar a precariedade da saúde dos habitantes. Chamou-lhe a atenção o número de pessoas com "papeira", apesar de que o tratamento desta doença com iodo já era conhecido na época ${ }^{58}$. Nos negros, submetidos a todo esforço necessário para o desenvolvimento das mais variadas atividades, era visivel a precocidade do envelhecimento. Enfim, depois de percorrerem um breve caminho dentro de uma mata rala, a comitiva deparou com uma clareira onde, ao centro, se encontrava uma construção antiga em péssimo estado de conservação. Era uma casa grande que tivera parte de suas paredes internas derrubadas, formando, desta maneira, um grande salão irregular. Ali estava confinado grande número de doentes.

O médico-comissário cumprimentou um grupo de três pessoas que

58 'Papeira' é o nome popular dado ao 'bócio'. Em Minas, o bócio, endêmico, é descrito por viajantes desde o início do século XIX, conforme afirma FRIEIRO, citando, inclusive observações de D. Pedro II, quando da sua visita à província em 1881:

"Vi bons papos também aqui e o vigário tem principio dele. Aparecem sobretudo na gente de cor, talvez pela comida" (i).

BURMEISTER relata ter visto pessoas de papeira e anotou:

"notando-se o mal somente em mulatos e negros ... as vitimas não dão grande importância ao seu defeito fisico e orgânico..." (ii).

i. FRIEIRO, E. Feijão, angu e couve. Belo Horizonte: Itatiaia ; São Paulo: Edusp, 1982. p. $91-97$.

ii. BURMEISTER, H. Op. cit p 240 
estavam um pouco afastados da entrada e, após olhar rapidamente o interior, adentrou, acompanhado por João Alphonso. Os doentes estavam deitados no chão, sobre esteiras de palhas e em lamentável estado higiênico. Adultos e crianças misturavam-se e, não raro, familias inteiras se agrupavam em torno de duas esteiras. O choro de crianças novas se misturava a gemidos freqüentes de doentes em variadas condições da doença. João Alphonso observou que todos os doentes tinham as manchas avermelhadas espalhadas do rosto para os braços e palma das mãos e pelas pernas até a sola dos pés. Em alguns, as pápulas já tinham se tornado bolhas repletas de pus. Noutros, estas pústulas tomavam os membros. Freqũentes eram as complicações decorrentes das condiçōes a que estavam submetidos e, por isso, via-se muitos com visiveis problemas pulmonares. $O$ médico-comissário, lamentando a impossibilidade de melhor atender os doentes, quis insinuar resignação afirmando:

- Com a carência de recursos e falta de pessoal qualificado, só nos resta esperar que uma salvação nos venha dos céus.

João Alphonso, caminhando lentamente ao seu lado, ouviu as palavras do colega médico e, sem se dirigir a ele, recitou para si mesmo, em alemão, um verso de Heine apreciado por Morten:

- Den Himmel überlasen wir

den Engeln und den Spatzen ${ }^{59}$.

Ao sair da cabana, todos da comitiva esperavam a avaliação de

59 "Deixemos os céus

aos anjos e aos pardais"

Este verso de Heine ( Deutschland, I ) foi tomado de um texto de FREUD (*) que o cita referindo-se a Heine como sendo

"um de nossos companheiros de incredulidade".

A nota de rodapé do referido texto (*) informa que

"A expressão "Ungluubensgenossen" \{ "companheiros de incredulidade" \}

foi aplicada pelo proprio Heine a Espinoza no que Freud, em seu livro sobre o chiste (1905c), ...., citou como exemplo de um tipo especial de procedimento humorístico".

* FREUD, S. El pon enir de una ilusión. In : FREUD, S. Obras completas, v. 21, Buenos Aires. Amorrortu ed. , 1986. p. th 
João Alphonso. Este, entretanto, perguntou sobre os cuidados com que eram tratados os doentes:

- Doutor, o senhor sabe que não é fácil encontrarmos quem queira cuidar diretamente destes doentes. Tentamos o que nos é possivel - disse um dos médicos, que continuou a explicar;

- Além deste isolamento que providenciamos para os doentes, trazemos a eles, duas vezes ao dia, alguma comida, que é distribuida aos mais doentes por aqueles que ainda tem disposição para andar. Contamos também com a ajuda destes três bons cristãos - neste momento, apontou para as três pessoas que estavam à entrada da cabana quando chegaram - que têm ajudado os doentes em alguns momentos.

- E a limpeza... - quis perguntar João Alphonso.

- É mais ou menos no mesmo sistema. Os mais dispostos ajudam os mais fracos. Há muita gente de uma mesma familia aí dentro. Isto facilita um pouco e...

- E os óbitos?

- Nossos mortos são levados para o cemitério da igreja de Nossa Senhora das Dores do Calvário - disse o padre ${ }^{60}$.

- O senhor sabe, doutor, enquanto não dispusermos da vacina para todo este povo, é difícil evitar a morte.

Após o pequeno diálogo, houve alguns segundos de silèncio, tempo suficiente para João Alphonso tentar articular alguma contribuição ao tratamento da doença. Olhou novamente para dentro do galpão, envergonhou-se um pouco de si, mas não conseguiu deixar de fazer algumas consideraçōes médicas. Falou alguma coisa quanto à alimentação, que não deveria conter alimentos quentes e com muito

${ }^{60}$ A Igreja de Nossa Senhora das Dores do Calvário é uma construção de 1788 e tem um pequeno cemitério à sua esquerda. Mortos por doença infecciosa eram enterrados ali, já que não podia ser em outros cemitérios.

"por causa do risco de contágio" $\left(^{*}\right)$.

* GUSTAfSON, M. Vila Rica, Ouro Preto, verdade e lenda. 4a. ed. Belo Horizonte, Una Graphos Impressora, 1983. p. 45-6. 
tempero, da necessidade de cuidados para evitar complicações da ferida, além de discutir com o médico um ou outro procedimento terapéutico possivel.

Os dois homens da administração, que acompanhavam a comitiva, propuseram voltar à cidade para continuarem a discutir, em melhores condições, a situação. Ao retornarem à repartição, todos falaram novamente, até que um dos médicos da cidade, que aparentemente comandava as ações contra a epidemia falou, cautelosamente:

- Como o senhor viu, doutor, temos poucas ou nenhuma arma para enfrentar o mal. Falta-nos desde a vacina até medicamentos, alimentação, tudo enfim. O senhor testemunhou isto tudo. Bem sabe o senhor que para termos tudo isto que nos falta é necessário recursos, muitos recursos - falou o médico que, neste momento olhou para um dos homens da administração, que continuou a falar:

- É o senhor é um doutor esclarecido, que conhece as facilidades da Europa e até mesmo da corte, e há de convir conosco que sem recursos é impossivel implementar ações de bom nivel. Gostariamos muito que o senhor, cujo sogro é da intimidade dos ministros, interviesse não por nós, mas pelo povo da provincia de Minas Gerais. Os recursos precisam chegar até nós.

- Isso mesmo - disse o padre - Quem sabe não possamos nos reunir com o presidente e elaborarmos um documento descrevendo a gravidade da situação para enviarmos à corte?

A proposta do padre contou com a aprovação de todos, exceto de João Alphonso, cujos pensamentos estavam absorvidos pelas imagens da cabana variólica. As vezes, seu olhar, percorrendo o ambiente, fixava um ou outro adorno de ouro que abundava na decoração da repartição pública ou nos trajes austeros mas luxuosos dos membros do grupo com quem conversava. Com um súbito e discreto espanto, recebeu o pedido para comentar a proposta do padre:

- Talvez não seja necessário nos reunirmos com o presidente. Quanto ao documento, creio que os senhores podem elaborá-lo e eu me 
comprometo a opinar sobre uma ou outra questão que vi ou que sugeri afirmou João Alphonso.

- O senhor assinaria o documento ? Veja bem, doutor, isto em nome de uma calamidade que assola e faz temer a população da provincia - perguntou um dos membros do grupo.

João Alphonso deu-se conta da situação em que se envolvera. pressentiu que em torno da variola estabelecia-se um calculado jogo, no qual ele não tinha nenhum interesse em participar. Procurou ganhar tempo, pois qualquer tempo ganho fazia-o aproximar-se do momento em que deixaria a cidade rumo a Lagoa Santa. E comentou:

- Antes de avaliar isto, gostaria de saber um pouco mais sobre a doença em Mariana, onde é mais grave.

- Não é má idéia. A situação na cidade é calamitosa. A maioria das familias jà se mudaram - responderam-lhe.

- A própria igreja tem feito o que pode. Além das orações, tem-se confortado a todos contra o desespero que toma conta neste momento. Também têm sido feitos doações aos pobres - disse o padre.

- Comenta-se que o bispo tem estado preocupado com a situação do seminário já que - comentou um dos homens da administração com os olhos arregalados - parece ter havido mortes entre os seminaristas.

Um dos médicos da cidade apressou-se a comentar:

- Sim, é verdade. Houve morte, mas não sabemos exatamente quantas. Além disso, è certo que o nosso bondoso bispo Dom Viçoso já tomou as precauções para debelar a variola que ronda o santo seminário61.

61 Dom Antônio Ferreira Viçoso (1787-1875), foi o sétimo e por trinta e um anos bispo de Mariana, a partir de 1844 (i). Padre Lazarista (Congregação da Missão), Dom Viçoso teve influente papel no 'movimento da igreja' na segunda metade do século XIX. Neste período, especialmente na década de 70 ,

"as relaçðes entre o estado e a igreja se tornaram tensas ... O conflito teve origem nas novas diretrizes do Vaticano, a partir de $1848 \ldots$ O pontífice [Pio [X] condenou as 'liberdades modernas' e tratou de afirmar o predomínio espiritual da igreja no mundo" (ii).

O ápice desta tensão, no Brasil, é a prisão dos bispos de Olinda e Belém, Dom Vital e Dom Macedo, respectivamente. Os meandros desta crise são polèmicos e extensos. Afirma-se, por exemplo, 
- Não sei se os senhores já sabem, mas Dom Viçoso já tomou providências quanto aos seminaristas - comentou o Padre.

Por alguns segundos criou-se uma expectativa quanto à afirmativa do padre, já que, aparentemente, ninguem ali conhecia as tais providências do bispo. Foi João Alphonso que, com uma curiosidade discretamente irônica, pediu informaçōes:

- Senhor padre, que providências são estas que o bispo teria tomado?

O padre, notando o ineditismo de sua declaração, impostou-se e, pretendendo salientar a sapiência do bispo Dom Viçoso, respondeu:

"que tal conflito é em suma uma expressão brasileira da grande luta entre a igreja de então e o mundo liberal" (iii).

Por ocasião deste conflito, Dom Viçoso enviou 'uma enérgica carta a D. Pedro II', protesto este que marcou seu posicionamento. O bispo também participou ativamente da reforma católica, reforma esta que representava um

"esforço de conquista do espaço religioso no Brasil" (iv).

Como padre, Dom Viçoso foi um dos dois primeiros lazaristas que chegaram ao Brasil em 1820. Foram ambos que, por doação da Coroa, tomaram posse e iniciaram as atividades, em Minas Gerais, do Colégio Caraça É importante compreender o papel de Dom Viçoso em suas diversas manifestações, entre elas

"o de reformador da vida religiosa em Minas no século XIX" (v)

e na condição de padre lazarista que, atualmente, tem um processo de beatificação em andamento (i ; vi), processo este já com a

“autorização oficial da Santa Sé para o prosseguimento da causa" (i).

i. Conforme o prospecto "Dom Antônio Ferreira Viçoso (13-05-1787 - 07-07-1875)" elaborado pela "Vice-postulação e secretariado da beatificação de D. Antônio F. Viçoso". Mariana, 07 de julho de 1984. Arquidiocese de Mariana, MG.

ii. FAUSTO, B. Op. cit., p. 229 - 30.

iii. HAUCK, J. F. et al. História da igreja no Brasil - segunda época: A igreja no Brasil no século XIX. tomo II/2. 3a. ed. Petrópolis, Ed. Paulinas, 1992. p. 186 - 92.

iv. AZZI, R. O altar unido ao trono: um projeto conservador. São Paulo, Ed. Paulinas, 1992. (História do pensamento católico no Brasil; v.3). p. 29-38.

v. ZICO, J, T. Caraça: peregrinação, cultura, turismo. 5a. ed. Belo Horizonte, Ed. Littera Maciel, 1988. p. 36-7. 
- Os seminaristas menores irão para a fazenda da diocese. Os seminaristas maiores, onde, aliás, devo dizer, não me consta ter havido mortes, serão transferidos para o Santuário de Nossa Senhora Mãe dos Homens.

- Muito boa a decisão. Acho até que todos deveriam ser levados para o santuário - afirmou um dos médicos, com a aquiescência dos demais.

- Infelizmente lá não há lugar para todos, porisso enviar os menores para a fazenda - disse o padre.

- Então os seminarista serão isolados. - afirmou João Alphonso, que perguntou - Mas neste santuário as condições sanitárias permitem alojar todos os alunos satisfatoriamente ?

- Sem dúvida, doutor Magalhães, este santuário é previlegiadíssimo. Há edifícios para abrigar a todos que irão e o local é muito salubre. Se todos morássemos aí, estariamos livres de doenças. Morte, só por velhice - afirmou entusiasmado um dos membros do grupo.

- Hum ! Parece que estamos diante de um daqueles lugares que Boccaccio descobriu para proteger seus contadores de histórias ${ }^{62}$ - disse João Alphonso, provocando um ligeiro desconforto nos presentes,

62 O italiano Giovanni Boccaccio (1313-1375) escreveu sua obra mais conhecida, Decamerão (i), entre 1348-53. O livro compõe-se de várias histórias narradas por sete mulheres e três homens jovens que, refugiando-se de uma grave epidemia de peste bubônica, instalam-se sucessivamente em agradáveis sítios campestres da região de Florença. A obra, 'rica em detalhes autênticos e literários', marca o nascimento da prosa italiana (ii).

Por seu lado, a peste bubônica é considerada uma das epidemias que mais matou na história da humanidade. Apenas no século XIV, 75 milhões de pessoas teriam morrido na Europa (iii). Matou mais que o tifo, a desinteria, a sífilis ou a febre amarela, não distinguindo ricos, pobres, jovens, velhos, etc. (iv).

i. BOCCACCIO, G. Decamerão. São Paulo, Abril Cultural, 1971.

ii. KEINHENZ, C. Boccaccio. In: Grolier Multimedia Enc. Op. cit.

iii. Bulbonic Plague. GROLIER Mult. Enc. Op. cit.

iv. BROSSOLET, J \& MOLLARET, H. Pourquoi la peste? Le rat, la puce et la bubon. Paris, Gallimard, 1994. 
sobretudo ao padre - Este santuário fica próximo daqui ? - indagou.

- Sim. Poucas léguas. É na serra do Caraça. - afirmaram-lhe - O senhor deveria conhecer, doutor. Confirmará com os próprios olhos as vantagens do local.

O Padre se prontificou a dar mais informações do Santuário a João Alphonso.

- O santuário se refere apenas à capela que o seu fundador ergueu na serra há muitos anos passados ${ }^{63}$. Na verdade, até 42 funcionou por lá um proficuo colégio, o Colégio do Caraça, que teve que ser desativado

${ }^{63}$ A respeito da capela de Nossa Senhora Mãe dos Homens, na Serra do Caraça, afirmase:

“... situada 8 léguas ao norte de Mariana, em cuja planície da sua sumidade existia um templo de elegante arquitetura e dedicado a Nossa Senhora sob o título especiosíssimo de Mãe dos Homens, junto ao qual habitavam vários indivíduos a quem o retiro do mundo, a devoção, ou outros motivos, haviam atraído, e onde alguns ermitães se empregavam no seu decente trato. Pertencia esta capela e as terras adjacentes a um Lourenço de Nossa Senhora Mãe dos Homens, que por seu falecimento, em outubro de 1819, e disposição testamentária ficaram pertencendo a El-Rei, nomeado herdeiro de tudo, a quem pediu o testador a instituição de um hospício de missionários".

$O$ relatório encerra-se afirmando:

"Esta casa promete muito crescimento e os seus habitadores distinguem-se por uma grande piedade religiosa"(i).

Os padres Lazaristas ocuparam as terras do Caraça acidentalmente. Vindos de Portugal, deveriam dirigir-se, em missão, para o Mato Grosso.

"El-Rei entregara as missões mato-grossenses aos Frades Capuchinhos. E, como D.João acabava de receber um testamento do falecido Irmão Lourenço de Nossa Senhora, doando-lhe a Capela e as terras da Serra do Caraça, em Minas Gerais, propunha-lhes, em troca, assumirem aquela propriedade e saírem a missðes. Leandro [Padre Leandro Rebelo Peixoto] aceita jubilosamente o legado inesperado e apresta-se para partir, em companhia de Viçoso [Padre Antônio Ferreira Viçoso]" (ii).

i. MATOS. R. J. da C. Corografia histórica da província de Minas Gerais (1837). Belo Horizonte : Itatiaia ; São Paulo : Edusp, 1981. v.2, p. 157-8.

ii. CARRATO, J. F. O caraça português (Contribuição para o estudo da história do Colégio Caraça). São Paulo, 1970. [Tese de Livre Docência - Faculdade de Filosofia, Letras e Cièncias Humanas da USP]. 
naquela data, por causa das disputas políticas. $\mathrm{Na}$ época, o diretor do Caraça era o nosso bispo, Dom Antônio Ferreira Viçoso, que transferiu as atividades para outra localidade da provincia. Durante todos estes anos o Colégio permaneceu fechado, sem atividades de ensino. Volta agora a abrir pelas mãos do nosso bispo, que tanto amor consagra às terras do Caraça.

O farmacêutico presente no grupo, morador antigo da cidade e eximio conhecedor da região, deu mais algumas informaçōes:

De fato, vale a pena conhecer o Caraça. Aliás, não é raro um ou outro naturalista estrangeiro, percorrendo as terras brasileiras, elegerem 0 Caraça como rota indispensável. Saint-Hilaire, que eu mesmo, ainda jovem, cheguei a conhecer, estudou a região, como também os alemães Spix e von Martius ${ }^{64}$. A natureza realmente é pródiga naquele lugar. $\mathrm{O}$ ar

4 O naturalista francês A. de Saint-Hilaire (1779-1853) visitou o sítio onde já existia o Santuário do Caraça. É dele um relato de grande importância histórica, pois, naquela época - 1816 - esteve pessoalmente com o fundador da "Capela de nossa Senhora Mãe dos Homens", o Irmão Lourenço.

“... chegamos, enfim, à espécie de planície em que está situada a Ermida de Nossa Senhora Mãe dos Homens ... Fica-se chocado ao avistar assim de repente um edifício tão vasto e tal altitude e tão longe de todas as habitaçðes ... Essa fundação não data mais de quarenta e poucos anos. $O$ fundador ainda vivia por ocasião de nossa viagem ..." (i).

J. B. von SPIX (1781-1826) e C. F. P. von MARTIUS (1794-1868), naturalistas alemães, em viagem pelo Brasil (ii), também visitaram o Caraça em 1818. Em um registro intitulado "Hospício da Mãe dos Homens: Hospício de eremitas e lugar de romaria no cume da Serra do Caraça perto de Oiro (Ouro) Preto", escrevem:

"Finalmente, chega-se por uma estreita subida, por entre mato baixo cerrado, a um vale alto, fechado em forma de anfiteatro, no qual se destaca o aprazivel edificio do Hospício. Toda a natureza respira contentamento, e uma indizivel sensação de doce tranquilidade e bem-estar apodera-se da alma do viajante" (iii).

i. SAINT-HILAIRE, A Viagem pelas provincias do Rio de Janeiro e Minas Gerais. Belo Horizonte, Itatiaia ; São Paulo, Edusp, 1975. p. 99-101.

ii. SPIX, J. B. von \& MARTIUS, C. F. P. von. Vlagem pelo Brasil. Rio de Janeiro, Imprensa Nacional, 1938. 


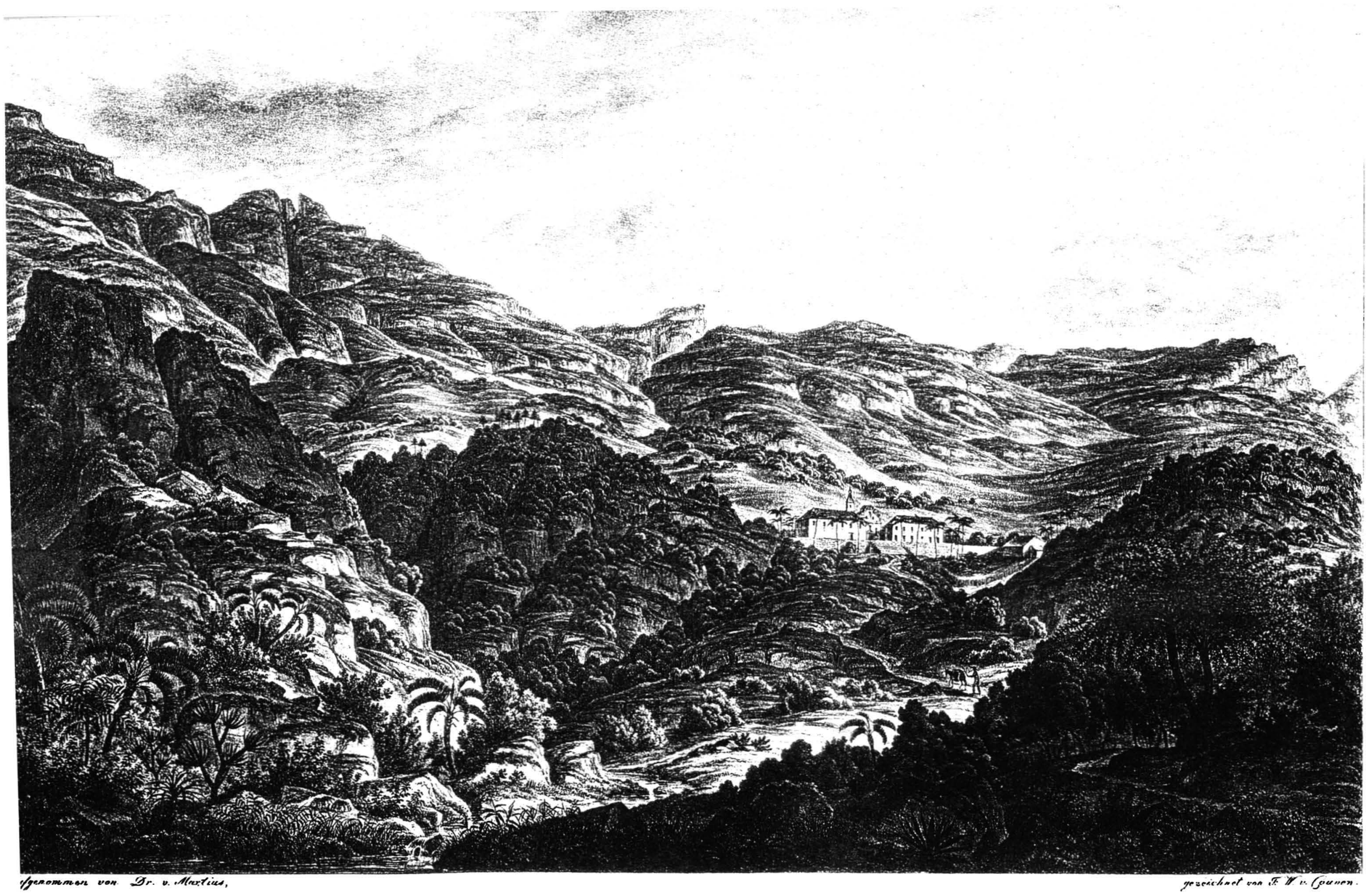

O Caraça, em 1818, por ocasião da Expedição J. B. von Spix e C. F. P. von Martius. 
a água impedem qualquer tipo de doença, mesmo com o rigor das friagens do inverno.

João Alphonso ouviu os depoimentos e, já pretendendo retirar-se, comentou:

- Eu gostaria de conhecer o local. Talvez numa outra viagem os senhores pudessem conduzir-me a um local tão aprazivel. Na Europa, como sabem, em regiões altas e de clima ameno, há estações para repouso e cura de algumas doenças.

Por fim, disseram-lhe:

- Pois bem, doutor, nós o acompanharemos ao hotel e, mais tarde, o procuraremos sobre a carta. Providenciaremos a redação e contamos com o seu empenho na corte.

Sem se recompor da viagem do Rio a Ouro Preto, João Alphonso só queria ir para o hotel e descansar. Mais uma vez, não aceitou o convite para uma refeição com membros do grupo com quem se reunira. Com fome, preferiu tentar comer alguma coisa no próprio hotel. Lá, foi solicitamente atendido e, após uma breve ida a seu quarto, retornou à sala de refeições. Tão logo iniciou a pequena refeição, foi abordado pelo porteiro do hotel:

- Senhor dr. João Alphonso Azevedo Magalhães !?

- Pois não! - disse João Alphonso, incomodado pelo fato de que pela segunda vez não conseguia fruir uma refeição sossegadamente.

- Há um senhor na portaria querendo falar com o senhor urgentemente.

- Já estou indo - afirmou João Alphonso, enquanto tomava um gole d'água, limpando os lábios com o guardanapo.

$\mathrm{Na}$ portaria, um homem forte, em trajes de montaria apresentouse:

- Boa tarde, doutor. Sou um emissário vindo do Rio de Janeiro. Recebi instruções de procurá-lo pelo caminho e lhe entregar

iii. Reise in Brasilien in den Jahren 1817-

1820. Stuttgart, Brockhaus, 1967. item 7.

Obs: Esta edição é ornamentada com gravuras. E, neste sentido, uma delas pode ser considerada como o primeiro registro do Santuário e seu ambiente. 
pessoalmente esta carta - o homem tirou de dentro de um pequeno embornal a tiracolo um envelope e entregou-o a João Alphonso, que, com alguma ansiedade, abriu o envelope e leu a carta:

Rio de João Janeiro, 28 de março de 1854.

Meu querido esposo;

Espero que Deus o tenha guiado numa boa viagem, mas necessitamos de seu retorno imediato. Alguns dias após sua saída, seu pai teve um grave problema de saúde e morreu imediatamente. Sua mãe e irmãos aguardam a sua chegada.

Com carinho, sua esposa

Beatriz.

João Alphonso cerrou os olhos por alguns segundos, apertando o envelope numa das mãos. Em seguida, olhou para o emissário e o porteiro, e disse:

- Meu pai morreu.

Os dois homens, abaixando a cabeça levemente, deram-lhe os pêsames sem apertar-lhe as mãos. $O$ emissário, em voz baixa procurando apresentar-se servil, disse:

- Eu estou a seu serviço, doutor. Deram-me ordens para acompanhar o senhor na volta. Se o senhor quiser, podemos partir a qualquer momento. Há muitas tropas pelo caminho, indo e vindo, e não estariamos andando a sós por muito tempo.

João Alphonso pediu ao emissário que tomasse as providências para a partida. Disse ao porteiro que deixaria o hotel e subiu a seu quarto. Lá, abriu a janela para o horizonte noroeste. Era a direção provável de Lagoa Santa. Neste instante, pensou no pai, no Dr. Lund, entristeceu-se e deixou surgir algumas lágrimas.

Após uns dez minutos, escreveu uma carta e um bilhete, envelopados separadamente. Arrumou seus pertences e desceu. Na portaria, pediu ao porteiro que encaminhasse imediatamente o bilhete a um dos médicos da cidade, com quem se reunira, e solicitou que a carta fosse enviada ao Dr. P. W. Lund, em Lagoa Santa. Pouco tempo depois, 
retornava o emissário que o acompanharia até o Rio de João Janeiro e, enquanto se preparava para iniciar a viagem de volta, chegou o médico da cidade, montado, em passos rápidos.

- Vim imediatamente, doutor Magalhães - afirmou.

João Alphonso tirou do bolso a correspondência da esposa e the mostrou.

- Meus sentimentos, disse o médico.

- Eu estou partindo agora mesmo. Eu espero retornar brevemente para prosseguiu minha viagem. Infelizmente, neste momento não posso ficar, mas, se forem ao Rio me procurem.

- Naturalmente - disse o médico, desconcertado pela instantaneidade da situação e sem saber como proceder quanto à questão discutida em reunião. Mas disse, sem convicção:

- E a carta, doutor?

- O senhor não se importa de tratarmos disto num outro momento? A viagem é longa, cansativa e preciso sair já, doutor - concluiu João Alphonso.

- Claro, claro - afirmou o médico.

Despediram-se discretamente. João Alphonso, sem concluir sua viagem, iniciava o retorno. O céu de Ouro Preto apresentava-se nublado; na saida da cidade, moleques ofereciam aos viajantes alimentos diversos, desde frutas a carnes de fonte irreconhecivel. Um cheiro pútrido e repugnante enjoou João Alphonso. Tirou um lenço, cobrindo o nariz, e apressou a montaria. Na direção do Rio, morros, picos... a distância. 


\section{SEGUNDA PARTE}

A antiga fazenda Alenlé foi comprada e reformada para ser o 'celeiro da familia'. É que por aqueles anos previa-se um aumento nos preços dos gêneros alimenticios, com possibilidade de escassez $z^{65}$. O abastecimento da Corte envolvia transações com as provincias e o exterior e, no momento, preocupava especialmente o provimento de carnes e laticinios oriundos de Minas Gerais. Desde os primórdios da colônia, esta provincia tinha demonstrado a vocação para a agropecuária, com suas fazendas que se espalharam pelos vales dos rios. Pelo rio São Francisco desceram colonizadores vindos do nordeste e que foram se fixando com suas fazendas em vários pontos do interior. Com a

O sucesso da monocultura do café provocou uma nova convergência econômica, com prejuízo à produção de outros gêneros. O mecanismo deste processo era simples,

"Em geral os principais produtores de café, visando lucros certos e imediatos na venda deste gênero, começaram desde logo por aplicar todas as suas forças na cultura exclusiva dos cafezeiros, e até abandonaram a dos gêneros alimentares, milho, farinha, feijão, com que sustentavão seus fâmulos! Fizeram este falso raciocínio: - com os lucros realizados nas vendas do café compraremos o sustento para nossas famílias e trabalhadores, e ainda assim o ganho será maior porque a farinha, milho e feijão pouco custam, e não vale a pena distrair os braços do serviço importante para empregá-los com menor vantagem ... O resultado de tão errôneo raciocínio devia infalivelmente trazer a alça do preço dos gêneros alimentícios, e portanto isto sucedeu ..." (i).

IGLÉSIAS (ii), citando relatórios dos Negócios do Império de 1858 e 1859, afirma que "... muitas regiōes brasileiras, sobretudo as litorâneas, recebiam do estrangeiro parte dos seus alimentos".

E, nesta circunstância,

"Situação comum foi a falta de gêneros, que conduziu à carestia, - objeto de curioso inquérito do govêrno imperial -, verificando-se mesmo a fome".

i. SOARES, S. F. Notas estatisticas sobre a produção agricola e carestia dos gêneros alimenticios no império do Brasil. Rio de Janeiro, IPEAINPES, 1977. Cap. XVI : Carestia dos gêneros alimentícios.

ii. IGLÉSIAS, F. Política econômica do governo provincial mineiro (1835-1889). Rio de Janeiro, MEC INL, 1958. 
descoberta do ouro e diamante, o extrativismo mineral passou a ser a atividade econômica mais importante não apenas de Minas Gerais, mas, enfim, de toda a colônia. Assim, a extração mineral obscureceu todas as outras atividades. Foi um periodo em que o abastecimento da provincia mineira tornou-se bastante dependente de outras provincias e do exterior ${ }^{66}$. A agropecuária tornou-se atividade de subsistência em torno das minas, mas, mesmo nesta condição era insuficiente. Do sal, açucar, às carnes e cereais, a provincia mineradora dependia de fora. Neste época, alimentar-se na provincia tornou-se um ato exorbitantemente caro. Os lucros com a extração do ouro e diamante, entretanto, geraram mais expectativa do que investimentos $e$ riqueza na provincia. Monopolizada, a extração do diamante foi severamente fiscalizada pela metrópole. O ouro extraido era centralizado por comerciantes maiores e também pela metrópole, de forma que os pequenos mineradores repassavam o seu produto a um preço que, para a grande maioria, cobria os custos de uma sobrevivência precária, alimentada por um sonho de riqueza que se renovava a cada garimpagem ${ }^{67}$. Com tanta carestia e

\footnotetext{
66 ZEMELLA (i) estudou minuciosamente a questão do abastecimento de Minas Gerais durante o auge o periodo áureo, o século XVIII. Naquele período o preço dos bens, cotados em oitava de ouro ( $=3,585$ gr.), atingiu valores exorbitantes. A título de ilustração, no início daquele século

"pagava-se por uma galinha 3 ou 4 oitavas de ouro; por um pastel, 1 oitava;

por um barrilote de aguardente, 100 oitavas; por uma arroba de açucar, 32

oitavas" (i, p. 200).

O valor corrigido de alguns itens, tomando por base o valor da grama do ouro em 22-895, seriam (ii): 1 galinha, de 124,02 a 165,36 reais; 1 pastel, 41,34 reais; 1 barril de cachaça, 4 134,00 reais; $15 \mathrm{~kg}$ de açucar, 1322,88 reais.
}

\section{i. ZEMELLA, M. P. O Abastecimento da capitania das Minas Gerais no século XVIII. 2. ed. São Paulo, Hucitec/Edusp. 1990.}

ii. Valor da grama do ouro da BM\&F : $R \$ 11,53$ ( 1 oitava : $R \$ 41,34$ ).

67 Se por um lado a coroa portuguesa controlava oficialmente a comercialização do ouro através da cota a titulo de imposto, outra grande parte da produção do ouro nem mesmo chegava às estatisticas.

"Contrabandeado em larga escala" (i, p.50)

o ouro de esmolas e donativos parece ter representado 
escassez, houve a ocorrência de fome em geral e, entre os escravos, em particular, cuja saúde foi bastante agravada. Depois do esgotamento do subsolo rico, a provincia intensificou a produção agropecuária e já na primeira metade do século XIX exportava carne. A pecuária desenvolve-se e, a seu lado, uma importante indústria' de laticinios. A intensificação da lavoura de café na zona da mata empurra as fazendas de criação de gado para mais longe da Corte, e isto não deixa de ser motivo que justifique aumentos eventuais nos preços de carnes e laticinios ${ }^{68}$. Nesta expansão

\footnotetext{
"elevadíssimas quantidades de ouro em pó" (i, p.51).

Certo é que todo este ouro

"não ficou incorporado em empreendimentos de grandes resultados para o futuro ..."(i, p. 52).

Quanto à exploração de diamante, o processo foi energicamente controlado. Com a criação da Intendência dos diamantes, em 1734, as terras do atual município de Diamantina - e circunvizinhanças - constituiram em verdadeiro encrave com administração indepentente da capitania, completo controle pela metrópole e com rígidas normas que regulavam a vida de todos seus habitantes. SANTOS (ii) descreve em detalhes fatos e personagens deste momento singular do extrativismo mineral em Minas Gerais por Portugal. Talvez, a expressão mais importante deste controle seja o famoso regimento diamantino, conhecido como "o livro da capa verde". Estabelecendo normas rígidas de controle da extração, comercialização e, enfim, da própria organização social da área, o "livro" foi objeto de um importante e recente estudo onde a autora, J. F. FURTADO (iii), tematiza

“... a vida social do distrito diamantino de 1772 a 1808, analisando a aplicação do Regimento Diamantino, as conseguências do monopólio real sobre os diamentes, ...", etc. (iii, p. 31)
}

i. LIMA JÚNIOR, A. A capitania das Minas Gerais. Belo horizonte : Itatiaia, São Paulo :Edusp, 1978. p. 43-53 : O ouro.

ii. SANTOS, J.F. dos. Memórias do distrito diamantino. Belo Horizonte : Itatiaia, São Paulo : Edusp, 1976

iii. FURTADO, J. F. O livro da capa verde : o regimento diamantino de 1771 e a vida no distrito diamantino no pertodo da real extração. São Paulo, Annablume, 1996.

68 Os ciclos da economia mineira influênciaram não apenas o abastecimento alimentar interno, como é evidente, mas também outras províncias. Apesar da monocultura cafeeira que teria reduzido a produçào alimentar (i), em Minas evoluiu economias de subsistências em regiðes como no sul da província,

"voltada para fora, em busca de mercados" (i). 
da agricultura na provincia mineira, destacaram-se dois produtos básicos: o milho e o feijão. Do milho, que também alimentava porcos e galinhas, elaborava-se a angu, prato trivial na mesa dos mineiros. Assim, o toucinho e outros produtos derivados da carne de porco, mais as aves passaram a ter, ao lado da carne bovina e laticinios, alguma importância no abastecimento do Rio de Janeiro e São Paulo. Este processo de "ruralização" da economia mineira alterou também a oferta de alimentos internamente. As familias ricas mantiveram um padrão de consumo que teria se alterado pouco. No entanto, não é raro o relato de que a alimentação na provincia, para muitas pessoas, centrava-se em um ou, no máximo, dois alimentos ${ }^{69}$.

É provável que as novas fronteiras agrícolas dentro do estado tenham diminuído o impacto da monocultura cafeeira (na zona da mata especialmente) sobre a produção de alimentos e conseguente abastecimento de centros como o Rio de Janeiro. Por exemplo,

"A exportação de gado vacum foi, em 1842/43, de 45.421 cabeças e, em 1889 , de 147.058; a de gado cavalar, em 1842/43, de 1.173 cabeças e, em 1888 , de 1.782; quanto aos suínos, os números foram 44.819 e 24.498 cabeças respectivamente. A exportação de queijos atingiu a 377.230 quilos, em 1842/43, e a 1.543.294 quilos, em 1889. Também foi alta a exportação de toucinho e aves domésticas" (ii)

i. GONTIJO,R.M. A parceria e o café na zona da mata mineira: 1850 - 1906. Belo Horizonte, 1992. [Dissertação de Mestrado - Faculdade de Filosofia e Ciências Humanas da UFMG]

ii. SECRETARIA DA AGRICULTURA DO ESTADO DE MINAS GERAIS. $\boldsymbol{A}$ agropecuária mineira - sua historia, sua evolução. Belo Horizonte, 1978.

69 Com o refluxo da mineração, o século XIX em Minas Gerais transformou-se num periodo caracterizado pela

"ruralização da economia, a fazenda transformando-se em verdadeiro microcosmo da vida social e cultural" (i, p.45).

"A alimentação básica dos abastados não pareceu ter variado muito em relação ao periodo anterior. Seu cardápio consistia de feijão com farinha de milho, ou mesmo de mandioca, acrescido de torresmo ou carne cozida ou porco assado; também consumian galinha com arroz. Da horta ... couve, a abóbora, a batata-doce. As carnes de caça ... Na sobremesa ... canjica, doces variados, ... compotas de frutas e o café com rapadura" (i, p.78).

Quanto a alimentação do "roceiro pobre", parece que a mudança do perfil econômico não trouxe alteraçð̃es significativas. FRIEIRO (ii). comentando um "inquérito oficial" de 1857, comenta: 
A compra da fazenda atendia também a um velho anseio do sogro de João Alphonso: tornar-se proprietário de terras, próximas do Rio, e onde houvesse uma confortável sede para recreios periódicos. As terras da fazenda eram próximas da conhecida fazenda da Mandioca, propriedade do Barão de Langsdorff, nobre russo e que empreendeu viagens pelo Brasil ${ }^{70} .0$ casarão antigo da fazenda já era vistoso antes mesmo das reformas. Estas agregaram mais uma ala ao prédio antigo, aumentando os cômodos do andar de cima. $O$ andar de baixo continuou o mesmo, já que a nova construção aproveitava a elevação lateral do terreno. Com isso, a ala antiga do andar superior foi transformada num aprazivel salão enorme, com janelas amplas e portas que davam acesso a uma sacada que margeava toda a ala. A grande virtude deste salão é que ele dava para a vista mais bela da fazenda: via-se a mata atlântica cobrir

"A condição do roceiro pobre é a mesma do século XVII. ... A base da alimentação continua a mesma: feijão com angu. No melhor dos casos, carnede-sol, isto é, charque de má qualidade. Antes, sim. Agora nem isso. $O$ charque desapareceu. As crianças morrem como moscas, desnutridas" (ii, p.128).

i. ABDALA,M.C. A cozinha e a construção da imagem do mineiro. São Paulo, 1994. [ Dissertação de Mestrado - Faculdade de Filosofia, Letras e Ciências Humanas USP].

ii. FRIEIRO,E. Feijâo, angu e couve. Belo Horizonte : Itatiaia, São Paulo : Edusp, 1982.

70 O Barão G. H. von Langsdorff (1774-1852) desde 1803 esteve no Brasil, em períodos variáveis, até 1829. Por praticamente oito anos a partir de 1821, comandou uma grande expedição pelo Brasil (i). Foi como membro desta expedição que o pintor $\mathrm{M}$. Rugendas (1802-1858) fez, em 1824, aquela que é uma das duas primeiras gravura do colégio Caraça. Langsdorff adquiriu a fazenda Mandioca em 28-9-1816, com suas terras localizadas no hoje município de Magé. Além de desenvolver a agricultura e um projeto pioneiro com colonos alemães, a fazenda, cujo nome se devia às excelentes raízes de mandioca aí produzidas, se prestava a recepçðes oferecidas pelo proprietário (ii).

i. KOMISSAROV, B. Expedição Langsdorf: Acervo e fontes históricas. São Paulo : Editora Unesp, Brasília : Ediçðes Langsdorff, 1994.

ii. BECHER, H. O Bardo Georg Heinrich von Langsdorff: Pesquisas de um cientista alemão no século XIX. São Paulo : Ediçðes diá, Brasília : Editora UnB, 1990. 
esplendorosamente a serra do mar, favorecendo um ar fresco que invadia toda a área da fazenda. No amplo salão, além de mesas para reuniões e jogos, havia estantes e um local reservado, delineado por dois balcões de madeira trabalhada, que servia de escritório ocasional. Espalhadas por todo o salão, várias cadeiras de descanso, tipo espreguiçadeira, ofereciam-se às pessoas. Por este motivo, era comum a família e convidados encontrarem-se neste salão várias vezes ao dia.

A familia de João Alphonso achou oportuno o convite do seu sogro para que sua mãe, com quem lhe conviesse, passasse uns dias na fazenda após o falecimento do marido. Além da mãe, filhas, a nora Beatriz, entre outros, permaneceram por algum tempo na fazenda. João Alphonso permaneceu alguns dias por lá, e o seu sogro também compareceu por alguns dias. Numa tarde em que ambos estavam descansando no salão, o sogro principiou um diálogo com o genro:

- Ultimamente tenho tido muitos contatos com os seus colegas médicos da Junta de Saúde Pública e da Academia de Medicina...

- Mas tenho pouco contato com estas pessoas... às vezes numa reunião... ocasionalmente no hospital...

- É, mas todos eles são unânimes em afirmar a sua competência!

- O senhor acha mesmo que eles têm acompanhado e avaliado meu dia a dia como clínico ? - perguntou João Alphonso, com uma discreta ironia.

- Eles acabam sabendo, de uma ou outra maneira. Mas o fato é que, se desejar, as portas da academia estariam abertas a você. $O$ diretor acha que é importante ter professor formado na Europa, e as escolas da Alemanha são muito bem vistas.

Introspectivo, João Alphonso respondeu ao comentário do sogro:

- É, mas eu não tenho disciplina para ensinar...

- Não entendi, João, disciplina !?

- Sim, as normas ... a ciência, os cânones, a instituição - afirmou já um pouco desconfortavelmente, mas notando que o sogro não se satisfez com a resposta. E continuou:

- Ensinar exige obediēncias a limites que estão aquém de qualquer liberdade que nos garantam. Tornar-me professor de medicina seria uma 
opção de vida e coerentemente significaria impor limites aonde não os desejo.

O sogro, sem nenhuma disposição em acender a discussão neste ponto, procurou ser pragmático $\mathrm{e}, \mathrm{em}$ tom fraterno, disse:

- Você é um moço jovem, João, capacitado e respeitado, deve aproveitar o seu momento para solidificar a sua posição na sociedade. Pode fazer uma bela carreira e, quem sabe, até mesmo retornar por uns tempos à Europa para aprofundar seus estudos.

- O senhor sabe que não preciso estar na faculdade para retornar à Europa e os motivos para não pretender ingressar na faculdade eu já lhe disse.

- Está bem - disse o sogro, resignado - você tem suas idéias e suas convicçōes a este respeito. Mas eu continuo lhe afirmando a necessidade de aproveitarmos, cada um, o seu momento. Você já pensou na carreira política ? Uma cadeira na assembléia, por exemplo. Eu não teria dificuldades, e o faria com satisfação, em estabelecer contatos que facilitariam uma campanha.

Com uma expressão perscrutativa, que ,ele sabia, imitava seu excolega Morten, João Alphonso indagou do sogro:

- O senhor acha mesmo que eu teria chances na politica me tornando um deputado?

- Claro ! E porque não ? Aliás, a Beatriz me disse que você estabeleceu contatos com pessoas conhecidas da administração provincial em Ouro Preto ...

- Aquilo foi um emaranhado de casualidades. Acharam que eu teria algum poder para conseguirem recursos. Aliás, é o que devem fazer os deputados: depositários de pedidos por mais e mais recursos.

- Ora, ora , Joāo! Isto é coisa menor. Faz parte do oficio de um deputado. Uma formalidade prática que não merece reflexão.

- Mas o senhor não acha que esta 'formalidade prática' freqüentemente não se avizinha com a imoralidade politica, através da má administração, corrupção ...

- A política é um jogo difícil e neste jogo entram as debilidades dos homens, vocè sabe. $O$ ser humano não é perfeito. $O$ importante é que a corstituição não seja desrespeitada e que se mantenha a unidade da nação. 
- Então nós não devemos nem mesmo reagir às instituições em ruinas, estas 'debilidades humanas', etc. ? O Senhor não acredita que explicar a politica assim, serve apenas para legitimar aquilo que os governos querem?

Olhando fixamente para o genro, ele respondeu, como se estivesse efetuando um ensinamento:

- Exceto na teoria, João, a política é assim mesmo. Para cada ato, uma moral.

- A não ser que não exista mais o Estado, o governo ... - falou João Alphonso.

- Bobagem ... Qualquer governo com qualquer constituição seria preferivel a esta balbúrdia. Aliás, para um moço que se pretende na politica, estas considerações não contribuem muito.

- Eu agradeço a disponibilidade do senhor mas devo lhe dizer que a política não está em meus planos. Por uma questão de prudência.

- De qualquer forma, se reconsiderar sua opinião, venha falar comigo.

João Alphonso espichou-se na espreguiçadeira e, convicto, retomou a leitura de uma edição em latim de A Cidade do Sol, sabendo que jamais seria um deputado.

As autoridades sanitárias do Brasil já sabiam que uma epidemia de cólera avançava pelo mundo. Da Índia, em 1852 irradiara-se, agressiva, para a Europa e havia fortes suspeitas de que não tardaria a chegar às Américas. O governo, através da Comissão Central de Saúde Pública, antiga Junta Central de Higiene, procurou preparar-se para enfrentar a moléstia. O primeiro passo seria tentar evitar a sua importação com severa fiscalização nos portos. Segundo, acontecendo a indesejável manifestação, assistir o mais rapidamente possivel todos os doentes. Para isso, a Comissão convocou os serviços do maior número possivel de médicos, aptos a assumirem as diversas comissões sanitárias que foram criadas em várias partes da cidade. Da mesma forma, os hospitais também se preparavam para a provável chegada da temida 'cholera- 
morbus 71 . Comissões eram organizadas para ditar os preparativos necessários e, nesta época, todo o corpo médico foi acionado. João Alphonso, pelo fato de já ter acompanhado a manifestação da cólera na Europa, teve que assumir um papel atuante. Por causa disso, seu projeto de encontrar o Dr. Lund arrefeceu. Uma carta do naturalista lamentava a morte do seu pai, deixando para o futuro um eventual contato.

Mas o ano de 1855 trouxe algumas surpresas a João Alphonso. A cólera bateu à porta da sua familia e levou um parente próximo, fato que abalou profundamente o médico. A guisa de cuidar diretamente do paciente, com todos os seus conhecimentos, a perda do cunhado, jovem de pendor poético, que gostava de examinar os seus livros e com quem mantinha diálogos estimulantes, remeteu João Alphonso a uma mudez que preocupou os mais próximos, inclusive os colegas da Santa Casa. Num desses dias, quando se encontrava a sós na sala reservada aos

71 Esta primeira manifestação da cólera no Brasil é uma extensão de uma terceira pandemia (1852-1859) que, por sua vez, segundo TORNERO

"foi resultado de recrudescimentos locais da pendemia anterior [ 1829-1851

], aliados a um novo surto iniciado na Índia em 1852. Foi no decorrer dessa epidemia que, na Inglaterra, em 1854, John Snow demonstrou a transmissão da cólera pela água de beber e objetos contaminados com fezes de pessoas doentes" (i).

No Brasil, a cólera chegou pelo Pará, assolando, em especial, as províncias litorâneas. No Rio de Janeiro

"os dois primeiros casos ocorrerem em 19 de julho de 1855. ... Para socorrer o grande número de indivíduos, que diariamente eram acommettidos por ella, as primeiras enfermarias não chegaram e, por isso, mandou o governo transformar os postos médicos do interior da cidade em 'enfermarias espaçosas' ... todas ellas munidas de medicos, enfermeiros, irmãs de caridade, de botica, etc" (ii).

Quanto ao número de vitimas fatais desta epidemia no Brasil, elas teriam sido para mais de 200 mil (i). No Rio

"até o dia 10 de maio de 1856 o número de victimas era calculado em 4899" (ii).

i. TORNERO, N. Caminhos da cólera. São Paulo, Moderna, 1995. p.10.

ii. BARBOSA, P. \& REZENDE, C. B., Op. cit., p. 79. 
médicos do hospital, entrou o Capelão. João Alphonso, com os braços cruzados e encostado na parede, olhava perdido através da janela. $O$ padre o cumprimentou-o solicitamente:

- Bom dia, doutor João, podemos trocar algumas palavras ? João Alphonso recompôs-se pela presença do capelão, e falou:

- Bom dia, padre ... algum problema?

- Creio que a cidade enfrenta vários problemas - falou o capelão com um forte sotaque francês - e não somos espiritualmente imunes a eles.

João Alphonso percebeu que nenhuma urgência trazia o capelão até ali e convidou-o a sentar-se numa poltrona já velha, mas confortável, sentando-se, em seguida, ao seu lado.

- Mas então, padre, eu posso ajudá-lo em alguma coisa ?

Com consciência e simpatia, o padre comentou:

- Os médicos sempre acham que alguém que se aproxima sempre precisa de ajuda. O hábito faz o frade e estamos quites, não é mesmo ? Mas eu gostaria mesmo é de conversar um pouco com o senhor, se me permite.

- É curioso, veja que nunca conversamos antes. Encontramo-nos pelos corredores, vejo-o assistindo os pacientes mais graves ...

- De fato. E eu também nunca o vi na nossa capela, mesmo nas datas comemorativas.

- Quanto à consciência espiritual, cada um vivencia a sua e estamos quites, não ê mesmo ?

Inteligente, o padre mediu a extensão do argumento do interlocutor e concordou com o acordo, reiniciando o diálogo:

- Doutor João! A capelania tem um compromisso de assistência espiritual, não apenas aos pacientes, mas a toda comunidade hospitalar. Especialmente neste época em que a cidade, o pais, enfim, sofre com os graves casos de cólera, as perdas ocorrem freqüentemente e a dor é imensa. Sei que o senhor perdeu recentemente um parente muito querido, vitima da doença e reconheço o sofrimento que toda sua familia tem vivido. Eu não desejo ser inoportuno, mas, caso o senhor deseje, a capelania se coloca à disposição para ajudá-lo a transpor este momento tão difícil.

- Eu compreendo o seu cuidado, padre. Creio que tenho despertado preocupações em muitos. Mas o senhor sabe o peso e as exigèncias de 
uma experiência vivida. A gente acaba estabelecendo maneiras próprias de enfrentâ-la.

- Mas nem sempre conseguimos, pelos próprios meios, acalmar ou aceitar resignadamente nossos sofrimentos.

- Para mim, não se trata exatamente de acalmar ou aceitar. Eu prefiro vivenciar, o que talvez incomode a quem nos cerca.

O capelão, na tentativa de evitar mais uma vez uma discussão de principios, indagou:

- O senhor não considerou a hipótese de se licenciar temporariamente do trabalho para se refazer do desgaste sofrido pela morte do pai e do cunhado, mais recentemente?

- Não. Não considerei esta hipótese. Aliás, a última vez que usei desta prerrogativa, não alcancei o resultado esperado.

- Trabalhou mais do que descansou - disse, perguntando, o capelão.

- Pior. Foi quando meu pai morreu. Eu havia me licenciado para ir a Minas Gerais encontrar-me com um naturalista dinamarquês que vive em Lagoa Santa. Já bem próximo, em Ouro Preto, recebi a notícia e tive que retornar. Além disso, em Ouro Preto me envolvi com uma outra epidemia que grassava na região de Mariana, a variola.

- Sei muito bem o que o senhor deve ter passado. Foi terrivel aquela epidemia de variola, com seqüelas ainda frescas a nos lembrar.

- O senhor estava lá naquela época ?

- Não estive pessoalmente. É que a nossa congregação missiona naquela provincia, mantendo várias outras atividades por lá ${ }^{72}$.

72 A documentação sobre os padres Lazaristas e a capelania da Santa Casa do Rio é farta no arquivo central na Congregação. O Padre José Tobias Zico, em entrevista concedida entre os dias 15 e $17-07-1996$, assinalou aspectos funcionais deste exercício. Entre os autores que mencionam a relação dos religiosos da Congregação da Missảo com aquele hospital está ZARUR (*) que afirma:

"crescia a rede hospitalar da Irmandade e urgia organizar um serviço de assistência religiosa nos moldes do que existia na Europa.

Depois de estabelecer negociaçðes com a Congregaçðes das Irmås de Caridade São Vicente de Paulo, na França, ... O primeiro grupo ... desembarcou em 20-9-1852... As irmãs de Caridade e os Padres lazaristas foram os anjos de bondade que socorreram legiðes de vitimas. Muitas religiosas foram imoladas...". 
- Em Ouro Preto fui bem informado sobre a ação do bispo de Mariana durante a ocorrência da variola.

- O Dom Antōnio Viçoso ! - exclamou o capelão.

- Ele mesmo.

- Ele é da nossa congregação. Somos padres da Congregação da Missão, ou lazaristas, como somos conhecidos.

- Sabe que eu nunca tinha me interessado nesta particularidade ? Quer dizer, saber a qual ordem ...

- Congregação, doutor - corrigiu o capelão.

- ... pertence a capelania da Santa Casa !?

- Talvez não seja o único que não saiba. Mas isto só nos ensina sobre a quantidade de coisas que não sabemos, não é mesmo, doutor?

- De fato, umas mais, outras menos importantes.

Desistindo no momento de qualquer comentário mais abstrato, o capelão quis confirmar:

- Então o senhor teve informações sobre o nosso bispo de Mariana?

- Aliás, fui muito bem informado. Na época, os seminaristas estavam sendo transferidos para um colégio mantido pela congregação.

- É. O colégio Caraça, a poucas léguas de Mariana. Muitos dos padres e irmãos que estão lá, inclusive jâ prestaram serviços aqui na Santa Casa. O último deles foi o Irmão Leben 73 .

- Um alemão? Agora eu me lembro, o dr. Lallemant havia me falado alguma coisa a seu respeito. E de Potsdam, se não me engano. Mas, sobre o Caraça, falaram-me muito bem deste colégio. Disseram-me que fica numa região previlegiadíssima quanto às condições naturais. Fui até convidado a visitar o local.

* ZARUR,D. Uma velha e nova história da Santa Casa. 2a. ed. Rio de janeiro, Binus Artes Gráficas Ltda., 1985. p. 68-9.

73 Irmão João Fernando Leben, natural de Potsdam, Alemanha, nasceu em 30-01-1826. Chegou ao Brasil em 18-8-1853, servindo na Santa Casa do Rio de Janeiro. Morre no Caraça em 05-01-1878 (*)

(*) Esta informação está contida em um manuscrito que se encontra no Colégio Caraça, sob o título "Congregados no Caraça: 1820-1952" de autoria do Padre Pedro Sarnel. Doravante, o referido manuscrito será citado apenas como "Congregados no Caraça". 


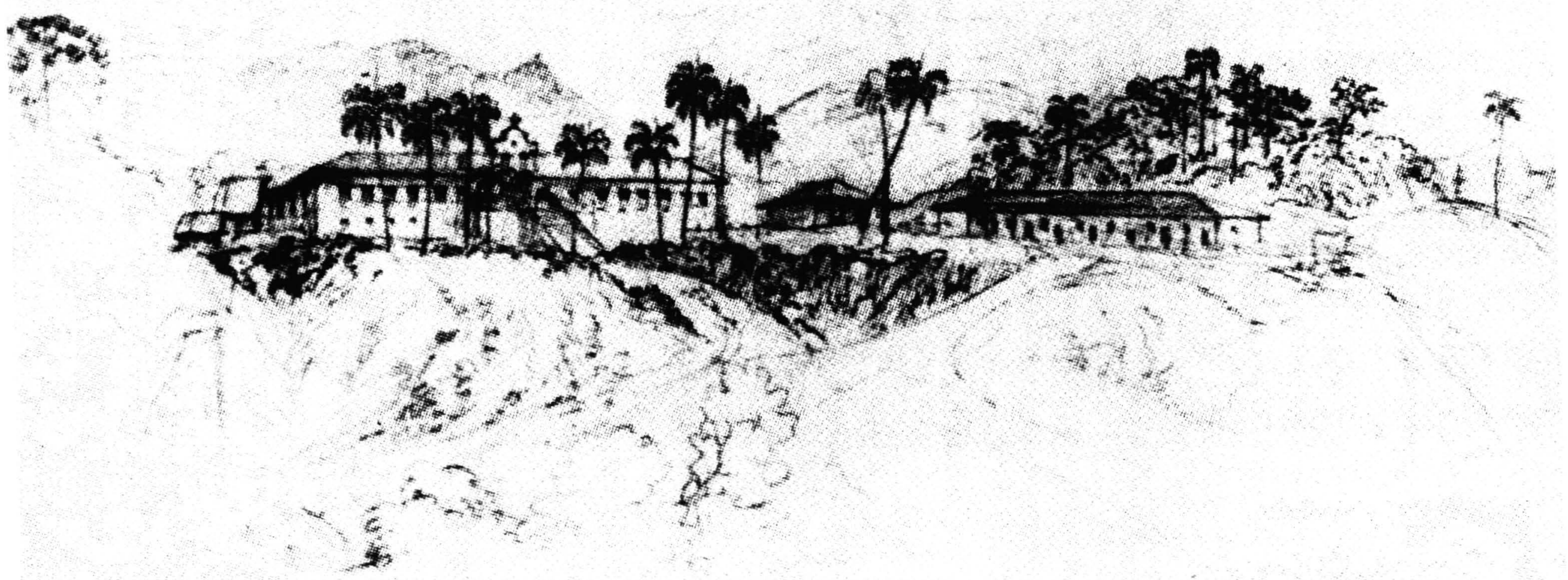

O Colégio Caraça, em 1824, visto por Rugendas, por ocasião da Expedição Langsdorff. 
- Que interessante. Creio que o senhor não se arrependeria. E por acaso o senhor aceitaria um outro convite e nos honraria com sua presença no Caraça?

- Eu agradeço muito o convite, senhor padre, mas não posso afastar-me do Rio tão cedo. Mas, quem sabe um dia eu possa visitar este falado Caraça. Tenho um compromisso de viagem a Lagoa Santa, completar o projeto que não pude terminar, e como os dois lugares são relativamente próximos, talvez eu aceite o convite.

- Estaremos à disposição. De qualquer forma, doutor João, eu gostaria de ter mais oportunidade para conversar ...

O diálogo dos dois foi interrompido por uma enfermeira que solicitou a presença imediata de João Alphonso numa das enfermarias. Despedindo-se brevemente, houve apenas tempo de João Alphonso dizer ao capelão que conversariam noutra oportunidade.

Morten Schwarzkopf havia escrito uma carta longa, onde dissertava acerca de vários assuntos. Afirmava que ia se dando bem em Breslau ${ }^{74}$. A clientela, fiel, aumentava e já era médico de um bom número de familias. Dizia também que era bastante respeitado por seus colegas da cidade e de outras proximas, como da vizinha Posen. Reuniase periodicamente com os colegas, para comunicações e discussões de casos. Ele se relacionava muito bem com os médicos rurais, de quem recebia pacientes encaminhados. De um modo geral, os médicos rurais de Breslau eram, dizia Morten, perspicazes e seguros, qualidades que poderiam ser explicadas pela necessidade de uma clinica que considerasse a inserção natural dos pacientes e por uma ação que

\footnotetext{
74 Breslau (Atualmente Wroclaw, Polônia) é uma antiga cidade fundada no século X e que

"cresceu como centro comercial da rota entre o sul da Europa e o mar Báltico".

A sua universidade é de 1726 e a cidade mantém, além da Catedral, várias igrejas góticas $(*)$.

- GROLIER MUltimEDIA ENC., Op. cit. : Wroclaw.
} 
compensasse a ausência de recursos como hospitais, etc. Morten dizia ainda que ele próprio, às vezes, clinicava na zona rural, em substituição a algum dos colegas. Declarava que até gostava destas substituições ocasionais. À cavalo, era a oportunidade de percorrer caminhos onde o horizonte era infinito. Entretanto, dizia que sair de Breslau neste momento seria impossivel. As tarefas quotidianas tinham-no absorvido de tal forma, que se sentia impotente para tomar novos rumos. Por isso é que andar a galope em torno de Breslau, imaginando coisas, fazia-lhe muito bem. Ele confessava ainda que a cidade despertava a saudade que mantinha dos tempos de Gōttingen. As igrejas góticas, os edificios medievais ... a universidade. Esta última, também conceituada em diversas áreas, criada no início do século XVIII, parecia-lhe aberta às exigências de investigações em áreas básicas da biologia e quimica, o que é de grande valia para a medicina, opinou Morten. Neste sentido, quanto ao progresso da disciplina médica, Morten aconselhava João Alphonso a não perder de vista os ensinamentos de Jakob Henle em seu livro Pathologische Untersuchungen, acerca da reprodutibilidade de doenças por germes ${ }^{75}$. Dizia ainda que o futuro da Tropenmedizinische estaria ligado a esta categoria de investigações.

75 F. G. Jakob Henle (1809-1885) foi um atento anatomista com muitas contribuições à histologia (i). Em 1940 publicou o livro Investigações patológicas (Pathologische Untersuchungen).

"Este livro, graças à sua primeira seção, relativa a 'miasmas e contágios e doenças miasmático-contagiosas', é hoje considerado um marco na história da bacteriologia e das doenças comunicáveis. Diferentemente de outras contribuiçðes médicas importantes, porém, o ensaio de Henle não contém uma única descoberta nova. Sua contribuição é de outra ordem; louvando-se em reflexס̃es deduzidas de observaçðes de outros, e mediante argumentos lógicos e convincentes, Henle formulou uma teoria em que se considerava os organismos vivos a causa das doenças contagiosas e infecciosas" (ii).

Jakob Henle, ainda em 1840, afirmara que

"o germe precisava ser identificado no organismo afetado; que tinha de ser isolado do organismo afetado e cultivado em ambiente puro, para que suas propriedades morfológicas e funcionais pudessem ser estudadas; e que, a partir da cultura em ambiente estéril, seria necessário reproduzir a doença em animais de laboratório, dos quais seria então preciso recuperar o germe" (iii). 
João Alphonso respondeu sem o mesmo ânimo do amigo. Falou dos infortúnios que the ocorreram ultimamente: da morte do pai, que provocou o desencontro com o Dr. Lund, à epidemia de cólera que lhe tirara um cunhado. Lamentava a escassez dos recursos humanos frente ao sofrimento oriundo das tragédias cotidianas. Mas que acreditava no silêncio a ser ocupado pela reflexão criativa. Era desta forma que ele esperava se fortalecer para viver, pelo menos na sua subjetividade, minimamente confortado. Não era por outro motivo que mantinha seus projetos pessoais, entre eles o de reiniciar a viagem a Minas. Achava, escreveu João Alphonso, que apanhar, compreender a cotidianeidade do Dr. Lund, o seu mundo comum, o ajudaria construir uma noção razoável sobre a importância, as dificuldades e os limites, as incertezas de uma razão acolhida plenamente pelo conhecimento científico. Ainda nesta carta, ele reclamou de pessoas próximas que o viam como um indivíduo de bastante 'imaginação especulativa'. Solicitavam-lhe que colocasse sua capacidade especulativa a serviço da pesquisa médica e, para isso, não era raro receber convites para montar laboratório parecido aos alemães. Disse ao amigo que não polemizava sobre tais argumentos, mas ponderava sempre que a medicina não deveria prescindir de conhecimentos que não os da biologia. Por fim, João Alphonso pedia informações sobre o projeto de saúde publica proposto por e Neumann e que tinha em Virchow, no plano político, uma das pessoas mais combativas. Lamentava que no Brasil não houvesse nenhuma iniciativa em prol da saúde pública e que aqui se esperava que o conhecimento médico fosse, de fato, o grande empreendedor da saúde da população ${ }^{76}$.

Estas deduçðes teriam que esperar algumas décadas para completa comprovação experimental.

i. GROLIER MULTIMEDIA ENC., Op. cit. : Henle, Friedrich.

ii. ROSEN, G., Op. cit., p.233-4.

iii. STEINBRÜCK, P. Robert Koch. A saúde do mundo. Janeiro, 1982.

76 Segundo FONTENELLE (*), comentando a atuação da Junta Central de Higiene Pública na primeira metade da década de 1850 , 
Neste sentido, descrevia as condições de pobreza de grande parte da população e a lastimável situação da instrução pública.

Logo nos primeiros meses de 1856, João Alphonso recebe uma carta de Berlim com uma noticia que o deixaria consternado: aos 42 anos de idade, falecera, em 11 de novembro último o filósofo dinamarquês Kierkegaard. Este acontecimento além de lhe oferecer um outro momento de profunda introspecção, remeteu-o a pensar no possivel estado do Dr. Lund. Quem sabe este até estaria em preparativos de viagem para a sua terra. A partir de então, João Alphonso foi gradativamente se desinteressando de planejar uma nova viagem a Lagoa Santa. Não imaginava ele que não só o Dr. Lund ficaria sabendo da morte do parente bem mais tarde, como tambèm jamais ele voltaria à sua terra ${ }^{77}$. Era dificil para ele se imaginar conversando com o Dr. Lund sobre um parente morto recentemente. $O$ conhecimento e a relação de experiência que gostaria de estabelecer com o naturalista estariam profundamente prejudicadas, avaliou. Assim, reconsiderou a possibilidade de uma nova viagem e deixou em aberto a sua realização em outra época.

Sem a perspectiva de uma nova viagem a Minas e sem um outro projeto a curto prazo, passou a corresponder-se com mais freqüência e a se dedicar com mais intensidade à clínica. Na Santa Casa encontrava-se às vezes com o Capelão. Estes encontros agradavam-no pelo respeito

“... salientamos aqui nessa epocha estava a Hygiene ainda limitada a procurar actuar principalmente sobre a ambiencia, quasi nada podendo fazer em relação à prophylaxia dos males epidemicos, pelo desconhecimento da acção dos individuos como fontes de contágio e dos meios de obsta-la".

* FONTENELLE, J. P. Op. cit., p.424.

77 De acordo com STANGERUP (*), Dr. Lund ficou sabendo desta mcrte muito tempo após:

"Numa carta de Henrik Ferdinand, com atraso de mais de dois anos, fica - Dr.

Lund - sabendo da morte do mais jovem dos Kierkegaard".

A demora nas correspondèncias, especialmente para o interior do Brasil, às vezes eram desanimadoras. Por vários motivos. Entretanto, não era habitual tanto tempo sendo mais comum poucos meses entre a Europa e o Rio de Janeiro.

* STANGERUP., Op. cit., p. 255. 
mútuo entre ambos e pela ausência de ilações alusivas a vaidades pessoais, porque evitava contatos, tão freqüentes no seu meio, permeados pela ambição de ascensão política, econômica e social. Com um ou outro colega, mantinha relações cordiais e era respeitado por eles. Certo dia, foi convidado por um destes colegas para acompanhá-lo durante um atendimento domiciliar. O colega gostaria de ter um segundo diagnóstico de determinado paciente. Iriam consultar o botânico Luís Riedel, que trabalhava no Museu Nacional e que tinha aproximadamente 70 anos de idade $^{78}$. João Alphonso já conhecia de nome o velho naturalista, mas nunca tivera oportunidade de estabelecer um contato pessoal mais prolongado com ele, a não ser uma vez, numa reunião patrocinada pelos Lallemant, quando the foi apresentado formalmente. Agora, aceitou com satisfação o convite e viu a possibilidade de conhecer melhor o cientista berlinense que, segundo o colega que o convidou, era amante de Göethe, Schiller ...

Riedel foi diligente e paciente para falar de si e corresponder à curiosidade dos dois moços. João Alphonso surpreendeu-se com os relatos da viagem do botânico na expedição organizada por Langsdorff, das suas estadas na fazenda da Mandioca e, para espetacular surpresa de João Alphonso, da sua viagem de estudos, entre os anos de 1833 e 1834, na companhia do naturalista dinamarquês Peter Lund ${ }^{79}$. Por conta

78 O berlinense Ludwig (Luiz) Riedel ( 1790-1861) foi assistente de Langsdorff (i) em suas pesquisas e segundo LACERDA (ii)

"Entrou para o Museu Nacional do Rio de Janeiro em 1842. Diretor da secção de botânica, por decreto de 11 de fevereiro de 1842; designado para substituir o diretor do Museu, por portaria de 4 do 01 de 1844, deixa 0 exercício das funçðes deste cargo em 4 de março do mesmo ano. Falecido, em exercício do cargo de diretor de secção, em 4 de agosto de 1861".

i. BECHER, H. Op. cit., p. 66.

ii. LACERDA, L. B. Fastos do Museu Nacional do Rio de Janeiro. Rio de Janeiro, Imprensa Nacional, 1905.

p. 175.

79 A participação de Riedel na sua expedição com Lund é documentada nos diversos relatos sobre a vida do naturalista dinamarquès, entre eles os de MATTOS (i) e 
destes relatos, João Alphonso passou a visitar Riedel com alguma freqüência, sempre obedecendo o estado de saúde deste. Foi Riedel quem o alertou da complicada personalidade do Dr. Lund. Para Riedel, o recolhimento e a solidão a que se submeteu o naturalista de Lagoa Santa tinha raizes profundas e que dificilmente ele conseguiria estabelecer uma relação, um diálogo, nos níveis desejados por João Alphonso. Ainda mais agora, com a morte de mais um Kierkegaard. Mas como conseguia aquele homem organizar sua vida cotidiana? Quis saber João Alphonso. Riedel, que mantinha contatos com o ex-companheiro de expedição cientifica, informou que Lund, um homem de familia dinamarquesa rica, contava há muito tempo com um zeloso secretário, que também era eximio desenhista. Era o norueguês Peter Brandt, cuja história era fantástica. Riedel contou que Brandt, depois de ter estado no Chile, teria chegado a pé a Curvelo, não muito longe de Lagoa Santa, e trabalhado por algum tempo com um outro dinamarquês que ali tinha uma fazenda e desenvolvia uma ciência de qualidade duvidosa. Foi ao final da sua viagem com Lund, contou Riedel, que ambos conheceram o fazendeiro e seu desenhista. Desde então, Brandt trabalha para Lund.

João Alphonso concordou que a história era inacreditável. Viajar do Chile a Curvelo a pé... E recordou, há tempos atrás a resposta do Dr. Lund a uma carta: viera assinada por Peter Andreas e com um sobrenome que ele não distinguiu adequadamente. Agora, relacionava as pessoas. Mas João Alphonso queria lembrar que teria ouvido alguma referência a um certo Brandt, quando esteve na Alemanha. Comentou com Riedel e quis saber de que cidade norueguesa era o desenhista. Riedel lhe contou que não tinha certeza, mas poderia ser de Kristiana. Estupefato, João Alphonso lembrou da sua estada em Travemünde e da

STANGERUP (ii). iNo primeiro, há um equívoco do autor, ao transcrever parte do testamento do Dr. Lund. Com data de 21-6-1871, o naturalista refere-se ao Sr. Augusto Riedel que não é, obviamente, o botânico Ludwig, como aponta o autor. Entretanto, nas outras referências há concordâncias biográficas e históricas que demonstram tratar-se do referido botânico.

i. MATTOS,A. Op. cit., p.9, 288.

ii. STANGERUP. Op. cit., p. 100-23. 
conversa do pai de Morten sobre um norueguês "fujão" que se encontrava em algum lugar da América do Sul. Sobre este assunto, Riedel fez dissipar a ansiedade do outro: contou-lhe que Lund, numa carta, comentou que Brandt havia recebido a visita inesperada do filho mais velho, negociante próspero em Nova York ${ }^{\mathbf{8 0}}$. Assim, apesar das informações que o deixaram pessimistas quanto ao seu possivel encontro com o Dr. Lund, João Alphonso sentiu-se muito bem na companhia daquele senhor que, muito mais que um botânico, conhecia bem várias disciplinas da história natural. Foi assim que, em um dos seus encontros, Riedel mostrou-lhe alguns livros. Alguns já raros e envelhecidos pelo tempo, uns da sua coleção particular, outros emprestados para estudo. João Alphonso interessou-se por uma edição de "De Medicina Indorum" do médico holandês Jacobus Bontius. Riedel esclareceu-lhe que a primeira ediçāo deste livro surgiu em 1642 em Leyden e que o dr. Bontius, além de médico, foi um arguto naturalista e o escreveu na possessão holandesa de Java, onde foi o primeiro médico da Companhia Holandesa das Índias Ocidentais ${ }^{81}$. Sugeriu a João Alphonso

\footnotetext{
80 Peter Brandt, que viria a falecer em Lagoa Santa no ano de 1862 , reencontrou um dos seus filhos anos antes.

"Ao completar sessenta anos Brandt recebe inesperadamente a visita de seu filho mais velho, vindo de New York, onde fez transaçðes comerciais por uma firma de Bergen que agora lhe pertence..."

* STANGERUP,H. Op. cit., p. 246.
}

81 A Companhia Holandesa das Índias Ocidentais foi uma importante companhia comercial estabelecida na Holanda no século XVII. Através da atividade corsária, construiu colônias em várias partes do mundo (i). Por exemplo, no Brasil os holandeses se fixaram em Pernambuco por vários anos e na Ásia controlaram, por mais de três séculos, muitas ilhas da Indonésia, entre elas a mais importante, Java. Somente em 1945 as ilhas tornaram-se independente da Holanda, que reconheceu esta independência em 1949 (ii). Jakob Bontius (James de Bondt) (1598-1631) foi nomeado, a um só tempo, como governador em Java e primeiro médico da Companhia. Durante os quatro anos em que esteve na ilha, escreveu sobre a história natural e as doenças do local, sendo que "De Medicina Indorum" foi publicado, pela primeira vez, por seu irmão, em 1642, seguindose várias outras ediçðes. Além deste, um outro livro de sua autoria, mas inacabado, foi posteriormente publicado (1658) em Amsterda, juntamente com o "Tratado de Plantas do 
ler alguns trechos do livro sobre a descrição de doenças, onde poderia ver que as limitações do conhecimento de uma época não poderiam ser vistas como empecilho à formulação de hipóteses inteligentes para explicar fenômenos ainda a serem esclarecidos. O cientista deve ser, disse Riedel a João Alphonso, antes de tudo, atrevido, já que mesmo os erros pelo atrevimento podem ser bastante úteis a outros cientistas, encurtando seus caminhos. E concluiu dizendo que não seria bom se houvesse apenas cientistas parcimoniosos e excessivamente calculistas. Mas este alemão, que acabou tomando um certo gosto pelo médico brasileiro que falava agradavelmente sua lingua, a ponto de preferir conversar com este não em português, recomendou a aquele que consultasse também a obra de um naturalista brasileiro muito expressivo por suas longas pesquisas na Amazônia, em fins do século XVIII, Alexandre Rodrigues Ferreira ${ }^{82}$. Nele havia um bom material sobre

Brasil", de Guilherme Piso (ou Pison) (iii). Este último naturalista esteve no Brasil durante a ocupação holandesa no nordeste.

i. ROWEN, H. H. Dutch West India Company. In: Grolier Multimedia Enc. Op. cit.

ii. KLEE, G. A. Java. In: Grolier Multimedia Enc. Op. Cit.

iii. SANDWITH, F. M. A historical note on beri-beri and rice from the writings of $\mathrm{dr}$. Bontius. Transactions of the .... , II (7,8): 257-259, 1909.

82 O naturalista Alexandre Rodrigues Ferreira (1756-1815), natural da Bahia, estudou em Coimbra, onde se matriculou em 1770. Na sua viagem exploratória pelo Brasil, entre 1783 e 1792, percorreu os estados do Amazonas, Mato Grosso Sul e Norte, e Pará. Esta viagem atendia 0 anseio do governo português, que

"planeou conhecer mais cabalmente os recursos coloniaes, por meio de esplorações confiadas a sabedores exímios" (i, p. 17).

O naturalista, segundo REIS (ii), no Diario da Viagem philosophica pela Capitania de S.José do rio Negro,

"falla sobre a deficiencia da alimentação dos naturaes, ... Para suas observaçð̃es sobre o beriberi, que foi o primeiro a reconhecer no Brasil, solicitou a opinião do cirurgião Antonio José de Araújo Braga que afirmou: a paralysia a que chamam beriberi ou beriberium acontece neste paiz pela mesma causa e do mesmo modo que em Java".

Nestes termos, é factivel admitir que o cirurgião baseasse sua comparação, direta ou indiretamente, a partir de Bontius em "De Medicina Indorum". 
doenças do meio, algumas endêmicas, e João Alphonso - disse Riedel poderia confirmar que não basta um trabalho ser bom para que o mesmo se preste à melhoria das condiçōes de vida das populações.

Durante alguns dias, João Alphonso pensou nos ensinamentos do professor Riedel, como alguns o chamavam. Passou a ler as obras recomendadas e ainda por algum tempo viria a comentar com o botânico algumas observações tiradas dessas leituras. Desta forma, chamou-lhe a atenção que ambos os autores, J. Bontius e A. Ferreira, fizessem menção, entre tantos assuntos de que trataram, a uma doença que ele próprio raras vezes viu mencionado, o beribéri. Bontius mencionava que indigenas javaneses conheciam uma doença a que chamavam de beribéri, chegando mesmo a prescrever tratamento para pacientes com a doença. Diz ainda que ele próprio, mulher e filho sofreram da doença. Sendo de causa desconhecida, é curioso que o médico experimentasse uma hipótese exótica para entender o aparecimento da doença em algum dos seus estágios. Sem afirmar que o arroz da dieta fosse a causa da doença, afirma que este cereal quente era perigoso.

Por outro lado, Alexandre Ferreira comenta a alimentação deficiente dos habitantes da região e observa casos cujos sintomas assemelham-se aos do beribéri. $O$ naturalista brasileiro, a serviço de Portugal, relata a doença e concorda com a opinião de um cirurgião português. Este, categoricamente, não só reconhece o quadro de beribéri, como também afirma sua semelhança com o beribéri em Java. É provável que esta comparação tenha se baseado na descrição do dr. Bontius. Para completar sua observação, o cirurgião Araújo Braga acaba oferecendo seu tratamento para aquele mal, baseado em fomentações e banhos de vapor à base de ervas aromáticas, recomendação parecida com a que é sugerida pelo médico holandês em sua obra. Riedel pôde ainda informar a João Alphonso que havia alguma referência sobre a dcença na obra de

i. CORRÊA FILHO, V. Alexandre Rodrigues Ferreira: vida e ubra do grande naturalista brasileiro. São Paulo, Companhia Editora Nacional, 1939. (Brasiliana, Série 5!, vol. 144).

ii. REIS, A. A. de S. A história da medicina no Brasil (Notícia Synthetica). In: Diccionario histórico, geographico e ethnografico do Brasil. Up. cit. p. 1286. 
Guilherme Pison, que por sete anos esteve no Brasil durante a ocupação holandesa. De fato, observou posteriormente João Alphonso, este outro médico e naturalista holandês descreveu, entre outras enfermidades, sobre as paralisias que eram vulgarmente chamadas de 'stupôr' mas que não se confundiam com o beribéri.

Os contatos de João Alphonso com o botânico Riedel foram abreviados pelo estado de saúde deste. Em 1861, ele viria a falecer e deixaria um vazio, que se fazia presente através de uma tristeza miúda que acompanhou por algum tempo a vida do novo e breve amigo. Ao velho amigo, Morten, João Alphonso falou do botânico e de suas leituras sobre a Beriberikrankheit. Apesar das referências de A. Ferreira e G. Piso, especialmente controvertidas no que se refere ao quadro clínico da doença, até aquela data não havia uma memória médica que descrevesse pontualmente a doença no Brasile3.

A higiene, enquanto disciplina curricular, se fazia presente desde o início do curso médico no Brasil como um conjunto de principios e práticas cujo objetivo seria o de melhorar e preservar a saúde. A disciplina abarcava valores e conhecimentos distintos. Da natureza moral e espiritual aos conhecimentos científicos disponiveis, a hygiene assumia a função de enunciar normas que se prestavam ao melhoramento físico e moral dos homens ${ }^{84}$.Assim, principalmente após

83 SALLES $\left({ }^{*}\right)$ afirma que

"Na literatura medica nacional sôbre o beribéri, parece que a primeira publicação é uma comunicação de $\mathrm{A}$. Medeiros a respeito do aparecimento da doença no Ceará, durante uma das graves sêcas da região, em 1825".

* SALLES, P. História da medicina no Brasil. Belo Horizonte, G. Holman Ltda, 1971. p. 234.

84 SFEZ (i) assinala que o século XIX é marcado por um forte apelo à higiene, à saúde fisica e moral e, portanto, à repressão. Não se pode esquecer, que neste período, especialmente no que se refere às teorias médicas, as questð̃es do meio ambiente se relacionavam sobremaneira com a etiologia de muitas doenças: a teoria miasmática. FREYRE (ii) afirma que

"os miasmas eram a obsessåo dos higienistas da época" 
uma reforma em 1854, o ensino médico, que continuou mantendo os principios básicos da reforma maior de 32 , mantinha a higiene como disciplina norteadora da própria conduta dos esculápios. À higiene interessavam todas as atividades do individuo. Esta relevância da disciplina repercutiu na opção temática das teses que os formandos do curso médico, como exigência para concluir o curso e exercer a profissão, elaboravam, em latim ou português, ao final do curso.

Nestas circunstâncias é que chegou às mãos de João Alphonso, atraves de um lente da Faculdade de Medicina que lhe solicitou uma avaliação pessoal, a tese intitulada Esboço de uma Hygiene dos Collegios, cujo subtítulo continha: applicavel aos nossos. Regras tendentes à conservação da saúde $e$ ao desenvolvimento das forças physicas $e$ intellectuais, segundo as quaes se devem regular os nossos collegios ${ }^{85}$.

e que neste universo foi que

"...o Dr. Luís Correia de Azevedo, em discurso na Academia Imperial de Medicina, que a construção das habitações no Rio de Janeiro era 'a mais defeituosa que existe no mundo'. ... 'nenhuma condição de ventilação, salas quentes e abafadas, alcovas humidas, escuras e suffocantes, corredores estreitissimos, e sempre este exgotto na cozinha, essa sujidade bem junto à preparação dos alimentos quotidianos, tendo a aseu lado uma area, lugar infecto, nauseabundo, onde os despejos agglomerados produzem toda sorte de miasmas"”.

Dentre muitas, pode-se citar algumas teses que tratam da questão da higiene em variados aspectos sociais (iii), (iv), (v).

i. SFEZ, L. La santé parfaite: critique d'une nouvelle utopie. Paris, Éditions du Seuil, 1995 , p. 110.

ii. FREYRE, G. Op. cit., p. 209.

iii. COUTINHO, C. T. de A. Esboço de higiene nos colégios. Rio de Janeiro, 1857. [Tese apresentada à : aculdade de Medicina do Rio de Janeiro].

iv. AUGUSTO. A. Higiene dos colégios. Rio de janeiro, 1858. [Tese apresentada à Faculdade de Medicina do Rio de Janeiro].

v. COELHO, J. F. de B. Dos casamentos sob o ponto de vista higiênico. Rio de Janeiro, 1878. [Tese apresentada à Faculdade de Medicina do Rio de Janeiro].

85

COUTINHO, C. T. de A. Op. cit. 
Avesso a este tipo de conduta, aceitou ler a tese por sentir, naquele instante, curiosidade sobre o que se produzia na faculdade. Até porque conhecer o universo era reconstituir um pouco do seu tempo de acadèmico. De fato, isto ficou asseverado desde quando leu a primeira frase da tese:

"A humanidade em luta continua contra a destruição creou a hygiene" ${ }^{86}$.

João Alphonso lembrou prontamente das discussões que tinha com o Morten membro de sociedade estudantil, acerca dos propósitos da saúde pública. Mais à frente, afirmava o autor da tese:

"O seculo XIX deve dar à hygiene o lugar que ella ocupa entre as sciencias, os progressos da chimica, da physica, da physiologia, as observações meteorologicas prestão-lhe 0 contingente de suas leis, que se convertem em principios hygienicos, evitando e attenuando a acção dos agentes externos, e corrigindo a sua influência sobre as funcções do organismo"87.

A importância dada às condições meteorológicas é condizente com o paradigma da época, que via nelas uma das origens das doenças. Assim, é que o autor da tese afirma também que

"O ar que se respira nas cidades não é certamente saudavel ... [e, assim] ... julgamos conveniente que os collegios fossem situados nos arrabaldes, os quaes são entre nós admiraveis, quer pela beleza da situação, quer pela salubridade"88.

A tese segue pronunciando-se sobre diferentes aspectos que influênciariam o desenvolvimento do indivíduo: a educação literária, moral e religiosa, a atividade física, sobre as substâncias que servem para a alimentação do homem, etc. Aplicadas à conservação da saúde e ao desenvolvimento das forças fisicas e intelectuais dos colegiais, como o

\footnotetext{
86 COUTINHO, C. T. de A. Op. cit., p.3

87 COUTINHO, C. T. de A. Op. cit., p. 6

$\$$ COUTINHO, C. T. de A. Op. cit., p. 10.
} 
próprio titulo afirmava, as proposições da tese tornavam-se próximas de um receituário com regras para que no ambiente colegial brotasse o homem ideal para a sociedade 89 . Esta função de brunir os meninos prestes a se tornarem homens é, de certa forma, uma extensão das obrigações da familia ${ }^{\circ}$. Duas proposiçōes da tese que lia chamaram a atenção de João Alphonso. A questão da educação literária e moral, proposição que ele viria a discutir com o Padre Bos, e a proposição relativa à alimentação. É que João Alphonso considerou atualizados os conceitos emitidos pelo autor. Isto é, as investigações científicas sobre os processos nutricionais que se desenvolviam na Europa, na Alemanha e na França, principalmente, quando traduzidas em recomendações práticas, não estavam muito distantes daquelas vistas na tese. Ele,

89 ARIĖS (i), descrevendo o nascimento da instituição 'colégio' na França, afirma, a certa altura, que

"O estabelecimento definitivo de uma regra de disciplina completou a evolução que conduziu da escola medieval, simples sala de aula, ao colégio moderno, instituição complexa, não apenas de ensino, mas de vigilância e enquadramento da juventude"(i, p. 170).

Para ANDRADE (ii), a instância colegial

"era (bem) aceita pelas familias, sensiveis à necessidade da aquisição de uma cultura letrata por parte dos filhos, garantindo-lhes a distinção social e o acesso (e permanência) aos estratos sociais mais elevados"

i. ARIĖS, P. História social da criança e da familia. 2a ed. Rio de Janeiro, Editora Guanabara, 1981 p. 169-171: Uma nova instituiçăo: o colégio.

ii. ANDRADE, M. G. de. Op. cit. p.56-7.

- FREYRE (i) considera que a educação nos colégios de padres - e ele cita a educação do Jesuita,

"foi a mesma que a doméstica e patriarcal nos seus métodos de dominação, embora visando fins diversos dos patriarcais".

De qualquer maneira o colégio não está desgarrado da sociedade em que se estabelece. Sociedade que apresenta a estes colégios jovens

"desobrigados do trabalho, em média dos dez aos vinte e cinco anos" (ii).

i. FREYRE, G. Op. cit., p. 71

ii. ANDRADE, M. G de. Op. cit., p. 57 
pessoalmente, não se interessou pelos detalhes destas investigações, mas mantinha-se bem informado através de periódicos, sustentado pela boa formação básica que obteve no seu curso, durante o qual o colega Morten discutia com interesse os avanços da fisiologia da nutrição. De um modo geral, João Alphonso aplicava à nutrição a mesma regra que permeava algumas das suas interpretações sobre os processos de saúde e doença: a regra de que todo o conhecimento especifico dentro das varrias disciplinas relacionadas à saúde humana é apenas posterior à vida humana. Ou seja, circundar ou condicionar a 'existência' a partir de certas descobertas cientificas, não é um bom caminho para se compreender os modos e os efeitos da apropriação deste conhecimento pelos individuos em suas comunidades. Existindo antes de se saber porque e como, as pessoas constituiram estratégias, umas mais e outras menos precárias, que permitiram a sobrevivência em situações diversas. Assim é que, para João Alphonso, as pesquisas da época sobre a nutrição poderiam se relacionar a casos particulares de enfermidades, mas isto não excluiria a necessidade de se compreender de que maneira os resultados destas pesquisas eram 'assumidos' pelas pessoas; qual o significado destes produtos (os resultados) frutos de uma atividade ( a pesquisa) que se colocava distante do seu dia-a-dia e, além disso, no embate de tantos valores (científicos, religiosos, etc.), como se organizariam os [valores] prioritários ? Carregado em suas indagações, João Alphonso procurou compreender a proposição alimentar do jovem autor da tese ${ }^{91}$.

91 "Ingesta" é o título do tópico da referida tese (i), em que estão enunciados os princípios da alimentaçåo. No dizer do autor

"Debaixo d'esta denominação -Ingesta- comprehende-se as substancias, que servem para a alimentação do homem".

Nesta tese, os principios subjacentes à alimentação preconizada sãc os seguintes:

"Importa à saude publica uma alimentação sufficiente e conveniente; sendo o alimento um reparador indispensavel do organismo, cujas perdas são continuas e remediadas pela ingestão, e assimilação de alimentos...";

“... sem uma boa alimentação sacrifica-se o desenvolvimento physico dos alumnos";

"Nos collegios deve haver um regimen aconselhado pela consciencia dos directores...";

"As refeiçðes se faråo tres vezes por dia: 
a primeira constará de café, leite e pão ...

a segunda constará de sôpa, um prato qualquer de legumes, carne assada e arroz;

a terceira constará de uma sôpa de arroz, marmelos, chá e pão".

"A quantidade dos alimentos varia segundo as idades, maior no sexo masculino do que no feminino ... e regulará nas seguintes proporções: 9 a 12 annos quatro onças, de 12 a 15 annos cinco onças, de 15 a 18 annos seis onças de carne; o leite, o pão devem regular na mesma proporção. O peixe deve seu usado uma vez por semana sendo fresco e de boa qualidade".

Afirma ainda o autor, entre outras assertivas, que a carne é indispensável à nutrição "... por ter maior quantidade de azoto do que outros alimentos...";

Que a alimentação deve ser variada, pois

“... o melhor prato muitas vezes repetido repugna; assim na qualidade, quantidade e variedade das substancias se resumem grandes vantagens para 0 corpo: uma alimentação mixta - vegetal e animal - é a mais saudàvel ..."

$O$ exame da orientação alimentar acima, baseado nos conhecimentos atuais, foi possivel fazendo-se alguns ajustes para suprir a falta de algumas informaçðes. Assim, a quantificação dos alimentos por refeição e a faixa etária considerada foram assumidas como valor médio daqueles sugeridos. Para a ausência de qualquer quantificação para alguns alimentos (p. ex., açucar e gordura), sugeridos por COUTINHO(i), optou-se por utilizar as quantidades médias encontradas para alimentos similares, em um inquérito realizado em colégios do Rio de Janeiro em 1933 (ii). Desta forma, a possível dieta sugerida na tese de 1857 , em 3 refeições, seria composta pelos seguintes alimentos e suas quantidades: $300 \mathrm{ml}$ de café e chá; $143 \mathrm{ml}$ de leite de vaca; 72 gr. pão francês; 350 gr. de preparação à base de legumes; 100 de abóbora; 143 gr. de carne magra de boi; 150 gr. de arroz polido; 80 gr. de doce; 50 gr. de laranja; 50 gr. de banana; 117 gr. de açucar, 70 gr. de banha de porco.

Destes valores foram calculados o conteúdo nutricional da dieta pelo "Food Processor", (iii) com dados da tabela do IBGE (iv). Os valores encontrados, que representariam o consumo médio diário de um colegial, foram comparados com as recomendações nutricionais sugeridas pela SBAN (v) para a população brasileira. Neste caso, optou-se por considerar as necessidades de um adolescente do sexo masculino, na faixa de 12,1 a 14 anos.

Enfim, os resultados mostram que a dieta estimada a partir das orientaçð̃es da tese de 1857 atenderia a maioria das necessidades nutricionais do individuo médio. Ou, em termos de calorias, proteínas, vitaminas A, B1, B2, C e niacina e ainda o mineral ferro, a dieta de 1857 cobriria todas as necessidades. Apenas no que se refere ao cálcio, haveria um grancie risco da dieta ser insuficiente.

i. COUTINHO, C. T. de A. Op. cit., p.16-18. 
Foi enquanto conversava com o colega médico sobre a tese que João Alphonso conheceu um padre recém chegado à Santa Casa. Era o padre Pedro Maria Bos, francês, e que iniciava seus trabalhos no Brasil. Jovem e de diálogo amável e conciliador, Padre Bos se constituiu num interlocutor apreciável. Motivado, o jovem padre gostava de falar da sua terra na França92. Era de Frayssinet, localizada entre os rios Dordogne e Lot, numa região repleta de memória medieval. Da infância, distante há menos de duas década, recordava os alegres passeios campestres e a fé cristã da familia que traçaria seu destino. Em outros momentos, falavam das mudanças que a França vinha sofrendo sob o segundo império.

ii. COUTINHO, R. Valor social da alimentação. Rio de Janeiro, Civilização Brasileira, 1937. p.313-356 : Dieta nos colégios do Rio de Janeiro.

iii. ESHA Corporation. The food processor ${ }^{T M}$ : computerized nutrition system. Salem, Bob \& Betty Geltz, 1984.

iv. FUNDAÇÃO IBGE. Tabelas de composição dos alimentos. Rio de Janeiro, 1977.

v. VANNUCHI, $\mathrm{H}$ et alli., ed. Aplicações das recomendações nutricionais adaptadas à população brasileira.

Ribeirão Preto, Legis Suma Ltda, 1990. (Cadernos de Nutrição, v.2).

92 O Pe. Pedro Maria Bos (1834-1916) chegou ao Brasil em 02-02-1859, ano em que se encontrava na Santa Casa (i). Entre 1895-1896 assume o superiorato do Caraça num período de dificuldades do colégio.

"Era preciso para as circumstancias criticas porque passava o Caraça, um homem afeito ao manejo dos negocios, intelligente e activo, e ninguem melhor do que o $P$. ${ }^{e}$ Bos estava nessas condiçðes, levando ainda a vantagem de ter deixado no Caraça um nome feito quer como professor, quer como procurador e missionário" (ii).

i. Congregados no Caraça. Op. cit.

ii. SILVA, F. Caraça apontamentos históricos e notas biográficas. Revista do Archivo Publico Mineiro, ano XII: 5-205, 1907. (*)

* Este trabalho do padre Francisco Silva CM (Congregação da Missão) é considerado como sendo a mais importante descrição da trajetória do Caraça desde sua fundação. em 1820 com a chegada dos dois primziros padres portuguêses, até os primeiros anos do século $\mathrm{XX}$ 
Concordavam especialmente quanto às transformações econômicas e as repercussões que acarretariam na sociedade ${ }^{93}$.

Numa dessas conversas, João Alphonso quis ouvir os argumentos do Padre Bos, que o teriam convencido a trilhar a vida religiosa. Mais tarde, acharia inútil perguntas desta natureza. Depois de uma fé harmoniosa, sólida formação e praticamente recém-saido do seminário, jorravam argumentos. Mas não foi, contudo, sem valor a interrogação. Sem ser elegíaco e munido de uma facúndia invejável, o jovem sacerdote acabaria contando a João Alphonso toda a história da sua congregação religiosa.

Os Lazaristas são os Padres da Congregação da Missão que também são conhecidos como Vicentinos. A congregação foi fundada por São Vicente de Paula na década de 20 do século XVII. São Vicente, que morreu em 1660 aos 79 anos, foi canonizado em 1737. Foi autor de inúmeras obras de caridade e quando da sua morte a congregação contava com cerca de 500 membros espalhados por vários paises europeus. O nome vulgar lazaristas deve-se ao fato de que a Sociedade dos Padres da Missão, que teve sua obra aprovada por uma bula do papa Urbano VIII em 1633, passara então para o priorado de São Lázaro, em Paris. A congregação enfrentou todos os delicados momentos políticos da Europa até então. Pilhados durante a Revolução Francesa, foram também cerceados na Polônia, Rússia, Alemanha, Portugal. Neste último,

93 A França, sob o segundo império (1852-1870), é marcada por importantes transformaçðes econômicas e sociais que lhe permitiram tirar, pelo menos em parte, $o$ atraso em relação a outras regiões mais desenvolvidas da Europa. Sob um poder político estável e forte, uma série de transformaçðes ocorrem na economia (crédito, comércio, transporte, comunicação, indústria, agricultura, etc), com repercussåo na sociedade. Paris, a grande "vitrine" do regime, recebe melhoramentos e acolherá em 1855 e 1867 as exposiçðes universais (i, ii).

i. BLANADET,R. La France sous le second empire (1851-1870). Alliance Française, Cordination Pédagogique, Săo Paulo, s.r.d. [ Texto didático mimeografado].

ii. PLESSIS,A. Napoléon III: Un Empereur "socialiste"?. L'Histoire, no 195, Janeiro, 1996. 
ficaram conhecidos também por Rilhafolenses, por inicialmente terem se instalado na Quinta de Rilhafoles, em Lisboa94.

A ação missionária era destacada como sendo a mais relevante atividade da Congregação, através das incansáveis missões de seus sacerdotes. Aliadas a esta atividade, a instrução e casas de caridade compunham a grande demanda95. Desta forma, entendeu João Alphonso, a manutenção de uma escola, situada num lugar tão ermo como a serra do Caraça, justificava-se pela necessidade de assegurar a doação real, mantendo ali um colégio de excelência que pudesse acolher filhos de familias de posses. Este assunto entre o padre e o médico não era tratado facilmente. A congregação sabia da precariedade do ensino público, mas não sendo objetivo do ensino religioso substituir o estado nesta obrigação, ela se colocava equidistantemente dos três motivos que erigiam o colégio: o fazer $o$ bem, atender aos pedidos dos pais e a subvenção às missōes. Como João Alphonso afirmara que jâ tinha algumas informações sobre a chegada da congregação no Brasil, o Padre Bos abreviou a sua narração sobre a chegada dos primeiros padres da Congregação da Missão - Padres Leandro Rabelo e Antônio Viçoso - ao Rio de Janeiro. Assumindo a posse e a direção do Santuário de Nossa Senhora Mãe dos Homens, o Caraça, este tornou-se a primeira casa da

94 RANDOLPH,B. Congregation of priests of the mission. In: Herbermann,C.G et al., ed. The catholic encyclopedia: An international work of reference on the constituition, doctrine, discipline, and history of the catholic church. Albany, The Encyclopedia Press Inc, 1913. v.10, p. 357-367.

GRANDE Enciclopédia Portuguesa e Brasileira. Lisboa; Rio de Janeiro, Editorial Enciclopedia Ltda, 1954. v. 14, p.772.

-5 Nas primeiras páginas do manuscrito Congregados no Caraça $\left(^{*}\right) 0$ autor enumera os motivos para abertura do colégio:

"1) animo do bem fazer

2) anuirem as repetidas instancias que as familias lhes dirigiam ...

3) para terem recursos pecuniários com que pudessem pregar gratuitamente as suas santa missőes, visto que não rendia bastante nem a propriedade do Cara̧a nem a Irmandade de N. S. Mãe dos Homens”.

* Congregados no Caraça Op. cit. 
Congregação no Brasil96. Em 1852, os padres lazaristas assumem a capelania da Santa Casa de Misericórdia, que tem a atuação acentuada de irmãs vicentinas. Até 1860 , os padres residiam na própria Santa Casa, quando passam, então, para a Casa São Vicente de Paulo, fundada naquele ano97.

Foi o Capelão da Santa Casa que, certo dia, apresentou a João Alphonso um jovem estudante de medicina, natural da provincia mineira. O rapaz, bastante jovem, havia estudado em Mariana e era filho de uma familia tradicional de Diamantina, a famosa cidade dos diamantes, no norte de Minas. Polido e curioso, o estudante afirmou que o Capelão havia lhe informado sobre o médico que estudara na Alemanha e com quem costumava conversar. Antes que João Alphonso dirigisse alguma palavra ao estudante, o Capelão comentou que o médico já estivera em

96 Primeira casa da Congregação da Missão de S. Vicente de Paulo no Brasil. Relação sobre o primeiro Superior da serra do Caraça em Minas gerais. Documento do arquivo do Caraça, (*).

(*) ZICO,J.T. Caraça: Peregrinação ... Op. cit. p.39.

97 Conforme afirmado anteriormente, a relação entre os padres da Congregação da Missão e a Santa Casa do Rio de Janeiro é amparada por uma série de referências em documentos (i) constantes nos arquivos da Casa Central da Congregação no Rio de Janeiro. Aqui, merece destaque um contrato (ii) entre a provedoria daquele Hospital e os Lazaristas. O contrato descreve direitos e deveres de ambas as partes. Por exemplo, exige a permanência fixa do padre no Hospital ; estabelece gratuidade de médico e farmácia ao religiosos, etc.

i. Doc. 8(2)CM/5, CR-118; Doc. $13(1) \mathrm{CM} / 12$, HI-2 ; Doc. 1(1) CC/10, HI-37 , referem-se, entre outras coisas, à residência dos padres na Santa Casa e à fundação da Casa São Vicente de Paulo, em 1860 no bairro de Botafogo, pelo Pe. Lamant.

ii. Doc. 13(1)CM/1, SA-1: "Termo das obrigaçðes dos reverendos padres da Congregação da Missão de São Vicentu de Paulo. Rio de Janeiro, 06/02/1857". 
Minas, tendo tido inclusive informaçōes sobre o bispo D. Viçoso. Surpreso, o estudante quis saber detalhes, e João Alphonso respondeu:

- Foi há alguns anos atrás, quando irrompeu na cidade uma epidemia de variola. Mas é provável que você ainda não estivesse lá.

- É verdade. Mas eu tenho conhecimento desta epidemia. Aliás, por conta dela o seminário foi transferido para o Colégio Caraça e ainda continua instalado lá.

- E a variola, não mais apareceu por lá ? - quis saber João Alphonso.

- Aparentemente sim, doutor, mas continuam a aparecer outros problemas. Há pouco tempo ocorreu uma outra epidemia naquele seminário.

- Não me diga que a cólera já anda residindo por lá.

- Não, não foi a cólera. Foi a epidemia das 'pernas inchadas' - respondeu o estudante.

- Epidemia das pernas inchadas ? Mas este è o nome vulgar de uma neurite que conhecemos por beribéri ! - disse João Alphonso.

- Eu ouvi este diagnóstico por parte de um outro médico. Parece que houve muitas vitimas.

O Capelão, com alguma informação sobre o caso, interveio:

- Não consta que tenha havido vitimas fatais. Parece que não havia muitos alunos e, além disso, as providencias foram imediatas.

- De qualquer forma, caso vocês tenham alguma outra informação sobre esta epidemia, gostaria que me comunicassem. Estive lendo algumas notícias sobre o beribéri e é a primeira vez que ouço dizer que anda ocorrendo esta doença atualmente no Brasil - disse João Alphonso, despedindo-se do padre e do estudante ${ }^{98}$.

- ALMEIDA (i) considera que as descriçð̃es do beribéri nc Drasiı anteriores a 1858 estão "cheias de incerteza" e que, por isso mesmo, "parece-nos mais acertado considerar a epidemia das 'pernas inchadas' occorrida em 1858 no Seminario de Mariana, em Minas Gerais, como tendo sido o primeiro surto epidemico do beriberi no Brasil de que se tem noticia" (i, p, 18).

Apesar da conviç̧ão do referido autor, não foi possivel encontrar referèncias a esta ocorrència, quer seja na literatura médica - exceto as que, posteriormente, reproduziram a citaçåo de ALMEIDA - quer seja através dos jornais da éfoca. Neste sentido, foram 
O diálogo de João Alphonso com os seus colegas não lhe trazia nenhum entusiasmo. Aliás, mais do que algumas divergências conceituais no dia a dia, havia, na verdade, abismos no que se refere à concepção e entendimento geral da realidade. Ele considerava exagerada a idéia de uma compreensão exata da realidade a partir unicamente dos métodos oriundos das ciências naturais. $E$ ele nunca encarava os fenômenos relativos à saúde e à doença como sendo unicamente concernentes às disciplinas das ciēncias biológicas. Entendia que a adoção de um esquema rigorosamente exato para se compreender o processo saúde-doença, ainda que trouxesse contribuiçōes, deixava de fora aspectos primordiais que envolviam o homem: a espontaneidade do homem, que se manifesta cotidianamente, a imediação, tanto quanto o sentimento, que muitas vezes atropela a ordem da razão e ainda, para o

pesquisados os periódicos de Ouro Preto e Mariana, de anos próximos a 1858, que se encontram disponiveis para consulta no Arquivo Público Mineiro - APM (ii).

Quanto ao autor, Theophilo de Almeida (1891-1988) estudou no Colégio Caraça entre os anos de 1905 e 1909 . Após uma brilhante passagem pelo colégio, entrou na Faculdade de Medicina do Rio de Janeiro, onde se formou em 1916 com a tese "O beriberi no Brasil". A fonte de informação para este suposto 'surto epidêmico' de beriberi no seminário de Mariana é um trabalho de um outro médico mineiro, Antônio Felício dos Santos (1843-1931), que estudou no referido seminário. Cedo, em 1863, A.F. dos Santos formou-se em medicina no Rio de Janeiro e em 1874 publicou a memória intitulada "Beriberi na Província de Minas" ( iii). Ao lado da atividade médica, envolveu-se na política, indústria e imprensa, onde se destacou como um atuante 'jornalista católico' (iv, v).

i. ALMEIDA, T. de. O beriberi no Brasil. Rio de Janeiro, 1916. [ Tese de conclusão de curso apresentada à Faculdade de Medicina do Rio de Janeiro em 26-05-1916].

ii. A relação dos jornais da época, disponíveis no APM e que foram examinados, pode ser vista na bibliografia do presente trabalho.

iii. SANTOS,A.F. Beriberi na provincia de Minas. In: AZEVEDO, A . C. de M. Beriberi. Rio de Janeiro, Typ. Acadèmica, 1875.

iv. COUTO, S. Vultos e fatos de Diamantina. Belo Horizonte, ..., 1954. p.239-40: Antônio Felício dos Santos.

v. FRIDERICHS, E. Perfis de grandes médicos. 2a ed. ..., Ediçð̄es Paulinas, 1964. p.39-58 : Dr. Antônio Felício dos Santos. 
que costumava haurir argumentos aplicados, o poder das tradições. Considerava positivo para o desenvolvimento da medicina a polêmica entre os contagionistas e os infeccionistas, mas via em ambas a mesma extensão de uma racionalidade que segregava, de um lado, a natureza e, de outro, as paixões e a história. A conseqüência disto, concluia João Alphonso, seria a enunciação de teorias que se fecham em si mesmas, ou seja, teorias que dariam conta de fenômenos já internamente descritos e que, portanto, teriam alcance relativo. Desta forma, estas teorias poderiam ser atropeladas por eventos os quais as ciências especificas ignoram ou desdenham.

Certo dia, no hospital, João Alphonso foi abordado por um professor do curso médico:

- Doutor João Alphonso, eu precisava conversar alguns momentos com o senhor ...

- Creio que temos algum tempo para isto agora!

- Doutor João - disse o professor aproximando-se e abaixando o tom de voz -, tomamos conhecimento de que o senhor andou enunciando, a nossos alunos, conceitos pouco amoldados a nós, médicos.

- As vezes converso com ou outro grupo de alunos, mas a quais conceitos o senhor se refere? - perguntou João Alphonso.

- Certamente que não se trata de contestar os seus conhecimentos clinicos. Nossos alunos até os apreciam. No entanto, ao contestar a capacidade do homem de imperar sobre a natureza e, enfim, sobre todas as formas de vida, o senhor subverte principios fundamentais à formação destes jovens.

- Ora, Professor, o senhor sabe que eu não sou um mestre da nossa escola médica e que por isso não estou a par destes principios fundamentais' a que se refere. Creio que o senhor poderia instruir-me a este respeito - disse João Alphonso.

O professor, que não imaginava seguir por esta trilha, procurou ser breve:

- Oh, doutor! O senhor bem sabe que, enquanto médicos, nossa eficácia está baseada no conhecimento científico. Sem o culto a este saber volveremos às trevas da ignorância e suas consequeencias.

Enquanto conversavam, passou e cumprimentou-os o Capelão, vindo do atendimento a um moribundo. 
- Se bem entendi, professor, se sem o conhecimento científico, resta-nos as trevas, suponho que aqueles que não 0 possuam se encontrem permanentemente na escuridão absoluta !? - argumentou João Alphonso. Levemente impaciente o professor afirmou:

- O senhor compreende que as vantagens da ciência se estendem a várias atividades humanas, beneficiando a todos, e neste percurso de beneficios vai desalojando a ignorância dos espíritos.

- Sabe, professor, eu fico preocupado com o nosso Capelão. Um homem culto, que estudou anos, mas pobre em conhecimentos cientificos. Eu imagino que o senhor ache pouco importante percebermos outras dimensões da realidade que não seja aquela possível através da ciência!

- De que dimensões o senhor está falando, doutor João ? - perguntou, investigando, o professor.

- Religiosa, por exemplo, mas pode ser estética ou mesmo moral.

O professor respondeu com um riso ligeiro nos lábios:

- Ora, ora, João Alphonso, sejamos sensatos. A vida depende é de nós, homens da ciência. A religião já teve a sua vez e não nos elucidou nada; é hoje um conforto para almas despreparadas. A estética e a moral, devemos deixá-las aos argumentos dos filósofos. Não há dúvida, meu caro colega, que através da ciência alcançaremos um exato conhecimento do ser humano. Um conhecimento que nos permitirá elaborar diagnósticos mais precisos e intervenções mais eficazes.

João Alphonso não conhecia o interesse discursivo do colega e, motivando-se, compreendeu que não deveria deixar que o palavreado deste fizesse descansar as próprias convicções do professor. E provocou:

- Mas professor, o senhor não acredita que o nosso capelão seja portador de algum conhecimento, não demonstrável experimentalmente, e que possa ser útil a alguma fração da existência humana?

- E, pode-se pensar. Mas desprezivel. Aqui, por exemplo, no hospital, não se compara o número daqueles que vêm em busca da nossa salvação com aqueles que preferem a salvação do padre.

- Creio que estariamos em desvantagem se tomássemos um culto religioso como referência... ou uma manifestação artística, como o teatro, por exemplo. O senhor que tão bem conhece Paris não deve ter deixado de experimentar outros sentimentos que não aqueles que um laboratório 
eventualmente pode produzir. A propósito, o senhor naturalmente deve ter visto alguma encenação de "O doente imaginário" !?

- Sim, sim. Mas prefiro "Tartufo", vi uma grande encenação desta peça com atores da época. Uma beleza!

- Muito interessante, professor! Devo confessar uma certa inveja. Sabe, apesar de ter vivido alguns anos na Alemanha, não cheguei a conhecer Paris. Algumas vezes, problemas politicos, outras, meu pai, que se preocupava com a possibilidade de eu me dissipar dos estudos.

- É mesmo ? Eu achei que o senhor conhecesse bastante a França. Ouvi algumas vezes o senhor conversar fluentemente em francês com padres aqui no hospital ...

- Achar, achamos muita coisa sobre tudo que quisermos. Mas nos enganamos às vezes ! Mas, professor, às vezes penso em retornar à Europa e, obviamente, conhecer a cidade das luzes. O senhor conhece a cidade o bastante para me oferecer algumas informações ...

- Oh, mas é claro. Isso me faz relembrar fatos memoráveis. Um outro mundo... é maravilhosa a noite parisiense. Sabe como é, caro colega, nós lutamos para manter a vida...

- ... mas às vezes temos a sensação que não vivemos, ou que não sabemos o que seja a vida. Eu já tinha ouvido isto antes - completou João Alphonso, após ter interrompido o professor.

Apreciando o comentário, o professor tentou retomar:

- Poderia lhe contar muito sobre Paris. São muitos lugares, pessoas e historias - disse o professor. num saudoso sorriso de boas lembranças.

- Conte-me, professor, conte-me tudo - disse João Alphonso, enquanto passaram a andar em passos lentos em direção a algum lugar do hospital.

A casa central da Congregação da Missão no Brasil situava-se na mesma rua do Hospicio de D. Pedro II, em Botafogo. Havia sido inaugurada não há muito tempo e os padres mostravam-se satisfeitos com isto. Com o crescimento das atividades da Congregação no Brasil, fazia-se necessária uma sede na capital. Aos poucos, a casa central tornar-se-ia o ponto de convergencia de padres vindos do exterior, mais 
aqueles que transitavam pelo pais, somados aos colegas que afluiam de diversos pontos para tratar de diferentes questões relativas à Congregação.

João Alphonso teria sido convidado a visitar a casa por causa da indicação do professor que lhe havia solicitado a leitura da tese de higiene nos colégios. Aquele professor havia dito ao capelão que, na formação médica de João Alphonso, uma boa ênfase era dada à saúde escolar. Os lazaristas queriam saber alguma coisa disto. Sendo responsáveis pela condução de seminários e colégios, responsabilizavamse por centenas de jovens cuja saúde exigia atenção. No momento, a congregação agregava esforços em torno do colégio Caraça, que, reaberto há alguns anos, vinha a cada ano recuperando o prestigio que tivera na primeira metade do século. João Alphonso sabia das dificuldades em converter-se num consultor médico para os padres. Ele percebia que havia outros médicos que, mais próximos dos seminários e colégios e com maior afinidade espiritual, poderiam desempenhar melhor este papel. Mas aceitou o convite por gentileza aos religiosos da Santa Casa, que lhe demonstravam um sincero prazer em conversar e respeitar suas opiniōes. Além disso, ele já conhecia alguma coisa da história desta congregação e, mais recentemente, chamara-lhe a atenção a informação sobre a possivel ocorrência de beribéri no seminário de Mariana. E ele, brincando com as ideias, havia pensado se as suas conjecturas sobre o processo saúde-doença se prestaria para entender, pelo menos em alguma proporção, a ocorrência de determinadas doenças em seminários, etc.

João Alphonso foi recebido amavelmente e conduzido a uma sala agradável, de onde era possivel acessar a biblioteca. De fato, disseramlhe, os lazaristas tinham dado um grande impulso em suas açōes no Brasil, especialmente sob a direção do padre Etienne, superior geral, com sede em Paris99.

99 O padre Etienne foi superior geral da Congregação da Missão - os "Lazaristas" - de 1843 a 1864. Neste período

"eles se espalharam particularmente na América do Sul e em paises de missðes (regiðes do mediterrâneo oriental, China, Abissinia)... (*) 
- Quando eu estive em Ouro Preto, fui informado que o seminário maior havia se transferido para o Caraça por conta de uma epidemia de variola. Mais recentemente, fiquei sabendo que teria havido casos de beribéri no local - comentou João Alphonso.

- De fato houve alguns infortúnios, doutor. Mas, em geral, conseguimos preservar as nossas condições higiênicas, tendo em vista a disseminação de males que ocorrem fora dos nossos muros. A variola, como o senhor sabe, quando se abate sobre um povo tem um controle dificil e conseqüências imprevisiveis, mas felizmente não voltamos a ter novos casos. Quanto a esta doença a que o senhor se refere, não se conseguiu ainda um diagnóstico consensual entre os médicos que nos assistem em Minas Gerais. Mas estamos seguindo todas as recomendações que nos são dadas para evitar o mal - comentou o religioso antes de uma pergunta de João Alphonso.

- O seminário continua instalado no colégio Caraça?

- Sim. A casa oferece condições. Agora, como o senhor já sabe, temos lá o seminário e o colégio, reaberto em 56. Claro que providenciamos reformas e, conforme as necessidades e disponibilidade financeira, novas benfeitorias. $\mathrm{Na}$ época da transferência, além de renovar as plantações, construimos um moinho para fazer fubá...

- O terreno é fértil !?

- Duplamente, doutor - disse o padre sorrindo. Há poucos anos atrás adquirimos a fazenda do Engenho, cujas terras são propicias ao plantio e ainda recebemos como doação uma outra, a fazenda Capivari, usada para criação de gado100.

(*) MARC-BONNET, H. Histoire des ordes religieux. Paris, Press Universitaires de France, 1949. p. 120.

100 A fazenda Capivari foi uma doação do capitão Cotta ao lazaristas, com quem mantinha relaçðes muito apreciadas:

"Um que tinha sempre sua bolsa aberta para vir em socorro dos P.es do Caraça, era um bom vizinho e amigo dedicado, e mereceu mais tarde o titulo de bemfeitor insigne do Caraça, dando-lhe a fazenda do Capivary com mais de 200 alqueires de terra" (*).

* SILVA, F. P. Apontamentos historicos ... Op. cit. p.32. 
- A produção própria, então, consegue abastecer as principais necessidades da casa ? - quis confirmar João Alphonso.

O religioso foi parcimonioso:

- Infelizmente, não. Dependemos de aquisições externas. O número de pessoas que se alimentam no Caraça supera a nossa capacidade de produção de alimentos, que ainda não é tão elevada. Não posso the fornecer um número exato, mas entre o nosso pessoal, seminaristas, colegiais, e empregados diversos, sem contarmos visitantes ocasionais, devemos atender a aproximadamente 270 a 300 pessoas. Temos as nossas exigências quanto às refeições e custa-nos mantê-las.

Em seguida, o religioso, após apanhar uma pasta com papéis, entregou algumas folhas a João Alphonso, afirmando:

- Isto aqui é a base do nosso regulamento, escrito ainda pelo saudoso padre Leandro. Creio que seria interessante o senhor conhecer algumas normas. Veja, por exemplo, o capitulo 11, que trata dos enfermeiros.

João Alphonso principiou a folhear o regulamento, enquanto o religioso, licenciando-se, saiu por alguns minutos por uma porta.

$O$ regulamento que era visto, com o imponente complemento "Do Seminário da Imperial Casa de Nossa Senhora Mãe dos Homens na Serra do Caraça", havia sido escrito, em 1835, pelo padre Leandro Rebello, lazarista pioneiro no Brasil, que, junto com o então bispo D.Viçoso, havia fundado o colégio Caraça. Era considerado ainda um documento representativo 'do esforço educacional Lazarista'. Inicia afirmando, nas "noções preliminares", que "uma casa de educação bem organizada é um grande tesouro para a Igreja e para os Impérios". As regras do 10 ao 12을 capitulo estão descritas segundo as atividades e atribuições de cada um dos envolvidos com a vida da instituição. Referem-se, por exemplo, ao superior, ao diretor, aos professores, cozinheiro, enfermeiro, além de tratar dos estudes, de advertir aos estudantes, etc. No capítulo 9o, que reza sobre o cozinheiro, pode-se ler, entre outros itens que:

"As comidas não sejam carregadas de sal pelo dano que o muito sal causa na saúde;

"Os manjares sejam bem guizados, e como variedade deleita, e as mesmas comidas repetidas muitas vezes ainda que boas aborresem, haverá para isso variedade no guizamento; 
"No almoço haverá um prato de comida solida; a saber de carne simples, ou com legumes, ou com arroz, e o café;

"No jantar quatro pratos entrando neste número o da sobremesa;

"Às cinco horas da tarde no fim das aulas hum pão a cada um, ou biscoitos; e é então permitido café, ou mate para quem quiser;

“Na ceia dois pratos sólidos, um deles de legume."

No capitulo 11 , relativo aos enfermeiros, lia-se:

"Tenha a enfermaria, ou lugar dos doentes bem arranjados, e aceados, as camas dos doentes compostas, arejadas, e a miudo defumados os ditos lugares com especies aromaticas;

"Não aparte um ponto do que lhe ordena o médico;

"Observará os acréscimos, ou diminuição da enfermidade, e mudança do enfermo para saber informar ao médico;

"Em dias de purgante não permitam que sejam visitados e quando sejam procure que as visitas não sejam dilatadas;

"Se houver algum enfermo cuja enfermidade for incurável e contagiosa como tísica, e mal de S. Lázaro, quando o doente morrer, ou mudar, todas as coisas do seu uso sejam queimadas, e quebradas, e o aposento lavado, arejado e bem caiado"101.

Enquanto o religioso servia-lhe uma bebida refrescante, João Alphonso quis saber se aquele regulamento continuava vigorando como tal, especialmente no que se refere à cozinha e enfermaria. Foi informado que houvera algumas mudanças mais administrativas, como alteração de horários, por exemplo, do que de conteúdo e que aquele regulamento do padre Leandro ainda era a referência normativa ${ }^{102}$.

102 ANDRADE (*) afirma em sua dissertação que 
- Mais de uma vez eu fui informado da excelente salubridade do local. Todos que me informam são unânimes em garantir o privilégio topográfico e as excelentes condições climáticas do sitio onde se encontra o colégio e seminário do Caraça. Os senhores nunca observaram nenhum incômodo à saúde dos habitantes de lá ? - perguntou João Alphonso.

- Creio que o senhor esteja bem informado sobre a localização privilegiada da nossa casa de Nossa Senhora Mãe dos Homens. Às vezes o inverno costuma ser muito rigoroso. E um momento difícil para quem não está acostumado com temperaturas baixas. Por isso, os alunos em férias colegiais saem neste periodo de frio intenso. Os que ficam, seminaristas principalmente, resignam-se a esta condição. $O$ senhor sabe, a elevação da alma pressupõe superar estas vicissitudes da natureza... e não temos tido problemas com isso. Quanto a manifestação de doença, sempre todos gozaram de boa saúde. Entretanto, andou nos preocupando um mal-estar estranho que acometeu alguns alunos recentemente. Tivemos que providenciar algumas pequenas mudanças nos alojamentos, um ou outro aluno foi enviado à sua casa e, graças a Deus, não tivemos mortes. Agora, o mal parece ter se distanciado de lá respondeu o religioso 103 .

"O Regulamento do Seminário da Imperial Casa de N. S. Mãe dos Homens na Serra do Caraça, de 1831, escrito pelo padre superior Leandro Rebello Peixoto e Castro, manteve-se aparentemente o mesmo até o fechamento do Colégio, em 1912".

Assim como a referida autora, também não encontramos, no decorrer do exame de documentos no Caraça, nenhuma indicação de que outro regulamento tenha substituído substancialmente o regulamento de 1831 .

${ }^{103} \mathrm{Na}$ expressão de A. Felício dos Santos, o beribéri

"em 1861, continuando em Mariana, fez explosão no Caraça" (i)

É de dificil precisão a data de aparecimento dos primeiros casos de beribéri no Caraça. A ausência de qualquer documentą̧̃õo dá instituição é consensual entre o presente estudo e ANDRADE (ii). Os estudiosos (iii) da doença tem no documento de A.F. dos SANTOS (i), produzido no ano de 1873 , a principal referència sobre a doença no local. Opção que sera adotada no presente estudo. Na documentação do governo provincial, disponivel no Arquivo Público Mineiro, não há nenhum registro sobre eventual relatório sobre a ocorrência da doença no período.

No que se refere a eventuais óbitos nos anos até mesmo próximos ao primeiro registro do beribéri, no "Livro de Óbito" do Caraça (iv), um valoroso manuscrito que acompanha a instituiçăo desde a sua fundação, há o registro de 2 óbitos em 1859: uma 
- O senhor tem mais informações sobre este "mal" que teria ocorrido ?

- Infelizmente doutor, as informações que nos chegaram são muito esparsas. Até mesmo nossos irmãos que vieram de lá não puderam ser precisos e não temos o relatório do médico que nos aconselha. A propósito, estamos sabendo que o senhor tem se informado sobre a nossa instituição e suas obras, especialmente o nosso seminário e colégio na serra do Caraça. Sabemos também que pretenderia retornar a Minas para concretizar uma viagem interrompida. Gostariamos de convidá-lo para uma visita à nossa instituição. Assim, o senhor poderia verificar melhor o ambiente para um eventual aconselhamento. Sempre temos companheiros de missão, mensageiros, enfim, viajantes para o local...

- Muito obrigado pelo convite. A minha viagem a Minas foi interrompida pela morte do meu pai e, infelizmente, outros acontecimentos me desmotivaram a retomá-la. O senhor não é o primeiro a me fazer este convite. O que me chama a atenção é o carisma desta instituição. Todos que se ligam a ela parecem tomados por um magnetismo um tanto mistico e um tanto divino. A natureza do local parece ter uma força

criança de 6 anos, sobrinho de um empregado, e a do escravo Manoel, com aproximadamente 120 anos, e que teria servido ao fundador do casa, o Irmão Lourenço. Ambas as mortes sem registro de causa. A seguir, o livro registra 5 óbitos em 1862: Um escravo (em ?); um indivíduo sem especificação (no mês de abril); um diácono (em 194) e dois alunos (Fructuoso L. de Mello Lins, matriculado em 1-4-1857 e que morreu em 27-4-62; Fulgêncio $A$. da Rocha, admitido em 17-10-61, morto em 01-04). Dado à precariedade das informaçð̃es, seria inconsistente deduzir a causa destas mortes. Examinando o Livro de Óbitos, nota-se que em 1862 há a maior concentração de óbitos num mesmo ano. Sendo um documento particular da instituição, a ocorrência de subnotificação é um dos fatores que pode fazer com que o manuscrito ( o livro de óbitos) não reflita verdadeiramente a estatística de mortalidade na instituição. Por que ocorreria subnotificação?

i. SANTOS, A. F. O beriberi na provincla de Minas . Op. cit.

ii. ANDRADE, M. G. de. Op. cit., p. 43.

iii. Destacam-se as teses inaugurais das faculdades de medicina do Rio de Janeiro e da Bahia, que sảo citadas no decorrer do presente estudo. Entre elas, merece destaque a tese de ALMEIDA (*), ex-aluno do colégio Caraça e médico pela FMRJ em 1916.

* ALMEIDA,T. Op. cit., p.71.

iv. "Livro de Óbito". Arquivo do Colégio Caraça, sob a guarda pessoal do Pe. José Tobias Zico, CM. 
muito grande sobre a possibilidade de contemplação que, por sua vez, enalteceria aquela - afirmou João Alphonso.

- O senhor tem razão. Plantado naquele sítio, o santuário de Nossa Senhora Mãe dos Homens parece ser a porta do céu. Por tudo isso, tranqüiliza-nos convidá-lo a nos visitar - disse o religioso ${ }^{104}$.

- Prometo avaliar a possibilidade desta visita. Mesmo porque não demorará muito para que meu filho mais velho inicie seus estudos de humanidades e quero avaliar bem para onde encaminhá-lo.

- Aguardaremos um novo encontro - disse, despedindo-se, o religioso.

Quando João Alphonso chegou em casa foi avisado pela esposa de que havia uma pessoa esperando-o na sala de visitas. Recém chegado da Alemanha, dizia ter encomendas para João Alphonso. Era um senhor alto, olhos cinza azuis, cabelos escuros e muito bem penteados, elegantemente vestido. Sua pele, um pouco mais escura que a de outros alemães conhecidos, não deixava identificar rapidamente sua origem. Sugeria ser latinizado em alguma proporção. Ao ver João Alphonso entrar na sala, o senhor levantou-se e recebeu-o com um semblante gentil. Ao cumprimento protocolar de João Alphonso, o senhor interpôs, num alemão bem dito:

- Creio que devemos conversar em alemão. Ficaremos mais à vontade.

- Naturalmente senhor ...?

- Bruhns. Paul Bruhns.

- Muito prazer, senhor Bruhns! - exclamou João Alphonso.

- O prazer é meu, doutor Magalhães. Eu precisava encontrar o senhor, pois lhe trago algumas encomendas enviadas pelo doutor Schwarzkopf.

- Encomendas do Morten ? Então o senhor o conhece ?

- Sim. Minha familia tinha grande amizade pelo pai dele. Somos de Lübeck e veraneávamos em Travemünde com freqüência. Como vê, sou mais velho do que ele e, por isso, posso até dizer que tenho parte em sua criação, especialmente no periodo que o nosso Morten cursou o ginásio em minha cidade.

- O senhor voltou a encontrá-lo em Lübeck? 
- Não. Recentemente estive em Breslau, a negócios, e o revi. Disse-lhe que viria ao Brasil e, então, ele me pediu que o procurasse - respondeu o senhor Bruhns, ao mesmo tempo que lhe entregava uma caixa volumosa. - Que ótimo ! - exclamou João Alphonso - Sente-se, por favor, senhor Bruhns. Está a negócios no Brasil, ficará por quanto tempo ?

- A negócios e a passeio também. Aproveito para conhecer alguns lugares no interior da provincia. Pretendo descansar o suficiente antes do regresso. A viagem é cansativa e demorada.

- Como foi a travessia, muitos transtornos?

- Um tanto - respondeu o senhor Bruhns - , é longa a distância e, por isso, temos que criar meios para o tempo não tornar a viagem monótona. Aproveitei para colocar em dia algumas leituras. O senhor sabe, há sempre livros que nos aguardam nas estantes.

- É mesmo. A leitura é sempre um procedimento oportuno.

- A propósito, doutor Magalhães, sabendo pelo nosso Morten que o senhor aprecia uma boa leitura, eu gostaria de lhe oferecer a obra de Cervantes, que li nesta minha viagem maritima. É o Dom Quixote de la Mancha, espero que o senhor ainda não o tenha lido - disse o senhor Bruhns, enquanto pegava os volumes de uma pasta e os entregava a João Alphonso.

- Oh! Muito obrigado senhor Bruhns, eu ainda não li... é uma dívida com este clássico. Já me falaram que esta tradução de Tieck é excepcional. Mais uma vez, muito obrigado. Surpreende-me que o Morten não tenha me falado do senhor! $\mathrm{E}$ como ele está ?

- E um bom médico e tem uma boa clientela. Vocês se entendiam bastante, ele me disse.

João Alphonso respondeu com um breve aceno da cabeça, lábios cerrados e timido sentimento de saudade que não conseguia ocultar. $O$ senhor Bruhns, bem postado na cadeira, olhar firme e direto sobre seu interlocutor, perguntou:

- E o senhor, tem se encontrado na medicina?

A súbita pergunta encontrou João Alphonso desguarnecido:

- Eu?

- Naturalmente!

- Como não ? Tenho uma boa clientela, inclusive assisto familias alemãs... 
- O senhor sabe que não pergunto da sua clientela - afirmou o senhor Brunhs.

João Alphonso considerou inoportuna esta estranha provocação e olhou fixamente para o senhor Brunhs. Encontrou, porem, uns olhos brilhantes, de cores que variavam com o seu olhar e se sentiu impotente para encerrar o diálogo. Tentou, então, uma saida que lhe desse tempo para se recompor:

- Mas porque o senhor me pergunta isto ? Acredita que me conheça tanto, a partir de um relato de um amigo ?

- Ora, ora, João Alphonso, sabemos que o que pergunta não nos leva a lugar nenhum. E mais uma besteira inteligente que costuma dizer para evitar você mesmo. Você insiste na falta de confiança em si próprio - dizo Sr. Bruhns que, virando-se na poltrona, pega um livro que se encontrava sobre uma mesinha de canto, comenta - vejo que continua lendo Kierkegaard!

- Sim. Estou lendo o ensaio sobre o Don Giovanni de Mozart - responde um desprotegido João Alphonso.

- São as marcas dos tempos longinquos de Berlim. Pensei até que se dedicaria mais a estes estudos depois das mortes tão próximas que te ocorreram.

- Eu sou médico Sr. Bruhns, e tenho meus deveres enquanto tal - tentou reagir João Alphonso.

- Daquilo que aprendeu em Göttingen, você só tem disposição para aplicar o minimo, praticamente se igualando com outro qualquer formado numa destas escolas daqui. Anima a você mais a sensibilidade para compreender os fenomenos sociais que interagem com os processos que levam à saúde e à doença do que a clínica e a experimentação. Não é dificil compreender este seu enrustido procedimento. Talvez até consiga oferecer alguma contribuição à sua hipocondriaca ciência ...

Antes que o senhor Bruhns terminasse, entra na sala a esposa de João Alphonso, acompanhada de uma escrava circunspecta, que conduzia uma bandeja com sucos e quitutes. João Alphonso, acuado na poltrona, levantou-se após o senhor Bruhns, que comentou:

- Esta é uma terra ainda indomável. Há muitas forças que agem sobre nós. Agora, tenho que ir. Espero revè-lo noutra oportunidade - disse o senhor Bruhns, que agradeceu e dispensou as guloseimas. 
Sem força e vontade para insistir com o senhor Bruhns, acompanhou-o à porta, enquanto sua esposa lastimava a incompreensivel interrupção da visita.

Após a saida do enigmático visitante, João Alphonso acomodou-se na poltrona e dormiu profundamente. Acordado, quis sair à procura de informações do senhor Bruhns, mas, sem se sentir disposto, resolveu escrever a Morten. A encomenda remetida por este amigo era sortida. João Alphonso desembrulhou o pacote com cuidado e examinava cuidadosamente cada conteúdo que estava embrulhado separadamente. Três garrafas do vinho, que ambos várias vezes saborearam juntos, além de uma bebida finlandesa que Morten sempre trazia de Travemünde; alguns periódicos médicos e três volumes do livro Handbuch der historisch geographische Pathologie, de A. Hirsch, editado em Erlangen em $1860^{105}$. Na sequeencia do tempo que viria, João Alphonso leria atentamente algumas partes deste livro. Notou que o autor relatava praticamente tudo o que se conhecia acerca do beriberi, sua distribuição e as contribuições de muitos cientistas ao estudo da patologia, resultado de miasmas de procedência desconhecida. Contudo, o relato é pouco instrutivo no que se refere à clínica da doença propriamente dita.

A coincidència entre leituras e relatos envolvendo o beriberi não deixou de lhe chamar a atenção. Outras vezes havia encontrado com o jovem acadêmico diamantinense e este insistia nos relatos sobre a

105 August Hirsch (1817-1894), professor em Berlim, foi epidemiólogo e historiador da medicina, tendo participado de várias expedições para estudo de epidemias (peste, cólera, meningite). Seu livro é considerado uma obra clássica dentro da geografia médica "prépasteuriana" (").

* LACAZ, C. S. et al. Introdução à geografia médica do Brasil. São Paulo, Edgard Blücher Ltda. : Edusp, 1972. p. 9-10.

106 Denominação popular e regional dado ao beriberi em Minas Gerais, assim como em Mato grosso foi chamada de "perneiras". Porém, esta sinonímia teve pouca importância nos comunicados da doença, podendo-se concordar com ALMEIDA (*), para quem, em meados do século XX, 
existência de casos de 'inchação'106 em internatos mineiros, incluindo o Caraça. Junto aos colegas práticos e professores procurou informações sobre a possível descrição da doença no meio brasileiro. Não obteve informaçōes significativas e os maiores especialistas em epidemias não mencionavam o beriberi ${ }^{107}$.

Por esta época, chegaram às mãos de João Alphonso os primeiros números de um periodico médico que vinha sendo bastante comentado, a "Gazeta Medica da Bahia" publicada por uma associação de facultativos. Esta publicação passaria a interessar vivamente João Alphonso, pela consistência cientifica dos estudos ali veiculados, pela localização' dos articulistas, fora da tradicional faculdade de medicina da Bahia, em Salvador. Ele entendia que a efetivação de um grupo de pesquisadores fora da faculdade contribuiria bastante para a qualidade do debate das teorias médicas. Com certeza haveria repercussão na qualidade das pesquisas. Pouco tempo após a leitura dos primeiros números do periódico baiano, João Alphonso viria a saber que um dos mais destacados membros daquele grupo que publicava a "Gazeta", o dr. Wucherer, havia cursado medicina na tradicional universidade alemã de Tübingen, na mesma época em que estudava em Göttingen ${ }^{108}$. E eram

107 Em seus estudos acerca das epidemias brasileiras, o Dr. Pereira Rego (i, ii, iii) "passa em completo e absoluto silencio qualquer qualquer questão que pudesse ter affinidade com o beriberi".

i. REGO, J. P. Esboço histórico das epidemias que têm grassado na cidade do Rio de Janeiro de 1830 a 1870. Rio de Janeiro, 1872.

ii. Memória histórica das epidemias da febre amarella e cholera-morbo que têm reinado no Brasil. Rio de Janeiro, Typographia Nacional, 1873.

iii. Apontamentos sobre a mortalidade da cidade do Rio de Janeiro particularmente das crianças ... Rio de Janeiro, Typographia Nacional, 1878.

108 Na segunda metade do século XIX, um grupo de médicos na cidade de Salvador compõe um movimento técno-científico na área médica, que dará origem à chamada "Escola Tropicalista Bahiana". A articulação desta "escola" ficou a cargo de três médicos, que são os maiores expoentes do movimento: J. L. Paterson (Aberdeen, Escócia, 1820-1882, Salvador); O. E. H. Wucherer (Porto, Portugal, 1820-1873, Salvador); J. F. da SILVA LIMA (Vilarinho, Portugal, 1826-1 110 , Salvador). O primeiro 
exatamente os estudos deste médico, nascido em Portugal, filho de alemão e com infância em Salvador, sobre a ancilostomiase que repercutia. Na época o dr. Wucherer tentava demonstrar que um verme era a causa de uma enfermidade denominada "opilação", "cansaço" ou ainda hipoemia, enquanto que a idéia dominante dizia que tal verme seria efeito e não a causa da doença. A polêmica teria chegado a Academia Imperial de Medicina, que teria decidido por votos sobre a questão. Wucherer, diante do episódio da votação, escreveu:

"questões sôbre causa e feito não se decidem por opiniōes ou por votos, e sim pela apreciação rigorosa dos fatos" ${ }^{\prime 109}$.

estudou medicina na sua terra natal, o segundo, na Alemanha e o terceiro, na Bahia. Segundo CONI (i)

"O movimento da Bahia,..., floresceu extramuros da sua tradicional Faculdade e, a princípio, em franco antagonismo com ela. ... foi um choque de idéias, um conflito de escolas, uma luta entre o sistema e o método. De um lado, os médicos estrangeiros..., exercendo medicina assentada solidamente em pesquisas microscópicas e em estudos percucientes de anatomia patológica, esta já bastante desenvolvida...; do outro, os vultos proeminentes a Faculdade de Medicina, adeptos professos da doutrina vitalista ..., oriunda do pensamento médico francês, aos quais repugnava o abrirem-se cadáveres com o fito de nêles elucidar problemas da vida" (i, p.34-5).

$\mathrm{Na}$ cronologia do grupo, Silva Lima teria se 'convertido' ao método experimental dos outros dois e com eles promoveu reuniões de caráter cientifico em 1865. É a partir destes encontros que surge, em 1866, a "Gazeta Médica da Bahia".

Além de CONI (i), que contempla a história pessoal da "Escola Tropicalista", outros dois estudos constituem referência sobre este movimento: LUZ (ii) e OLIVEIRA (iii). Ambos se propðem a estudar a elaboração cientifica e o discurso político da "Escola".

i. CONI, A.C. A escola tropicalista bahiana: Paterson, Wucherer, Silva Lima. Bahia, Tip. Beneditina Ltda., 1952.

ii. LUZ, M. Medicina e ordem política brasileira. Rio de Janeiro, Ed. Graal, 1982. Segunda Parte, capitulos IV (p.129) e V (p.139).

iii. OLIVEIRA, C.R. Medicina e estado: ... Op. cit.

109 GMB, 1a. série vol 2, 15-1-68. p. 150

Sobre esta polèmica é importante afirmar que ainda em 1873, e diante de amplas evidencias experimentais, a Academia Imperial de Medicina indagava: ' $O$ Anchylostomum duodenale é effeito ou causa da hypoemia intertropical, vulgo oppilação ou chlorose do Egypto ?' ("). 
Nesta circunstância é que João Alphonso "descobre" e passa a acompanhar com interesse os artigos publicados na "Gazeta" por um colega do dr. Wucherer, o dr. Silva Lima, sob o título "Contribluição para a história de uma moléstia que reina actualmente na Bahia, sob a forma epidemica e caracterisada por paralysia, edema e fraqueza gerap. As observações clínicas do autor, bem como a caracterização nosológica e diagnóstico diferencial, não deixaram dúvida quanto à especificidade da doença. Pareceu-lhe que o dr. Silva Lima estava mesmo no caminho para investigar corretamente um mal que agregava as três caracteristicas acentuadas nos artigos (paralisia, edema e fraqueza): o beribéri110.

\section{* OLIVEIRA,C.R. Medicina e estado. Op. cit., p.201-2.}

110 Em fins de 1863 e início de 84 surgem na Bahia casos de uma doença de diagnóstico impreciso. A partir dos estudo destes casos pelo dr. Silva Lima, consolida-se uma sequência de investigações que passarão a ser relatadas nos primeiros números da "Gazeta". A afirmação de que se tratava do beriberi não foi imediata. Segundo o próprio autor,

"a convicção de que essa doença é o beriberi nasceu lenta e gradualamente da observação clínica de mais de tres annos, e robusteceu-se tambem com as opiniðes authorisadas dos nossos mais distintos praticos" (i, p. III) Segundo MIRANDA AZEVEDO (ii), na sua tese inaugural de 1874,

"O nome do Dr. Silva Lima é o que brilha entre todos aquelles que têm se occupado com as investigações e etiologia do beriberi".

Os artigos do Dr. Silva Lima sobre o beriberi e publicados no periódico da "Escola Tropicalista", foram copilados no livro intitulado "Ensaio sobre o beriberi no Brazil" (i). É consenso de todos os estudos sobre o beriberi (amplamente citados no decorrer do presente trabalho), especialmente nas teses inaugurais das faculdades de medicina da Bahia e do Rio de Janeiro, que estes estudos do Dr. Silva Lima é o marco inicial das investigaçðes científicas desta patologia no Brasil:

"Não ha negar, porém, que a litteratura medica sobre o beriberi no Brasil, propriamente, nasceu com os valiosos trabalhos publicados por J. F. Silva Lima, na Bahia. Foi elle o arauto da novidade, o descobridor da molestia, como o proclamam as suas proprias palavras" (iii).

Desta forma, considerando que todos os artigos sobre beriberi publicados na "Gazeta" estão reunidos no livro, este será utilizado como única fonte para os referidos estudos de Silva Lima.

i. LIMA, J. F. de S. Ensaio sobre o beriberi no Brazil. Salvador, Typ. J. G. Tourinho, 1872. 


\section{TERCEIRA PARTE}

A condição geográfica da cidade, alojada entre o mar e a serra, sugeria um corredor por onde passavam malandros, vagabundos e toda sorte de desocupados que eram recrutados para a guerra. A estes tipos somavam-se outros tantos que compunham o exército que, entre $1864 \mathrm{e}$ 1870, lutaria na Guerra do Paraguai111. Esta guerra havia encontrado o

ii. AZEVEDO, A . C. de M. Beriberi. Rio de Janeiro, Typ. Acadêmica, 1875. p. 17.

iii. ALMEIDA, T. de. $O$ beriberi no Brasil. Op. cit. p. 18

111 A Guerra do Paraguai ( "Guerra Grande", para os paraguaios) foi um acontecimento que continua trazendo à tona novas investigaçðes e interpretaçðes sobre sua origem, desenvolvimento e repercussão. No presente trabalho, as referências acerca deste episódio baseiam-se em SALLES (i), especialmente no que se refere à "organização de um exército nacional"; CHIAVENATTO (ii) e POMER (iii), especialmente no que se refere à crise econômica do império brasileiro no periodo da guerra; TAUNAY (iv), especialmente no que se refere às dificuldades e repercussðes do dificil suprimento para as tropas brasileiras no teatro de operações; SALLES (v) e CERQUEIRA (vi), especialmente quanto à assistência médica e às doenças durante a guerra; por último, $o$ filme de BACK (vi), 'Guerra do Brasil' que, segundo a sua sinopse,

"misturando documentário e ficção, abre o dabate sobre este autêntico, embora omitido, ensaio da $1^{\mathrm{a}}$. Guerra Mundial, que envolveu Brasil, Argentina, Uruguai e Paraguai, vitimando aproximadamente um milhão de pessoas em todo Cone Sul".

i. SALLES,R. Guerra do Paraguai: escravidão e cidadania na formação do exército. Rio de Janeiro, Paz e Terra, 1990.

ii. CHIAVENATTO,J.J. Genocidio americano: A guerra do Paraguai. 24a. ed. São Paulo, Brasiliense, 1990.

iii. POMER,L. A guerra do Paraguai: a grande tragédia rioplatense. 2a. ed. São Paulo, Global, 1981.

iv. TAUNAY,A.d'E. A retirada da Laguna. 13a. ed. São Paulo, Melhoramentos, 1952.

v. SALLES,P. História da medicina no Brasil. Op. cit.

vi. CERQUEIRA,D. Reminiscência da Campanha do Paraguat. Rio de Janeiro, Biblioteca do Exército, 1980 
Império despreparado para a luta. A Guarda Nacional e as polícias provinciais eram em número insuficiente para o combate, apesar do tratado do Brasil com a Argentina e Uruguai que também participariam com seus combatentes. Assim, o contigente brasileiro completava-se com os voluntários e os escravos. Recrutar era apenas o início de um caro processo preparatório para a guerra. Além das exigências diárias dos recrutados ( alimentaçāo e vestimentas, por exemplo), a formação do exército exigia um mínimo de treinamento para uso de armamentos, etc., além do transporte e provimento da tropa nos locais de conflito. $O$ endividamento do Brasil foi inexorável.

No campo de batalha, as lutas desenvolviam-se violentas e problemas de toda natureza se mostraram: dificuldades de organização, desconhecimento de áreas de combate, escasseamento de alimentos, doenças, ... Destas últimas, a assustadora cólera irrompeu impiedosamente. Indios agregados às tropas foram os primeiros a sucumbir. Atormentado, um oficial escreveu:

"A que causa deviamos atribuir esta irrupção da cólera ou, melhor, a que causa não a atribuirmos? Seria talvez a carne estragada que éramos obrigados a comer, ou a fome curtida quando as náuseas venciam o apetite, ou ainda o insuportavel ardor dos incêndios que nos escaldavam o sangue, quiçá a infecção oriunda de todas as substâncias vegetais que devorávamos, brotos, frutos verdes e podres, ou também, enfim, a insalubridade do ar viciado pela água estagnada dos charcos e lodaçais que naquela região tanto abundam"112.

Improvisada, a assistência médica não conseguia responder às demandas. Em Mato Grosso do Sul, sede dos primeiros combates da guerra, um único hospital militar em Cuiabá e mais algumas enfermarias dispersas pelo interior eram os locais disponiveis para prestar os

vii. "A guerra do Paraguai". Longa metragem produzido e dirigido por Sylvio BACK e livreto "algumas palavras sobre a produção".

112 TAUNAY,A.E. A retirada de Laguna. Op. cit. p. 106. 
socorros necessários. O aprisionamento e morte de médicos agravava a assistência aos feridos:

"Capitão-cirurgião Antônio Antunes da Luz, aprisionado e morto de doença e inanição em 6-12-1867; Benevenuto Pereira do Lago, que apesar de socorrer soldados paraguaios feridos, foi prêso e parece que fuzilado; João dos Reis, fuzilado, e Teófilo Clemente Jobim, morto de doença"113.

Além da cólera e da variola, outras doenças parecem ter incidido sobre as tropas em combate. Ainda no início da luta,

“... forçoso se tornou romper ao acaso, através do pestilento pantanal, onde a coluna foi desde o princípio provada pelas febres. ... arrastando-se penosamente, conseguiu atingir a povoação de Miranda ... Ai uma epidemia climática de novo gênero, a paralisia reflexa, ou beribéri, acabrunhou-a, dizimando-a ainda mais ${ }^{114}$.

A alimentação provavelmente tornou-se o mais sério problema para as expedições brasileiras no Paraguai, especialmente nos primeiros anos da guerra. A idéia de que uma boa alimentação é um dos principais fatores que contribuem não apenas para uma adequada nutrição, mas

113 SALLES,P. História da medicina no Brasil. Op. cit. p. 214.

Os relatos sobre a assistência médica durante a guerra do Paraguai descrevem os variados momentos de um exercicio cercado pela tensão circunstancial, dificuldades materiais e pelas limitaçðes impostas pelo estágio de conhecimento da medicina da época.

Associados, estes motivos produziram situações que iam do desespero ao ridículo, como a que descreve CERQUEIRA (*):

"Nos hospitais havia, também, perigos e alguns bastante sérios. A maior parte dos nossos médicos eram hábeis e caridosos, mas havia um ou outro, que causava arrepios aos nossos pobres camaradas. Servia no 'Soladero', nosso hospitai em Coirientes, um médico contratado, que tinha horror a sua enfermaria, por casos de moléstias contagiosas que lá apareceram. Todos os dias chegava à porta, pedia ao enfermeiro noticias dos doentes e receitava verbalmente: para os do lado direito - purgantes; para os do lado esquerdo vomitórios. No dia seguinte os do lado direito tomavam 'vomitório'e os do esquerdo 'purgante'; alternava sempre".

* CERQUEIRA,D. Reminiscências da campanha do Paraguai. Op. cit. p.236.

TAUNAY,A.E. Retirada de Laguna. Op. cit. p. 32. 
também para a auto-estima do soldado, é um conceito muito posterior a estes acontecimentos da guerra do Paraguai115. Nesta época, o provimento alimentar da tropa necessitava contar com uma boa dose de sorte. Os rebanhos que acompanhavam os pelotões freqüentemente dispersavam-se; as longas jornadas se faziam por regiões desprovidas de recursos suficientes para abastecer a todos; os frutos e raizes da terra não eram tantos e nem garantiam a necessária boa nutrição. A fome, dizem os relatos, em muitos momentos tornou-se mais agressiva do que os inimigos paraguaios ${ }^{116}$. Nesta época, são vários os relatos sobre a

115 Discutindo "as condições sociais e econômicas do país e a mobilização no nordeste" na segunda guerra mundial, Collier ( ${ }^{*}$ ) ao se referir a guarnição de Fernando de Noronha, que se submetia a uma dura permanência na ilha, afirma que

"O que a ciência moderna nos ensina também, é que a alimentação é um fator de importância considerável não só para o desenvolvimento como para a própria saúde, e o equilibrio neuropsíquico do organismo humano. Não é possivel, assim, ter bons soldados alimentando-os habitualmente mal. ... o soldado depende inteiramente da alimentação que lhe é fornecida pelo 'rancho'.

O autor encerra o comentário afirmando:

"Falta de cuidados, ausência de uma orientação mais científica que, no isolamento de Fernando de Noronha, em que os soldados dependiam inteiramente da alimentação fornecida ao quartel, teve como conseqüência numerosos casos de beriberi e outras agudas avitaminoses, alguns deles fatais".

* ARRUDA,D.C. et al. Depoimento de oficiais da resenva sôbre a F.E.B. 3a. ed. Rio de janeiro, Cobraci Publicaçð̃es, s.r.d. p. 490-1.

116 Certa feita, logo no inicio da guerra, um faminto grupamento deparou-se frente a frente com uma tropa paraguaia, que fustigava ocasionalmente os adversários. $O$ confronto foi inevitável, apesar do lastimável estado dos soldados brasileiros. Ao cabo de algumas horas, mortos de ambos os lados, os paraguaios se retirarn. O ccmandante brasileiro ordena que, amontoados os mortos, os paraguaios sejam queimados. Os sobreviventes e famintos soldados brasileiros que participavam da cena não resistiram aus primeiros odores da carne humana em chamas e alguns se precipitaram em querer comê-la. Teria sido necessário a enérgica ação do comandante para que se evitasse o consumo da carne.

Este acontecimento é parte de um relato pessoal sobre a guerra do Paraguai, feito por um atual (1996) Capitåo da reserva do Exército. Este militar, que pediu anonimato, refere-se a um conjunto de fatos sobre a campanha brasileira contra o Paraglai que são 
ocorrència do beribéri na zona de guerra, relatos estes que foram reproduzidos em sucessivas teses inaugurais sobre a doença, feitas nas duas faculdades de medicina do império, a da Bahia e a do Rio de Janeiro:

"Póde-se inferir das descripções dos Drs. Macedo Soares, D. Freire Junior e do Sr. Taunay, que o beriberi manifestou-se no Paraguay, affectando principalmente a fórma oedematosa, emquanto que em Matto-Grosso revestio principalmente a fórma paralytica, conforma a notícia que lèmos no $\mathrm{Sr}$. Taunay..." 117 .

"Para o Hospital da Marinha da Côrte, desde 1869, entram doentes de beriberi, como se póde vêr na Estatistica deste Hospital, quasi todos é verdade, vindos do Paraguay .... Em Matto-Grosso, na villa de Miranda, em Nioac, segundo os documentos de Alfredo Taunay... reinou elle [o beriberi ] em varias épocas, sob differentes denominações..."118.

"Por occasião das operações do nosso exercito contra o governo do Paraguay, grande numero de medicos e cirurgiões das nossas forças belligerantes, observaram uma epidemia de uma

omitidos nos relatos históricos conhecidos. De uma forma geral, este "conjunto de fatos" versa sobre o cotidiano das tropas e narra desde a precariedade das condiçðes dos soldados na frente de batalha à truculência com que alguns comandantes, como o Duque de Caxias, por exemplo, dirigiam as tropas. Sobre este último, segundo o mesmo militar, é sabido o seu excessivo rigor disciplinar que produzia um misto de medo e temor. $\mathrm{O}$ relato sobre o quase consumo da carne humana na circunstância descrita, de acordo com o Capitão da reserva - hoje com 65 anos - veio-lhe através de um tio, que garantiu ter ouvido a história de um sobrevivente da guerra, numa data provável entre 1910 e 1915.

A veracidade do relato não está em jogo. Ou, se estivesse, poder-se-ia até admitir que ele não estaria distante de uma realidade possível, já que outros tantos relatos - como o do próprio Visconde de Taunay - oferecem descriçðes bem próximas àquelas. Mas 0 relato de um Capitão da reserva, hoje aos 65 anos e que, segundo ele, "fez a revolução de 1964", relato este 130 anos após o acontecimento, deixa clara uma vastidão de sinais que nos mostra a fluidez da memória pelo tempo e a sua capacidade de reaparecer, lânguida ou inopinadamente, no teatro de encenaçðes do presente.

117 AZEVEDO, A.C. de M. Beriberi. Op. cit. p.19.

118 CAIRE, P.A. Das condiçðes pathogenicas, causa, diagnostico e tratamento do beriberi. Op. cit. p. 19. 
molestia desconhecida, da qual o edema era o principal phenomeno, sendo mais tarde capitulada por uns, de paralysia reflexa; por outros, de hydropisia paludosa; e finalmente alguns julgaram que se tratava do beri-beri, considerando-o como resultado de uma intoxicação paludosa, como consta dos documentos officiaes que de la vieram" ${ }^{119}$.

João Alphonso acompanhou, introvertido, os relatos da guerra. Entre os médicos, sempre a história de um colega que participava do embate. Entretanto, nenhum parente seu esteve diretamente envolvido no episódio. O filho de João Alphonso, apesar da possibilidade de ir cursar humanidades no colégio Caraça, estudou no Rio, ingressando, a seguir, na Faculdade de Direito de São Paulo, no periodo em que transcorria a guerra do Paraguai. O recrutamento não colocava em risco o futuro dos filhos de pais bem situados na sociedade. Se em alguma situação este risco houvera, uma prática usual era substituir um senhor por escravos ${ }^{120}$. Este rumo do seu filho mais velho mudaria o destino de viagens que João Alphonso eventualmente faria; de Minas Gerais para São Paulo. O curso jurídico de São Paulo era uma das duas opções existentes naquele tempo e para lá fluiam especialmente estudantes da Corte, fluminenses, mineiros, das provincias do sul... Nesta época já era um curso com praticamente 40 anos de existência, preservando uma tradição que se instalara no prédio do antigo convento de São Francisco' ${ }^{121}$. A opção do filho pelo curso de direito tinha-se materializado

119 NICOLÁO,A.J. Beri-beri. Op. cit. p. 20.

120 Este procedimento é suficientemente abordado por SALLES (*) quando, no capitulo IV, discute "a formação de um exército nacional e o fim do Império".

* SALLES,R. Guerra do Paraguai: ... Op. cit.

121 A faculdade de Direito de São Paulo foi proposta pela Assembléia Constituinte em 1823 e instalada em 1827. Porém, não foi sem votos contrários que se instalou o curso jurídico na província paulista. Talvez um dos argumentos contrários mais hilário que se manifestou veio do constituinte José da Silva Lisboa, futuro Visconde de Cairu, que afirmou ser contrario porque 
diante do seu gosto pelas letras, pelas discussões de temas literários com amigos e por um certo desinteresse em atividades práticas que envolvessem procedimentos objetivos e dirigidos. Ou seja, a vida militar, engenharia ou mesmo medicina escapavam ao seu interesse. João Alphonso argumentou com o filho que o curso de direito seria uma opção interessante. Futuramente, caso ele - o filho - não se constituisse como jornalista, por exemplo, - de acordo com o seu desejo - poderia fazê-lo como jurista. Mas o próprio João Alphonso tinha dúvidas quanto à retidão deste seu conselho. Ele sabia que a sociedade não faz concessão fácil a quem não segue as expectativas que ela - a sociedade -constrói. Sobre o caminho acadèmico do filho, João Alphonso chegou a conversar com padres lazaristas. Estava ele na Casa Central em consulta a um padre recém chegado do Caraça para tratamento de saúde, quando comentaram sobre o destino acadèmico de colegiais. O padre caracense afirmou que a decisão sobre o futuro do colegial era assunto acordado pela familia, em especial o pai. Tal como sucedeu com ele, disse João Alphonso. O padre referiu-se a sua experiência com os jovens do Colégio. Praticamente todos eles sabiam seus destinos: as academias, os negócios ... Achava que João Alphonso não deveria se preocupar, já que pior seria - dissera ele - se não soubesse ou não tivesse condições de orientar e enviar o filho à faculdade. Entretanto, João Alphonso dissertou sobre a personalidade $e$ as preocupações do filho $e$ a necessidade de se compreender serenamente este tipo de individuo que, segundo ele, se vive em dobro, corre risco de, também, sofrer em dobro. O padre fez uma brevissima reflexão e procurou associar o filho de João Alphonso a um caso conhecido do Caraça.

Tratava-se de um jovem estudante gaúcho que chegou ao Caraça já aos 16 anos. Altivo, educado e com bastante habilidade com as palavras, escrevia freqủentemente ao pai em cartas que denotavam não apenas um apego muito grande às letras, como também conflitos nascidos de uma personalidade "incomodada", nas palavras do padre. Este jovem

"a pronúncia incorreta e o dialeto desagradável dos paulistas havia de influir para que a mocidade adquirisse o mesmo defeito" ( $*$ ).

* amaral,A.B. Dicionário de história de Sáo Paulo. São Paulo, Govêrno do Estado, 1980 
preparava-se, com a aquiescência do pai, para os exames de acesso à faculdade de direito de Pernambuco, já que, para ele, "São Paulo não passaria de um foco de perdições”. O padre afirmou que não queria discutir a opinião do estudante sobre o curso juridico de São Paulo; ele próprio tinha suas criticas, mas considerava comprometedor por parte da familia "soltar as rédeas" de um jovem talentoso, mas de espirito indisciplinado, plein d'humour. Certamente, disse ainda o religioso, esta "indisciplina" tenha levado este jovem a ser reprovado em Pernambuco e, até onde sabia, teria ainda conseguido do pai uma viagem à Europa ${ }^{122}$. João Alphonso, entendendo-o, não aceitou o argumento do religioso e discretamente teria comentado:

- Sabe, padre, quanto aos filhos eu não creio que devemos utilizar eventuais problemas do futuro como empecilho à aventura da vida. Cedo ou tarde perdemos para o mundo a capacidade de influência-los à nossa maneira. Sob outro aspecto, uma vida atormentada não é menos vida que uma vida pacata. Ao contrário. Eu mesmo creio que meus tormentos deveriam ser maiores.

122 No período de $1868-69$, período em que a tríplice aliança guerreava com o Paraguai, estudou no Caraça o gaúcho Artur de Oliveira, matriculado com a idade em torno de 16 anos. A breve vida de Artur - morreu em 1882, de tuberculose, aos 31 anos de idade seria marcada por seu tipo fulgurante nos salões do Rio de Janeiro, especialmente após seu retorno da Europa. Não escreveu obras que sejam referências na crítica literária, sendo, inclusive, desqualificados de qualquer valor os pouco registros que vieram a ser publicados (i, p.9) mas, segundo alguns, era ele

"um espirito imaginoso e brilhante, que apenas esplendeu quanto bastava para deslumbrar-nos... Ele não podia escrever. Quando tentava fazê-lo, a fecundidade de seu espírito e a pasmosa erudição que adquirira eram-lhe outros tantos estorvos" (i, p.7-8).

O bom relacionamento com intelectuais da época, entre eles Machado de Assis, lhe valeram, por parte deste, a indicação para patrono da cadcirc nümcro 2 da Academia Brasileira de Letras. Durante o período em que esteve como interno no Colégio Caraça escreveu cartas (23 as que são conhecidas) à sua familia (i). ANDRADE (ii) utiliza o conteúdo destas cartas para delas extrair informaçðes sobre a disciplina, tradicionalmente rígida, do Caraça.

i. SOUTO.L.F.V. Dispersos: vida e obra de um escritor esquecido. Rio de Janeiro, Civilização Brasileira, 1936.

ii. ANDRADE,M.G. de A “Porta do céu:..." Op. cit. 
Os dois religiosos do ambiente entreolharam-se rapidamente após o comentário do João Alphonso. Este, notando, levantou-se, após uma prescrição, e entregou a folha de papel a um dos padres, dizendo:

- Aqui está ! Os seus problemas, padre, não são nada que uma boa botica não possa curar.

As medidas que deveriam enfrentar a precariedade da situação sanitária da corte e do império em geral estiveram estancadas durante o periodo da guerra. A Gazeta Médica da Bahia, com os proficuos trabalhos do grupo que nela circulavam, ocupou produtivamente um periodo de apreensão para a saúde, já que as epidemias, em particular a febre amarela, não cessavam ${ }^{123}$. No meio científico, discutia-se acanhadamente as novidades que chegavam da Europa. Entre elas, as que davam conta de inovadoras pesquisas de um laureado químico francês, Louis Pasteur. Desde a década de 50, Pasteur desenvolvia trabalhos na área agricola e de alimentos e a sua histórica comunicação, em 1864, em que refuta todos os argumentos contra a geração espontânea, revigora a emergente área de pesquisa, a microbiologia ${ }^{124}$.

123 Anteriormente à guerra do Paraguai, uma série de medidas, implantadas parceladamente, alterava as atribuições e a estrutura administrativa da saúde pública. Contudo,

"A guerra do Paraguai, em 1864, veio sustar esse prurido de legislação parcellada, e, absorvendo todas as attençðes e energias, fez esquecer, por varios annos, o problema sanitario" ( *)

* FONTENELLE,J.P. Hygiene e Saude Publica. Op. cit. p. 425)

124 A atividade científica de Louis Pasteur (1822-1895) durante a segunda metade do século XIX foi decisiva para o estabelecimento da microbiologia e suas aphicaçðes. Químico com trabalhos iniciais nesta área relacionada à cristalografia, ROSEN (i) reconhece que foram estes estudos que

"conduziram Pasteur até suas descobertas fundamentais no reino da microbiologia".

Especialmente após 1870, Pasteur, que já havia se envolvido em estudos quase nada conclusivos sobre a cólera, começa a "vislumbrar um outro mundo:

"o mundo dos virus-fermentos. Dois séculos antes o físico inglês Robert

Boyle dissera que aquele que pudesse sondar ate o fundo a naturezd dos 
Como na França, médicos brasileiros relutavam em aceitar contribuições não apenas vindas da quimica, mas, principalmente, vindas de químicos. Esta posição era claramente expressa na introdução do conhecido Traité de Thérapeutique, de Trousseau e Pidoux, publicado em 1855:

"O quimico que encontrou as condições quimicas da respiração, da digestão, da ação deste e daquele medicamento, crê ter dado a teoria destas funçōes e destes fenômenos. E sempre a mesma ilusão, e os quimicos nunca se curarão dela. Tiremos nossas conclusões; mas abstenhamo-nos, todavia, de aproveitar pesquisas preciosas a que eles provavelmente nunca se entregariam se não fossem estimulados pela ambição de explicar o que não é de seu domínio"125.

Mas a "força" científica dos "não-médicos", especialmente químicos e biólogos, no que se refere às pesquisas para o conhecimento do

fermentos e das fermentações, seria, indubitavelmente, mais capaz que qualquer outro para explicar certos fenòmenos mórbidos. Estas palavras vinham com muita frequência ao espirito de Pasteur" (ii).

De fato, o reconhecimento dos trabalhos de Pasteur como sendo de incomparável préstimo à medicina veio com a sua eleição - acirrada, é verdade - para a academia de medicina, em 1873. A originalidade e a contribuição de Pasteur no campo científico são marcadas pelo reconhecimento público e político de suas açð̃es, não sendo por acaso que fosse cortejado pelo estado e idolatrado pelo povo (iii, iv).

i. ROSEN,G. Uma história da saúde pública. Op. cit., p. 238-9.

ii. VALLERY-RADOT,R. $A$ vida de Pasteur. 3a. ed. Rio de Janeiro, Vecchi Editor, s.d, p. 195.

iii. ROMAIN,A. de S. Pasteur: as verdadeiras razões de uma glória. IN. LE GOFF,J. (Apres.) As doenças têm história. Op. cit., p.85-90.

iv. DARMON,P. Pasteur, le saint laïque. L'Histoire, $\mathrm{n}^{9} 187$, avril 1995.

125 Também segundo VALLERY-RADOT (*) Pidoux nunca reconsiderou suas opiniðes, inclucive as de que

"entre um fato fisiológico e um fato patológico, existe a mesma separaçăo

que entre um mineral e um vegetal"

$e$ ainda que

"não está no poder da fisiologia explicar a mais simples das afecçð̃es mórbidas".

Trousseau, ao contrário, reconsiderou e tornou-se 'vivamente interessado pelos trabalhos de Pasteur'.

- VALLERY-RADOT,R. Op. cil. p. 195. 
organismo humano, ocupou espaços a "marteladas". E da Alemanha, onde a adoção dos conhecimentos da química pela medicina era diferente do que na França, uma avalanche de pesquisas descortinavam-se. Paralelamente às promissoras pesquisas microbiológicas, a quimica fisiológica desenvolvia-se com menos alarde, mas com resultados decisivos para a medicina. Com o sucesso desta disciplinas, a nutrição, disciplina abordada até então de maneira intuitiva e um tanto quanto obscura, adquiria "status" cientifico através de exaustivas pesquisas laboratoriais ${ }^{126}$. No âmbito da critica dos conhecimentos da época e do desenvolvimento de enunciados cientificos sobre a nutrição, dois cientistas alemães e um norte-americano, entre outros, foram inovadores na segunda metade do século XIX: Moritz Traube (1826-1894) e Max Rubner (1854-1932). O primeiro, contestando o renomado químico

126 Sobre o nascimento da nutrição como disciplina cientifica, há quem tome como marco da

"primeira descoberta de importância fundamental do ponto de vista da nutrição"

os trabalhos do inglès R. Boyle [ 1627-1691; filósofo natural, químico de grande habilidade experimental, insistia na necessidade da experimentação como elemento de prova científica. Exerceu influência no desenvolvimento cientifico de I. Newton (16431727) ] que estabeleceu a lei do comportamento dos gases na segunda metade do século XVII (i). Toma-se também como marco as descobertas do dióxido de carbono, em 1757, por Joseph Black, do hidrogênio por Cavendish (1766), etc (ii); Contudo, há algum consenso sobre as contribuições de A-L. de Lavoisier (1743-1794):

"em seus estudos e pesquisas sobre combustão, respiração e calor animal, [Lavoisier] introduziu procedimentos, apresentou resultados e chegou a conclusðes que deram impulso decisivo à concepção de que os processos relacionados à nutrição eram químicos" (iii).

i. MAZZILLI, R.N. Contribuição da química na origem da ciencia da Nutrição. Faculdade de Higiene e Saúde Pública. s.r.d [mimeo.]

ii. TODHUNTER, N. Development of knowledge in Nutrition. J. American Dietetic Association, +1: 335:340, 1962.

iii. SANTOS,K.M.O. dos. $O$ desenvolvimento histórico da ciência da nutrição... Op. cit., p. 11. 
J.Liebig que afirmava o contrário, disse que a oxidação ("queima") de substâncias não-nitrogenadas (carboidratos e gorduras) associava-se à produção de energia. Resolvia, assim, não sem polêmicas, uma questão central para o desenvolvimento da calorimetria moderna. O segundo, incorporando conceitos de Traube, viria a confirmar que seria através do metabolismo que o organismo animal obtém toda energia necessária.

W.O.Atwater (1844 - 1907) foi um fisiologista que trabalhou em laboratórios na Alemanha, inclusive com Rubner. Ao retornar ao seu pais conduziu seus estudos para fins objetivamente pragmáticos, sediando-os no Departamento de Agricultura , criado desde 1862, e que tinha como base as estações experimentais agricolas. O programa de pesquisas de Atwater arrolava os seguintes propósitos:

"estudo dos padrões de dieta norte-americanos, a análise química de alimentos, determinação do valor calórico de alimentos, de sua digestibilidade e utilização intestinal, determinação das necessidades energéticas humanas e estudo econômico da produção e utilização de alimentos"127.

Apesar das atraentes novidades que chegavam das pesquisas sobre as necessidades nutricionais humanas, a associação destas com a etiologia de doenças não era asseverada. Ainda que, neste caso, fosse necessário metodologias especificas para demonstrar alguma hipótese a respeito, por outro lado as teorias sobre a origem das doenças - como a miasmática, por exemplo - começavam a enfrentar uma teoria concorrente que chegava com bastante fôlego: a teoria bacteriológica ${ }^{128}$.

${ }^{127}$ SANTOS,K.M.O. dos. O desenvolvimento histórico da ciência da nutrição. Op. cit., p. 106.

128 Prever que pequenissimos seres vivos ccavionassem doenças, não é exatamente privilégio de cientistas da segunda metade do século XIX. No entanto, as condiçð̌es que possibilitaram o êxito de uma hipótese similar só vieram neste periodo. ROSEN (*) analisa assim a queståo:

"Pensar que agentes vivos particulados pudessem originar as doenças infecciosas năo era novidade em meados do século passado. Desde a antiquidade remota observadores atentos e argutos tinham aventado a hipótese de serem essas doenças transmitidas por contágio, e causadas por 'sementes', 'animalculos' ou 'vermes'. Essa idéia nasceu sem o auxilio da 
Quando em 1872 João Alphonso recebe o livro "Ensaios sobre o Beribéri no Brasi" , do já conhecido médico baiano J.F.Silva Lima, ele praticamente conhecia seu conteúdo. É que o próprio autor, no prefácio, afirma que se trata da série de artigos originalmente publicados na Gazeta Medica da Bahia entre os anos de 1866 a 1869. Apenas o apêndice, com observações e com comentários criticos, era inédito. Compartimentalizados, os assuntos abordam aspectos históricos da doença, sintomas gerais e particulares da moléstia e, em seguida, as observações clínicas tiradas de casos observados em Salvador. Nos capitulos seguintes, o autor refere-se à origem, desenvolvimento e extensão geográfica da doença, a anatomia patológica, marcha e duração, mortalidade, propagação, diagnóstico, caracterização nosológica, diagnóstico diferencial, prognóstico, etiologia, natureza, patogenia, tratamento e profilaxia. Cuidadoso, o autor não se deixa seduzir, apesar de meticuloso, pelo alcance do seu trabalho, chegando a afirmar:

"Ninguém espere encontrar aqui uma acabada monografia do beriberi, mas apenas o imperfeito esboço de uma moléstia cujo nome, natureza, e afinidades patológicas me eram desconhecidos..."129.

No que se refere especificamente à etiologia do beribéri, Silva Lima afirma:

"Determinar qual a causa productora da moléstia de que me tenho occupado n'este trabalho, è certamente um dos pontos mais difficeis da minha tarefa, os escassos, insufficientes $\mathrm{e}$ incompletos dados que disponho sobre este

Bacteriologia, e mesmo antes de se descobrir os germes houve progresso neste sentido. Apenas na segunda metade do século XIX, porém, a opinião começou, lentamente, a se voltar com mais decisão parâ essc rumc. Em parte essa mudança se deveu a uma reação contra a ineficiência da teoria miasmática. Mas revelou-se ainda mais significativa a evidência, rapidamente acumulada, de que microorganismos específicos causavam doenças contagiosas e epidèmicas".

* ROSEN, G. Uma história ... Op. cit.

129 LIMA, J. F. da S. Ensaio sobre o beriberi no Brasil. Salvador, Typographia de J. G. Tourinho, 1872. p. II. 
importante assumpto não me permittem, infelizmente, sahir do campo vago das conjecturas"130.

De fato, o médico baiano analisa as teorias que alguns autores aludiam para explicar a causa do beribéri, sem, entretanto, se contentar rigorosamente com nenhuma delas. A base cientifica e experimental que caracterizaria as atividades da Escola tropicalista Baiana, da qual Souza Lima é um dos expoentes, sugerirá algumas das indagaçōes que contam do seu estudo sobre a causa do beribéri:

"Qual seja porem, o agente d'essa intoxicação previa do sangue, onde e como se produz, è o que se não pode, por quanto, averiguar. Mas é certo que esse agente, qualquer que elle seja, e que a similhança perfeita dos effeitos nos induz a reputar analogo ao que produz o beribéri, se é que causas e effeitos não são respectivamente identicos, tem as condições de sua existencia e desenvolvimento mais particularmente na zona intertropical, ou até pouco alem d'ella, e parece depender de circumstancias climatericas especiaes, como acontece com outras molestias endemicas, susceptiveis ou não de extenderem-se epidemicamente" ${ }^{131}$.

Os trabalhos anteriores ao de Silva Lima relatam casos de uma doença que se poderia chamar: paralisias epidêmicas, intoxicação e caquexia palustre, paralisia reflexa e até mesmo beribéri. Um dos trabalhos mencionados por Silva Lima é uma tese de concurso na Faculdade de Medicina da Bahia, surgido em 1871 ${ }^{132}$. Neste trabalho, o autor, ainda que não considere o beribéri de procedència palustre, afirma quanto a sua etiologia:

"a malaria, decompondo o sangue, e empobrecendo-o, proporciona a progressão e intensidade na molestia”.

\footnotetext{
130 Idem, p. 127.

131 Idem, p. 128.

132 COUTO, J. L de A. Quais são os melhores meios terapêuticos de combater o beriberi ?. Tese de Concurso, Bahia, 1871.
} 
Mas este mesmo autor arrola o que chama de "causas predisponentes da_doença": a alimentação de má natureza, o puerpério, as impressōes morais e o alcoolismo e avalia que a doença origina-se de um elemento tóxico no sangue cujo agente é desconhecido. Silva Lima analisa ainda as impressões de outros autores nacionais, cita as conclusões do médico Sá Pereira, que afirma em seu trabalho sobre o beribéri em Pernambuco:

"a causa do beriberi parece ser miasmática, e de origem vegetal a mais funesta; porque a molestia por ella produzida é mui similhante a outras que teem a mesma origem ... sua causa (do beriberi) parece ter origem na evaporação dos miasmas que resultam da decomposicão putrida dos vegetaes enterrados"133.

Silva Lima enumera as teses dos autores nacionais para afirmar que

"a origem paludosa do beriberi observado no Brazil é adoptada pela maioria dos escriptores... ${ }^{134}$.

A seguir, Silva Lima, a partir de várias consideraçōes, contrapõe-se ao pressuposto acima. Entre os oito argumentos citados contra a origem

133 PEREIRA,C. de S. O beriberi em Pernambuco. Recife, 1871. Citado por SOUZA LIMA, Op. Cit. p. 210-11.

134 SOUZA LIMA, Op. cit. p 211.

É importante reconhecer que a influência da 'teoria palustre' para explicar a gênese de várias doenças já era antiga. Desde que, em 1717, o médico italiano Giovanni $M$. Lancisi (1654-1720) publicou o livro "Sobre as emanaçðes nocivas dos pântanos" (i), a idéia de que os pântanos, áreas palustres, produziriam emanações capazes de gerar doenças, ganhou o campo para explicação da etiologia de várias doenças. A malária ("ar ruim, mal ar"), doença secular na Europa, teve que esperar quase duzentos anos após as assertivas de Lancisi ( que identificou também um tipo de emanação animada mosquitos - capaz de carregar matéria patogènica) para ver descrito seus macanismos de transmissão. A influència dos conhecimentos acerca da malária para explicação etiológica do beriberi é significante. Há inclusive trabalhos explicitos acerca desta relação como, por exemplo, a tese de Ribeiro Nery (ii).

i. ROSEN,G. Uma históna ... Op. cit. p. 89.

11. NERY, I. de S. R. Analogias entre o beriberi e a malária. Rio de Janeiro, 1899. [Tese de conclusão do curso de Medicina]. 
miasmática do beribéri, é importante atentar para alguns. $O$ primeiro, que oferece uma idéia da elaboração metodológica e, atê mesmo, epistemológica que norteia a "filosofia" de trabalho da Escola tropicalista Baiana", afirma que

"O fato de ter sido observado o beribéri conjunctamente com a intoxicação palustre não prova a identidade da causa, mas apenas a coincidencia de logar e de tempo"135.

Aparentemente "lógico", este enunciado denuncia a precariedade da pesquisa médica experimental até então. Baseadas em deduções e induções tiradas de fatos observados ou relatados sem nenhum tipo de controle metodológico, os enunciados "cientificos" carregavam-se de vícios que pouco sustentavam as afirmativas. Ou seja, não está em jogo o critério de verdade ou falsidade de uma determinada afirmativa possibilidade também existente pelo método experimental - mas as regras de verificação (metodologia)e de enunciação que foram utilizadas para produzi-las ${ }^{136}$.

Uma outra ponderaçào que Silva Lima faz à tese de origem paludosa do beriberi diz respeito às pessoas acometidas pela doença. Afirma ele:

"As molestias procedentes da malaria acomettem de preferencia, e com mais intensidade, as pessoas estramhas à localidade, e as não aclimadas; succede o contrario com o beriberi, que attaca de ordinario os naturaes, e os estrangeiros

Idem, p. 212 .

136 A primeira parte do presente trabalho refere-se à característica nada experimental da pesquisa médica no Brasil durante quase todo o século XLK. Nos termos abordados naquela primeira parte,

"A medicina continuou, por quase todo século XIX, vinculada aos princípios e aos fundamentos da ciência européia, com as distorções e as deformações impressas pelo meio ambiente ainda de todo infenso ou impróprio à pesquisa, à experimentação... a Arte médica aqui continuará orientada no mesmo sentido teórico" $\left({ }^{*}\right)$.

* HOLANDA,S.B. de. (org.). História geral... Op. cit. p. 467. 
que já teem muitos mezes ou alguns annos de residencia nos paizes onde elle é endemico" ${ }^{137}$.

Nos termos da teoria científica que veio enunciar a etiologia do beriberi, a afirmação do médico baiano é epidemiologicamente pertinente. Naturalmente que_localizar' o agente, isto é, afirmar que as pessoas mais susceptiveis à doença são as "aclimatadas", não define automaticamente a natureza do agente etiológico - e nem isto foi possivel no caso do pesquisador em questão - mas trata-se de um 'achado' que encurta caminhos das novas pesquisas sobre o tema. Por fim, em um dos contrapontos à teoria da origem paludosa do beriberi,Silva Lima pondera que

“... o beriberi não se observa na infancia, e è rarissimo em edade inferior a 18 annos; entretanto que succede o contrario com as molestias de origem palustre ${ }^{\text {138 }}$.

Evidentemente que o próprio autor, ao estar contrapondo, tem noção do caráter polêmico da suas afirmativas, ainda que para ele se trata de uma constatação verossimil. Aqui, mais do que precisar tal verossimilhança, o importante é conhecer que tal hipótese existiu - foi enunciada - ainda no início de um ciclo de estudos sobre o beriberi. Como será visto, a afirmação de que o beriberi teria sido endêmica em colégios, onde a idade amplamente majoritária é inferior a 18 anos, foi generalizada no Brasil. Esta idéia', fruto das circunstâncias cientificas que modelaram as pesquisas médicas majoritárias na época, produziu influência direta na legislação sanitária, tornando o beriberi doença de notificação facultativa ${ }^{139}$. Por fim, para concluir seus estudos acerca da

137

LIMA,S. Op. cit. p. 212-3.

138

Idem, Op. cit. p. 213

139 Dentre os primeiros atos do governo republicano, um decreto de 18 de dezembro de 1889 instituia:

1) vacinação anti-variólica obrigatória, nos primeiros seis meses de vida;

2) notificação compulsória dos casos de doenças transmissiveis;

3) desinfecção obrigatória, aplicada ao locais e objetos contaminados e

4) isolamento hospitalar, quando o doente não estivesse em condiçð̃es de receber tratamento no próprio domicilio. 
etiologia do beriberi, Silva Lima ressalta que, na sua opinião e baseado nos casos observados, a falta de exercício físico ao ar livre constituiria num fator predisponente da doença. Este último princípio foi bastante consagrado durante toda a segunda metade do século XIX, constituindose num dos pilares da moderna higiene, que norteou,_particularmente, a regularização da atividade fisica em colégios da época ${ }^{140}$.

Na sua exposição sobre a etiologia do beribéri, Silva Lima, na moderação do enunciado cientifico que lhe é peculiar, não afirma uma hegemonia de nenhuma causa em especial. Em outras partes do seu livro, o autor, ao discutir, por exemplo, diagnóstico e propagação da moléstia, bem como o seu tratamento e profilaxia, alude a hipóteses distintas. Assim, ao comentar o caso em que quatro pessoas de uma mesma familia teriam sido afetadas sucessivamente pela doença, o autor insere no panorama etiológico da doença:

Além disto, o referido decreto considerava de notificação compulsória as seguintes doenças:

"... febre amarella, o cholera, a peste, a diphtheria, a variola, a escarlatina e o sarampo, e de notificação facultativa a tuberculose, a febre typhoide, a coqueluche e o beriberi" (grifo do presente estudo) $\left(^{*}\right)$

* FONTENELLE,J.P. Op. cit. p. 428

140 Os benefícios da educação fisica para o desenvolvimento, e como atividade profilática, são destacados, por exemplo, por COUTINHO (i):

“... não é ao abandono que se deve deixar o desenvolvimento e crescimento dos meninos, - os exercícios corporeos são úteis e indispensaveis á intelligencia; - uma constituição debil se vigora pelo exercicio moderado e conveniente, os musculos se desenvolvem, as funç̧ões se regulisão."

e descrita dentro da rotina de um colégio por POMPÉIA (ii), entre outros:

"Acabadas as evoluções, apresentaram-se os exercicios. Músculos do braço, músculos do tronco, tendðes dos jarretes, a teoria toda do corpore sano foi praticada valentemente ali, precisamente, com a simultaneidade exata das extensas máquinas. ... Uma desordem de contorçð̃es, deslocadas e atrevidas; uma vertigem de volteios à barra fixa, temeridades acrobáticas ao trapézio, às perchas, às cordas, às escadas ... triunfo espetaculoso da saúde, da força, da mocidade".

i. COUTINHO, C.T.A. Esboço de uma hygiene dos collegios. Op. cit. p. 18.

ii. POMPÉLA, R. O Ateneu. Op. cit. p. 13-14. 
"Ainda que estes factos estejam muito longe de demonstrar a_propagação da doença por contagio ou por infecção, isto é, por meio de um producto morbido resultante da sua evolução pathologica, e que a reproduza como a semente reproduz a planta de onde nascera, julgo que não deviam ser omittidos neste logar, simplesmente como elementos historicos que podem ter cabal explicação no futuro, e contribuir, com outros ja conhecidos, e com os que estudos ulteriores possam revelar, para esclarecer a pathogenia, obscura ainda, d'esta molestia singular"141.

Sob o ponto de vista da terapêutica, Silva Lima discute os agentes para as três formas da doença: paralítica, edematosa e mista. É importante observar que, dentre a multicausalidade possivel que explique a etiologia da doença, o tratamento designado impõe, no mínimo, uma conclusão: que a causa da doença guarda relação com o juizo (o conhecimento da sua patologia) que se tem para o tratamento medicamentoso preconizado. E assim, por exemplo, quando o autor descreve o uso do arsênico:

“... de todos os agentes pharmaceuticos de que até hoje tenho lançado mão na forma paralytica da doença, o que mais decididas vantagens promette, e cujo emprego recommendo com particular empenho aos meus collegas, é o arsenico ... todos os doentes, e_alguns até em periodo adiantado d'esta affecção, a quem n'estes ultimos 3 mezes tenho administrado o arsenico, ... todos teem melhorado por modo muito notavel, e muito mais rapidamente do que outros que d'antes approveitavam com a strychnina"142.

\section{LIMA,J.F.S. O beriberi no Brasil. Op. cit. p. 77}

142 idem, p. 165

$\mathrm{Na}$ seqüência do seu livro, Silva Lima retoma a discussão sobre o tratamento da doença e acrescenta:

"De todos os agentes therapeuticos que tenho empregado até hoje, os que me teem parecido mais vantajosos são - o arsenico, o phosphoro, o ferro, e a 
Como já foi salientado, além do questionamento e conseguente contestação da teoria miasmática - ou palustre - para explicar a etiologia do beriberi, Silva Lima acolhe outros meios que se inscreveram no tratamento da moléstia:

"Tanto em uma como em outra das formas principaes da doença tiveram a possivel applicação os preceitos da hygiene, taes como a mudança de ares, o agazalho da pelle na estação humida, e a alimentação substancial acompanhada do uso do vinho generoso do Porto: todos estes meios pareceram de vantagem, e será util não os omittir sempre que estejam ao alcance dos doentes, o que, infelizmente, não sucede com todos $^{n 143}$.

Além dos preceitos citados, a mudança do doente para fora da localidade onde o doente adquiriu a doença, os banhos de mar e a mudança de clima foram medidas reconhecidas como pertinentes pelo autor, como tratamento para a enfermidade. Estas medidas higiênicas "preceitos da boa hygiene" - basicamente correspondem às que o autor lista para a profilaxia.

"Alem da boa alimentação, que deve ser variada e sufficiente, convem, nas regiões tropicaes, recommendar que haja ao mesmo tempo todo o empenho possivel em evitar o abuso dos prazeres da_mesa, e particularmente o das bebidas alcoolicas. As affecções moraes deprimentes, resfriamentos subitos da pele, ..."144.

strychnina; e acessoriamente, conforme as indicaçðes particulares, os purgativos, os diuréticos, e os revulsivos, ...

$\mathrm{O}$ arsenico é um dos poucos modificadores medicamentosos que teem adquirido crescente reputação no tratamento do beriberi. Infelizmente não é applicavel senão em casos de marcha lenta, e que permittem o seu uso prolongado" (idem, p. 223).

143 idem, p. 174

it idem, p. 177 
E ainda, na impossibilidade de que todos os acometidos pela doença façam viagem dispendiosas como também, conforme afirma o autor, as pessoas afetadas são de classe de vida pouco ativa fisicamente, ele recomenda a seus doentes

"não só o exercicio compativel com suas forças, como, principalmente, as mudanças frequentes de localidade; e para tornar praticavel este preceito para o maior numero possivel de enfermos, tenho aconselhado passeios diarios de algumas horas pelos caminhos de ferro urbanos, e e isto com uma vantagem superior à minha expectativa. A outros aconselhei, com egual proveito, viagens amiudadas nos vapores que diariamente cruzam a bahia, entre a capital e os portos do Reconcavo ..."145.

João Alphonso sabia da relação entre etiologia, profilaxia e tratamento e por isso ponderava as incertezas na abordagem da doença pelo dr. Silva Lima. Para ele, o grande mérito do trabalho do médico baiano era a descrição sintomatológica e caracterização de um quadro clínico, chegando brevemente à enunciação do diagnóstico diferencial, baseado na observação e experimentação ${ }^{146}$. A precisão do seu estudo,

\section{5 idem, p. 266}

146 Silva Lima, para suas conclusðes acerca da patologia do beribéri, serviu-se de algumas autópsias que, naquela época, se realizavam em escravos e presos sujeitos a exame policial. Assim, de acordo com OLIVEIRA (i),

"Para um modelo médico que se baseava na observação e na experimentação, como é o caso do modelo adotado pela 'Escola Tropicalista Baiana', fazia-se imprescindivel a realização de autópsias. $\mathrm{Na}$ ausência destâs, não estava preenchida a experimentação, paralisando, assim, a pesquisa".

No entanto, a utilização dos recursos da anatomia patológica para investigação do beriberi não era consensual . COSTA ALVARENGA (ii), no seu livro sobre o assunto, publicado no ano seguinte ao de Silva Lima, afirma:

"Muito variada e divergente tem corrido a opinião dos medicos sobre a pathogenia do beriberi, isto é, sobre a determinaçào das condiçðes, das modificaçðes primordiaes, fundamentaes, do organismo, dónde resulta $o$ quadro de symptomas que caracterisa o beriberi... 
no que se refere à caracterização da doença enquanto entidade mórbida distinta, marcaria definitivamente sua obra como referência para outros trabalhos. Duas abordagens da doença por Silva Lima chamariam a atenção de João Alphonso: o 'peso' dado à higiene na sua determinação e a influência que sucessos recentes de outros estudos do grupo que constituira a 'Escola Tropicalista Baiana'. No primeiro caso, a higiene era assumida como disciplina que, recebendo de outras matérias, enunciava principios sobre os cuidados físicos, psíquicos e ambientais com o objetivo de proteger a saúde dos individuos. Assim, pensava João Alphonso, não se tratava de uma novidade relacionar beriberi à higiene, mas chamava a atenção a maneira como o fez o autor ${ }^{147}$. Ele investigou

\begin{abstract}
"Uns medicos teem recorrido à anatomia pathologica com o intuito de ahi descobrirem a origem e a natureza da doença; outros teem considerado este ou aquelle dos principaes symptomas do beriberi, indagado a sua causa e natureza, e sobre elle teem estabelecido a pathogenia d'esta doença.

"O primeiro modo não tem dado resultados satisfactorios, pela inconstancia e variabilidade das alterações encontradas, as quaes além d'isso não dão razão sufficiente dos phenomenos clinicos, da feição característica do beriberi; 0 segundo processo é por extremo vicioso, porque attende sómente a uma parte da doença, quando devera abrangel-a toda"
\end{abstract}

i. OLIVEIRA,C.R. Medicina e Estado: .... Op. cit. p. 238.

ii. ALVARENGA, P. F. da C. Symptomatologia, Natureza e Pathogenia do Beriberi. Lisboa, Typographia da Academia Real das Sciencias, 1875

147 No capítulo em que descreve o estudo do beriberi por Silva Lima, OLIVEIRA (i) quer ver uma originalidade (e importância) do autor ao tratar da relação entre higiene $e$ doença:

"... Esta afirmação a nosso ver indica a importância dada pelos membros da "Escola Tropicalista Baiana" à relaçăo entre higiene e doença, tanto sob o ponto de vista causal (etiologia) quanto sob o ponto de vista da evoluçåo da doença (patologia)".

A par dos esforços para valorizar os qualificados trabalhos da referida "Escola", é razoável admitir que à higiene uma importância fundamental já era atribuída. COUTINHO (ii), em sua tese de 1857, escreveu:

"O seculo XIX deve dar à hygiene o lugar que ella occupa entre as sciencias,

os progressos da chimica, da physica, da physiologia, as obervaçðes meteorologicas prestão-lhe o contigente de suas leis, que se convertem em principios hygienicos, evitando e attenuando a acção dos agentes externos, e corrigindo a sua influència sobre as funç̧ðes do organismo". 
minuciosamente os casos particulares que estudou e tratou de estabelecer uma relação entre os hábitos cotidianos dos mesmos e a doença que estudava. Com isso, no que se refere ao beriberi, deixava o campo das conjecturas e alargava o campo para compreensão da patologia.

Quando à segunda abordagem, os médicos facultativos' que pesquisavam e se reuniam em torno do periódico "Gazeta Médica da Bahia" colecionavam importantes contribuições para o conhecimento de algumas doenças. Destas, a mais importante foi a ancilostomiase, que, após calorosa polêmica com a escola médica clássica do Rio de Janeiro, passou a prevalecer como teoria que convenientemente explicasse o ciclo da doença ${ }^{148}$. Este 'modelo' que norteava os procedimentos metodológicos

Da mesma forma, em outra tese de conclusão de curso médico em 1862, ao tratar da "Hipoemia Intertropical", o médico diamantinense Antônio Felício dos SANTOS (iii, p. 57), ao tratar da "prophylaxia e Hygiene", escreveu:

"Na subtracção às causas está a prophylaxia; vamos apenas indicar uma ou outra medida hygienica que acreditamos mais util. Uma alimentação bôa na quantidade e qualidade ... O trabalho regular não exposto ao sol nas horas caniculares ... A superficie cutânea merece cuidados especiaes; o vestuario mais hygienico do que o ordinario, o uso dos banhos ...

A construção de habitações deve ser longe de lugares baixos e humidos, com uma boa ventillação, sem accumulo de indivíduos e asseiadas sempre".

Por fim, na esfera governamental também já existia um consenso sobre a essencialidade de práticas higiênicas, de acordo com o nível de conhecimento em diferentes periodos, particularmente durante a segunda metade do século XIX, conforme mostra FONTENELLE (iv)

i. OLIVEIRA,C.R. Medicina e estado: ... Op. cit. p. 235

ii. COUTINHO,C.T. de A. Esboço de uma hygiene ... Op. cit. p.6

iii. SANTOS,A.F. dos. Hypoemia intertropical. Rio de Janeiro, 1862. [Tese de doutoramento - Faculdade de Medicina do Rio de Janeiro]

iv. FONTENELLE, J. P. Hygiene e saude publica. In: ... Op. cit.

$1+8$ Como se sabe, no Brasil foram os estudos do dr. O. Wucherer, um dos três maiores expoentes da "Escola Tropicalista Baiana", que elucidaram a etiologia da doença que se chamava por 'opilação', 'hipoemia', etc. Wucherer identificou ancilóstomos em cadáveres, relacionou-os com a doença e expôs os mecamismos causais. No entanto, a aceitação não foi pacifica $\mathrm{A}$ então poderosa Academia Imperial de medicina do Rio de Janeiro, numa sessão de 12 de agosto de 1867 , resolveu decidir por voto 
da 'Escola Tropicalista' certamente monitorava as abordagens do grupo. Desta forma, pensou João Alphonso, mesmo se Silva Lima suspeitasse de uma hipótese capaz de melhor dar conta do beriberi, haveria um cerceamento anterior por parte de um 'modelo', pode-se afirmar, bem sucedido. Caso Silva Lima não dispusesse de uma hipótese que confrontasse com aqueles do seu 'modelo', tal 'modelo', então, surgia como um labirinto de cartas marcadas: não se sabe qual é a saída, mas sabe-se que ela existe; obedecendo os limites do proprio labirinto.

João Alphonso, discutindo o assunto com um colega clínico, afirmara suas suposições, mas diante da incompreensão do colega explicou que não se tratava de uma questão particularizada na pessoa do médico baiano. Era, metaforicamente, uma questão semelhante a uma aporia que se colocava à possibilidade do conhecimento. João Alphonso ponderava ainda que, pelo fato de não se ter uma solução razoável para a questão, a crítica era uma das formas de se evitar o confinamento da razão num curral sem porteiras. Neste sentido, ele se lembrou de uma certa discussão que, em Göttingen, havia tido com Morten, acerca das possibilidades de eventuais mudanças estruturais na sociedade ${ }^{149}$. Ele recordou que, naquela ocasião, nem se tratava do fato de não haver alternativas; o fato era que a solução apontada pelo amigo tornava-se mais atraente aos espíritos e mais de acordo com as exigências imediatas de uma época que descobria as possibilidades da ação in totum. Nestes

"que em geral não deve ser considerado este verme como causa promotora e unica, sine qua non da hypoemia intertropical, e antes como um effeito desta..." (*).

Wucherer, numa correspondência cientifica à Gazeta Médica da Bahia (*), repudia a decisão e ironiza os membros da Academia que decidiram um fato científico não baseados em fatos e argumentos, mas em voto:

“... questð̃es sobre causa e effeito não se decidem por opinið̃es ou por votos, e sim pela apreciação dos racios.

"A co-existencia constante dos anchylostomos com a hypoemia está assaz demonstrada, e parece mais logico consideral-os antes como causa, senão unica, ao menos aggravante, do que como effeito (?) da molestia.

* WUCHERER,O. Anchylostomos duodenaes. Gazeta Medica da Bahia. n. 37, p. 150,15 de janeiro 1868 .

149 Sobre este acontecimento, ver a Primeira Parte, (p. 30-4). 
termos, a nascente curiosidade nosológica relativa ao beriberi teria que superar alguns obstáculos antes que alcançasse resultados convencedores: o caráter restritivo dos 'modelos' teóricos que norteavam a pesquisa médica naquele momento; a ausência de uma base experimental nas escolas médicas que não gerava atitudes criticas, questionadoras $\mathrm{e}$ inovadoras capazes de aceitar ou produzir conhecimento e técnicas também inovadoras; além disso, o forte apelo circunstancial do tema começava a proviocar uma 'corrida acadêmica' à moléstia - sem que as bases para tal investigação estivessem constituídas - e isto poderia levar não apenas ao desejo do ineditismo, como também desconsiderar conhecimentos importantes sobre doenças que já haviam sido alcançados ${ }^{150}$. Os próximos anos seriam capitais para o exame destas conjecturas, pensou um João Alphonso que se amparava no que escreveria um autor que ele gostava de ler:

"Eu gosto de catar o mínimo e o escondido. Onde ninguém mete o nariz, aí entra o meu, com a curiosidade estrita e aguda que descobre o encoberto"151.

João Alphonso havia sido chamado à Casa central da Congregação da Missão para atender o padre Guilherme Holtappel, alemão da região de Trier, que acabara de chegar ao Brasil. O padre iria desenvolver, a partir do Caraça, trabalho missionário na provincia mineira, mas chegara ao Brasil necessitando de assistência médica. Conhecedor da comunidade Lazarista e, neste caso, familiarizado com o idioma alemão, João Alphonso era preciso para atender o padre Holtappel ${ }^{152}$. O Padre

150 Neste sentido, há que se considerar os laços, nem sempre claros, existentes entre paradigmas, modismos e pesquisa cientííca. Este emaranhado de atitudes individuais e institucionais que definem o rumo das investigaçðes deve ter a sua influência na pertinácia dos resultados. Sem alongar o necessário para dar conta da questão, deve-se recordar que várias foram as evidências, anteriores ao estudo do beriberi, de que , por exemplo, aspectos alimentares encontravam-se envolvidos com a etiologia de doenças.

151 Machado de Assis. A Semana, vol. III, p. 772. Ed. coligida por Mário de Andrade, 1910. 
logo se sentiu à vontade com João Alphonso. Estava sendo

152 Segundo SARNEL (i) , o padre Guilherme Holtappel, nascido em Gelsdorf, região de Trier em 31 de janeiro de 1847, chegou ao Brasil em 1873. Em 1874, está no Colégio Caraça, de onde se baseia para o trabalho missionário. Em 1875, exatamente em 16 de setembro, retorna à Europa doente dos olhos.

Sobre a atividade missionária dos padres Lazaristas, não é demais lembrar que ela constituí-se numa das principais tarefas desta congregação. Conforme já citado anteriormente, a abertura do colégio foi internamente assumida como sendo uma das maneiras para que a congregação obtivesse recursos que - os missionários -

"pudessem pregar gratuitamente as suas santas missões" (ii).

No acervo histórico da Casa Central da Congregação (iii), um livro manuscrito discorre sobre as atividades missionárias. ANDRADE (iv) destaca o trabalho missionário de padres caracences em Itabira, MG. Neste local, entre os anos 1904 e 1908, os padres franceses Alberto Toor e Felipe Matta, mais o holandês Guilherme Vassen, missionaram por lá. A autora citada descreve:

"Registros de imagens... permitem o conhecimento de como a cidade recebia as missões lazaristas: ruas e becos calçados de hematita congestionados de fiéis, procissões e andores acompanhados pelos cidadãos proeminentes, bandas de música, ornamentos, etc. $E$, sobretudo, meninos a quem os padres do Caraça dedicavam atenção especial, em razão do trabalho missionário e do seu colégio"

O poeta Carlos Drummond de Andrade, nascido em Itabira no ano de 1902, e que ali viveu até 1917, deu-nos suas impressões sobre as missð̃es caracences em Contos de Aprendiz , no conto "A salvação da Alma"(iv):

"Novas notícias chegaram sobre os missionários. Eram estrangeiros - de que país mesmo, ninguém sabia, tão atrapalhado o português que falavam -, muito vermelhos, e 'estavam dispostos a fazer uma boa colheita de almas para Deus', no dizer da piedosa D. Antonina. E pregavam, pregavam. Todos os dias, de hora em hora, a partir das duas da tarde, um deles subia ao púlpito e narrava os horrores do inferno, os jardins do paraíso, a miséria da alma em pecado mortal, a traição de Judas, a aflição dos ricos no juízo final, a doçura de sofrer e ser humilhado, o perigo de casar somente no civil, a necessidade de contribuir para as obras pias, a loucura de lidar com maçons e espíritas...Enquanto um pregava, os outros padres ouviam em confissão. Veio primeiro a gente dos distritos ... E só no fim as crianças, que, já trabalhadas, ardiam no desejo de ajoelhar-se e contar suas faltas, tão contagioso é o exemplo das pessoas grandes, e porque, afinal, seria uma vergonha nào ter pecados quando toda gente os tinha e vinha confiá-los ao padre vermelho".

(i) Congregados do Caraça. Op. cit. p. 56.

(ii) Idem, p. 3-4.

(iii) ANDRADE, M.G. de. Op. cit. p. 83-4.

(iv) ANDRADE, C.D. de. Contos de Aprendiz. $13^{\text {a }}$ ed. Rio de Janeiro, Ed. José Olympio, 1976. 
surpreendente, dissera ele, encontrar um médico brasileiro formado em Göttingen e, apesar de tanto anos sem ter estado na Alemanha, falando um Alemão praticamente correto. João Alphonso explicou que exercitava bastante o idioma com as familias alemãs que assistia, médicos de lá que clinicavam ou visitavam o Brasil, além da correspondência profissional e pessoal que mantinha em língua alemã. Falou com entusiasmo - já que nesta época ele andava satisfeito e entusiasmado com o retorno do filho que concluira o curso de direito em São Paulo e estava se instalando na cidade - da sua amizade com Morten. Sobre isto, disse que, apesar de não se encontrarem após a formatura, ambos conseguiram enfrentar quase que estoicamente, movidos por um forte sentimento de uma amizade verdadeira, a força desbotante do tempo sobre uma relação à distância. E diante de um simpático espanto do padre frente a uma situação em que o tempo, a distância e a amizade são detidos por uma subjetiva malha de interesses e bem estar mutuamente pessoais, João Alphonso comentou, acendendo um diálogo:

- Sabe Padre, creio que eu e o Morten não podemos lamentar... Kierkegaard, um filósofo dinamarquês que conheci em Berlim em, se não me engano, 42, escreveu que o matrimônio é uma situação cômoda na qual instalamos nossa existência. Uma amizade instigante e próxima talvez não comporte acomodações.

- Eu não conheço Kierkegaard, talvez não deva concordar com ele ou ..., isto é, acho que não devo, mas ... Bem, o senhor tem tido dificuldades de consciência, doutor? Deseja uma confissão?

Cuidadoso com o jovem sacerdote, João Alphonso respondeu:

- Acredite, Padre, eu estou me sentindo muito bem e não desejo uma confissão. Não sei se seus compromissos religiosos permitirão, mas, se permitirem, leia Kierkegaard. Talvez lá o senhor comece a investigar porque, existencialmente, os medrosos se acomodam e se conformam mais do que aqueles que aceitam desafios postos por um viver em decisão.

- O seu Kierkegaard diz isto? - perguntou Holtappel.

- Não li assim. Mas li coisas dele que me fazem pensar. Coisas como: "Encontrava-me tão profundamente comovido que compreendi 
com claridade meridiana que não me seria possivel seguir uma vida trilhada e conformista como a que vivem a maioria dos homens"153.

O diálogo dos dois foi consensualmente encerrado com a chegada de um segundo padre, que quis conhecer o diagnóstico e prognóstico médico. Tarefas e viagens esperavam pelo padre Holtappel e João Alphonso quis, por sua vez, saber se a vida no Caraça transcorria normalmente. O segundo padre, veterano e sabedor dos fatos e rotinas da Congregação, simpatizou-se com o interesse do médico amigo da casa e o convidou-o para o almoço. O encontro se tornaria frutuoso.

É que João Alphonso ficaria sabendo que, desde 1867, o Colégio Caraça vinha experimentando uma fase de grande evolução, com salutares ganhos no campo administrativo e educacional. Naquele ano, havia assumido o superiorato do Colégio o padre francês Júlio José Clevelin. O número de alunos aumentava ano a ano, havia um grupo de professores abnegados e capacitados, além de que projetavam-se novas construções no local. João Alphonso observou que havia muita expectativa quanto à presença do Padre Clavelin à frente do colégio instalado em Minas, na Serra do Caraça. É que, antes de assumir esta direção, o Padre Clavelin foi, por mais ou menos cinco anos, um discreto professor que, dadas as suas aulas, refugiava-se para suas leituras em lugares que the permitissem interagir com a natureza eternamente vigorosa e constantemente acolhedora do colégio isolado. Esta disposição do Padre Clavelin foi destacada porque um dos padres conhecia profundamente o Padre Caio que, no Caraça, tomava conta da vinha e era ali que, preferencialmente, Clavelin se refugiava. Na verdade, comentou-se à mesa, a predileção pela vinha provinha das lembranças familiares do Clavelin. Ela era filhos de vinhateiros da aldeia de Ney-sur Seille e, além disso, havia estudado no Seminário menor de Nazeray, que se instala numa graciosa colina margeada pelo rio Ain. Estas circunstâncias, consensuaram os padres, predisporiam a identificação de Clavelin com o Caraça. Um dos padres à mesa destacou, ainda, querendo reforçar a influência do passado no presente de Clavelin, que, além de ter sido um aluno educado sob sólida disciplina e intelectualmente bem

153

KIERKEGAARD,S. Sobre o meu trabalho como autor..... p. ? 
sucedido, caracteristicas estas que já se relacionavam a seu superiorato, no arraial de Nazeray uma das tradições e orgulho era uma igreja gótica que enfeitava o lugarejo. Por isso, continuou o padre, não lhe parecia estranho que Clavelin projetasse substituir a velha capela do Caraça, erigida ainda pelo legendário Irmão Lourenço, por uma nova e vistosa igreja de estilo arquitetônico semelhante à de Nazeray.

O fato é que - continuaram a contar os sacerdotes - após ter chegado à Bahia em 1861, o Padre Clavelin envolveu-se por apenas uns sete meses na direção dos seminários baianos quando, então, acabou se instalando como professor no Caraça.

- Pelo que os senhores me relatam, o Padre Clevelin desenvolve um trabalho muito bom e as expectativas são melhores ainda!? - observou, com um discreto questionamento, João Alphonso.

Sem perda de ritmo e tempo, um dos padres descreveu as obrigaçōes da administração do Caraça:

- Veja, doutor, muitos desconhecem o papel do Caraça. O Colégio é uma franja dentre as outras atividades de formação que mantemos naquela casa de Nossa Senhora Mãe dos Homens. Além dos colegiais, que neste ano são em torno de 200, mantemos o Seminário Maior Diocesano que, desde 1854 , por conta de uma epidemia de variola, se transferiu de Mariana para lá em episódio que o senhor já nos descreveu e assistiu, pois se encontrava em Ouro Preto ...

- Isso mesmo. Eu me lembro perfeitamente de, nesta ocasião, ter recebido as primeiras informações sobre o Caraça.

- Pois bem - continuou o Padre - temos lá, então, o Colégio, o Seminário Maior Diocesano, um Seminário Interno da Congregação, que desde 68 está funcionando, além de ser a casa de referência para nossos missionários que vão ao encontro da gente desalistada do nosso interior. Lembre-se ainda, doutor, que há os nossos congregados, os irmãos coadjutores, os empregados permanentes e eventuais e sempre um ou outro que, por diversos motivos, é acolhido temporariamente na nossa casa na Serra do Caraça.

- Deve mesmo ser complexo administrar toda esta estrutura; ponderou João Alphonso, que perguntou: - e as questōes educacionais e de abastecimento atendem às necessidades e exigèncias da Congregação e dos estudantes? 
Um dos padres respondeu que, dado o número de alunos e a disponibilidade de professores, a vida colegial no Caraça era intensa. Os estudos ocupavam rigorosamente os alunos. Para exemplificar, e associando rigor com intensidade, o padre declarou que só de latim o aluno tinha cinco anos, de forma que, ao final deste periodo, cada aluno tinha intimidade com os principais autores que se expressaram nesta lingua. Esta intimidade com o latim, afirmou o padre, fazia com que autores como Virgilio, Horácio e Ovídio, entre outros, fossem decorados e recitados facilmente. Ao latim seguia-se a história, retórica, matemática, literatura, filosofia e ciências naturais. O próprio padre Clavelin lecionava regularmente. No seu inicio de Caraça, ensinou francês e história e, posteriormente, ficou responsável pelas cadeiras de filosofia $e$ matemática.

Interceptando discretamente o padre que descrevia o atual ambiente caracense, João Alphonso retomou parte da pergunta anterior e falou:

- E quanto ao abastecimento ? Como têm sido suprido as necessidades das pessoas que se encontram lá, especialmente os estudantes ? Alimentação, higiene ...

- Esta é uma questão às vezes dolorosa para a instituição - afirmou o padre que falava antes, e que continuou - o senhor sabe que a produção de alimentos no pais tem passado por momentos dificeis. Mas, pelas informações de que dispomos, o Caraça tem se provido de duas fontes principais: a produção própria e possivel nas terras do santuário e através dos produtores da região. Nosso principal empecilho para um abastecimento regular é o dificil acesso. Estamos a uma altitude elevada, em pleno cume, e os caminhos são árduos. Nesta condição, o transporte é penoso e mesmo a aquisição è uma operação que deve ser cuidadosamente tratada. Quanto à higiene e saúde dos colegiais, procuramos cumprir as recomendações do médico que nos assiste e mantemos uma enfermaria e botica em permanentes condições para atender nossas necessidades imediatas.

- Eu gostaria de ter mais informaçōes sobre os episódios desta doença no Caraça. Na área médica, a cada dia tẻm surgido mais estudos sobre o mal que, aparentemente, tem alguma predileção pelo Brasil e que 
se manifesta em outros países - disse João Alphonso, já ao final da refeição.

Já à saída do Casa Central, João Alphonso foi abordado novamente pelo padre Holtappel, que se encontrava acompanhado:

- Doutor João Alphonso, um momento, por favor. Antes que se vá, eu gostaria de apresentar ao senhor o nosso irmão coadjutor Humberto Schmitz. Irmão Schmitz. Como eu, ele também é alemão, de Colônia, e nos próximos dias também seguirá para o Caraça ${ }^{154}$.

João Alphonso e o Irmão Schmitz cumprimentaram-se. O irmão alemão, de aproximadamente 28 anos, mostrou-se interessado em falar da Alemanha. Disse que conhecia Göttingen e que um parente, de Colônia, havia estudado farmácia naquela universidade. Mas a conversa entre ambos, ainda que fraterna, foi breve. João Alphonso lamentou as circunstâncias em que se encontraram e desejou ao irmão Schmitz felicidade na sua vida caracense. $O$ médico não imaginava que seria a partir deste instantâneo encontro que, alguns anos mais tarde, ele teria informações valiosissimas sobre a botica do Caraça. Isto porque, pela amizade do irmão Schmitz com o irmão Mourão, farmacêutico, hortelão e enfermeiro do Caraça, este forneceria, através de uma correspondência, informações importantes sobre doenças e tratamentos no Colégio Caraça ${ }^{155}$.

154 O irmão coadjutor Humberto Severino Schmitz, nascido em 24-10-1846 em Colônia, chegou ao Caraça em 1873, servindo especialmente como carpinteiro e encanador durante os 29 anos em que viveu, já que lá morreu em 29-01-1902. Foi este irmão que, em 1881, saudaria em alemão o imperador D.Pedro II em sua visita ao Colégio (*).

* Congregados do Caraça. Op. cit. p. 165.

155 O irmão Mourão (Bernardo Mourão), nascido em Portugal e que chegou ao Caraça, vindo de Buenos Aires, em 22-7-1872, detém, junto ccm outro irmão coadjutor Joaquim de Freitas - o recorde de permanência no Caraça entre todos os religiosos que por lá passaram: 57 anos. Assim, chegando ao Caraça com 23 anos de idade, ali viveu até 1929, quando, então, morreu, aos 80 anos. Nestas quase seis décadas de vida dedicada ao Caraça, o irmão Mourão deve ter desempenhado funçð̃es variadas. Segundo SARNEL no Caraça ele foi: "farmacèutico, enfermeiro, hortelão e jardineiro" (*). No decorrer das pesquisas que fundamentaram o presente trabalho, infelizmente não se encontrou nenhum manuscrito ou documento que ilustrasse com detalhes a passagem dos prestativos irmãos coadjutores da Congregação da Missão: seus trabalhos, suas vidas, 
A entrada da residência de João Alphonso chamava a atenção pelo conjunto harmonioso que o portão formava com o jardim bem cuidado. De tranca macia que se abria, sem rangidos, com um leve toque, o portão tinha uma arcada suave que, por sua vez, parecia se prolongar jardim a dentro, já que arbustos uniformes cresceram até a sua altura e simulavam a sensação de que nada havia mudado. Estes arbustos margeavam quase toda a entrada que ia do portão aos três degraus que davam acesso ao alpendre amplo e com parapeito de madeira que circundava toda sua extensão. Pela ala lateral deste alpendre, de onde se avistava parte do habitual quintal da casa, acessava-se também 0 escritório de João Alphonso, onde ele recebia raros amigos, colegas de profissão, etc., para eventuais conversas. Já cinqüentenário, ele se desfez de algumas obrigações profissionais e se deixava passar horas entre o escritório e as confortáveis cadeiras dispostas na ala lateral do alpendre onde preferia ler.

Foi numa circunstância assim que ele receberia, por um portador particular, uma correspondencia que lhe era remetida da cidade de Diamantina, Minas Gerais. Ao ler a carta que acompanhava um manuscrito técnico, ele conseguiu lembrar-se vagamente do remetente; um ex-aluno da faculdade de medicina, natural daquela cidade mineira, cuja familia era conhecida dos padres lazaristas. Este aluno lhe foi apresentado no hospital e, na sequeência do seu curso, encontrou-o várias vezes. João Alphonso até recordou que havia lido a tese de conclusão de curso deste médico diamantinense, sobre um assunto que polemizava o meio médico, já que, na Bahia, Wucherer, um dos expoentes do circulo de facultativos que compunham a chamada escola tropicalista baiana, defendia tese contrária e de bastante consistência,

suas impressðes. Assim, ficam a cargo de inferèncias as possiveis ligações destes com eventuais documentos que são utilizados e citados aqui. Por exemplo, é o caso do Livro da Botica do Caraça, que será oportunamente citado, e que, provavelmente, tenha sido, pelo menos em parte, também subscrito pelo do irmão Mourăo, por conta das funções que desempenhou.

\footnotetext{
* Congregados do Caraça. Op. cit. p. 164.
} 
baseado em evidências experimentais e observações irrefutáveis até então ${ }^{156}$.

- Sim ! - pensou João Alphonso - é o dr. Antônio Felício dos Santos, cuja tese de doutoramento, de 1862, é sobre a hipoemia intertropical.

$\mathrm{Na}$ carta, o dr. Antônio Felício, então com cerca de 30 anos de idade, solicitava a João Alphonso o exame da memória que estava preparando a pedido de um formando da faculdade de medicina, cuja tese de doutoramento seria sobre o beriberi. Nesta tese, o formando examinaria a incidência da doença em cada uma das principais provincias brasileiras e a ele, A. Felício, foi solicitado escrever sobre a doença em Minas Gerais ${ }^{157}$. João Alphonso sentiu-se atraído pela leitura,

156 A tese em questão, do médico diamantinense, é "Hypoemia intertropical" citada anteriormente.

A polêmica entre a Escola tropicalista Baiana e a Academia Imperial de Medicina acerca da etiologia da hipoemia é abordada anteriormente e circunstanciada na nota de rodapé número 38 desta parte.

157 Conforme visto anteriormente, o trabalho de Antônio Felício dos Santos, "O Beriberi na província de Minas Gerais", foi preparado como subsídio à tese de doutoramento de Augusto Cesar de Miranda Azevedo, paulista de Sorocaba, que se formou em 1875. Contudo, o trabalho de Felício dos Santos foi habitualmente citado como documento avulso, i.é, uma memória, relato, da doença na província mineira.

Antônio Felício dos Santos era filho de uma tradicional e influente família diamantinense; dentre seus parentes mais importantes destacam-se dois: Joaquim Felício dos Santos, advogado, industrial e jornalista, criador do jornal O Jequitinhonha (1860), em cujas páginas se imortalizaria através do apontamentos que deram origem ao livro "Memorias do Districto Diamantino da Comarca do Serro Frio (Província de Minas Geraes)" (cf. citação no presente trabalho). Tal livro, no dizer do ensaísta Alexandre Eulálio,

“é leitura obrigatória do estudioso de Brasil"(i).

Outro parente influente de Antònio Felício foi o primeiro bispo de Diamantina, Dom João Antônio dos Santos, irmão de Joaquim Felício. Ex-aluno lazarista, estudou no Caraça na primeira metade do século XIX e foi o primeiro padre ordenado por Dom Viçoso (ii) bispo de Mariana e um dos pioneiros das atividades lazaristas no Brasil. Dom Antônio também exerceu intensa atividade e jornalística em "O Jequitinhonha".

"O Jequitinhonha" na qualidade de jornal

"po'ítico, literário, comercial e noticioso"(iii) 
pois notava que algumas ocorrências levavam-no a interagir com as pesquisas e literatura sobre o beriberi. Neste caso especifico da memória sobre a doença em Minas Gerais, quis encontrar ali subsidios para responder algumas perguntas que os padres lazaristas lhe fizeram, já que o beribéri, diziam, já havia chegado ao sitio do tradicional colégio Caraça.

$\mathrm{O}$ texto do dr. Antônio Felício inicia-se com uma crítica à tendência abusadamente européia da ciência no Brasil, em especial, medicina:

“De pathologia estudamos o que nos vêm de Europa e sahimos

da Academia verdadeiros medicos ... francezes"158.

Dr. Antônio Felicio escreve que o beribéri surgiu pela primeira vez em Diamantina em março de 1871, precedido particularmente de uma epidemia de tifo. Mas antes de aprofundar as circunstāncias de tal surgimento, ele descreve as caracteristicas fisicas da região onde se encontra Diamantina, destacando que, às margens do rio Jequitinhonha, que corre a três léguas da cidade, não há registros de beribéri, apesar destes serem dominados pela malária. Esta constatação, pensou João Alphonso, é coerente com a tese já então veementemente defendida por Silva Lima, no seu "Ensaios sobre o beribéri no Brasil", de que o beribéri não seria de natureza palustre. Voltando ao aparecimento

serviu às manifestaçðes opocisionistas dos Felícios dos Santos, declaradamente republicanos. Neste jornal era habitual a família analisar, opinar e relatar fatos. Para o presente estudo, foram examinados todos os exemplares existentes no Arquivo Público Mineiro(iv) e em nenhum deles encontraram-se notícias sobre a ocorrência do beriberi no Caraça.

i. SANTOS, J.F. dos. Memórias do Distrito... Op. cit. p. 11.

ii. ZICO, J. T. Caraça: Ex-alunos e visitantes. Belo Horizonte, Ed. São Vicente, 1979. p. 30.

iii. EULÁlIO, A. A história como romance: A obra menor de Joaquim Felício dos Santos. In: REMATE DOS MALES, Op. cit., p. 33.

iv. A coleção deste periódicc semanal no Arquivo Público Mineiro encontra-se catalogada com os códigos: J.A 08 e J.A 26 e correspondem aos seguintes períodos:

Maio de 1863

Janeiro a Agosto de 1869

Abril de 1870

Novembro de 1871

Junho de 1872 
do beribéri na cidade, A. Felício afirma que, naquele primeiro caso observado em março,

"era um pardo de 24 a 25 annos, casado, robusto e sanguineo, mineiro, sempre sadio. Repentinamente affectado de uma infiltração geral, começando pelas pernas e depois invadindo o corpo todo, com grande entorpecimento desde o principio e dôres nos membros inferiores, attribuia tudo à uma insdisposição de estomago com vomitos que tivera sem causa conhecida"159.

Após descrever o exame físico, lamenta que o paciente viesse a falecer, assim como dois outros nos meses seguintes, em condições semelhantes ao primeiro. Até aí, citando estes casos, A. Felício não aventa, como hipótese diagnóstica, o beribéri. Os fatos que o levarão a esta hipótese vieram do Seminário Episcopal, pois

"Desde fins de março appresentavão-se sucessivamente á consulta varios estudantes queixando-se de fraqueza geral, desanimo, cansaço, pallidez, edema das pernas, ora indolente, ora acompanhado de contracções dolorosas e formigamento" 160 .

Estes incessantes casos no Seminário deram origem ao que passou a ser conhecido como epidemia das pernas inchadas, desde que, das 100 pessoas que habitavam o local, 20 teriam sido acometidas pela mesma doença. Curioso é que apenas os estudantes sofreram, sendo que, entre estes, os mais velhos foram os mais atacados. Nenhum caso teria sido fatal, mas um em especial havia chamado a atenção do médico diamantinense: um estudante de 20 anos, que viera do Colégio Caraça e, em Diamantina, desenvolvera um quadro semelhante aos dos outros alunos do seminário. A recuperação só teria sido possivel após o estudante retornar à sua terra natal, Grão Mogol, léguas ao norte de Diamantina. Em continuação, A. Felício relata que em março de 1872 a epidemia das pernas inchadas reapareceu no seminário, com apenas três casos que ele consideraria grave e, destes, apenas um rapaz de 18 anos,

\footnotetext{
159 idem, p. 3

160 idem, p. 4
} 
natural da cidade de Montes Claros, norte de Minas, teve recuperação dificil, mas, ao mesmo tempo, surpreendente, porque se deu a partir do uso do Joá bravo, vegetal muito empregado pelo povo contra doenças do figado. No outono de 1873 , teria surgido uma nova epidemia no seminário. Poucos casos, sem gravidade.

João Alphonso já tinha conhecimento de que, assim como no Caraça, em_Diamantina, cujo seminário foi fundado pelos lazaristas, casos de uma enfermidade não esclarecida haviam se manifestado em alguns estudantes. No seu texto, o dr. A. Felício confirma esta circunstância, ao afirmar que

"Desde que appareceu na Diamantina a inchação de pernas os professores do Seminario a conhecerão como a mesma moléstia do Caraça e de Marianna. É que já de longa data a epidemia do Caraça era notoria"161.

Ao descrever o Caraça e os casos de beribéri, Antônio Felício primeiro admite as favoráveis condiçōes naturais da localização do "legendário seminário", como escreve, para concluir que

"Na crista da cordilheira que divide as aguas do Rio das Velhas das do Rio Doce, isolado, quasi sem relações com as povoaçōes adjacentes, não admira circumscrever-se ahi qualquer epidemia de carater transmissivel

"É possivel que o Beribéri fosse para lá importado de Marianna onde appareceu pela primeira vez em 1858 no Seminario e mais intenso se mostrou em 1859. Antes nem os mais antigos habitantes o virão.

"O mesmo aconteceu em relação ao Caraça antes de 1861, e á Diamantina, antes de 1871, Marianna está a 6 legoas do Caraça. Os dous Seminarios, regidos pela mesma congregação de Lazaristas, entretêm frequentes comunicações"162.

\footnotetext{
161 idem, p. 6

162 idem, p. 7
} 
Assim como já havia notado nos trabalhos do médico baiano dr. Silva Lima, João Alphonso observou que o dr. A. Felício imputava à transmissibilidade a razão do surgimento de casos de beribéri no Caraça. Paralelamente a esta questão, sobre a qual poderiam ser tecidas apenas considerações hipotéticas, João Alphonso recordou uma conversa que teve, certa vez, com um professor da faculdade no hospital 163. Mas exatamente porque eu estaria lembrando desta circunstância ? Perguntou-se um João Alphonso curioso com $o$ resultado do aparentemente desorganizado mundo das conexões que se elabora irrefletidamente quando se pensa. Tirando os olhos do texto que lia, e descansando o olhar nas ültimas folhas do cume de uma árvore que via, João Alphonso conjeturou que duas instâncias colocavam-se como necessárias à compreensão do beribéri nos seminários: os processos e procedimentos inerentes à existência e formação religiosa nestes locais e, como segunda instância, o exame a que se prestava, por exemplo, o trabalho do dr. A. Felício, isto é, dispor a ciência à explicação possivel dos determinantes, profilaxia e tratamento da enfermidade. Sem enveredar momentaneamente na exploração desta interpretação, João Alphonso optou por continuar a leitura do trabalho de Antonio Felício.

Em 1861, o beribéri, na forma edematosa, teria se abatido sobre o Caraça, com ocorrência de casos fatais. Devido a este quadro - afirma dr. A. Felício - na assembléia provincial mineira a questão foi discutida, ainda mais que a "opinião pública impressionou-se tanto" ${ }^{164}$. Após esses

163

cf. $p$.

164 A ausência de documentos que possam precisar com alguma exatidão a extensão das doenças no Caraça é um fato definitivo. Claro está que esta situação refleto o que é habitual sobre informações de saúde e doença na época: se quase nada havia de estatistica de saúde, muito menos ainda chegou aos dias atuais. Sobre a ocorrência do beribéri no Caraça em 1861, do ponto de vista documental .... A crônica médica referência é o estudo, ora em análise, do dr. Antônio Felício dos Santos. É a partir dele que outro médico mineiro, Theofilo de Almeida, examina o caso. Tanto um como o outro são unànimes em afirmar a passionalidade daquela discussão na assembléia da província, especialmente pelo caráter especulativo 'frouxo' e preconceituoso em relação aos padres lazaristas: 
casos, viria a década de 70 , onde teriam ocorrido novos casos tanto no Caraça como no seminário de Diamantina, sem, entretanto, haver quantificação dos casos qualificados:

"Em 1870 e 1871 os casos de edema simples forão muitos, mas nenhum de paralysia. Em 1872 houve 3 casos d'esta ultima forma... Em 1873 a epidemia assumio grandes proporçōes. De 230 estudantes do Seminário 45 forão, em poucos dias affectados... No seminario fallecerão $2^{n 165}$.

\begin{abstract}
"Um grande numero de medicos tinhão assento na Assembléa e todavia o debate arrastou-se no terreno das accusações sem prova e das aleivosias mesmo, sem jamais elevar-se à altura do problema hygienico da prophylaxia. Um medico, apoiado por outros deputados, fazendo-se écho de calumnias, procurou demonstrar (por exclusão) que a causa da epidemia era o nitro que os padres dissolvião na àgua de beber dos alumnos para abater-lhes a função genital !!!” (i).
\end{abstract}

"Além de numerosas outras filiações etiologicas do beriberi temos mais esta, a do azotato de potassio aventada pelos hippocrates da Assembléia mineira e que, se não tem grande merito scientífico, encerra comtudo muita côr local e seria optimo assumpto para a verve de Erasmo, de Rotterdam, para um novo capitulo de seu celebre livro ..." (ii).

De acordo com o livro de óbitos (iii) nos anos 1862 e 1863 ocorreram, respectivamente, 5 e 3 óbitos no Caraça. Destes, no ano de 1862, 2 eram alunos não constando a 'causa mortis'. Para estes anos não foi possível obter o número de alunos matriculadas no colégio, mas em 1860 este número girava em torno de 170 (iv).

i. SANTOS, A. F. dos. O Beriberi... Op. cit. p. 7

ii. ALMEIDA, $T$ de $O$ Beriberi no Brasil. Op. cit. p. 71-2.

iii. Livro de óbitos do Caraça - Arquivo do Caraça.

iv. Livro de matrículas, de 1856 a 1910 - Arquivo do Caraça.

165 SANTCS, A. F dos. O beriberi... Op. cit. p. 7.

$O$ livro de óbitos (ref. citada) não registra mortes neste ano. A ausência de registros dificulta a determinação exata da extensão de possiveis doenças, entre elas o beriberi, no local. O padre José Tobias Zico, diretor do Caraça, guardião do seu acervo e historiador da instituição, afirma numa comunicação pessoal:

“... aumentando o número de alunos ou habitantes no Caraça, surgia o fantasma do beriberi." (*)

* Correspondência enviada pelo Pe. J. T. Zico, CM, de 24 de julho de 1995. 
Passado recente, João Alphonso tinha intactas na memória as informações sobre a vida no Caraça, nesta época sob a direção do padre Júlio Clavelin. $E$ foi nesta circunstância do colégio que teriam se reunido com o dr. Moreira, médico do Caraça, os médicos Carlos de Magalhães, de Ouro Preto e Joviano Jardim, de Sabará. Do encontro acordaram que o beriberi poderia ser atribuído à aglomeração, umidade, às chuvas frias da estação e um dos médicos suspeitou ainda do arroz, considerando a doença - beribéri - semelhante ao ergotismo. $O$ texto do dr. Antônio Felício adianta que o relatório dos três médicos não foi publicado e, como documento particular, era de conhecimento restrito dos envolvidos ${ }^{166}$. Mas o próprio autor escreve que, quanto à aglomeração e estudantes, naquele ano de 1874 o número de alunos era ainda maior e que nenhum caso houvera da doença. João Alphonso estranhou ao ler que dois professores haviam sido vitimas do beribéri, tendo um deles ficado paralítico dos braços. Este teria sido visto pelo médico diamantinense em sua cidade. Na Casa Central ou no hospital nenhum lazarista havia lhe contado algo semelhante. Disseram-lhe, assim como escrevia Antônio Felício, que tanto no Caraça como no seminário de Diamantina os diretores cumpriam todas as determinações médicas:

\footnotetext{
166 O referido relatório foi alvo de busca durante todo o processo que gerou o presente trabalho. Unanimemente desconhecido dentro e fora do Caraça, não foi encontrada nenhuma pista que sugerisse o seu encontro. Entretanto, a sua existência é confirmada pelas referências explícitas que lhe são feitas. Bueno Marmoré , em sua tese inaugural de 1873, afirma:

“...as graves pertubaçð̃es funcionais dos aparelhos da inervação da sanguificação e secreção, sua marcha ascendente, sua tendencia à terminação fatal; a série de desordens complexas que lhe imprimem um cunho especial, fizeram nascer a idéia de que só um envenenamento profundo do sangue poderia razoavelmente explicar esta conflagração da economia, ..., assim como o seu desenvolvimento epidêmico.

São desta opinião, entre outros, os illustres médicos: Drs. Demétrio Tourinho, Almeida Couto e Moraes Jardim (1).

(1) 'Reflexð̃es sobre trinta observaçð̃es tomadas no Colégio Caraça, em Minas Geraes, por ocasião da epidemia que alli grassara no corrente ano'. Pelo Dr. J.R. de M. Jardim, trabalho inédito cuja oferta muito agradecemos ao seu autor" $\left(^{*}\right)$.

(*) MAMORÉ, J. B. B. Das condiçðes path. do diag. E tratamento da mol. Conh. Pelo nome de beriberi.
} 
"Um poço d'aguas quasi estagnadas, jacente na proximidade, foi aterrado. O maior asseio das salas e a remoção de todo lixo dos pateos, a mudança de alimentação, a escolha dos viveres, tudo foi experimentado. Os banhos frios forão suspensos, os longos passeios cessarão, o uso de fructos mal sasonados foi prohibido. Nada influio sobre a marcha da epidemia que cessava sempre espontaneamente em Agosto. $\mathrm{O}$ edificio é perfeitamente ventilado: as aguas são excellentes, os salões vastos e o regimen todo hygienico" ${ }^{167}$.

Antes de concluir a sua memória, A. Felício, em meio ao desconhecimento quanto à etiologia da moléstia, insinua que o beribéri pode ter como causa um "agente" especifico, dado que

"As causas determinantes das molestias, podem-se dividir de uma maneira geral em duas classes:

1a Ou são agentes ordinários operando de um modo anormal, quer por si mesmos, quer pelas predisposições organicas e produzindo pertubações organicas e produzindo pertubações e desvios fuccionais variaveis, vencida a resistencia vital (causas communs).

$2^{a}$ Ou são substancias especiaes, geradas no organismo ou extranhas, deleterias, introduzidas na economia por absorpção ou penetração mecanica. N'esta $2^{\text {a }}$ classe, como nas offensas mecanicas, a alteração dos solidos ou dos liquidos está por assim dizer em relação definida com a causa geradora, de sorte que dada a molestia tem-se a causa e vice-versa. $O$ agente morbigero obra electivamente e pode reproduzir-se (contagio) e transmittir-se a outros individuos ou ser infecundo e limitar-se ao organismo atacado (infecções)...

O contagio demonstra cs_unins, como as epidemias exigem a presença dos miasmas e eflluvios. É licito esperar que o microscopio ou outros meios de observação nos revelem esses mysterios. Por analogia suppômos a existencia de causas 
especificas em certas epidemias, e é esse argumento que torna a hypothese mais ou menos plausivel"168.

João Alphonso leu as últimas páginas da memória do dr. Antônio, onde este sintetizava suas observações acerca do beribéri em Minas Gerais; ou seja, o médico mineiro - concluiu João Alphonso - ocupou-se da manifestação do beribéri em Diamantina, no Caraça e, com menor ênfase, em Mariana. Naturalmente que a maior parte da provincia carecia de análise, ou, o que parecia mais provável, nesta maior parte a doença inexistia ou então não se manifestava gravemente. Se isto fosse verdadeiro, o beribéri em Minas Gerais seria uma doença cujo locus se

168

Idem, p.8-9

Na mesma época do escrito de Antônio Felício, sai na Bahia uma publicação de dois estudantes do sexto ano de medicina sobre o beriberi (i). Este estudo, no rastro do trabalho de Silva Lima (ii), reafirma a natureza infecciosa do beriberi, hipótese esta que ganhava terreno nesta época:

"Em um bem elaborado artigo bibliográfico sobre a obra do Dr. Silva Lima, acceita o Sr. Dr. Demetrio Tourinho a natureza infectuosa do beiberi. ... Segundo o illustrado professor [Demetrio Tourinho] 'todas as pertubações funcionais assustadoras e fataes do beriberi estao ligadas e dependentes da intoxicação do sangue, como o são em todas as moléstias zymoticas. Há alteração do sangue por um agente morbido ainda não conhecido; esse agente, como os outros das molestias infecciosas, exerce sua acção de preferencia sobre determinados systemas, ou orgãos da economia:no beriberi esta morbificação é electiva, como o é na diphteria, na febre palustre, etc" (i, p. 139).

Os autores da obra citada relatam que, da mesma forma que os "estragos" produzidos pelo sarampo, varíola, escarlatina, etc, alarmavam as cidades, o beriberi também gerava pânico:

"O que não se pode negar é que em 1872 grassou uma extensa epidemia na capital do Maranhåo; por cartas particulares tivemos roticia de que partião às vezes em um vapor 20 pessoas affectadas do beriberi ! Terror panico espalhou-se então por toda a população; tão grande foi o numero de casos que deo-se uma verdadeira epidemia" (i, p. 152).

i. ARAUJO, A. J. P. da S. \& CUNHA, M. J. R. da. Estudos sobre a pathogenia do beriberi. Bahia, Typographia Americana, 1874.

ii. LIMA, J. F. S. O beriberi no Brasil. Op. cit. 
encontraria nos seminários. João Alphonso passou a mergulhar no labirinto de suas idéias a partir desta circunstância, enquanto, ao longe, escutava o badalar dos sinos de uma igreja. Supôs, então, que a hipótese do dr. Antônio Felicio estivesse correta e que, de fato, fosse mesmo beribéri a doença enunciada naqueles seminários. Supôs porque ele considerou que a descrição dos casos não obedecia a uma compatibilidade necessária para um diagnóstico diferencial preciso como aquele feito por Silva Lima, na Bahia. Mas, mesmo assim, admitindo-se o aparente consenso entre algumas autoridades médicas mineiras, uma outra questão surgia: num seminário ou colégio religioso, qual o sentido de processos como doença, saúde, e suas relações com, por exemplo, o pecado ?

João Alphonso desconfiava que, apesar dos progressos da ciência, esta tinha uma influência significativamente parcimoniosa sobre alguns valores seculares da igreja. Morte e pecado estabeleciam um vinculo indissociável, num retrato bem constituido de uma passagem biblica:

"Você pode comer qualquer fruta da Árvore do Conhecimento do Bem e do Mal. Isso porque essa fruta abrirá os seus olhos e você ficará com a consciência despertada para o certo e para o errado, para o bem e para o mal. Se comer essa fruta, você estará condenado a morrer"169.

Ele sabia que não se tratava de explicar religiosamente a etiologia de moléstias, mesmo sabendo que na esfera da fé muitos procuravam atribuir às faltas contra Deus a origem de todo mal170. Mas João

ASSOCIAÇÃO RELIGIOSA EDITORA MUNDO CRISTÃO. A Bíblia viva. $3^{\text {a }}$ ed. São Paulo, Editora Mundo Cristão, 1988. p.3, Gênesis (2, 15-17).

170 BON $\left({ }^{*}\right)$, ao estudar as enfermidades como sendo causadas pelo pecado, discorre sobre a ação patógena deste, citando autores da área médica:

"Stohl, en su Patología general, ve en las pasiones, los vicios, los defectos, la causa principal de todas las enfermidades. El Dr. Descuret escribe: 'Las enfermidades producidas por las pasiones. son ellas solas, incomparablemente, más frecuentes que las demás. Y el Dr. Sexe: ‘... si la Humanidad renunciara a sus taras espirituales, suprimiria de golpe la inmensa mayoría de las taras fisicas que la aquejan...'. ...la tesis del Dr. Paule Giraud- 
Alphonso se perguntava sobre como se manifestavam numa comunidade religiosa os intricados processos genitivos que amalgamam religião $\mathrm{e}$ medicina. Ou seja, pode ser, pensava ele, que a singularidade de um determinado processo mórbido encontre no universo religioso uma dimensão desconhecida numa investigação médica. Mas na prática o que tal conjectura significaria, já que os próprios religiosos recorriam à ciência para elucidar a causa de seus males físicos ? À esta questão, que ele proprio lhe colocava, o médico leitor de Kierkegaard organizava o seguinte esquema para uma possivel resposta: estando certo de que nestes seminários e colégios religiosos a abnegação cristã é incomensurável, Jesus Cristo constitui-se como o absoluto no plano da instrução destes moços; Cristo, na condição de filho de Deus, è seu instrumento máximo de manifestação do poder da fé, e é esta que viabiliza as miraculosas curas efetuadas pelas mãos de Cristo. Tornar-se cristão - ou na perspectiva da instituição, formar o cristão - significaria, então, incutir uma certa compulsão no individuo de que nada é mais eterno e, portanto, mais verdadeiro e cheio de possibilidades do que o salvador. Nestes termos, buscar na ciência a cura de suas doenças daria aos religiosos apenas a medida de suas rusticidades espirituais, a fraqueza de recursos que ainda os impede de acessar convenientemente os mistérios e os poderes divinos, enfim, o recurso da ciência è a confissão da inexpressão humana diante da grandiosidade de Jesus. Assim sendo, diante da natural falibilidade cientifica, sobraria o recurso do aprimoramento diante de desígnios postos como prova. Aprimoramento necessário e cada vez mais eficaz, do ato de tornar-se cristão. Movimento absoluto que suplantaria as instâncias do conhecer e fazer humano, terreno.

E foi pensando assim que João Alphonso não se importou com o chamado da familia para a refeição e, mais uma vez, dirigiu-se à Casa Central dos Lazaristas. Nesta época era visitador da provincia da

Michel: ... 'La enfermidad espiritual precede a la enfermedad corporal y la determina' (*, p. 315).

(*) BON, H. Medicina católica. Buenos Aires, Editorial Poblet, 1940. 
Congregação da Missāo o padre Benit. Foi com ele que João Alphonso se encontrou:

- Doutor João, a que devemos a sua visita ?

- Padre Benit, vejo que as viagens lhe deram uma trégua. Estive lendo uma memória médica que se refere a uma doença nos seminários lazaristas mineiros e pensei que os senhores pudessem me fornecer algumas informações que me auxiliariam na sua compreensão.

- Com certeza, o senhor deve estar se referindo ao beribéri !

- Os relatos afirmam que sim e eu suponho que possa ser esta moléstia.

Franzindo a testa levemente, mas com a voz calma, o padre quis esclarecer:

- Se os relatos afirmam e o senhor supöe, haveria alguma incompatibilidade lógica entre as duas sentenças, ou eu estaria enganado?

João Alphonso achou elegante a intuição do padre Benit e sentiuse obrigado a esclarecer seu enunciado:

- Os relatos que chegaram não me pareceram conclusivos. A mim faltariam informações mais objetivas. Quanto às causas das doenças, parece que a medicina está passando a usar a contaminação ou infecção não mais como uma hipótese, ad hoc eventualmente, mas como "a" hipótese acima de tudo.

- Não posso dialogar cientificamente com o nosso amigo, mas desconfio que o que diz não seja muito bom para se aprender sobre a causa de doenças - afirmou o padre Benit.

- O pressuposto acerca da unicausalidade das coisas sempre nos cerca com algumas limitaçōes, creio. Mas isto não seria peculiar apenas quanto às possibilidades da medicina, da ciência. No campo religioso enfrentariamos grandes desafios, e no plano existencial, individual, as conseqüèncias de um horizonte amplo, aberto, sem fronteiras; é como um tiro a esmo: as conseqüências são imprevisiveis.

Tornando-se mais cauteloso e aumentando o tempo entre o elaborar e o expressar, o padre ponderou:

- Creio que não deveriamos estender o raciocinio que o senhor faz para criticar os procedimentos da ciència para outras necessidades humanas ... 
- Mas eu sou o mesmo, meu espirito não é compartimentalizado ? Como evitar a dissociação ? - interrompeu João Alphonso, incomodando o padre, que retomou o diálogo.

- Oração e reflexão em Cristo. Penitências às vezes. Os infortúnios pelos maus pensamentos e ações requerem o preparo para enfrentá-los. Eu já tive notícias de que a sua mente não lhe dá descanso e que não raras vezes provocou diálogos nada confortantes com os nossos irmãos e vossos colegas. Descanse e reflita, doutor, o cansaço do corpo nos predispõe a elucubrações fantasiosas e desgastantes. O senhor, homem experiente e bem formado, deveria saber disso há muito tempo.

Sem considerar as ponderações do padre Benit, que, notando esta indiferença, não conseguiu evitar algum mal estar, João Alphonso dirigia a conversa ao seu objetivo:

- Veja, padre, o diálogo entre a religião e medicina é um diálogo eterno. A cura pela fé ou pela ciência tem um mesmo fim; compreender o alcance de cada um destes atos, e como nos relacionamos com cada um deles, é um procedimento vantajoso na busca da compreensão do próprio individuo.

- Havemos de compreender sempre, doutor João, que o alcance da ação humana é sempre limitado. Deus nos deu o seu filho e com ele a possibilidade de ampliarmos o alcance de nossas ações, nas condições mencionadas anteriormente.

Esperançoso quanto ao rumo da conversa, João Alphonso quis saber:

- Na esfera da instrução, essência dos seminários e colégios da instituição, o modelo cristão prepara os alunos para a cura ou para a resignação diante da morte sempre eventual e possivel ?

- Os objetivos das nossas instituições se diferenciam, como é do conhecimento do senhor: os seminários e os colégios. Mas, essencialmente, a religiosidade é o bastião que garante a formação do jovem dentro da moralidade e honradez, necessárias como virtudes a uma sociedade mais afinada com os principios cristãos ${ }^{171}$.

171 ANDRADE (i), baseado nas fartas referências que há sobre o assunto, destaca, no capítulo intitulado "O homem educado", que 
- Mas, diante da doença, como opera esta formação ? - provocou João Alphonso.

Com um sóbrio sorriso nos lábios e simplificando a pergunta de seu interlocutor, o padre Benit quis ser didático e optou pelo latim, ao iniciar a resposta com uma citação biblica:

- "Quid prodest hómini, si mundum univérsum lucrétur, ánimae vero suae detriméntum patiátur? Aut quam dabit homo commutatiónem pro ánima sua ? $^{\prime 172}$. Nossa imortalidade é, pela alma, preservada e engrandecida nos principios da fé; esta alma enaltecida em Deus é que tem valor e por sua causa o homem é mais valoroso que a natureza, que o mundo. Nosso destino é eterno, enquanto o mundo é passageiro. Então, a nossa imortalidade advém da nossa capacidade de superar os

"A formação do aluno caracence - 'lustrosa e para o futuro', como a definia um regente lazarista - tinha inegavelmente fins análogos, ou seja, dotá-lo de uma cultura necessária para o trânsito político e social ...

"Formar o homem, o homem honrado, socialmente ativo, educado na religiåo e nas letras, está na essência dos objetivos do Colégio Caraça".

Esta tradição de um ensino notadamente voltado para o ensino humanístico, "dogmático e retórico", é característico no Brasil, especialmente no século XIX (ii, entre outros). O caso mineiro é especialmente relatado como, por exemplo, por LIMA (iii):

"O humanismo mineiro da educação deve pois ser entendido em dois sentidos. Um é a nota histórica que fez de Minas, por muito tempo, o centro das humanidades clássicas. A educação mineira tradicional, em nível superior ou mesmo médio, era feita sobre a base latina clássica. Daí sua feição universal e ordenada. [ $O$ outro sentido] ... faz com que a educação mineira coloque a formação do homem no centro e na base de toda tarefa educativa ... uma educação para a sabedoria ... a educaçào visava formar homens de bem e não apenas saber ou canudos com um diploma ...".

i. ANDRADE, M. G. de. Op. cit., p. 160.

ii. AZEVEDO, F de. A cultura brasileira. São Paulo, Melhoramentos/ Ed. UnB, 1963.

iii. LIMA, A. A. A voz de Minas. Rio de Janeiro, Ed. Agir, 19:6, p. 130.

172 "Que aproveita ao homem ter lucrado o mundo inteiro, se vier a perder sua alma? Ou que dará o homem em troca de sua alma ?" (Mt 11, 26) (i);

"Que vantagem há em alguém ganhar o mundo inteiro - e perder a vida eterna ?

Que é que se pode comparar com o valor da vida eterna ? (Mt 16, 26) (ii).

i. O LIVRO DO SEMINARISTA. 3a. ed. São Paulo, Editora “Ave Maria” Ltda, 1959.

ii. ASSOCIAÇÃO RELIGIOSA... A Bíblia Viva. Op. cit., ץ. 20. 
sofrimentos e as provaçōes, que nos são impostas, como prova de nosso merecimento ao reino de Deus. Assim como a lascividade da vida não condiz com a salvação, os males eventuais e possiveis, como o disse, não constituem mais do que provações necessárias, no âmbito da fé, da resignação e do caminhar rumo à eternidade.

João Alphonso desconfiou que conduzira mal sua investigação. Lance que quase sempre geraria um xeque-mate. Nos termos em que colocava a questão da adoção, pela religião, do conhecimento cientifico, este seria sempre submergido por uma lógica que praticamente não oferecia tentáculos que sustentassem uma possivel contra-argumentação nos termos permitidos pela dinâmica do conhecimento científico. Mesmo se ele reconhecesse e tivesse certeza - pensava João Alphonso - que o padre Benit fosse apenas um bom argumentador sob a erudição humanistica que possuia, na prática isto de nada valeria para desqualificar o discurso da instituição. $E$ justamente para não se desqualificar, pois por este caminho a discussão se tornaria redundante segundo as conviç̧ōes de cada um, é que João Alphonso procurou encarar o encontro como uma conversa cordata, mais do que uma discussão de principios. Nesta perspectiva, preferiu absorver o comentário do sacerdote:

- Parece-me muito interessante pensar na busca da salvação como um mecanismo de eterna repetição, ou seja, ser cristão é repetir Cristo, tendo como meta a infalibilidade deste. $E$ o que não falta são obras que anunciam as vantagens dos principios cristãos no exercício cotidiano do existir.

- A primeira parte do seu comentário mereceria uma reflexão bastante justa. Eu me pergunto sobre as suas intençōes em relação a Deus, doutor João, por tudo que sei do senhor e pelo que já conversamos.

- Eu gostaria de entender melhor essa opinião do senhor - disse João Alphonso.

Sem uma conviç̧ão marcante, mas olhando diretamente para o médico, o padre falou:

- As vezes vejo o senhor tão longe de Deus; outras vezes tão próximo... E não consigo nunca prever a que distância tenderá. 
Preocupam-me bastante as conseqũências desta posição. O senhor já pensou nestas conseque ências ?

- Ora padre, nós somos o que devemos ser; em outras palavras, que prefiro, viver é vivenciar e decidir. As conseqüências são, de fato, neste caso, imprevisiveis. Mas o que valeria uma vida previsivel ? - Disse João Alphonso, também olhando diretamente para o padre Benit. Notando o teor provocativo do comentário, João Alphonso retomou imediatamente a segunda parte do seu comentário anterior e disse:

- Eu me lembro de ter lido, nos meus tempos de colégio, livros que enalteciam as virtudes da moral cristã.

- Sem dúvida que é uma literatura vantajosa. É provável que o senhor tenha lido François de Salignac de la Mothe Fénelon - disse o padre, citando o autor com uma voz impoluta.

- Fénelon ? Naturalmente. Les Aventures de Télémaque foi leitura precoce na minha formação. O senhor o conhece muito bem, é claro ! ?

- Adotamos o livro nos nossos colégios por conhecê-lo muito bem. O livro é apreciável tanto no que se refere à constituição poética do sujeito quanto ao que se relaciona à política ou à moral ${ }^{173}$.

Após discorrerem sobre Fénelon, ambos trataram de temas corriqueiros de suas práticas, o que acabou resultando na repetição de um velho convite, por parte do padre Benit, a João Alphonso:

- Gostariamos muito que o senhor se dispusesse a nos visitar no Caraça. Ainda neste mès um grupo da nossa Congregação estará rumando para lá e sua companhia nos seria prazerosa. O senhor poderia atestar por si mesmo as condições, a movimentação e a vida daquela

173 Tudo indica que Les Aventures de Telémaque, livro do francês F. de S. de la M. Fénelon (1651-1715), foi um livro bastante utilizado no Caraça. Ainda se encontram na biblioteca do antigo colégio três exemplares do livro em ediçăo francesa dos anos 1807 , 1851 e 1870. Mas em documentos que registram compras da instituição, há referèncias da aquisiçào do livro em diversos momentos. Para o presente trabalho foram consultadas duas ediçðes (i; ii) do referido livro:

i. FENELON, F. S. de la M. As aventuras de Telêmaco. Trad. M. de Souza e F. M. do Nascimento. Paris, Baudry, s.r.d.

ii. FÉNELON, F. S. de la M. Les Aventures de Télémaque. Paris, J. De Gigord, Éditeur, $19 j 5$. 
nossa casa. Além do mais o senhor propiciaria a si mesmo uma oportunidade de reflexão que nunca é tardia e é sempre necessária à vida de um homem.

- Eu agradeço o convite, padre. Aliás, tenho-o agradecido em vários momentos por conta das vicissitudes que me impedem de aceitálo. Não é raro eu me ver apegado a um velho sonho: visitar, conhecer, falar com o Dr. Lund em Lagoa Santa. Mas tenho noticias que há anos ele praticamente já não recebe quase ninguém, e que se encontra muito doente. Seria uma bela viagem: rever Ouro Preto, conhecer o famoso colégio de vocês, doutor Lund. Mas é um grande circuito para se fazer só. E já não sou jovem, apesar de muitos sonhos permanecerem os mesmos.

- Sinta-se à vontade, caso aceite nosso convite. Quanto aos sonhos, vigie-os, doutor João, vigie-os, especialmente os que pertencem ao passado. Não os deixe martelar seu presente e muito menos o seu futuro.

- Desculpe-me, padre, mas o que me sugere é subjetivamente inconcebivel. Sentimentos meus mais profundos não tèm acolhida no futuro... e o passado me cativa, sim.

Neste instante, tirando os olhos do padre e fixando-os num quadro, retratando a santa ceia, que adornava a parede da sala onde conversavam, João Alphonso comentou:

- Este nosso diálogo me faz lembrar o verso de um poeta francês morto há alguns anos atrás:

"Eu tenho mais recordações do que há em mil anos"174.

As interrupções que se tornavam freqüentes anunciaram aos dois interlocutores que eles não dispunham de mais tempo para o diálogo. Viram-se na necessidade de combinarem, descompromissadamente, um novo encontro para o prolongamento da conversa e despediram-se.

174 BAUDELAIRE,C. Poesia e prosa: volume único. Rio de Janeiro, Nova Aguilar, 1995. p. 161.

O referido verso é de um poema ( Spleen, LXXVI) parte do livro "As Flores do Mal", cuja primeira ediçăo ( Les Fleurs du mal) saiu no ano de 1857. 
A febre amarela castigava sem trégua o Rio de Janeiro. Já então endêmica, exigia da Junta Central de Higiene Pública medidas que enfrentassem a situação em um momento em que a população da cidade aumentava ${ }^{173}$. As condiçōes higiênicas da cidade eram sofriveis. Assim, por exemplo, as ruas centrais encontravam-se imundas, exalando odores insuportáveis; as moradias não obedeciam as minimas regras sanitárias e cortiços, verdadeiras espeluncas, prolifervam sem nenhum controle; na orla maritima, o lixo era jogado nas praias com a trivial e ingênua idéia de que o ciclo das marés assearia o ambiente, além da precária situação do escoamento do esgoto. Este cenário não se alterava significativamente em função da vida social, comercial e politica da cidade e do país imperial. O cotidiano da cidade acomodava todas as cenas socialmente determinadas num cenário que conciliava ambiente e indiferença. As instituições procuravam organizar-se, tentando dar conta da pluralidade de velhos e emergentes problemas. A Faculdade de Medicina ressentia-se da carência de recursos, especialmente laboratoriais, que permitissem formar médicos mais capacitados. Neste caso,

"não obstante os esforços empregados por vários professores que à Europa foram estudar a organização das escolas de medicina e que em relatórios apresentados ao Governo mostravam as necessidades, de que se ressentia nossa organização, nada foi feito"176.

A dificuldade de operar mudanças estruturais em instituições como o ensino estimulava e exaltava o ânimo de pessoas importantes na esfera social, entre eles professores da faculdade, que na intimidade, mesmo usufruindo de titulos de nobreza, não deixavam de registrar a falta de desenvoltura do império para agilizar as referidas mudanças estruturais.

175 De acordo com o Anuário estatístico (*), o crescimento anual da população do Rio de Janeiro, entre os anos $1872-1880$, foi de $3,84 \%$ e no periodo de $1880-1890,4,54 \%$. Em números absolutos, entre 18721890 a população passou de 266 a 522 mil habitantes.

(*) ANUÁRIO ESTATÍSTICO DO BRAZIL (1908-1912). V. I, P. XVIII.

176 REIS, A. A. de S. História da medicina no Brasil (Notícia synthetica). In: DICCIONARIO HISTORICO, GEOGRAPHICO E ETHNOGRAPHICO DO BRASIL. v. 1, Rio de Janeiro, Imprensa Nacional, 1922. 
De certa forma, no hospital, João Alphonso era depositário destes registros pela condição da sua discrição e indiferença política. Mas era exatamente por estes motivos que, às vezes, ele estabelecia alguma discussão com colegas:

- Vocês crêem fielmente que mudanças políticas garantem mudanças estruturais e que estas, por sua vez, garantem mudanças sociais. Não seria interessante pensarmos de uma forma diferente? propôs João Alphonso.

- Ora, a realidade é a história acontecendo e os homens têm em suas mãos os resultados de suas ações - afirmou um dos interlocutores.

- Crèem mesmo que seja assim ? - perguntou João Alphonso que baseou a sua pergunta ao continuar - Eu não acredito que um homem, e todos nós estamos nessa condição, posicionado em certa atividade, naturalmente histórica e mais ou menos significante, é bom que se diga, eu não acredito que este homem possa ter uma visão nitida acerca não apenas da atividade em $\mathbf{s i}$, mas muito menos da repercussão dela mesma. Creio que, se é verdade que a história humana tem como atores os homens, nós e nossas atividades, não temos, por outro lado, nenhum dominio sobre o desenrolar destas ações.

- Creio que haja muita especulação da sua parte. Caso o senhor fosse mais prático, poderia espelhar-se na própria ciência médica e verificar os inúmeros beneficios que esta ciência tem trazido à humanidade por meio de ação controladas em todas suas etapas: princípio, meio e fim - rechaçou o argumento de João Alphonso um outro participante da conversa.

- Primeiro, gostaria que o senhor não tivesse medo das especulações. Por acaso só as especulações clínicas, para efeito de diagnóstico, têm valor ? Depois, compreender que a existência autêntica de cada hornem possa ser determinada simplesmente pela história de sua atividade, coloca-nos, a meu ver, uma questão de várias derivações: estarmos sempre modelando a compreensão do futuro a partir de formas do presente e neste processo a existência individual é sempre postergada em nome da história. O que pensam disso?

- Caro doutor, a minha recente estada na Europa - afirmava em tom de fidelidade um dos interlocutores - mostrou-me a infinita possibilidade do homem e seu trabalho. As pesquisas laboratoriais 
impõem uma abordagem irreversivel ao destino do homem. Precisão e segurança são as palavras que melhor definiriam este processo. $O$ senhor bem sabe do que falo, pois se formou num pais que praticamente doma $o$ presente e molda o seu futuro pelo estupendo empenho científico lá existente. Tenho certeza que em situação como esta florescerá uma sociedade mais justa, positiva e com menos tirania.

- O senhor já examinou o passado daquela gente ? E que cada passado comporta uma imensidão de momentos que foram presente $\mathrm{e}$ futuro ? - Perguntou João Alphonso, não conseguindo encerrar o colóquio informal.

- O senhor e o seu irresistivel apelo ao passado. Deixe-o em paz, avistemos o futuro que nos espera - disse o interlocutor anterior lembrando ao grupo que aqueles minutos de conversa estavam se encerrando e que os afazeres das enfermarias proibiam-nos de continuar ali. Antes, alguém ainda disse a João Alphonso:

- Doutor, como o senhor já leu e nos comentou algo sobre o beribéri, se fosse possivel gostaria que visse duas teses de doutorandos da nossa faculdade sobre o assunto. Uma delas, especialmente, é um trabalho brilhante.

- Deixe-as comigo. Lerei assim que puder - disse João Alphonso, que continuou na sala após a saída dos colegas. Levantou-se, atravessou a sala em passos lentos e colocou-se à janela de onde se avistava parte da cidade. Respirou fundo e sentiu um mormaço desagradável que carregava um ar de maresia e podridão. Sem necessidade aparente, tirou o lenço, limpou a testa e saiu.

Ao chegar em casa naquele dia, João Alphonso encontrou, depois de muito tempo sem resposta, uma longa carta do amigo Morten Schwarzkopf. Feliz, esquivou-se dos apelos da familia e trancou-se no seu escritório para ler a correspondência. Morten, numa enigmática carta onde lembrança e eternidade se digladiavam no presente, começava falando se si e da familia. Ele mantinha-se estabelecido em Breslau e dois dos seus filhos mais velhos moravam em Posen, cidade vizinha. Um militar e o mais velho, numa importante função pública, casara-se com moça de uma familia de artistas e músicos. Morten se permitiu uma 
brincadeira, ao dizer que este relacionamento do filho lhe dava esperanças de que, no futuro, alguém da familia pudesse se dedicar e se destacar no mundo da ópera, preferência que ele aprendeu a apreciar, constituindo-se hoje num compromisso obrigatório da sua vida. Esta revelação alegrou bastante João Alphonso que, numa visão rápida, viu o jovem Morten de Göttingen assistindo emocionadamente a uma apresentação da ópera de Mozart, Don Giovanni, com um seu descendente em um dos papéis principais.

Após algumas reminiscências sobre os anos em Göttingen e a amizade de ambos, Morten afirmava ao amigo que foi em Posen que conheceu um jovem médico que, como eles, também estudou em Göttingen, formando-se em 1866. Este jovem médico havia estado na guerra franco-prussiana na condição de médico militar, e há poucos anos havia se estabelecido como médico rural de Wollstein, cidadezinha nas cercanias de Posen. O motivo deste encontro com este jovem médico, contava Morten, é que através de um dos seus filhos, o dr. Robert Koch, era este o nome do jovem colega de Göttingen, sabedor que o dr. Scharwzkopf, além da identidade da escola médica, também conhecia em Breslau professores importantes da universidade. Entre estes, o bacteriologista Ferdinand Cohn, o quimico Moritz Traube, etc. O dr. Koch tinha um modesto laboratório em sua própria casa e andara fazendo umas investigações sobre uma doença que atacava humanos, mas especialmente o gado da região. Com estas investigaçōes, teria conseguido descrever a causa e a patologia da brucelose, epidêmica até então. $O$ dr. Koch afirmara que havia conseguido comprovar experimentalmente as teorias do conhecido professor de Göttingen Jakob Henle $^{177}$. Por causa disso, o jovem médico havia lhe solicitado que

177 Robert Koch (1843-1910) nasceu em Clausthal im Oberharz e morreu, aos 67 anos, em Baden-Baden. A primeira e uma das grandes realizaçðes deste cientista foi o desenvolvimento de um meio de cultura estéril que permitisse $o$ isolamento $e$ identificaçåo ao microscópio de um determinado germe. A obra e a vida deste pesquisador, aclamado como o pai da bacteriologia médica, são fartamente descritas. Para as presentes consideraçðes a seu respeito, foram consultadas as seguintes referèncias: 
intercedesse junto aos professores de Breslau para que lhe permitissem uma exposição acerca de suas pesquisas, seus métodos e resultados. Mesmo antes disso, ele, Morten, manifestou-se surpreendido pela qualidade do trabalho do dr. Koch. O que mais havia the chamado atenção era a habilidade e originalidade do pesquisador em criar condiçōes para que um germe suspeito pudesse se desenvolver fora do organismo e, inoculado novamente num outro organismo, fosse capaz de provocar a mesma doença original. Esta comprovação - nas palavras de Morten - abria um imenso campo para novas pesquisas que redundariam no esclarecimento da etiologia e na cura de várias doenças até então enigmáticas para a medicina ${ }^{178}$. Não passou despercebido de João Alphonso o entusiasmo do amigo com as descobertas do jovem dr. Koch. Realmente, a décadas havia uma grande expectativa entre os cientistas da área biológica, de que os pressupostos de Henle fossem experimentalmente demonstrados. Mas quis João Alphonso ordenar as noticias que recebia para, em seguida, embaralhando-as, tentar percebêlas em outras circunstâncias, apenas aparentemente ordenadas. Assim, após terminar de ler calmamente a carta do amigo, espichou-se em sua poltrona, fechou os olhos e retomou, linha a linha, a carta lida.

i. STEINBRÜCK, P. Robert Koch, Op. cit.

ii. WALKER, M. E. M. Pioneers of public health. New York, The Macmillan Company, 1930. p. $178-92$.

iii. LEIBBRAND, W. Robert Koch. In: Die Grossen Deutchen: Deutsche Biographie. v.4, Berlin, 1957.

iv. WINAU, R. Robert Koch und seine Zeit. http://www.rz.charite.huberlin.de/ch_koch.html.

v. ASIMOV ,I. Enciclopedia biográfica de ciencia y tecnologia. Madrid, Alianza Editorial, 1982. p. 395-6.

OBS.: Sobre F. G. Jakob Henle e sua teoria, ver nota de rodapé número 74.

17 De fato, em 30 de abril de 1876 Koch, durante três dias, esteve reunido em Breslau com alguns cientistas, entre eles o botânico Ferdinand Cohn, e apresentou os resultados de sua investigação. Esta apresentação rendeu a Koch o apoio de Cohn à publicação de sua descoberta. O trabalho foi ampla e imediatamente reconhecido, sendo considerado que

"Pela primeira vez a origem microbiana de uma doença tinha sido reconhecida, sem contestação, e elucidada sua história natural" (*)

- ROSEN, G. Uma história da saúde pública. Op. cit. , p. 201. 
Se a eficácia da intervenção médica viria a ser favoravelmente influenciada pela descoberta do dr. Koch, qual o sentido da descoberta 'em si' e de sua repercussão ? - pensou João Alphonso. Quanto ao 'sentido da descoberta', haveria que se ponderar que o conhecimento de que 'germes' se relacionavam diretamente com doenças humanas já era fato há muito tempo reconhecido. Não apenas se sabia sobre o 'germe', como também, e principalmente, utilizavam-se processos terapêuticos para combater doenças infecciosas e contagiosas. Os estudos e descobertas do francês Louis Pasteur, a imunização, o isolamento (quarentena), etc., eram procedimentos administrados desde longa data pela medicina. Assim, o 'sentido' da descoberta do dr. Koch, que por sinal confirmava proposições de três décadas atrás, residiria no fato de que, aproveitando-se de tecnologias oriundas de outras áreas ( como a ótica, por exemplo) e do volume de informações das disciplinas básicas da biologia (botânica, p.ex.) e quimica, ele, tendo uma valorosa capacidade observacional, conseguiu organizar, experimentar e demonstrar aquilo que já era do universo da prática médica ${ }^{179}$.

Quanto à repercussão do incremento da microbiologia médica para a medicina, caberia um exame meticuloso, posicionou-se João

179 As referências citadas na nota de rodapé 67 mostram, com variado grau de precisão, a confluência de fatores técnicos que contribuiram para o sucesso das pesquisas de Robert Koch. A referência "iii" da referida nota (LEIBBRAND) transcreve anotações do próprio pesquisador, sendo possivel acompanhar etapas de seu trabalho, observando a especificidade das opções metodológicas a partir de conhecimentos acumulados.

Quanto à incorporação e manipulação dos conceitos de infeção e contágio nas condutas preventivas e terapêuticas pela medicina, vale ressaltar o esclarecedor e objetivo texto de SALGADO $\left({ }^{*}\right)$ que, a certa altura, afirma:

"Se antes do século XIX já se preveniam e já se curavam as infecçðes, se já se conlieciañi a imunização e a medicação antiinfecciosa, anti-séptica e antifebril, se já se havia descoberto o micróbio, o contágio e a quarentena em que consistiu o advento da era microbiológica ? Consistiu na utilização convergente da observação experimental, de equipamentos recém-disponiveis $e$ de conhecimento acumulados, para fazer aceleradamente, em décadas e anos, o que a medicina popular já vinha fazendo lentamente em milênios, por meios intuitivos" $(*$, p. 15) [grifo do autor].

* SALGADO, J. A. Os meios de vida, as infecçðes e o destino do homem. In.: TONELLI, E. Doenças infecciosas na infancia. Rio de Janeiro, Medsi, 1987. Cap. 1, p. 3-17. 
Alphonso. Para ele, nos termos descritos por Morten, as investigações do jovem dr. Koch não apenas eram convincentes, mas, principalmente, consistentes. O primeiro resultado prático, além da elucidação das primeiras doenças estudadas pelo próprio dr. Koch, era a disponibilidade de uma metodologia tecnicamente acessivel a um número cada vez maior de pesquisadores. Esta metodologia naturalmente acolhia uma teoria; neste caso, a teoria microbiana de causalidade de doenças. Por ela, um agente especifico causaria uma tal doença e, uma vez determinado tal agente, a medicina estaria em condições de providenciar a cura. Já de início, João Alphonso entendeu que um número maior de doenças teria sua causa atribuída aos micróbios, condição que inverteria o critério de veracidade que está sendo, inicialmente, uma das causas do sucesso do dr. Koch. Ou seja, a força' dos estudos do jovem médico alemão deve-se também ao fato de que suas pesquisas, originais em vários aspectos, eram exceção e agiriam, neste primeiro momento, como 'o critério de verdade' frente ao que era desconhecido; mas com a proliferação deste modelo explicativo, o que era exceção passaria a ser regra e, neste caso, se não houvesse critica interna com desenvolvimento de novos elementos cientificos de igual força explicativa, estariamos diante - raciocinou João Alphonso - de um modelo de uso indiscriminado. Os riscos disso ele não quis tentar dimensionar, mas pretendeu ter tempo suficiente para acompanhar a repercussão de tudo isso.

Por fim, João Alphonso, num jogo sem regras circunstanciais, intentou enxergar o encaixe da 'boa nova' que Morten lhe passava na sua vivência científica. Lembrou, então, do que leu e pensou sobre o beribéri, especialmente o trabalho dos doutores Silva Lima, na Bahia, e Antônio Felício, em Minas Gerais. Em ambos, apesar de não afirmarem categoricamente, a idéia de um agente etiológico microbiano para esta moléstia não era descartadá, no meio da variedade de fatores que poderiam predispor o organismo ao ataque causal. $\mathrm{Na}$ verdade, as consideraçōes deste tipo preparavam um terreno fértil para a propagação da teoria microbiana ${ }^{180}$.

180 Dentre diversas passazens, algumas delas citadas anteriormente, SILVA LIMA (i), no capitulo onde discute a propagação da moléstia, descreve casos clínicos, como, por 
Quando João Alphonso deveria ler e opinar sobre as duas teses de doutoramento sobre o beribéri, atendendo à solicitação de colegas médicos da faculdade, o seu filho advogado apareceu para uma visita rápida, que consumiu toda a tarde daquele dia. João Alphonso envolveuse tanto na conversa com o filho que nem o cuidado deste em não querer tirar o pai dos seus afazeres e nem as lembranças da esposa, lembrandoo de compromissos do dia, convencera-o de adiar o pequeno colóquio. É que o seu filho havia recebido uma proposta para trabalhar no interior de São Paulo, mais precisamente em Campinas, e ele quis discutir com o pai a possibilidade. A proposta provinha de um colega, com quem havia cursado Direito na Capital, que lhe enunciou vantagens e oportunidades profissionais na cidade que vinha recebendo vultosos investimentos. Os grandes cafezais ditavam modos e modelos de organização social através da movimentação financeira que geravam. Naqueles anos, os serviços públicos produziam melhoramentos urbanos e o sopro de modernidade produzia um entusiasmo generalizado nos círculos políticos e econômicos, que viam em Campinas uma cidade promissora. A região,

exemplo, de uma familia onde quatro pessoas foram sucessivamente atacadas pela doença. Afirma ele que

"Ainda que estes factos estejam muito longe de demonstrar a propagação da doença por contagio ou por infecção, isto é, por meio de um producto morbido resultante de sua evolução pathologica, e que a reproduza como a semente reproduz a planta de onde nascera, julgo que não deviam ser omittidos neste logar, simplesmente como elementos historicos que podem ter cabal explicação no futuro, e contribuir, com outros já conhecidos, e com os que estudos ulteriores possam revelar, para esclarecer a pathogenia, obscura ainda, d'esta molestia singular".

Felício dos SANTOS (ii), por sua vez, ao discorrer sobre as condições de contágio e infecção, antevê que

"É lícito esperar que o microscopio ou ouitros meios de observação nos revelem esses mysterios".

Mas ao referir-se especificamente ao beribéri, diz:

“... quanto ao genero não achei elementos já sufficientes para preferir a hypothese de um miasma contagioso ou simplesmente portátil, à de agentes parasitas transmissiveis. Uma e outra cousa são possiveis”.

i. LIMA, J. F. S. O beribéri no Brasil. Op. cit., p. 77.

ii. SANTOS, A . F. dos. O beribéri na provincia de Minas Geraes. Op. cit., p. 9. 
vista como uma fronteira econômica em expansão, oferecia a imagem de um eldorado onde massas de trabalhadores de outras terras chegavam lotados de ideais e disponibilidade braçal. A estrada de ferro que chegava da capital, os investimentos, a modernização da cidade, industrialização incipiente, as máquinas que a cada dia chegavam, tudo isso emanava otimismo de um futuro promissor a todos, um futuro que parecia mais próximo e que cada um queria usufruir o mais depressa possivel ${ }^{\mathbf{1 8 1}}$.

- Disseram-me que Campinas tem progredido rapidamente, parecendo ser promissora - disse o pai ao filho.

- O senhor tem conhecidos por lá ?

- Sim. Médicos que conheci aqui. Um deles é o Dr. Silveira Lopes, de Lisboa, e que também se formou na Alemanha. Em Rostock. Nós nos conhecemos na Sociedade Germânica e desde então ele me encontra quando está por aqui. Pelo que diz, parece gostar de Campinas. Mas ele é

181 Nas últimas décadas do século XIX, a cidade de Campinas experimentou uma grande prosperidade.

"Fazendeiros e negociantes unem-se, conjugam esforços, aplicam capitais, constituem companhias para a execução de serviços públicos e dotam a cidade dos melhoramentos existentes nos maiores centros urbanos do pais e do mundo" (i)

Estas mudanças na estrutura da cidade refletiam o desenvolvimento da cidade a partir, principalmente, da exploração cafeeira. É desta época o início do fluxo de imigrantes para a região. Já na década de 1860 ,

"o núcleo urbano de Campinas, ... , tinha 70 lojas de fazendas e ferragens, 126 armazéns de secos e molhados e cerca de 25 estabelecimentos diversos. Já funcionavam sete escolas primárias e três secundárias, um teatro e duas associaçðes científicas" (ii).

A aceleração deste processo de crescimento mostrou que, em 1881

"a cidade possuía fábricas importantes de máquinas para lavoura, com fundição de ferro e bronze, fábricas de cerveja e gelo, de jáūù, de chapéus, curtumes, marcenaria e carpintaria a vapor, além de outras de menos monta"(ii).

i. SANTOS FILHO, L. de C. A Febre Amarela em Campinas: 1889-1900. Campinas, Área de Publicaçðes CMU/UNICAMP, 1996. P. 13.

ii. NUNES, E. D. \& BEVILAQUA, L. D. P. Transformaçðes sócio-econômicas e perfis de mortalidade no municipio de Campinas: 1900-1930. Universidade Estadual de Campinas, 1991 (Relatório final). P. 21. 
um viajante incorrigivel e não sei se ainda continua residindo lá. E há não muito tempo atrás conheci um médico norte-americano no Hospital. É um emigrante, que veio com a familia, por conta da guerra da Secessão. Ele esteve aqui cuidando da legalização de seu diploma e iria residir em Campinas, que já conhecia. Mas, diga-me, a proposta do seu amigo te interessou?

- É isto que estou avaliando. Na circunstância política e econômica da região, certamente as circunstâncias juridicas estarão apenas requerendo do direito a legalização de interesses particulares. Quer dizer, isso acontece em qualquer lugar, mas acredito que nas circunstâncias atuais daquela região as pressões não serão poucas. É que eu acredito que a euforia, por causa do progresso material, costuma anuviar a noção de direito tanto na esfera das pessoas físicas ou jurídicas.

- Eu creio que compreendo sua observação - afirmou João Alphonso ao filho. - E é mesmo bom que você seja crítico a este respeito. Vivemos numa época em que as decisões são tomadas sob a égide da eficácia imediata. Nesta euforia em que se encontra a região de Campinas, a racionalidade do direito certamente estará sendo compreendida como sendo a racionalidade da economia, das indústrias que chegam, da ciência em geral, ou seja, com a própria idéia de desenvolvimento.

- ... e eu seria sempre um forasteiro na cidade. Especialmente se usar, como penso, a imprensa como meio de expressão de idéias.

- Não me culpe se um dia você não se tornar jornalista plenamente disse João Alphonso, antes de continuar, numa discreta forma cômica Mas, sabe filho, pensando bem não é simples tentar entender porque o homem, senhor do progresso das ciências e das técnicas, ao invés de humanizar as relações, cria sempre maneiras diferentes de opressão.

- Talvez porque a ação humana só se realiza plenamente na tirania, oprecsão, em vários niveis - opinou o filho ao pai.

- Só que nestas condições a dignidade humana é esfacelada. E pode ser que isto explique a sua observação sobre a realidade atual de Campinas que, talvez mais do que outra região no pais, parece totalmente absorvida pelas dádivas do mundo moderno. Haverá sempre um valor que subjugue a liberdade humana, creio. 
- O senhor está se saindo um bom iluminista. Mas creio que sua pista não esteja incorreta - disse o filho, retribuindo agora a maneira cômica do pai.

- Olha, eu não me definiria assim facilmente. Acho até que resistiria. De qualquer forma, se por um lado eu penso que, de fato, todo homem deve ser dono do seu destino, por outro lado acho complicado explicar, por exemplo, o preconceito, ou outra forma de segregação, apenas sob o prisma cultural.

- Veja bem, pai, se todo homem deveria, sabes que não é assim. As aberrações estão a nossos olhos: nas ruas, nas fazendas - e numa inquieta cumplicidade com o pai, continuou - e mesmo dentro das nossas casas. Mas, voltando à situação de Campinas, veja o caso que estamos tratando: essa massa, operários, investidores, etc., que chegam à cidade. Que unidade molda suas faculdades de julgar ? A mecanização do trabalho ? O comércio ? O consumo?

- Se for isto, estaremos perdidos. Mas é possivel. Mas você não deve acreditar que diagnosticando corretamente o problema vocè encontre necessariamente uma boa solução para resolvê-lo. Esta unidade a que você se refere, certamente não será oferecida pela educação, que se voltará, gradativamente, para a operacionalização técnica; penso que esta unidade será produzida pela idéia de que todo este progresso cientifico, e suas derivações no comércio, possui uma neutralidade que está acima do bem e do mal.

- A conseqũência disto não seria o dilaceramento de laços afetivos importantes ? Nem a amizade escaparia desta idéia ? Por exemplo, como reagirá o meu amigo quando eu lhe disser que não irei para Campinas ?

- Na minha área, eu não teria dúvidas em te responder. Há muito o escrúpulo foi corroído pela idéia da retidão e neutralidade da ciência. São raros os amigos. P.arissimos os cientistas e amigos. Mas lembre-se do La Boétie, que você já folheou na estante. Para ele, "não pode haver amizade onde há crueldade, deslealdade e injustiça. Entre os maus, quando se reúnem, é um complô, não é companhia. Eles não se entretèm, mas entretementem-se. Não são amigos, mas cúmplices".

O filho levantou-se da cadeira, passou a mão pelos cabelos, folheou desinteressadamente as teses sobre beriberi que estavam sobre a mesa do escritório e perguntou ao pai: 
- E o seu amigo Morten, ainda lhe escreve?

- Sim. Recebi uma boa carta dele, quer ler?

- Hum ! O senhor não se lembra que, de alemão, só me ensinou a contar de um a dez? - e recitou numa discreta tonalidade musical como se brincasse com o pai - eins, zwei, drei, vier, fünf, sechs, sieben, acht, neun, zehn!

- Nada mal para quem só pensava no francês. O Morten dá notícias dos filhos e saúda a vocès. Continua ganhando a vida como médico, mas aprendeu a gostar de ópera.

- Acho que preciso ir, meu pai. Posso levar o La Boétie por uns dias?

- Mas é claro. Pegue-o na estante.

Naquela altura da investigação cientifica do beribéri, as duas teses sobre o beribéri que seriam lidas por João Alphonso surgiam como uma completa revisão do assunto. Atualizadas, sob o ponto de vista especulativo, especialmente a tese de Miranda Azevedo, consideravam uma constelação de possiveis causas para a doença. Ambas traziam uma generosa revisão bibliográfica e procuravam otimizar as contribuições de médicos brasileiros estudiosos do assunto. Até este momento, e continuaria a ser por muito tempo ainda, os estudos mais consistentes e originais acerca da moléstia no Brasil era o trabalho de Souza Lima, na Bahia. De fato, a originalidade e lastro cientifico do trabalho de Silva Lima, ligado à tendència de investigação cientifica baiana conhecida como 'Escola Tropicalista', referenciou a maioria dos trabalhos sobre o beribéri que surgiriam no Brasil a partir das últimas décadas do século XIX. O surgimento das publicações brasileiras sobre o beribéri guardam relação cronológica com a explosão de trabalhos sobre o assunto no exterior ${ }^{182}$.

182 Mesmo CARTER (i) admitindo arbitrariamente que o ocidente interessou-se seriamente pelo beribéri a partir de 1880, SCHEUBE (ii) cita que, entre 1800 e 1809 , houve duas publicaçðes sobre esta moléstia e que nas décadas seguintes este número subiu sucessivamente para $8,10,11,30,64,80$, para chegar, na década entre 1880-1899, a 181 publicaçðes. De acordo com Braddon, citado por CARTER (i), chegou a 200 o número de artigos sobre o benberi na década de 1890 a 1899 , e a 250 no periodo entre 
O trabalho de Miranda Azevedo183 é estruturado nos modelos clássicos das teses da época. Inicia-se com a descrição da sinonimia, etimologia e definição do termo que expressa a moléstia em questão. Jacobus Bontius, em 1642, e Nicolaas Tulp, em 1652, ambos médicos holandeses, são tidos como os dois primeiros a descrever clinicamente esta moléstia ${ }^{184}$. A partir daí, uma longa lista de autores investigam e nomeiam o beribéri. No Brasil, os nomes mais comuns para a doença foram "perneiras", no Mato Grosso, e "inchação", em Minas Gerais. Revendo a bibliografia sobre o beribéri até aquele momento, Miranda Azevedo elenca as principais hipóteses sobre a etiologia da doença. Assim è que, em 1871, um autor escreveu que

"como o escorbuto, o beribéri reconhece como uma de suas causas a alimentação muito uniforme, insufficiente e de má qualidade" 185 .

Mas em função de uma descrição vaga, o autor modificou sua hipótese, tendo em vista o aumento do número de casos em situações aparentemente adversas à sua teoria. Fica claro, a partir do detalhado

1900 a 1910. Mas CARTER (i) estima que uma bibliografia completa sobre a doença neste período poderia chegar a 500 itens. Por isso, a revista LANCET (iii) afirma, em uma de suas ediçðes de 1911, que provavelmente não houve outra doença cuja etiologia tenha sido tão discutida como o beribéri.

i. CARTER, K. C. The germ theory, beriberi and the deficiency theory of disease. Medical History, 21: 119-136, 1977.

ii. SCHEUBE, B. Die Beriberikrankheit. Jena, Gustav Fischer, 1894, p. 14.

iii. THE ETIOLOGY of beriberi. Lancet, II : 842, 1911.

183 AZEVEDO, A . C. de M. Beriberi . Rio de Janeiro, Typ. Academica, 1875. [ Tese inaugural apresentada à Faculdade de Medicina do Rio de Janeiro].

184 Apesar de serem referèncias importantes ná história da medicina, e em especial por seus estudos sobre o beriberi, especialmente N. Tulp (1593-1674)

"é mais lembrado como figura central no famoso quadro de Rembrandt, Lição de Anatomia (1632)". (*)

"www.mc.vanderbilt edu biolib/hc/nh1.html.

185 ALMEIDA, R. de. Est sobre as cond. hygi. dos nav. enco e as mol. mais freq. A seu bordo. Rio de Janeiro, 1871, p.99. Citado por AZEVEDO, A . C. de M. Op. Cit. p., 19 
histórico de Miranda Azevedo, que mesmo reconhecido no meio médico, o beribéri carecia de uma abordagem detalhadamente científica, fato que só viria a acontecer efetivamente com os trabalhos de Silva Lima, na Bahia, realizados nos anos de 1866 a 1869 e publicados em $1872{ }^{186}$. O delineamento da tese de Miranda Azevedo sustentava-se em informações sobre o beribéri fornecidas por médicos de diferentes lugares do Brasil. $O$ autor elaborou uma espécie de questionário, que seria respondido em conjunto. Mas o próprio autor afirma que

"com magoa vimos que nenhum desses individuos dignou-se responder à nossa intercessão”

mas que, felizmente, houve quem atendesse o seu interesse,

“... Dr. Felício dos Santos... foi o único que respondeu ao nosso pedido" ${ }^{187}$.

186 Em 1867, surgiu na Faculdade de Medicina da Bahia aquela que seria a primeira tese inaugural consagrada ao beribéri. De Pacífico Pereira, a tese

"dissertou sobre o 'diagnostico differencial das paralysias e seu tratamento', occupando-se da paralysia epidemica então reinante, approximando-a do beribér" (i).

Na Faculdade de medicina do Rio de Janeiro, a doença teria sido abordada pela primeira vez em 1871, com as teses de Rocha Leão e José Antônio Murtinho, ambos com um mesmo nome: "Das cond. pathog. da parapl." (ii).

i. FRAGA, C. O beribéri na Bahia. Salvador, Imprensa Official do Estado, 1917. p.8.

ii. AZEVEDO, A . C. de M. Beribéri. Op. Cit. p. 21.

187 AZEVEDO, A . C. de M. Beribéri. Op. Cit. p. 23.

Posterior à sustentação da tese de Miranda Azevedo, surgiu no meio acadèmico um escrito do médico italiano radicado em São Paulo, Dr. Betoldi, intitulado 'O BeriBeri na Provincia de São Paulo" (i) . O texto dirigia-se ao Dr. Miranda de Azevedo e recebeu criticas pelo conteúdo. Uma das mais contundentes finitiu ¿i: :MCOLÁO que, em sua tese de 1877, escreveu, entre outras coisas:

"Da leitura d'esta carta nada podemos concluir que nos guiasse pelas verêdas escabrosas que nos offerecia a difficuldade do assumpto. Melhor seria que o Dr. Betoldi se tivesse limitado á única exposição completa dos symptomas da supposta epidemia de Beri-Beri, porque assim não teria cahido em palpaveis contradiç̧ðes quando aprecia os symptomas e procura interpretar os phenomenos do seo morbo epidemico que tudo será menos Beri-Beri" (ii). 
No capitulo terceiro, quando trata de uma fração da epidemiologia do beribéri, Miranda Azevedo aborda a possivel influência dos aspectos topográficos, climatológicos e etnográficos na determinação da moléstia. De um modo geral, pode-se afirmar, a respeito destes aspectos, que havia algumas concordâncias, tais como:

"a latitude para o beriberi póde-se estender até perto de $40^{\circ}$ para ambos os hemispherios";

"o clima de um paiz tem uma influência manifesta no desenvolvimento do beriberi"

"... as estatisticas sempre offereceram resultados que autorisam a affirmar que não tem esta affecção preferencia para esta ou aquella raça, sem que alguma dellas esteja isenta de seus insultos" 188 .

Desta forma, era previsivel que a etiologia do beribéri guardasse, até ali, relação com as condições topográficas, mas especialmente com as climáticas:

“... na etiologia e genese do beriberi, se fazem sentir as influências cosmicas, as emanações $e$ as variações climatericas"189.

A terminologia acima indica uma 'memória conceitual' ainda cara à medicina; residuo de uma época recente onde os sistemas especulativos, enunciados ainda no século XVIII, influenciavam significativamente a abordagem médica ${ }^{190}$. Naquela altura da especulação médica, abordar o

i. Dr. BETOLDI. O Beri-Beri na provincia de São Paulo: Carta ao Dr. A . C. de Miranda Azevedo. Rio de Janeiro, B. L. Garnier, 1877.

ii. NICOLÁO, A . J. Beriberi. Rio de Janeiro, Typographia Carioca, 1877. p. 27.

188 Idem, p. 28 - 31.

199 Idem, p. 33.

190 O século XVIII foi profícuo no surgimento ou aprimoramento de sistemas 'médicofilosóficos' que marcaram profundamente a abordagem médica. Estes sistemas, por conseguinte, ditavam teorias de tratamento, etc. John Brown (1735-85), com o seu sistema de 'estimulação', a partir do qual administrava altas doses de sedativos ou 
beribéri significava romper com certos 'paradigmas' que o trabalho de Silva Lima ainda não conseguira ultrapassar totalmente, mesmo porque ele próprio não havia sido esclarecedor quanto à etiologia da moléstia. Assim, o estudo do capítulo da tese de Miranda Azevedo que trata da etiologia e patogenia do beribéri, revela que mesmo o diagnóstico da doença estava cercado de incertezas. É praticamente correto afirmar que muitas doenças se passaram por beribéri e a extensão e gravidade destas estiveram associadas à presença de outras moléstias que acometiam

estimulantes; Samuel Hahnemann (1755-1843) com o sistema homeopático, etc. Influente nas duas escolas médicas brasileiras de então, o 'vitalismo' do médico francês Paul-Joseph Barthez (1734-1806) afirmava que todo ser vivo possuia $L$ 'élan vital, uma força vital. Esta teoria havia sido aperfeiçoada por Barthez a partir da teoria flogistica de Georg Ernest Stahl (1660-1734), professor de medicina em Halle. Por sua vez, esta teoria concebia que o movimento nos seres vivos devia-se à presença daquilo que se chamava 'ânima', ou alma (i).

CONI, no seu estudo sobre a Escola Tropicalista Bahiana, estuda a influência destes sistemas especulativos na medicina brasileira da época:

“Época dos sistemas teóricos (de 1808 a 1866) ... é a época da influência dos sistemas especulativos europeus que, aparecidos no século XVIII, se apoiavam numa fisiologia hipotética. CULLEN, BROWN, BROUSSAIS, RASORI, TOMASINI, BARTHEZ e outros criadores de teorias médicofilosóficas tiveram seus adeptos e panegiristas no seio das gerações médicas que iam saindo da Escola de Cirurgia (1808-1815), do Colégio Médico Cirúrgico (1815-1832) e da Escola ou Faculdade de Medicina (de 1832 em diante)".

"Quanto à Faculdade de Medicina sofreu ela marcante influência da doutrina vitalista de BARTHEZ, influência que, talvez, tivesse contribuído para desviar, por algum tempo, os médicos baianos dos conceitos patológico e clínico, originados também no século XVIII, os quais se firmavam numa anatomia já elevada à categoria de ciência" (ii).

Neste caso particular inclui-se a trajetória do genial médico baiano José Francisco da Silva Lima, citado no presente trabalho como autor do original e importante estudo sobre o beritúri. SIL V'A LIMA doutorou-se pela Faculdade de Medicina da Bahia emi 1851 , com a tese Dissertação filosófica e crítica acerca da fôrça medicatriz da natureza e somente sob a influência da medicina anglo-saxônica de WUCHERER e PATERSON é que se converteu à medicina observacional, experimental, que teve seu apogeu no século XIX, com o grupo que se expressou a partir da Gazeta Médica da Bahia, conforme foi descrito anteriormente no presente estudo (cf. Segunda Parte).

i. FREEDMAN, A . D. History of Medicine. Grolier Multimedia Enc., Op. Cit.

ii. CONI, A . C. A Escola Tropicalista Bahiana. Op. Cit. p. 22-30. 
populações expostas a uma série de riscos: má alimentação, condições sanitárias inadequadas, em especial as condições de um certo meio que expunha os individuos a um processo de transmissibilidade grave, etc. ${ }^{191}$. Um bom exemplo para isto é um caso clássico na história do

191 Se atualmente, através dos recursos da epidemiologia, consegue-se distinguir com alguma clareza os conceitos de epidemia e endemia, como nos ensina, p. ex., ALMEIDA $F^{0} \&$ ROUQUAYROL (i), nem sempre foi assim. Numa tese de concurso para professor da Faculdade de Medicina do Rio de Janeiro em 1879, ABREU (ii) escreve:

“... procuremos vêr se há grande differença entre as epidemias e endemias.

"À primeira observação, parece que a linha de separação entre estas manifestações do estado morbido, se achão perfeitamente discriminadas.

"Se attendermos, porém, reconheceremos que este limite é bastante transitório, e depois de exame mais detido, não deveremos ter a velleidade de, com os progressos da sciencia moderna, conservar esta divisão como absolutamente verdadeira.

“... não se póde deixar de admittir que as endemias têm uma existencia real, mas não se achão separadas das epidemias senão por circumstancias instaveis, ...".

Assim, como pode ser observado na bibliografia da época sobre o beribéri, houve quem tratasse as manifestaçðes de beribéri como epidemia ou endemia. Em referências mais recentes, falou-se também em 'surtos'. Um bom exemplo de como os conceitos de epidemia e endemia foram tratados no século XIX é oferecido por Ignaz Semmelweiss (1818-1865), oportunamente citado porA YRES (iii):

"Para classificar a febre puerperal como doença epidêmica ou endêmica é preciso ignorar por completo o número de pacientes que adoecem ou morreram. A causa da doença ou morte determina se a enfermidade é epidêmica ou endêmica. A febre puerperal epidêmica é induzida por influências atmosféricas-cósmico-terrestres; ... Se ... é causada por fatores endêmicos, ...., fatores cuja atuação se limita a uma localização específica, então a febre puerperal é endèmica...".

Além do aspecto conceitua', é intcressante observar que uma discussão sobre os conceitos numa determinada época deve ter em conta os critérios de diagnóstico específico para cada uma das doenças (ou grupo de doenças) em estudo, conforme explica SOURNIA \& RUFFIE (iv):

"Com efeito, doenças endèmicas e epidêmicas podem acumular-se. Por exemplo, todos os estudos que foram feitos sobre o estado sanitário das províncias francesas no século XVIII mostram a coexistência de febres eruptivas, pulmonares e intestinais; seria completamente ilusório distinguir uma das outras segundo o nosso vocabulário moderno". 
beribéri, que dá conta da ocorrência de uma "epidemia" da doença no navio francês Parmentier. Sabe-se, contemporaneamente, que o desenvolvimento do beribéri, num processo que se inicia com a deficiência alimentar severa de tiamina (vitamina $B$ 1) até a morte, não demoraria menos do que, em média, seis meses, mas o relato dos acontecimentos do navio diz que:

"A 10 de outubro de 1861 sarpou este navio [Parmentier] de Martinica para Pondichéry levando a seo bordo 401 coolis, dos quaes falleceram 258, victimas da epidemia do beriberi, que manifestou-se em janeiro de 1862, quando o navio estava nas altas latitudes do hemispherio austral, a qual reinou até chegar à ilha Mauricia. Alli o Parmentier, sob a acção dos ventos de terra que traziam os effluvios palustres, vio cessar o beriberi e apparecer o cholera-morbus, uma das manifestações do impaludismo, o qual cessou logo que afastaram-se das influências miasmáticas, pela sua partida. Quando não podiase de modo algum admittir a existencia da malaria, voltou o beriberi que só deixou de fazer victimas quando o Parmentier chegou a Pondichéry" 192.

Neste caso, a ocorrência de tantas mortes pelo beribéri só se explicaria se os tripulantes fossem uma população já anteriormente exposta à doença. Assim, ao embarcarem, e submetidas imediatamente

Ao presente trabalho, cujo objetivo não é quantificar epidemiologicamente a doença, a precisão do conceito que melhor expresse a extensão do beribéri, é relevada a segundo plano.

i. ALMEIDA F $F^{q}, \mathrm{~N}$. de. Introdução à epidemiologia moderna. 2. Ed. Belo Horizonte/Salvador Rio: Coopmed/APCE/Abrasco, 1992. Cap. VIII : Padrões de distribuição de doença. p. 116-141.

ii. ABREU, J. B. Das epidemias. Rio de Janeiro, Typographia Universal de Eduardo \& Henrique Laemmert, 1879. p. 2.

iii. AYRES, J. R. de C. M. A doença na sociedade como entidade e como processo: subsídios para pensar a epidemiologia. Saúde e sociedade, 2 (2), 1993. p. 147.

iv. SOURNIA, J-C. \& RLFFIE, J. As epidemias na história do homem. Lisboa, Ediçð̃es 70, 1984. p. 116.

192 AZEVEDO, A C. de M. Beribéri. Op. Cit. $\mu$. 35-6. 
a um regime carente de vitamina B 1, estariam agravando o quadro de deficiência. Mesmo admitindo mortes pela deficiência vitamínica, é certo que muitas das mortes anunciadas não tenham ocorrido por beribéri. $\mathrm{Ou}$ são casos de doentes diagnosticados como beribéricos, mas que não o eram; os falsos positivos. De fato, na história do Parmentier é citada ainda a ocorrência da cólera e da malária e em ambos os casos havia controvérsias quanto ao diagnóstico diferencial em relação ao beribéri. A indefinição quanto à etiologia da doença favorecia o surgimento de muitas teorias. Alguns fatos, se não eram enunciados como entidades causais, eram como fatores predisponentes. Miranda Azevedo discute o aspecto alimentar na determinação da doença, mas não reconhece, de imediato, a unicausalidade daquele em relação a esta:

"A alimentação insufficiente póde causar molestias as mais graves com o character assustador, e predispor para as mais terriveis epidemias ... Entendemos por alimentação insufficiente nem só a não satisfação das exigencias das leis da Physiologia que estabelecem a quantidade dos alimentos compativeis com a saude, mas tambem a falta de variedade dos mesmos, produzindo uma uniformidade perniciosa na alimentação, pois a variedade desta é exigida imperiosamente pelas necessidades do nosso organismo"193.

$\mathrm{Na}$ verdade, havia uma racionalidade na suspeita de que a alimentação estivesse relacionada com processos mórbidos. As pesquisas em curso sobre os processos digestivos e inferências epidemiológicas esparsas faziam suspeitar da ação etiológica de processos nutricionais. Por exemplo, a teoria que afirmava que uma alimentação à base de arroz predisporia $o$ individuo ao beribéri. Dois pesquisadores franceses, Franquet e Rochard, definiam o regime à base dents soreal somo causa da doença. É certo que

193 Idem, p. 39 
“... este ultimo autor modificou um tanto sua opinião; comtudo acredita que o regimen deste cereal 'deve contribuir poderosamente para a sua [ do beribén] producçãom194.

Para Miranda Azevedo, relacionar o consumo de arroz ao beribéri não parece uma suposição absurda, visto que

"Se a nutrição pelo milho produz pellagra, cuja causa é o sporisorium maydes, porque não admittir que se tenha desenvolvido no arroz um parasita airıda não estudado o qual seja o causador do beribéri ?"198.

Se é verdade que a pelagra seja conseqüência de uma vitamina (niacina), é verdade também que a suposição de que um parasita, presente no milho, causasse a doença estimulou estudos que investigasse a possibilidade de parasitas, em outros alimentos, provocassem outras doenças. Por esta equação, a dificuldade de elucidar o processo causal a partir do estabelecimento de associaçōes confiáveis encontrou, no caso de doenças relacionadas à alimentação, um aliado que o tempo mostraria ser de pouca utilidade a curto prazo: a emergente e poderosa teoria microbiana. Somente com o tempo, ao se verificar a insatisfatória resposta desta teoria para explicar algumas doenças como o beribéri, é que se alterou o rumo das pesquisas. Mas isto demoraria algumas décadas. $\mathrm{E}$, antes que isto viesse a acontecer, a lista de possiveis fatores predisponentes ou causais para o beribéri era longa. Por exemplo, o médico e conselheiro imperial, professor da Faculdade de Medicina, Dr. Jobim, que havia se envolvido em uma polêmica com a 'Escola Tropicalista Baiana' sobre a ancilostomíase, afirmou que a causa do beribéri em São Luis era a água consumida, já que esta era proveniente de uma fonte cujas águas passavam por um cemitério ričxims. Miranda Azevedo contesta esta possibilidade. Nän unntests, contudo, e sugere atenção e estudo ao fato de que, no Pará, o surgimento do beribéri, em região de igarapés, estivesse relacionado com os periodos de cheia e estiagem. Nesta região a doença era atribuida à queda de

\footnotetext{
194 Idem, p. 40.
} 
frutos e folhas de uma árvore, a cachinduba. Em Santa Catarina teria ocorrido uma epidemia de beribéri em 1870 e sobre os fatos circundantes a ela (chuvas e enchentes), Miranda Azevedo afirma que

“... devem chamar a attenção dos pathologistas para investigarem a ligação que possa existir entre estes phenomenos metereologicos e o apparecimento da terrivel moléstia, que estudamos"196.

A intoxicação por produtos químicos também foi dada como causa para o beribéri: chumbo, pelos canos de condução de água; arsênico, usado como formicida. A consistência de certa hipótese que explicasse a origem da doença dependia da credibilidade e 'atitude' cientifica do pesquisador. A credibilidade parecia ser um fenômeno variável, já que estava sempre ligado não apenas ao reconhecimento social, mas, principalmente, à consistência científica dos seus enunciados. Ou seja, no meio científico o prestígio social não abonava inteiramente o que afirmava o 'pesquisador'. Um bom exemplo deste quadro parece ter sido o do conselheiro Jobim. De grande prestigio social, o seu reconhecimento cientifico, defasado, foi perdendo crédito até mesmo entre estudantes ${ }^{197}$. Por outro lado, neste mesmo meio científico a 'atitude' cientifica, diferentemente da capacidade, mas que pode estar ao lado desta, pode promover o reconhecimento de uma dada hipótese pela capacidade de

196

Idem, p.41.

197 Conforme abordado no presente trabalho (cf. Segunda Parte), o Dr. Jobim foi 'derrotado' na sua polêmica com a Escola Tropicalista. Esta 'derrota' só é entendida sob a perspectiva de que na ciência o 'certo' e o 'errado' não necessariamente funcionam como critério de capááidade científica do pesquisador, se se consideram os argumentos e procedimentos decisórios do Conselheiro na discussão sobre a ancilostomíase. O seu descrédito científico aparece também nas palavras do doutorando Miranda de Azevedo

(*) que, ao comentar sua explicação para os casos de beribéri em São Luís, escreve:

"O Dr. Jobim, sem examinar convenientemente a questão, e com a excentricidade de idéas que o caracterisa,...".

* AZEVEDO, A . C. de M. Beriberi. Op. Cit., p. 41. 
articulação do 'pesquisador' em, com base em conhecimentos cientificos estabelecidos, elaborar racionalmente uma proposição, mesmo que esta careça de 'consistência' (analitica e experimental, por exemplo) interna. Esta situação é identificável na tese de Miranda Azevedo, em especial quando o autor expõe as possibilidades dos hábitos cotidianos condicionarem o aparecimento do beribéri. A falta de exercícios fisicos ao ar livre, hipótese que influênciará profundamente os colégios internos, como o Caraça, que providenciaram áreas especificas para a prática de exercícios; o modo de vida extravagante, devasso, de muitas pessoas, etc. Neste rol de hipoteses "beriberigênicas", a mais curiosa delas, parte de um caso clínico especifico acompanhado e descrito pelo proprio Miranda Azevedo:

“... um individuo, que offerecia uma symptomatologia um tanto analoga à do beriberi, isto é, formigamentos e fraqueza nas pernas e nos pés, dores lombares principalmente na região cervical, diminuição de força muscular, etc., indágamos-lhe da historia que muito veio nos esclarecer em relação à pathogenia da affecção que viamos. O doente tinha o hábito de copular de pé; e sempre depois de ter cohabitado com uma mulher por esta fórma, sentia maior intensidade dos symptomas que o affligiam.

“Impressionou-nos esse facto e, estabelecendo o parallelo desta affecção com o beriberi, fizemos investigaçōes a respeito, tendo obtido dados muito interessantes para a sciencia, em uma questão, a qual somos o primeiro a agitar.

“As experiencias modernas de physiologia nos ensinam o papel do systema nervoso no acto da copula, e o abalo que deve soffrer, quando não é exercitada esta função naturalmente; esse abalo póde predispor os individuos para o beriberi ou ser até a causa determinante do seu apparecimento.

“A observação clinica veio confirmar as nossas previsōes; soubemos, por informaçōes de nosso distincto collega, o Sr. Cypriano de Freitas, que no Maranhão algumas pessoas que tinham esse máo habito foram victimas da epidemia reinante, embora observassem todas as condiçōes hygienicas. 
"Pelas circumstancias que revestem os factos que acabámos de narrar, é para nós fóra de duvida e perfeitamente explicavel esta causa beriberigena. Oxalá estas nossas considerações sirvam de ponto de partida para estudos completos e perfeitos neste assumpto"198.

Sem que houvesse uma teoria que abarcasse integralmente todas as suspeitas clinicas e epidemiológicas acerca da etiologia do beribéri, todas estas suspeitas acabavam mais ou menos no mesmo patamar de veracidade. Assim, ao observar que cozinheiros e criados possuem certa imunidade ao beribéri, dizia-se que estes individuos, ao dispor de uma alimentação melhor e mais variada, resistiam melhor a invasão do mal. Hegemonicamente prevalecia a compreensão do valor da alimentação vista no seu conjunto (quantidade e qualidade), compreensão que explica favoravelmente a finalidade da alimentação quando o individuo encontrase sadio. Do contrário, esta compreensão é frágil e, naquela altura do conhecimento cientifico acerca da nutrição, sobrava relacionar a alimentação como veiculo de agentes produtores de doenças ou, no último caso, afirmar que um organismo debilitado estaria mais predisposto a determinado mal. E o que foi feito para explicar a "imunidade" de cozinheiros e criados ao beribéri.

Também as vestimentas estiveram implicadas com a origem do beribéri:

"Um facto, porem averiguado, è a acção das roupas molhadas e humidas, que, predispondo e produzindo, ora rheumatismo, ora o escoburto nos maritimos, tambem é productora do beriberi" 199 .

O autor, reportando aos acontecimentos da Guerra do Paraguai, crê que, das condiçōes adversas enfrentadas pelos soldados, o vestuário tenha desempenhado um papel importante na etiologia do beribéri. Esta

\footnotetext{
198 Idem, p. 42.

199 Idem, p. 43
} 
possibilidade deve ser compreendida dentro do conceito de integralidade do organismo humano. No caso, a ausência de roupas ou usá-las molhadas afetariam as secreções do organismo e estas, uma vez não desempenhadas regularmente, produziriam perturbaçōes, em diferentes graus, para a saúde. Miranda Azevedo expressa esta noção, ao escrever que

"Existe uma harmonia relativa para as secreções physiologicas regularisadas por leis invariaveis. A desordem dessas funcções ou o seu desvio acarretam naturalmente pertubações ... a irregularidade dessas funcçōes, reflectindo-se para o lado do systema nervoso, ou viciando o sangue, póde predispor os individuos victimas della a contrahirem o beriberi.

A supressão de uma dellas, como a da transpiração, tem influência reconhecida no desenvolvimento desta afeç̧ão..." 200 .

$O$ raciocínio médico que sustentou esta hipótese foi também desenvolvido sob o principio de que um organismo 'desequilibrado' altera funções e produz suas doenças. Aparentemente simples, este sistema encontrava sua compatibilidade com a própria terapeutica disponivel até aquela época, conforme será visto oportunamente. A explicação para o caso da transpiração, dada por um clinico cearense, parece ilustrar a situação:

“Na suppressão de transpiração o suor detido pelo aperto dos orificios por onde deveria escapar-se póde ser reabsorvido, e tambem occasionar uma intoxicação do sangue, mandando para o interior da circulação um princípio acre, sem ser preciso o tal veneno no ar; pois bem, admittimos que no beriberi haja um veneno alterando o sangue, mas formado dentro do próprio organismo, e não lhe sendo imposto por um agente toxico qualquer vindo do exterior"201.

O beribéri foi descrito como uma doença que se manifestava de forma endèmica em algumas localidades. Desta forma, discutia-se a

200 Idem, p. 44.

201 SILVA, F. B. da. Consult. Sob o beriberi. Fortaleza, 1874, p. 12 
maneira de sua propagação. De acordo com as teorias da época, a propagação do beribéri poderia ocorrer tanto pela via contagiosa como infecciosa. A natureza infecciosa, ou miasmática, foi a primeira a ser descartada pelos primeiros estudos mais especificos sobre a doença. Os casos de beribéri verificados em alto mar neutralizavam a teoria de infecção palustre, já que esta teoria calcava-se na ação que teriam produtos da putrefação vegetal e animal sobre o ar ambiente. Aristides Caire, autor da tese sobre o beribéri, contemporânea à de Miranda Azevedo, admitia a hipótese de que as condições miasmáticas predisporiam o organismo à doença:

“... o miasma palustre por si só não é capaz de produzir a molestia; porém admittimo-lo como causa predisponente e poderosa, actuando sobre as funcções hematopoieticas, tornando o organismo mais apto a receber a nova moléstia"202.

Quanto à natureza contagiosa do beribéri, havia algum consenso. Isto se devia à formulação da teoria na época. Esta formulação acolhia várias hipóteses que propunham explicar a natureza da doença. Assim é que Miranda Azevedo afirma:

"Até hoje parece-nos que ninguem ainda duvidou da não contagiosidade beriberica; todos os escriptores, una voce, proclamam-no tal"203.

A partir da memória do Dr. Felício dos Santos, Miranda Azevedo cita uma situação que se tornará freqüente nos trabalhos onde se trata da possibilidade de contágio do beribéri. Trata-se da compreensão do beribéri nos educandários lazaristas Caraça e Mariana. Os fatos, afirmados por Felício dos Santos e acordados por Miranda Azevedo, indicavam que o beribéri teria chegado ao seminário de Mariana trazido pelos padres que se comunicavam com o Caraça ${ }^{204}$. Este caso tanto

${ }^{202}$ CAIRE, P. A . Das cond. pathog. ... Op. Cit., p. 35

${ }^{203}$ AZEVEDO, A .C. de M. Beriberi. Op. Cit., p. 45

Os comentários sobre as teorias contagionista e infeccionista (ou miasmática) no século XIX foram feitos na Primeira Parte do presente trabalho, capitulo XX. 
possibilitou preservar a teoria contagiosa para o beribéri, como contribuiu para refutar a teoria infecciosa. Foi utilizando este exemplo, tirado originalmente da memória do médico mineiro solicitada por Miranda Azevedo, que Aristides Caire completa a sua contestação a respeito de uma hipótese infecciosa para o beribéri:

"No collegio do Caraça, 12 leguas distante de Ouro-Preto (Minas), segundo observaçōes do Dr. Joviano R. Moraes Jardim, appareceu o beriberi, mas na vizinhança não há pantanos, nem aguas estagnadas $\mathrm{e}$ não consta ter havido alli febres intermittentes

"Em Diamantina (Minas) não reinam as affecções paludosas, e o lugar onde atacou o beriberi foi o ponto mais elevado da cidade e completamente livre de qualquer suspeita a este respeito, como relata o Dr. Felicio dos Santos"20s.

É verdade que vários estudiosos, entre eles Silva Lima, referiram-se a fatos que insinuavam o caráter contagioso do beribéri. Contudo, não é verdade afirmar que não houvesse quem discordasse desta possibilidade. No mesmo ano de edição da tese de Miranda Azevedo - 1875 - saía em Portugal a memória, em forma de livro, do médico brasileiro, professor na Escola Médico-cirúrgica de Lisboa, sob o título Symptomatologia, natureza e pathogenia do Beriber ${ }^{206}$. Antes deste estudo, Costa Alvarenga havia

204 A afirmação do Dr. Felício dos Santos, de que o beribéri apareceu primeiro em Mariana (em 1858), depois no Caraça (em 1861) e posteriormente em Diamantina (em 1871), 'popularizou' o juizo de que a doença teria acompanhado os padres sucessivamente. Esta conclusão foi reproduzida na grande maioria das teses da época, sobre o beribéri, como, por exemplo, por MELLO:

“... em Minas observou o Dr. Felicio dos Santos, que a molestia acompanhou

os padres francezes do Caraça para Marianna e d'esta cidade para

Diamantina e que estas localidades não forão atacadas senão sucessivamente" *.

* MELLO, E. M. H. de Beriberi. Rio de Janeiro, Typographia Carioca, 1877. p. 37.

${ }^{205}$ CAIRE, A. P. Das cond. pathog. ... Op. Cit., p. 35.

206 ALVARENGA, P. F. da C. Symptomatologia, natureza e pathogenia do beriberi. Lisboa, Typographia da Academia Real das Sciencias, 1875. 
publicado alguns estudos de casos de beribéri em periódico médico de Portugal. Estes estudos, então conhecidos de Miranda Azevedo, são menosprezados por este com a justificativa de que o autor deixa de abordar questões fundamentais à observação clínica, como o tratamento, opinião com a qual, posteriormente, não concordou outra tese ${ }^{207}$. Na publicação posterior, Costa Alvarenga analisa as principais opiniōes sobre a natureza a patogenia do beriberi e praticamente rechaça-as integralmente. Inclusive opõe-se a muitas afirmativas de Silva Lima, cujo trabalho constitui um marco divisor dos estudos da moléstia no Brasil. Neste ponto, há que se considerar a 'direção' da critica de Alvarenga. Os estudos de Silva Lima tornaram-se consulta obrigatória sobre o assunto e apareceram no auge das atividades do grupo que se organizava em torno da Gazeta Médica da Bahia. Alvarenga tornara-se professor na escola de Medicina de Lisboa, sócio da academia real de ciências, além de sócio correspondente e honorário de diversas sociedades médicas ${ }^{208}$. Nesta condição, além do esforço científico de compreender e tentar responder adequadamente a indagações que cercavam o exame do beribéri, Alvarenga deixa transparecer o desejo de também ser reconhecido pela aparente atualização e talento cientifico. Ele acentua as contradições internas da obra de Silva Lima, provocando-o, como, por exemplo, ao comentar um trecho do livro onde o autor da Bahia discute a possibilidade de o beribéri ter o seu centro no sistema nervoso cerebro-

207 NICOLÁO (*), comentando os referidos artigos do Dr. Costa Alvarenga, afirma:

"Não prestamos o nosso assentimento à opinião dos que julgam as observaçðes do illustre Dr., destituidas de caracter clinico, por quanto fomos testemunha ... de varios individuos beribericos que, á conselho de seos medicos assistentes, se retiraram para a Europa onde entregaram-se aos cuidados do eximio pratico ..." * p. 18.

Também nesta tese, o autor reproduz integralmente (p. 26) as principais conclusões de Felício dos Santos, destacadas na memória sobre o beribéri em Minas Gerais.

* NICOLÁO, A . J. Beriberi. Op. Cit.

208 Na página de abertura do seu livro, Costa Alvarenga enumera, apenas na condição de sócio correspondente, 32 entidades médicas em vários paises da qual faz parte. Além de sócio honorário, inscreve-se como redator de periódico médico, lente catedrático e laureado. A esta relação segue-se uma indicativa trinca: etc. etc. etc. 
espinhal, e no grande simpático, os quais estão paralisados por congestão, inflamação e amolecimento. Escreve Costa Alvarenga:

"N'este trecho parece claro que o auctor admitte a congestão e a inflammação das meninges e da medulla e o amollecimento d'esta, lesões que devem constituir o estado pathologico primitivo do systema nervoso, de que nos fallou. Se esta é com effeito a opinião do nosso distincto collega, porque não o diz claramente ? Porque é tão vacillante, tão perplexo, tão hesitante, tão equivoco ?"209.

Entre natureza infecciosa e contagiosa para o beribéri, Alvarenga não faz opção. Ao contrário, está inclinado a considerar, ao lado de uma constatação consensual, que

“... não nos parece que o beriberi seja doença contagiosa nem infectuosa; mas todos concordam que é doença endemica"210.

Alvarenga reconhece que, quanto à etiologia desta moléstia, apenas se suspeita de algumas circunstâncias que favoreceriam o seu desenvolvimento sem, contudo, identificar claramente a causa produtora:

"Hypotheses sobre hypotheses, opiniōes sobre opiniōes, muitas vezes encontradas, nenhuma das quaes dá conta satisfactoria nem da evolução nem dos symptomas do beriberi" ${ }^{211}$.

Diante de uma moléstia de etiologia e patogenia obscuras, que manifesta-se sob formas variadas e que é epidêmica, não é de se esperar que os procedimentos profiláticos e terapêuticos sejam eficazes. Desta forma, a revisão de Miranda Azevedo reproduz as condutas sugeridas por estudiosos da moléstia, assim como de médicos que tiveram pacientes beribéricos sob seus cuidados. A primeira recomendação, ao se deparar com a beribéri epidêmica, era o afastamento do lugar onde ela ocorresse. Esta recomendação essencialmente se baseava na possibilidade de

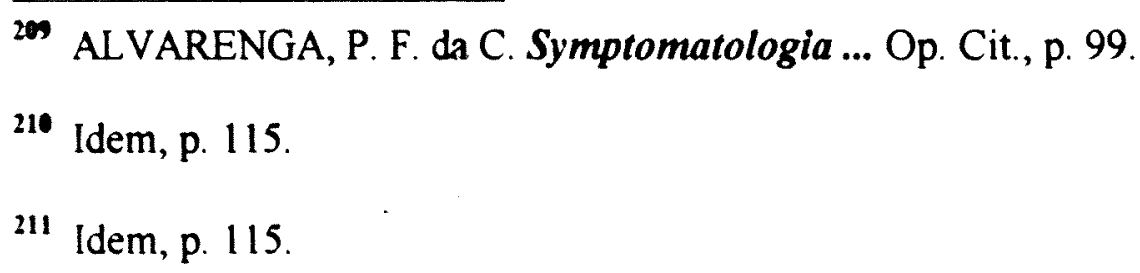


propagação da doença, afirmando que todos os indivíduos expostos ao risco que afeta alguns individuos estão, em grau variado, se expondo à possibilidade de adoecerem também. Esta medida, sugerida genericamente aonde quer que se manifestasse a doença, determinou comportamentos de repercussões variadas. Aos pacientes ricos acometidos pela doença recomendava-se temporadas na Europa; àqueles que não podiam fazer esta viagem, sugeria-se curtos retiros. Na Bahia, por exemplo, a ilha de Itaparica costumava ser indicada para este fim. Do Maranhão, narra-se que, durante a epidemia da doença em São Luís, habitantes transferiram-se da cidade pelas embarcações que zarpavam do porto:

"O que não se pode negar é que em 1872 grassou uma extensa epidemia na capital do Maranhão; por cartas particulares tivemos noticia de que partião ás vezes em um vapor 20 pessoas affectadas do beriberi ! Terror panico espalhou-se então por toda a população; tão grande foi o numero de casos que deo-se uma verdadeira epidemia"212.

Nos colégios internos e seminários, a simples noticia do beribéri justificava o encerramento das atividades e a saida dos alunos. Este procedimento foi adotado no Caraça várias vezes e, ao final, debilitado com esta ocorrência, o estabelecimento foi questionado a respeito da sua existência enquanto colégio interno. As medidas que se aplicavam no Caraça advinham do conhecimento que se tinha, até aquele momento, da doença. Em primeiro plano, melhoria da alimentação ${ }^{213}$ e exercícios ao ar

212 ARAUJO, A . J. R. da S. \& CUNHA, M. J. R. da. Estudo sobre a pathogenia do beriberi. Bahia, Typographia Americana, 1874. p. 152

213 A relação da alimentação com o beribéri, como está sendo visto, ainda é genérica neste período. A relação mais 'articulada' fálava apenas que certos alimentos (arroz, milho) seriam veiculos que transportariam para dentro do indivíduo algum princípio que estaria relacionado com a moléstia: um veneno, um germe, etc. Sobre este ponto, encerram bem os autores de um trabalho da época:

"A perversão do movimento intimo da nutrição caracterisa todas as molestias em geral: consequeentemente ahi não podemos lançar as bases da pathogenia do beriberi" (i).

Livresco, o conhecimento que se tinha a respeito da nutrição nos cursos de medicina brasileiros correspondiam àqueres disponiveis nos livros mais recentes editados 
livre; caso o número de pessoas afetadas no colégio fosse mínimo, estas eram removidas para uma chácara afastada, onde os enfermos eram tratados. Caso aumentasse o número de individuos afetados, as atividades eram suspensas e os alunos entravam em férias antecipadas. Estas condutas permaneceriam em vigor até meados do século $\mathrm{XX}$, minando as energias da Congregação da Missão que via aumentar, a cada ano, o ônus material, social e político de se manter um colégio em sítio de tão difícil acesso.

na Europa. A leitura de uma tese inaugural de 1876, cujo título é "Da Nutrição", revela que o autor organiza a revisão a partir dos resultados de pesquisas européias, discutidas anteriormente no presente trabalho. A conclusão que se pode tirar da leitura de "Da Nutrição" garante totalmente a afirmativa da citação (i); ou seja, a generalidade da nutrição exige acuidade ao relacioná-la com algum distúrbio particular, já que

"Na nutrição se confundem todos os actos e todas as necessidades do

organismo, em uma palavra, todos os phenomenos da vida, no estado physiologico, como no estado morbido" (ii, p.34).

No caso do beribéri esta acuidade exigirá longos anos de pesquisas. A importância da nutrição, reconhecida e cada vez mais demonstrada, calcava-se na seguinte classificação dos alimentos, que desconhecia as vitaminas (adaptado de ii,p, 24):

Inorgânicos $\left\{\begin{array}{l}\text { Água } \\ \text { Cloreto de Sódio } \\ \text { Ferro, Fósforo, etc }\end{array}\right\}$ Sais

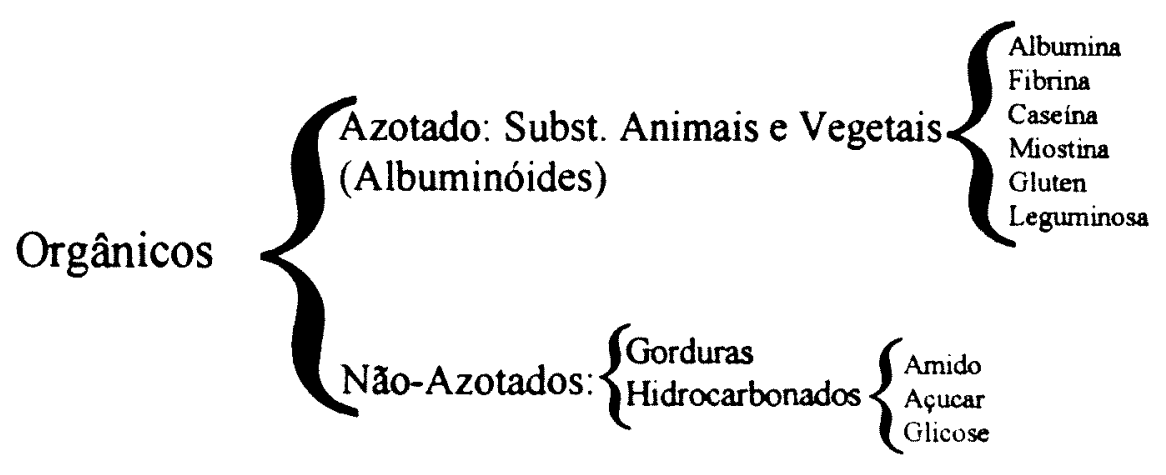

i. ARAÚJO, A. J. P. da S. \& CUNHA, M. J. R. da. Estudo sobre... Op. Cit., p. 138.

ii. LUZ, F. A . F. da. Da Nutriçåo. Rio de Janeiro, Typographia Cinco de Março, 1876. 
As constantes referências aos episódios de beribéri no Caraça fizeram João Alphonso retomar seus encontros com os padres da Congregação da Missão. Sem saber exatamente como tratar o assunto, ele presumia a necessidade de ter tantas informaçōes que possibilitassem compreender a presença da doença no Colégio e Seminário da Serra do Caraça. Assim, combinou com o Capelão do hospital que visitaria a Casa Central dos lazaristas proximamente. Antes desta visita, João Alphonso refletiu sobre seu interesse pelo Caraça e se convenceu de que sempre relacionava o isolamento e caracteristicas do Caraça com o ostracismo do Dr. Lund em Lagoa Santa. Para João Alphonso, a figura do velho dinamarquês funcionava como um farol que iluminava uma apelativa fração da realidade, realidade esta que ele, João Alphonso, apenas conseguia transformar num capcioso labirinto que zombava da sua sagacidade e roubava a cada dia a sua vitalidade. Nesta circunstância, a realidade caracense situava-se como um poderoso e atraente entreposto. A provocativa situação geográfica do local, harmonizando um ambiente multifaceado e ambivalente: ordenado e intelectual; indulgente e disciplinador, solidão em comunhão. Então, João Alphonso admitiu a si próprio que, ao interpelar quem estivesse envolvido com o Caraça e com o beribéri, ele estabelecia um trilha particular de acesso a uma realidade desconhecida, mas magnética. Foi pensando assim que João Alphonso sentiu-se impelido para escrever a Morten. Em certa altura desta carta, ele afirmava:

"... a você eu posso afirmar que estou envolvendo-me com esta moléstia não com o empenho de satisfazer designios da ciência ou promover-me socialmente; mas sim para satisfazer necessidades profundas do meu espirito ... inquieto ... que não me alivia".

Ao encerrar a carta, João Alphonso experimentou uma suave e continua hipotensão e durante este processo viu descortinarem-se imagens dināmicas de um personagem já conhecido, o Sr. Paul Brunhs, o que visitara anos atrás.

A doença que se manifestava no Caraça era mesmo beriberi? Havia possibilidade de tratar-se de alguma outra enfermidade nàc conhecida? Por que atacava alguns e outros não? Qual seria a causa mais provável 
da doença? A movimentação dos religiosos entre o Caraça e as cidades de Mariana e Diamantina estaria contribuindo para o surgimento da doença nas casas lazaristas? Qual o tratamento indicado? $O$ que poderia ser implementado no Caraça para evitar ou atenuar a presença do beribéri? Estas eram algumas das questões que os padres da Casa Central colocaram, durante o encontro programado, a João Alphonso. Este lembrou a todos que a medicina ainda não conseguia responder satisfatoriamente a estas perguntas, e que uma boa razão para isto era o fato de que não se sabia a etiologia da doença. Neste instante, a conversa quase deságua numa discussão de natureza ontológica, diante da ponderação de um dos padres presentes, que afirmou:

- Mas doutor João, o conhecimento das causas materiais primeiras não é condição necessária para se evitar um mal. Por acaso a medicina só acerta diante da garantia do conhecimento causal de uma dada doença?

João Alphonso percebeu a cilada que poderia traí-lo caso não compreendesse corretamente a assertiva do padre. Sabia que, realmente, a medicina tem muito mais chances de ser eficaz se conhece todas as etapas de um processo mórbido - da etiologia à terapêutica e profilaxia. Mas sabia, também, que, mesmo sem se conhecer suficientemente as etapas, especialmente a etiologia, de certas enfermidades, era possivel preveni-las com alguma eficiência ${ }^{214}$. A própria higiene, tomada em toda sua extensão, que vai dos beneficios dos exercicios físicos, passando pelas virtudes morais até as regras alimentares, desempenha na história da medicina um importante papel na profilaxia de doenças, cuja etiologia, ou mesmo existência, era desconhecida ${ }^{215}$. Enfim, na

214 Sobre este aspecto pode-se afirmar que

“... a humanidade descobriu como prevenir (imunização, quarentena) muito tempo antes de saber diagnosticar etiologicamente e tratar farmacoquimicamente as infecçðes. *

* SAlgado, J. A. Os meios de vida, as infecçðes ... IN.: TONELli,E. Doenças infecciosas na infancia. Op. Cit. p. 4.

215 Na história da medicina, a higiene teve sempre um papel profilático. O saneamento e abastecimento de água foi, para a medicina romana, um atestado de que estes meios 
perspectiva do homem relacionando com seu ambiente, o conhecimento da etiologia de doenças não tem sido uma condição indispensável, ainda que fosse desejável, para a cura (ou o não morrer de). Considerando tudo isto numa rápida articulação, é que João Alphonso evitou a discussão, respondendo:

- Sobre isto que diz, padre, somos treinados para pensar desta forma, mas a história mostra-nos que não é exatamente assim. Em medicina, o correto seria admitir que estamos sempre pressupondo que certas condutas, mesmo naqueles casos em que conhecemos a etiologia, são momentaneamente mais eficazes que outras. O que se pretende, ao se questionar a insuficiência do conhecimento sobre certa doença, é , de uma maneira ilustrada, evitar que se corte a mão como tratamento para um dedo doente. No caso do beribéri, acredito que medidas profiláticas e terapêticas abusivas estejam sendo tomadas diante do desconhecimento que se tem sobre a moléstia.

- Desculpe-nos, doutor João, compreendemos o que disse, mas o senhor poderia nos dizer mais claramente a extensão do seu argumento para o beribéri? Por exemplo, a partir de qual pressuposto adotam-se estas medidas "abusivas"?

- Para mim, o pressuposto é simples e um só: quando se está diante de um enigma - no nosso caso as causas do beribéri - e ao mesmo tempo há uma enorme quantidade de pessoas vaidosas a pesquisá-lo, cada uma destas pessoas quer atribuir a si o eventual sucesso de uma dada conduta. Entre estas tantas pessoas certamente haverá uma ou outra mais próxima da verdade. Mas o esnobismo, tão comum no meio cientifico, impede a adoção imediata e geral do benefício. Quanto ao beribéri, eu penso que as orientações que têm sido dadas para se debelar

relacionavam-se com a sáude. Enfim, em cada estágio do conhecimento médico é possivel que determinadas medidas tenham exercido papel importante na prevenção e terapêutica. Com certeza este é o caso da prevenção e tratamento de alguns tipos de avitaminoses, que estariam indiretamente sendo abordadas ao se prescrever alimentação variada e em quantidade que satisfizesse 0 indivíduo. Sobre este aspecto, ver, por exemplo:

i. FREEDMAN, A . D. History of medicine. Grolier Mult. Op. Cit.

ii. AUGUSTO, A. Higiene dos colégios. Rio de Janeiro, 1858. Op. Cit. 
a moléstia obedecem à fórmula explicativa' que a medicina utiliza no momento: o mecanismo infecto-contagioso. Creio até que esta tendência vá se intensificar por conta dos estudos recentes que têm associado organismos pequenissimos, os microorganismos, à doenças.

- E por causa destas vaidades, incertezas e, se nos é correto compreender, da alternāncia destas fórmulas explicativas' na medicina, as comunidades ficam à mercê da desconfiança dos médicos ? interrogou um dos padres.

Tranqüilo, João Alphonso saboreou uma resposta que, sabia, desconfortaria os religiosos:

- Mas não exageremos, padre. Bem sabe o senhor que a saúde não é uma condição rigorosamente dependente do médico. Seria menos ainda se atentássemos para a lógica do bem viver.

- Lógica do bem viver?

- Vejam só - e João Alphonso começou a discorrer muito mais como um leigo inteligente do que um epidemiólogo inquiridor - os jovens que os senhores instruem no Caraça são jovens oriundos de regiões diversas, predominantemente da provincia mineira. Pelo que tenho lido e ouvido, até hoje não foi estabelecida nenhuma relação entre os lugares de onde vieram estes jovens e a doença no Caraça. Parece mesmo que esta relação nem poderia ser estabelecida, pois, em Minas Gerais, relatase o beribéri no Caraça e nas casas de Diamantina e Mariana, em menor número, mas raramente em outros locais. Nestes três lugares, a natureza palustre ou miasmática do beribéri é totalmente descartada. Como afirma o Dr. Felício dos Santos, ai "estão preservados da malária". Agora, tentemos imaginar uma coisa: e se déssemos a estes jovens que estão no Caraça a mesma condição de vida que mantinham em suas casas? Será que se tornariam vulneráveis ao beribéri ? Ou, numa outra situação um pouco mais rigorosa, se déssemos ectas condiçōes apenas aos estudantes atacados pela doença, que são em número bem inferior aos sadios, será que não recuperariam satisfatoriamente a saúde ? Pensemos também no fato que os próprios senhores me relataram: quando um aluno, supostamente afetado pelo beribéri, retorna à sua familia, não é raro curar-se a caminho ? Isto que estou denominando de 'a lógica do bem viver' seria a lógica de não submeter aqueles jovens a mudanças drästicas nos seus hábitos de vida: horários menos rigorosos, atividades 
fisicas por tempo maior e ao ar livre, alimentação que não os faça sentir saudades das refeições familiares, etc.

- Ora, doutor, retomar os hábitos familiares seria retornar a um estado, digamos, bruto. A educação presume superar estágios evolutivos em crescente ascensão. Estágios estes que abordam tanto aspectos espirituais quanto materiais. Os estudos, as orações, os retiros, os recreios, as refeições, férias. Para nós, cada aluno é como uma planta que aspira a seu mais completo desenvolvimento e cabe-nos monitorar esta vocação, especialmente através do estudo e de uma vida disciplinada capaz de suportar as tentações dos descaminhos. Se é penoso em muitos momentos, sabemos, mas é necessário. Gostariamos muito que o senhor conhecesse nossa casa na serra do Caraça. Talvez isto subsidiasse o senhor nas suas especulações sobre o beribéri no nosso meio.

Perscrutativo, João Alphonso respondeu, afastando-se do ambiente da pergunta:

- É. Talvez eu não deva prolongar por mais tempo esta viagem. Tantas vezes os senhores convidaram-me. E os chamados são tantos !

Um dos padres, atento, provocou-o:

- "Chamados", doutor João ?

- Sim, - respondeu João Alphonso fitando-o atentamente - imagine que para os senhores o ato da incardinação seja o coroamento de um chamado. Pois bem, no meu caso incorporar-me às minhas próprias exigências existenciais também é coroar os meus chamados.

Os padres entreolharam-se num misto de surpresa, inquietação e desconfiança. Mas não pretendendo atiçar o diálogo nesta direção, retomaram o assunto do beribéri. Após algumas observações mútuas sem maiores conseqũências, durante as quais João Alphonso expôs as últimas abordagens sobre a doença no meio médico, os padres propuseram que planejassem com antecedencia $a$ cogitada viagem do médico ao Caraça. Para isto, combinaram novos encontros.

Enquanto dimensionava o significado da viagem que faria a Minas Gerais, João Alphonso encontrou satisfação em desempenhar suas velhas atividades profissionais: clinicava, dialogava com colegas e atendia jovens estudantes de medicina que tinham nele a imagem de um 
profissional introspectivo e tecnicamente competente, de onde esperavam alguma consideração nada habitual sobre a medicina, os caminhos e descaminhos, certezas e ilusões de uma profissão marcada pela exigência da abnegação. João Alphonso também aguardava notícias do Dr. Lund. Queria ter o máximo de informações sobre a saúde, o cotidiano do velho dinamarquês, na fiel certeza de que conseguiria vê-lo, encontrá-lo. Viu renascer, então, um entusiasmo que experimentara há a muitos anos atrás ... e nestes momentos lembrava-se da sua viagem até Ouro Preto: os tropeiros, os mascates, os recém-formados, a cidade, o hotel, os homens da administração provincial, a variola, Mariana, o seminário, as descrições do Caraça, a morte do pai, a carta para Dr. Lund, o retorno.

Teses e trabalhos sobre o beribéri surgiam a cada dia em maior velocidade, e João Alphonso, alêm do acesso que tinha aos estudos estrangeiros, era solicitado a opinar sobre teses produzidas no âmbito da Faculdade. Algumas delas ele conhecia antes da publicação final, mas nem por isto costumava opinar incisivamente sobre seus conteúdos. Assim é que tomou conhecimento de uma tese sobre beribéri que o interessou duplamente: o autor e o conteúdo. David Benedicto Ottoni, mineiro, era um jovem filho de uma familia tradicional e formava-se em medicina com uma tese inaugural sobre o beribéri apresentada na faculdade do Rio de Janeiro, mas defendida na Bahia. Seu tio, Teóphilo Ottoni, era bastante conhecido e estivera envolvido numa polêmica com o médico alemão Avé-Lallemant sobre a colonização do vale do Mucuri, no nordeste de Minas Gerais e sul da Bahia. David havia feito seus estudos básicos no colégio dirigido pelos padres lazaristas em Diamantina. Portanto, seu testemunho sobre a ocorrência da doença naquela região deveria oferecer importantes subsídios à compreensão da moléstia. Um outro motivo teria contribuido para que João Alphonso se inteirasse desta tese. Através de colegas, ele conhecera Joaquim Vieira de Andrade. Raras foram as vezes em que alguém the causara uma impressão tão marcante quanto este homem. Vieira de Andrade era um colega médico e politico da cidade do Serro, próximo a Diamantina, em Minas Gerais. Mais velho, era primo de David: sua mãe também era irmã de Teóphilo Ottoni. Alèm das suas habilidades como médico, Vieira de Andrade era reconhecido pela sua rigorosa religiosidade, excessiva disciplina quotidiana, nunca se casara, tinha sua vida orientada pela devoção 
cristã e obediência materna. Neste ponto, dividia com o irmão, que era padre - Theophilo Vieira de Andrade - o exercicio da caridade, distribuindo esmolas e consultando gratuitamente os pobres da sua região. Quando em atividade legislativa, dava-se pouco a diversões. Permitia-se apenas freqüentar ocasionalmente o teatro lirico, onde, como eximio conhecedor de música, acompanhava na partitura a ópera cantada. Vieira de Andrade fizera a João Alphonso relatos sobre a eventual aparição do beribéri na região de Diamantina, relatos estes que seriam descritos na tese de David Ottoni. Durante os encontros que foram possiveis, João Alphonso sentia-se tentado a entender a personalidade impar daquele homem estranhamente interessante. Apesar de sentir até alguma repulsa por certos comportamentos de Vieira Andrade, João Alphonso acreditava que captava nele toda a tensão psicológica de uma existência centrada nas contradiçōes entre a contundência cristã e os 'tremores' próprios da angústia, angústia de um viajante que desconfia que o porto de uma ilha no meio do oceano é o fim da linha da sua viagem, apesar da integridade da sua embarcação. Não sem motivos, os dois discutiram a viagem de João Alphonso ao Caraça, e mesmo tendo Lagoa Santa na rota de viagem, por causa do Dr. Lund, ambos aventaram a possibilidade de se encontrarem e estudarem juntos a questão do beribéri na região do Serro e Diamantina.

João Alphonso analisou com atenção a tese do primo de Vieira Andrade. Neste momento da abordagem do beribéri, ele já sabia que encontraria nas teses brasileiras uma revisão bibliográfica satisfatória dos estudos propriamente científicos feitos no exterior, além de relatos seguidos de comentários dos relatos da doença por médicos brasileiros. Nada absolutamente original seria encontrado. Depositários das tendências cientificas européias, particularmente francesa, os trabalhos brasileiros, incluindo as teses inaugurais, adequavam e reproduziam aqui estudos desenvolvidos por lá. Alguma ousadia era tentada aqui ao se tratar da etiologia e terapêutica. Na etiologia, ao relacioná-la a condições ambientais estritamente locais; na terapêutica, ao sugerir o efeito de fármacos tipicos da flora brasileira. Por isso, João Alphonso ter concentrado a leitura da referida tese nas referências que o autor desta fazia sobre a ocorrència do beribéri em Minas Gerais e, mais especificamente, no colégio Caraça, Diamantina e Mariana. 
A grande referência sobre o beribéri na provincia de Minas Gerais continuava a ser o trabalho de Felício dos Santos ${ }^{216}$. Entretanto, uma tese contemporânea à de David Ottoni sugeria alguma dúvida sobre a doença relatada pelo médico diamantinense. $O$ autor discorria sobre qual teria sido a primeira provincia do Brasil em que casos sistemáticos de beribéri teriam ocorrido:

"Foi a Bahia a primeira provincia do Imperio ( à não querermos considerar como tal a de Minas, onde, segundo supposiçōes [grifo do autor] do Dr. Felicio dos Santos, o beriberi appareceu em 1858, que recebeu em seu seio o flagello, no anno de $1863^{\text {"217. }}$.

Mas David Ottoni, ex-aluno lazarista, admite a especificidade e correção de Felício dos Santos, citando-o em várias oportunidades. Ou seja, além de afirmar anos e locais do aparecimento da doença na provincia, Ottoni discutirá as observações clínicas que Santos efetuou em Diamantina na época em que, nesta cidade, ele - David - era interno do colégio dirigido pelos padres lazaristas. Nesta circunstância, ele descreve:

"E em minha provincia, Minas, eu a vi [a doença beribér] na cidade de Diamantina grassar intensamente no Collegio dos Padres Lazaristas ; mas nem por ser uma casa de educação a nossa condição lá era superior a de muitos pobres que vagavam pela cidade, se não em relação ao domicilio, pelo menos no que dizia respeito ao sustento"218.

216 Outras duas teses inaugurais, cujo tema foi o beribéri, seriam apresentadas nas faculdades de medicina da Bahia (i) e do Rio de janeiro (ii). Em ambas a revisão histórica tem na memóriá de Felício dos Santos a grande fonte sobre a moléstia em Minas Gerais.

i. PEREIRA, F. B. Beriberi no Brazil. Bahia, Litho-typographia de Joåo Gonçalves Tourinho, , 1881.

ii. CASTRO, F. P. de A . Beriberi. Rio de Janeiro, Imprensa Industrial, 1880.

217 BRITO, E. T. de. Beriberi. Rio de Janeiro, Imprensa Industrial, 1880. p. 17.

218 OTTONI, D.B. Beriberi. Rio de Janeiro, Imprensa Industrial, 1880. P. 19. 
Amparado na sua experiência pessoal e nas descrições de Felício dos Santos, David se baseará ainda nas observações do seu primo Veira de Andrade, que teria tratado de beribéricos na região:

"Em 1870 pois no Seminario da bella cidade da Diamantina tornou-se conhecido o beriberi. Por essa occasião Felício dos Santos via casos perfeitamente identicos ... Depois dessa época a molestia é frequentemente observada; eu tive occasião em 1874 de ver alguns collegiais curvados ao peso da terrivel affecção. O nosso amigo Dr. Vieira Andrade, medico do estabelecimento religioso não poupava cuidados aos seus beribericos e apressava-se a transportal-os ao Serro, que fica a 10 leguas sudéste da Diamantina e ahi mudadas as condições más o estado pathologico cedia diante do desvelo, da dedicação paternal daquelle illustrado clinico"219.

Sobressai na tese de David Ottoni a contundência com que, às vezes, indica alguns fatores que predisporiam ao beribéri, como por exemplo, ao discutir a qualidade da alimentação e o ambiente no colégio diamantinense onde estudou:

"A alimentação era má em qualidade, insufficiente, pouco animalisada.

"Fazia-se uso em larga escala de uma massa de fubá de milho, chamada cuscuz [grifo do autor]. O recreio tinha lugar em uma area, no meio da qual se achava uma latrina pouco asseiada.

"O dormitorio relativamente acanhado; a tudo isso juntese o pouco asseio"220.

A especificidade de uma dada causa, como a alimentação, encontrava-se dispersa na generalidade da abordagem. Assim é que, ao mesmo tempo que admitia a

"poderosissima influência da alimentação"221,

\footnotetext{
219 OTTONI, D. B. Op. Cit., p. 20.

220 OTTONI, D. B. Op. Cit, p. 40.
} 
David Ottoni admite também que

"o onanismo é uma causa de muita importância e quero crêr que elle tenha sido uma das que mais tenham concorrido para o beriberi nos seminarios, onde esse vicio tão nocivo é posto em pratica em tão larga escala".

Da mesma forma,

"A crapula, o deboche são igualmente causas poderosissimas"222.

João Alphonso notava que, pelas abordagens podia-se ver o reflexo negativo da ausência de pesquisas cientificas, desenhadas com a cumplicidade metodológica necessária para a aprovação de uma dada hipótese. Modelo científico caro à tradição anglo-saxônica, tradicionalmente alemão, das escolas médicas brasileiras, ainda teria que se aguardar um tempo para se ter alguma atividade de pesquisa nestes termos. Apesar disto, ele sabia que eram estas as fontes sobre as quais se apoiaria para abordar o beribéri no Caraça. E foi com David Ottoni que confirmou o que já sabia e havia conversado com os lazaristas:

"As viagens $\mathrm{e}$ as mudanças para fóra do lugar onde a molestia desenvolve-se é um dos melhores meios de tratamento que se conhece. Tivemos, em Minas, occasião de apreciar suas incontestaveis vantagens; os estudantes do Seminario de Diamantina que eram affectados, melhoravam consideravelmente desde que eram levados para o Serro, que fica a dez legoas de distancia daquella cidade" 223 .

Para elaboração da sua tese, David Ottoni utiliza o recurso que Miranda de Azevedo, anteriormente, usou para realizar seu estudo sobre o beribéri: envia cartas e pede informações sobre a moléstia a diversos médicos brasileiros. Destes, o mais significativo na época e para o

\footnotetext{
221 OTTONI, D.B. Op. Cit., p. 42.

222 OTTONI, D. B. Op. Cit., p. 53.

${ }^{223}$ OTTONI, D. B. Op. Cit , p. 86.
} 
assunto foi o Dr. Silva Lima, pioneiro na descrição da doença no país ${ }^{224}$. Ao 'dialogar' com os jovens formandos, Silva Lima, entre outras respostas relativas à patogenia e sintomatologia da enfermidade, sintetizará a compreensão que se tinha no meio médico da época, a relação entre alimentação e beribéri:

"PERgunta: Não será o beriberi devido antes a má alimentação reunida a outras condições, proprias dos paizes quentes, como acontece entre nós, onde a par de grandes calores, existe muita humidade na atmosfera?

"RESPOSTA: A má alimentação por si só poderá ser, quando muito, uma predisposição e, mesmo reunida ás outras condições apontadas, não poderá ser responsabilizada como causa efficiente da molestia.

A má alimentação é mais comum na classe pobre do que na abastada, e as outras condições são communs a uma e outra. Mas a observaçào mostra ser o beriberi muito mais frequente nos ricos e abastados de vida inactiva e sedentaria do que nos pobres laboriosos, emquanto o são, e principalmente se excitam as suas forças physicas ao ar livre e em logares que sejam sempre os mesmos"225.

Após cada leitura sobre beribéri, João Alphonso passou a fazer anotações sobre o assunto, em especial as observações sobre a presença da enfermidade no Caraça. É que ele começou a se interessar pela

\footnotetext{
224 Na verdade, a correspondência de David Ottoni com Silva Lima deu-se por iniciativa de outro doutorando que, simultaneamente, estudou o beribéri, Eugenio Toscano de Brito. Este autor afirma que

"Quando recebemos 2 primeira carta do digno Sr. Dr. Silva lima, autorisounos elle á, se alguns outros esclarecimentos desejassemos sobre certos pontos determinados do beriberi, formular as respectivas questoes. Utilisando-nos do delicado e honroso convite, dirigi um questionário (no qual collaborou o meu colega David Ottoni) que foi, pelo distincto pratico respondido de um modo cabal e completo" $\left({ }^{\star}\right)$.

* BRITO, E. T. de. Op. Cit., p. 72

225

OTTONI, D. B. Jp. Cit. , p. 107 e 109
} 
elaboração de um texto que discutisse a doença naquele colégio, fato que correspondia à solicitação dos padres lazaristas. Não pretendia ser longo, mas considerou a possibilidade de dialogar com as principais hipóteses sobre a doença que estava em voga. Pensando tratar-se disto foi que ele atendeu a um chamado da Casa Central da Congregação. Assim, poucos dias depois, após atender em domicilio um paciente, ele dirigiu-se à Casa onde, após anunciar-se, foi recebido pelos padres Delemasure e Verschueren 226. O último era 0 atual visitador da provincia, inspecionando e relatando as condições das casas lazaristas na sua área de abrangência, e o primeiro viria a ser o próximo visitador.

- Obrigado por ter vindo, doutor Azevedo Magalhães - era assim que o padre Verschueren tratava João Alphonso, num sotaque carregado - temos que lhe falar sobre a visita que o senhor estaria disposto a fazer ao Caraça. Creio que temos novidades.

- Não há o que agradecer pela minha visita, padre. Eu estava mesmo precisando falar aos senhores sobre este assunto. É que eu tenho me envolvido em leituras e estudos sobre o beribéri e isto, de certa forma, é influenciado pela minha relação com os senhores. Na última vez que estive aqui, sugeriram-me que redigisse algumas considerações sobre a doença e, em especial, dela no Caraça. Decidi colocar em ação a idéia e creio que precisarei de subsidios.

- Muito bom, muito bom mesmo. Sabiamos que contariamos com o senhor no momento oportuno. Nós e todos os nossos amigos e colaboradores ficaremos gratos pelo senhor tratar de um assunto que tem nos tomado tanta energia. Mas além deste motivo, cremos que o senhor terá outro para, enfim, conhecer nossa casa caracense - exclamou o padre Delemasure, cheio de alegria, que pediu: - conte-lhe padre Verschueren.

- Sim, doutor Azevedo Magalhães. Nossa Congregação jã está em preparativos. Sua Majestade, nosso Imperador D. Pedro II, e a Imperatriz

226 De acordo com lista avulsa do acervo do arquivo da Casa Central da Congregação da Missão no Rio de Janeiro, o Padre A. Verschueren foi o oitavo visitador da província, tendo exercido esta função entre os anos de 1878 e 1880 . Entre os anos de 1880 a 1886 , Padre P. Delemasure exerceu o cargu, ainda de acordo com a mesma fonte. 
D. Thereza estarão em visita à provincia de Minas e já está certo com o palácio que a comitiva estará nos honrando com sua visita no Caraça227.

- Realmente, trata-se de um grande acontecimento para a instituição. Mas em que medida a minha visita tem relação com a do Imperador ? Um plebeu como eu teria pouco a se importar com o evento, a não ser congratular-se com os senhores pela manifestação de estima que o Imperador parece ter pela Congregação, o que, aliás, é compreensivel, se considerarmos as relações que o avô e o pai de Sua Majestade tiveram com os lazaristas, afirmou João Alphonso, que não disfarçou totalmente uma delicada ironia.

Padre Verschueren fingiu não reconhecer aquela ponta de ironia ( $\mathrm{e}$ intimamente se perguntou rapidamente porque acolh ia como amigo da casa este médico agradavelmente inquieto ) e comunicou, com um prazer que beirava a uma sutil e carinhosa vingança:

- Não acreditamos que o senhor seja qualquer plebeu, doutor Azevedo Magalhães, e por isso mesmo indicamos o senhor como um dos médicos da comitiva imperial que, aproveitando a visita do imperador, efetuaria uma viagem de estudos ao Caraça. Só estamos aguardando o seu aceite para certificar o palácio, que, por sinal, aceitou prontamente sua indicação. E então?

Desprevenido e desinformado, João Alphonso tentou ganhar tempo:

- Isso significaria que eu teria que acompanhar a comitiva em todo seu percurso, ou me estabeleceria especificamente no Caraça?

- Isso ainda é objeto de discussão. Há um desejo de que o senhor acompanhe a comitiva em todos seus passos. Mas ponderamos que talvez fosse preferivel poupar as forças e manter o senhor no Caraça e mais um ou outro lugar de apoio à comitiva, já que haverá pelo menos

227 A visita de D. Pedro II a Minas Gerais em 1881 deu-se entre 26 de março a 30 de abril. Especificamente no Caraça, o Imperador esteve do dia 11 a 13 ( $\mathrm{i}$; ii).

i. ANUÁRIO DO MUSEU IMPERIAL. Diário de viagem do Imperador a Minas Gerais em 1881, v. XVIII, Petrópolis, 1957.

ii. ZICO, J. T. Caraça e a familia imperial. Belo Ho.izonte, Editora O Lutador, 1991. 
um outro médico na comitiva permanente. Assim, o senhor se manteria concentrado em seus estudos sobre o beribéri.

- Os senhores têm os locais a serem visitados pelo Imperador ?, quis saber João Alphonso.

- Isso ainda constitui um segredo da intimidade do grupo que cuida de planejar a viagem. O senhor sabe ! Este tipo de viagem é precedido de cuidados que devem ser rigorosamente observados... questōes de segurança. Por confidência e interesse direto para recepção no Caraça, passaram-nos algumas informações. É certo que, antes de chegar ao Caraça, o Imperador percorrerá, nesta excursão, entre outros lugares, Barbacena, Ouro Preto, Morro Velho, Sabará, Santa Luzia e Lagoa Santa228.

Imediatamente, João Alphonso captou e relacionou o nome "Lagoa Santa". Neste momento, desviou o olhar dos dois padres e procurou algum ponto onde pudesse concentrar todo seu pensamento, que já articulava: Lagoa Santa - Dr. Lund. Enfim - pensou João Alphonso, inesperadamente tomado por uma ansiedade sem conta - chegara o momento exato de concluir um velho projeto, perdido, estraçalhado, mas cujas partes reluziram anos a fio dentro de si. Chegara o momento de, recomposto o projeto, executá-lo e encerrá-lo definitivamente, para, quem sabe, então, descansar em paz. $E$ afirmou, voltando-se para os padres:

- A idéia é excelente. Eu aceito o convite, a indicação dos senhores. De antemão posso garantir aos senhores que assistiria o Imperador e sua comitiva não apenas no Caraça, mas também em Lagoa Santa.

228 O imperador tinha interesse pessoal pelas atividades do cientista dinamarquês. Conde D'Eu, genro de Dom Pedro, anteriormente chegou a ir pessoalmente ao encontro de Lund, com a esperança de que este lhe mostrasse as cavernas que havia descoberto. Doente na ocasião, e aparentemente desinteressado em franqucaí ás "Súas" lapas à invasão curiosa, Lund parece que, durante toda sua vida, omitiu-se de ensinar a localização exata dessas descobertas. Ainda segundo o que há escrito sobre a vida de Lund, este teria se negado a deixar-se fotografar em meio às ossadas encontradas durante seus estudos, fotografia esta desejada pelo Conde, que estaria atendendo a uma solicitação pessoal do sogro. A determinada indisposição do Dr. Lund para formalidades, deixou-o esperando, no Rio de Janeiro, em vão e por longo tempo, duas homenagens governamentais: uma do governo dinamarquès e outra do brasileiro. Nada conseguiu motivá-lo a sair de Lagoa Santa. 
- Levaremos esta informação ao palácio, que a aceitará sem restriçōes. Talvez peçam para o senhor dar apoio também em Morro Velho ou Sabará, lugares próximos do Caraça e de Lagoa Santa. O senhor deverá ser comunicado oportunamente da necessidade de se encontrar com o corpo médico do palácio, que passará ao senhor informações sobre a saúde de Suas Majestades Imperiais e de outros membros da comitiva. E quanto a nós, o senhor disponha: tanto aqui, assim como quando estiver no Caraça, estamos à disposição para lhe providenciar o necessário à elaboração do texto que o senhor deseja sobre a ocorrência do beribéri no nosso querido "Hospicio de Nossa Senhora Mãe dos Homens"229.

229 Entre as denominações que são dadas ao Caraça (Colégio, seminário, santuário) encontra-se a de "hospício". Esta denominação é favorecida pelo testamento do próprio fundador do local, o Irmão Lourenço, que afirmava:

"... de todos os meus bens que me pertencem fiz oferecimento por mim a Sua Alteza Real para estabelecimento de um hospício de missionários..." (i).

Habitualmente tomada como sinônimo de "asilo de loucos", hospício inscreve-se com outro significado no âmbito das instituiçðes religiosas.

"Em Minas, era proibido o estabelecimento de conventos. Houve muitos e insistentes pedidos $e$, afinal, foi dada aos franciscanos permissão para 0 estabelecimento de hospicios. A melhor maneira de explicar o que eram esses hospícios, será mostrar a diferença entre eles e os conventos. Convento era residência permanente de frades; o hospício, uma residência temporária, onde os frades esmoleres se hospedavam e descansavam, depois de longas caminhadas pelo sertão. No hospício, permanentes eram só os serviçais. ... O primeiro hospicio de Minas foi instalado em Vila Rica, em 1726; em São João del-Rei e Sabará, em 1740; em Mariana e Diamantina, em 1750. O de Paracatu foi o mais importante de Minas, pois foi o único, em Minas, a obter autorização para celebração pública de missa e administração de sacramentos. O papa Bento XIV, pelo breve de 26 de janeiro de 1756, alitorizou a construçåo, no hospicio ..., de um 'oratório público' ..."(ii).

A instituição de hospicios em Minas, durante o século XVIII, assinala uma associação suficientemente reconhecida mas, provavelmente, insuficientemente especificada: a igreja e o ciclo do ouro nas gerais. A natureza dos hospícios em Minas relaciona-se ao fato de que

"alguns frades da ordem de São Francisco dedicavam-se a pedir esmolas para

a conservaçăo dos Lugares Santos" (i ).

ZEMELLA (iii), ao tratar do comércio das Minas, refere-se mais de uma vez a atividades comerciais de religiosos. FREYRE (iv) diz que 
- Esta presteza do senhor veio em boa hora, padre Verschueren. Eu tinha em mente solicitar aos senhores que, se fosse possivel, me fornecessem informaçōes sobre a botica do Caraça. Gostaria de saber os medicamentos usuais, as prescrições, enfim, um indicativo do que se usa no seminário.

- Isto não é impossível, mas acredito que o senhor poderá obter maiores e melhores informações no próprio Caraça. Mas tentaremos obter alguma informação preliminarmente. Não podemos prometer um levantamento integral, jã que dispomos de um registro em livro próprio; mas um levantamento que represente a medicação de determinado periodo será tentado. Sabe Deus o quanto ficaremos gratos ao senhor se conseguir diminuir os nossos infortúnios com esta moléstia tão inoportuna - afirmou o padre Delemasure, enquanto o grupo se preparava para os cumprimentos de despedida.

Beatriz estranhou quando João Alphonso disse que teria que começar a providenciar roupas e acessórios adequados para sua viagem a Minas Gerais. Neste aspecto era parcimonioso, discreto, e raramente manifestava grande interesse. Por isso, ele passou a percorrer lojas de onde sempre trazia algo que se relacionava à viagem. Ele dizia que gostaria de ter o conforto necessário para não se preocupar com questões práticas que $o$ absorvessem dos objetivos maiores que o faziam viajar. Numa tarde em que se encontrava com o filho advogado pelo centro da cidade, João Alphonso decidiu visitar velhos conhecidos de uma firma alemã de importação e exportação. Bem recebido e sempre estimado, todos se surpreenderam com aquela visita inesperada: João Alphonso havia deixado o hábito de visitar amigos há muito tempo e era tido como uma pessoa introspectiva e afeita a relacionamentos seletivos, sem,

“... nas cidades de Minas apareceram, entre os exploradores da falta de víveres na área de mineração, não tanto os tão falados Judeus, nem Ciganos, nem "Gringos", mas frades. Simplesmente frades".

i. ZICO, J. T. Caraça: peregrinação, cultura, turismo. Op. Cit., p. 20.

ii. BARBOSA, W. de A. Dicionário da terra e da gente de Minas. Op. Cit., p. 105-6.

iii. ZAMELLA, M. P. O abastecimento da capitania ... Op. Cit., cap. V.

iv. FREYRE, G. Sobrados e mucambos. Op. Cit., p. 168. 
contudo, obscurecer sua capacidade profissional ou mesmo sua lealdade. Enquanto conversavam sobre o cotidiano de suas vidas, o grupo se afastava pouco a pouco do português e dedicavam-se a dialogar em alemão, para desconforto do filho de João Alphonso que, percebendo o envolvimento do pai na conversa, afastou-se discretamente do grupo até a porta do estabelecimento, de onde observava o movimento da rua. Minutos mais tarde, quando João Alphonso relembrava ao grupo sua passagem por Travemūnde, nos afastados anos de estada na Alemanha, chegou à firma um conhecido de todos, ligado a uma agência financeira que intermediava operaçōes financeiras entre o Rio de Janeiro e a Europa. Este encarregado de negócios trazia as novidades da Europa no campo político e social, transmitindo, em especial, noticias recémchegadas sobre o governo de Bismarck ${ }^{230}$. Alguém quis saber das operações financeiras no mercado nacional, dos investimentos. $O$ encarregado queixou-se das dificuldades e da perda de contas de clientes que, se pequenas individualmente, tinham algum valor no conjunto. Isso era especialmente representativo no momento em que, nas transações comerciais, o nivel de concorrência era grande. Em resposta, o encarregado ponderou alguns motivos que, acreditava, teriam reduzido, no caso da sua firma, a captação e o trânsito de capitais entre a Europa e o Rio de Janeiro. Destacou em especial a perda de clientes regulares e lembrou particularmente um deles:

- Agora mesmo perdemos a conta de um cliente regular, por meio do qual estabelecemos um sólido intercâmbio na Dinamarca.

- Mais um dinarmaquês falido - brincou um alemão do norte.

Circunspecto, o encarregado, com a testa franzida, olhos arregalados e cabeça baixa, respondeu:

230 Otto von Bismarck (1815-1898) é considerado o grande "arquiteto da unificação alemã" na segunda metade do século XIX (i). Através de "hábeis compromissos", conseguiu integrar a burguesia alemá, estabelecendo acordos que satisfizessem 0 interesse de todos, acordos estes moldados numa economia que entrava de vez na era industrial e capitalista (ii)

i. HOLLYDAY. F. B. M Otto von Bismarck. Grolier Mult. Enc. Op. Cit.

ii. DROZ, J. História da .tlemanha. Op. Cit., p. 43-4. 
- Não é bem isso. Foi a morte. Uma grande perda. Lamentável.

Diante do estado respeitoso do encarregado, todos se entreolharam e esperaram saber de quem se tratava.

- Morreu há algumas semanas atrás o Dr. Lund, cientista reconhecido na Europa, de importante familia dinamarquesa e que há anos morava em Lagoa Santa, Minas Gerais.

Um breve silêncio acometeu a todos. E logo os outros descobriram que João Alphonso, pálido e fitando pontualmente o piso, enchia os olhos de lágrimas. O silêncio do grupo lá dentro despertou a atenção do filho de João Alphonso, lá fora. Este, percebendo o paradoxo da situação, dirigiu-se ao grupo e rapidamente visualizou a situação de sofrimento do pai:

- Pai, pai ! O que está acontecendo ?

Perplexo, o grupo não compreendia o que se passava, e alguém disse ao filho:

- Falávamos da morte do Dr. Lund, em Lagoa Santa quando ...

- O Dr. Lund, o dinamarquês parente dos Kierkegaard, morreu ? perguntou, interessado, o filho, enquanto enxugava com o lenço as lágrimas do pai.

- Ele mesmo - respondeu o encarregado, comunicando que talvez fosse melhor encaminharem o doutor João Alphonso a um médico.

- Irei para minha casa - disse João Alphonso, levantando-se da cadeira sob o amparo do filho. Sem cumprimentos e carregando no rosto um olhar de indiferença ao mundo ao redor, ele e o filho sairam lentamente do local. $\mathrm{Na}$ rua, a indiferença do mundo à perturbação do pai inquietou o filho, que se esforçava para compreender tanta dor.

Na véspera de sua viagem a Minas, o Imperador efetuou mudanças na administração da saúde pública. O Dr. José Pereira Rego, então já conhecido como Barão de Lavradio, foi exonerado, em um só tempo, da presidência da Junta Central de Higiene Pública, do Instituto Vacinico e da Inspeção de Saúde do Porto, cargos que ocupava desde 1864. A febre amarela e a variola continuavam a castigar duramente a cidade do Rio de Janeiro e comprometiam seriamente a qualidade sanitária do país. As mudanças que viriam a ocorrer devido às substituiçōes administrativas 
não surtiriam efeitos na condição sanitária da cidade e do país. Basicamente, aqueles que assumiram a direção da saúde pública, na ausência de alternativas efetivas - ou porque não as conhecia devido, por exemplo, à falta de pesquisas científicas na área, ou porque não dispunham de criatividade e retaguarda política necessária vieram a 'investir' na reformulação de disposições legais (normas, organogramas, etc.) com que, esperavam, pudessem efetivamente enfrentar os graves problemas de saúde pública. Desta forma, uma comissão foi criada e viria a ser conhecido que

"Do trabalho dessa comissão resultou um regulamento, que foi mandado observar por decreto ... que incluia disposições ... remodelações ... sobretudo em relação ao pessoal, que teve que ser aumentado. ... Esse regulamento, porem, não chegou a entrar em plena execução, porque nunca foram votados pela Assembléia Geral os créditos precisos para pagamento dos cargos novos e para outras despesas permanentes, continuando o Governo a usar de medidas occasionaes para fazer face às contingencias de cada momento"231.

Na sua viagem, o Imperador viria a certificar-se das condições de saúde da população, descrevendo em seu diário situações e imagens que refletiriam este processo, na região visitada. Chamou-lhe a atenção, em especial, o bócio, que ele relacionou à carência da alimentação local.

Ao visitar o Caraça, Dom Pedro II repetia o ato do seu pai, Pedro I, que em 1831 visitara o Colégio. Afinal, os lazaristas mantinham uma afinada relação com a coroa: os dois padres que iniciaram a congregação no Brasil eram portugueses, padres Antônio Viçoso e Leandro Rebello. Este último tornara-se amigo pessoal de Pedro I que o tratava na intimidade de "Padre sujo", pois como usuário de rapé, a batina do padre estava sempre manchada do pó. Menos de dois meses após sua visita ao Caraça, o imperador Pedro I assinaria sua abdicação e retornou a Portugal. Assim, quando o filho retorna ao Caraça ficam restaurados,

FONTENELLE, J. P. Hygiene e saude publica. Op. Cit., p. 425. 
mesmo após os acidentes que marcaram a relação da igreja com o estado no decorrer do segundo reinado, os elos que estabeleciam a afinidade entre os lazaristas e a monarquia 232 .

232 Os passos do Imperador e as cerimônias das quais participou no Caraça são descritas detalhadamente pelas crônicas caracenses. A perspectiva lazarista do relato desta visita, ameniza o principal acidente ocorrido lá, em nome da erudição que cercava o ambiente. O Imperador, numa sessão solene, foi saudado em 9 línguas (francês, latim, grego, hebraico, espanhol, inglês, português, italiano e alemão) e teria cumprimentado a quase todos nos idiomas falados, etc. O discutido incidente ocorreu durante a visita que $\mathrm{D}$. Pedro fazia ao Seminário Maior, numa aula de Direito Canônico. O Imperador abordou uma questão polêmica: o que se ensinava a respeito do placet ("aprovação régia para os documentos pontificios"). Assunto polêmico porque ainda eram recentes os episódios da questão religiosa (1871-1875) envolvendo igreja, governo e maçonaria. Para responder à S.M, um seminarista foi solicitado e afirmou ser contrário à necessidade do placet, justificando:

"- Há dois poderes, o eclesiástico e o civil, e ambos vêm de Deus. Sobre o segundo, as opiniões divergem: imediatamente ou mediante o povo. O poder eclesiástico é superior ao civil, porque tem objeto mais nobre, espiritual, sobrenatural, o bem das almas, e extensão territorial maior, pois abrange o mundo todo. O poder civil tem como objeto o bem temporal e se limita a uma nação particular. Estes dois poderes são distintos e livres na sua esfera..."

"- E nas questões mistas ?", quis saber o Imperador.

Tomando a palavra, o professor da disciplina, padre João Chavanat, disse:

"- Para estas... a decisão pertence à Igreja".

"- Protesto - disse o Imperador - como chefe do poder civil e defensor nato da constituição brasileira, protesto contra esta doutrina".

$O$ episódio teria se encerrado na sala de aula, se o padre, durante o recreio de alunos, assistido por D.Pedro II, não houvesse interpelado S.M:

"- Não admito o protesto de V.M. É escandaloso um Monarca católico

protestar contra a Doutrina da Igreja diante de um Seminário Maior".

Ao que o Imperador teria respondido:

"- Eu sou mais católico que o lente. Sou católico tolerante, ao passo que o serihcr é intolerante".

A crônica caracense dá conta de que o Imperador não guardou mágoa do padre Chanavat. Ao contrário, no próprio Caraça e posteriormente em Ouro Preto, teria a comitiva dito que ele "era digno da batina que vestia", e o próprio D. Pedro comentado: "- Gosto do padre Chanavat, é um homem" (i ; ii).

i. ZICO, J. T. Caraça e a familia imperial. Op. cit., p.39-42.

ii. SILVA, F. de P. e. Caraça, apontamentos históricos e notas biográficas. Op. cit., p. 83-93. 
O capelão da Santa Casa alegrou-se ao avistar João Alphonso em uma das enfermarias do hospital. Apesar de notícias esparsas, todos ali esperavam seu retorno, às atividades, depois de ter passado algum tempo na propriedade de parentes, próxima do Rio.

- Eu já estou no Rio há algum tempo, padre. É que tenho retomado as atividades profissionais lentamente. Acho mesmo que, na minha ausência, nada perdeu o rumo que deveria ter.

- Não diga isso, doutor João, o senhor sabe o quanto é importante. A sua familia, os doentes, os amigos. Lamentamos profundamente que não pudesse ir ao Caraça quando da visita do Imperador.

- Li notícias da visita nos jornais. Parece que o nosso rei não andou se portando muito bem por lá. Ao que parece, nosso amigo padre Clavelin teve que exercitar toda a sua habilidade e inteligência para controlar os ânimos.

Sem saber como tratar o assunto, mas não escondendo algum orgulho pela audácia do aluno e do padre Chavanat, o capelão respondeu:

- Ora, doutor, foi um acidente desnecessário... O senhor sabe os riscos de se perguntar o que não se deve, isto é, ... bem, .... Sua Majestade pode inquirir a qualquer um. Magnânimo, ele relevou o acontecimento.

- Pode ser. Mas para mim, que não presenciei o episódio e que dele tomei conhecimento apenas através dos jornais, tudo isso me surge como um grande espetáculo. Aliás, o senhor não acha que cada vez mais a vida real é um grande espetáculo?

Surpreso, o capelão, num primeiro momento, não soube como discutir a questão. Ele e João Alphonso haviam acabado de atender seus doentes e saiam da enfermaria, andando, agora, por um corredor:

- Vejo que o senhor, mesmo em descanso, não evitou especulações abstratas. Sabe, doutor João, eu admiro sua vocação para a especulação de temas mais afeitos a outros campos do que propriamente à medicina. Mas eu me pergunto se, para o senhor, este trabalho intelectual é estruturado corretamente para lhe gerar frutos proveitosos.

Com um sorriso agradável para o capelão, João Alphonso respondeu: 
- Eu senti falta das nossas conversas, padre. Agrada-me saber que o senhor pensa como eu: a forma e o conteúdo do diálogo são mais importantes do que a concordância que possamos ter sobre o tema. A consideração que o senhor faz, creio que é nutrida por obrigações caras à formação religiosa: a finalidade do estudo, suas motivações, etc. $O$ senhor sabe da relatividade de um juízo estabelecido nestes termos; não acredito que necessitamos conhecer todas as razões que, por sua vez, possam justificar todos nossos atos e ações. Do contrário, já pensou nas conseqüências disso ?

Intranqüilo quanto ao rumo da conversa, o capelão procurou uma opção, que imaginou ser menos polêmica, para tratar do assunto, e voltou a ele com uma outra pergunta:

- Mas o senhor não se preocupa com a salvação ?

- "Quid prodest hómini ?" "233. Lembro-me que tive um diálogo semelhante com o padre Benit - Neste instante, João Alphonso parou de andar, virou-se para o capelão e, após alguns segundos pensativo, afirmou: - Durante este periodo que estive afastado do hospital, eu reli livros que há muito tempo não manuseava. Quando estive na Alemanha, ganhei um livro de um amigo que havia estudado filosofia em Berlim. Não era o filósofo de sua preferência, mas ele dizia que fazer filosofia não é um ato de preferência; é uma necessidade da existência e que por isso, não cabia condescendência. Mas o autor deste livro que ganhei, Ludwig Andreas Feuerbach, este filosofo escreveu algo que, acredito, pode nos ajudar a discutir a salvação. Ele afirma que "sem dúvida nosso tempo prefere a imagem à coisa. A ilusão é sagrada, a verdade profana".

$O$ capelão optou por abortar o diálogo. Ponderou a exiguidade do tempo e, definitivamente, finalizaria a conversa com um outro assunto:

- ... e antes que eu possa esquecer-me, devo dizer ao senhor que recebemos do Caraça a informação de que o pedido que o senhor nos fez acerca da nossa botica, não foi esquecido. Está sendo providenciado e lhe chegará em mãos. $O$ senhor havia dito que pretenderia escrever algumas consideraçōes sobre o beribéri, lembra-se?

233 "Que aproveita ao homem ?". 
- Como não ? - disse João Alphonso, surpreendentemente satisfeito com a noticia e sem se importar com a interrupção do diálogo anterior. Eu pretendo utilizar estas informações na elaboração de uma memória sobre o beribéri, quando, então, eu faria considerações sobre a moléstia no Caraça.

- Estamos aguardando sua contribuição. Espero eu mesmo entregar ao senhor o que lhe chegar do Caraça. Mais uma vez, Doutor João, seja bem vindo, e até breve.

No aguardo das informaçōes sobre a botica do Caraça, João Alphonso recebeu do Serro uma carta de Joaquim Vieira de Andrade. Este mostrou-se agradavelmente surpreso com a carta, que afirmava o caráter leal e humanitário do remetente. Vieira de Andrade, que ficara sabendo do afastamento temporário de João Alphonso do hospital e que, esperançoso, estimava o retorno breve com a saúde completamente recomposta, também lamentou que ele não tivesse ido a Minas, por ocasião da visita do imperador. Não era surpresa para João Alphonso a formalidade da carta do colega, que não conseguia esconder uma conduta séria, asseverada por uma disciplina de tal ordem e uma formalidade dificil de se ver ${ }^{234}$. Estranhamente, João Alphonso imaginava que compreendia o gesto de um homem de tal tipo lhe escrever para the desejar pronto restabelecimento. Imaginava, porque não queria

234 Sobre Dr. Joaquim Vieira de Andrade, é interessante atentar para o testemunho de Joaquim de Salles (1879-19620) que, quando criança, o conheceu na cidade do Serro e que acompanharia importantes momentos da vida do médico. No seu livro de memórias, SALLES ( $\left.{ }^{*}\right)$ afirma sobre Vieira Andrade:

"A população do Serro e das comarcas circuivizizinhas tinha por ele um verdadeiro culto, sobretudo por causa de sua incomparável austeridade pessoal ... A sua respeitabilidade, ..., ressumbrava da sua própria fisionomia de asceta. Na cidade ninguém fumava em sua presença! Seu sistema de clinicar era o de receber dos abastados ou remediados o que lhe quisessem dar e, quanto aos pobres, receitava-lhes de graça e dava a cada um o dinheiro necessário para pagar a botica. Era o pai da pobreza, e o povo sentia por ele todos os excessos de fascinação".

* SALLES, J. de. Se não me falha a memória. Op. Cit., p. 200. 
reivindicar apenas para si a sensibilidade para descortinar o horizonte existencial de alguém; este mesmo alguém poderia também ser sensivel para descortinar o seu horizonte.

Outra motivação impulsionou João Alphonso a escrever para Vieira Andrade: teria ele tratado casos de beribéri, que ocorreram no seminário de Diamantina. Seu primo David Ottoni, em sua tese inaugural, afirmara isto e ele próprio, na época em que se conheceram, havia afirmado a existência da doença naquela região. É verdade que, quando ouvira a afirmativa dos casos, ele - João Alphonso - achou o diagnóstico diferencial esparso, abrindo, então, a suspeita de que casos tidos como o de beribéri eram, clinicamente, outra enfermidade. Afeito à divulgação cientifica, Vieira de Andrade nada tinha transmitido, ao menos na forma de comunicação, sobre a ocorrência do beribéri na sua região. Apesar da tese inaugural do seu primo, era mesmo a memória do Dr. Felício dos Santos que continuava a ser a grande referência sobre o beriberi em Minas Gerais. $\mathrm{Na}$ impossibilidade de discutir $\mathrm{o}$ assunto nas circunstāncias em que se encontraram no Rio de Janeiro, foi que ambos aventaram a possibilidade de se encontrarem em Minas, quando da viagem, que não aconteceu, de João Alphonso.

O projeto de escrever sobre o beribéri e, aí, tecer algumas considerações sobre a provável ocorrência da enfermidade no Caraça, pressupunha, para João Alphonso, informaçōes derivadas do médico serrano. E a estrutura deste escrito ia se delineamento lentamente e sobre ela - a estrutura - escreveu a Vieira Andrade: uma abordagem geral que revisasse não tanto a distribuição da doença, mas as matrizes conceituais que determinavam uma ou outra hipótese etiológica. Dai, dois caminhos: um investigaria a pertinência anatomopatológica das hipóteses e o outro caminho procuraria testar a consistência daquelas matrizes conceituais ( se universais ou particulares) à luz, também, da referida pertinēncia. Feito isso, imaginava João Alphonso, a caracterização da doença e de suas principais hipóteses etiológicas estaria assegurada e, então, poder-se-ia dedicar ao exame dos fatores predisponentes que a cada dia aumentavam, segundo os trabalhos $\mathrm{e}$ teses que surgiam seguidamente. Neste momento, um oceano de possibilidades surgia à análise: dos fatores ambientais aos religiosos; dos 
econômicos aos culturais. Quando, então, considerar a doença no Caraça, os principais elementos de identificação interna e externa não apenas da doença, mas também de seus prováveis fatores predisponentes e causais, estaria assumido no texto.

$\mathrm{Na}$ época, a terapêutica do beribéri era sintomática, incerta, particularizada, refletindo, enfim, o desconhecimento que se tinha da moléstia, especialmente a sua etiologia. Havia, entretanto, uma conduta que gozava do apreço de qualquer clínico, já que os resultados de sua aplicação eram bastante satisfatórios: transferir o doente da localidade onde se manifestou a doença. Silva Lima, com a transferência de beribéricos de Salvador para a ilha de Itaparica; Alvarenga, com as transferências dos mais abastadas: do Brasil para a Europa; Felicio dos Santos, com a transferência de colegiais do Caraça para suas cidades; Vieira de Andrade, de Diamantina para o Serro, etc. Em todas os casos, o resultado era o mesmo: a doença desaparecia com a mudança ${ }^{235}$. Contudo, as transferências nem sempre eram possiveis, em decorrência de vários fatores, entre eles as questōes pessoais: renda, família, etc. Derivada disto, a necessidade de se estabelecer medidas curativas cuja eficiência era incerta.

$\mathrm{Na}$ ordem destas medidas, dois grupos de terapia podiam ser visualizados: as aplicaçōes externas e as internas. As primeiras podem ser classificadas como sendo de natureza fisica ( banhos de alta

235 Alfredo Augusto GOMES (*), em sua tese inaugural defendida a 20 de dezembro de 1883 na Faculdade de Medicina do Rio de Janeiro, afirma:

"O meio curativo por excellencia aquelle ao qual se recorre com uma segurança tanto mais consoladora e heroica quanto a raridade do seu insucesso deve ser attribuida a alguma complicação, é a mudança de localidade [grifo do autor].

"Esta influència é tão patente e incomprehensivel que o individuo affectado do mal beriberico não precisa muitas vezes para curar-se mais do que estabelecer morada a algumas leguas de distancia do logar onde soffreu o insulto ...".

- GOMES, A . A . Natureza e tratamento do beriberi. Rio de Janeiro, Typ. de Francisco Leonardo Gomes. 1883. p. 63. 
temperatura, hidroterapia, eletricidade) ou de natureza medicamentosa ( banhos e friç̧ões com soluções vegetais e minerais diversas, além de pedilúvios sinapizados, sinapismos e vesicatórios). Os banhos de alta temperatura eram recomendados na ausência de dispnéia; a hidroterapia como estimulante das funções orgânicas e do sistema nervoso; a eletricidade era a menos difundida, mas contava com recomendações. Já os medicamentos para uso externo eram numerosos. Alguns mais difundidos que outros, mas,

"todos falliveis em casos especiaes ou complicados"236.

Para os banhos, mangenda, eucalipto, pau perreira, etc.; para as friç̧ões, óleo de copaiba, tinturas, arnica associada à amônia, tintura de noz-vômica, etc. Assim como estes, os outros medicamentos para uso externo eram tidos como sendo de poucas virtudes para enfrentamento do beribéri. Havia ainda alguns tratamentos externos que eram indicados nos casos da doença já avançada, tanto no beribéri com edema como na sua forma paralitica. Nestes casos, aplicava-se desde clorofórmio e alfazema até querosene. Os banhos de mar eram especialmente lembrados para os casos do beribéri na forma paralítica, mas eram especialmente indicados desde quando acompanhados por uma alimentação satisfatória em quantidade e diversidade. A propósito, a alimentação não era considerada uma forma de tratamento propriamente dito. Era vista mais como uma prática que coadjuvaria as aplicações externas ou internas.

O grupo de terapias, ou aplicações internas guiava-se basicamente pela sintomatologia, tendo em vista que procurava

“... apenas combater exclusivamente o estado geral de fraqueza organica, depressão nervosa e dyscrasia sanguinea, peculiares ao beriberi" ${ }^{\text {237. }}$.

O sulfato de ferro associado à estricnina é um dos medicamentos com maior tempo de uso na terapêutica do beribéri. Mas o ferro entrava em outros preparados (sulfato de quinina e noz-vômica, por exemplo), cuja principal finálidade era atuar como tônico e estimulante do sistema

\footnotetext{
${ }^{236}$ Idem, p. 64.

${ }^{237}$ Idem, p. 65
} 
nervoso, cumprindo a missão de reverter o quadro de mal-estar geral e fraqueza orgânica. Ainda como estimulantes, usavam-se: vinhos diversos (preferencialmente o do Porto), o centeio espigado, a ergotina, etc. $O$ ópio chegou a ser recomendado para o tratamento do beribéri, mas os resultados práticos desaconselharam o seu uso; as fórmulas que faziam uso do arsênico, e que tinham no Dr. Silva Lima, da Bahia, um defensor, eram aplicadas desde que fossem acompanhadas de banhos de mar e alimentação satisfatória; as fórmulas à base de sais eram tentadas variadamente, segundo a expectativa de cada estudioso da doença; os efeitos, entretanto, não correspondiam às expectativas. Quatro classes de medicamentos eram utilizadas internamente nos casos de beribéri edematoso: diuréticos, purgativos, sialagogos e drásticos.

Os diuréticos mais utilizados na fase edematosa do beribéri eram o acetato, nitrato e binitrato de potássio, a digitalis, erva tostão, etc. Entre os purgativos, o sulfato ou citrato de magnésio; como drásticos, que deveriam ser empregados com cautela por seu efeito rápido e depressivo, eram indicados a escamonéa, o andá-açu, a tintura de jalapa composta, entre outros. E como sialagogo prescrevia-se o acetato e o cloridrato de amônia, as flores de borragem e o jaborandi . Genericamente, tanto nos casos de beribéri paralítico ou edematoso, a utilização de novas plantas na terapêutica medicamentosa funcionava como uma 'pesquisa invertida' da doença. Isso porque, sem que se houvesse caracterizado a etiologia, esperava-se obter um sucesso medicamentoso a partir de tentativas pontuais com novas espécies. Assim, o joá capote e o joá branco foram tentados em Minas e o último, citado por Felicio dos Santos; foram indicados também, entre outras espécies, a erva de bicho, o guaiaco, a salsaparilha, açafrão e jurubeba ${ }^{238}$.

${ }^{238}$ De acordo com a primeira British pharmacopoeia (1864), as opçðes medicamentosas para o médico daquela época compreendiam: digitalis, ópio. atropina, morfina, quinina, éter, clorofórmio, sulfato ferroso, iodo, bicarbonato de sódio, este grupo representava o que havia de melhor (i). Em uso, ainda, os remédios de origem vegetal - ou vegetais usados como remédio - sem identificação de princípio ativo e, muito menos, da estrutura química.

A incorporação de drogas modernas à terapêutica é, de fato, um processo historicamente recente. Até a quarta década deste século tais drogas representavam não 
mais do que $25 \%$ dos medicamentos comercializados (i). De fato, observando o receituário de médicos no periodo entre 1910 e 1930, PAULA (ii) afirma que “... oitenta por cento do receituário médico era manipulado artesanalmente pelo farmacêutico... Sais de quinino, sais de bismuto, de mercúrio, de cálcio, de magnésio, de potássio, de sódio. Extratos fluidos variados, tinturas, ...".

E o mesmo autor ainda afirma que

"... outros processos vindos do passado, ainda estavam em voga: purgativos, vomitórios, ventosas, vesicatórias, clisteres, lavagens intestinais. Sinapismos.

Cataplasmas, banhos, escalda-pés, bichas ou sanguessugas, etc."

Curiosamente, neste livro o autor transcreve receitas emitidas nas últimas décadas do século XIX e início do XX por médicos que clinicavam na cidade de Montes Claros. Destas, destacam-se as do Dr. Carlos Versiani (1819-1903) que, aliás, estudou no Colégio Caraça na década de 30 do século XIX. Estudou medicina no Rio de Janeiro, concluindo o curso com a tese inaugural "A simpatia orgânica", em 1845. Em 1879 ele prescreveu a seguinte receita:

"Dr. Carlos Versiani

Para a Caridade de Montes Claros

Para o Sr. Manoel de Oliveira

Pílulas anti-syphiliticas de Dupuytren $\mathrm{n}^{\circ} 50$

Para tomar huma pilula de manhã e outra à tarde.

Externo

Cauterizar as úlceras com Nitrato de prata.

Montes Claros, 2 de janeiro de 1879.

Numa outra receita, o Dr. Carlos prescrevia:

Para a Sra. Laudelina

Uso interno

Digitalis - cinco centigramas

Extrato de meimendro - dois centigramas

Extrato de valeriana - cinco centigramas

Sabão medicinal - um decigrama

Decocto de flor de laranja - q.s

Para uma pílula e mais 23.

Tome uma pilula com chá de herva cidreira, quando sofrer palpitaçðes."

i. DUKES, M. N. G (Ed.). Drug Utilization Studies: Methods and uses. WHO Regional Publications, European Series No. 45. p. 5.

ii. PAULA, H. de. A medicina dos médicos \& a outra ... . Belo Horizonte, Imprensa Universitária, 1982. pp. 33-5; 315-321. 
Enquanto o padre Caio, nos intervalos das aulas que lecionava, cuidava da vinha, o irmão Bernardo Mourão dedicava cuidados especiais à horta e aos jardins. Ambos portugueses, o empenho no cultivo estabelecia entre eles uma rica troca de experiências que culminava com o cultivo de uvas aptas para o vinho e de plantas medicinais e outras ervas que serviam às necessidades do Caraça. Na condição de 'farmacêutico' e 'enfermeiro' do colégio, o irmão Mourão cultivava em seus canteiros incontável número de espécies até mesmo aromáticas e de especiarias, entre as medicinais: poejo e hortelã comum, erva-cidreira, artemisia, funcho, coentro, açafrão, alecrim, manjericão, salsa, sálvia, borragem, camomila, losna, gengibre, pimentas, etc. A fitoterapia no Caraça nada mais era do que o prolongamento espontâneo da reputação desta terapia como conduta médica, reputação esta que se confunde com a própria história da medicina. A rara edição da Matéria Médica de Dioscórides $^{239}$, disponivel na biblioteca do colégio, testemunhava o valor das plantas e de suas propriedades terapêuticas. Além do cultivo racional das espécies, a diversidade do meio ambiente em torno do colégio proviao de inúmeros vegetais com recomendações para fins terapêuticos. Esta riqueza não passou despercebida aos naturalistas e viajantes que fizeram do Caraça rota necessária às suas andanças pelo pais. Os naturalistas Saint-Hilaire, francês, Spix e von Martius, alemães, que estiveram no Caraça durante alguns dias entre os anos 1816-1818, coletaram

239 Pedacio Dioscorides Anarzarbeo foi um médico grego do século I da era atual. Teria nascido em Anazarbe, na Cilícia. Matéria Médica ( "acerca dela materia medicinal y de los venenos mortiferos")

"foi muito lido e freqüentemente reproduzido na idade média, pelos gregos, os latinos e os árabes" (i).

A edição ( Salamanca, Comelio Bona , ed., 1586) pertencente ao acervo do Caraça, foi traduzida da língua grega para o espanhol e tem figuras de inúmeras plantas exóticas e raras. O tradutor, que era médico de Julio III, foi Andres de Lagunia.

Galeno, outro médico de origem grega do século II,

“... redige uma súmula de todos os conhecimentos eruditos da arte de curar.

Aí menciona mais de 450 plantas medicinais e insiste na necessidade, para qualquer médico, de ter uma sólida bagagem de botânico e ervanário" (ii).

i. EXPOSIÇÃO de livros da biblioteca do Caraça. Promovida sob os auspicios da sucursal de "O Globo" de Belo Horizonte. Imprensa Oficial, 1960. p. 33.

ii. LE GOFF, J. As plantas que curam. In. Le GOFF, J. (Apres.) Op. Cat., p. 349. 
vegetais para pesquisas, escrevendo as particularidades encontradas no local em livros publicados e divulgados na Europa ${ }^{240}$.

Foi diante da possibilidade de obter informaçōes especificas sobre os medicamentos usuais da botica do Caraça que João Alphonso procurou informaçōes sobre a flora da região. A insinuação de Felicio dos Santos de que haveria um efeito benéfico para o tratamento do beribéri a partir de espécies locais era desprovido de veracidade para outros médicos. O próprio doutor Vieira Andrade desconfiou da eficiência dos vegetais citados, posição que era generalizada desde que determinado médico apontasse a eficácia de certa espécie vegetal no combate ao beribéri. Ou seja, não havia confirmação e muito menos concordância. Diante desta situação, não sobrava a João Alphonso a alternativa que o levava a admitir que a terapéutica do beribéri era basicamente sintomática e que a mudança de local do individuo adoecido era a alternativa viável para se enfrentar a enfermidade. Ele voltou a pensar na conversa que tivera na Casa Central com o padre Visitador e concluiu que seria melhor tentar responder a questão: Por que um aluno, com diagnóstico de beribéri, cura-se ao voltar para casa e por que este mesmo aluno, ao retornar ao Caraça, necessariamente não adoece novamente ? Discutindo por carta com Vieira Andrade, João Alphonso justificava que, assim fazendo, estaria abarcando algumas questões importantes à abordagem da doença, mesmo que estivesse admitindo premissas que

20 Naturalistas e viajantes menos ilustres teriam percorrido as terras do Caraça. Nos relatos sobre a vida e o cotidiano da instituição, um ou outro autor alude à presença destes no colégio. Por exemplo, em "Contos Caracenses" (*), o autor conta a passagem por lá de um certo E. Frank,

“... um judeu naturalista que passou uma temporada no Collegio Cara̧a, collecionando orchideas, e outras plantas, para museus da Europa, e para fabrico de productos pharmaceuticos...

“... veio ao Caraça em busca de alguns especimens da flora e fauna caracense, que Martius e $\mathrm{S}$. Hilaire tinham revelado aos sabios do velho mundo".

- SILVA, F. de P. Contos Caracenses. IN. SILVA, F. de P. Caraça: apontamentos historicos e notas biographicas. Op. Cit. p. 234-239. 
pudessem vir a ser contestadas. Abarcaria, por exemplo, a noção de que fatores que protegeriam o individuo contra a doença, e que a medicina ainda desconhecia, estivessem presente no lar, junto à familia, e ausentes no colégio; se a doença tivesse caráter infeccioso e o processo infeccioso tivesse afinidade particular para cada individuo, a natureza desta infecção era totalmente diversa do que era conhecido, já que o aluno doente que retornava são não costumava 'pegar' a doença novamente. Vieira Andrade considerava justas as especulações de João Alphonso, apesar de considerá-las distantes de um verificação convincente. E por pensar assim foi que ele sugeriu a João Alphonso que, primeiramente, elaborasse as "Consideraçōes sobre o beribéri no Caraça", destinadas, prioritariamente, ao consumo da instituição que precisava tratar o problema da doença. Isto significaria, na opinião do médico serrano, ser bastante acessivel - restringir a terminologia técnica ao necessário -; indicar medidas profiláticas e terapêticas imediatas e evitar aquelas especulações que não tivessem condicência com os conhecimentos e a prática médica atual. Esta última consideração inquietou João Alphonso. O véu que, para ele, cobria Vieira Andrade tornou-se mais escuro e, portanto, exigia-lhe melhor acuidade para entender este estranho personagem. Na carta em que teceu estas considerações, Vieira Andrade afirmou que, através do seu irmão padre, fora convidado - mas que infelizmente não poderia ir - a assistir no Caraça às cerimônias de consagração da igreja gótica e de inauguração do órgão.

Bem lembrado, João Alphonso ponderou que os preparativos para esta cerimônia no Caraça estariam retardando a chegada das informações da botica que solicitara. A Casa Central estava completamente envolvida na organização do evento. O próprio bispo do Rio de Janeiro, D. Pedro Maria de Lacerda, participaria da solenidade, em companhia do bispo da diocese de Mariana, D. Antônio Maria Correia de Sá e Benevides e do arcebispo da Bahia e primaz do Brasil D. Luiz Antônio dos Santos. João Alphonso pensou na satisfação que atravessaria aquele padre inteligente que anos atrás conhecera na casa central dos lazaristas, o padre Júlio Clavelin, idealizador, arquiteto e responsável pela construçāo da nova igreja que, depois de mais de seis anos, encontrava-se pronta. Mas ele ficara sabendo que a alegria do 
padre Clavelin não era completa. É que o seminário maior, que por mais de duas décadas funcionou no Caraça paralelamente ao Colégio, retornara a Mariana. Além do mais, o funcionamento do seminário junto ao colégio permitiu a este contar com um quadro regular de professores auxiliares, monitores, etc., que permitiram manter a qualidade do ensino no periodo. Mas a igreja estava lá241. Pronta. Adornando-a, um órgão construído no próprio Caraça, pelas mãos do padre português Luís Gonzaga Boavida, que desde 1870 vivia no colégio e que viria a substituir o padre Clavelin no superiorato. Este órgão também era motivo de orgulho da instituição, até porque toda a madeira utilizada na construção do instrumento musical fora obtida na terra caracense: jacarandá, cedro, etc. Padre Clavelin gozava, então, de muito prestígio entre os colegas da congregação e não raras vezes o capelão reafirmava a João Alphonso as virtudes do colega. Mas nem por isso João Alphonso desconfiava que, em pouco tempo, reencontraria ali mesmo, na sua cidade, com o padre Clavelin, que se tornaria superior da Santa Casa.

Enfim, manteve-se a promessa do padre visitador e chegaram algumas informações sobre a botica do Caraça. João Alphonso abriu o envelope bem escrito e distribuiu os papéis sobre a sua mesa. Como era costume em muitas ocasiōes, pediu à esposa que não permitisse que o incomodassem, mas, também como era de costume, exercia

241 Segundo SILVA (i), nada resta sobre a cerimônia de sagração da igreja do Caraça “... além da resumida e laconica acta que foi lavrada então ... Sabe-se apenas por tradição que a ceremonia começou as 7 horas da manhã e terminou-se as 3 da tarde...".

Sobre a construção da igreja, ZICO (ii) dá alguns detalhes, entre estes:

" - Dizem que trabalharam na construção da igreja 40 operários, sendo a maioria espanhóis e portugueses. Nåo consta houvesse escravos";

"- O mármore é todo mineiro, da serra de Antônio Pereira, perto de Mariana";

"- A pedra sabão veio da chácara de Santa Rita, no Caraça";

"- O vitral do meio é doação de D. Pedro II", etc.

i. SILVA, F. de P. Caraça: apontamentos históricos... Op. Cit. p. 77.

ii. ZICO, J. T. Caraça, peregrinaçdo ... Op. Cit. p. 70. 
inconsistentemente a consentida autoridade patriarcal da época e, por isso, não deixou de receber o filho advogado que aparecera com aparência desoladora:

- Lembra do filho do Dr. Antônio que estuda em São Paulo ?

- Aquele rapaz que tem escrito artigos no mesmo jornal que você, sob o pseudônimo de "Rapp" ?

- Exato. Ele mesmo. Pois acaba de se transferir para Recife. Não apenas ele, mas 93 alunos do quarto ano, que após uma greve, foram perseguidos na faculdade e que, para se formarem, resolveram-se pela transferência.

- Você conhece bem aquele ambiente... mas imagino que tenha algo a ver com as discussões de idéias abolicionistas, monarquistas, republicanas ...

- Inevitável. Mas tudo isso descontenta-me. Que diabos não poder ter as idéias livres numa faculdade !?

- Tolice rapaz! - disse o pai, tentando amenizar o impacto do ocorrido, para o filho - Você sabe perfeitamente que habitamos uma sociedade rigorosamente disciplinar. $\mathrm{E}$ sabe também que este tipo de sociedade forma-se a partir de processos de várias naturezas: politico e jurídico, econômico e, vamos aceitar, no próprio processo de constituição da ciência, que tem na educação científica sua mais fértil aliada.

Entristecido, o filho fitou o pai e disse:

- Sabe, pai, o senhor consegue fazer com que eu, tendo coragem de assumir os conceitos, entenda o processo que me angustia. O diabo é que o seu esclarecimento não me conforta. Ao contrário ! Será mesmo verdadeiro que monarquistas e republicanos obedeceriam a esta mesma lógica opressora da ordenação?

- Você se lembra da conversa que tivemos quando esteve para ir para Campinas? Lembra-se do que me disse sobre c exercicio do direito e sua relação com a sociedade? Não estariamos, então, diante de um processo disciplinar que se ocultaria num pseudo inofensismo e, ao mesmo tempo, utilidade? E reafirmo, filho: a ciência em geral, e aqui incluo a medicina, não se encontra fora deste esquema.

- Falando em Campinas, da última vez que o Raul esteve aqui falamos do jornal que os proprietários rurais conservadores mantêm naquela cidade, o Diário de Campinas. E o senhor acredita que ele, de 
volta a São Paulo, fez uma charge contra este jornal, provocando grande ira nos donos dos escravos?

- Certa vez, quando conversava com o pai dele por ocasião daquela herança do seu tio, eu o conheci, e o doutor Antônio disse-me que o filho também desenhava com competência. Pareceu-me um rapaz introspectivo, naquele dia. É difícil imaginá-lo no meio destas discussões, mesmo já sendo um jornalista reconhecido. São os mistérios do destino.

- Por que o senhor diz isto?

- Se eu soubesse exatamente, eu lhe diria. Talvez, pelo caminho que tomou, ele não encontre nesta sociedade a benevolência que um espírito perscrutativo e criador necessita.

O filho observou o pai abrir a janela, reclamando de um calor que não era tanto naquele final de dia e afirmou:

- Diga-me uma coisa, pai: o senhor vê casos deste tipo como uma epifania ? É a impressão que tenho, apesar de não entender porque.

Sem esconder a emoção, João Alphonso olhou para o filho e disse, antes de assentar-se, cansado:

- Mesmo que eu também não entenda porque, eu não poderia te desmentir jamais. Se o fizesse, eu me assustaria com a humanidade; o inferno aqui, o paraiso acolá, e assim seguindo. Aliás, de mundo e epifanias, entendem os poetas...

- Já sei: "o mundo é infestado de epifanias". Goethe - disse o filho, imitando encenar a afirmativa.

- Eu não lembrava que já havia lhe falado alguma vez esta frase.

- Com certeza, o senhor não se dá conta também que anda relendo todos os livros de poesias que trouxe da Alemanha. Conversamos sobre isso dias atrảs.

- Oh! Desculpe-me, filho. Isso acontece quando para nós o presente é a realização do futuro. Na velhice, merecemos ser compreendidos pelos esquecimentos. Vocè nāo me providenciaria uma xicara de café ?242

\footnotetext{
242 "Rapp" foi um dos pseudônimos usado pelo escritor Raul Pompéia (1863-1895). O seu trabalho mais conhecido é O Ateneu, publicado em 1888. Estudante de direito em São Paulo, em 1883 é reprovado e
} 
Os dados da botica vieram acompanhados de uma breve nota explicativa, saudações pessoais e assinado pelo irmão Mourão. Nas saudações, uma notícia: o irmão Schmitz cumprimenta-o e deseja graças no seu ofício. João Alphonso lembrou deste irmão que, de passagem pelo Rio, vindo da Alemanha, tinha conhecido na Casa Central. Algum tempo depois, ao pedir notícias, João Alphonso seria informado que o irmão Schmitz cumpria habilmente as tarefas de carpinteiro e encanador do Caraça. Na nota explicativa, o irmão Mourão diz apenas que as informações sobre a botica dizem respeito aos principais medicamentos aviados pela botica do colégio no periodo indicado. Ao exame da lista,

"por perseguição de um professor, segue com 93 acadêmicos para Recife, a fim de concluir o curso juridico" (i, p.14).

Filho de um conhecido advogado, Dr. Antônio d'Ávila Pompéia, o jovem Raul já era conhecido no meio jornalístico. De

“... temperamento esquisito, sujeito a constantes mutaçðes de humor, acessivel a súbitos impulsos de cólera, que levavam a choques $\mathrm{e}$ desentendimentos com os companheiros. Desconfiado ao extremo, dificil no trato, era, também, em outros momentos, jovial, brincalhão e entusiasta."

Ainda em São Paulo, aonde também exercia seus talento como desenhista, em charge contra o Diário de Campinas (ii, p. 54 ) ousou

“... ferir a suscetibilidade religiosa dos donos de escravos. Com isso, 0 estudante Raul Pompéia passou a ser perseguido pelos conservadores. A Faculdade de Direito refletia a crise política; os estudantes abolicionistas e republicanos entravam em choque com a direção retrógrada de alguns de seus professores" (iii, p. 4).

Sempre envolvido em polèmicas políticas, Raul Pompéia viveu breve: 32 anos. Suicidouse com um tiro no coração em 25 de dezembro, morrendo sob os olhares da mãe, viúva, e das très irmãs. Para Agripino Grieco:

"Foi ele [R. Pompéia] uma vítima da desproporção entre os seus entusiasmos e a mediocridade do ambiente. Um tal homem não podia permanecer longo tempo no mundo, destruindo-se assim um pouco todos os dias" (iv).

i. COUTINHO, A . (Org.). Raul Pompéia: Obras. v. 1. Rio de Janeiro, Civilizaçãc Brasileira, 1981

ii. BATTISTONI Fo., D. Campinas, uma visão histórica. Campinas, Pontes, 1996.

iii. CURVEllo, M. (Org.). Raul Pompéia. São Paulo, Ed. Abril, 1981

iv MENEZES, R. Dicionário literário brasileiro, $2^{\mathbf{a}}$. ed. Rio de Janeiro, Livros Técnicos e Científicos, 1978. p.542. 
João Alphonso detectou que não havia nenhum medicamento que não fosse usual na prática médica. Todos eram conhecidos e indicavam que as condutas obedeciam basicamente à sintomatologia presente. Se isto indicava que não se procurasse, no Caraça, a cura, por medicamentos não usuais, para o beribéri, por outro lado, entretanto, indicava que se o beribéri fosse realmente uma enfermidade prevalente por lá, os medicamentos da botica estariam incluídos entre os que são utilizados no tratamento da doença. Visto que nenhuma medicação especifica, ocasionalmente proposta, lograva êxito na cura da doença, restava à medicina prescrever remédios

"dirigida exclusivamente aos symptomas..."243.

De fato, os medicamentos da lista da botica do Caraça destinam-se a tratamento sintomático 244 . Do total de medicamentos aviados pela botica, destacam-se três tipos de remédios: o óleo de bacalhau, os considerados 'digestivos' ( entre eles destaca-se o vinho quinado), e os purgantes, que compreendem uma grande variedade de medicamentos com a mesma finalidade purgativa. O óleo de figado de bacalhau, utilizado na medicina por longas décadas, foi prescrito como um poderoso "fortificante", isto é, fortalecer o organismo. Era especialmente recomendado para crianças e adolescentes com diagnóstico de raquitismo. Desta forma, em muitos processos mórbidos que gerassem "fraqueza" no individuo, o óleo de bacalhau era indicado ${ }^{245}$. Pela

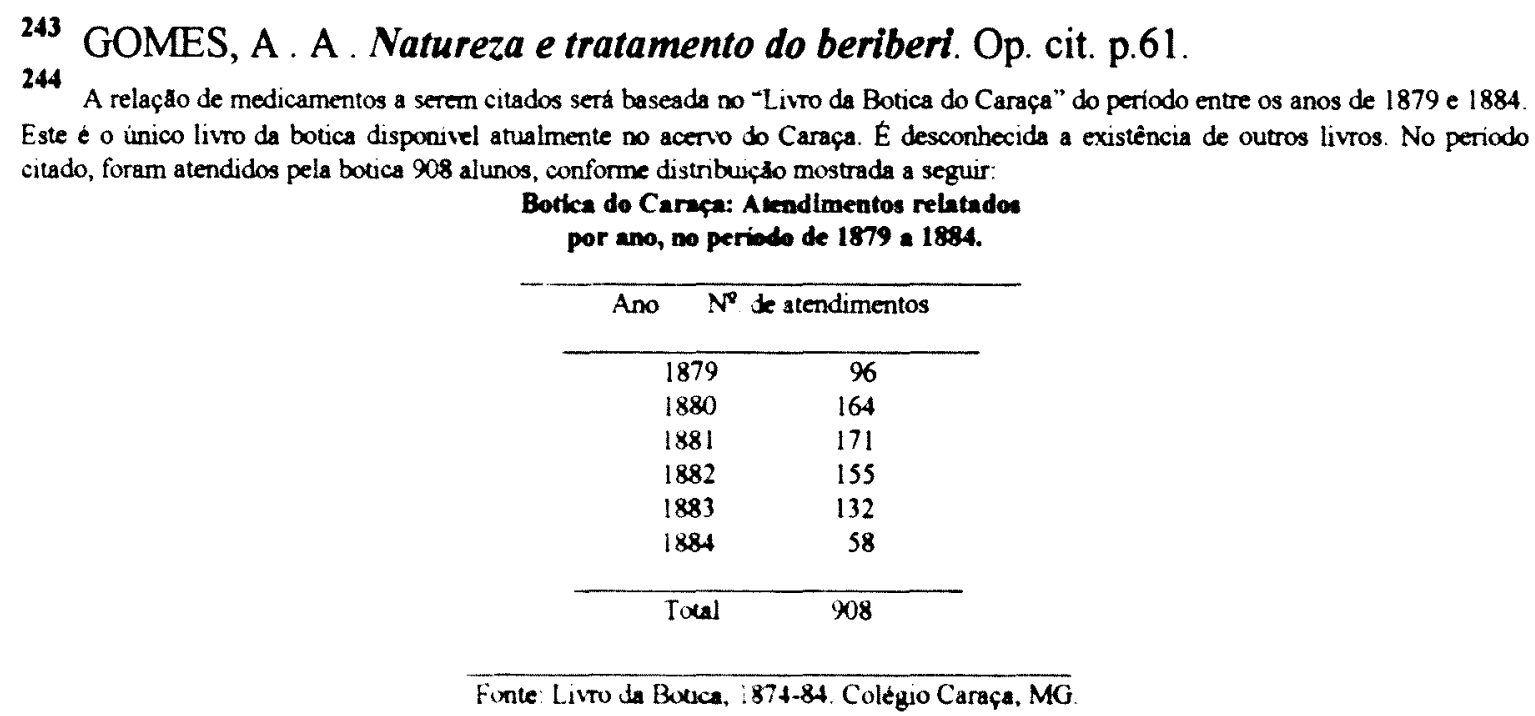

${ }^{243}$ GOMES, A . A . Natureza e tratamento do beriberi. Op. cit. p.61

A relaçăo de medicamentos a serem citados será baseada no "Livro da Botica do Caraça" do periodo entre os anos de 1879 e 1884 Este é o único livro da botica disponivel atualmente no acervo do Caraça. É desconhecida a existência de outros livros. No periodo Cotca do Carapa: Aleadlma seguir por ano, no periodo de 1879 a 1884.

Fonte: Livro da Bucica, :874-84. Colegio Caraça, MG 
Destes atendimentos, foi tirada de maneira estratificada e aleatória uma amostra de 200 medicamentos e, destes, os mais citados foram:

\section{Medicamento aviados mais vezes pela botica do Caraça. Colégio Caraça, 1879-1884.}

\begin{tabular}{lc}
\hline Medicamento & $\mathrm{N}^{\mathrm{o}}$. de vezes aviado \\
\hline Purgantes diversos & 33 \\
Óleo de Bacalhau & 22 \\
"Digestivos" & 15 \\
\hline
\end{tabular}

Fonte: Livro da Botica. Caraça, 1879-84

245 Ainda de acordo com a British pharmacopoeia de 1864, um outro grupo de medicamentos (além do ópio, atropina, morfina, quinina, etc.) integrava o 'seleto' grupo do que melhor existia para terapêutica na época:

“ ... as fontes de algumas vitaminas, as quais ainda não haviam sido descritas" (i, p. 5).

Este é o caso do tradicional óleo de bacalhau, que contém quantidades vantajosas de vitaminas A e D. A vitamina A, além da sua fundamental importância para a visão, é importante para a integridade do tecido epitelial, pele, crescimento e desenvolvimento ósseo e dentário, e ela só viria a ser identificada nas primeiras décadas do século XX, ainda que

"Na história da vitamina A observa-se que certos sintomas de sua deficiência já eram reconhecidos na metade do século XIX, e sua causa ligada à inadequação da alimentação" (ii, p. 9).

A vitamina $D$, essencial na formação e manutenção de ossos e dentes, já era plenamente aceita como remédio de combate ao raquitismo. Porém, o isolamento da substância química que exerce a função vitamínica só ocorreu em 1935. Mas o óleo de figado de bacalhau,

"era um remédio conhecido do povo, e aceito pelos médicos como um agente medicamentoso para o raquitismo" (ii, p. 15).

É curioso notar que: se o efeito de uma dada substância independe e antecede o seu próprio conhecimento ( no caso, as vitaminas em geral e a $D$ neste momento), os motivos que proporcionaram o uso de certas substâncias com poder curativo são ainda mais distantes do conhecimento destas substâncias. Assim é que

"A obtenção do óleo de figado de hacalhau deve-se ao fato de que as pescas maritimas atravessaram desde o século XI, très fases principais. Do XI ao XV século, desenvolveu-se e floresceu a pesca do arenque. A partir do século $\mathrm{XVI}$ iniciam-se as expediçðes transatlânticas à terra-nova e o bacalhau substitui 0 arenque, como produto de grande comércio. Face à abundância do bacalhau em certas regiỏes e ípocas do ano e a industrializaçåo da parte 
composição atualmente reconhecida do óleo, o teor de vitaminas A e D garante $o$ atendimento das necessidades fisiológicas destas vitaminas. Estas vitaminas presentes no óleo de bacalhau são do tipo liposolúveis, isto é, solúveis em gorduras, e são mais estáveis do que o outro grupo de vitaminas, as hidrosolúveis. Faz parte deste último grupo a vitamina B1 que, entre outras funções, previne o organismo contra o beribéri. Nenhum dos medicamentos da lista constitui fonte de vitamina B1 e, portanto, não poderia exercer nenhum efeito protetor contra a possivel manifestação do beribéri no Caraça.

No grupo dos "digestivos", destaca-se, entre outros, a 'quassia', planta que

“... é para o estômago o principal remédio digestivo. Produz, tomado pouco antes da comida, o apetite e digestão. Empregado na dispepsia, azedume, flatulência, arrotos, inapetência, etc. 246 .

Outro vegetal bem empregado nesta função era o ruibarbo:

"Raiz, tônico em pequena dose e purgante em alta. Nas moléstias das crianças é um remédio importante"247.

Por sua vez, o vinho quinado tinha seu valor reconhecido pela presença do quinino, cuja aplicação mais conhecida é o uso no tratamento da malária e em outras doenças com presença de febre. Na formulação apresentada, admite-se que o vinho quinado, na combinação apresentada, auxilie a digestão através da estimulação de secreções digestivas ${ }^{248}$.

muscular, levaram os industriais a aproveitar o óleo ... que apresentam cerca de $63 \%$ de seu peso sob a forma de óleo" (ii, p. 15).

i. DUKES, M. N.G. Drug utilization studies. Op. Cit.

ii. FRANCO, G. Nutriçdo. Rio de Janeiro: Såo Paulo, Atheneu, 1982.

246 LANGGAARD, T. J. H. Diccionario de medicina domestica e popular. v.3. Rio de Janeiro, Laemmer, 1873. p. 149.

247 Idem, p.438 


\section{Purgante ou purgativo é o}

"Medicamento que provoca a evacuação intestinal" 249.

$\mathrm{Na}$ lista de medicamentos da botica, é grande o número de medicamentos com a função purgativa. Destes, o mais tradicional e conhecido é o óleo de rícino, mas também integram a lista nesta categoria alguns como: purgante de sal amargo, purgante de sulfato de soda, purgante de óleo, purgante de óleo e vinagre, sal de glauber (sulfato de sódio), citrato de magnésio purgativo, etc. A intensa utilização dos purgantes pode ser vista como resultante das influências dos sistemas especulativos que durante décadas norteou o ensino médico ${ }^{250}$. É correto admitir que, já na metade da segunda parte do século XIX, as teorias médico-filosóficas ganharam a 'concorrência' de uma concepção mais 'cientifica', na qual pesquisas mais criteriosas orientavam os estudos acerca da etiologia, e outras especificidades, de um dado processo mórbido. Mudança de uma concepção a outra não é, naturalmente, automática e sem experiências intercessoras. Principios de uma concepção que deixa de ser hegemônica podem continuar a prevalecer por conta não apenas de processos culturais, mas também por conta da incapacidade da nova concepção responder 'convincentemente' a questões complexas e que esperam exame meticuloso a partir da produção de novos conhecimentos. A questão da 'purga' obedece, em alguns sentidos, a esta abordagem. Se é verdade que as correntes médicas descendentes do vitalismo de Barthez concebiam que

248 No século XVII, missionários espanhóis na América do Sul descobriram um extrato da casca da árvore cinchona (quina) que mostrava alguma eficácia no tratamento da malária. Mas apenas no século XIX, 1820, o químico francès P. J. Pe!letier (1788-1842) isolou a quinina, reconhecidamente o principio ativo antimalárico $\left(^{*}\right)$.

* Kauffman, G. B. Pelletier. Grolier Enc. Mult. Op. Cit.

${ }^{249}$ ANDREI, E. (Ed.) Dicionário Médico Blakiston. $2^{\mathrm{a}}$. ed. São Paulo, Organização Andrei Editora Ltda, 1982. p. 878.

250 Sobre estes 'sistemas especulativos', ver nota de rodapé 191 
“... a saúde se expressa na naturalidade das propriedades orgânicas, enquanto a doença é o fenômeno que deriva se seu aumento, sua diminuição ou alteração"251,

a idéia de que aquilo que 'desequilibra' o meio orgânico interno - o organismo - deve ser expelido, purgado. Esta concepção guarda coerência com a possibilidade da terapêutica medicamentosa da época. O que se observa é a existência de um equilíbrio significante entre o conhecimento da doença, as possibilidades terapêuticas do momento e o modelo teórico que orienta tanto a produção de conhecimento acerca da doença como a busca de recursos terapêuticos, entre eles o medicamentoso. Se este 'modelo teórico' è historicamente determinado, inclusive sob o pressuposto da disponibilidade cientifica e tecnológica da época, corre-se - risco, se assim tomado, de perder-se na redundância de um evolucionismo esteril e deixar de compreender as maneiras como os homens vivenciaram seus problemas em um dado momento. $O$ fato é que, se a terapêutica da purgação guardava coerência com os critérios de diagnóstico e recursos medicamentosos da época, os seus efeitos satisfaziam a expectativa clinica em função não apenas da variedade de purgantes disponiveis, como também por se tratar de uma das condutas mais difundidas e duráveis na medicina e, o que não devendo ser relevado, inclusive como conduta em procedimentos médicos alternativos 282 .

\footnotetext{
251 NOVAES, R. L. O tempo e a ordem: ... Op. Cit. , p.57.

252

Discutindo as

"transferências de remédios de umas classes e de umas raças para outras e também de regiðes: da metrópole ou do litoral para o interior e do interior para o litoral",
}

FREYRE (ii, pp. 380 e 419) cita um curioso estudo, surgido em abril de 1835, do médico J. F. Sigaud, no qual, a certa altura, ele afirma que

"A classe inferior da sociedade gosta e gostaria sempre dos purgantes, e entre estes os drásticos seråo os mais queridos...".

A manifestaçăo de preferência segundo a classe social nem sempre é o único limite ao uso generalizado da medicaçăo, conforme indicou FREYRE. Assim é que PAULA (i, p.316), narrando o receituário de médicos norte-mineiros entre os anos 1910 e 1930 afirma que apesar da introdução de novas alternativas medicamentosas para o médicc, 
Fora desta lista dos três grupos de medicamentos da botica mais citados, surgem outros medicamentos sugestivos: "cabeça de dormideira", que é derivado da dormideira,

"Planta cujos frutos formam cápsulas (cabeças) com uma coroa

no topo, que contém grande quantidade de sementes pequenas

... em menor grau tem o efeito do ópio e se empregam como

calmante e narcótico"253.

Ainda na lista de calmantes, os pós de dower (nitrato de potássio pulverizado, sulfato de potássio, ipecacuanha e alcaçuz) que em dosagem diferente era usado como diaforético, aumentando a transpiração; o xarope de bromureto de potássio, como sedativo e hipnótico, cuja formulação básica da época era:

"500 gr. de xarope de cascas de laranja

50 gr. de bromureto de potássio"254.

Para casos do aparelho respiratório, pilulas expectorantes de várias formulações, poção contra-estimulante ( água de louro-cereja + sais de morfina, etc.). A pomada de Helmerich foi usada para tratamento da

"... outros processos vindos do passado, ainda estavam em voga: purgativos, vomitórios, etc.".

Práticas médicas não convencionais admitem a utilização de purgantes como condutas perfeitamente usuais contemporaneamente, como escreve KIKUCHI (iii, p. 163-4):

"Em diversos casos antes de aplicar-se qualquer tratamento para os problemas do aparelho digestivo, ou seja, do intestino e do estômago, convém utilizar um laxante. A grande utilidade do purgante poderá ser verificada, principalmente, por aqueles que tratam de crianças. Com elas, freqüentemente aparece a necessidade de induzir a evacuação. Para quase todos os problemas abdominais, antes de tudo recomendamos esvaziar o aparelho gastrointestinal com óleo de rícino"

i. FREYRE, G. Sobrados e mucambos. Op. Cit.

ii. PAULA, H. de. Á meciicina dos médicos \& a outra ... Op. Cit.

iii. KIKUCHI, T. Autocuraterapia. Prática global do tratamento preventivo. São Paulo, Musso Publicaçðes, 1981.

203 LANGGAARD, T. J. H. Diccionario de medicina domestica e popular. Op. Cit., p. 682.

24 SANTOS, A. F. dos. Formulário para o hospital da Santa Casa da Misericórdia do Rio de Janei,o. Rio de Janeiro, Almeida Marques, 1879. p. 194. 
psoriase; a água vegeto-mineral, à base de vinagre de chumbo e álcool, era utilizada externamente nas contusões; contra náuseas e vômitos, a poção anti-emética de Rivière, etc.

João Alphonso havia discutido com o farmacêutico do Hospital da Santa Casa algumas fórmulas de medicamentos da lista. $\mathrm{Na}$ época prescreviase, para casos de beribéri, o xarope anti-anèmico, cuja fórmula e posologia era a seguinte:

"Xarope de genciana + tintura genciana + tintura canella + pyro-phosfato de ferro + arseniato de soda + sulphato de strychnina + essencia de cravo.

Toma uma colher de sopa 3 vezes ao dia na anemia, nas cachexias, sobretudo com phenomenos de anemia medullar, no béri-béri"25s.

Os sais de arsênico e estricnina vinham sendo utilizados como tônicos e tinham no médico baiano Silva Lima um defensor do seu uso, especialmente o arsênico. Dos 'tônicos' utilizados, grande sucesso fez o famoso xarope de Easton, indicado também na terapêutica do beribéri. Easton, professor da tradicional escola médica da universidade de Glasgow, formulou assim o seu xarope:

"sulphato de ferro. 5 oitavas

phosphato de soda 6 oitavas

sulphato de quinina 192 grãos

ácido sulphurico diluído q.s água d'ammonia q.s strychnina 6 grãos

ác. phosphorico diluído 14 onças assucar branco 14 onças" $^{256}$.

${ }^{255}$ SANTOS , A . F. dos. Formulário para o Hospital ... Op. Cit. , p. 186.

${ }^{256}$ Esta é a fórmula apresenta por Silva Lima (*) que, em seguida à ela, orienta o modo de preparar.

* LIMA, J. F. S. Ensaio sobre o beriberi no Brasil. Op. Cit., p. 223. 
Mas o grande interlocutor de João Alphonso para assuntos farmacêuticos era o proprietário da Farmácia Peckolt, Theodoro Peckolt. Não eram exatamente amigos, mas ambos assim se consideravam porque, entre outros motivos, também o farmacêutico fez o seu curso em Göttingen. Peckolt ponderava a João Alphonso a riqueza da flora brasileira e as suas possibilidades farmacológicas. Um dos seus estudos mais importantes diz respeito ao uso do Teite' da gameleira ou figueira branca como poderoso vermífugo. Ele próprio isolou e descreveu as propriedades de um principio ativo presente na planta, denominado doliarina. A João Alphonso, Theodoro opinava que a utilização de novas plantas na terapêutica deveria ser precedida de exaustivos estudos e que, na sua opinião, a maioria dos médicos que sugeriam uma ou outra erva para o tratamento de doenças, como o beribéri por exemplo, o faziam sem - necessário recurso prévio da experimentação. João Alphonso concordava e acrescentava que a busca incessante por drogas que curassem males muitas vezes desfocava o olhar do médico da integralidade do doente, isto é, ao centrar a cura na droga, corria-se o risco de não se valorizar adequadamente os modos do sujeito manter-se vivo e suficientemente saudável. Enfim, João Alphonso e Theodoro concordavam também que as escolas médicas deveriam implementar urgentemente atividades cientificas de laboratório, mas não apenas como um espaço de divulgação de técnicas e criação de metodologias e produtos mais eficazes, mas também como espaço de avaliação critica dos efeitos do uso dos produtos cientificos e tecnológicos na sociedade ${ }^{257}$.

257 Theodoro Peckolt nasceu na Alemanha em 1822 e faleceu, aos 90 anos de idade, em 1912, no Rio de Janeiro. Formado em Göttingen,

“... chegou ao Brasil em novembro de 1847 fixando residência em Cantagalo, ... até 1868 quando se mudou para a Corte. Lá revalidou seu diploma de farmacêutico e instalou em sua Farmácia Peckolt um laboratório onde passou a analisar as nossas plantas. ... [publicou trabalhos cientificos] na Alemanha, Inglaterra e nos Estados Unidos, os resultados de análises de mais de 6 mil espécies vegetais. ... A sua obra aparece em português, p. ex., nos 8 volumes de sua História das Plantas Alimentares e de Gozo (Rio 1871-1882) e nos 7 volumes de sua História das Plantas Medicinais e Úteis do Brasil (Rio, 18881899)" (*) 
Após anos sem se corresponderem, João Alphonso recebe uma breve carta com noticias de Morten. Vinha de Davos-Platz, nos Alpes suiços e ele dizia que conciliava duas necessidades: repousar por algum tempo para recompor a saúde e rever um colega, o Dr. Behrens, médico no Sanatório Internacional de Berghof. Afirmava, ainda, para João Alphonso não se preocupar, pois a ligeira tuberculosis pulmonum encontrava-se controlada sob a competente vigilância do amigo Behrens. João Alphonso experimentou algum incômodo com a notícia, pois sabia da astúcia daquela doença, algumas vezes sob prognóstico favorável. Era estranho que, décadas após ter convivido com Morten e agora ambos já idosos, vislumbrando a possibilidade da morte, pudesse querer acolher 0 amigo e protegê-lo daquilo que os separaria eternamente. Tentou, então, não se preocupar, seguindo a orientação do próprio Morten, e pôs-se a rascunhar o trabalho que intitulou de "Considerações sobre o beribéri no Caraça".

Em meio aos trabalhos que surgiam acerca, especialmente, da etiologia do beribéri, João Alphonso não se surpreendeu quando o médico e pesquisador do Museu Imperial, João Batista de Lacerda, anunciou que encontrara o micróbio causador do beribéri e, com isso, classificava 'cientificamente' a enfermidade como sendo de natureza

Com sua farmácia bastante conceituada, adquiriu o 'status' de "farmacêutico da Casa Imperial". Sua vasta produção [a relação dos seus trabalhos pode ser encontrada em (ii)] como pesquisador coloca-o como um dos pesquisadores que mais estudou os recursos medicamentosos da flora brasileira no século XIX.

i. FALCÃO, E. de C. Gazeta Médica do Rio de Janeiro: Coletânea. Tomo I, II, III, p. XVI e XVII.

ii. BLAKE, A . V. A . S. Diccionario bibliographico brazileivo. v.? R. . de Janeiro, Imprensa Nacional, 1902.

OBS.: As obras raras da biblioteca de Theodoro Peckolt são hoje parte do acervo da seção de obras raras da Biblioteca Central da Universidade Estadual de Campinas. Dentre as obras da área de farmácia e manipulação de medicamentos, é encontrada, por exemplo, na coleção de $T$. Peckolt a publicação de Augusto Ferreira dos Santos ("Formulário para o hospital da Santa Casa da Misericórdia do Rio de Janeiro, de 1879"), citada no presente trabalho. 
infecciosa. Ele já estimara, após Morten ter-lhe escrito sobre os primeiros estudos do jovem médico Koch na Alemanha, que em breve ter-se-ia uma enorme seque ência de estudos que pretenderiam confirmar a natureza infecciosa de muitas enfermidades, a partir do isolamento do agente causal especifico ${ }^{258}$. A teoria infecciosa de Lacerda era dinâmica quanto ao agente:

"A principio era uma moléstia parasitária. Julga haver encontrado um bacillo, e a conviç̧ão de sua descoberta leva-o a descrever o germe em suas várias formas. É semelhante ao bacillo do carbunculo, cultiva-se no sangue pelo methodo de Pasteur, e tendo sido inoculado em porquinhos da Índia, produziu symptomas análogos ao do beriberi typico, com morte consequente. Mais tarde, em 1906, o exame microscópico de cortes de medullas de beribéricos obtidos nos hospitaes desta cidade the revela um trypanosoma, cujos caracteres morphologicos descreve com minúcias, bem como a technica empregada"259.

Nesta mesma época, a teoria microbiológica para a etiologia do beribéri ganharia impulso com os estudos de pesquisadores holandeses

258 João Batista de Lacerda (1842-1909) formou-se na Faculdade de Medicina do Rio em 1870 e, após clinicar em sua cidade natal, Campos, RJ, veio a trabalhar no Museu Imperial, onde desenvolveu pesquisas no laboratório de fisiologia (*). Até a sua morte, defendeu a tese de que o beribéri era, de fato, uma doença de natureza infecciosa. Sobre o assunto, publicou os seguintes trabalhos:

Etiologia e gênese do beribéri, em 1884; O micróbio do beribéri, em 1887; Trypanosoma do beribéri, em 1906.

O ciclo de trabalhos que se orientaram pelo princípio do contágio influenciava fortemente as abordagens nas escolas médicas. Assim é que, numa tese inaugural da Faculdade de Medicina da Bahia. o autor afirma:

“... a theoria microbiana está fundada e cada dia mais se fortifica, clla dominará na medicina, porque é a única na actualidade que dá uma explicação simples e natural dos factos. O seu passado responde pelo seu futuro". (*)

* FREIRE, B. A Os microbios e as molestias contagiosas. Bahia, Imprensa Popular, 1887. p. 94.

259 ALMEIDA, T. de. O Beriberi no Brasil. Op. Cit. p. 103 
em Java. Um grupo de especialistas investigou a causa da moléstia e, sob a assistência do microbiologista Eijkman, que havia estagiado com Koch na Alemanha,

"Concluiram que essa doença era um tipo de polineurite e chegaram a isolar do sangue de pacientes e do ar, bactérias que consideravam possiveis causadoras do beribéri"260.

Contrariamente ao que sucedeu com Lacerda, este mesmo grupo, que chegou a isolar a bactéria' possivel causadora do beribéri, viria a revisar suas pesquisas, trazendo contribuições decisivas à nutrição. $O$ patologista C. A . Pekelharing (1848-1922), que conduziu trabalhos em Java na década de 1880 , depois de ter retornado à Holanda convencido da natureza infecciosa do beribéri, passa a conduzir, na primeira década do século XX, estudos controlados com alimentos, o que o leva supor a presença de substâncias ainda desconhecidas, mas essenciais para a saúde. Por sua vez, o microbiologista Christiaan Eijkman (1858-1930), mesmo permeado por sua especialidade, foi sendo convencido pelos resultados de seus trabalhos, a ponto de concluir, ainda no fim do século XIX, que

"um fator (mais tarde denominado Vitamina B-1) presente no arroz integral era necessário para o funcionamento do sistema nervoso e metabolismo de carboidratos"261.

Mas ainda em meio às teorias infecciosas para a etiologia do beribéri, uma importante comunicação surgia através do médico militar japonês Kanehiro Takaki (1849-1920)262. Na segunda metade do século

20 SANTOS, K. M. O . dos. O desenvolvimento histórico da ciência da nutrição... p. 157-8.

\section{EIJKMAN, C. Grolier Enc. Mult. Op. Cit.}

Por suas pesquisas na área de nutrição, C. Eljkman foi agraciado com o Prêmio Nobel (Fisiologia/Medicina) de 1929, juntamente com o bioquímico inglês que também desenvolveu estudos na ärea, Sir Frederick G. Hopkins (1861-1947). Coincidentemente, no mesmo ano que o descobridor da vitamina anti-beribérica ganhava o Prêmio Nobel, na area de literatura o ganhador foi o escritor alemão Thomas Mann (1875-1955). 
XIX, alguns paises asiáticos, entre eles o Japão, experimentaram repetidas epidemias da doença. A marinha japonesa sofria com o mal ( lá conhecido como Kak'ke) e as primeiras açōes que vieram combater satisfatoriamente a enfermidade nasceram das investigações e medidas preventivas deste médico. Ele concluiu, após quatro anos de estudos, que era a desproporção, na dieta, de nitrogênio (proteinas) e carboidratos a possivel causa do Kak'ke: excesso do último e insuficiência do primeiro. Assim, concluindo, ele alterou profundamente a qualidade e quantidade da dieta oferecida aos marinheiros, e, mesmo sem estar certo em suas conclusões e suposições, praticamente conseguiu reduzir a niveis minimos os casos de beribéri nas esquadras japonesas.

Nas teses de conclusão do curso médico, os formandos das duas escolas brasileiras continuavam a 'trabalhar' a doença no âmbito da sua sintomatologia, etc., sem efetivamente nenhuma investigação sistematicamente controlada. Marcha, duração, terminação, diagnóstico, tornavam-se tópicos descritivos dos trabalhos e os pressupostos etiológicos eram resultado de um inteligente exercício lógico que, mesmo inferindo conclusões veridicas, acabava tendo o mesmo grau de veracidade do que conclusōes não tão verídicas, pois o grande número de teses e artigos que utilizavam a mesma estratégia metodológica, sem que se praticasse nenhum critério aceitável de distinção, homogeneizava praticamente a maioria das 'boas' e 'más' hipóteses ${ }^{263}$. Discutiam-se

262 Este trabalho de K. Takaki é considerado um "clássico" na área de nutrição e metabolismo. Inicialmente publicado pelo periódico Transactions of the SEI-I-KWAI, 39(Suppl. 4): 29-37, 1885, foi reimprimido integralmente no periódico NUTRITION, v.8, n. 5, sept./oct., 1992, pp. 376-84. com comentários ("Prospective Overview") de K. Yokoi e H. H. Sandstead.

263 Seria cansativo e desnecessário listar todas as hipóteses que, na história do beribéri, foram levantadas para explicaí jua ctiologia. Citar sem contextualizar certamente ridicularizaria algumas e este não é um procedimento que nos ajuda a compreender os complexos caminhos que o processo de saúde e doença percorre na sociedade. Um bom exemplo disto são a "masturbação" e a "relação sexual mantida em pé" como fatores predisponentes - que alguns autores já citados também consideraram fatores causais - ao beribéri. Estas hipóteses nascem de suposiçðes lógicas fisiologicamente aceitáveis, e que, na ausència de recursos metodológicos satisfatórios, prevaleceram como hipóteses "sérias" durante muitos anos. A sofisticação dos processos investigativos veio a mostrar, não apenas do ponto de vista clínicu, como também epidemiológico, que o corpo ( na 
ainda questões relativas ao diagnóstico diferencial da doença e, neste sentido, algumas doenças mereciam ser destacadas. São moléstias que podiam ser confundidas com o beribéri mas, na leitura de alguns estudiosos, este risco relacionava-se mais com a qualidade do diagnóstico do que pelas semelhanças sintomatológicas. Alguns exemplos são:

"MYeltre (mielite). - A myelite aguda fica desde já excluída porque a confusão é impossivel"

"HYPOEMIA INTERTROPICAL (ancilostomiase; "opilação") . - “... pode assemelhar-se á opilação; ... Não é, porém, no seu começo... mas sim no periodo adiantado; ... então, a confusão também não é possivel ..."

"MAL DE BRIGHT (nefrite). - “... nesses casos, para differençal-os, não precisamos mais do que fazer a analyse das urinas... ";

"LESOES CARDIACAS. - “... a presença da lesão ovo-valvular constante $e$ as pertubaçōes sensitivo-motoras bem como o tratamento do beribéri, bastam para distinguil-as"264.

condição de possibilidades fisiológicas) ofereceu ao investigador do beribéri nuanças sutis cuja percepção dependeu mais de como se 'olhou' a doença (ou do "paradigma" que moldou este 'olhar'), do que dos recursos tecnológicos (e que são necessários) disponíveis para as pesquisas. Quando Eijkman "desconfia" que o problema do beribéri não está na esfera da microbiologia, o ex-aluno do respeitável R. Koch efetua, antes, uma operação de natureza conceitual que, amadurecida, o levará a desenvolver os artefatos necessários ao exame da sua nova suspeita: a possibilidade de doenças por deficiência alimentar.

A mesma discussão poderia ser feita se cesíviamos da fisiologia para a psicologia, etc. Se a eletro-hidroterapia foi indicada ( S. F. Souto, "Tratamento do beribéri pela eletro-hidroterapia", Gazeta Médica da Bahia, 1881), aspectos psicológicos também o foram ( E.M. da G. Coelho. 'Algumas observações sobre o beribéri examinadas do ponto de vista psicológico". RJ, 1886 ), como também o hipnotismo ( A . A . V. Barcelos, "Hipnotismo no beribéri", Brasil-Médico, RJ, 1889).

264 CARVAlHO, A. A de. Beriberi. Rio de Janeiro, Typ. de G. Leuzinger \& Filhos, 1886. p. 59-61. 
Por esta época, o padre Júlio Clavelin era instalado no Rio na condição de superior da Santa Casa. Sempre que se encontrava com João Alphonso conversavam sobre o Caraça e tornou-se um informante privilegiado do médico, fornecendo subsídios a este na elaboração do texto sobre o beribéri. Em mais de uma oportunidade, João Alphonso ponderou que, ao invés de escrever um texto, poderia reunir-se com os padres na Casa Central e comentar e recomendar verbalmente o assunto. Em todos os momentos, foi 0 padre Clavelin que argumentava 0 contrário. Dizia da autoridade do documento escrito e, principalmente, da manutenção da fidelidade ao autor, risco que não poderia controlar em caso de comunicação verbal. Além do mais, o mais provável é que seu texto deveria chegar ao Caraça. João Alphonso sentia-se ingênuo ao ouvir os argumentos do padre e, concordando sem restriçōes, dialogando consigo mesmo, dizia que a pretensa 'assepsia' do texto científico e sua estrutura, que mais parecia um 'corpo sem sangue', não era culpa dos padres lazaristas e que, por isso mesmo, eles mereceriam um texto lúcido, com anima, vivo, onde as palavras, como o sangue, inundassem o corpo, como o texto.

Com o padre Clavelin veio também o seu fiel amigo, o padre Caio. Professor e com várias atividades no Caraça por quase vinte anos, era um vinhateiro caprichoso e deu muitas informações sobre plantas a João Alphonso. Português, havia se ordenado em Paris e gostava de conversar com João Alphonso. Por seu interesse, é provável que o próprio padre Clavelin, conhecedor de João Alphonso, houvesse sugerido a ele que se aproximasse do médico amigo da Casa, mas existencialmente inquieto. João Alphonso aceitou a aproximação do padre Caio, moço de pouco mais de quarenta anos, e dizia-lhe, sorrindo, que sua presença tinha a agradável aparência de uma vinha em frutos: inteligência e potencial enorme que originaria bons produtos à Congregação. Se pade ser verdade ou não a sugestão do padre Clavelin, o fato é que João Alphonso perderia mais um amigo. Padre Caio faleceu de febre amarela, após incessantes cuidados que o próprio João Alphonso providenciou. $\mathrm{O}$ acompanhamento do enfermo e o seu envolvimento pessoal com o sofrimento do sacerdote 
levaram-no a mais um esgotamento, que precisaria de um bom tempo para ser superado265.

Enquanto as autoridades da capital imperial planejavam medidas para enfrentar a sua insalubridade, o ambiente da cidade deteriorava-se com o aumento da população. O saneamento da Lagoa Rodrigo de Freitas era uma necessidade urgentissima, bem como a drenagem do solo da cidade, a fim de se evitar

“... o humedecimento dos alicerces das habitações e remover a agua escapada dos exgottos, evitando o accumulo de microbios, que nesse tempo se acreditava sempre promptos a fazer irrupção, dadas as condições propicias ao seu desenvolvimento" 266 .

Neste ambiente, os políticos e a sociedade discutiam o destino dos escravos, discussão esta que vinha se arrastando desde 1871, quando foi decretada a Lei do Ventre Livre. $O$ jogo de interesses que motivava os diversos setores da sociedade em torno da escravidão ia do estado imperial à classe dominante, que temia a rebeldia dos negros, passando também pelos decadentes cafeeiros que tinham a mão de obra escrava como parte de suas fortunas. Assim, quando a Princesa Isabel sanciona a lei que abolia a escravidão, sem restriçōes, findava a questão da fundamentação legal desta escravidão e iniciava, entre outros, dois processos que atravessarão épocas no Brasil: a questão da inserção do negro da sociedade ( cidadania, acesso a bens e serviço, racismo, etc.) e as controvérsias sobre o papel da escravidão na história brasileira ${ }^{267}$.

${ }^{265}$ O padre Francisco Rodrigues Caio, português, nasceu em 1844 e chegou ao Brasil em 1868, indo !ccionar no Caraça. Morreu no Rio de Janeiro, em 1888, de febre amarelc ( $(*)$.

* Congregados no Caraça, manuscrito. Op. Cit.

266 FONTENELLE, J. P. Hygiene e Saúde Pública. IN: DICCIONARIO Historico... Op. Cit., p.427.

${ }^{267}$ Para FAUSTO $\left({ }^{*}\right)$

"Poucos temas da história brasileira têm sido tão discutidos e investigados como a escravidão. Há apaixonadas controvérsias sobre os indices de 
No Caraça houve escravos e, registrado, o mais antigo deles é um certo Manoel, morto a 9 de dezembro de 1859:

“... o velho Manoel, que fôra escravo do Irmão Lourenço, e que devia ter seus 120 annos passados, pois trabalhou na construcção da Igreja....268.

João Alphonso já estava a par das questões abolicionistas por aqueles lados da provincia mineira, pois o Dr. Vieira de Andrade, na última vez em que se encontraram no Rio, havia-lhe exposto os acontecimentos da sua região. Na sua cidade, Serro, a Câmara Municipal criou, anos antes da abolição, um fundo municipal

“... que liberta, de modo geral, mulheres em idade de 40 a 50 anos, algumas já sofrendo de males crônicos devido às atividades constantes de procriação"269.

mortalidade de escravos na travessia do Atlântico, sobre as possibilidades de organização familiar dos escravos, sobre o significado das alforrias..."

* FAUSTO. B. História do Brasil. Op. Cit., p. 221.

Obs.: Algumas questões mencionadas acima são descritas na Primeira Parte do presente trabalho.

268 SILVA, F. de P. Caraça: apontamentos históricos ... Op. Cit., p. 33-4.

Este falecimento é registrado no precioso manuscrito "Livro de óbitos do Caraça" (*), mas com a data de 9 de outubro de 1859. Neste mesmo manuscrito encontra-se registrada a morte dos seguintes escravos, com os respectivos dados:

\begin{tabular}{|c|c|c|c|}
\hline 1856 & & 90 anos & Escravo (do Ir. Lourenço) \\
\hline 186 & José Bahia & & Escravo \\
\hline Em 24-08-1874 & Vicente & 51 a 54 a & Ex. Escravo d \\
\hline Em 25-08-18 & Daniel & & Ex. Esc \\
\hline
\end{tabular}

O manuscrito cita, ainda, a morte de outros empregados diversos da casa, sem, contudo, especificar se se tratavam de escravos ou não. As ruínas da senzala, à esquerda do antigo portão principal e logo abaixo da ex-casa das sampaias, atestam a existência regular de escravos em número provavelmente bastante inferior ao de outras propriedades com características semelhantes às do Caraça ( demanda de serviçais para tarefas básicas, populaçåo fixa elevada, etc.).

* Livro de Óbitos do Caraça (Manuscrito). Arquivo do Colégio Caraça.

269 SOUZA, J. M. de. Cidade: momentos e processos. São Paulo, ANPOCS: Marco Zero, 1993. p. 138 
Ele afirmara, ainda, que

"E pela ação da Diocese que a voz antiescravista toma feições radicais de propor até mesmo um golpe de Estado para alcançar a abolição... [e que] Valendo-se da oportunidade do jubileu de S.S. Leão XIII, D. João [ Bispo de Diamantina e tio do médico Antônio Felício dos Santos, autor da memória "O BERIBERI NA PROVINCIA DE MINAS GERAIS” ], alinhado ao episcopado brasileiro, sob o comando do arcebispo primaz do Brasil, expede pastoral..., na qual, além de se referir ao engajamento pessoal à luta pela abolição desde 1849 , lembrando ainda a participação em 1862, conclama a população a se unir para celebrar o jubileu de sua Santidade ${ }^{\text {270 }}$.

Esta situação naquela região foi também sustentada e comentada com João Alphonso através do padre Bartolomeu Sipolis, que nessa época era o atual padre visitador da Congregação e que havia sido Superior do Seminário de Diamantina, conhecendo bem, portanto, a região ${ }^{271}$. Mas ambos não se delongaram muito neste assunto. João

270 Idem, p. 139.

$\mathrm{O}$ autor $\left({ }^{*}\right)$ afirma ainda que

“... o 13 de maio foi comemorado com solene Te Deum, muitos fogos, discurso, vinho do Porto e cerveja importada, além da cachaça dos inúmeros engenhos de cana".

Em nota baseada em registros do Arquivo da Prefeitura de Diamantina, comenta ainda que:

"Os meses de março e abril foram aqueles em que mais entraram barris, escarotes e piparotes de vinho e caixas de cerveja vindos da Corte, possivelmente preparando as festas do Divino e do rosário. Seguramente serviram para os festejos da Abolição no dia 14 de maio. Francisco Martins de Oliveira recebeu da Câmara $500 \$$ para ajuda, foram cinco vezes mais do que se dava para os festejos de Corpus Christi".

* Idem, p. 141.

271 O padre B. Sípolis é irmão do padre Miguel M. Sípolis, que por duas vezes ( 1854 57 e 1861-67) foi superior do Caraça. Ambos foram protagonistas da tentativa de se construir um cenáculo nas proximidades do colégio. Esta construção

“... é uma capellinha solida mas simplesmente construida a uns 500 metros a éste da casa e as uns duzentos metros mais alta que esta... Ao lado esquerdo 
Alphonso havia ido lá para entregar aos religiosos seu texto - que todos preferiram chamar de 'memória' - sobre o beribéri. Neste mesmo dia, a Casa central acabara de receber um lote de livros recém chegados da França e o padre visitador, que também ia inspecioná-los, convidou-o a examinarem os títulos, antes que falassem da 'memória'. Os livros que vieram estavam em diferentes estados de conservação: usados, novos, deteriorados pela viagem, etc., e seriam separados para que compusessem o acervo bibliográfico das diversas casas da Congregação. João Alphonso avistou entre os títulos uma publicação recente da área médica, L'Hygiene de L'Estomac: Guide Pratique de l'alimentation, do Dr. E. Monin. De fato, dissera-lhe o padre Bartolomeu, não era anormal que recebessem ocasionalmente livros recém saidos em Paris. Tudo dependia da simultaneidade de lançamento, compra, remessa de encomendas e saida de navios. L'Hygiene... é um guia sobre alimentação e nutrição, discutindo os regimes alimentares, com descrição de alimentos e bebidas, o processo digestivo e os alimentos, etc. Neste livro, a classificação dos

da capella levantaram um sobrado de dous andares tambem de pedras, com acomodações bastantes para uma commodidade de umas 20 pessoas. Sua ideia e realisação veio do Pe. Bartholomeu Sipolis que era lente e Director do Seminario Maior aqui [ no Caraça ]" (i, p. 46).

Apesar dos esforços dos empreendedores para, dentro da Congregação, conseguirem o apoio necessário à obra, o fato é que esta encontrava bravas resistências internas. As consequêências do acirramento desta disputa e o final melancólico da construção iniciada - que ainda hoje está representada pelas ruínas lá existentes - podem ser medidas pela expressão do padre Francisco Silva:

"O Cenaculo!... É uma pagina triste da historia do Caraça. É o melhor testemunho da inconseqüência dos homens; a prova que os mais santos mesmo se deixam cegar pela apparencia e determinam-se com as mais nobres intençð̃es, impulsionados pelo veneno subtil de alguma paixão ou ressentimento mal contido" (i, p.45).

Esta capela (Capelinha do Sagrado Coração de Jesus), décadas adiante, ligar-se-á à história do beribéri, já que a mesma será restaurada sob o superiorato do padre F. Silva, “... como promessa, feita a Deus, pedindo libertasse o Caraça da terrível doença do beribéri" (ii, p. 93-4).

i. SILVA, F de P. Caraça, apontamentos históricos... Op. Cit.

ii. ZICO, J. T. Caraça, peregrinaçao, cultura e turismo. Op. cit. 
alimentos não acrescenta nada mais além daquilo que já era conhecido há alguns anos pela medicina:

"Une division plus scientifique consiste à reconnaître des aliments minéraux ou inorganiques (comme l'eau, le soufre, le fer, le sel de cuisine, etc.) et des aliments végeto-animaux ou organiques (comme les viandes, les sucres, les graisses). Les aliments organiques renferment deux divisions importantes: les albuminoides, qui renferment de l'azote (albumine, fibrine, gélatine, etc.) et les hydrocarbonés, qui nén renferment pas (fécules, sucres, graisses, gommes, etc.)"272.

Após o breve exame de livros recebidos, João Alphonso retirou da pasta o seu texto e entregou-o ao padre. Disse que se tratava de uma contribuição e que aquele conteúdo era o resultado de uma reflexão que insiste em compreender a manifestação da doença como um processo absolutamente normal. Isso significaria, quis adiantar João Alphonso, que, antes de se pensar em, por exemplo, fechar o colégio e imaginar isolá-lo do mundo, a vida, em toda sua normalidade, deveria se fazer presente para os alunos que também lá cresciam e se desenvolviam. $O$ padre preferiu não dialogar sem antes ler, e folheou o manuscrito em

MONIN, E. L'Hygiene de l'estomac: Guide pratique de l'alimentation. Paris, Octave Doin éditeur, 1888. p. 5.

Este livro, em formato $10 \times 16,371$ p., integra o acervo da biblioteca do Caraça. Danificado pelas traças, o livro contém nas suas primeiras 70 páginas sinais e observações de um leitor padre (Pe. Francisco Maria de Siqueira ?). Sendo ou não este o padre, não foi possivel definir se as anotaçð̃es marginais foram feitas por um lazarista no Caraça ou não. De qualquer forma, entre as interrogaçðes que constam, duas se referem à seguinte passagem, sendo que uma interrogação chama a atenção para o trecho que o presente trabalho destaca em itálico:

"L'action des aliments sur les divers organes est, d'aillcurs, bien différente, selon leur composition; cette action s'éllève même à une véritable importance sociale. Supposez, dit un grand chimiste, trois personnes, dont l'une s'est rassasiée de boeuf et de pain, l'autre de pain et de fromage, la troisième de pommes de terre: ces trois personnes considéreront chacune à un point de vue bien différent une difficulté qui se présentera à elles. C'est que l'action de ces divers aliments sur le mouvement nutritif du cerveau, organe de la pensée, variera certainement, suivant les principes spéciaux que ces aliments peuvent renfermer" (p. 4). 
letras miúdas e uniformes que pareciam ter sido escritas de uma só vez. $\mathrm{Na}$ capa, o título "Considerações sobre o beribéri no Caraça" e, logo abaixo, anunciava-se o autor: Dr. João Alphonso Azevedo Magalhães. Na segunda página, um indice atípico causou estranheza ao padre, tanto na forma como no conteúdo. A leitura rápida desta página, o padre arregalava os olhos e a testa discretamente, como se manifestando espanto e curiosidade:

1. O que se vê, como é e os modos de contar: ensaio introdutório;

2. As doenças, suas denominaçōes e classificação: como combinar cores;

3. Uma doença, um pesquisador e o arco-iris branco: como isolar uma cor;

1.1. Dizem que o beribéri é endêmico no Caraça: quem conta o que;

2.1. O meio e a doença ou o meio e as doenças: do que pode se adoecer no Caraça;

3.1. Se é beribéri (ou outra doença): como lidar, o que fazer, o que não fazer.

O padre interrompeu a consulta preliminar e, antes que se despedisse de João Alphonso, afirmou que submeteria a memória à apreciação dos colegas, que aguardavam esperançosos a contribuição do médico para se armarem eficientemente contra o beribéri.

Das discussões que gravitavam em torno da eventual proclamação da república, João Alphonso se ateve a um aspecto que o Clube Republicano do Rio de Janeiro vinha realçando esporadicamente: a restauração da memória do inconfidente Tiradentes. Este assunto sobreveio-lhe porque era recente a leitura que fizera do livro "Memorias do Districto Diamantino da Comarca do Serro Frio". No livro, o autor, tio e ao mesmo tempo cunhado do Dr. Antônio Felício dos Santos, refere-se ao entusiasmo daquela região com as articulações que se constituiriarn no movimento que seria denominado de Inconfidência Mineira:

"Talvez que em parte nenhuma da Capitania fosse ela aceita com mais entusiasmo que na Comarca do Serro Frio: $\dot{e}$ que sobre nós mais pesava o jugo da metrópole. Os 
conciliábulos faziam-se alta noite em casa de José da Silva e Oliveira, pai do padre Rolim.... Os conjurados eram todos iniciados na maçonaria, introduzida por Tiradentes, quando por aqui passou vindo da Bahia para Vila Rica. Contavam com o apoio de toda a população e só se esperava o rompimento em Vila Rica..."273.

Os laços reconhecidamente republicanos de Joaquim Felício, tio, e Antônio Felício dos Santos, sobrinho, que nesta época já morava no Rio, onde, inclusive, foi deputado por duas legislaturas, insinuavam que a figura de Tiradentes se adequaria convincentemente aos ideais republicanos. A contemporaneidade e incapacidade de estabelecer um vinculo dos cidadãos com o ideal, desqualificavam os "atores" republicanos a se constituirem como heróis' do processo ${ }^{274}$. Reservadamente, conforme a sua própria discrição, Vieira de Andrade, que fora colega de Antônio Felício numa mesma legislatura, assegurava $o$ despropósito de se associar a figura do inconfidente ao ideal republicano. Era uma questāo complicada de se tratar com o reservado Joaquim, que mantinha, enclausuradas em si, as convicçōes e opiniões sobre muitos temas, apesar de pertencer ao partido liberal: a moeda religiosa pesava forte na demarcação dos seus valores. Menos falante que Antônio Felício, ele reservava aos intimos consistentes juizos de valores. $O$ fato é que Joaquim de Andrade pronunciou-se sobre Joaquim José de maneira que desqualificava o personagem. Na provincia mineira, a memória de Tiradentes, ao contrário do que se supunha, não gozava de idolatria irrestrita. Polèmico, havia quem visse Tiradentes apenas como um

273 SANTOS, J. F. dos. Memórias do distrito diamantino. Belo Horizonte, Ed. Itatiaia ; São Paulo, Edusp, 1976. p. 166.

274 Aqui, o conceito de 'herói' é tomado de Carvalho $\left({ }^{\star}\right)$, referência que estimulou a abordagem deste tema republicano no presente trabalho. Para ele,

"Heróis são símbolos poderosos, encarnações de idéias e aspiraçðes, pontos de referência, fulcros de identificação coletiva. São, por isso, instrumentos eficazes para atingir a cabeça e o coração dos cidadãos a serviço da legitimação de regimes politicos".

* CARVALHO, J. M. de A formação da almas - o imaginário da república no Brasil. São Paulo, Companhia das Letras, 1997. p. 55. 
coadjuvante no núcleo esclarecido que, concentrado em Vila Rica, discutia idéias de liberdade, independência, etc., sem, necessariamente, nenhum lastro formal que garantisse a exequibilidade dos resultados daquelas discussões. Assim, a inconfidência, segundo esta opinião, teria sido um "movimento de idéias" de um dado "circulo ilustrado", plasmado em circunstâncias que exacerbavam o discurso separatista, desprovido, entretanto, de qualquer projeto estratégico que sustentasse a efetivação do incipiente ideário inconfidente. Neste meio, Tiradentes teria sido a vítima que pagaria por duas propriedades suas: não era um 'esclarecido' do grupo, politicamente talvez fosse o menos influente', sem lastro familiar, e também teria sido aquele que propangandeava vulgarmente o sentido das discussōes do mesmo grupo, assumindo, sem nenhuma vantagem prática, graves riscos diante da polícia política da metrópole ${ }^{\mathbf{2 7 5}}$.

O que João Alphonso procurava era perceber os mecanismos que tornavam o elemento mítico um poderoso agente emulsificador da sociedade com o processo político em andamento. Era interessante observar, lendo os discursos dos lideres, como este 'elemento' surge, e o faz como esteio do próprio discurso e não apenas como peça decorativa que ilustra uma idéia. $O$ mito não surge como metáfora, insurgia-se contra a própria idéia de qualquer metáfora; o mito surgia como condição irrestrita para a propria existência do projeto. Sem acentuar suas observações a respeito da transformação do inconfidente em 'herói' da república, João Alphonso projetava seu interesse no impacto de uma nova ordem na inteligencia e mentalidade canonicamente disciplinada do amigo Joaquim de Andrade. Mais de uma vez, quando se deparava com teias de aranhas, João Alphonso se lembrava de Joaquim: fios tênues,

${ }^{275}$ Em "A sombra do Tiradentes" (*, p. 109) E. FRIEIRO, citando vários autores, discute as circunstâncias históricas e a figura de Tiradentes na Inconfidência. $O$ autor manifesta concordância àqueles que

“... subestimam a importância histórica da conjura larvar de 1789 e reduzem a proporçðes modestas o papel do homem afoito que pagou com a vida por falar de mais e deitou a perder poetas, padres, doutores e militares, pelo único crime de terem externado o seu inconformismo político."

* FRIEIRO, E. O diabo na livraria do cônego. Belo Horizonte; Ed. Itatiaia : São Paulo; Edusp. 1981. 
espirito delicado, simetricamente estruturado, e um mundo em volta a disparar flechas, pedras e tiros.

O calor da cidade não se despedia ao entardecer. João Alphonso procurou a varanda para descansar, pois não se sentia bem acomodado em cômodos nunca suficientemente ventilados. Desde que voltara a trabalhar depois da morte do padre Caio, costumava queixar-se do pouco conforto dos consultórios e enfermarias, mas, mesmo sob a recomendação de colegas, que o incentivavam a se submeter a um descanso prolongado, insistia em manter suas atividades regulares. Ao se acomodar, teve a sensação de que um sonho desejasse o seu sono. Uma lâmina medianamente opaca parecia ter se colocado entre os seus olhos e o mundo natural e, esmaecido, resignou-se sobre o que poderia ser. Não conseguiria opor-se a nada que se manifestasse. Fechando os olhos, visualiza uma bolha que cresce à medida que madorna. No exato momento que uma agulha imensa rompe e explode a bolha, ele é interpelado por alguém da casa, comunicando que um visitante aguarda ser atendido:

- Disse ser o dr. David Ottoni e que gostaria de falar com o senhor. João Alphonso, sem muito esforço, lembrou-se do parente de Joaquim de Andrade que, anos atrás, se formou com uma tese sobre o beribéri. Com certeza David traria notícias do Serro e do amigo que havia sido eleito na última eleição do império. Como estaria agora ?

- Faça-o entrar. Eu o receberei na sala. - Disse João Alphonso, levantando-se.

- É um prazer revê-lo, doutor Magalhães, como vai o senhor ? Disse David.

- Bem, obrigado. Andam dizendo que eu preciso repousar um pouco mais ... essa gente acredita que me farei eterno descansando ! Assente-se, por favor, fique à vontade.

- Mas com certeza todos desejam ter o senhor trabalhando saudável por muito tempo ... - procurou o diálogo, David.

- Será mesmo ? Pois para mim o que está em jogo, quando preocupamos em demasia com a saúde dos idosos, è a transitoriedade. - 
Disse João Alphonso, que, diante do semblante incerto do jovem David, pôs-se a esclarecer:

- A transitoriedade nos faz ser nos limites do nascer e morrer. São os limites do tempo de cada um. Acudir os mais velhos é a tentativa mesma de romper este limite.

- Mas os velhos, quer seja pela família ou pelos médicos, nem sempre são cuidados satisfatoriamente, nós sabemos bem. - disse David.

- E continuarão a não ser por não sei quanto tempo. Um velho é sempre uma fotografia da estação final da transitoriedade. Este mundo desumano em que vivemos não se interessa por estas coisas. Nascimento e morte, começo e fim ... Mas não creio que você tenha vindo aqui para conversarmos sobre estas coisas; continua a estudar o beribéri?

- A clínica tem me afastado das investigações, mas procuro manter-me informado. Tive informaçōes de que o senhor elaborou uma memória acerca da doença no Caraça. Eu gostaria de consultá-la oportunamente. Mas o motivo da minha vinda até aqui é outro.

David, desajeitadamente, procurou acomodar-se na poltrona, para, em seguida, diante de João Alphonso que o mirava como se mesclasse instantaneamente diálogo e reflexão, dizer:

- Talvez o senhor ainda não saiba o que ocorreu com o meu primo, o Dr. Joaquim, e como o senhor é uma das poucas pessoas com quem ele mantinha contato regular, a familia encarregou-me de comunicar ao senhor pessoalmente.

Sem que houvesse nenhuma reação de João Alphonso, David continuou:

- Meu primo estava a caminho do Rio de Janeiro, quando, em Barbacena, tomou conhecimento da proclamação da república e dos primeiros decretos do governo provisório. O senhor o conhece bem... Rigorosamente religioso, devoto, Joaquim foi profundamente perturbado pela situação e de uma hora para outra perdeu completamente a razão. Está internado no manicômio de Barbacena mesmo.

João Alphonso manteve-se impassivel. Após um breve tempo, perguntou:

- Você que conhece o quadro, qual o progróstico ? 
- Eu não pude entrar em detalhes com os médicos que o atenderam e eles não quiseram ser conclusivos. Acharam melhor transferi-lo para o Hospício Nacional daqui.

- E o que você acha disso ? - Perguntou João Alphonso, ainda impassivel.

- Pessoalmente eu gostaria de cuidá-lo no Serro, na nossa família, entre seus amigos.

- Herr Doktor, das ist schön von Euch - disse João Alphonso, deixando a aparência impassivel e tornando-se emocionado. David insinuou que não havia entendido, e João Alphonso reafirmou:

- "Isso é bonito de sua parte, senhor doutor". É Goethe. Fausto. Leia-o .

João Alphonso levantou-se e, dirigindo a David, disse, com cordialidade:

- Muito obrigado por trazer-me a notícia. Agora, você não se incomodaria se eu lhe dissesse que preciso ficar a sós?

- Naturalmente que não, doutor. Espero revê-lo noutra ocasião276.

Dados biográficos do médico Joaquim Vieira de Andrade são mínimos e esparsos. $\mathrm{Na}$ sua cidade natal, Serro, nem referência bibliográfica foi encontrada a partir da 'Casa da Cultura' do município. Salles (i, p.201), em suas memórias, descreve assim as circunstâncias em que o médico adoeceu:

"Em fins de 1889 tinha sido [J.V.Andrade] ainda uma vez eleito deputadogeral, mas ao chegar a Barbacena com destino à Corte foi surpreendido com a revolução republicana e os primeiros atos do Governo Provisório: separação da Igreja e do Estado, casamento civil, cemitérios leigos. todas essas medidas anticlericais o perturbaram tão profundamente, que perdeu por completo o uso da razão. Permaneceu os primeiros tempos de loucura internado no manicômio de Barbacena, sendo transferido para o Hospício Nacional, em seguida para o Sanatório de São João d'El-Rei, até finalmente voltar para o Hospício Nacional".

É certo, conforme informação da "Casa de Cultura do Município do Serro", e, ainda segundo Senna (ii, p. 17), que Vieira Andrade morreu sete anos após ter manifestado a doença e que foi enterrado em São João d'El-rei:

"Morreu louco, depois de atrozes 7 annos de perda da razão, no Hospital de Alienados da cidade de S. João d'El-Rey, em 26 de Fevereiro de 1897".

i. SALLES, J. de. Se não me falha a memória. Op. Cit.

ii. SENNA, N. de. Serranos ilustres. Op. cit. 
João Alphonso dirigiu-se a seu escritório, procurou em seus arquivos e encontrou um antigo exemplar da Revista trimensal da Sociedade Instituto Acadêmico. Abriu na página 70 e começou a ler o artigo "Influência da civilização sobre as moléstias", escrito por Joaquim Vieira de Andrade. Não sendo interrompido por ninguém, permaneceu durante horas no escritório. Na manhã seguinte, acordou cercado pelos familiares e um médico conhecido em torno da sua cama.

- Posso saber o que me aconteceu?

- Pai, encontramos o senhor desmaiado no escritório. Parece que está tudo bem, o senhor já foi medicado. O senhor lembra-se do que aconteceu?

- Lembro apenas que lia um artigo e, depois de algum tempo... não sei quanto... não lembro de mais nada.

- Bem doutor João Alphonso, acredito que o melhor é o senhor repousar. O esforço que tem feito para assumir os compromissos tem lhe causado algum desgaste. - Disse o médico, sem muita conviç̧ão diante de um colega mais experiente.

Olhando para o esposo, Beatriz expôs sua idéia:

- João, porque não vai descansar na Alenlé? A fazenda é confortável e o ar muito bom. Em poucos dias estaria pronta para te receber.

- Não é má idéia, mas antes ainda quero ver o mar.

A fazenda Alenlé continuava como propriedade da familia de Beatriz. A casa, bem cuidada, continuava de acordo com as mudanças que foram feitas na época em que foi comprada. Houve melhorias nas instalaçōes: currais novos, moinhos, uma pequena represa e outras construções que serviam aos empregados e à manutenção. A visão que se tinha da mata atlântica a partir do salão superior continuava a mesma: esplendorosa. Também de uma parte da ala esquerda dava para ver, agora, os currais novos, cuja movimentação João Alphonso costumava observar: a ordenha, o pasto, o recolhimento e apartação dos bezerros, a ordenha; a entrada e saida de vacas com bezerros novos e velhos e o muito e pouco leite de cada uma. Atento, conseguia perceber a rebeldia de algumas vacas que derrubavam com um coice $o$ balde de leite, 
dificultavam a 'apeação' ou mesmo simulavam investir contra o vaqueiro. A resposta a isso era um pedaço de pau, falas ríspidas e grosseiras... O curral era um templo simplório, uma arena de fezes e urina, onde as rotinas diárias, sabidas e conhecidas, se desenvolviam à mercê puramente dos instintos.

João Alphonso passava a maior parte do tempo no salão superior. Costumava não deixar o salão para fazer as refeições regulares, e, por isso, foi providenciado servi-lo lá mesmo. Lia e conversava pouco corn familiares. Um dos padres amigo, sabedor do seu estado de saúde, havia chegado para visitá-lo na tarde anterior, e subiu ao salão para conversar. João Alphonso cansava-se com diálogos longos, por isso o padre sabia que os diálogos deveriam ser abreviados.

- Então, meu amigo, espero que não tenham the enchido de recomendações sobre como tratar-se comigo. Não sabem que conhecemos tanto nossos limites... - disse João Alphonso ao padre.

- Não se preocupe, doutor João...

- Trate-me por João Alphonso, sem cerimônia, padre.

- Estamos a par do seu estado de saúde e a escolha do local para se recuperar foi excelente. É um belo sítio.

- Às vezes creio que eu esteja tentando recuperar-me de mim mesmo. Melhor seria se eu estivesse fugindo da peste, que nem os jovens do Bocage. Eu preferiria.

- João Alphonso, o senhor precisa evitar este tipo de consideração. Precisa recuperar as suas forças, o seu trabalho é necessário e aguardado.

- Desculpe-me, padre, o senhor não teria uma outra proposição ? O local, como o senhor mesmo disse, é muito belo para perdermos tempo repetindo nós mesmos. Diga-me, o que fizeram com o texto que escrevi sobre o beribéri no Caraça?

O padre não conseguiu manter a naturalidade. Numa ação rápida, solicitou alguns minutos para beber água e, ao voltar, comentou cautelosamente, procurando ser cordial:

- De fato, a memória que o senhor escreveu possui muitas utilidades. O senhor hả de convir que, para qualquer instituição alterar seus procedimentos e rotinas, requerem-se discussões e tempo. A Casa 
Central preferiu enviar o texto para ser examinado pelos próprios colegas do Caraça, antes que qualquer medida fosse tomada.

Percebendo a sutileza do religioso, João Alphonso preferiu ser genérico:

- Padre, às vezes reclamam que a medicina quer ordenar os comportamentos dos individuos na sociedade, ditando regras higiênicas; às vezes reclamam de nós médicos, dizendo que usufruímos, para causa própria, do nosso prestígio social. Não é necessário dizer que existe uma certa dose de razão nestes argumentos, eu sei. O que mais me espanta, entretanto, é que os individuos em particular e a sociedade em geral jamais levam em conta a dependēncia que eles mesmos criam em relação aos médicos e à medicina em geral. Doença e saúde, especialmente esta, que são processos naturais, estão cada vez mais se tornando processos médicos, de politica médica. Sabe, padre, eu me pergunto o que querem as pessoas, as instituições... Transformarem o corpo, os colégios, as cidades, paises, a terra, enfim, numa bolha asséptica por responsabilidade e cuidados dos médicos? Uma vez, conversando com o padre Benit, eu tive a esperança de que a prática religiosa pudesse estabelecer uma reflexão sobre os problemas da sociedade desumana. Entretanto, mesmo a igreja teme correr riscos. Minhas esperanças eram infundadas. Nolite locum dare diábolo ${ }^{277}$. Medicina e religião estão unidas pela doença e pelo pecado como demônio. Um casamento vantajosos para ambos.

Notando que João Alphonso era cada vez mais veemente, o padre tentou amenizar, ressalvando sua citação biblica:

- Eu entendo o seu argumento, meu amigo, mas fico mais feliz em saber que lê a biblia sagrada. Deus acolhe os filhos não pela filiação nominal, mas pela ação. Sempre tive dificuldade de compreender suas inquietações e questionamentos, mas posso lhe garantir que estes predicados não o impedem de se considerar um legitimo filho de Deus.

João Alphonso quis detestar a observação do padre, mas lembrou que já havia aprendido: retaliar uma consideração dogmática favoreceria

277 "Não deis em vós lugar ao demônio." (Ef 4,27) 
muito mais o interlocutor, e preferiu argumentar, tangenciando o comentário do padre:

- Ora, padre, como eu não poderia ler a bíblia ? Uma obra que está presente na formação dos jovens, na reflexão de adultos, enfim, um calhamaço de paginas que governa a vida de milhões de pessoas mundo a fora. Como conhecer o ser humano sem, pelo menos, ter informações do seu guia espiritual ? A propósito, e ainda sobre o que lhe falava, o senhor não crê que eu e o Mateus não nos entenderiamos muito bem? Ele diria ao mundo: "Vigiai e orai para não cairdes em tentação " e eu diria: Investigai e tratai para não cairdes em doença.

Antes que pudessem continuar a conversa, alguém os avisara que o médico, que acompanhara João Alphonso por uns dias, estava pronto para retornar ao Rio de Janeiro, João Alphonso quis ir ao encontro do colega para a despedida. Acompanhado do padre, desceu lentamente a escada de madeira e, já na sala, encontrou o seu médico conversando com familiares seus:

- Então o senhor acha mesmo que estou ficando curado, doutor. É uma grande notícia. - disse João Alphonso, amistosamente.

- Eu estou satisfeito com a sua recuperação, doutor João Alphonso. Quando eu retornar aqui nos próximos dias, espero vê-lo ainda melhor. Estou deixando toda a medicação necessária até meu retorno. - disse o médico.

- O nosso padre parece que gostaria da sua companhia para retornar, o senhor o acompanharia ?

Surpreso com o comentário, já que planejara retornar apenas no dia seguinte, o padre compreendeu que João Alphonso talvez se sentisse melhor na ausência de visitantes e, com resignação, aceitou a orientação, dirigindo-se ao médico:

- É claro, doutor, podemos partir quando desejar.

João Alphonso resolveu acompanhá-los até o pátio. O tempo fresco e uma brisa agradável traziam da mata um aviso: olhai-me. De fato, a mata atlântica estava maravilhosa. O céu claro permitia ver, de longe, árvores floridas que, em meio ao verde intenso, portavam-se como uma tela imensa e bem pintada com pontos vivamente coloridos. A mata não é um quadro e um quadro não é a mata. Por que nos elegem para este encontro ? João Alphonso sorriu discretamente desta sua abstração. $O$ 
grupo no pátio percebeu, entreolharam-se sem comentários. $O$ médico e $o$ padre aprontaram-se, despediram-se mais uma vez e João Alphonso quis acompanhar os dois, avistando-os pelo caminho até perderem-se de vista na primeira colina. Beatriz, enquanto João Alphonso avistava os viajantes, ajeitava os ramos de flores que pendiam de uma grande panela velha, feito vaso. Num gesto inesperado, o marido tomou a esposa pelos braços e disse:

- Você já reparou a mata, está mais colorida hoje ?

- É verdade, João. Meu Deus, como está bonita!

- Aquelas flores te merecem, Beatriz.

Beatriz sorri e convida o marido a entrarem. João Alphonso sugere que ela vá, enquanto ele aproveita um pouco mais a agradabilidade daquele dia. Sozinho, observa mais um vez a mata e as flores e ainda vê, pela última vez, a mulher cruzar a porta. Em passos lentos, mas determinados, seguiu rumo à mata para colher flores para Beatriz. 


\section{QUARTA PARTE}

Pequenos prados cobertos de flores eram avistados de um lado e outro do caminho que avançava pela serra do Caraça. Estes prados floridos comportavam-se como ilhas de pétalas entre a serra rochosa que se espalha num mar de morros, avistados em número maior na medida em que se ganha mais altitude. Nesta situação, a vegetação competia delicadamente com a aparente inospitalidade do terreno: além da beleza das velosiáceas, donde sobressaiam as estéticas canelas-de-ema, o solo era generosamente atapetado por gramineas que escondiam em vão plantinhas diminutas que floriam rente ao chão, enfeitando o solo rico em minério de ferro. Um festival de tonalidades de cores e formas que surpreendia olhares. Além disso, apegada às rochas, uma vegetação alpestre esperada: liquens diversos, musgos, fetos e, parecendo sair diretamente das rochas, orquídeas de flores esplêndidas que cresciam das fendas e sugeriam vigiar discretamente a pequena caravana que passava.

O irmão Jean-Baptiste Moermans observava curioso esta natureza tão diversa daquela em que nascera, sobre um cavalo, a passos lentos, subindo a serra. Quando criança - ele lembrava - passeava com amigos pela margem do rio que cortava a cidade, Antuérpia, e observava inflamados patrícios, cantando o hino flamengo. Inspirado pela circunstância, tentou lembrar timidamente o hino e o cantarolou baixinho, mas com fervor, a primeira parte:

"Zij zullen hem niet temmen,

de fiere Vlaamse Leeuw,

al dreigen zij zijn vrijheid

met kluisters en geschereeuw.

$\mathrm{Zij}$ zullen hem niet temmen

zolang één Vlaming leeft,

zolang de Leeuw kan klauwen,

zolang hij tanden heeft"278. 


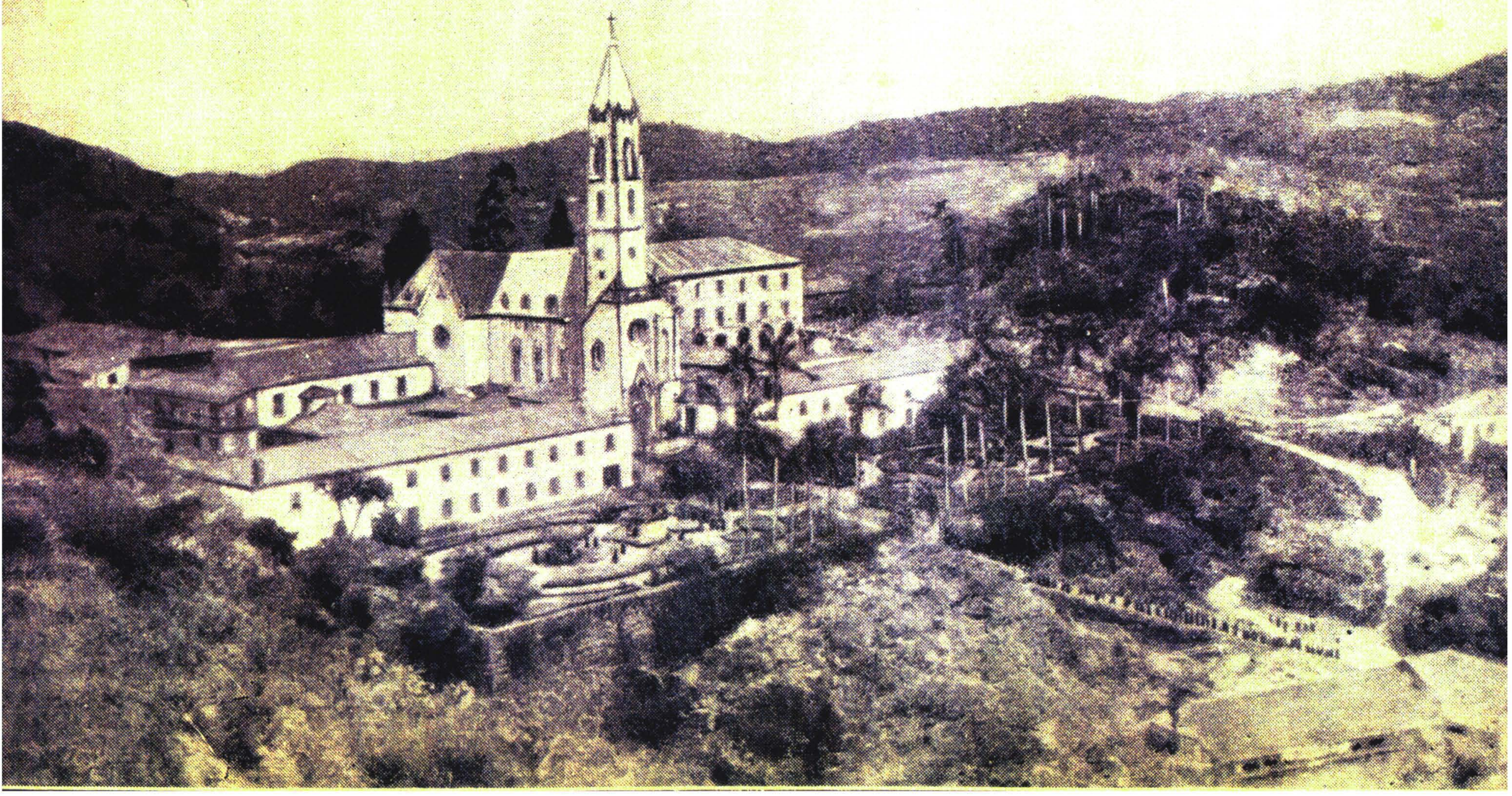

O Caraça, em foto de 1890.

O jardim, à direita de quem entra, foi, poucos anos depois, transformado num pátio destinado à prática de atividade física, cuja ausência era tida como uma das causas do beribéri. 
Surpreso, Moermans percebia também a variedade de árvores nos campos serranos. Seus conhecimentos de botânica permitiam distinguir as bignoniáceas $\mathrm{e}$, como hábil marceneiro, tentava avaliar as propriedades de cada tipo de árvores, parando, em alguns momentos, para examinar uma ou outra. A sua curiosidade era atiçada pela sinuosidade e ingremidade da estrada, que escondia surpresas a cada curva. A fauna parecia querer competir em cores e especificidade com a flora: após uma das curvas, um gavião caçador levanta vôo predando uma pequena serpente; adiante, codornas em vôos curtos; uma vez ou outra, beija-flores e tucanos em vôos ágeis riscavam de cores a visão do horizonte ${ }^{279}$.

Este percurso para o Caraça era indicado para quem saisse de Mariana, como era o caso do irmão Moermans, que aportara por lá vindo do Rio de Janeiro e antes de seguir para o colégio da serra. Caminho já centenário, sua beleza e singularidade eram proporcionais à sua dificuldade. De Mariana ou do Caraça, todos conheciam histórias de viajantes que empreenderam viagem por este percurso. Destas histórias,

278 "Não dominarão

o orgulhoso leão flamengo

mesmo impedindo sua liberdade

com jaulas e gritos.

Não o dominarão

enquanto um flamengo viver

enquanto o leão tiver garras

enquanto ele tiver dentes."

"O leão flamengo" é um hino inspirado na obra principal de Hendrik Conscience (18121883), o mais conhecido escritor flamengo do século XIX. Esta obra, de 1838, é "um verdadeiro épico nacional (i). A letra do hino é de $\mathrm{H}$. Van Peene (1811-1864), a música de K. Miry (1823-1889) e a presente tradução, do original flamengo (ii), para o português deve-se à Sra. Agnes Wauters Jansen (1936- )

i. D'HAEN, T. Hendrik Conscience. Grolier Mult. Enc. Op. cit.

ii. De Vlaamse Leeuw. http / www.ping.be/ ping2881/vlale.txt

279 J-B Moermans nasceu em Antuérpia, Bélgica, em 24 de junho de 1836. Em 1891 chega ao Brasil e, neste mesmo ano, segue para o Caraça. Aí, após doze anos servindo como irmão coadjutor, morre, a 8 de agosto de 1903. Seu capricho como marceneiro está registrado nos bancos que ainda hoje mobiliam a igreja do colégio. Estes bancos foram feitos, com a colaboração do Pe. L. G. Boavida, utilizando madeira da regiåo. 
a mais conhecida dizia respeito à memorável viagem que Dom Frei Cipriano, então bispo de Mariana, fez até o Caraça, em 1805. Obeso, o bispo enfrentou sérias dificuldades para cumprir o trajeto:

“... não sabemos quem mais sofreu: se o cavalo que o transportava, se o cavaleiro que muitas vezes se arrependeu da empresa começada"280.

Moermans, entretanto, não se importava tanto com o cansaço inevitável. Preferia admirar a paisagem e a imponência do pico do Inficionado, que despontava pela sua altitude e que, então, era considerado o mais alto das proximidades ${ }^{281}$. Naquela altura da viagem, já se criava a expectativa em quem, pela primeira vez, iria conhecer o Colégio Caraça. Atingia-se o ponto de onde, após vencer uma última curva, se poderia avistar completamente o vale onde o irmão Lourenço edificara o seu santuário. A distância permitia apenas ver um ponto que prenunciava edificaçōes e, ao avançar, ficava mais nítida a torre da

280 A circunstância desta viagem é descrita em relatório do próprio bispo que, por ordem régia, visitou o então "Hospício de Nossa Senhora Mãe dos Homens", conforme transcreve ZICO (i) que, em entrevista por ocasião do presente trabalho (ii), conta hilaricamente a difícil viagem do bispo "gordo", a cavalo, de Mariana ao Caraça.

Pe. Sarnel, em seu manuscrito (iii), relata a morte, em 1913, do padre francês M. J. E. Dorme, citado na literatura sobre o colégio como Pe. José Dorme, que morreu

"subindo a serra do Caraça onde ia repousar".

O Pe. Dorme (1845-1913) chegou para o Caraça em 1879 e em 1891 era, aí, o diretor das missð̃es, i.é, responsável pela atividade missionária dos religiosos, especialmente pelo interior de Minas Gerais. Pode ser que o Pe. Dorme trafegasse pela estrada de Mariana, mas, caso tenha sido noutra estrada, o que deve ser registrado é a dificuldade de acesso ao Colégio ainda nas primeiras décadas deste século. A primeira estrada de rodagem viria a ser construída em 1926 e o asfalto, posto em 1976.

i. ZICO, J. T. Caraça: peregrinação, cultura e turismo... Op. Cit., p. 23.

ii. Entrevista concedida pelo Padre José Tobias Zico, em julho de 1996.

iii. "Congregados no Caraça". Op. Cit. p. 64.

2814 “... em 1890 o padre Arcádio Dorme teria medido a altitude do pico do inficcionado (2000 metros de altitude" $(*)$.

* SIl VeirA, A da. Floras e Serras Mineiras. Belo Horizonte, Imprensa Oficial, 1908. p. 146. 
igreja. Diante desta igreja, o irmão Moermans, em momentos extremamente introspectivos, iria recordar novamente sua infância belga: sem comparar as proporções de beleza, a pequena igreja de traços góticos do Caraça fazia-o lembrar da majestosa catedral da sua cidade natal, tão distante, tão próxima, e que jamais voltaria a ver ${ }^{282}$.

Enfim, após percorrer o caminho já dentro da bacia que moldava o relevo onde o Colégio se assentava, a pequena caravana aproximava-se do pátio da casa. Neste momento já havia mais de uma pessoa a esperar: receber companheiros, visitantes, encomendas, correspondências, etc. Moermans foi atendido em francês por um padre e, ao mesmo tempo que observava atentamente sua nova casa, foi conduzido ao interior do prédio. O superior, padre Boavida, saudou o novo irmão coadjutor com quem conversou alguma coisa sobre a oficina de marcenaria que ele próprio mantinha zelosamente. Combinaram em breve conversar sobre carpintaria e marcenaria: havia muitos serviços a serem feitos e, entre eles, os novos bancos para a igreja. Enquanto ao Irmão Moermans era apresentado o colégio, Padre Boavida pôs-se a examinar as encomendas e correspondencias que chegaram. De um envelope comum sacou um manuscrito intitulado "Considerações sobre o beribéri no Caraça" e, pelo nome do autor, historiou rapidamente o documento, porque $o$ conhecia através do irmão Mourão, que lhe remetera informações sobre a botica. Mas ao manuscrito, que ele preferiu separar para leitura posterior, estava anexado apenas um breve bilhete, indicando que se tomasse conhecimento e o arquivasse. Em seguida, o superior examinou as últimas deliberaçōes da Congregação, os comunicados gerais e leu, então, correspondência do superior do Rio de Janeiro, na qual ele

282 A Catedral de Antuérpia - igreja de Notre-Dame -, cuja torre mede 123 metros de altura, é um edifício gótico de "beleza e elegância incomparáveis", adornada com verdadeiros tesouros artísticos, entre eles trabalhos do pintor Rubens (1577-1640). Sua construção foi iniciada no século XIV, mas, em algumas circunstâncias, sofreu consideráveis avarias:

“... um incèndio em 1533, pelos iconoclastas em 1566 e pelos revolucionários em 1794" (*)

* SEYN, E. DE. Dictionnaire historique et geographique des communes belges. Bruxelles, A. Bieleveld, Éditeur, 1924. v. 1, p. 31. 
comunicava o falecimento do médico da Santa Casa, e amigo da Congregação, Dr. Joāo Alphonso. Naturalmente voltou o olhar para o manuscrito que separara para leitura posterior e até admitiu que o "arquive-se" recomendado tivesse a ver com a morte do seu autor. Esse comunicado fizera-o lembrar-se do colega e amigo que falecera no Rio sob cuidados intensos do Dr. João, o padre Caio. Por alguns eternos segundos recordou a contribuição, abnegação e qualidades do padre Caio nos seus anos caracenses, concluindo sobre o quanto este colégio deveria ser grato a homens que dedicaram suas vidas à sua existência tão proficua. Ainda tomado por este breve momento de reflexão, o superior deixou de lado o restante da correspondencia e quis procurar pessoalmente o irmão Mourão283. Foi encontrá-lo na enfermaria, a cuidar de um aluno que se queixava de indisposição. Chamando-o reservadamente, comunicou a ele que acabara de receber correspondência dando conta do falecimento do médico, amigo da casa, Dr. João Alphonso, ao mesmo tempo que recebia uma memória do médico acerca do beribéri no Caraça. Irmão Mourão perguntou sobre as circunstâncias do falecimento. O superior disse que, conforme lhe escreveram, o doutor João Alphonso estava em repouso, sob tratamento, na fazenda de familiares, e que havia sido encontrado morto numa trilha ingreme que alcançava a Serra do Mar, mesmo estando sob orientação de repouso absoluto. O Irmão Mourão lembrou das informações sobre a botica que havia enviado a ele, por recomendações do padre Clavelin; lembrou do que já ouvira dizer do doutor João Alphonso por parte daqueles que o conheceram no hospital ou na Casa Central no Rio e, fechando os olhos, abaixou levemente a cabeça, oferecendo ali mesmo

283 Ainda sobre o Irmão Bernardo Mourão, o ex-aluno caracense que o conheceu assim o descreveu em suas memórias (*):

“... era, no Colégio, uma espécie de faz-tudo: hortelão, vinhateiro, enfermeiro, boticário, um grande médico curandeiro e sobretudo um santo homem.

"Nunca vi homem que inspirasse tanta confiança como aquele Irmão, tão impressionante na sua desambiçåo e simplicidade."

- JALLES, J. de. Se não me falha a memória. Op. Cit., pp. 417-19. 
uma oração ao médico que nunca conheceu, mas que lhe parecia tão familiar.

O trabalho no Caraça não se constituia exatamente numa azáfama, mas era uma atividade disciplinada e contínua. Os irmãos coadjutores tinham muito claramente definidas suas tarefas, e exerciamnas num plano de regularidade tal, que, naturalmente, a função se confundia com o executor. Devotados principalmente ao trabalho artesanal, os irmãos prestavam indispensáveis serviços ao colégio e, como os padres, provinham de vários paises. Além dos brasileiros, passavam pelo Caraça irmãos portugueses, alemães, belgas, franceses, ou ainda provenientes da Hungria, Itália, Luxemburgo, Holanda, etc. Suas atividades, diversas: encanadores, vinhateiros, carpinteiros, marceneiros, porteiros, encadernadores, jardineiros, "farmacêuticos" e "enfermeiros" leigos, hortelōes, alfaiates, sapateiros, cozinheiros, e outras tantas atividades vitais à vida da instituição. Comum era, unidos pelo destino do Caraça, encontrar dois ou mais irmãos de nacionalidades diferentes trocando experiências e discutindo alternativas para os aparentes pequenos problemas do cotidiano caracense: providências para melhorar a qualidade das uvas, aumentar a produção de frutas e verduras, identificar plantas com propriedades medicinais e determinada madeira para certo fim, resolver consertos com instrumentos alternativos, subsistir, enfim, à distância dos centros urbanos, quando era necessário tomar medidas imediatas. A experiência de cada irmão coadjutor potencializava o trabalho do grupo e esta relação era muito importante para aqueles que chegavam, particularmente da Europa, iniciando uma convivência com natureza e cultura diferentes.

Dias após sua chegada, o Irmão Moermans percorria a área da horta quando avistou ao fundo o irmão Mourão cuidando do canteiro de ervas que, com sapiência e delicadeza, eram utilizadas na enfermaria. Moermans aproximou-se, passando por entre pés de erva-doce, melissa, menta... ao mesmo tempo que tentava desvencilhar-se de pequenos insetos que sobrevoavam as plantas. Mourão, reconhecendo o embaraço do colega recèm-chegado, abordou-o sorridente, afirmando-lhe que não devia preocupar-se com aqueles 'bichinhos'. Era um tipo especial de 
abelhas, conhecidas como jatais. Além de serem mansas, eram fundamentais para a polinização destas plantas medicinais e também para várias hortaliças e condimentos: almeirão, cebola, manjericão, salsa e outras. Isto era muito importante para que se pudesse obter sementes que abasteceriam o plantio. As abelhas maiores, 'aquelas que ferroam mesmo', procuram pouco estas plantas. Surpreso, Moermans quis saber mais das jatais e, então, Mourão, pacientemente, explicava-lhe, enquanto percorriam a horta e arredores. Ainda que selvagens, as jatais eram amistosas e não tinham ferrão. $O$ mel, diferentemente de outros méis, tinha um sabor azedo saborosamente delicado e tinha ainda excelentes indicações medicinais: cicatrização de feridas, problemas respiratórios, etc. O enxame costumava instalar-se em troncos e paredes ocas e, ilustrando a preleção, Mourão mostrou a Moermans um velho tronco, servindo como mourão de uma cerca, onde havia uma colmeia de jataí. Não foi dificil para Moermans entender que as jatais aproveitaram a parte oca do tronco que correspondia ao espaço da parte mole da madeira que teria sido destruída por cupins. Mourão afirmou que a abundância de flores e água favorecia a aproximação das abelhas, mas que as jatais manifestavam preferências quanto às plantas e suas respectivas flores: na horta, a salva era muito procurada, no mato, a medicinal dormideira, nos jardins e no pomar havia sempre as mais visitadas. A abundância de flores inundava o cardápio das abelhas, mas, mesmo trabalhando com fartura, cada colmeia de jatai produzia pouca quantidade de mel, comparada às outras abelhas. Isso era compensado, insistiu o irmão Mourão, por suas propriedades medicinais e gosto incomparável. Enquanto conversavam, afastaram-se dos canteiros e já andavam margeando o muro que separava o pátio interno da horta. Logo alcançaram o velho moinho.

O moinho, já reparado algumas vezes, funcionava desde 1853, quando foi instalado sob o superiorato do padre Miguel Maria Sípolis, que reabriu o Caraça com a transferência do seminário de Mariana devido à epidemia de variola daquela época. O moinho, utilizado no beneficiamento dos cereais, foi inicialmente construido para o fabrico de fubá ${ }^{284}$. Esta farinha recebia o nome de biché e era largamente utilizada 
284 No decorrer das pesquisas para o presente trabalho, não foram encontradas informações técnicas sobre o moinho construído no Caraça na época citada. A julgar pelo trabalho de SCHMIDT (i) a azenha,

"moinho com roda de água horizontal, diretamente ligada à mó pelo eixo vertical, até poucos anos atrás era extremamente comum no sul de Minas Gerais, na área vizinha à Mantiqueira ... Mas não exclusivamente aí. Também em toda a zona da Mata (Minas Gerais), o moinho de roda deitada e eixo em pé, está integrado na paisagem geral, cumprindo sua dupla utilidade, fazendo fubá para a alimentação humana e quirera para facilitar a engorda de capados. ... Em meado do século passado a azenha encontrava-se difundida por grande parte do território mineiro, em fazendas maiores e em pequenos povoados ...".

A água farta e o declive privilegiado em vários pontos do terreno do Caraça permitiu vida longa ao moinho. Pode-se 'desconfiar' que 0 beneficiamento dos cereais, especialmente o arroz, tenha alguma relação com a diminuição da oferta alimentar de vitamina B1, cuja carência é responsável pelo beribéri. Para CURTIN (ii), reafirmando a convicção científica predominante, existe uma relação entre o fato de beneficiamento de cereais ter se tornado comum no século XIX e o surgimento de verdadeiras epidemias da enfermidade no leste asiático. É evidente que moinhos são muito, mas muito anteriores ao século XIX, mas é fato que a partir do século XIX, com o surgimento de moinhos mais modernos e eficientes, acionados a vapor e, em seguida,

"... acionados a energia elétrica..." (iii),

o processo de descorticação (processo pelo qual o arroz integral, sendo polido, torna-se o "arroz branco", com diminuição acentuada do teor de vitaminas e fibras) comprometeu mais acentuadamente o teor de vitaminas. Aparentemente, os métodos mais antigos, anteriores ao advento do modernos moinhos a vapor e a eletricidade, não eram tão eficientes no polimento quanto estes últimos.

Relatos pessoais, obtidos de agricultores, em função do presente trabalho (iv), dão conta de que na primeira metade do século XX, e até mesmo no alvorecer da segunda metade, nas regiðes rurais o consumo do "arroz de pilão" era prática costumeira. Enquanto no moinho preparava-se o fubá e outras farinhas de cereais, no monjolo ou no pilão o arroz era descascado:

"O pilão, herança indígena que nossos colonos adotaram, chegou a ser, nas fazendas, nos sítios, casebres, choupanas, instrumento indispensável. Sempre foi, no passado, objeto das mais variadas aplicaçðes. Ora tosco e mal acabado, ora bem tomeado e bem feito, o fato é que se tornou objeto de mil utilidades. Nos pilðes se descascavam arroz e café; do milho se preparava a canjica. Mesmo nas grandes fazendas providas de monjolo, o arroz era limpo no pilåo, pois no monjolo se quebrava muito" ( $v$ ).

Deve-se ressaltar que o "arroz de pilão" é o mesmo "arroz integral", isto é, o descasque do arroz no pilão mantém grande parte do seu teor original de vitaminas. A película que cobre o grảo do arroz integral é retirada por processos de beneficiamento mais sofisticados tecnicamente, resultando num griso de arroz mais branco. 
na alimentação diária do colégio, sendo que o milho era também consumido na forma de canjica, ou seja, milho pilado e cozido. $O$ alimento básico, entretanto, era mesmo o arroz, cujo abastecimento se fazia à custa de grandes dificuldades de transporte, já que a produção local era insuficiente para o sustento da casa. Aparentemente não havia um local adequadamente preparado para o estoque de cereais. A concepção contemporânea de estocagem segura de alimentos não era cogitada como prática habitual. Por isso, a deterioração de parte das colheitas ou estoque de provisão era comum, as perdas, inevitáveis e, seria licito supor, ocorria de alguma forma o consumo de alguma cota de alimento teoricamente impróprio para a alimentação. Numa época em

Logo após a construção do moinho no Caraça, o padre Domingos Musci, que substituíra por pouco tempo o padre M. Sípolis na direção da casa,

“... comprou a fazenda do engenho a Silverio Glz' de Araujo em 1858. É a porção mais fertil e melhor de todo o Caraça, já pelas suas terras de cultura, já pelas suas gordas pastagens" (vi).

Assim, é provável que o moinho serviu à obtenção de farinhas diversas, a partir não apenas da produção local, mas de fornecedores dos arredores. A luz elétrica, que chega acanhadamente ao Caraça em 1893, mal e mal dá para iluminar o Colégio (vii), sendo pouco provável (não se encontrou nenhum registro neste sentido) que tenha sido utilizada para acionar máquinas mais modernas de beneficiamento de cereais.

Desta forma, o presente trabalho descarta a possibilidade de que eventuais casos de beribéri no Caraça tenham relação com o tipo de beneficiamento que os cereais, particularmente o arroz, tenham sofrido no próprio colégio. Ou seja, o estoque dietético de tiamina (vitamina B1) dependeria, então, menos do beneficiamento de cereais na área do colégio do que de outros fatores relacionados à dieta em geral: variabilidade alimentar, quantidade oferecida, etc.

i. SCHMIDT, C. B. O milho e o monjolo: aspectos da civilização do milho. Técnicas, utensilios e maquinaria tradicionais. Rio de Janeiro, Ministério da Agricultura : Serviço de Informação Agrícola, 1967. cap. 11: Os Moinhos.

ii. CURTIN, P. D. Death by migration. Cambridge, Cambridge University Press, 1989. p. 77.

iii. PORTO, A \& HOFFMANN, A . Moinhos: Na roda do tempo. Globo Rural, (dez.): 10-110, 1994.

iv. Relatos pessoais de agricultores das regið̌es mineiras de Barão de Cocais e Francisco Sá.

v. BARBOSA, W. de A . Dicionário da terra e da gente de Minas. Op. Cit. p. 152-3.

vi. SILVA, F. de P. e. Caraça: apontamentos históricos. Op. Cit., p. 31.

vii. ZICO, J. T. Caraça: peregrinaçđo ... Op. Cit., p. 146. 
que a microbiologia dava os seus primeiros passos, não se tinha a idéia de que houvesse seres microscópicos que alterassem os alimentos em qualquer fase da sua utilização. Assim, os cuidados que se tomavam na armazenagem levavam em conta as ameaças das chuvas e alguns roedores como o rato, mas estes cuidados nem sempre eram adequados para evitar as perdas. A toxi-infecção alimentar, não sendo conhecida na sua etio-patogenia, tinha suas consequeências atribuídas às características orgânicas do individuo e à relação destas com o tipo de alimento consumido, etc. Quanto à relação da qualidade sanitária dos alimentos e a ocorrência de uma certa avitaminose, como o beribéri, por exemplo, esta se faz muito mais pela disponibilidade quantitativa dos alimentos do que por suas alteraçōes. Ou seja, eventuais casos de beribéri não teriam como causa direta a má conservação dos alimentos, pois ai o aporte de tiamina é pouco alterado. Indiretamente, influenciaria se esta má conservação determinasse a quantidade de alimentos oferecidos. E interessante observar que, não sendo estéril, o alimento natural, cru, o mais nutritivo está sujeito a se deteriorar com mais rapidez, exatamente por serem mais nutritivos - inclusive para os microrganismos presentes. Assim, o arroz integral e outros cereais sem ou com beneficiamento "grosseiro" estragam com maior rapidez. O beneficiamento adequado aumenta a vida útil dos produtos naturais, sendo este, inclusive, um dos motivos da expansão do comércio e consumo do arroz branco. $O$ preço deste mecanismo é a perda significativa de vitaminas, entre elas a $\mathrm{B} 1^{285}$.

285 Na literatura e na documentação disponível sobre o Caraça, não há registros de 'situaçð̃es' que possam ser interpretadas como sendo uma toxi-infecção alimentar ou, genericamente, um "envenenamento de origem alimentar", em nenhum dos seguintes eventos que o caracterizam:

“l) envenenamento (doença) produzido por substância tóxica;

"2) doenças causadas por microrganismos que usam o alimento como meio de transmissão;

“3) doenças ocasionadas por microrganismos que usam o alimento como meio de crescimento." (i, p.78)

As preparaçðes alimentares costumeiras eram, no Caraça, elaboradas para co.nsumo imediato. Esta prática diminui os riscos de contaminação, ao contrário do que 
Ao completarem a caminhada da horta ao átrio do colégio, passando pelo moinho, os irmãos Mourão e Moermans encontraram o superior Luis Boavida, que portava alguns papéis nas mãos. $O$ irmão Mourão, depois de afirmar a familiarização de Moermans com o colégio, perguntou ao superior da Memória sobre o beribéri que chegara da Casa Central. Por acaso, disse-lhe o superior, tenho em mãos o texto, mas o farei arquivá-lo, pois as apreciações não o têm recomendado, devido à inviabilidade de executar as sugestōes do doutor Joäo. Diante da categoria do superior, o irmão pôde apenas ver, num momento em que uma rala brisa maleou as folhas da memória, parte do índice, do qual ainda conseguiu ler: 1 . O que se vê, como é e os modos de contar: ensaio introdutório.

Quanto às refeições, no Caraça

“... a regra era almoçar, jantar e cear..."286.

“... almoço às 7,30 , jantar ao meio-dia e, finalmente a ceia, às $19,30^{\text {"287. }}$.

A reconstituição de um cardápio do colégio Caraça é um processo no qual muitas variáveis devem ser consideradas, especialmente porque se relata uma determinada enfermidade, o beribéri, que se relaciona diretamente à alimentação diária do individuo ou coletividade. Uma possivel documentação sobre o assunto (cardápios, dados acerca do abastecimento regular, produção local, etc.) inexiste, ou, se há, não foi encontrada nos arquivos disponiveis. A interpretação sobre o que, de

se tem quando os pratos são preparados com muita antecedência e apenas "requentados" ao serem servidos. De um modo geral,

"Os micróbios apreciam a temperatura tépida. A maior parte não agüenta o calor, sendo por ele muito prontamente destruídos" (ii, p.30).

i. GAVA, A . J. Principios de tecnologia de alimentos. São Paulo, Nobel S.A, 1978.

ii. CHRISTIE, A . B. \& CHRISTIE, M. C. Higiene alimentar e riscos da alimentação. Porto, Livraria Lopes da Silva - Editora, 1973.

SALLES, J. de. Se não me falha a memória. Op. cit. p. 387.

287 LEITE, A . du C. Saudades e lembranças do Caraça. Op. cit. p. 163. 
fato, se comia no Caraça é corriqueiramente baseada em relatos de exalunos. Estes relatos, bem como a utilização que se faz deles, obedecem genericamente, a duas perspectivas: uma negativa e outra positiva. Correntemente, a negativa acentua a má qualidade da alimentação num contexto que questiona, e até mesmo quer denunciar, as fragilidades estruturais, pedagógicas, etc., do colégio encravado na solidão da montanha e gerado sem as necessárias obediências às mais simples regras do bem-estar, como a alimentação, por exemplo. A perspectiva positiva relativiza as criticas, absorvendo algumas contextualmente, enaltecendo o papel social da instituição, baseada na sua trajetória, centrada principalmente na figura de vários personagens - leigos e eclesiásticos - que passaram por lá. No primeiro caso, vê-se, por exemplo:

"A fama de má alimentação que ministravam aos alunos do Caraça, desde tempos imemoriais, corria de boca em boca e essa verdade, infelizmente, tornou-se assás divulgada, porque ao Colégio afluiam alunos de todos os recantos deste e de outros Estados"28s.

"Os gêneros estragados não iam para o lixo: entravam nas panelas e eram distribuídos pelas mesas. Descuido na fiscalização da cozinha" 289 .

No segundo caso,

“... aumentando o número de alunos ou habitantes no Caraça, surgia o fantasma do Beribéri. A tradição diz que na década de 1870 havia no Caraça 400 (quatrocentos alunos); 400 alunos não acredito, 400 pessoas, acredito: 300 alunos, 40 operários na construção da igreja, mais as Sampais, mais os operários da casa, os Professores. Faltando a qualidade na

288 Idem, p. 163.

289 FRIEIRO, E. Feijdo, angu e cuuve. Op. cit., p. 174 
alimentação, faltando frutas, etc., surgia o Beribéri como nos quartéis e outras corporações"290.

E preciso compreender que no primeiro estágio de compreensão sobre a alimentação no Caraça há algum consenso sobre a sua insuficiência, ou seja, a negatividade ou positividade da interpretação gira em torno das circunstâncias em que se instala esta insuficiência, sua extensão e significado. O próximo passo é questionar a pertinência científica dos relatos: é possivel inferir deles que, de fato, a alimentação do Caraça foi nutricionalmente insuficiente ? Quantitativamente, não. E impossivel afirmar categoricamente que, por exemplo, alunos em tal ano ou em tal mês ingeriram, em média, quantidades aproximadas de qualquer nutriente. Para que isto fosse possivel, seria necessário saber o que e quanto foi oferecido aos alunos, a composição de cada preparação (os ingredientes) e, do que foi oferecido, o que foi realmente ingerido por estes alunos. $O$ regulamento de 1835 do Caraça, ao tratar no capitulo 9o do "Cozinheiro", detalha algumas informações sobre a alimentação. Contudo, este regulamento vinha de anos anteriores e não era válido na segunda metade do século XIX ${ }^{291}$. Assim, quanto à alimentação no

290 Esta citação é parcialmente transcrita na nota de rodapé 166.

291 Diz o capítulo nono do regulamento "Do seminário da Imperial Casa de Nossa Senhora Mãe dos Homens na serra do Caraça" ("):

1. "O bom cozinheiro concorre muito para a boa ordem, se o Estudante descontente do refeitório em vez de recrear-se, ou estudar estará murmurando, perturbando-se e perturbando a casa;

2. O Presidente da cozinha deve ser um homem muito asseado na sua pessoa, e em tudo, e procurara que os estudantes também sejam asseados, e que tudo façam com limpeza:

3. Não deve por comidas requentadas, e cheias de fumo;

4. As comidas não sejam carregadas de sal pelo aano que muito sal causa na saúde;

5. Os manjares sejam bem guisados, e como variedade deleita, e as mesmas comidas repetidas muitas vezes ainda que boas aborrecem, haverá por isso variedade no guisamento;

6. Será cuidadoso que tudo esteja pronto às horas determinadas; 
colégio entre o final e início de séculos, a principal fonte são os relatos, dos mais pessimistas aos mais otimistas. Através destes relatos é possivel observar que alguns alimentos estavam presentes rotineiramente no colégio: cereais e derivados, carnes e doces. Outros alimentos têm consumo raramente mencionado: frutas, verduras, legumes e laticinios, principalmente. Estes correspondem àqueles alimentos cuja possibilidade de produção no Caraça é subentendida, mas sem registro que possibilite conhecer a participação dos mesmos na alimentação dos moradores do educandário. Em época de safra, a laranja era oferecida regularmente como sobremesa, assim como jabuticabas e outras frutas. Tomando por base os alimentos mais freqūentemente citados e com base ainda em dois critérios para quantificação de consumo por pessoa, é possivel supor duas possibilidades de alimentação básica. A partir desta quantificação é também possivel simular o quanto cada alimentação ofereceria de nutrientes, quando comparadas com as necessidades nutricionais de um jovem entre 15 e 18 anos de idade 292 :

7. No almoģo haverá um prato de comida sólida; a saber de carne simples, ou com legumes, ou com arroz, e o café;

8. No jantar quatro pratos entrando neste número o da sobremesa;

9. Às cinco horas da tarde no fim das aulas um pão a cada um, ou biscoitos; e é então permitido café, ou mate para quem quiser;

10. Na ceia dois pratos sólidos, um deles de legume;

11. Nas festas maiores saberá do Superior se deve aprontar algum prato mais".

* CAMELlo, M. J. de O . Caraça, centro mineiro de educação e missão (1820-1830) - Textos e Documentos. Belo Horizonte, 1973. p. 205-6.

292 A indicação dos alimentos mais freqüentes está especialmente baseada em relatos esparsos no decorrer da obras de ex-alunos:

ALMEIDA, T. de. O beriberi no Brasil. Op. cit. LEITE, A da C. Saudades e lembranças do Caraça. Op. cit.

RESENDE, A . de L. Memórias. 2 v. Belo Horizonte, Ed. do autor, 1970.

SALLES, J. de. Se não me falha a memória. Op. cit.

A quantificação dos alimentos (ou preparaçðes), dado não especificado nos autores citados, está baseada em dois critérios: na primeira possibilidade, as porçðes basearam-se na distribuição daqueles alimentos em três refeiçðes diárias, em "per-capita" econòmico para um aluno médio; na segunda possibilidade, estimaram-se as quantidades a partir dos 
1А POSSIBIIDADE:

\begin{tabular}{|c|c|}
\hline $\begin{array}{l}\text { ALITENTOS E } \\
\text { QUATITDADES } \\
\text { POR PESSOA/DIA }\end{array}$ & $\begin{array}{l}\text { ARROZ POLIDO (150 g.); BANHA DE PORCO (10 g.); CANJICA } \\
(100 \text { g.); CARNE (210 g.); FUBA (100 g.); MARMELADA } \\
(100 \text { g.); PAO (30 g.). }\end{array}$ \\
\hline $\begin{array}{l}\text { VALOR } \\
\text { NUTRITIVO E } \\
\text { PERCETTUAL DE } \\
\text { ADEQUAÇAO }\end{array}$ & $\begin{array}{l}\text { CALORIAS: } 1727 \text { (97 \%); PROTEINA: } 71 \text { g. (192 \%); } \\
\text { VITAMINA B1: } 0.58 \mathrm{mg}(58 \%) \text {; VITAMINA B2: 0,6 mg (50 } \\
\%) \text {; VITAMINA C: } 4 \mathrm{mg}(7 \%) \text {; CALCIO: } 100 \mathrm{mg} \mathrm{(8 \% );} \\
\text { FERRO: } 11,9 \mathrm{mg}(66 \%) \text {; FIBRA: } 4,5 \mathrm{~g} .(25 \%) .\end{array}$ \\
\hline
\end{tabular}

2A POSSIBILIDADE

\begin{tabular}{|c|c|}
\hline $\begin{array}{l}\text { ALIMENTOS E } \\
\text { QUATTIDADES } \\
\text { POR PESSOA/DIA }\end{array}$ & $\begin{array}{l}\text { ARROZ POLIDO (150 g.); BANHA DE PORCO (50 g.); CANJICA } \\
\text { ( } 200 \text { g.); CARNE ( } 150 \text { g.); FUBA ( } 70 \text { g.); MARMELADA ( } 100 \\
\text { g.); PAO ( } 35 \text { g.). }\end{array}$ \\
\hline $\begin{array}{l}\text { VALOR } \\
\text { KUTRITTVO E } \\
\text { PERCENTUAL DE } \\
\text { ADEQUAÇAO }\end{array}$ & $\begin{array}{l}\text { CALORIAS: } 2007 \text { (112\%); PROTEINA: } 57,9 \mathrm{~g} .(157 \%) \text {; } \\
\text { VITAMINA B1: } 0.51 \mathrm{mg}(51 \%) \text {; VITAMINA B2: } 0,52 \mathrm{mg} \\
\text { (44 \%); VITAMINA C: } 4 \mathrm{mg}(7 \%) \text {; CALCIO: } 123 \mathrm{mg}(10 \\
\%) \text {; FERRO: } 9,72 \mathrm{mg}(54 \%) \text {; FIBRA: } 4,65 \mathrm{~g} .(26 \%) .\end{array}$ \\
\hline
\end{tabular}

Aos sábados e, especialmente, em dias santificados, ocorriam apreciadas variações no cardápio: arroz, tutu de feijão, carne de porco e pão doce.

O próximo passo seria, então, responder: qual o grau de veracidade que esta "suposição" encerra a ponto dela permitir que se avalie extensão de uma doença de origem nutricional no local, como o beribéri ?

Aqui, vale considerar, antes, os dois momentos' da pergunta. Primeiro, o "grau de veracidade" e, depois, a "extensão da doença". A "veracidade" pode ser medida estatisticamente, tomando desta ciência conceitos próprios. Mas esta medida estatística é metodologicamente

mesmos critério utilizados e descritos no capítulo VI, p. 109, da segunda parte do prisente trabalho. 
recomendada nos casos em que se tem dados (amostrais ou não) a partir dos quais é possivel efetuar cálculos. No caso da alimentação no Caraça não é possivel nenhuma série quantitativa que permita manipulação estatística representativa. Mas a imputação estatística como elemento demonstrativo, ou de prova, é sempre uma peça que favorece uma compreensão particular do fenômeno. No caso do beribéri no Caraça, numa época em que a etiologia da doença era desconhecida, as razões que determinaram a insuficiência vitaminica da dieta não seriam abordadas por inferências tipicamente matemáticas. Mas admitindo, num jogo de exploração lógica de hipótese(s), que a suposição sobre a insuficiência nutricional da alimentação caracense seja confiável, podese, no segundo momento, relacionar esta suposição com outra caracteristica da doença, isto é, sua extensão. A extensão de uma dada doença é também objeto de uma medida estatística, especialmente se for tomado o aspecto epidemiológico da mesma. A ocorrência e extensão do beribéri no Caraça é sabida por depoimentos esparsos, sem aferição quantitativa minimamente criteriosa, e ainda sob circunstâncias científicas peculiares: não se conheciam as vitaminas $e$, por conseguinte, - que suas carências poderiam provocar à saúde. Nem mesmo os acanhados registros de ocorrência de doenças do final e início dos séculos XIX e XX oferecem informações sobre a doença. O exame do livro de óbitos anula a possibilidade de uma doença de mortalidade significativa, mesmo admitindo - tanto para mais como para menos - a notificação das ocorrências. Assim, pode-se tanto admitir que, mesmo não matando muitos, o beribéri tenha se manifestado e deixado muitos ou poucos doentes. Mas continuando ainda dentro daquele jogo de exploração lógica', aceitando que muitos tenham adoecido de beribéri, pode-se responder à questão da relação entre dieta e beribéri no Caraça. A conclusão é antecipadamente prevista: se a dieta é insuficiente e a incidência da doença é alta, a relação entre ambas é incontestável. Mas, tomando suposições diferentes, é possivel afirmar, numa perspectiva mais otimista, que: sim, a dieta era pobre, mas num grau tal que a incidência da doença não era tão alta. A primeira conclusão avaliza as narrativas - médicas e leigas - que "dizem" do grande número de pessoas que eram "atacadas" pelo beriberri; a segunda relativiza a circunstância, afirmando que, se por um lado a dieta era insuficiente, esta insuficiência 
não era de tal modo significativa que pudesse provocar um número elevado de casos da doença no colégio. Sabe-se que o beribéri

“... é regularmente encontrado em populações cujas dietas contém menos de 0,3 gramas de tiamina por 1000 calorias não provenientes de gorduras"293.

Nenhuma das duas possibilidades de dietas vistas anteriormente atenderia a esta condição. Ou seja, ambas as possibilidades encerram teores de tiamina (vitamina B1) superior a $0,3 \mathrm{~g}$. por 1000 calorias, ainda que, de fato, a dieta seja realmente insuficiente. Mas não o seria apenas em vitamina $B 1$. Outras vitaminas certamente teriam seu suprimento melhorado com o consumo de frutas, por exemplo. É o caso da vitamina C, cuja deficiência provoca uma doença bastante conhecida anteriormente à época do beriberi: o escorbuto. As cotas alimentícias de cálcio e ferro parecem ter sido inadequadas, mesmo se forem agregados às duas possibilidades dietéticas citadas laticinios ocasionais e frutas. Nos relatos sobre a instituição, não se encontram relatos sobre outras doenças, além do beribéri, que tenham incidido significativamente no Caraça. Resta a possibilidade de que eventuais deficiências nutricionais, que não fosse de vitamina $B 1$, tenham se confundido com esta e, então, neste caso, passa ser questionável se esta deficiência de vitamina B1 foi realmente significante, ou, se entre os casos de beribéri não estariam casos provenientes de outras deficiências. Provavelmente esta é uma questão para a qual jamais haverá uma resposta satisfatória, pois quando, no Caraça, a alimentação tornou-se balanceada, adequada, todos os possiveis problemas decorrentes da insuficiência qualitativa e quantitativa desta dieta foram resolvidos indistintamente, sem que houvesse sido criteriosamente especificado quais as deficiências nutricionais que ocorriam e a proporção de uma em relação a outra.

Aquém desta discussão, o colégio Caraça convivia com o "fantasma do beribéri"294 que, nas décadas finais do século XIX e inicio do XX,

ENSMINGER, A . H. et al. Foods \& Nutrition Encyclopedia. v. 1. Clovis, California, Pegus Press, 1983. p. 201.

294

Expressåo do Padre José Tobias Zico que, em carta de 24/07/1995 (Op. cit.), diz: 
assolaram a instituição. A Escola Apostólica ${ }^{295}$, criada pela Congregação para formar os seus religiosos, teria suas atividades encerradas no Caraça alguns anos mais tarde, em meio a justificativas genéricas ( "estado precário da escola") e especificas ("Pois que o beribéri não deixava o Caraça, era aconselhável retirar de lá a Escola Apostólica...”). A repetição de casos da doença contribuía para que os relatos providenciassem uma temporalidade tipicamente assemelhada a doenças infecciosas:

"Dava quasi todos os annos, mas as mais crueis epidemias do Caraça foram, além da de 1862, as de 1873, 1878 e as três recentes de 1901,1906 e 1910. Quasi sempre abrangia o beriberi grande numero de estudantes, embora fossem pouquissimos os casos fataes. Assim mesmo, era espantalho continuo aos alumnos e muito concorreu para a morte do Collegio"296.

“... aumentando o número de alunos ou habitantes no Caraça, surgia o fantasma do beribéri."

O termo "fantasma" sugere bem a magnitude do beribéri para o Caraça. Mesmo tomado simplesmente sob o aspecto sinonímico, "fantasma" pode ser visto como:

"1. Imagem ilusória; fantasmagoria; 2. Visão terrífica, medonha, apavorante;

... 4. Coisa espantosa, medonha; ...". (*)

$\mathrm{O}$ desconhecimento sobre a doença, mas principalmente a forma como a ciência a tratava, e de ocorrer numa instituição de renome, transformaram a possibilidade de ocorrência da doença em verdadeiro 'fantasma' para a Congregação lazarista. É que este 'fantasma' repercutia na própria 'saúde' do colégio: o número de matrículas caia, as repercussð̃es políticas aumentavam, etc.

* NOVO Dicionário básico da língua portuguesa. Rio de Janeiro, Ed. Nova Fronteira, 1988.

293 A Escola Apostólica era o seminário da Congregação da Missão.

"Eram aceitos meninos que desejassem ser padres, e, se fossem muito pobres, - Caraça os manteria gratuitamente, durante toda sua formação" $\left({ }^{*}\right)$.

Iniciada no Caraça em 1885, sob a direção do padre Luís G. Boavida, após 10 anos ai foi transferida para Petrópolis, voltando ao Caraça em 1909 onde ficou até 1968.

* ZICO, J.T. Caraça: .... Op. cit., p. 76.

2* CRUZ, A . da . Centenário do Caraça. Rio de janeiro, Besnard Freres, 1920. p. 81. 
De fato, no inicio do século XX o Caraça enfrentaria algumas crises que marcariam seu destino. Após o Padre Boavida ter deixado a direção, o padre Pedro Maria Bos assumiu por um curto periodo (1895 - 1896) o superiorato. $O$ breve periodo como superior e as dificuldades com que se deparou não permitiram que este superior abordasse efetivamente a memória daquele médico que ele conheceu logo que chegou ao Brasil. Bos recordava com precisão do seu encontro com João Alphonso no Rio e chegou até mesmo a considerar a possibilidade de retomar a interpretação da referida memória. Mas entre os problemas que enfrentou na sua gestão, há o pouco esclarecido caso de

“... que um dia appareceu no Caraça uma doida vinda não se sabe de onde: e com as variolas em completa floração.

"Bexigas no Caraça ! ... Foi o grito assustador que circulou como faisca eletrica!

"O P.e Superior providenciou logo na remoção da doente, mas uma das Sampaias já tinha contrahido o mal.

"Foram dias de angustia para o P.e Superior que conseguio a força de despendio atalhar o mal ; porem o que não poude conseguir foi impedir a impressão desastrosa que produzio fóra a noticia espalhada muitas vezes sem criterio algum. O primeiro effeito foi a não vinda de mais alumnos e por isso a mingua de recursos para fazer face as primeiras despezas de um anno que começa, despezas que são sempre grandes"297.

Diante da situação do Caraça naquele momento, o padre Boavida, que retornara de uma viagem à Europa, foi chamado a reassumir a direção do educandário. Esteve neste posto entre os anos de 1896 e 1898 e não conseguiu reverter o quadro de decadência da instituição, com muitos problemas a pedir soluções, entre estes a falta de docentes. Doerite e cansado, pediu afastamento, e no seu lugar entraria o padre francês Henrique Lacoste, professor, e que desde 1882 missionava pelo interior de Minas. $O$ perfil deste novo Superior ajudou a reerguer 0 colégio. É que, por conta da sua condição de missionário, conhecia várias 
localidades do estado, de onde viriam novos alunos, bem como pessoas influentes que em muito contribuiriam para que o colégio Caraça fosse equiparado ao Colégio Pedro II (Ginásio Nacional), pelo decreto 3701, de 16 de julho de 1900. Foi a partir desta equiparação que os alunos do colégio deixaram de usar batina, uniforme clássico desde sua fundação. Em 1903, o padre Lacoste foi indicado para assumir o seminário de Diamantina e, em seu lugar, entraria o primeiro superior brasileiro no Caraça, o padre Francisco de Paula e Silva, que assumiu o superiorato em 9 de setembro. Mineiro, o novo superior fora ordenado na França em 1886 e estivera na Bahia e Petrópolis antes de trabalhar no Caraça. Logo no inicio da sua gestão é restaurado a capela do Sagrado Coração de Jesus, por conta de uma promessa para que Deus libertasse o Caraça do beribéri298. Mas o fato que marcará a gestão do padre Francisco Silva é a retomada da Escola Apostólica que, anos atrás, havia sido transferida para Petrópolis. Objetivando formar seminaristas preparados para o sacerdócio, a escola conviverá com o Colégio durante alguns anos, já que o próprio superior deixava clara a preferência da Congregação:

"O collegio embora obra secundaria da Congregação, foi aqui sempre zelado pelos Padres. Obra penosa e ingrata, exigindo maior dedicação, desde 80 annos tem visto os filhos de S. Vicente de Paulo consagrados a elle com uma constancia que os honra...

"A Escola Apostólica que começa apenas de reviver já deixa entrever ricas esperanças para o futuro.

"Si um dia o Collegio vier a desapparecer, ficará ahi a escola Apostolica a formar clerigos e missionarios que continuem a levar a semente divina do ensinamento evangelico pelas diversas localidades de Minas"299.

Nesta época, inicia seus estudos no colégio um rapaz vindo de Pará de Minas, Theophilo de Almeida. Nascido em 1890, ingressa no Caraça em 1904 e forma-se em 1909, mesmo ano em que ingressa na Faculdade

298 Sobre esta circunstância, ver nota de rodapé 272.

299 SILVA, F. de P. e. Caraça: apontamentos históricos. Op. Cit., p. 132. 
de Medicina do Rio de Janeiro ${ }^{300}$. Em sua tese de conclusão do curso médico, "O beribéri no Brasil", Theophilo procurará, a partir da sua

Dr. Theophilo de Almeida (1890-1988) viveu quase um século e é considerado como um dos mais brilhantes entre os ex-alunos do Caraça. Talentoso, soube usar adequadamente a formação humanística adquirida no Colégio, mesclando-a adequadamente com a formação cientifica em medicina. Feito médico, dedicou-se à clínica médica e dermatologia e, a seguir, à saúde pública. Nestas áreas publicou inúmeros trabalhos científicos. Em 1923 foi nomeado médico do então 'Departamento Nacional de Saúde Pública', na época dirigido por Carlos Chagas. Com cursos no exterior, dedicou-se também à profilaxia de doenças venéreas e hanseníase, bem como administração hospitalar, área em que foi um dos pioneiros no Brasil. Em 1941 tornouse diretor da 'Divisão de Organização Hospitalar' do Ministério da Saúde (i).

Em 1950 ele foi o paraninfo da turma de 10 apostólicos que concluiriam o seminário menor (ii). No seu discurso de paraninfo aborda vários temas ('religião e ciência'; 'a igreja e a pátria'; 'a igreja e os hospitais', etc.) e, entre estes, o beribéri. Destacando então, já em 1950 - o beribéri como uma avitaminose, ele ainda enumera fatores que estariam ligados à ocorrência da doença:

"E não só pela deficiência de vitaminas $B$ e de outras encontradas nos alimentos crús, como também devido a certos hábitos locais e fatores mesológicos ocasionais: como a inação, a humidade, o frio, que podem concorrer para perturbar a assimilação dêsses elementos nutritivos e ocasionar ou agravar os distúrbios patológicos"(iii).

$\mathrm{Na}$ época, as variáveis acima tinham, para alguns pesquisadores, algum peso, indefinido; na etiologia pode-se, entretanto, supor que o médico caracense tenha amenizado o aspecto qualitativo da alimentação na instituição que lhe era cara. Mineiro e devotado às coisas do seu Estado, tendo, inclusive, na condição de historiador ( era membro do Instituto Histórico e Geográfico de Minas Gerais), escrito sobre a história de sua cidade natal (iv), Dr. Theophilo de Almeida residiu sempre no Rio de Janeiro. Casado com Sarah Pentagna, natural do município de Valença, Rio de Janeiro, com ela teve um filho, Fernando Teófilo de Almeida, nascido em 1926, e também médico pela Universidade Federal de Minas Gerais em 1950, e que foi entrevistado por ocasião das pesquisas de campo do presente trabalho. Residindo no mesmo local onde o pai morou por décadas, no bairro de Copacabana, Rio de Janeiro, Fernando T. de Almeida conserva farto material (bibliografia, fotos, material de uso pessoal, etc.) pertencente ao pai, morto, na época, há 7,5 anos atrás. Além do filho, deu depoimento sobre o Dr. Theophilo a responsável pelos serviços gerais da familia, Sra. Maria, que durante anos o acompanhou, bem como à esposa $e$, agora, o filho. $O$ filho, em vários momentos do depoimento, ressaltou as virtudes do pai ( "culto", "poliglota", "profissional sério e competente", etc.) e sua infelicidade nos negócios ("tentou o comércio, no ramo de farmácia"; "proprietário e diretor de revista médica"; "mas não nasceu para comerciante") e as honestas e boas relaçðes do pai, entre estas, com o também mineiro Carlos Drummond de Andrade Sobre este, Fernaindo referiu-se à sua filha, companheira eterna do poeta, que ele, o 
condição de ex-aluno e médico, compreender a persistência da doença no local, especialmente porque, para ele,

"E aqui que vamos encontrar uma physionomia especial do beriberi do Brasil, ou antes uma entidade morbida a parte, autonoma, cujo diagnostico se alicerça na pureza da etiologia inconfundivel, na feição clinica particular e principalmente no tratamento facil, e prognostico sempre benigno"301.

Mas, antes que ele viesse a elaborar seus estudos sobre o beriberi, a doença continuava sendo investigada. No início do século, a despeito de trabalhos que associavam positivamente o consumo do arroz polido com o beribéri, houve um recrudescimento de pesquisas que abordavam esta enfermidade como sendo de natureza infecciosa. Vista como doença endêmica exclusiva das regiões tropicais e subtropicais do planeta, os esforços, pelo mundo afora, para esclarecer a sua etiologia ficam concentrados na área da medicina tropical, cujo objeto preferencial de investigação, na época, são as moléstias infecto-contagiosas ${ }^{302}$. Em

jovem Fernando, observava enamoradamente, enquanto os pais conversavam. Quanto à governanta que acompanhou o Dr. Theophilo diariamente, por anos a fio, ela quis destacar os últimos anos do anciåo: "recolhido no seu apartamento, sentindo a morte da esposa (em torno de 5 anos antes) e parecendo pensar não sei no que, vez por outra lamentava: É, Maria, a vida é assim" (v).

i MINISTÉRIO DA SAÚDE. Boletim Informativo da D. O . H. Ano II, n. 18, Junho, 1966.

ii. ZICO, J. T. Caraça, ex-alunos e visitantes. Op. cit. p. 189.

iii. ALMEIDA, T. de. Discurso de paraninfo pronunciado na solenidade de colação de grau dos diplomados do colégio do Caraça, em 3 de dezembro de 1950. $O$ Diário, n. 5325/5327, Belo Horizonte, 1951. [Separata].

iv. ALMEIDA, T. de. Historia antiga de Pará de Minas: de 1700 a 1859. Belo Horizonte, Ediçðes Mantiqueira, 1959.

v. Depoimentos prestados por ocasião de entrevista realizada no Rio Janeiro, em novembro de 1996.

${ }^{301}$ ALMEIDA, T. de. O beriberi no Brasil. Op. cit. p. 70.

${ }^{302}$ Seria desnecessário e cansativo enumerar a vasta bibliografia que, no início do século $\mathrm{XX}$, trata o beribéri na esfera da medicina tropical. Pode-se, por exemplo, citar: 
muitas regiões, pacientes beribéricos hospitalizados foram tratados em isolamento; este procedimento, inclusive, ganhava coerência com uma teoria da época, que afirmava que a infecção tornar-se-ia possivel onde houvesse agregação de individuos susceptiveis. Por este princípio, explicava-se a alta incidência da doença em prisões, quartéis, colégios, etc. ${ }^{303}$. Mesmo quando aumentaram as evidências da relação entre consumo de arroz e beribéri, o 'peso' da teoria infecciosa se manteve e isso se devia, em parte, à dificuldade de se explicar o mecanismo de produção da doença a partir deste cereal. Assim, ao final da década primeira do século $\mathrm{XX}, \mathrm{o}$ arroz branco era apontado como o causador do beribéri, mas o modo pelo qual poderia produzi-lo era controverso e distinto, a saber: i) o arroz conteria um veneno que provocaria a doença; ii) devido à carência de nitrogênio, haveria uma deficiência de proteina na dieta do arroz branco, e isto causaria a doença; iii) o arroz branco não constituiria uma dieta suficientemente nutritiva, tornando o organismo do paciente susceptivel à invasão por um agente específico causador do beribéri ${ }^{304}$.

DÄUBLER, K. Die Grundzüge der Tropenhygiene. 2 v. Berlin, Verlag Von Otto Enslin, 1900. p. 224-38.

STANLEY, A . The nature of beri-beri. The Journal of Hygiene, II: 369-81, 1902.

DURHAM, H. E. Notes on beriberi in the malay peninsula and on Christmas Island (Indian Ocean). The Journal of Hygiene, II: 112-155, 1904.

DANGERFIELD, H. V. Le Béribéri. Paris, A . Maloine Ed., 1905.

303 STANLEY $\left({ }^{\star}\right)$, por exemplo, aborda estas questðes ao discutir a etiologia do beribéri entre prisioneiros chineses em Xangai.

(*) STANLEY, A. The nature of beri-beri. Op. cit.

304 FLETCHER, W. Informe preliminar de un experimento realizado en el asilo para lunaticos de Kuala Lampur. Salud Publica de Mexico, 35 (4), 1993 (http://www.insp.mx/salud/).

Sobre a discussão do arroz como causa do beribéri no fim da primeira década do séc. $\mathrm{XX}$, ver, por exemplo, artigos publicados no periódico Transactions of the Society of Tropical Medicine and Higiene (i, ii, iii, iv). Nestes artigos fica clara a "desconfiança" que a emergente medicina tropical teve em relação à teoria do arroz para explicar a etiologia do beribéri. Inclusive, esta era a posição daquele que é considerado "o pai da medicina tropical" (v), o renomado Patrick Manson (1844-1922), fundador, em 1899, da Escola de medicina Tropical de Londres, que mais tarde (1924) tornou-se Escola de 
Antes que, por deliberação tipicamente epidemiológica, fosse alterado o periodo de férias no colégio, estas ocorriam nos meses de julho a setembro, em casa dos pais. Este periodo de férias era para coincidir com o inverno, quando as temperaturas eram bastante baixas. Esta estação era inóspita para grande parte dos alunos oriundos de regiões onde a temperatura média nesta época do ano era bem mais elevada. Os alunos da escola apostólica, que funcionava paralelamente ao colégio, permaneciam no Caraça nesta época do ano e costumavam descansar na chácara de Santa Rita, mesmo quando, no início do século, foi alterada a época das férias:

"No Caraça a molestia [ o beriberi] 'sempre surgia nos ultimos mezes do anno, e em Janeiro, isto é correspondendo justamente às grandes chuvas, o que levou a Directoria do Collegio, como acertada medida de prophylaxia, a mudar para essa epoca o periodo das férias, a sahida dos alumnos, que costumava ser até então no meiado do anno.

Higiene e Medicina Tropical, parte da Universidade de Londres. Manson, em um encontro sobre o assunto em 21 de maio de 1909, afirmou que muitos fatos apresentados a favor da teoria do arroz favoreciam mais a teoria contrária (iii, p. 255-6). Por exemplo, muitos indivíduos que apresentaram a doença após a adação de uma dieta baseada em arroz branco, antes passavam a ter contato com doentes. Ou seja, o contato anterior com um doente era mais importante que a dieta. Mas ele não descartava nenhuma teoria, realçando a necessidade de mais pesquisas que apresentassem provas conclusivas. Com o avanço das pesquisas, ele próprio elaborou uma nova. Nesta, intermediando teorias opostas, ele afirma que o individuo é intoxicado através do solo e não infeccionado. Isto é, um agente vivo produz uma toxina que se instala no corpo humano, não através dos alimentos ou água, mas por um mecanismo que lembra mais o miasmático.

i. BRADDON, L. The cause of true or tropical beri-beri. Trans. soc. trop. and hig., II $(5,6): 212-225,1909$.

ii. WELLINGTON, A . R. Notes on beri-beri. Trans. soc. trop. and hig., II (5,6): 226243, 1909.

iii. ADJOURNED discussion on the cause of beri-beri. Trans. soc. trop. and hig., II $(7,8): 245-255,1909$.

iv. FRASER, H. \& STANTON, A . T. The etiology of beri-beri. Trans. soc. trop. and hig, III (5): 257-267, 1910. 
"Essa coincidência do apparecimento das epidemias com o tempo das chuvas prolongadas é egualmente observada no Japãon30s.

A chácara Santa Rita estava a uma légua do Colégio e era uma antiga fazenda das proximidades que fora comprada, em 1823, pelo primeiro superior do colégio, o padre Leandro. Ali, o inverno era menos rigoroso, a altitude ( 838 metros ) inferior à do colégio (1450 metros), e nesta situação o local prestava-se tanto à produção de alimentos para o colégio, especialmente de frutas, como também para o descanso e recuperação de religiosos e alunos enfermos ${ }^{306}$. A estrada, "carroçável e

ALMEIDA, T. de. O beribéri no Brasil. Op. cit. p. 74-5.

306 Há registros de permanência de doentes na chácara Santa Rita em diferentes fontes bibliográficas sobre o Caraça. O enfermo, assistido espiritualmente, tinha, quando ocorria, a morte registrada resignadamente. Dois casos de morte na chácara ( de um religiosos e de um aluno ) ilustram a circunstância:

"Aos 25 de dezembro de 1853 foi sepultado... o bom irmão João Rigler ( era alemão ), falecido aos 24 do referido mês na chácara Santa Rita depois de complicada moléstia (Tísica pulmonar...). Foi este irmão um dos que vieram da Europa em 1848 com o Pe. João R. da Cunha; entrou na Congregação em Roma, onde fez seu noviciado em 1836. Era exemplo de paciência, humildade e regularidade; antes e todo o tempo que durou sua moléstia; ... Assistiu a seus últimos momentos e a seus funerais os padres $\mathrm{J}$. B. Cornaglioto e D. Musci ... e os irmãos J. Bernardo, Claro (ainda noviço) ..." (i)

"Como diversos outros, fui atacado pelo beri-beri e tive de passar duas semanas na chácara de Santa Rita... Entre outros, desceu também para a chácara, onde eu já me achava, o meu colega Pedro Andrade, cearense, que lá no dia 26 de setembro [ 1910 ], foi vitimado pelo mal que nos aterrorizava. “... pude sentir, admirar e amar o santo homem que era o Pe. João [ Vaessen ]. Ouço ainda hoje a voz meio fanhosa e dulcificada de carinho com que ele falava ao moribundo, ali junto de nós todos, de joelhos: "Pedro, meu filho, diga comigo: meu Jesus, misericórdia ! Fique tranqüilo, meu filho. Nosso senhor é muito bom e vai receber você no céu". E chorou ao cerrar os olhos do adolescente, dirigido seu, que ele via ali morrer longe da família, lá das lonjuras do Ceará"(ii). 
bem conservada", tinha metade do seu trecho assentado sobre um terreno de bonita tonalidade esverdeada. A rocha que determinava esta cor era a dunita, cujo teor de platina pode, em algumas circunstâncias especificas, tecnicamente indicar vantagens do aproveitamento econômico. Por isso,

"Os proprietários do estabelecimento (o collégio) ... mancinham sérias esperanças de poder ser explorada a dunita como matriz da platina"307.

A inviabilidade econômica da intenção sepultou o projeto dos padres, mas, por outro lado, preservou o local do extrativismo que atacaria seriamente o tênue equilibrio ecológico da área. Mas da região da chácara foi extraída a pedra-sabão que, entre outras finalidades, entrou na construção da nova igreja. Desde que foi incorporada às terras do Caraça, a chácara Santa Rita desempenhou suas funções por mais de um século, sendo abandonada e substituída pela fazenda do Engenho já da década de 1930. Tanto a chácara como a fazenda tiveram importante papel na convalescença dos doentes caracenses. Não é sem razão, contudo, que lá tenham morrido religiosos membros da Congregação, bem como alunos, todos assistidos até o último suspiro de vida. Estes sítios eram considerados, cada um em sua época, "celeiros do Caraça". Frutas, alguma quantidade de cereal e laticinios, entre outros, eram produzidos aí. Considerando que o número de pessoas fixas nestes locais era pequena, a disponibilidade de alimentos era sempre maior do que no colégio. A fama' de fartura da chácara corria entre os alunos e não era rara a simulação de doenças para se merecer uns dias na "pequena chácara do Morro da Bondade", onde o propósito da estada relacionavase ao descanso, recuperação, férias. ... e descreve um ex-aluno que a vivenciou, ainda no século XIX:

i. LIVRO de óbitos do Caraça. Arquivo do Colégio Caraça. [manuscrito ]. Op. cit.

ii. RESENDE, A de L. Memórias. Belo Horizonte. Edição do autor, 1970. 2 v.

307

SILVEIRA. A da. Floras e serras mineiras. Op. cit., p. 145. 
"Mas como era diferente a bóia do Caraça da de Santa Rita!... Que saudades dos admiráveis quitutes do irmão Pedro! E quanto o tutu de feijão daquele mesmo dia nos distanciava da magra ceia em que no arroz abundante era possivel, com algum esforço, descobrir aqui e acolá um ou outro desgarrado pedaço de carne de boi, como se fossem raros náufragos lutando contra as águas de glaucas do vasto oceano..." 308 .

Nos primeiros anos no século $\mathrm{XX}$, a memória de João Alphonso sobre o beribéri era praticamente desconhecida. Arquivada em alguma estante da biblioteca, houve quem, na época, a mencionasse por ter ouvido sobre ela através de quem a conhecia. Foi ventilado que a melhora de alguns beribéricos na chácara, e especialmente ao retornarem às casas de seus pais, era uma situação que guardava bastante coerência com as proposições presentes na memória do médico carioca. Vez ou outra, quando um padre que conhecera João Alphonso no Rio encontrava-se no Caraça, ele reafirmava a enfática posição de João Alphonso, que insistia na necessidade de se privilegiar aspectos sociais e individuais na prevenção da doença, mesmo quando a etiologia desta não estivesse completamente esclarecida. A memória, diziam, trazia detalhadamente recomendações e comentários sobre procedimentos que o colégio deveria instituir para enfrentar os casos recorrentes da doença. Estas recomendações, ainda segundo quem ouviu falar da memória, não tratavam especificamente de "causas" do beribéri, mas admitiam que experiências acumuladas pela instituição na convivência com a enfermidade ofereciam pistas interessantes e seguras sobre como prevenir e, se necessário, curar a doença. Na Congregação, quem leu evitou sempre detalhar o conteúdo da memória, parecendo, entretanto, que a profanidade da mesma, o estilo do autor, incomodavam mais do que a eventual coerência interna dos "conselhos" médicos. Certa vez, um dos religiosos teria comentado que, para alguns, João Alphonso portava uma erudição, cientifica e humanística, niilista, e até mesmo, em alguns momentos, iconoclasta em ambos os sentidos. Quando um ou outro 
médico, que atendia o Caraça, ouvia falar da memória, havia desinteresse. $O$ exercício médico ainda devotava significativa crença nos poderes da imunização e tratamento das doenças e isto inibia a adoção de idéias não biológicas da doença ${ }^{309}$. Esta tendência remanescia das últimas décadas do século XIX, notadamente marcada pelas conquistas da microbiologia nascente.

Assim é que, no que diz respeito aos serviços e proteção sanitária, os primeiros atos do governo republicano instruiam, entre outras coisas, sobre a notificação de doenças transmissíveis. Assim, pelo decreto de 18 de dezembro de 1889

“... foram consideradas de notificação compulsoria a febre amarella, o cholera, a peste, a diphtheria, a variola, a escarlatina e o sarampo, e de notificação facultativa a tuberculose, a febre typhoide, a coqueluche e o beriberi" ${ }^{310}$.

Quando do regulamento sanitário de 1904, o beribéri é tratado no mesmo grupo das doenças infecciosas que mereciam ser notificadas, isoladas, e os locais serem submetidos à desinfeção e à vigilāncia sanitária. Sob estas condições, o regulamento nomeava as seguintes doenças como sendo de notificação compulsória:

“... febre amarella, a peste, o cholera e doenças choleriformes, a variola, a diphteria, a infecção puerperal nas maternidades, a ophthalmia dos recemnascidos nas maternidades, crèches e estabelecimentos analogos, o typho e a febre typhoide, a tuberculose aberta, a lepra, o impaludismo, o

${ }^{309}$ NUNES, E. D. Medicina social: origens e desenvolvimentos. Revista Cultura Vozes, (84): 5-20.

Neste pequeno texto, o autor sintetiza o movimento histórico da medicina social, periodizando as tendências médicas que abordam diferentemente o processo saúdedoença.

310 FONTENELLE, J. F. Hygiene e saude publica. in.: Diccionario historico, geographico e ethnographico. Op. Cit., p. 428 
beriberi, a escarlatina e o sarampo, quando ocorressem em collegios, asylos e estabelecimentos analogos"3i1.

A lei sanitária refletia o conhecimento científico estabelecido. Os estudos procuravam reforçar cada vez mais a noção de que um agente infeccioso era, em última análise, o causador do beribéri. $O$ micróbio é localizado, enunciado e morfologicamente determinado. Já em 1887, num artigo publicado, um conceituado pesquisador brasileiro mostra figuras com legendas, onde se lè:

"Fig. 2. - Preparação da medulla espinhal de um doente beriberico. Methodo de Gram, coloração pela safranina. ... Vêse um vaso capillar da medulla, tortuosos e ramificado, completamente cheio do microbio, sob a forma embryonaria, colorido pela safranina. As mesmas formas microbianas existem esparsas no tecido, por onde transita o vaso" ${ }^{\mathbf{3 1 2}}$.

ou

"Fig. 6. - Corte transversal da medulla de doente beriberico, na região dorsal; parte correspondente aos cordões antero-lateraes. Methodo de Gram, coloração pela violete methyl. ... Vê-se na superficie do tecido as mesmas fórmas microbianas, ora isoladas, ora formando cadeias de streptococcos. Esparsos no tecido apparecem numerosos nucleos de tecido conjunctivo"313.

A convicção sobre o caráter infeccioso do beribéri (também, em alguns trabalhos, chamado de mal de Ceilão) oferecia um vasto campo para pesquisas que, a partir desta certeza, procuravam encontrar a cura desta moléstia. Numa tese de conclusão do curso médico, o autor escreveria que

311 Idem, p 432.

312 LACERDA, J. B. O micróbio do beribéri. 1887 [ Texto original microfilmado e disponibilizado pela Biblioteca Nacional, RJ ].

313 Idem, estampa 11. 
"Alguma coisa há na historia etiologica do mal de Ceylão e essa está inteiramente acceita pelos scientistas, conseguintemente escapa de controversias, - é a natureza infectuosa da moléstia"314.

Mas não basta aos "scientistas" a demonstração de sua hipótese; torna-se necessário tentar imobilizar definitivamente os argumentos contrários. Neste sentido, o autor anterior, na mesma tese de conclusão de curso, procura desqualificar as originais pesquisas de Eijkmann, afirmando:

"O trabalho de seis annos de Eijkmann se compõe de pesquizas abundantes, porem superficiaes, contradictorias, cheio de observações incorretas, que em vez de algo provar de positivo, só evidencia que as theorias das molestias provocadas por taes ou quaes alimentos, à parte excepções sufficientemente conhecidas, vão sendo por completo esquecidas $^{\text {"315. }}$.

Quando Eijkmann começou a estabelecer uma relação entre o consumo de arroz polido e não polido com uma polineurite, idêntica ao beribéri, em galinhas, ele supôs que a causa estivesse numa toxina presente no cereal, toxina esta cujos efeitos seriam suprimidos por alguma substância presente na película do arroz integral. Estes resultados foram, em geral negligenciados pela comunidade científica,

314 NERY, I. S. R. Analogias entre o beribéri e a malária. Typografia Montenegro, Rio de Janeiro, 1899. p. 19.

315 Idem, p. 32.

Ainda neste periodo surgiram trabalhos clássicos sobre a natureza infecciosa do beribéri. $\mathrm{Na}$ condição de pesquisadores e divulgadores desta teoria, Lacerda (i) e Fajardo (ii ; iii) destacaram-se, publicando seus resultados em periódicos francês e alemão.

i. LACERDA, J. B. de. Contributions l'etude de la cause do beriberi, 1907 [ microfilme, Biblioteca Nacional, RJ].

ii. FAJARDO, F. C. Hematozoaire du beriberi, 1900 [ microfilme, Biblioteca Nacional, RJ].

iii. FAJARDO, F. C. Die Hämatozoarie des Beri-beri im Gehirn. Zentralblatt für Bacteriologie, Parasitenkunde und Infectionskrankheiten, XXVII(6,7,8), 1900. 
que os consideravam sem "consistência", justificando, ainda, que experimentos com galinhas não poderiam ser aplicados a seres humanos. Posteriormente, outros pesquisadores holandeses, em Java, deram continuidade aos trabalhos de Eijkmann, alguns sob sua orientação, e ainda em 1901, Gerrit Grijns (1865-1944)

“... publicou um artigo relatando seus resultados e propôs que a causa do beribéri era a falta de alguma substância essencial que o pericarpo do arroz continha"316.

A teoria infecciosa mantinha-se e seriam necessárias duas condições para "fortalecer" definitivamente a teoria nutricional: o isolamento de uma substância no arroz integral que recuperasse beribéricos e a falta de resultados positivos das pesquisas microbiológicas e parasitárias, capazes de convencer satisfatoriamente quanto à relação de um agente com a doença. Estas condições não tardariam a acontecer, sem, entretanto, garantir que a teoria nutricional tivesse imediata unanimidade.

Na Faculdade de Medicina, a teoria infecciosa para a origem do beribéri encontrava eco. Os alunos, respaldados por seus mestres, tratavam de vasculhar a literatura existente sobre 0 assunto, preferencialmente reforçando a teoria hegemônica. Por esta época, colegas que trabalharam com João Alphonso no hospital solicitaram à sua familia exemplar da memória "Considerações sobre o beribéri no Caraça". A alegação era que o manuscrito entregue aos padres havia sido enviado ao Caraça e que, portanto, o acesso a ele estava dificultado. $O$ filho advogado de João Alphonso, herdeiro dos livros e guardião das anotações do pai, dedicava as suas horas de folga a vasculhar esta herança. Verificava livros, cartas, receituários, anotações de leituras e notas diversas, sendo que muitas delas encontravam-se em alemão. Para o filho, tratava-se de um passeio singular pelo misterioso percurso intimo, reservado, de um homem. Quantos destes percursos haveria mundo afora ? Um mundo tão real, tão distante, tão próximo e essencial quanto o mundo aparente. As trilhas intercambiantes entre um e outro mundo nutriam-se de tantas possibilidades que se tornava dificil definir 
os limites de cada uma e, muito mais, quais as conseqũências desta dualidade. Nestes momentos, o filho de João Alphonso recordava o pai exageradamente, procurando, numa atitude francamente exegética, compreender o mundo do seu pai e o mundo tal qual ele viveu. Era impossivel ao filho não se impor a questão de como o pai teria vivenciado a temporalidade, diante das suas exigências e conflitos. Ele sabia aquilo que seu pai lhe dizia, isto é, que o homem sonha em ser dono de seu próprio destino, mas que se confunde já na primeira encruzilhada: que destino é este ? Aquele que lhe é dado ou aquele que rigorosamente expressa sua vontade de foro mais intimo ? Eram pontuações deste tipo que geravam curiosidade do filho em relação ao pai. Numa dessas circunstâncias, enquanto arrumava e folheava livros antigos do pai, especialmente aqueles que foram trazidos da Alemanha, ele notou o livro Saudades do Brasil, livro que o pai dizia ter sido presente do Sr. Theremin por ocasião de uma visita que este lhe fizera em Göttingen. $O$ livro é um belo álbum com gravuras bem feitas da cidade do Rio de Janeiro. Ao folheá-lo, notou um envelope amarelado pelo tempo entre duas páginas praticamente coladas. Curioso, ele tomou cuidadosamente o envelope e o abriu sem dificuldade, pois não estava colado. Dentro, em meia folha envelhecida de papel, algo escrito em alemão, definitivamente com a letra do pai. Não entendendo o significado do que estava escrito, o filho reconheceu pela forma que se tratava de um pequeno poema, sem, contudo, ter certeza se o pai o havia criado ou copiado. Passou os olhos no poema e fitou por vários instantes o velho pedaço de papel, onde estava escrito:

Meine Welt !

Eine wirkliche Welt:

teuflisch, göttlich ...

/dialektisch

folglich

Die Kühnheit

neue Wege zu gehen 
ist

Die Freude, sie wiederzusehen. 317

Sem conter a vontade de saber o significado, ele alcançou um dicionário alemão-francês-alemão, conseguindo, assim, apreender algumas palavras e, então, deduzir a noção do poema. Examinou o poema mais vezes e, repetindo um hábito do pai, sentou-se na poltrona do seu escritório, fixando o olhar em algum ponto do ambiente; um ponto fixo de apoio para reflexões que se comportavam como penas em tempestade.

O poema, ele o devolveu ao lugar onde o pai o colocara e, quanto a 'memória', não a encontrando, dizia sempre o mesmo: o único texto disponivel era aquele que foi entregue aos padres congregados missionários. A única referência encontrada entre suas anotações era a folha de papel correspondente à página de rosto da memória, onde se lia $o$ indice:

1. O que se vê, como è e os modos de contar: ensaio introdutório;

2. As doenças, suas denominações e classificação: como combinar cores;

3. Uma doença, um pesquisador e o arco-íris branco: como isolar uma cor;

1.1. Dizem que o beribéri è endêmico no Caraça: quem conta o que;

2.1. O meio e a doença ou o meio e as doenças: do que pode se adoecer no Caraça;

3.1. Se é beribéri (ou outra doença): como lidar, o que fazer, o que não fazer.

Os amigos do pai que o procuravam liam surpresos o tal indice e the perguntavam se realmente aqueles tópicos correspondiam a itens da memória, mesmo não havendo dúvidas de que a letra era mesmo de João Alphonso e o titulo era claro no alto da página. O filho não conseguia

"Meu mundo!

Um mundo real:

diabólico, divino ... dialético

Portanto,

A coragem de percorrer

novos caminhos

é a alegria de revè-la." 
explicar - convencer ? - ao interlocutor os motivos dos enunciados e como eles teriam sido desenvolvidos pelo pai, mas também não se esforçava em buscar pistas coletivamente. Além da memória abordar tema que não era da sua área, ele não enxergava, naqueles que o procuravam por conta do trabalho, disposição para perceber as sutis trilhas percorridas pelo pai. Em reflexão intima, ele captava naquele indice a presença de elementos que o pai tomara de outras áreas que não a médica. Por exemplo, a referência ao 'arco-íris branco', provavelmente seria resultado da afinidade do pai por Goethe. É que o pai lhe contara, em diferentes etapas da vida, a visão de um arco-iris branco que o poeta teve numa madrugada, nos arredores de Frankfurt e as repercussōes desta visão. Mas por que o pai expressaria em metáforas o conteúdo da sua memória sobre o beribéri ? - perguntava o filho. $O$ próprio entendimento do fenōmeno do 'arco-íris' branco era plural, múltiplo, um acaso que foi capaz de repercutir intensamente na atividade do artista. Palmilhando respostas, poder-se-ia conjeturar que "como combinar cores" bem poderia referir-se à ordenação, classificação, destas 'casualidades' que, no caso, seriam as doenças; um processo taxionômico mediante consensos que favoreceriam padronizações de intervenções, com desvantagens para as particularidades, menosprezadas pela força da institucionalização de determinado modelo terapêutico. Se João Alphonso concordasse com a dinâmica deste raciocinio, é admissivel pensar que o referido processo legitimaria algo - uma determinada doença, por exemplo - que tem significado, é até real, mas que necessariamente não é uma "coisa". Por outro lado, "isolar uma cor" acrescentaria ao processo taxionômico o recrudescimento da especialização, com exaltação de uma casualidade e sua transformação em icone auto-promocional, pretensamente revelador de talento particular. Obviamente que a história do "arco-íris branco" de Goethe não comportaria nenhuma analogia com o uso que fez João Alphonso ou, se comportasse, seria em sentido negativo e, então, aquela história teria sido utilizada ironicamente. Neste sentido, 'combinar' e isolar' aproximariam do 'explicar' e 'saber' os mecanismos de uma dada doença, 
etapas indispensáveis à identidade da doença, pela qual sua existência é oficialmente aceita e seu controle possivel ${ }^{\mathbf{3 1 8}}$.

Mesmo não sendo um sanitarista, o filho de João Alphonso vivenciava a organização sanitária que vigorava na capital da república e, atentamente, acompanhou os acontecimentos de 1904, que viriam a ser conhecidos como 'a revolta da vacina'. Nesta época dirigia o serviço de saúde pública, desde 23 de março de 1903, o médico Oswaldo Cruz, indicado pelo então presidente Rodrigues Alves. O sanitarista tratou de unificar e organizar no nivel federal os recursos de proteção sanitária existentes através

“... de instrucções technicas para os serviços de policia sanitária, vigilancia e isolamento, e para os trabalhos de desinfecção domiciliar, estas ultimas muito pormenorizadas..."319.

O 'programa de higienização' da capital do pais, planejado por Oswaldo Cruz, prescrevia atacar sucessivamente três graves problemas de saúde pública: a febre amarela, a peste bubônica e a variola. $O$ método de abordagem destas doenças epidêmicas parece ter entusiasmado higienistas da época, pois, segundo um deles,

“... foi no conceito epidemiológico adoptado para as

doenças transmissiveis, encaradas não mais no modo de ver da

Hygiene antiga, que as punha na dependência da influência do

318 Mas, como esclarece NOVAES (*),

"Na verdade, as coisas não correm com tal simplicidade. McKeown, por exemplo, mostra que o comportamento da tuberculose, (em termos de mortalidade especifica) na Inglaterra e Gales, durante o período 1830-1960, pouco tem a ver com as inovaçðes do saber médico e com seu correspondente domínio técnico. Quando o bacilo da tuberculose foi identificado por Koch (1882), a taxa de mortalidade da doença havia diminuido pela metade e, cem anos depois, quando surge a quimioterapia, havia atingido um ponto que, se comparada com aquela inicial, poderia ser considerada desprezivel".

* NOVAES, R. L. A saúde e os conceitos. Op. cit. p. 2.

319 FONTENELLE, J. F. Hygiene e saude publica. in.: Diccionario historico, geographico e ethnographico. Op. Cit., p. 433 
meio, porém como tendo suas fontes nos proprios doentes, delle se diffundindo por modos varios até alcançar os individuos sãos. É a Hygiene publica já se apresentando na segunda phase de sua evolução"320.

Como advogado e jornalista, o filho de João Alphonso prestou atenção aos acontecimentos e não era raro, num exercício que the agradava bastante, estimar a compreensão que o pai teria dos fatos daquele ano. A obrigatoriedade da vacinação contra a variola exacerbou sentimentos de protestos que, especialmente, vinham sendo contidos desde a agressiva campanha de combate à peste:

Cerca de 2500 mata-mosquitos espalharam-se pela cidade. Para prevenir resistências dos moradores, as brigadas faziam-se acompanhar de soldados da policia. Pode-se ter idéia da dimensão do esforço através da seguinte estatistica: só no segundo semestre de 1904 foram visitadas 153 ruas; foram feitas no primeiro semestre, 110224 visitas domiciliares, 12971 intimações, 626 interditos.

Tal atividade evidentemente provocou rebuliço na cidade e perturbou a vida de milhares de pessoas, em especial os proprietários das casas desapropriadas para demolição, os proprietários de casas de cômodos e cortiços anti-higiênicos, obrigados a reformá-los ou demoli-los, e os inquilinos forçados a receber os empregados da saúde pública, a sair das casas para desinfecções, ou mesmo a abandonar a habitação quando condenada à demoliçãon ${ }^{\text {321 }}$.

Quando, então, os ânimos exaltaram-se, o filho recordava do que o pai the contara sobre epidemias de variola pais afora. É que marcara muito João Alphonso a epidemia que ele assistiu em Mariana e Ouro

320 Idem.

O dr. J. F. Fontenelle foi médico do Departamento Nacional de Saúde Pública, criado a 2 de janeiro de 1920, a partir da reorganização dos serviços sanitários federais.

321 CARVAlHO. J M de. Os bestializados. Såo Paulo, Companhia das Letras, 1987 cap. IV, p. 94-5. 
Preto, por ocasião da sua primeira tentativa de se encontrar com o Dr. Lund. Naquela ocasião, as autoridades mineiras reclamaram da falta da vacina e que, apesar de resistências esparsas, era isto que mais os angustiava na provincia. Além disso, vacinar contra a variola era uma experiência que desde a primeira metade do século XIX vinha sendo executada na capital. Assim, era improvável que isoladamente fosse apenas a obrigatoriedade da vacinação a causa geradora dos distúrbios típicos de insatisfação. $O$ fato é que estas açōes, pontuais e especificas para determinadas doenças, contribuiram para asseverar a crença na natureza infecto-contagiosa de doenças e, conseqūentemente, controle através da higiene pública e - por que não ? - imunização. No ritmo desta concepção, às evidências de que o beribéri associava-se ao consumo de arroz, a escola francesa, de tradicional influência nas escolas e práticas sanitárias brasileiras, acordava que

"O beribéri é muito provavelmente uma doença de origem alimentar e de causa infecciosa, [e que] o arroz parece ser o veiculo habitual do germe infeccioso" 322 .

No entanto, a dificuldade dos infectologistas em identificar convincentemente o provável agente causador da doença reforçou a desconfiança de pesquisadores, que trabalhavam com a possibilidade de encontrar no farelo de arroz alguma substância ainda desconhecida e com propriedade de curar a enfermidade. Um destes pesquisadores foi o bioquimico inglês Frederick Gowland Hopkins ${ }^{323}$, que já na primeira década do século $\mathrm{XX}$ iniciou estudos controlados com dietas quimicamente quantificadas. Hopkins notara que os nutrientes conhecidos (minerais, gorduras, carboidratos e proteinas) não eram capazes de, sozinhos, promover o crescimento satusfatório de cobaias. Ao introduzir alimentos naturais - como o leite, por exemplo - notou melhoras nas cobaias e supós que isto fosse devido à presença de

322 HÉBRARD. Béribéri. In. GRALL \& CLARAC. Traité de pathologie exotique. Paris, Libraire J D Balliere, 1911. p. 42. 
substâncias essenciais, necessárias, inclusive, ao aproveitamento adequado dos nutrientes conhecidos.

"Com base nesses resultados, introduziu o conceito de "fatores acessórios": substâncias adicionais - em relação aos quatro grupos de nutrientes reconhecidos - necessárias em quantidades minimas para uma nutrição adequada, de natureza ainda desconhecida" ${ }^{324}$.

Entre outros, Casimer Funk (1884-1967), bioquímico polonês radicado na Inglaterra e posteriormente naturalizado estadunidense, despontaria com seus estudos acerca destes "fatores acessórios" presentes nos alimentos. Exatamente em dezembro de 1911, ele comunica a identificação de uma substância, isolada do farelo do arroz, com propriedades antineuriticas, isto é,

“... substancia que evitava ou curava a polineurite análoga à do beri-beri humano, observada ou provocada nas aves e nos mamiferos"325.

Em seguida, Funk publicou um artigo intitulado "A etiologia das doenças de deficiência", onde discute algumas doenças (escorbuto, pelagra, raquitismo), além do beribéri, como sendo de provável origem nutricional, de acordo com as evidèncias presentes em diversos trabalhos. A estas substâncias, cujas deficiências geravam doenças especificas, ele chamou de vitaminas. Assim, os trabalhos de Hopkins e Funk se complementaram; enquanto o primeiro

'... chegou ao conceito de 'atores nutricionais acessórios' através de experimentos de dieta purificada... Funk estabeleceu o conceito de doenças de deficiència nutricional relacionandoas à deficiência de vitaminas ${ }^{\mathbf{m} 26}$.

\footnotetext{
324 SANTOS, K. M. O . dos. O desenvolvimento histórico ... Op. cit. p. 162.

325 McCOLLUM, E. V. et al. Os novos conhecimentos da nutrição. Op. cit. p. 491.

326 SANTOS, K. M. O dos. O desenvolvimento histórico ... Op. cit. p. 163.

Originalmente, Funk, em inglês, denominou as substàncias encontradas de "vitamine" (vital + amine). Posteriormente descobriu-se que algumas destas substàncias ( "vitamine"
} 
Se uma hipótese, externa à teoria infecto-contagiosa, estava praticamente excluída dentre as possibilidades etiológicas do beribéri, a irônica confirmação desta hipótese diferenciada significaria um 'peso' para importantes segmentos da medicina. A adesão à nova teoria explicativa do beribéri trilhará um caminho tortuoso, pleno de contestações. Ou seja, a polêmica sobre a etiologia do beribéri não se encerrará com o alvorecer da nova descoberta científica. $O$ que se verá nos próximos anos será uma eloqũente argumentação sobre as atribuições e os limites da ciência, argumentação esta que vem sob a forma de 'contestação científica', mas que se revela como uma interessante tentativa de 'problematização' de um tema que se impunha para debate e conseqüente adoção, ou não, pela sociedade. Esta ponderação poderia ser sintetizada na seguinte questão: por que a descoberta das vitaminas e a teoria das doenças por deficiência não encerraram a discussão sobre a etiologia do beribéri ?

Enquanto empreendimento cientifico, estas duas descobertas não se deram em campo estéril, isto é, quando elas foram anunciadas, um corpo de hipóteses e teorias competiam num campo onde praticamente todos os grandes pesquisadores da emergente área da medicina tropical já haviam assumido suas teorias no âmbito da teoria infecto-contagiosa da doença. Sendo assim, e adjetivamente falando, o 'científico' não irrompe incontestavelmente. Por motivos que vão da conviç̧ão à intriga e vaidade, um fato 'cientifico' numa comunidade cientifica pode ser o inicio

) eram aminas (i, ii). Então, o termo passou a ser "vitamin", cuja tradução para o português não deve admitir a contração 'vital + amina'. Após os primeiros estudos sobre substâncias essenciais presentes nos alimentos, pesquisas subsequentes confirmariam aqueles achados, e uma mesma substância recebeu várias denominaçðes. A tiamina vitaritiná $B 1$ - teve, nos primórdios de sua identificação, os seguintes nomes, de accíli com o pesquisador, além de vitamina (Funk): orizanina (Suzucki), antiberiberina (Tsuzuki), torulina (Edie), eutonina (Abderhalden), antineuritina (Hofmeister), hidrosolúvel B (McCollum e Kennedy), etc.(iii).

i. GROLIER Enc. Mult. Op. cit. Funk, Casimir.

ii. BECHTEL, W. Reconceptualization and interfield connections: the discovery of the link between vitamins and coenzymes. Philos. Sci, (51) : 273, 1984.

iii. McCOLLUM, E. V. et al. Os novos conhecimentos da nutrição. Op. cit. p. 491 
de polêmicas que podem se desenvolver a curto, médio ou longo prazo. Outro motivo que 'problematizava' a adoção da nova teoria das deficiências nutricionais localizava-se muito mais no poder de 'denúncia' inerente à adoção desta teoria para explicar a doença. De que maneira ? O meio físico, como "locus" de emanação de doenças, de alguma forma descompromete a ação humana. 'Domar'a natureza, enquanto obsessão ontológica do ser humano, admite percalços dentro de um horizonte evolucionista consentido. Contudo, a subtração ou privação alimentar, e, portanto, as doenças oriundas destas circunstâncias, não gozam daquele mesmo beneplácito. Há, ai, algum grau, variável, de intencionalidade humana, independentemente do nivel de conhecimento que se possa ter sobre o assunto. Independente porque a relação entre o que se come e a existência corporal, com relativo bem ou mal estar, é uma experiência individual assimilada na própria trajetória de vida deste individuo. $\mathrm{Ou}$ seja, com mais ou menos vigor nutricional os individuos vivem, reproduzem e, o que é altamente convincente empiricamente, aumentam de número. A essencialidade, e até mesmo uma certa involuntariedade, do ato alimentar oferecem à humanidade um nivel mínimo de conhecimento, que permite aos individuos pressupor a necessidade de uma alimentação com, pelo menos, niveis minimos de qualidade e quantidade. Quando a fome e suas conseqüências se manifestam, manifesta-se também a 'denúncia' de um quadro amplamente conhecido, causas nitidas e que, da responsabilidade à comiseração ou indiferença, perpassam cada ser humano com algum nivel de sentimento. Quando então esta deficiência alimentar (qualitativa ou quantitativa) se dá no âmbito de instituições socialmente reconhecidas, etc., arranha-se a reputação, imprimem-se rótulos, estremecem alicerces pretensamente sólidos de instituiçōes que, na maioria das vezes, têm como guardiões eminentes figuras sociais, tanto do meio científico como político. $O$ beribéri no Brasil legalmente teve sua identidade reconhecida, como já foi visto, como doença de natureza infecciosa e circunscrita a colégios, quartéis, asilos, etc. Admitir francamente a falência alimentar como principio etiológico para esta enfermidade não seria, então, uma mera operação de lógica cientifica; necessitaria haver uma meticulosa 'negociação', que viria fantasiada dos mais variados argumentos, até que 
se adequasse o discurso cientifico a todas as situações de ocorrência da doença ${ }^{327}$.

O superiorato do Padre Francisco de Paula e Silva seria encerrado com a sua sagração como bispo de São Luís do Maranhão. Hábil, procurou sempre evitar que notícias sobre doentes no Caraça se propagassem indiscriminadamente. A repercussão de qualquer notícia deste tipo beirava sempre o desastre, no que se refere ao número de matriculas, por isso o cuidado em preservar internamente noticias de enfermos e enfermidades ${ }^{328}$. Ao sair, o padre Francisco deixaria vasto e

327 O questionamento da teoria das doenças por deficiência alimentar pela comunidade científica brasileira durará décadas, como será visto oportunamente. Um bom exemplo inicial diz respeito às comunicações médicas por ocasião das sessões da Academia Nacional de Medicina. Em uma delas $\left(^{*}\right)$, realizada em 30 de setembro de 1915, falando sobre a etio-patogenia do beribéri, o médico Henrique Autran

"Refere-se à theoria alimentar, tratando de todas as hypotheses em torno do arroz e, fazendo considerações sobre ellas, estuda o papel das vitaminas de FÜNCK. Não achando que a theoria alimentar resolva o problema da etiologia, entra nas theorias infecciosas ...

"Entra em consideraçðes sobre as vitaminas no escorbuto e na pellagra, achando que ellas não resolvem o problema. Tendo estudado a questão no ponto de vista de ser o beribéri uma entidade morbida autonoma, envereda pela etiologia, ventilando todas as hypotheses apresentadas pelos scientistas. Termina, trazendo ponderaçð̃es sobre o contágio e citando observações que o provam. ... Fala ainda do contagio indirecto por meio de insectos, sobre o que se extende, e termina considerando o beriberi molestia contagiosa".

* AUTRAN. H. Etio-pathogenia do beriberi. Brasil Médico, 29 (45): 342.1915.

328 No Arquivo da Casa central da Congregação, no Rio de Janeiro, há cartas que sugerem esta preocupaçăo, umas meños e outras mais explícitas, como a que segue $\left(^{\star}\right)$, onde o Pe. F. de P. e Silva comunica ao visitador que tudo vai bem, exceto um menino que agoniza, salientando que ele teria vindo doente de casa:

"Agora estou sossegado. Sossegado é o modo de dizer pois ainda agoniza o pobre menino doente e o médico chamado de Ouro Preto não chega. É um bem triste fim de superiorato. Já tomei todas as medidas para amortecer a noticia da morte, caso ela se dê e estou a empregar as medidas divinas para que assim seja. O colégio vai tão bom caminho que seria pena qualquer contratempo. ... este caso veio já de casa. Tenho aqui o irmão dele 
rico material, que seria publicado na Revista do Arquivo Público Mineiro, em 1908329. Para a Congregação, a grande obra deste superior foi a restauração da Escola Apostólica, fato este que ele próprio reconhece, ao finalizar os seus "apontamento históricos":

"A Escola Apostólica que começa apenas de reviver já deixa entrever ricas esperanças para o futuro.

"Si um dia o Collegio vier a desapparecer, ficará ahi a Escola Apostólica a formar clerigos e missionarios que continuem a levar a semente divina do ensinamento evangelico pelas diversas localidades de Minas" ${ }^{\text {330. }}$

... e a suposição do padre Francisco se fez cumprir em bem pouco tempo, pois no último ano da sua função de visitador, o padre Dehaene determinou:

"Achando muito reduzido o número de alunos no Colégio e devendo ainda diminuir com a suspensão da equiparação, determinei, de acordo com os Consultores Provinciais, que o Caraça, dora em diante, não receba senão jovens que tenham inclinação para o estado eclesiâstico"331.

que é diácono no seminário de Mariana... que assim livrou um pouco a responsabilidade do superior".

* Arquivo geral da Casa Central. Documento 8 (2); CM/5; CR - 178.

Obs.: Primeiro, a grafia da carta transcrita acima não obedece ao original. Manuscrita, a letra do Pe. Francisco de Paula oferece dúvidas sobre algumas letras que, entretanto, não impedem de ler e compreender o significado do documento. Segundo, a existência do documento no Arquivo da Congregaçăo no Rio de Janeiro não significa que necessariamente a correspondência tenha sido remetida, por exemplo, do Caraça para aquela cidade. Os padre visitadores ( nesta época - entre 1900 e 1912 - era o padre P. Dehaene ) percorriam outras instituiçð̃es da congregação, além do Caraça. Assim, é possivel que a citada carta, pelas circunstâncias descritas, tenha sido remetida pelo superior ao visitador que deveria se encontrar mais próximo do colégio.

329 Estes escritos do Pe. Francisco de Paula e Silva constituem-se em importante referência bibliográfica para a história do Caraça. Túubiicados ua Revista do Arquivo Público Mineiro, traz os seguintes textos:

1) Caraça: apontamentos históricos e notas biographicas - Parte segunda 1845-1903; 2) Monographia da Irmandade de N. S. Mãe dos Homens: estudo Theologico - Histórico; 3) Contos Caracenses; 4) Histórias da Edade Media.

${ }^{330}$ SILVA, F. de P. e. Caraça: apontamentos históricos. Op. Cit., p. 132.

${ }^{331}$ ZICO, J. T. Caraça: peregrinação, cultura e turismo Op. cit. p.95-6 
O último superior do colégio, em substituição ao padre Francisco de Paula, foi o Pe. Van Pol, holandês com doutoramento em filosofia e teologia feito em Roma. Na época da sua escolha para o Caraça, dirigia o seminário de Petrópolis. Pe. Van Pol era admirado não apenas pela solidez da sua formação religiosa e conhecimentos de 'ciência eclesiástica e profana', mas também por ser, de fato, um eximio poliglota. Consta que ele dominava sete linguas vivas e lhe eram familiares outras quatro consideradas mortas: hebraico, siriaco, grego e latim. Durante o seu superiorato, e antes que fosse desativado, o colégio sofreria sérios golpes. Estes fatores provocaram uma significativa redução no número de matrículas para o colégio e, conseqüentemente, contribuiram para o seu fechamento.

"As causas da diminuição dos alunos, nós as sabemos: fundação de Colégios em várias cidades, dificuldade de acesso ao Colégio da Serra, notícias alarmantes do beribéri, repetição dos velhos boatos sobre a rigorosa disciplina" ${ }^{332}$.

São desta época os dois óbitos de alunos ocorridos na chácara Santa Rita, conforme relato anterior de um ex-aluno. O então superior, padre Van Pol, tratou com o visitador, através de várias correspondências, sobre a situação sanitária da instituição, sempre relacionando-a à presença do beribéri. Numa carta de 1910, ele tece considerações sobre o estudante cearense, então adoecido e sob cuidados na chácara, e afirma que:

“...ainda há uma manifestação mais ou menos forte de beribéri" ${ }^{333}$.

Em duas outras cartas da mesma época, ele tratará com o Visitador sobre a antecipação de férias, viagens à chácara e outras providências, "... por causa da epidemia de beribéri no Caraş" ${ }^{\text {"334 }}$

332 Idem, p. 95.

333 Arquivo geral da Casa Central. Documento 8 (2); CM/5; CR - 178, Carta de 20,9:1910. 
A insistente preocupação dos padres caracenses com a saúde dos estudantes era, incorrigivelmente, preocupação corn a 'saúde' da própria instituição que se via ameaçada com o fantasma da insalubridade local. $\mathrm{Na}$ tentativa de cercar as possibilidades que geravam doenças no Caraça, não bastaram as melhorias sanitárias, aumento do tempo $\mathrm{e}$ disponibilidade de local para atividade fisica (tudo isso recomendado sob - mais rigoroso conceito de higiene da época), antecipação de férias, descanso na chácara, etc. Era necessário evitar que alunos supostamente doentes e incapacitados' freqũentassem o estabelecimento. Assim é que, atravès de uma circular, é estipulado “... providências para admissão na Escola Apostólica e diz sobre a saúde de todo aluno recém chegado [ que deverá ser ] examinado pelo médico da Casa. Não poderá ficar quem apresentar defeitos físicos ou principios de moléstias graves" ${ }^{\text {335. }}$.

Durante o tempo que estudou no Caraça, Theophilo de Almeida certamente não ouviu dizer da memória sobre o beribéri escrita por João Alphonso. Teria sido durante os últimos anos do seu curso médico, que transcorreu entre 1910 e 1915 , que ele teria ouvido falar neste trabalho. Lamentou não tê-lo conhecido detalhadamente no Colégio. Na Casa Central, onde o ex-aluno Theophilo era sempre bem recebido, ele recebeu informações já sabidas: a memória era um documento de poucas páginas, cuja única cópia foi remetida para o Caraça, onde, provavelmente, se encontrava arquivado em algum canto da biblioteca. $\mathrm{O}$ mais importante, para quem informava Theophilo, era que os padres que na época estimularam a elaboração e se interessaram pela memória do dr. Magalhães não se encontravam diretamente envolvidos com o Caraça e o beribéri. Esta circunstância desfavorecia a retomada das considerações e recomendações daquele médico que manteve bcas relações com a Congregação. $O$ jovem e quase médico Theophilo compreendeu a justificativa do prestativo interlocutor e até procurou

334 Arquivo geral da Casa Central. Documento 8 (2); CM/5; CR - 198, s.d; Documento 8 (2); CM/6; CR - 200, Carta de 07/10/1910.

335 Arquivo geral da Casa Central. Documento 8 (2); CM/6; ED - 111. 
justificar o desinteresse pelo estudo de João Alphonso. Argumentou que, com a 'avalanche' de pesquisas sobre o beribéri que sucederam a morte daquele médico, não seria exagero afirmar que a referida memória encontrava-se ultrapassada cientificamente. $O$ seu interesse posicionava Theophilo - era ler e descrever os procedimentos adotados para se debelar o beribéri, numa época em que muitos aspectos da doença eram desconhecidos. Certo é que, quando elaborou sua tese de conclusão do curso médico, Theophilo de Almeida utilizou os escritos do padre, já bispo nesta época, Francisco de Paula e Silva, publicados na revista do Arquivo Público Mineiro ${ }^{336}$.

Pelo novo regulamento da diretoria geral de Saúde Pública de 1914, - beribéri era tratado como doença infecciosa e, juntamente com outras dezessete doenças, entre elas febre amarela, peste, cólera, tifo, era tida como sendo de notificação compulsória ${ }^{337}$. Como no meio cientifico, onde a nova teoria sobre a etiologia do beriberi era objeto de intensas discussões, entre as autoridades sanitárias brasileiras a incorporação desta teoria também exigiria evidências clinico-epidemiológicas que sustentassem uma nova classificação da doença. Estas evidências teriam que ser providenciadas pela ciência local, pois até havia alguma suspeita de que o beribéri, no Brasil, nutria-se de particularidades asseguradas pelos pesquisadores - ou apenas "opinadores" - locais da doença. É esta opinião que sustenta a apreciação de Theophilo de Almeida quando, em seu estudo, afirma em relação ao beribéri no Caraça:

336 Por ocasião do presente trabalho, foi pesquisado na biblioteca do Caraça um volume da citada "Revista do Archivo Publico Mineiro". Curiosamente, foi encontrado um cartão do então Dr. Theophilo de Almeida, onde o próprio escreveu:

"O ex-aluno Theophilo de Almeida [ nome impresso ] restitue este livro, que esteve algum tempo em seu poder, por emprestimo, e pede que se lhe dê o destino, de retorno, à sua biblioteca.

Sinceramente agradece".

337

DIÁRIO OFFICIAL. Novo Regulamento da Directoria Geral de Saude Publica. 21-4914. 
"Depois que foram realizados certos melhoramentos no edificio do Collegio ultimamente, abrindo janellas, augmentando o arejamento dos salōes, tornando soalheiros os pateos, e feitas certas mudanças na dieta, consta-nos que de vez o beriberi desappareceu dos pavilhões que eram seus velhos hospedeiros" ${ }^{\text {"338. }}$.

$\mathrm{O}$ autor tem como referência médica mais importante, para tratar do beriberı no Caraça, a monografia do médico diamantinense Antônio Felício dos Santos. Apesar de ter estudado no seminário de Mariana, Felício do Santos, por ocasião da elaboração de sua memória, não esteve no Caraça. Ele se baseou em relatos, especialmente dos padres do seminário de Diamantina, que também eram lazaristas, sendo muitos oriundos do próprio Caraça. Para Theophilo, a grande fonte de informações sobre o cotidiano caracense foi o tempo que ele próprio passou estudando no colégio. Neste sentido, ele estrutura uma arriscada estratégia que considera o tempo como um túnel vácuo, onde, impunemente, as experiências de uma extremidade podem ser trazidas à outra para serem submetidas ao entendimento possivel de uma época diferente. Nada é mais comum do que isto, se não fosse o fato de que a lembrança de um acontecimento não é nunca a vivência do acontecimento. Mesmo porque a visão de um 'figurante' não avaliza necessariamente tudo que ele possa expressar sobre um certo acontecimento do qual ele tenha participado. Validação esta que não garante 'veracidade' dos fatos, mas em termos de compreensão totalizante, definitiva, de uma experiência sobre a qual se criou um farto leque alegórico de representações. Neste sentido, a própria evolução fisiopatológica da doença contribuiu para estimular significados que ela teria na comunidade estudantil:

"Via de regra a molestia è de prognostico muito benigno. Tanto no Caraça, como em Mariana e Diamantina, os obitos por beriberi sempre foram rarissimos, e ainda assim os poucos registrados correm por conta de complicações estranhas ao beriberi; ...

${ }^{338}$ ALMEIDA, T. O beriberi no Brasil. Op. cit., p. 80. 
"Esta benignidade, e sobretudo a tendencia para a cura facil, para a melhora providencial por uma simples remoção do doente para fóra do sitio onde contraiu o mal, eis o que constitue a principal individualização das epidemias de beriberi desses tres internatos mineiros.

"Tivemos ocasião de ver no Caraça alumnos edemaciados, jâ dyspneicos ás vezes, melhorarem promptamente ou terem mesmo cura immediata simplesmente com a migração para a "Chacara", ...

"No Caraça, a vis maldosa dos estudantes vadios, que os há sempre entre collegiaes, encontrou na simulação do beriberi porta facil para uma sahida em férias extemporaneas, para se fugir por alguns dias às exigências disciplinares do internato.

"Era simples a artimanha. ...

"O uso proposital de roupa molhada, principalmente ceroulas, calças, meias e sapatos, ao mesmo tempo que ligas de meias especiaes constrigiam as pernas na panturrilha a ponto de embaraçar a circulação sanguinea, eis o processo simples adoptado com efficiencia para produzir um pequeno edema nos membros inferiores simulando o beriberi incipiente...

"Tal o passaporte para uma excursão de recreio á Chacara, ou a alguma das povoações visinhas do collegio, ou mesmo à saudosa casa dos paes.

"Parece que tambem em nossas classes armadas entre inferiores, soldados e marinheiros, se observa semelhante ardil; a falsificação do beriberi em benefício do ocio ou da vadiagem. . Lembra-nos havel-o visto citado algures" ${ }^{\text {"339. }}$.

Ao tratar da etiologia da doença, Thenphilo discute as teorias que se consideravam na época: A teoria parasitária ou microbiana e a teoria alimentar. Com a relação à primeira, sempre houve quem defendesse a natureza infecto-contagiosa do beribéri, mesmo sem se conseguir demonstrar que a doença fosse transmissivel direta ou indiretamente. A

339 Idem, p. $78-9$ 
questão era que, na ausência de uma outra teoria que explicasse convincentemente o aparecimento e desenvolvimento da doença, as medidas profiláticas afeitas às doenças infecciosas eram implementadas quando da ocorrência do beribéri. Theophilo expressa este comportamento ao comentar o que era conhecido no Caraça: lá, pouco se acreditava, observando a manifestação da doença num ambiente com centenas de pessoas convivendo proximamente, que o beribéri fosse uma moléstia contagiosa ou que se transmitisse direta ou indiretamente de individuo para individuo. Mas os alunos que supostamente apresentavam sintomas da doença eram removidos do colégio e remetidos ou para casa dos pais, para a Chácara, ou ainda para cidades mais próximas do Caraça. Neste caso, não consta que nestas localidades tenha havido contágio, apesar de, em muitos casos, o doente ter ficado por longo tempo nas localidades. Da mesma forma, conforme discute Theophilo, em hospitais, asilos, sanatórios, etc., onde são tratados beribéricos, não se encontram relatos de que médicos ou enfermeiros tenham 'pegado' a doença por contágio ou transmissão. Evidências deste tipo, entretanto, não evitaram que o meio cientifico temporariamente anunciasse a identificação de "germes" responsáveis pela doença ${ }^{340}$. Ao

340 Ao listar resumidamente a lista de organismos 'causadores' do beribéri - com seus respectivos 'descobridores' - ALMEIDA $\left(^{*}\right)$ afirma, categórico

"a que extremo chegou o ancioso desejo de dar um agente vivo ao beriberi, pois por pouco se exgotava de vez o domínio dos micróbios, e toda a parasitologia, nesse afanoso empenho".

"PARASITOS ANIMAES

Protozoarios:

1) Plasmodium no sangue (Glogner)

2) Protozoario na urina (Hewlett, Korte)

3) Hematozoário no sangue (Voorthnis, Fajardo)

Nemathelminthos:

1) Certa forma de Trichinella (Gelpke)

2) Trichiuris trichiura (Erni, Kynsey)

3) Ancylostomo duodenal (Erni, Kyynsey)

"PARASITOS VEGETAES

Bacterias: 
terminar suas considerações acerca da teoria microbiana, Theophilo concluirá que

“... em vista dos estudos etiológicos mais recentes tudo faz crer que o beriberi não é uma molestia microbiana"341.

Quanto à teoria alimentar, esta comporta um grupo de outras teorias: intoxicação alimentar, pela qual o beribéri seria causado por certas substâncias tóxicas ( arsênico, chumbo, etc. ) que seriam ingeridas com água ou alimentos, ou ainda por substâncias produzidas pela deterioração de alimentos mal conservados; a teoria do arroz e, ainda, a teoria das vitaminas, relacionada à deficiência alimentar. A teoria do arroz teve seu auge com os estudos de $E_{i j k m a n}{ }^{342}$, e independente dos estudos de Casemir Funk, que culminaram com o isolamento de uma substância anti-beribérica no farelo do arroz, autoridades médicas asiáticas, em congressos, reafirmaram em duas oportunidades - 1910 e

a) Coccaceas:

1) Micrococco no tubo alimentar, etc. (Dangerfield)

2) Diplococco na urina (Tsuzuki)

3) Diplococco no sangue, urina e orgãos (post. mortem) (Okata, Kokubo)

4) Diplococco de Salomone

5) Quatro cóccos diversos (Musso, Morelli)

b) Bacillaceas

1) Bacillo de Taylor

2) Bacillo de Rost

3) Bacillo de Ogata

4) Tres bacillos de Nepveu

5) Bacillo de Eccke

6) Bacillo (toxina) do tubo digestivo (Hamilton, Wright).

C) Cocco e bacillo

Organismo pleomorpho obtido por Pekelhäring e Winckler, no sangue.

Bacillos e coccos de Lacerda.

Cogumelo no arroz mofado (Hose, Braddon).

* ALMEIDA, T. O beriberi no Brasil. Op. cit. p. 101-2.

${ }^{311}$ Idem, p. 110

342 Ver texto referente a nota de rodapé 39 
1912 - que o beribéri associava-se ao consumo do arroz branco quando este fosse a base ( prato principal) da dieta. O fato é que esta teoria, mesmo com a sentença dos asiáticos, não contou com unanimidade. Na época, as afirmativas contrárias pressupunham variáveis que interfeririam, como qualidade do arroz (novo ou velho), tempo de cozimento, presença de micróbios no cereal, verdadeiros causadores da doença, etc. Em 1913 ocorreu um congresso médico internacional em Londres, no qual foi discutida a questão do consumo de arroz e sua relação com o beribéri. Sobre este assunto, e através da seção de higiene e medicina tropical do congresso, foram ali deliberados alguns itens, entre os quais os que afirmam:

“... nos aborigenes cuja alimentação basica é o arroz o BERIBERI É PRODUZIDO pelo uso continuo do grão sob a forma de ARROZ BRANCO, isto, é, o arroz que foi desglutinizado, ou se acha alterado pela eliminação de princípios essenciaes no acto da moagem.

" Estando provado que o beriberi não é uma infecção, o Congresso recomenda a todos os postos e autoridades sanitarias a abolição de quarentenas e outras medidas restrictivas empregadas até agora contra a molestia" ${ }^{343}$.

O Brasil esteve representado neste congresso por médicos, inclusive professores das faculdades médicas. Pode ser que os especialistas brasileiros tenham participado de outras comissões deliberativas do congresso, mas é certo que não tenham participado da comissão que deliberou sobre o beribéri e sua relação com o consumo de arroz branco.

343 Esta declaração do congresso é praticamente um referendo à hipótese de Braddon (i) que, inclusive, teria sido o autor da citada deliberaçåo (ii).

i. BRADDON, L. The cause of true or tropical beri-beri. Op. cit.

ii. ALMEIDA, T. O beriberi no Brasil. Op. cit. p. 119-20. 
É esta a informação dada por Theophilo, baseada em comunicação pessoal de professores da faculdade:

“... os nossos delegados não tomaram parte na discussão dessa questão do arroz, nem empenharam sua palavra na respectiva sentença"344.

Sem que haja elementos explícitos de associação entre a deliberação do congresso e a participação da delegação brasileira no mesmo, a posição dos estudiosos brasileiros sobre a declaração do congresso pode ser sintetizada pela afirmativa pontual de Theophilo:

"O accordam de Londres, sobre ser uma sentença de

Sciencia, ipso-facto sempre discutivel ou reformavel, nada tem com o beriberi do Brasil; excluiu-o mesmo quando disse nos aborigenes cuja alimentação basica é o arroz ${ }^{m 345}$.

Citando autores e circunstâncias, Theophilo procura justificar que, realmente, a 'sentença' do XVII Congresso Internacional de Medicina não se aplicava ao 'beribéri brasileiro'. Neste sentido a incidência do beribéri e sua história durante os anos de construção da estrada de ferro MadeiraMamoré é tratada como uma importante prova que antagoniza a deliberação londrina. Relatos médicos esparsos e mais ou menos vagos, anunciam a ocorrência do beribéri naquela região, mas o trabalho mais especifico é o de um médico norte-americano que por mais tempo trabalhou na área de construção da ferrovia. Para ele, a relação entre beribéri e consumo de arroz não podia ser estabelecida, pelo menos no caso da doença na Madeira-Mamoré:

“... Os casos de beriberi em 1910, quando se suprrimiu o arroz, attingiram um numero trez vezes maior do que 0 total dos casos observados em 1911..."346.

\footnotetext{
344 ALMEIDA, T. O beriberi no Brasil. Op. cit. p. 120.

345 Idem, p. 120-1.

346 LOVELACE, C. O beriberi na Madeira-Mamoré. Brasil Medico. Rio de Janeiro, 1912. p. 331 .
} 
A contestação final ao consumo do arroz, como causa do beribéri foi afirmada por Theophilo, tendo por base o seguinte argumento:

"Em conclusão, se poderá entretanto apenas dizer que o beriberi do Brasil não se enquadra na celebre sentença do Congresso de Londres, mas que ao mesmo tempo a ella não se oppõe, porque não fazemos parte da lista dos povos que tem predilecção pelo arroz até ao exclusivismo às vezes, e a lei

A estrada de ferro Madeira-Mamoré tem seu projeto criado ainda no império e renasce na república como resultado do acordo entre Brasil e Bolívia, dando fím à peleja por conta da anexação - pelo Brasil - do atual estado do Acre:

“... O Brasil comprometeu-se a construir uma estrada de ferro - a célebre Madeira-Mamoré - e garantiu à Bolívia acesso aos rios da Amazônia. Pagoulhe ainda 2 milhões de libras esterlinas em duas parcelas"( $i$, p. 311$)$.

As diferentes análises dos fatos que envolvem a construção desta estrada de ferro são consensuais em vários aspectos, variando apenas em grau. Por exemplo, quanto a morbidade e mortalidade diz, que

"A construção da Madeira-Mamoré foi iniciada em 1871 e concluída apenas em 1912. Durante todo êsse tempo, trabalharam na estrada cerca de 22 mil homens, dos quais a maioria perdeu a vida em acidentes ou por doenças devidas à insalubridade do local. Tanto assim que, em quase todo o percurso, cruzes marcam as mortes que a estrada provocou" (i, p. 100).

“... nas duas fases em que se dará a construção da ferrovia: 1878-9 e 1907-12. A escassez crônica da força de trabalho combina-se com um alto grau de reposição de estoques, como resultado de sua dissipação precoce. Morticínio em massa (epidemias tropicais e acidentes nos locais de trabalho), deserções também em massa..." (ii, p.129).

Oswaldo Cruz, após o saneamento do Rio de Janeiro, empreendeu uma viagem pela amazônia e atendendo

"uma chamada de emergência da Brazil Railway Company [.] Esteve um mês inteiro na região da ferrovia; ... O relatório médico que apresentou em setembro de $1910 \ldots$ é o trabalho médico-sanitário mais completo sobre o Alto Madeira.

"Das observaçðes feitas, prepara lista pormenorizada das 'moléstias reinantes': pneumonia, sarampo, ancilostomiasc,..., beribéri...

"[outro médico] dr. Joaquim Tanajura... [em] suas anotações médicas... comenta: 'Por esse tempo o beribéri grassou com intensidade entre esses doentes, em sua maioria ex-marinheiros, fazendo algumas vitimas'” (ii, 1504).

i. NOVO Conhecer Brasil. v. 1. São Paulo, Abril S.A Cultural e Industrial, 1977.

ii. HARDMAN, F.F. Trem fantasma: a modernidade na selva. Săo Paulo, Companhia das Letras, 1988. 
dictada pelo congresso diz simplesmente: 'Entre os indígenas que tem como alimentação basica o arroz, o beriberi é produzido pelo uso prolongado do arroz branco ${ }^{\text {m47 }}$.

A outra teoria de origem alimentar para a etiologia do beribéri, complementa a "teoria do arroz", visto que no arroz polido há a ausência de "principios essenciais". Conforme foi visto, vários pesquisadores nomearam substâncias presentes no farelo de arroz e que foram anunciadas como sendo o 'principio ativo' que preveniria e combateria o beribéri. Nem todos estes pesquisadores conseguiram ser bem sucedidos em suas demonstraçōes, mas Funk o foi e passou a ter seus resultados avaliados com maior atenção. Theophilo estuda cuidadosamente a sequaencia de pesquisas que aperfeiçoaram o conceito de doenças por deficiência ou insuficiência alimentar. Aos nutrientes já conhecidos ( proteina, hidrato de carbono, gorduras e minerais) adicionava-se um novo grupo, as vitaminas que, sendo essenciais - isto é, não produzidas pelo organismo - uma delas, a tiamina, era responsabilizada pela ocorrência (no caso de falta) e prevenção (no caso de doses adequadas) do beribéri. A comunidade cientifica internacional passou, em escala cada vez maior, a acatar estes resultados. $\mathrm{E}$, no Brasil, esta teoria se aplicaria a etio-patogenia do 'beribéri brasileiro', como queriam eminentes pesquisadores? Theophilo responde:

"Ainda não se pode DE MANEIRA CATEGORICA responder QUE SIM; entretanto o que desde já se não poderá absolutamente dizer é que TAL THEORIA NAO CONVEM AO BERIBERI DO BRASIL" ${ }^{348}$.

O pressuposto do autor para este enunciado é que, no Brasil, os estudos não foram conduzidos de forma que pudessem aferir a alimentação de uma população beriberica antes e depois da doença. Mas apesar disso, salienta ainda Theophilo, vários estudos brasileiros já associavam a

\footnotetext{
${ }^{347}$ ALMEIDA, T. O beribéri no Brasil. Op. cit. p. 123-4.

348 Idem, p. 135
} 
alimentação - e mesmo o consumo de arroz - com o beribéri. Na verdade, esta consideração do autor é genérica, abstrata, e corresponde a enunciados vinculados a uma vastidão de incertezas. Nesta situação é comum descartar com segurança poucas hipóteses e ventilar muitas. De fato, e conforme foi visto no presente trabalho, estudos anteriores a esta época insinuaram a importância da alimentação na determinação do beribéri. Por exemplo, um dos mais importante estudioso da enfermidade no Brasil, o médico da reconhecida Escola Tropicalista Baiana - Silva Lima - é citado como sendo um dos que concediam muito favoravelmente a origem alimentar para o beribéri. Como já foi discutido, Silva Lima assumiu a natureza infecciosa da doença e enumerou vários fatores predisponentes sem, contudo, privilegiar algum de caráter especifico. $O$ mesmo raciocínio valeria para, por exemplo, Miranda Azevedo, Pacífico Pereira, entre outros. O próprio Theophilo irá, anos mais tarde, reivindicar para si a defesa, no meio cientifico brasileiro, da nova teoria das "doenças carenciais", concorrendo

“... para esclarecer uma etiologia ainda obscura, quando se acreditava, e mesmo entre nossos maiores mestres, na teoria de ser o beriberi mal contagioso ou de infecção" 349 .

Em sua tese, Theophilo afirma, além do reconhecido fator alimentar, a importância do estilo de vida (sedentário ou não):

“... nenhum grande obstáculo separa a etiologia beriberi do Brasil da theoria alimentar, pelo contrario tudo parece cooperar para o seu consorcio; que o arroz polido, alimento insufficiente' para a especie humana não pode ser apontado como único responsavel pela etiopathogenia de nosso beriberi, tal como nos paizes asiaticos é hoje considerado...entre nós [o beriberi] mostra accentuada predilecção pelas agglomerações humanas da vida sedentaria e alimentação uniforme e pouco variada"350.

\footnotetext{
349 ALMEIDA, T. de. Discurso de paraninfo pronunciado na solenidade de colação de grau dos diplomados do colégio do Caraça, em 3 de dezembro de 1950. Op. cit., p. 8. Para complementar informaçðes neste sentido, ver a nota de rodapé 23.
}

35. ALiMEIDA, T. $O$ beribéri no Brasil. Op. cit. p. 140 
A adoção, integral e definitiva, da teoria vitaminica pelo meio médico, para explicar a etiologia do beribéri, não seria feita nesta altura das pesquisas. Admitia-se a contribuição das pesquisas mas seus resultados eram relativizados. Grandes mestres das escolas médicas brasileiras haviam formulado hipóteses - especialmente na área infectocontagiosa - que, na prática, nada tinham a ver com a teoria da deficiência alimentar. A contundência $e$ originalidade com que foi avaliada, em seus aspectos metodológicos e ensaisticos, fez da teoria da deficiência alimentar, pelo menos em um primeiro instante, um poderoso contra-argumento à capacidade especulativa de muitos pesquisadores. Isto é, de alguma forma a questão alimentar de fato foi abordada pelos estudiosos do beribéri. No entanto, esta variável na maioria das vezes foi 'desprezada', tomada como coadjuvante simbólica, menosprezada, em favor de enunciados que privilegiaram complexos mecanismos clinicamente mais afeitos à emergente medicina das moléstias tropicais. Em 1917, um professor catedrático de clínica médica da Faculdade de Medicina da Bahia escreve:

"A etiologia alimentar é ainda o ponto mais discutido no estudo do beriberi, não obstante as ultimas contribuições... A etiologia imprecisa do beriberi é, sem dúvida, o ponto fraco na discussão de sua autonomia nosologica....351.

As repercussões de opiniōes deste tipo alongavam as discussões acerca da etiologia do beriberri, considerando especialmente a influência que os mestres catedráticos exerciam sobre seus alunos, especialmente sobre aqueles que gravitavam em torno deles, através de estágios e participação em pesquisas coordenadas por esses mestres. Assim, por exemplo, é o caso, de duas teses inaugurais ( como eram chamadas as teses de conclusão do curso médico ) apresentadas à faculdade de medicina da Bahia, uma em 1917 e a outra em 1919352. Nestes estudos

351 FRAGA, C. Beriberi na Bahia. Bahia, Imprensa Official do Estado, 1917. p. 22-4.

352 ASSIS, A . R. Estudos sobre carencia experimental e beriberi. Bahia, Livraria Citadina, 1918 [ apresentado à FMBA em 27/10/1917].

MENDONÇA, S. de S. Beriberi . Bahia, Imprensa Official do Estado, 1919. 
estão claros os marcos teóricos que orientaram não apenas as formulações hipotéticas, como também os estudos experimentais. No caso da tese de 1919, os questionamentos sobre a teoria da deficiência alimentar levaram o autor, como já havia acontecido em relação ao trabalhos de Eijkman no início do século, a beirar a ironia quanto às pesquisas de Funk:

"Aqui mesmo em nosso país, de pouco, Lovelace nega a relação da alimentação com o beriberi do vale do Amazonas, e Juliano Moreira e Murillo de Campos dedicam largos estudos em detrimento das esquisitas vitaminas de Funk.

"Entretanto ainda domina o conceito da natureza alimentar do beriberi, e as contestações não bastam para derimir a religiosidade de suas aquisições ${ }^{\text {"353 }}$.

A filiação teórica do autor leva-o a acatar os resultados das pesquisas sobre deficiência alimentar, sem ponderar o tratamento que tais pesquisas receberão no seu meio. Havia uma linha de pesquisa que admitia o beribéri em aves provocado pela carência nutricional, mas o beribéri humano não obedeceria a mesma lógica de causalidade. Neste caso, a carência alimentar predisporia o organismo humano a ação de um agente biológico, este, sim, causador da doença:

"Aqui na Bahia, o Professor Clementino Fraga, nosso sabio mestre, espirito lucido e alumiado, de sobreexcelente envergadura cientifica e de fiel dedicação à medicina nacional, em avantajado tirocinio, de muito vem seguindo as pegadas de Silva Lima, quem mais avultou estes estudos entre nós.

"O professor Fraga parece acreditar mais na natureza inficiosa do mal [beribéri] ... o Professor não aceita a carencia alimentar como causa eficiente do beriberi humano"354.

\footnotetext{
${ }^{333}$ MENDONÇA, S. de S. Beriberi . Op. cit., p. 15-6.

${ }^{354}$ MENDONÇA, S. de S. Beriberi . Cp. cit., p. 32-5.
} 
Mas também fora do Brasil, a teoria da doença carencial para o beribéri era um conceito que mais 'definia' a doença do que afirmava sua etiologia:

"It is a deficiency disease.

"The exciting cause is unknown, but theories are legion" 355 .

A idéia era a mesma: esta 'deficiência' aconteceria sob circunstâncias estimulantes e, neste sentido, várias eram as teorias. Por influência de especulações de respeitáveis nomes da medicina tropical, entre eles Sir Patrick Manson, condições atmosféricas e do solo eram tidas como fatores predisponentes à doença. Apesar do sucesso da teoria da deficiência alimentar e das pesquisas envolvendo seus pressupostos para explicar a etiologia do beribéri, admitia-se, ainda, enumerar teorias que há muito apresentavam dificuldades de demonstração convincente. Por esta época, envenenamentos, deficiências alimentares, intoxicações e parasitas incluiam-se no leque de teorias tomadas como possiveis causas estimulantes da doença: envenenamento por arsênico, chumbo, oxalato, dióxido de carbono; envenenamento alimentar (especialmente através de peixe estragado); intoxicação através do solo; autointoxicação; parasitas e micróbios. A deficiência alimentar era traduzida como possibilidade de deficiência de nitrogênio e, por derivação, de vitaminas; de gorduras, fösforo, etc ${ }^{366}$.

Ao sabor das polèmicas cientificas, o beribéri no Caraça insistia, como um fantasma, em assombrar o imaginário e adoecer corpos. A crônica guardiã e com acesso ao que eventualmente possa haver sobre o

MASTERS, W. E. Essentials of Tropical Medicine. New York, William Wood \& CO., 1920. p. 337.

356 MASTERS, W. E. Essentials of Tropical Medicine. Op cit.

ENSMINGER, A . H. et al. Foods \& Nutrition Encyclopedia. Op. cit.

CURTIN, P. D. Death by migration: Europe's encounter with the tropical world in the nineteenth century. Cambridge, Cambridge University Press, 1989. p. 77-9.

INOUYE, K \& KATSURA, E. Etiology and pathology of beriberi. Vitamin B research committee of Japan, Tokyo, 1965. 
assunto dá conta de que foi no superiorato do padre Francisco Pimenta, entre 1930 e 1935, que se debelou o beribéri ${ }^{357}$. Internamente, este processo relaciona-se com a construção da casa de férias na Fazenda do Engenho, fértil espaço de terra que substituiria a Chácara na sua missão de produzir alimentos e assistir apostólicos em férias e em convalescença. A partir de 1913 , deixando de existir a estrutura de colégio, o Caraça passou a ser Escola Apostólica; acabaram-se os colegiais e continuaram os apostólicos. Quando o superior Van Pol retirou-se, dando o lugar a outro padre holandês, Pe. João Vaessen, em 1913, o Caraça ainda recebia reformas materiais cuja finalidade era enfrentar os surtos de beribéri: mudanças e saneamentos de esgotos, abertura de janelas nos salōes, canalização de águas, reformas de cômodos, pinturas, etc. Naturalmente, todas estas reformas obedeciam orientações especificas, segundo as regras sanitárias e higiènicas vigentes. As influências acerca da etiologia infecciosa para o beribéri, somadas ao sucesso preventivo das medidas sanitárias de Oswaldo Cruz no Rio de Janeiro, contribuiam para determinar o tipo de ações destinadas a combater o mal.

357 ZICO, J. T. Caraça: peregrinação, cultura e turismo. Op. cit., p. 108. Caraça: Ex-alunos e visitantes. Op. cit., p. 16.

Por ocasião das pesquisas para o presente trabalho, tivemos a possibilidade de conhecer no Caraça o Pe. Benedito de Aguiar Ribeiro, C. M, que se encontrava em visita por lá. Pe. Benedito, mineiro natural de Santa Bárbara, estudou na Escola Apostólica do Caraça, completando seus estudos eclesiásticos no seminário de Petrópolis, onde foi ordenado em 1943. Disse o Pe. Benedito que, na sua época caracense - primeiros anos da década de 30 - colegas seus 'simulavam' pernas inchadas com o diagnóstico já formado de 'beribéri'. Durante este relato (não gravado, mas anotado), Pe. Tobias ( José Tobias Zico, autor dos livros citados no presente trabalho e contemporâneo caracense do Pe. Benedito) aparteou o colega, localizando o autor da referida simulação: um colega, estudante capixaba, muito afeito a brincadeiras, etc. Novamente vale destacar que a veracidade do fato neste instante não é a constatação principal. É o fato de que a 'notícia' sobre o beribéri associou-se, sob determinadas condiçð̃es históricas, ao 'estar' no Caraça. Fato é que, sem que seja constatado empiricamente, dos últimos apostólicos que ali estudaram - na década de 60 - alguns deles conhecem 'histórias' do beribéri, sem que se importassem com o significado concreto da doença para a instituição. 
Algum tempo antes da sua morte, o filho de João Alphonso recebeu em sua casa a visita de um moço jovem, que se apresentou como sendo estudante da faculdade de medicina. Chamava-se Paulo Brunhs cuja familia, conforme ele disse, era de Parati. Ele elaborava uma monografia sobre o beribéri, e teria tomado conhecimento da existência da memória escrita pelo pai do advogado. Este, indisposto e também inquieto na véspera, pretendeu evitar o encontro. Mas o visitante antecipou a chegada e já se encontrava na agradável e privativa sala de visitas da casa. Paulo era alto, tinha uns diferentes olhos cinza-azuis, cabelos escuros e muito bem penteados, estava vestido elegantemente e, cortês, colocou-se de pé assim que o advogado - a quem ele tratou por doutor durante todo o encontro - entrou.

- Boa tarde, senhor Paulo, é verdade que anda interessado no que o meu pai escreveu? - Cumprimentou, perguntando, o anfitrião, já tentando direcionar o diálogo.

- Muito prazer, doutor. É verdade sim; tenho interesso pelo que dr. João Alphonso escreveu e também por seu legado enquanto pai e amigo. Creio que, assim, posso conferir se é aceitável a compreensão que tenho daquele indice da memória que nos sobrou.

- Ora, ora, vejo que é um aluno aplicado - disse o doutor, que se sentou, convidando o outro a fazê-lo - então, o senhor já tomou conhecimento e já emitiu seu parecer sobre aquele indice. Ainda se encontra quem conservou pelo menos este indice?

- Mas é claro, como não? Acredito até que o que se conhece foi fornecido pelo senhor mesmo, já que ninguém ainda conseguiu reaver o texto integral que se acha no Caraça.

- Faz sentido. Eu me lembro que recebi solicitações de professores, colegas e estudantes que gostariam de ler o trabalho do meu pai. De tudo que ele me deixou, sobre a memória só encontrei o indice e a única cópis seguiu para os confins das Minas Gerais - afirmou o advogado com uma expressão que lamentava o rumo do estudo, e concluiu: - Parece que nem mesmo os padres sabem exatamente onde se encontra a memória lá nos arquivos do colégio...

Pouco se importando com a última parte lamuriosa da fala do advogado, Paulo comentou, com franca intenção de insinuar: 
- Talvez todos tenham se conformado com o destino da memória, mas talvez acreditassem que haveria outros escritos do dr. João Alphonso que iluminassem o deciframento do indice.

- Nunca me ocorreu isto. Pode até ser, mas seria lavrar em vão: meu pai nada escreveu de significância.

- Por que ? Ele escreveu coisas insignificantes?

Incomodado com a observação de Paulo, o filho de João Alphonso procurou uma resposta satisfatória, corrigindo-o.

- Eu não quis dizer o que o senhor entendeu. Quero dizer que nada que ele tenha escrito possa se relacionar com a memória sobre o beribéri.

- Doutor, o que o seu pai pensaria do que me diz ? Não era ele um homem que recolhia as contradiçōes do cotidiano para denunciar o absurdo que é a desintegração do viver ? Ele dissociaria uma coisa da outra?

Sem sobressalto, o filho de João Alphonso examinou desconfiadamente $\circ$ visitante, tentando captar o alcance daquela pergunta. Sereno, Paulo observou-o procurar uma resposta, que veio revestida por uma pergunta:

- Bem lembrado, caro rapaz, certamente papai não simplificaria esta consideração. Mas diga-me, através de quem o senhor conheceu a personalidade do meu pai ?

- Eu posso simplificar a resposta dizendo-lhe que no hospital e na faculdade estão muitas pessoas que conheceram dr. João Alphonso, os religiosos da capelania... mas posso também afirmar que deduzo a partir do indice e, por isso, estou aqui para aquilatar meus pressupostos. $\mathrm{E}$ também por isso fiz ao senhor a pergunta anterior. - Sem deixar de olhar diretamente para o filho de João Alphonso, Paulo sugeriu: - Mas creio que não seria proveitosa nossa conversa, caso o senhor queira sempre saber de que maneira sei deste ou daquele aspecto da vida do dr. João Alphonso. Afinal, bem sabe o senhor que a vida vivida é vida sabida. Vale-nos aqui, se bem posso dizer conforme seu próprio pai, a vida vivenciada, que se manifesta na simplicidade dos atos aparentemente ocultos e inacessiveis.

- Desculpe-me, rapaz, mas a vida do meu pai foi uma vida simples e recatada. Um homem que cultivava suas predileçōes, mas que às vezes se abatia com o sofrimento, as vicissitudes que acometem o ser humano. 
- O senhor não estaria sendo piedoso com o seu pai ? Este abatimento a que o senhor se refere não seria, em si, o veículo que carregava a visão de mundo do dr. João Alphonso ? Diga-me, doutor, o senhor sabe em que situação ele foi estudar na Alemanha ? Como ele se sentia ? O que ele almejava?

- Ora, o senhor deve saber que meu avô era comerciante bem sucedido, sócio de um alemão que foi cônsul aqui no Brasil. Este cônsul apreciava meu pai e aconselhou meu avô a enviá-lo à Alemanha para estudar medicina. Poucos jovens têm uma possibilidade desta e é natural que tenha sido uma situação satisfatória para o meu pai...

- Agora o senhor deve desculpar-me, doutor, mas esta resposta apenas o faz exercitar sua argumentação de tribunal. Mas não estamos em um. Parece-me que a estada na Alemanha só foi marcante para ele porque o encontrou receptivo às experiências que teve. $\mathrm{O}$ que acha disso ?

- Sim. Houve experiências expressivas para o meu pai, veja por exemplo o encontro dele com aquele filósofo dinarmaquês, Kierkegaard. Os desdobramentos deste encontro marcaram bastante a vida dele. Ele quis determinadamente encontrar o cientista dr. Lund, em Minas Gerais.

- O senhor e o seu pai chegaram a conversar sobre a obstinação dele em tal encontro?

- Não creio que tenha chegado a ser obstinação, mas de fato ele o desejou bastante. - O filho de João Alphonso, desconcertado e desconfiado, calou-se por alguns instantes e tentou encontrar na aparência de Paulo compreensão para aquele diálogo. Foi em vão. Naquele instante, encontrou um semblante acolhedor que aguardava o complemento da resposta, que viria - Meu pai era curioso quanto às condiçōes da existência humana e o dr. Lund era um eremita civilizado, isto é, um homem de grande saber que, sem motivo aparente, se deixa esquecer numa vila pequena do interior do Brasil. Meu pai conhecia a efervescência cientifica da Europa e o comportamento do dr. Lund, não há dúvida, o incomodava.

- Isto é o que o senhor acha, ou é o que ele lhe disse ?

- É mais o que eu sinto. Sabe, senhor Paulo, após a morte do meu pai eu encontrei pequenos escritos que ele deixou entre uma ou outra folha de livros, cartas não enviadas, etc. Posso lhe assegurar que a vida 
não conseguia garantir certezas para meu pai. As certezas reconhecidas ele as chicoteava freqũentemente. Elas sofriam nas mãos dele.

O filho de João Alphonso deu-se conta da sua afirmação, e não evitou um desconforto. Paulo, mudando para uma poltrona mais próxima dele, estimulou-o, numa voz que acalmava o doutor:

- Veja por onde expressamos o que somos, doutor. Seu pai lhe ensina. Kierkegaard o ensinou e é certo que Lund lhe disse mais do mundo, vivenciando-o mais do que demostrando-o . É o caminho que devemos perseguir para penetrar no indice da memória sobre o beribéri.

Sem conseguir deter o ritmo do diálogo, quase que por espanto, o filho de João Alphonso disse:

- Por este caminho, senhor...

- Trate-me por Paulo. Façamos este primeiro trato.

- ... por este caminho, Paulo, a viagem nem sempre é clara, fácil, e pode nos levar a lugar nenhum.

- Não tenha medo. Por que fazer concessão fácil ao trivial ? Ao senso comum, ao vulgar, que opera sobre uma realidade grosseira ? Seu pai compreendeu tudo isto. Ele, com certeza, narrou-lhe os episódios daquela viagem que fez a Minas, lembra-se ? Os tropeiros, os novos doutores, os árabes; uma trilogia articulada por uma meta imediata que quase lhe foi fatal. Alegrou-se com os últimos ao desconfiar que o mundo era ilimitado para eles. Infelizmente, enjaulam-se ao amanhecer em um primitivismo que os impede de vivenciar plenamente sua vocação criadora - Paulo disse a última frase encostando-se na poltrona e desprezando o estado de retração do filho de João Alphonso.

- Sobre esta viagem, meu pai sempre falou muito de Ouro Preto.

- Lembranças passionais de um barroco que ele aprendeu a apreciar na Alemanha, na companhia daquele amigo dele.

- O Morten ? O senhor tomou conhecimento até mesmo desta particular amizade do meu pai ? Eu ainda guardo cartas recebidas ... disse o filho de João Alphonso, sem conseguir evitar filetes de suor que lhe escorriam pelas temporas.

- Sim, o senhor Schwarzkopf. É possivel que, ao responder seu pai, ele também ajude a explicitar o sentido do que seu pai escreveu.

- Ele sentiu quando Morten lhe escreveu de um sanatório suiço disse o filho, sem saber exatamente porque lembrava esta situação. 
- Sentiu, como sentiu também a morte do botânico Riedel, do Pompéia, a demência de Vieira de Andrade, a morte natural do dr. Lund às vésperas da viagem dele na comitiva do Imperador, a febre mortal do Pe. Caio... São cantos, doutor. A morte é um canto que aprendemos a cantar. Uma canção que cada um canta a sua maneira, como este poeta brasileiro que escreveu:

"Meu canto de morte,

Guerreiros, ouvi:

Sou filho das selvas,

Nas selvas cresci;"

- Paulo recitou cativantemente os versos de Gonçalves Dias e interpelou o filho de João Alphonso:

- Não diz em nada ao senhor estas palavras ? O senhor se recorda das circunstâncias da morte do seu pai ? Ele apreciava os poetas.

Afastando a cabeça para trás e franzindo um dos olhos, o filho de João Alphonso tentou focalizar com precisão a imagem de Paulo, e perguntou, como se arrastasse a pergunta de dentro de si:

- Senhor Paulo, quem é o senhor, é mesmo um estudante de medicina ? Tem certeza que nunca esteve com o meu pai ?

- Por que ? Queres que eu avalie a sudorese e a taquicardia que o acometem neste instante ? Sugiro cuidar da sua hipocondria, doutor, e ter mais confiança em si mesmo. O senhor não cumprirá a sua missão se apegar-se primitivamente apenas às denominaçōes e ao carăter genitivo das coisas. Eu gosto de dizer em encontros mais nobres, e por favor tente tirar proveito da minha franqueza, que "o essencial não se ajusta inteiramente às palavras".

- Ora, pare com isto! De que missão vem o senhor me falar ? E também, como se atreve a entrar na minha casa e falar de "encontros" mais nobres ? Então por que você não fica lá com tais encontros e me deixa envelhecendo com as lembranças do jeito que as tenho ? E tem mais: não preciso dos seus diagnósticos para compreender o meu sofrimento. Guarde-os para quem os pedir.

Paulo ouvia o filho de João Alphonso com uma sobriedade que se aproximava da indiferença. Cerrando os olhos brevemente, abaixou a cabeça, passou as mãos pela testa e, voltando a fitar o advogado, falou: 
- É bom que me trate por você', e não 'senhor', assim ficaremos mais à vontade no nosso diálogo. Eu já havia me desculpado a propósito da nobreza do nosso encontro. Só lamento que o senhor se esconda na sua velhice para justificar sua acomodação. São marcas do medo, senhor doutor. O medo de seguir a trajetória de um tiro a esmo. A mesquinheza quer sempre um porto seguro, jamais romper o horizonte desconhecido. Quanto às lembranças, elas serão sempre insuficientes... Agora, e os seus sofrimentos? De que fala o senhor ? Sejamos francos, doutor, este seu sofrimento, esta sua dor lhe gera um mundo mesquinho, grosseiro. $\mathrm{O}$ seu pai, sim, percebeu a intencionalidade da dor e procurou capitalizar o que o afetava emocionalmente. O senhor tem idéia, por exemplo, da tragédia interior que foi para seu pai a guerra do Paraguai? Indiferente por fora, vivenciou enormemente as mortes de colegas médicos nos campos de batalha, a perversidade dos combates... Teria ido, se não fosse a futilidade dos motivos que a deflagraram, pois para ele a morte era perfeitamente compreensivel. O choro, as lágrimas, a dor, são os cantos. Apenas. Então veja, doutor, não podemos compreender a memória sobre o beribéri no Caraça, escrita por seu pai, se não passearmos atentamente pelo cenário da criação. Mas não basta desejar e ter consciência disto; a exegese é necessária. Não é fácil, o senhor como filho ainda é incapaz de realizá-la, mas eu vou ajudá-lo a elaborá-la.

Sentindo-se cansado, perpassado por uma incompreensivel sensação de agonia, o filho de João Alphonso sentiu-se absolutamente incapaz de estabelecer um diálogo de principios com seu interlocutor. Queria vê-lo indo embora, sem, contudo, ser capaz de fazê-lo. Tentou, então, abreviar o encontro:

- O que quer que faça ? Não sou médico, nem me interesso por disciplinas médicas e a memória escrita pelo meu pai já é cientificamente obsoleta Aliàs, nem aqui se encontra. É mais provável que se encontre comida pelas traças no arquivo do Caraça.

Sarcasticamente, Paulo brincou:

- Enfant terrible da ignorância, como pode ser ingênuo. Perdeu a confiança especulativa na sua própria ratio ? O seu pai e pessoas inteligentes que vocè conheceu, como o Raul, teriam vergonha do mundus intelligibilis que lhes sobrou. Fala da memória do seu pai como falaria qualquer 'pensadorzinho' evolucionista que a leia atualmente. Ao 
fim da vida, o senhor volta a confundir o bom uso da razão com verdade cientifica, confundindo necessariamente esta com aquela. Doutor, fazer ciència é 'matar' o tempo; não responde completamente ao esforço do existir. Quando o dr. João Alphonso escreveu sua memória, ele já se encontrava conscio do que valeria a pena, tanto quanto das circunstâncias epidemiológicas do beribéri no Caraça. Por isso escreveu como escreveu, e o que escreveu da doença é completamente compativel com qualquer conhecimento que se tem hoje. O que fizeram foi purificar mais a etiologia. Aliás, procurar a etiologia de doenças é a melhor forma de matar o tempo, e os pesquisadores adoram este jogo, porque acreditam que, assim, escapam ao tédio. É inacreditável, mas é verdade. Observe-os. Isto seu pai evitou, porque soube aproveitar bem de seus relacionamentos. Devo admitir que o seu pai foi forçado a alargar a compreensão do mundo, também pela convivência dele com aqueles religiosos. A eles também teria sido proveitoso se não entalassem suas vidas com dogmas rigidos.

Interrompendo, o filho de João Alphonso quis saber:

- Por que você mesmo não restitui a memória sobre o beribéri da forma como pretende que seja feita?

- Há dificuldades ainda inconfessáveis ao senhor, para que eu possa tirá-la do Caraça. Além disso, o senhor é depositário do que há do dr. João Alphonso. Basta combinarmos para fazer bom proveito do rico material que o seu pai lhe legou entre as páginas dos livros, recortes, bilhetes, etc. O senhor teria oportunidade de se redimir da sua inexpressiva atividade de jornalista...

- Eu não admito que me avalie assim, senhor Paulo. Exijo ...

- O senhor não pode exigir nada, senhor doutor. Por acaso existe algum texto, artigo que seja, publicado ou oculto, que o faça ser lembrado pela qualidade, pelo talento ? Mas não discutamos isso, voltemos ao nosso assunto. O senhor deve, então, dispor-se a ir ao Caraça. Seria bem recebido e facilmente teria acesso ao arquivo onde ainda se encontra a memória do seu pai. Não lhe será difícil publicá-la, acompanhada de um estudo caprichoso, pelo qual o senhor revelará qualidades que jamais serão reconhecidas se não cumprir tal empreendimento. F o senhor já andou especulando sobre os possiveis 
sentidos do que seu pai escreveu, isso já contribui bastante para que tenha sucesso nesta nova tarefa.

- E se eu não puder realizar esta tarefa ?

- Pense bem sobre isto, senhor doutor. Descontextualizada, a memória não vale a pena vir à tona, e o senhor, como eu disse, detém as informações que a circunstanciariam adequadamente. Se não quiser cumprir este compromisso pessoalmente, o senhor terá a velhice que já condicionou; quanto à memória, dr. João Alphonso se entristeceria se fizessem mau uso dela. Neste caso, é melhor que se evite que isso ocorra, de qualquer forma.

Trêmulo e praticamente esmaecido, o filho de João Alphonso apenas conseguiu dizer:

- Preciso pensar em tudo isso! Pensarei na proposta. Eu posso lhe responder...

- Não se preocupe, doutor, em me responder, saberei se devo ou não voltar a tratar do assunto com o senhor.

Paulo tomou o chapéu, despediu-se, com uma leve inclinação da cabeça, do filho de João Alphonso que, perplexo, tornara-se expromissor de uma acordo assumido à revelia, independentemente da decisão que tomasse. Seu interlocutor, sem que fosse percebido, saiu da casa que parecia deserta.

Nas primeiras décadas do século $\mathrm{XX}$, os estudos, no Brasil, sobre as propriedades dos alimentos apenas estavam nos seus primórdios. Estes estudos foram desenvolvidos a partir do intercâmbio, cada vez maior, que se fazia entre a atividade cientifica em construção no Brasil e a já influente politica cientifica estadunidense. Naquele pais, a tradição de pesquisa em alimentos e nutrição havia se consolidadc com os trabalhos de Atwater e colaboradores, que desenvolveram metodologias e conceitos úteis ao planejamento alimentar ${ }^{358}$. Assim è que, em 1921,

358 Sobre W. O. Atwater (1844-1907), ver página 128.

Do trabalho de Atwater e colaboradores, em 1906 o Departamento de Agricultura dos Estados Unidos publica um manual (*) com dados acerca do valor nutricional de 
surge um pequeno ensaio de dois professores, um da Faculdade de Medicina e outro da Escola Politécnica de São Paulo, sobre o valor calórico de alimentos. A publicação, patrocinada pelo Governo do Estado de São Paulo e pela Fundação Rockefeller, trabalha com alimentos usuais da cozinha paulista e também avalia o potencial calórico de dietas usuais da Santa Casa de Misericórdia ${ }^{359}$. Pouco a pouco, foram surgindo as primeiras tabelas sobre composição química de alimentos locais, sendo que, até entāo, todas as que eram utilizadas referiam-se a alimentos tipicos de outros paises. Para formulação de tabelas nacionais, contribuíram não apenas os estudos sobre doenças carenciais, como tambèm os trabalhos com animais sob dietas controladas ${ }^{360}$. Mas, na

alimentos consumidos pela população americana. Nesta época, com exceção das vitaminas ( e também das fibras, que são um componente alimentar não assimilado pelo organismo, mas com importante função estimulante do peristaltismo intestinal, mas que apenas nas últimas décadas tem sido valorizadas) todos os nutrientes mais importantes para a nutrição jả eram conhecidos: proteinas, lipídios, glicídios, minerais, água.

* ATWATER, W. A . \& BRYANT, A . P. The chemical composition of the American food materials. Washington, Government Printing Office, 1906.

359

SOUZA, G. H. de P. \& WANDERLEY, L. A . Ensaios de calorimetria alimentar. Boletim do Instituto de Hygiene, $6,1921$.

Geraldo Horácio de Paula Souza (1889-1951) foi o fundador e primeiro diretor da atual Faculdade de Saúde Pública da Universidade de São Paulo (USP), cuja primeira denominação foi "Instituto de Higiene". Paula Souza, que iniciara sua carreira de docente na Faculdade de Medicina de São Paulo, como assistente de química médica (i), foi bolsista da Fundação Rockefeller nos Estados Unidos, entre os anos 1918-1920, época em que doutorou-se em Saúde Pública pela universidade Johns Hopkins. Na sua volta, além da direção, era o responsável pela seção de quimica e bioquímica do Instituto. Historicamente, as primeiras pesquisas experimentais em nutrição estiveram a cargo de especialistas em quimica e bioquimica. Da experimentação às recomendaçðes, o assurito era abarcado pela higiene. No primeiro curso para Educadores Sanitários oferecido pelo Instituto (1926), além das cadeiras aplicadas à higiene, que davam noções de bacteriolugia, parasitologia, estatistica vital e epidemiologia, higiene mental, social e do trabalho, etc., encontrava-se também a cadeira de Higiene Pessoal, Nutrição e Dietética (ii).

i. TELLES, F. E. da F. Um grande nome nacional: Paula Souza. Anhembi, 48 (144) $474-80,1962$. 
medida de sua evolução, a nutrição ganha terreno enquanto conhecimento capaz de operar 'cientificamente' em diferentes segmentos da população, além das dietas hospitalares. Neste sentido, a alimentação na infância, que já era objeto de interesse desde o final do século passado através da higiene, tem seus estudos intensificados. A educação higiênica nas escolas é vista como importante instrumento para a prevenção de diferentes problemas de saúde.

"A. educação hygienica é igualmente o melhor factor para diffundir o uso de alimentação mais sensata entre as classes populares, ensinando-lhes as vantagens da variedade, as virtudes de certos alimentos como o leite $\mathrm{e}$ as verduras, a pratica da transição gradual, na primeira infância, a importância da mastigação, a influência do elemento psychico na digestão, o inconveniente das gulodices entre as refeições, os meios de combater a prisão de ventre, e tantas outras pequenas cousas, já sabidas na hygiene alimentar"361.

ii. CANDEIAS, N. M. F. Memória histórica da Faculdade de Saúde Pública da Universidade de São Paulo - 1918 - 1945. Rev. Saúde públ, 15 (Supl.): 2-60, 1984.

360 Além dos esparsos e primeiros esforços para determinação da composição química dos alimentos, ressaltam-se esforços posteriores abarcando maior variedade de nutrientes:

i. ANDRADE, A . A . Valor nutritivo dos alimentos brasileiros. In: CASTRO, J. $\boldsymbol{O}$ problema da alimentação no Brasil. São Paulo, Companhia Editora Nacional, 1934.

ii. SANTOS, O . P. Determinação dos sais de cálcio dos nossos alimentos. An. Fac. Med. USP, 12 (10): 401, 1936.

iii. COSTA, A . A . \& TAVARES, D. G. Composição e valor nutritivo de alimentos brasileiros. Kev. Soc. Bras. Quim., 5 (2-4) : 101, 1936.

iv. CAVALCANTI, T. A . A . et al. Valor nutritivo de alguns dos nossos alimentos (proteína, cálcio e ferro). Rev. med. Paraná, 7 (5) : 3, 1938.

v. SANTOS, O . P. \& NOGUEIRA, C. C. Fósforo total em nossos alimentos. $O$ hospital, $17(2): 207,1940$.

vi. RODRIGUES, A . P. O valor alimentar dos produtos vegetais brasileiros. Arq. Bras. Nut., 4(1) : 6, 1945.

vii. COSTA, D. Tratado de nutrição. Rio de janeiro, ed. Guanabara, 1947. 
Mesmo sem a tradição de pesquisas experimentais em nutrição, o conhecimento de princípios nutricionais manipulados pelos estudiosos brasileiros favoreciam a elaboração de normas sobre alimentação bastante razoáveis. Naturalmente que, diante da escassez de recomendações num quadro de grande demanda, as minimas, informações que surgiam produziam beneficios convincentes. A elaboração destas normas dispunha não apenas sobre os cardápios, como também sobre regras gerais que orientavam a respeito de procedimentos a serem observados, como, por exemplo, o que segue:

"1. Variar sempre a alimentação.

2. Obedecer rigorosamente ao horário.

3. Fiscalizar a qualidade e o estado de conservação dos alimentos.

4. Fazer examinar por medico as cozinheiras e copeiras e vigialas para que trabalhem com o maximo asseio.

5. Evitar as moscas na cosinha e no refeitorio, usando, para isso, telas de arame.

6. Ferver bem o leite.

7. Louças e talheres, cuidadosamente lavados em água quente corrente" 362 .

No Caraça, não consta que tenha havido orientações alimentares criteriosamente estipuladas segundo a população residente no colégio em diferentes épocas. No entanto, é provável que algumas orientações tenham sido dadas no decorrer das primeiras décadas do século $\mathrm{XX}$, por conta dos casos de beribéri ali relatados. Nos anos que coincidem com o fechamento do Colégio e manutenção apenas da Escola Apostólica, inexistem relatos sobre casos de beribéri. A crônica os relatará já em fins

361 ALMEIDA JUNIOR, A . A alimentação na idade escolar e pré-escolar. Boletim do Instituto de Hygiene , 15 , 1923.

362 Idem, p. 8 
da década de 20, quando, numa experiência frustrante, tenta-se reabrir o colégio entre os anos de 1928 e 1929. A abordagem médica do beribéri no Caraça esteve relacionada com as indefiniçōes que acompanharam a trajetória da enfermidade, especialmente no campo da etiologia. Assim, uma década após a caracterização das doenças por deficiência, alguns segmentos da medicina questionavam esta etiologia para o beribéri. Por exemplo, em 1921, numa tese médica da tradicional faculdade de medicina da Bahia, o autor se perguntava sobre a causa do beribéri, e agrupa as duas teorias com maior aceitação entre os cientistas: beribéri como sendo uma moléstia por carência e beribéri por infecção. Declara que prefere a última, pois, quanto a primeira,

"Quando muito serão factores predisponentes os vicios alimentares" 363 .

$\mathrm{Na}$ prática teórica, a teoria das doenças por deficiência aplicada ao beribéri tornou-se tão somente uma a mais. Teorias continuavam surgindo e outras, 'aperfeiçoadas'. Assim é que, baseados em estudos hematológicos e anatomopatológicos, houve quem propusesse que o beribéri fosse uma sindrome endócrina:

“... uma sindrome nervosa ligada a um desequilibrio endocrino produzido por um toxico alimentar ou por uma toxina microbiana"364.

363 GONDIM, E. M. A Novarsenotherapia no beriberi. Bahia, Livraria Econòmica, 1921. p. 14.

${ }^{364}$ PEIXOTO, A. A Contribuição ao estudo da hematologia do beribéri. Bahia, Papelaria Brasileira, 1921. p. 153.

Nesta mesma época, no exterior, a teoria dás doeniças por deficiência para o beribéri era a mais 'simpática' no meio científico. Mas, mesmo assim, mesmo admitindo a proeminència desta teoria, autores como STITT (i), por exemplo, enumeram as diversas teorias então existentes para indicar a origem da doença, não sem antes indicar que

There is probably no disease about which there exist so many views as to etlology as with beriberi (i, p. 269).

Quanto às teorias mencionadas, são indicadas, alèm daquelas por deficiència alimentar (deficiència de nitrogênio, vitaminas, etc.), teorias de envenenamento quimico, 
Diante da dificuldade da teoria carencial se constituir como hegemônica no meio médico, enquanto etiologia do beribéri, era até natural que o tratamento da doença recebesse condutas também diversas. Tais condutas abarcavam principios tanto na esfera da higiene em geral como na terapeutica particular. $\mathrm{Na}$ higiene a base era a profilaxia individual e coletiva. Nesta época, a notificação compulsória da doença já não era exigida, dado que a teoria do contágio não era mais admitida, mas a higiene preconizava, entre outras medidas, 'algum tipo' de isolamento, saneamento, ventilação de ambientes, etc. Estas medidas foram bastante desenvolvidas no Caraça, que teve seu sítio arquitetônico alterado significativamente por conta das recomendaçōes antiberibéricas. Um exemplo destas alterações foi a transformação da metade do jardim frontal em pátio de recreação e práticas esportivas. Mas a higiene, enquanto disciplina de saúde pública, preservava orientações comuns no século XIX, constituindo um corpo de orientações reconhecidas como "higiene moral", pela qual o médico aconselharia ao individuo:

teorias bacteriana e parasitária, teoria de glândula endócrina, etc. De fato, por esta época existiam ainda bastante controvérsias sobre a etiologia do beribéri. A certeza dependia da conviç̧ão de quem defendia cada uma das teorias, expostas nas publicações especializadas. Mais enfático, HARRISON (ii), tratando da "moderna ciência da nutrição", refere-se ao fator hidrosolúvel B como senco a vitamina anti-beribéri. Neste caso, esta vitamina seria responsável pela

degeneration of nerves, with loss of tone and power, result from prolonged restriction of this factor (ii, p. 281-2).

No mesmo ano, MEGAW (iii), discutindo beribéri, cita também as teorias que tentam esclarecer a etiologia da doença; encerra declarando que:

The know facts suggest strongly that a poison formed in rice under certain conditions of storage may be the essential cause of some forrias of ueriberi, and possibly of the disease in general (iii)

i. STITT, A . B. The diagnostics and treatment of tropical diseases. Fhiladelphia, P. Blakiston's Son \& CO, 1922. Section III.

ii. HARRISON, S. Notes on the vitamins. The j. of trop. med. and hygiene, 26 (17) 281-2, 1923.

iii. MEGAW, J. W. D. The beriberi and epidemic dropsy problem. The indian med. gaz, $58(5): 282,1923$ 
"O clinico deve aconselhar-lhe uma vida isenta de toda e qualquer fadiga. As preocupações, os excessos intelectuaes, devem ser evitados como meio preventivo especial”36s.

A terapêutica instituída, por sua vez, prescrevia vários tratamentos. Há uma grande variedade deles nas publicações sobre beribéri em diferentes periodos de sua abordagem. Contudo, existe um procedimento terapêutico que é unânime na grande maioria das publicações. Trata-se da conduta que recomendava a remoção do doente do local onde ficou doente, para outra região. Conforme foi visto, nos citados casos de beribéri no Caraça a conduta da remoção do doente exerceu, em todos eles, resultados completamente favoráveis. $\mathrm{Na}$ época, uma das explicações para o sucesso desta conduta era a mudança do doente para um clima mais propicio à recuperação. Nesta condição,

"... o doente se beneficia promptamente da mudança, não raro, de modo maravilhoso"366.

Se, décadas mais tarde, viria a ser admitido decididamente que o que mudava nestas remoções era a alimentação e não o ar, na época esta idéia de que a transferência se relacionava com a mudança do clima começaria a sofrer abalos, por não responder a algumas expectativas. Hospitais de isolamento construídos à beira-mar começaram a não recuperar beribéricos e, com isso, a idéia de que a mudança do local era um tratamento eficaz tornava-se ineficaz. No caso do Caraça, não houve a experiência do fracasso da remoção, visto que os alunos que teriam sido tomados pelo beriberi, quando transferidos, mudavam-se para locais onde, invariavelmente, a dieta oferecida era mais diversificada e, provavelmente, oferecida em maior quantidade: casa de familiares, a chácara - e posteriormente a fazenda do Engenho -, etc. Outros tratamentos que continuavam a ser empregados para combater $o$

${ }^{365}$ GONDIM, E. M. A novarsenotherapia no beriberi. Bahia, Livraria Economica, 1921 p. 22.

366 Idem, p. 23 
beribéri: a eletroterapia, usada para tratar as seqũelas, lesões residuais do aparelho neuro-muscular'; hidroterapia, vaporização com essências aromáticas; prescrição de tônicos, fortificantes, estimulantes, drásticos, diuréticos, sangrias, e até mesmo a dolorida e meticulosa punção lombar'

“... pelo acostumado accumulo de serosidade no canal rachidiano; nas grandes exasperações de dôres constrictivas do thorax, dyspnéa com angustia, pulso filiforme ${ }^{\text {367 }}$.

Além dos já citados, a relação de medicamentos empregados para tratamento do beribéri continuava longa ao alvorecer dos anos vinte deste século, como atesta o doutorando da época:

"Não podemos trazer nestas paginas a relação de todos os medicamentos empregados no tratamento desta molestia, pois seria enfadonho occupar-me dos mercuriaes de Christie ao laudanum de Marshall; das pilulas de electerio e genciana de Aitken, ao xarope de Easton dos modernos, largamente empregado no nosso meio. nenhum destes remedios logrou mais solido conceito no meio scientifico, sendo que alguns delles, tem trazido ao doente, maleficio.

Os Drs. Almeida Couto, Ramiro Monteiro, Domingos Carlos, Salustiano Souto, Barão de Itapoan, e muitos outros clinicos bahianos deixaram conselhos therapeuticos para o combate ao beriberi. Foram ainda ensaiados: os minerais que tem por base o phosphato de zinco (Torres Homem); o nitrato de prata (Dr. Santa Rosa); calomelanos e licor de Fowler (Silva Lima); e arsenicaes em geral (Dr. Victorino Pereira).

Ainda poderiamos citar grande número de preparados que trazem rotulada a especificidade do beriberi, mas, que na realidade, não tem dado resultados satisfactórios taes como: Elixir de linimento anti-beriberico de Floreano Serpa; Elixir de jurubeba e pegapinto do Dr. Carlos Bittencourt”368.

367 Idem, p. 24 
Regra geral, aos poucos as prescrições medicamentosas eram acompanhadas de orientações para um regime alimentar "substancioso" 369 , ainda que fosse tratada, na Europa e Estados Unidos, como uma doença eminentemente tropical. Ou seja, a literatura sobre o beribéri não trata explicitamente o assunto, mas é provável que a vinculação de uma dada doença carencial a uma região da terra introduzia uma variável que dificultaria a aceitação desta mesma teoria carencial. Por definição, uma doença carencial manifesta-se em qualquer lugar em que se verifica tal carência alimentar; ao contrário, a doença dita "tropical" relaciona sua ocorrência na região tropical do globo, correspondente aproximada da região equatorial, com algumas exceções. Naturalmente, é admitida a carência alimentar nos trópicos, por conta das condições sociais e econômicas a que estão submetidas as populações locais. Neste sentido, cunhou-se a expressão "doenças tropicais do metabolismo"370, tendo em vista, especialmente, as alterações que ocorreriam na composição do sangue por ocasião de doenças como o beribéri. A expressivamente maior incidência do beribéri nesta região, e conseqũentemente sua alusão como "doença tropical", não teria contribuido para que se tentasse um agente etiológico típico desta mesma região ? Esta tentativa não teria dificultado a adoção, pela saúde pública, da etiologia carencial para o beribéri ? Mesmo em texto que aborda casos de beribéri em paises como os Estados Unidos, é inevitável a associação do beribéri ao oriente, onde

\footnotetext{
368 Idem, p. 30-1.

Realmente, a lista de medicamentos é longa... e a ela estava sendo acrescido outro tratamento sugerido pelo autor citado. Esta nova terapia baseava-se numa nova formulação para uso do arsênico que, segundo seu autor,

"Os seus animadores effeitos o recommendam à consideração dos clinicos" (cf. nota 90, p.31).

369 É uma recomendação que consta, por exemplo, no LAROUSSE (*) que, por sua vez, sintetiza condutas de importantes segmentos da medicina francesa.

* LAROUSSE Médical Illustré. Paris, Librairie Larousse, 1923. p. 142.

${ }^{370}$ MENSE, C. Handbuch der Tropenskrankheiten. $3^{9}$ ed. Leipzig, J. A. Barth, 1924. v. 3 , p. 642-644.
} 
“... importantes fatores são reconhecidos como predisponentes ou que contribuem para o desenvolvimento do beribéri. Entre eles, malária crônica, gravidez, clima quente e úmido, higiene inadequada... ${ }^{* 371}$.

Foi no superiorato do Pe. Jerônimo P. de Castro, substituto do Pe. João Camilo de Almeida, que, em novembro 1928, inaugurou-se a estrada para automóveis até o Caraça. Com esta obra, o Superior pretendeu facilitar o acesso ao educandário, facilitando a reabertura do Colégio, paralelo à Escola Apostólica. O difícil acesso ao Caraça foi uma das justificativas que determinaram o seu fechamento na primeira década do século. A reabertura do Colégio, conforme relatado, foi uma experiēncia dolorosa para a instituição e o seu fechamento se deu praticamente um ano depois. O próprio relato histórico de lazaristas é implacável com esta experiência:

“... o ano de 1929 é cheio de problemas e decepções. ...

Cai a disciplina. $O$ ambiente está carregado. Um aluno enlouquece, justamente o protegido do Presidente do Estado. Dois conseguem fugir; foram capturados e entregues aos pais. Outros são expulsos... E o beribéri continua fazendo suas vitimas... obrigando-os a passar vários dias de tratamento, na Chácara de Santa Rita.

"Noticias alarmantes chegam às familias que vêm retirar os filhos. Professores escrevem ao Visitador pedindo para fechar - Colégio. Em julho os colegiais preparados à moda caracense e não segundo o figurino do programa oficial -, vão a Belo Horizonte submeter-se, no Ginásio Mineiro, ao exame de admissão. ... de 36 alunos somente sete são aprovados!

371 SHATTUCK, G. C. The relation of beri-beri to polyneuritis from other causes. The Amer. j. of trop. med., 3 (6), 540-3 
Urucubaca completa!... Alguns pais ficaram furiosos!... No fim do ano estava fechado o Colégio... ${ }^{372}$.

Nesta circunstância, em 1930 assume a direção do Caraça o Pe. Francisco Pimenta, com o propósito de qualificar a Escola Apostólica e enfrentar o beribéri que insistia na sua permanência. Neste superiorato, várias 'providencias higiennicas' foram tomadas, tendo em vista a melhoria da saúde através do ambiente físico, alimentação, recreação, etc. ${ }^{373}$. $O$ fim definitivo das atividades colegiais e o empenho na vocação apostólica da Congregação adequava a instituição ao seu tempo. Diversos colégios se espalharam por Minas Gerais e pelo Brasil, oferecendo um ensino mais de acordo não apenas com os programas de ensino da época, mas também contemporâneo de uma sociedade em mudanças comportamentais, praticamente incompativeis de serem assimiladas pelo Caraça. Ainda de acesso dificil e isolado do cotidiano mundano que, cada vez mais, fazia parte da sociedade, o antigo colégio carregava o peso de uma tradição que era cara às gerações intelectualizadas, pela formação humanistica da instituição. Em Minas, esta tradição exerce, tempo a fora, influência sobre o papel histórico do Caraça na formação das elites do estado:

"A natureza das disciplinas estudadas, muito contribuiu para formar no espirito mineiro, o hábito da reflexão, de prudência, de pesar as circunstâncias e os atos, e de raciocinio profundo. $O$ estudo da filosofia, ensinando a pensar,

\section{${ }^{372}$ ZICO, J. T. Caraça: Peregrinação, cultura e turismo. Op. cit. p. 106-7.}

373 Aqui, o termo "providências higiênicas" é usado de acordo com o conceito de higiene oferecido por um especialista da época, Afrânio Peixoto, então professor da Faculdade de Medicina e de Direito da Universidade do Rio de Janeiro. Segundo ele,

"A higiene não é precisamente sciencia, porque é aplicação prática de quase todas. É um conjunto de preceitos, buscados em varios conhecimentos humanos, mesmo fóra e além da medicina, tendentes a cuidar da saude e a

* PEIXOTO, A . Higiene. $5^{4}$ ed. Rio de Janeiro, Liv. Francisco Alves, 1930. v. I : Higiene Geral. p. 7. 
preparando o cérebro para as dificuldades, foi sem dúvida a base da formação do caráter das elites mineiras"374.

Para o peso da formação humanística caracense, muito teria contribuido a magnifica biblioteca do educandário que, considerando época e local, conseguiu reunir um invejável acervo, com obras verdadeiramente raras. Este acervo foi construido paulatinamente e correspondeu a esforços de todos os religiosos que por lá passaram e envolveu basicamente compras e doações. Das casas lazaristas de Portugal teriam vindo muitos livros, outros de Roma e muitos cuja origem exata é desconhecida. Atualmente, o livro mais antigo data de 1489 e é o História Natural, de Plínio, em italiano traduzido do latim. O Chronicon, de Eusébio, era tido como o livro mais antigo (1483). Porém, foi doado a D. Pedro II quando da sua visita ao Caraça. Além do significativo número das obras seculares, muitas impressas antes do ano de 1600 , obras didáticas de uso corriqueiro e literatura orientada para as leituras de salão e disciplinares compōem o acervo. A biblioteca estava instalada no mesmo prédio em que ficavam o dormitörio dos alunos, salas de aula e de encadernação e outros serviços. Documentação e manuscritos arquivados tinham seus lugares ordenadamente determinados em meio aos quase 30 mil volumes, num ambiente para onde professores se retiravam para estudar e preparar suas aulas. Não raro, quando os apostólicos iam para a fazenda do Engenho, transformada em "casa de férias" do Caraça, levavam consigo exemplares, ora clássicos portugueses ou francesa e mesmo brasileiros, tirados sob recomendação da biblioteca estimada pela Congregação. As férias davam-se nos meses de julho e agosto, que coincidiam com o inverno rigoroso do alto da serra do Caraça, e em meio aos passeios e recreações a leitura era obrigatória. Leitura e estudos, pois era ali que os alunos, quando deficientes em alguma disciplina, tinham oportunidade de se prepararem para novos exames que seriam realizado no retorno ${ }^{375}$.

${ }^{374}$ LIMA JÚNIOR, A O Colégio do Caraça. Rev. do Inst. Hist. e Geog. de Minas Gerais, $9: 21-32.1962$.

375

Lisciplinas estudadas na Escola Apostólica (*): 
Quando o Pe. Antônio Ferreira da Cruz substituiu o Pe. Pimenta como superior do Caraça, estava então consolidada a Fazenda do Engenho como casa de férias, descanso e repouso da instituição. Deste periodo em diante a crônica não mais menciona casos de beribéri no local. A partir desta época, o beribéri no Caraça deixa de ser um 'fato' independentemente da sua veracidade epidemiológica - e se coloca como um processo que vivenciou a eclosão e a abordagem cientifica de uma entidade mórbida, cujas etapas de investigação (da etiologia à profilaxia) atenderam a todas as exigências da incerteza e controversia. Esta "vivência" foi temporária, pois, se o beribéri deixou o Caraça, as incertezas e controversias não deixariam imediatamente o meio cientifico.

O final da década de 20 e início da de 30 marcariam o início de uma ofensiva da teoria da deficiência alimentar para o beribéri. Isso significa que, apesar desta teoria angariar a cada dia mais adeptos, havia ainda quem a contestasse. Para alguns, esta oposição se fazia ainda de modo radical:

"Beri-beri, esta molestia cuja autonomia pathologica é cheia de incertezas, cuja ethiologia é ainda inquinada de opiniōes, cuja pathogenia, diagnostico e tratamento são interscindidos de theorias e hypotheses, esta molestia, repetimos, se estende, se multiplica, se generaliza, se individualiza, de mil formas, de numerosas feições, por este mundo afora"376.

Para o processo de admissão, que se dava em algumas épocas do ano: Religião, Português, Geografia, História do Brasil, Aritmética e Caligrafia.

$1^{\mathbb{Q}}$ ano: Religião, Portuguès, Latim, Geografia, História do Brasil, História Sagrada, Matemáticas, Caligrafia ou Desenho, Música;

$2^{\mathfrak{Q}}$ ano: Religiåo, Português, Latim, Francês, Geografia, História do Brasil, Matemáticas, Música;

$3^{0}$ ano: Português, Latim, Francês, Geografia do Brasil, Matemáticas, História, Inglês, Música;

$4^{\mathcal{Q}}, 5^{\mathfrak{Q}}$ e $6^{\circ}$ anos: Religiåo, Literatura (portuguesa, brasileira e universal), Latim, Grego, Francês, Inglès, História do Brasil, História Natural, Matemáticas, Cosmografia.

* ZICO, J. T. Caraça: peregrinação, cultura e turismo. Op. cit. p. 119-20.

376 CAMPOS, E. G. de. Symptomatologia do mal de Ceylão. Bahia, Typ. S. Antonio, 1929. p. 3. 
As divergências de opiniões acirraram-se, também, porque se passa a questionar a extensão da doença. Na prática, isto significa questionar se os diagnósticos, clínicos e epidemiológicos, foram, de fato, verdadeiros, ao afirmarem a existência do beribéri em certos locais.

"No Brasil do Amazonas ao Prata segundo notícia de incontaveis auctores que apressadamente compulsamos, parece ter o beriberi assestado as suas preferencias... em que más interpretaçōes ou a ribaldia de alguns clínicos têm affiançado existir a molestia em apreço"377.

"Erros e confusões de diagnósticos colaboraram sempre em engrossar a cifra epidemiologica do beribere: há pouco Oswaldo Cruz e discípulos trouxeram da Amazonia a conviç̧ão que a fórma galopante era apenas lendária, talvez acidente agúdo de cronica infecção malárica e a fórma edematosa certamente paludica"378.

Este questionamento da extensão da doença pouco influia na definição da sua etiologia. Como foi dito, a teoria alimentar ganhava terreno, mas no Brasil a compreensão desta hipótese ficou sempre ligada ao consumo de arroz polido ou arroz branco. Acontece que este alimento não tinha consumo uniforme e quantitativamente significante, como ocorria no extremo oriente, onde o beribéri era endèmico. Desta forma, acreditava-se que poderia haver uma outra razão etiológica que permitisse compreender a gênese da doença nos diferentes locais em que se manifestava. Os autores que questionavam a teoria alimentar, faziamno sem excluí-la. Tratava-se de um processo delicado de contestação pelo qual preservava-se a critica sem que se perdesse a 'qualidade' do que era

377 Idem, p. 5.

378 PEIXOTO, A. Higiene. $5^{\text {a }}$ ed. Rio de Janeiro, Liv. Francisco Alves, 1931. v. II Medicina Preventiva. p. 214. 
criticado. Um eminente catedrático de doenças tropicais e infecciosas de uma escola médica brasileira afirmou, em 1936:

"A epidemiologia tem aspectos francamente favoráveis à natureza infecciosa do beriberi".

Para, em seguida, ponderar que

"no beriberi, há sempre um terreno carencial por deficiencia vitaminica, cuja symptomatologia outros reproduziram experimentalmente no homem e em animaes inferiores e curaram pela administração therapeutica do elemento deficitario. ... O que nos resta de duvidas, e estas accentuadas, é que a carencia da constellação vitaminica por si só possa explicar todos os surtos e todas as eclosões de carater epidemico que o universo, ainda hoje, comenta e registra" ${ }^{379}$.

379 PARREIRAS, D. Beriberi. Rio de janeiro, Flores e Mano Editores, 1936. p. 138 e 159.

O beribéri também foi estudado por um pesquisador cujas biografias qualificamno como um dos mais brilhantes e promissores pesquisadores de doenças tropicais no Brasil: o médico Evandro Chagas, filho do conhecido Carlos Chagas, e que morreu precocemente aos 35 anos, em 1940. Jovem ainda, era o interprete do pai em suas conferências internacionais em alemão, francês e inglês e foi ativo pesquisador em sua "intensa e curta vida". Foi autor de um "Manual de doenças tropicais e infeciosas" e, além do beribéri, estudou também a febre amarela, a malária, a ancilostomíase, a leishmaniose visceral e "principalmente a miocardite provocada pelo Trypanosoma cruzi". Durante sua estada no Pará, quando coordenava a Comissão de Estudos de Leishmaniose Visceral Americana, sugeriu - e foi aceita - ao governador do estado a criação do Instituto de Patologia Experimental do Norte (PEN). Após sua morte, o IPEN transformou-se no Instituto Evandro Chagas, vinculado ao Ministério da Saúde, que desenvolve importantes atividades cientificas e açðes de saúde pública (i, ii, iii).

i. CIÊNCIA \& TECNOLOGIA na AMAZÔNIA. Instituto Evandro Chagas, 1, 1995.

ii. INSTITUTO EVANDRO CHAGAS. 50 anos de contribuição às ciências biológicas e à medicına tropical. Belém, Fundação Serviços de Saúde Publica, 1986. (prefácio).

iii. LACAZ, C. da S. Vultos da medicina brasileira. Cp. cit. p. 96. 
Nesta discussão, é aparente que a opção por uma ou outra teoria estivesse afeita à 'matriz teórica' que orientava os pesquisadores. Aqueles que se vinculavam a uma tradição ortodoxa da medicina tropical, pela qual a natureza infecciosa ou contagiosa de doenças tem peso significativo, aceitavam menos a teoria vitaminica (alimentar) do que os pesquisadores vinculados à clínica médica, campo no qual as pesquisas em nutrição alcançaram sucesso. E o caso, por exemplo, do influente na América Latina - nutrólogo argentino Pedro Escudero, então catedrático de clínica médica em Buenos Aires e diretor do Instituto Municipal de Nutrição, que escreveu, em 1934:

"O achado de Funk e creação do euphonico termo vitamina', facultaram ser designados com os nomes de vitaminas $\mathrm{A}, \mathrm{B}$ e $\mathrm{C}$, corpos capazes de curar o rachitismo, o beriberi e o escorbuto.

De começo se acreditou na existencia de uma só vitamina B e que a sua privação occasionava o beriberi ou paralysia das pernas e outras desordens nervosas. Tudo se esclareceu. Quando se priva o organismo desta vitamina, os transtornos que surgem dependem do gráo da privação, do tempo que ella perdura e da edade do paciente" 380 .

A confusão sobre a doença, especialmente quanto à sua etiologia, não escondia, entretanto, os ganhos que a nutrição tivera nas últimas décadas. As vitaminas surgiram como a grande novidade no campo alimentar. Consolidados, estes nutrientes começaram a engrossar as tabelas de composição de alimentos, bem como as recomendaçōes sobre consumo alimentar. Na prática, o que se observou foi o burilamento de idéias que eram genericamente difundidas há muito tempo. Por exemplo, no campo da alimentação escolar, as considerações que surgiam, se, por um lado, vinham adornadas pelos novos conceitos científicos, por outro lado refletiam igualmente as mesmas metas e proposições de décadas atrás. Quando a higiene nos colégios do Rio de Janeiro é tratada nos anos 50 do século XIX, o núcleo da abordagem é o da construção da 
saúde através de medidas higiênicas disciplinares, pelas quais se desenvolverão 'as forças físicas e intelectuais' dos individuos ${ }^{381}$. Por esta noção, a alimentação ocupa lugar relevante e a orientação dietética que é dada naquela época é bastante compativel com aqueles baseados em conceitos mais modernos. Por exemplo, como foi verificado, a cota de vitamina $B 1$ de uma dieta sugerida em 1857 preenche as necessidades nutricionais de um adolescente do sexo masculino. Claro está que, na época, nem mesmo se cogitava da existência de um nutriente tão poderoso nos alimentos, mas claro é também que, obviamente, não é o desconhecimento de uma coisa que impede a sua existência; e mais, não é o seu desconhecimento que impede o exercicio de sua função. Mas as informações levam a crer que, apesar da disponibilidade de boas recomendações, a alimentação era ruim não apenas em colégios, mas também em asilos, prisões, etc. Um relato médico de 1933 diz que:

"Os alumnos da maioria dos nossos collegios, internatos e asylos, são sub-alimentados qualitativa ou quantitativamente; Essa sub-alimentação resulta da falta de idoneidade technica ou moral de muitos individuos, empresas ou congregações que exploram esse ramo de actividade, bem como da completa ausencia de fiscalização nesse sentido; Não somente os alimentos mas a sua distribuição e o ambiente das refeições devem ficar sob as regras da hygiene" ${ }^{\text {382 }}$.

${ }^{381}$ Confere, notas 20 a 27 , segunda parte.

382 BARRETO, A . C. Normas praticas a adoptar na alimentação do escolar, nos internatos do Brasil. A Folha Médica, (dez.) : 614-8, 1933. [ Apresentado à Conferencia Nacional de Protecção à Infancia].

Alguns anos mais tarde, COSTA (*), pesquisando escolares da cidade do Rio de Janeiro, mostra "as prováveis deficiências nutritivas (subnutrição especifica) encontradas" nas crianças Examinadas:

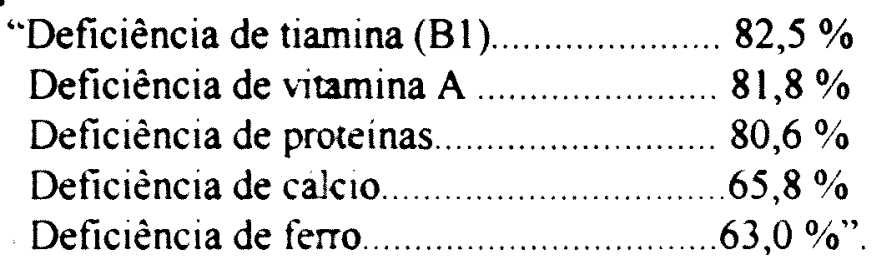


O entendimento da questão do beribéri durante a década de 30 do século vinte, isto é, duas décadas após Funk ter precisado e proposto o termo vitamina para designar substâncias presentes nos alimentos que, entre outras coisas, curaria o beribéri, não poderia excluir a teoria das doenças por deficiência, teoria esta que ainda não conseguia tornar-se incontestável. Beneficiária dos resultados das pesquisas com os alimentos, sua composição e a saúde, a nutrição consolidou seu espaço enquanto ciência e, curiosamente, independentemente das controvérsias sobre a etiologia da doença, o resultado desta nova ciência da nutrição foi a redução significativa dos casos de beribéri, assim como a possibilidade de controle de outros males. Convincentemente munida, a nutrição passa a ditar normas alimentares aos indivíduos em geral. Assim é que, numa publicação de 1938, o Instituto de Higiene de São Paulo edita os "Principios da Alimentação do Homem Normal", pelos quais a alimentação fornecerá ao organismo

"conteúdo energético suficiente; proporção adequada de proteinas, gorduras, hidratos de carbono, vitaminas, sais minerais e água" ${ }^{383}$.

Apesar da estruturação metodológica que a emergente ciência da nutrição humana adquirira nas últimas décadas, desenvolvimento este que deve significativamente ao estudo das doenças por deficiência, a questão da etiologia do beribéri continuava suportando algum grau de controvérsia. Nesta mesma publicação do Instituto de Higiene, o autor, ao discutir a vitamina $\mathrm{B} 1$, afirma:

"Cabe aqui esclarecer que, quanto à etiologia do beriberi, há ainda sérias divergências entre os autores. Se uns há convencidos da carência vitaminica, como causa fundamental,

* COSTA, D. Alimentação do escolar. Rio de Janeiro, Imprensa Nacional, 1948. (Ministério da Educação e Saúde/Serviço de Documentação). p. 64.

383 RIBEIRO, B. A . Princípios da alimentação do homem normal. Boletim do Instituto de Higiene de São Paulo, (63), 1938. 
atribuem-lhe outros origem tóxica ; ao passo que outros ainda o admitem como conseqüência a uma infecção, relegando o fator alimentar para segundo plano. $\mathrm{Na}$ própria medicina nacional os pontos de vista se apartam, quem em prol da teoria vitaminica, quem a favor de uma causa infecciosa"384.

A afirmação do beribéri como uma avitaminose teria como principal aliado o sucesso de trabalhos experimentais na área de fisiologia. Ao fim da primeira metade deste século, importantes relatos destas pesquisas surgiram em periódicos, congressos, etc. Curiosamente, tais pesquisas interessaram-se menos pela relação da vitamina $\mathrm{B} 1$ com $O$ beribéri e mais pela função biológica desta substância. Ou seja, na prática a polêmica sobre a etiologia do beribéri era equacionada indiretamente. Ao demonstrarem o papel fisiológico da tiamina e as conseqüências anatomopatológicas e clinicas de sua carência dietética, estas pesquisas colocaram em dificuldade a teoria não vitaminica para a etiologia do beribéri ${ }^{385}$. Caracterizado cada vez mais como uma avitaminose, os estudos a respeito do beribéri dedicavam-se cada vez mais a distúrbios especificos produzidos pela deficiência de tiamina ( cardiopatia, paralisias, etc.), através de investigaçōes de causas importantes que determinavam a avitaminose. E o caso do beribéri em alcoólatras, grupo onde a incidência da doença tornou-se reconhecida como sendo importante. Na região norte do Brasil, onde sempre foi relatada a doença, mesmo considerando as restrições de diagnósticos

384 Idem, p. 16.

Esta mesma incerteza, apenas mais fundamentada e esclarecedora quanto às teorias vigentes, pode ser observada em um recomendado livro da época (*):

- SCOTT. H.H. A history of tropical medicine. Baltimore, William Wood Book, 1939. p. 858-91: Beriberi.

$385 \mathrm{Na}$ década de 40, dois livros (i ; ii), entre outros, sintetizam bem o 'espírito' experimental que norteou os estudos de fisiologia da nutrição:

i. OLIVEIRA, J. D. de Vitaminas e àminoácidos. São Paulo, Mario M. Ponzini \& Cia, 1941.

ii. CAMPOS, F. A de M. Problemas brasileiros de alimentação. Rio de Janeiro, Serviço de Alimentação da Previdència Social , 1949. (Biblioteca Brasileira de Nutrição, v. 1). 
apontadas por Oswaldo Cruz, no início da década de 50, as formas de beribéri encontradas pareciam claras:

"Acreditamos que atualmente casos típicos de beribéri cardíaco, não alcoólico, dificilmente se encontrem no nosso meio"386.

Os anos seguintes firmariam a teoria do beribéri como resultado de uma deficiência vitaminica, mas permitindo que no seu interior

SOUZA, B. F. de. Beribéri e Cardiopatia. Belém, 1952. [Tese de Livre Docência Faculdade de Medicina e Cirurgia do Pará]. p. 62.

Em outra tese do mesmo ano (i), o autor reforça a afirmativa da autora acima, sumariando as causas que definem uma hipovitaminose $\mathrm{A}$ :

“... a causa exógena, alimentar, onde a ingestão insuficiente de substâncias ricas em tiamina acarreta o quadro do beribéri, o desperdício de um maior número de calorias, seja pelo trabalho físico exagerado, seja por um aumento do metabolismo determinado pela hiperfunção tireoidiana, pela hipertemia, etc. $\mathrm{O}$ alcoolismo crônico determinando a rutura do equilíbrio vitamina $\mathrm{Bl}$ reação calórica; a excessiva ingestão de hidratos de carbono, a gravidez, 0 aleitamento, o crescimento e os estados gastro-intestinais como vômito e diarréias crônicas, são causas que, ou por necessidade maior de ingestão de vitamina Bl levado pelo consumo exagerado ou por dificuldade da sua absorção, acarretam hipovitaminose. ... Apesar da sub-alimentação em que vivemos atualmente, ainda encontramos uma alimentação variada que cobre com certa dificuldade a nossa perda energética. Não encontramos no estado do Pará o beribéri de etiologia estritamente exógena, isto é, puramente alimentar".

Caracterizando o beribéri não somente como uma carência alimentar especifica, mas sim como uma doença da nutrição, REYNES (ii) observa que a pesquisa experimental é capaz de criar avitaminoses especificas, puras, como a avitaminose Bl; no entanto, a clínica, no seu dia-a-dia, observaria quadros policarenciais, Isso significaria que um indivíduo com beribéri, especialmente em um meio onde a doença é endêmica, apresentaria sinais clínicos de outras carências nutricionais, como, por exemplo, anemia, lesões de pele, etc.

i. FECURY, J. O coração beribérico. Belém, 1952. [ Tese de livre docência - Faculdade de Medicina e cirurgia do Pará]. p. 6-7.

ii. REYNES, V. Précis d'épidémiologie et prophyłaxie des grandes endeméies tropicales Paris, Masson \& $C^{i e}$, Éditeurs, 195\%. p. 395 
sobrevivessem dúvidas quanto às condições para a existência desta deficiência: doenças, alcoolismo, dieta desbalanceada, etc., e processos bioquímicos. Quanto a este último ponto, surgiu no oriente a hipótese de que alguns peixes conteriam uma substância (enzima) capaz de 'destruir' a tiamina (vitamina B1). Para alguns autores, a destruição da vitamina por esta enzima (tiaminase) poderia estar envolvida na etiologia do beribéri ${ }^{337}$. Na prática, a elucidação desta dúvida ( a enzima existe, mas é inexpressiva sua influência na incidência da doença / em nada contribuiria para justificar a drástica redução dos casos de beribéri no extremo oriente, onde o beribéri foi endêmico por várias décadas. Tradicionalmente, o declínio do beribéri está relacionado não apenas à compreensão científica da sua causa, como também a circunstâncias econômicas que teriam permitido o acesso a uma alimentação mais adequada às necessidades nutricionais ${ }^{388}$. Entretanto, parece que as circunstâncias da 'compreensão científica' e da 'alimentação mais adequada às necessidades humanas' tem lances mais sinuosos. Desde quando o quimico Robert Williams (1886-1965) primeiro isolou, em 1933, e depois, em 1935, sintetizou a vitamina B1, o 'olhar médico' sobre a doença mudaria pouco a pouco. Sintetizada e posteriormente comercializada, a tiamina se tornaria disponivel para o tratamento do beribéri $e$, neste sentido, a doença passa a ser completamente medicamentalizada ${ }^{389}$. Pela via alimentar, a fortificação com a vitamina

${ }^{397}$ KATSURA, E. \& OISO, T. Beriberi. In. BEATON, G. H. \& BENGOA, J. M., ed. Nutrition in preventive medicine. Geneva, World Health Organization, 1976. (Monograph series, 62).

SHIMAZONO, N. \& KATSURA, E., ed. Beriberi and thiamine. Vitamin B research committee of Japan, Tokyo, 1965.

389 AYKROYD, W. R. Conquest of deficiency diseases. Geneva, World Health Organization, 1970. (Basic Study, 24).

389 Robert R. Williams Jr., estadunidense nascido na İndia e filho de missionários batistas, formou-se em química pela Universidade de Chicago em 1907. Trabalhou nas Filipinas por vários anos na busca da cura para o beribéri e durante a primeira guerra mundial trabalhou no escritório de ciència do governo americano com o desenvolvimento de projetos. Após ter sintetizado a vitamina Bl em 1935, a companhia farmacèutica Merck \& Company iniciou sua produção comercial já em 1936. Além do beribéri, 
sintética de alimentos pobres neste nutriente, especialmente os cereais polidos, fecha o cerco terapéutico. Estes dois processos extraem, também, pouco a pouco, dos discursos médicos, as alternativas que a saúde pública oferecia como profilaxia da doença, através de sua influente ferramenta, a higiene. A alimentação humana é um fato cultural de expressiva significância, fixando-se como ponto de encontro de realizações necessárias e possiveis: biológica (nutrição) e culturais (psicossociais). O caráter inato da alimentação confere a ela tanto propriedades favoráveis para a realização de satisfações pessoais, como também a transforma em processo captável pelo lógica do consumo e, portanto, da mercadoria através dos alimentos. Sob este ponto de vista, os alimentos enriquecidos com vitaminas cumprem o fiel papel de atender necessidades nutricionais, e de atuarem como mercadorias que retribuem satisfatoriamente os mercadores.

O beribéri no Caraça é dado como extinguido desde o início da década de trinta, antes que ocorresse 0 isolamento, sintese ou comercialização da forma medicamentosa da tiamina (vitamina B1). Independentemente de se saber da gravidade da doença no local, tudo indica que o conjunto de medidas orientadas e, então, admitidas pela direção do colégio, tenham, no decorrer do tempo, tido efeito positivo na qualidade de vida dos moradores do Colégio, particularmente os alunos. Se tais medidas não foram eficazes e evitar a repetição da doença, é provável que não tenham sido por ausência de recomendaçōes genéricas, mas eficazes. Houve recomendaçōes que influiriam, por exemplo, na expansão qualitativa e quantitativa da alimentação usual, assim como houve, e foram satisfeitas, recomendações no âmbito do saneamento, atividade física, etc. A adoção das recomendaçōes alimentares foi feita lentamente $\mathrm{e}$ isto por causa de uma série de motivos apresentados no decorrer do presente trabalho. Um destes motivos refere-se ao fato de que, apesar de eficazes na sua generalidade, as recomendações

interessou-se por outras deficiências nutricionais e contribuiu significativamente para o desenvolvimento de processos de enriquecimento de farinhas e derivados de cereais com as vitaminas, cuja carència definia diferentes doenças $\left({ }^{*}\right)$.

* Rotert R. Williams. http://www.invent.org/book/book.text/109.htm 
alimentares eram pouco contundentes, já que não se conheciam muitos aspectos da nutrição e do metabolismo humano. Da medicina sempre se esperou resultados práticos definitivos, e dela, nos periodos vistos, não se poderia ter recomendaçōes especificas sobre nutrientes e doenças. Outro exemplo é a dificil compreensão do papel social da alimentação por uma instituição tipicamente monacal, na qual o alimento e a alimentação têm também função simbólica. Esta função orienta-se por regras que dificultam a afirmação do caráter mundano, profano até, da alimentação. As cores, as formas e o sabor dos alimentos aliciam o gosto, dão prazer, seduzem as necessidades espirituais (emaranhado de necessidades do intelecto de causas nem sempre sabidas, mas externadas de maneiras múltiplas através da criação em seus diferentes niveis, religiosidade, etc.), e na sua variedade e quantidade cumprem com discrição seu dever biológico de nutrir.

Mas, afinal, existiu beribéri no Caraça ? Conforme foi discutido no presente trabalho, não é difícil perceber que a veracidade clínica e epidemiológica pouca importância terá para a compreensão das repercussões que teve a doença, que pode ter existido ou não. Considerando a outra possibilidade, também em alguns aspectos já analisada, - que, de fato, existiu o beribéri no Caraça - é possivel afirmar algumas possibilidades: o beribéri existiu, mas é provável que muitos casos tidos como tal não o foram. Aqui, é certo admitir que tenha havido diagnóstico médico para todas as doenças do Colégio e, mesmo nos casos em que houve ato médico, podem ter ocorrido erros de diagnóstico, conforme foi admitido por pesquisadores já comentados. Outra possibilidade é admitir que a doença ocorreu, fazendo adoecer muitos alunos (doença de alta morbidade), mas matando poucos (doença de baixa mortalidade). Neste múltiplo campo de possibilidades sobre a ocorrência do berihéri no Caraça, um médico, ex-caracense, procurava, mais uma vez, compreender a doença no local. Haviam lhe chegado às mãos as informações que dão conta dos óbitos no Caraça entre os anos 1853 a 1957, ond $\epsilon$, além das datas em que ocorreram, havia em muitos casos a causa das mortes, o nome, a idade e a ocupação do falecido. A listagem provinha do livro de óbitos ${ }^{390}$, documento particular dos 
congregados caracenses $\mathrm{e}$, portanto, não constituindo um instrumento legal de notificação de óbitos do local. Em mais de um século de anotações, teriam ocorrido 59 mortes e, das 12 mortes de alunos, 3 teriam ocorrido, segundo o livro, por beribéri. A propósito, todos os alunos teriam morrido entre os anos 1858 e 1910 , periodo em que a crônica é mais incisiva quanto à ocorrência do beribéri no Caraça. Analisando a lista sob as variáveis possiveis, o velho médico admitia que a mortalidade do antigo Colégio não permitia falar, sob este conceito, de "epidemia". Então, epidemia de sintomas de beribéri ? Epidemia de beribéri com quadro clinico confirmado ? Epidemia de beribéricos diagnosticados ? Impossivel definir, pensou o médico. Endemia, surto, o médico pensou na melhor qualificação que exprimisse com precisão o que, de fato, teria ocorrido no Caraça. Lembrou as considerações do dr. Antônio Felício dos Santos que, num texto histórico, trouxe para o meio médico a discussão sobre a ocorrência do beribéri em Diamantina, Mariana, mas, principalmente, no Caraça. Lembrou também os relatos e as cartas que os religiosos lazaristas escreveram à Casa Central, relatando as dificuldades que enfrentavam por conta do beribéri. Assim como foi para muitos alunos que simulavam a doença para se afastarem das atividades regulares da instituição, os padres não teriam se alvoroçado a partir de sintomas mal esclarecidos ?, pensou o médico. Neste episódio de recordações, ele se lembrou da enigmática memória que teria sido escrita por um médico, o dr. João Alphonso Azevedo Magalhães. Lembrou-se que a única cópia da memória encontrava-se perdida em arquivos da biblioteca do Caraça - ainda existiria ? -, mas lembrou também que há muitos anos atrás obteve de familiares do dr. João Alphonso a única lembrança que tinham da memória, o indice dos assuntos. Com gestos cuidadosos, remexeu em suas coleções de anotaçōes e recortes e encontrou a página, já amarelada, na qual o filho do médico anotara os tópicos da memória:

1. O que se vê, como é e os modos de contar: ensaio introdutório;

2. As doenças, suas denominações e classificação: como combinar cores;

390 Livro de óbitos do Caraça. Arquivo do Caraça. 
3. Uma doença, um pesquisador e o arco-íris branco: como isolar uma cor;

1.1. Dizem que o beribéri é endêmico no Caraça: quem conta o que;

2.1. O meio e a doença ou o meio e as doenças: do que pode se adoecer no Caraça;

3.1. Se é beribéri (ou outra doença): como lidar, o que fazer, o que não fazer.

Ao ler, o médico achou-se em melhores condições de tentar entender o significado daqueles tópicos. Primeiro quis acreditar que o seu colega, há muitos anos atrás, quando ainda inexistia a palavra vitamina e a confusão sobre etiologia, etc., da doença era conflitante, teve clareza de que a classificação das doenças, e até mesmo as nomeações que the são dadas, nas suas mais diversas abordagens, são processos apenas artificialmente naturais mas que, na verdade, tudo não passava de algo naturalmente artificial. Neste sentido, e ai o médico reconheceu que seu colega utilizava recursos de outras formas de conhecimento da realidade, estas discussões apenas retardavam ou satisfaziam mais o preciosismo e vaidade dos pesquisadores, com aquiescência de grupos da sociedade - e ai o médico pensou por conta própria no exercício político. Desta forma, ele admitia que o dr. João Alphonso teria ponderado todos os relatos de beribéri no Caraça, inclusive dos próprios religiosos da Congregação, e concluindo que muito joio misturava-se ao trigo. Talvez porque, para João Alphonso, o importante fosse admitir um meio no qual, mais importante do que eliminar as causas de doenças, fosse interessante compreender e conviver com alguns agentes que potencialmente pudessem produzi-las. Poderia ainda ter pensado seu colega, imaginou o médico, que, no caso do Caraça, doenças - entre elas o beribéri - seriam evitadas se os padres observassem a regra lógica, e aqui ele usou uma expressão que parecia ter-lhe vindo por sopro, do "bem viver". Os padres, para diminuir a possibilidade de doenças, deveriam proporcionar aos alunos sadios que chegavam ao Colégio hábitos de vida, em termos de alimentação, atividade fisica, etc., que se aproximariam bastante daqueles existentes em suas casas. Para a maioria dos alunos, isto não seria dificil, visto que a grande maioria deles era oriundas da provincia mineira e, portanto, filiados a tradiçōes culturais comuns. O médico 
gostou desta interpretação que dera ao indice da memória de João Alphonso, mas, por gostar tanto, passou a acreditar que era ele mesmo quem interpretava assim. Releu novamente o indice, e preferiu desconfiar que aquela construção de João Alphonso expressava a ignorância dos conhecimentos que havia sobre a doença, quando comparados com os esclarecimentos que já tinham sido dados pela ciência moderna. Neste raciocinio, passou a acreditar que daria um curioso e excelente trabalho comparar o conteúdo da memória com os conhecimentos atuais sobre o beribéri. Para este fim, localizou os atuais descendentes do dr. João Alphonso, à procura de novas informações sobre a memória. Foram unânimes em afirmar que nada mais existia que lembrasse enfaticamente o dr. João Alphonso. Livros perderam-se na passagem por herdeiros, por ausência de conservação, etc., e possiveis escritos, anotações, estes jamais seriam reencontrados. Disseram-lhe que o último descendente que conservou algum destes materiais foi um filho de João Alphonso, advogado e jornalista, que morrera anos atrás, após breves anos de loucura, onde balbuciava palavras sobre o céu e o inferno.

Num lance de coincidência significativa, o médico, ao voltar do encontro com descendentes de João Alphonso, encontrou-se com um amigo religioso lazarista, que servia na Casa Central da Congregação. Das noticias que teve do Caraça, uma the chamara a atenção: o religioso teria ouvido que foram localizados na biblioteca do antigo colégio alguns documentos esquecidos e outros até tidos como perdidos. Entre eles, uma memória manuscrita sobre o beribéri, escrita no século passado por um médico amigo da Congregação. Admirado, o velho médico foi enfático:

- Eu estava mesmo pesquisando sobre este assunto e interessa-me bastante examinar esta memória.

Com a autoridade de ex-aluno e pessoa respeitável na sociedade, o médico recebeu dos religiosos a promessa de que lhe seria emprestada a memória, assim que ela viesse do Caraça. Sem querer perder tempo, pois previa que a correspondência entre a Casa Central, no Rio, e o Caraça não era tão ágil, o médico, disposto a examinar a memória o mais rápido possivel, se encarregou de buscá-la no colégio da serra. Chamou o filho, também médico, que na época trabalhava no Instituto Oswaldo Cruz, e confiou a tarefa: ir ao Caraça e, cuidadosamente, trazer-lhe a memória 
sobre o beribéri escrita no século passado pelo dr. João Alphonso. $O$ filho preparou-se para a viagem: seguir de trem até Belo Horizonte e, de lá, em carro alugado, chegar ao Caraça. Já era outono avançado de 1968 e, segundo o pai, que bem conhecia o local, o frio já deveria estar dando noticias lá pela serra do Caraça; seria bom o filho levar um agasalho. $O$ filho do médico sentiu-se desconcertado, pois incomodava-o deixar suas atividades no Instituto, mesmo sendo por poucos dias, e até porque não se sentia entusiasmado com esta viagem. Quis ver nesta falta de entusiasmo um presságio, mas foi dissuadido por colegas. Quis protelar, mas evitou contrariar o pai e, aconselhado pela mãe, decidiu cumprir de imediato o pedido. Numa noite abafada no litoral, tomou o trem que o levaria pelas serras mineiras. Após uma viagem inquieta, pois quase não conseguiu dormir durante o percurso, desembarcou na estação de Belo Horizonte. A manhã de 28 de maio na capital recebeu-o amena, mas ele próprio, portando-se como um áugure, interpretou como sendo um mau sinal um grupo de homens que ouvia noticias num rádio, em algum ponto da estação, sob vôos rasantes de pombos. Não se contendo, aproximou-se e quis saber o que ouviam. Sentindo-se importante por oferecer uma novidade ao homem bem arrumado e de traços finos, um dos ouvintes lhe disse:

- O Caraça pegou fogo. Um incêndio destruiu parte do colégio.

Um outro completou:

- Tiveram sorte de não morrer ninguém, mas perderam muita coisa. Os dormitórios, laboratórios, a biblioteca...

Antes que o homem terminasse a frase, 0 filho do médico agradeceu com um breve aceno $e$, parecendo entorpecido, viu a bilheteria, olhou mais uma vez os pombos, e antes que tomar alguma decisão, sentou-se em um banco da estação com um estranho sentimento de que nem mesmo as pedras tão sólidas que construiram o Caraça são imunes à tentação de desmancharem-se ao ar ${ }^{391}$.

391 incêndio no antigo Colégio Caraça, que na época continuou com a Escola Apostólica, ocorreu na madrugada do dia 28 de maio de 1968. O fogo teria principiado na sala de encadernação e se alastrado por todo o prédio onde se concentravam

$\therefore$ as salas de aula e biblioteca com 30 mil volumes..." (*) 


\section{BIBLIOGRAFIA}

\section{Livros, Artigos de Periódicos, Dissertações e Teses:}

ABDALA, M. C. A cozinha e a construção da imagem do mineiro. São Paulo, 1994. [Dissertação de Mestrado - Faculdade de Filosofia, Letras e Ciências Humanas - USP].

ABREU, J. B. Das epidemias. Rio de Janeiro, Typographia Universal de Eduardo \& Henrique Laemmert, 1879.

ADJOURNED discussion on the cause of beri-beri. Trans. soc. trop. and hig., II (7,8): 245-255, 1909.

ALMEIDA Fo., N. de. Introdução à epidemiologia moderna. 2. Ed. Belo Horizonte /Salvador / Rio: Coopmed/APCE/Abrasco, 1992.

ALMEIDA JR., A . A alimentação na idade escolar e pré-escolar. Boletim do Instituto de Hyglene, $15,1923$.

ALMEIDA, A. Vida e morte do tropeiro. São Paulo, Martins : Edusp, 1981.

ALMEIDA, M. A . de. Memórias de um sargento de milícias. 29a. ed. Rio de Janeiro, Ediouro, 1995.

ALMEIDA, T. de. Discurso de paraninfo pronunciado na solenidade de colação de grau dos diplomados do colégio do Caraça, em 3 de dezembro de 1950. O Diárto, n. 5325/5327, Belo Horizonte, 1951. [Separata].

entre outras dependências. A história do Caraça relata com alguma precisðoo os acontecimentos que envolveram esta catástrofe e, sobre a biblioteca, ZICO (*) afirma:

"Mais tarde constatcu que o heroísmo dos padres e alunos, em menos de uma hora, salvou 14 mil volumes, sendo 90 do século XVI. Lamenta-se a impossibilidade de salvar um objeto sequer da ala esquerda do prédio, onde estava o gabinete de física e química com as duas coleçðes de Martius. A biblioteca do Caraça compunha-se de 30 mil volumes, adquiridos, em grande parte, pelos padres Leandro, Viçoso, Garcês, Sípolis, Musci, Cardito e vários outros que, no Caraça, deixavam seus livros, quando eram transferidos para outra casa da congregação".

* ZICO, J. T. Caraça: peregrinaçăo, cultura e turismo. Op. cit. p. 158-65. 
ALMEIDA, T. de. História antiga de Pará de Minas: de 1700 a 1859. Belo Horizonte, Edições Mantiqueira, 1959.

ALMEIDA, T. de. O beriberi no Brasil. Rio de Janeiro, 1916. [ Tese de conclusão de curso apresentada à Faculdade de Medicina do Rio de Janeiro em 26-06-1916].

ALVARENGA, P. F. da C. Symptomatologia, Natureza e Pathogenia do Beribert. Lisboa, Typographia da Academia Real das Sciencias, 1875

AMARAL, A. B. Dicionário de história de São Paulo. São Paulo, Govêrno do Estado, 1980.

ANDRADE, A . A . Valor nutritivo dos alimentos brasileiros. In: CASTRO, J. O problema da alimentação no Brasil. São Paulo, Companhia Editora Nacional, 1934.

ANDRADE, C. D. de. Contos de Aprendiz. 13a ed. Rio de Janeiro, Ed. José Olympio, 1976.

ANDREI, E. (Ed.) Dicionário Médico Blakiston. 2a. ed. São Paulo, Organização Andrei Editora Ltda, 1982.

ANUÁRIO DO MUSEU IMPERIAL. Diário de viagem do Imperador a Minas Gerais em 1881, v. XVIII, Petrópolis, 1957.

ANUÁRIO ESTATÍSTICO DO BRAZIL (1908-1912). V. I, P. XVIII.

ARAUJO, A . J. R. da S. \& CUNHA, M. J. R. da. Estudo sobre a pathogenia do beribert. Bahia, Typographia Americana, 1874.

ARIES, P. História social da criança e da familla. 2a ed. Rio de Janeiro, Editora Guanabara, 1981.

ARRUDA, D. C. et al. Depolmento de oficlals da reserva sôbre a F.E.B. 3a. ed. Rio de Janeiro, Cobraci Publicaçōes, s.r.d.

ASIMOV ,I. Enciclopedia biográfica de ciencia y tecnologia. Madrid, Alianza Editorial, 1982. 
ASSIS, A . R. Estudos sobre carencia experimental e beriberi. Bahia, Livraria Citadina, 1918 [ Tese apresentada à Faculdade de Medicina da Bahia].

ASSIS, M. de. Contos. 2a ed. São Paulo, Ática, 1973.

ASSOCIAÇÃO RELIGIOSA EDITORA MUNDO CRISTÃO. A Biblia viva. 3a ed. São Paulo, Editora Mundo Cristão, 1988. p.3, Gênesis (2, 1517).

ATWATER, W. A . \& BRYANT, A . P. The chemical composition of the American food materials. Washington, Government Printing Office, 1906.

AUGUSTO. A. Higiene dos colégios. Rio de janeiro, 1858. [Tese apresentada à Faculdade de Medicina do Rio de Janeiro].

AUTRAN. H. Etio-pathogenia do beriberi. Brasil Médico, 29 (45).

AVÉ-LALLEMANT, R. Viagens pelas provincias da Bahia, Pernambuco, Alagoas e Sergipe. Belo Horizonte : Itatiaia ; São Paulo : Edusp, 1980.

AYKROYD, W. R. Conquest of deficiency diseases. Geneva, World Health Organization, 1970. (Basic Study, 24).

AYRES, J. R. de C. M. Elementos históricos e filosóficos para uma crítica da epidemiologia. Rev. Saúde Pública, 27 (2) :,135 - 44, 1993.

AYRES, J. R. de C. M. A doença na sociedade como entidade e como processo: subsidios para pensar a epidemiologia. Saúde $\boldsymbol{e}$ sociedade, 2 (2), 1993. p. 147.

AZEVEDO, A . C. de M. Beriberi . Rio de Janeiro, Typ. Academica, 1875. [ Tese inaugural apresentada à Faculdade de Medicina do Rio de Janeiro].

AZEVEDO, A . C. de M. Berlbert. Rio de Janeiro, Typ. Acadèmica, 1875.

AZEVEDO, F de. A cultura brastletra. São Paulo, Melhoramentos/ Ed. UnB, 1963.

AZZI, R. O altar unido ao trono: um projeto conservador. São Paulo, 
Ed. Paulinas, 1992. (História do pensamento católico no Brasil; v.3).

BACELLAR, R. C. Brazil's contribuition to tropical medicine and malaria. Rio de Janeiro, 1963.

BARBOSA, P. \& REZENDE, C. B. (Org.). Os Serviços de saúde pública no Brasil: de 808 a 1907 (Esboço e legislação). 2 v. Rio de Janeiro, Imprensa Nacional, 1909.

BARBOSA, W. de A. Dicionário da terra e da gente de Minas. Belo Horizonte, Imprensa Oficial, 1985.

BARRETO, A . C. Normas praticas a adoptar na alimentação do escolar, nos internatos do Brasil. A Folha Médica, (dez.) : 614-8, 1933. [ Apresentado à Conferencia Nacional de Protecção à Infancia].

BATTISTONI Fo., D. Campinas, uma visão histórica. Campinas, Pontes, 1996.

BAUDElaiRe, C. Poesia e prosa: volume único. Rio de Janeiro, Nova Aguilar, 1995.

BECHER, H. O Barão Georg Heinrich von Langsdorff: Pesquisas de um clentista alemão no século XIX. São Paulo : Edições diá, Brasilia : Editora UnB, 1990.

BECHTEL, W. Reconceptualization and interfield connections: the discovery of the link between vitamins and coenzymes. Philos. Sct., (51) : 273, 1984.

BENCHIMOL, J. L. História da febre amarela no Brasil. Historia, Clências, Saúde - Manguinhos, I (1): 121-24. 1994.

BENJAMIN, W. O Narrador . 2a ed. [vol. Benjamin, Adorno, Horkheimer, Habermas]. Col. Os Pensadores, Abril Cultural, São Paulo, 1983.

BLAKE, A . V. A . S. Diccionario bibliographico braztleiro. v.7. Rio de Janeiro, Imprensa Nacional, 1902.

BLANADET,R. La France sous le second empire (1851-1870). Alliance Française, Cordination Pédagogique, São Paulo, s.r.d. 
BLOCH, M. Os Reis Taumaturgos: o caráter sobrenatural do poder régio, França e Inglaterra. São Paulo, Companhia das Letras, 1993.

BOAVENTURA, M. E. \& CALIL, C. A. (Org.). Alexandre Eulálio Diletante. Remate de Males, Departamento de Teoria Literária do Instituto de Estudos da linguagem - UNICAMP. Junho de 1993.

BOCCACCIO, G. Decamerão. São Paulo, Abril Cultural, 1971.

BON, H. Medicina católica. Buenos Aires, Editorial Poblet, 1940.

BONNEFON, C. História da Alemanha. São Paulo, Companhia Editora nacional, 1945.

BORG, H. Dierche Lexikon Deustschland. Westermann, 1985.

BOYER, R. Eddas. In: Encycloaedia Universalis. Paris, Encyclopedia Universalis France S.A, 1985. v.6.

BRADDON, L. The cause of true or tropical beri-beri. Trans. soc. trop. and hig., $\boldsymbol{I}(5,6):$ 212-225, 1909.

BRITO, E. T. de. Beriberi. Rio de Janeiro, Imprensa Industrial, 1880.

BROCKHAUS Enziklopådie. Mannheim, F. A Brockhaus Mannheim, 1989. 9a. B.

BROSSOLET, J \& MOLLARET, H. Pourquol la peste $?$ le rat, la puce et la bubon. Paris, Gallimard, 1994.

BRUNEL, P. (org.). Dicionário de mitos literários. Rio de Janeiro, José Olyimpio, 1997. P.336.

BUDD, G. Disorders resulting from defective nutriment. Lond. med. gaz., $t i, 1842$

BURMEISTER, H. Viagem ao Brasil através das provinctas do Rto de Janeiro e Minas Gerats. Belo Horizonte: Ed. Itatiaia; São Paulo: Edusp, 1980.

CADERNOS de literatura brasileira. Instituto Moreira Salles, n. 2, set. 1996 : Raduan Nassar. 
CAMELlo, M. J. de O . Caraça, centro minetro de educação e missão (1820-1830) - Textos e Documentos. Belo Horizonte, 1973.

CAMPOS, E. G. de. Symptomatologia do mal de Ceylão. Bahia, Typ. S. Antonio, 1929.

CAMPOS, F. A de M. Problemas brasileiros de alimentação. Rio de Janeiro, Serviço de Alimentação da Previdência Social , 1949. (Biblioteca Brasileira de Nutrição, v. 1).

CANDEIAS, N. M. F. Memória histórica da Faculdade de Saúde Pública da Universidade de São Paulo - 1918 - 1945. Rev. Saúde públ., 15 (Supl.): 2-60, 1984.

CÂNDIDO, A. A personagem de flç̧ão. São Paulo, Perspectiva. p. 55.

CARDOSO, C. F. \& BRIGNOLI, H. P. Os métodos da história. Rio de Janeiro, Ediçōes Graal, 3ª. ed., 1983.

CARRATO, J. F. O caraça português (Contribuição para o estudo da história do Colégio Caraça). São Paulo, 1970. [Tese de Livre Docência - Faculdade de Filosofia, Letras e Ciências Humanas da USP].

CARTER, K. C. The germ theory, beriberi and the deficiency theory of disease. Medical History, 21: 119-136, 1977.

CARVALHO, A . A . de. Berlbert. Rio de Janeiro, Typ. de G. Leuzinger \& Filhos, 1886.

CARVALHO, J. M. de. A formação da almas - o tmaginário da república no Brastl. São Paulo, Companhia das Letras, 1997.

CARVALHO. J. M. de. Os bestializados. São Paulo, Companhia das Letras, 1987.

CASTRO, F. P. de A . Berlbert. Rio de Janeiro, Imprensa Industrial, 1880 .

CASTRO, M. W. de. O sáblo e a floresta: a extraordinária aventura do alemăo Fritz Müller no tróptco brasiletro. Rio de Janeiro, Rocco, 1992. 
CAVALCANTI, T. A . A . et al. Valor nutritivo de alguns dos nossos alimentos (proteina, cálcio e ferro). Rev. med. Paraná, 7 (5) : 3, 1938.

CERQUEIRA, D. Reminiscência da Campanha do Paraguai. Rio de Janeiro, Biblioteca do Exército, 1980.

CHAGAS, P. P. Teófilo Ottont: Ministro do povo. Belo Horizonte : ed. Itatiaia ; Brasilia : INL, 1978.

CHALHOUB, S. Cidade febril: cortiços e epidemias na corte imperial. Campinas, 1994. [Tese de livre docência - Departamento de História, IFCH, UNICAMP].

CHALHOUB, S. The politics of disease control: yellow fever and race in nineteenth century Rio de Janeiro. J. Lat. Amer. Stud. 25 : 44163, 1993.

CHASSOT, A . I. Cubeiro - Um profissional que afortunadamente desapareceu. In: D'ANGELO, A . L. V. (Org.). Histórias de trabalho. Porto Alegre, EU/Porto Alegre, 1995.

Chiavenatto, J. J. Genocidio americano: A guerra do Paragual. 24a. ed. São Paulo, Brasiliense, 1990.

CHRISTIE, A . B. \& CHRISTIE, M. C. Higiene alimentar e riscos da alimentação. Porto, Livraria Lopes da Silva - Editora, 1973.

CIÊNCIA \& TECNOLOGIA na AMAZONIA. Instituto Evandro Chagas, 1, 1995.

COELHO, J. F. de B. Dos casamentos sob o ponto de vista higiênico. Rio de Janeiro, 1878. [Tese apresentada à Faculdade de Medicina do Rio de Janeiro].

CONI, A.C. A escola tropicalista bahiana: Paterson, Wucherer, Silva Lima. Bahia, Tip. Beneditina Ltda., 1952.

CORREA FILHO, V. Alexandre Rodrigues Ferreira: vida e obra do grande naturalista brastletro. São Paulo, Companhia Editora Nacional, 1939. (Brasiliana, Série 5ạ, vol. 144).

CORVISIER, A . Sources et méthodes en histoire sociale. C.D.U. et SEDES. Paris, 1980. 
COSTA, A . A . \& TAVARES, D. G. Composição e valor nutritivo de alimentos brasileiros. Rev. Soc. Bras. Quím., $5(2-4): 101,1936$.

COSTA, D. Alimentaçāo do escolar. Rio de Janeiro, Imprensa Nacional, 1948. (Ministério da Educação e Saúde/Serviço de Documentação).

COSTA, D. Tratado de nutrição. Rio de janeiro, ed. Guanabara, 1947.

COUTinho, A . (Org.). Raul Pompéza: Obras. v. 1. Rio de Janeiro, Civilização Brasileira, 1981

COUTINHO, C. T. de A. Esboço de higiene nos colégios. Rio de Janeiro, 1857. [Tese apresentada à Faculdade de Medicina do Rio de Janeiro].

COUTINHO, R. Valor social da alimentação. Rio de Janeiro, Civilização Brasileira, 1937. p.313-356 : Dieta nos colégios do Rio de Janeiro.

COUTO, J. L de A. Quais são os melhores meios terapêuticos de combater o beriberi ? . Tese de Concurso, Bahia, 1871.

COUTO, S. Vultos e fatos de Diamantina. Belo Horizonte, ..., 1954.

CRUZ, A . da . Centenário do Caraça. Rio de Janeiro, Besnard Freres, 1920.

CUNHA, M. C. Negros, estrangetros. São Paulo, Brasiliense, 1985.

CURTIN, P. D. Death by migration: Europe's encounter with the tropical world in the nineteenth century. Cambridge, Cambridge University Press, 1989.

CURVEllo, M. (Org.). Raul Pompéta. São Paulo, Ed. Abril, 1981.

CZERESNIA, D. Construção científica e inovaçāo teórica: um desafio para a epidemiologia. Physis, 3 (1): 77-90, 1993.

DANGERFIELD, H. V. Le Béribért. Paris, A . Maloine Ed., 1905.

DARMON, P. A cruzada antivariólica. In.: As doenças tem história. Lisboa, Terramar, srd.

DARMON, P. Pasteur. le saint laïque. L'Histoire, no 187, avril 1995. 
DÄUBLER, K. Die Grundzüge der Tropenhygiene. 2 v. Berlin, Verlag Von Otto Enslin, 1900.

De Vlaamse Leeuw. http://www.ping.be/ ping2881/vlale.txt

DECCA, E. S. de. Literatura, modernidade e história. [mimeo.]

DECCA, E. S. de. Não me historicize, por favor, ou a curta estória do evento rebelde. [mimeo.].

DECCA, E. S. de. Narrativa e história. [mimeo.], 1994, p.2.

DER GROSSE Adac Städtführer. Stuttgard, VS Verlaghaus Stuttgard GmbH, 1993.

DEUTSCHE Geschichte - Epochen und Daten. Verlag Ploetz FreiburgWürzburg, Freiburger Graphische Betrube, 1991.

DORNAS FILHO, J. Tropas e tropeiros. In.: Seminário de estudos mineiros, 1, Belo Horizonte, 1956. Conferências. Belo Horizonte, Universidade de Minas Gerais, 1957.

DOMINGUES, I. O flo e a trama: reflexōes sobre o tempo e a história. São Paulo : Iluminuras; Belo Horizonte : Editora UFMG, 1996. Cap. V: Verdade, tempo e história. p. 195.

Dr. BETOLDI. O Bert-Berl na provincia de São Paulo: Carta ao Dr. A . C. de Miranda Azevedo. Rio de Janeiro, B. L. Garnier, 1877.

DROZ, J. História da Alemanha. Sintra/Portugal, Publicações EuropaAmérica, 1985.

DUKES, M. N. G (Ed.). Drug Utilization Studies: Methods and uses. WHO Regional Publications, European Series No. 45.

DURHAM, H. E. Notes on beriberi in the malay peninsula and on Christmas Island (Indian Ocean). The Journal of Hygiene, II: 112-155, 1904.

ENSMINGER, A . H. et al. Foods \& Nutrition Encyclopedia. v. 1. Clovis, California, Pegus Press, 1983. p. 201. 
ESCUDERO, P. Alimentação. Rio de Janeiro, Flores e Mano Editores, 1934. p. 98-9.

ESHA Corporation. The food processorTI : computerized nutrition system. Salem, Bob \& Betty Geltz, 1984.

EULÁlIO, A. A história como romance: A obra menor de Joaquim Felício dos Santos. In: REMATE DOS MALES, Op. cit.

EULÁLIO, A. Escritos, Ed. Unicamp, Campinas, 1992.

EXPOSIÇÃO de livros da biblioteca do Caraça. Promovida sob os auspicios da sucursal de "O Globo" de Belo Horizonte. Imprensa Oficial, 1960.

FAJARDO, F. C. Die Hämatozoarie des Beri-beri im Gehirn. Zentralblatt für Bacteriologie, Parasitenkunde und Infectionskrankheiten, XXVII $(6,7,8), 1900$.

FAJARDO, F. C. Hematozoaire du beriberi, 1900 [ microfilme, Biblioteca Nacional, RJ].

FALCÃO, E. de C. Gazeta Médica do Rio de Janeiro: Coletânea. Tomo I, II, III, p. XVI e XVII.

FAUSTO, B. História do Brasil. 2. ed. São Paulo, Edusp: FDE, 1995.

FECURY, J. O coração beribérico. Belém, 1952. [ Tese de livre docência Faculdade de Medicina e cirurgia do Pará].

FÉnELON, F. S. de la M. Les Aventures de Télémaque. Paris, J. De Gigord, Éditeur, 1935.

FENELON, F. S. de la M. As aventuras de Telêmaco. Trad. M. de Souza e F. M. do Nascimento. Paris, Baudry, s.r.d.

FIELD, G. W. Heine. In: Grolier Mult. Enc. Op. cit.

FLETCHER, W. Informe preliminar de un experimento realizado en el asilo para lunaticos de Kuala Lampur. Salud Publica de Mexico, 35 (4), 1993 (http://www.insp.mx/salud/).

FLORKIN, M. A History of biochemistry. Amsterdam, Elsevier, 1972. 
FONTENELLE, J. P. Hygiene e saúde pública. In. Diccionario historico, geographico e ethnographico do Brasil (commemorativo do primeiro centenário da independência) : primeiro volume, cap. 17\%., Rio de Janeiro, Imprensa Nacional, 1922.

FOUQUET, C. Origem da familia Avê-Lallemant e sua expansāo no Brasil. Revista Genealógica Brasiletra. Ano II, n.4, 1941. [Separata].

FRAGA, C. O beribéri na Bahia. Salvador, Imprensa Official do Estado, 1917.

FRANCO, G. Nutrição. Rio de Janeiro: São Paulo, Atheneu, 1982.

FRANCO, V. M. M. Viagens pelo interior de Minas Geraes e Goyaz. Rio de Janeiro, Imprensa Nacional, 1888.

FRASER, H. \& STANTON, A . T. The etiology of beri-beri. Trans. soc. trop. and hig, $\mathbf{m}$ (5): 257-267, 1910.

FREIRE, B. A .Os microbios $e$ as molestias contagiosas. Bahia, Imprensa Popular, 1887.

FREUD, S. El porvenir de una ilusión. In.: FREUD, S. Obras completas, v. 21, Buenos Aires. Amorrortu ed. , 1986.

FREYRE, G. Sobrados e mocambos. 8a. ed. Rio de Janeiro, Record, 1990.

FRIDERICHS, E. Perfis de grandes médicos. 2a ed. ..., Edições Paulinas, 1964.

FRIEIRO, E. Feljão, angu e couve. Belo Horizonte: Itatiaia ; São Paulo: Edusp, 1982.

FRIEIRO, E. O díabo na livrarta do cônego. Belo Horizonte; Ed. Itatiaia : São Paulo; Edusp. 1981.

FREEDMAN, A . History of medicine. Grolier Mult. Enc. Op. cit.

FUNDAÇAO IBGE. Sérles estatisticas retrospectivas. Rio de Janeiro, 1986, v.3, 1986.

FUNDAÇAO IBGE. Tabelas de composição dos alimentos. Rio de Janeiro, 1977. 
FURST, L. R. Hölderlin. Grolier Mult. Enc. Op. cit.

GAGNEBIN, J. M. História e narração em W .Benjamin. São Paulo: Perspectiva: Fapesp; Campinas: Ed. Unicamp, 1994.

GAVA, A . J. Principios de tecnologia de alimentos. São Paulo, Nobel S.A, 1978.

GEORG-AUGUST-UNIVERSITÃT GÖTTINGEN. Personal und Vorlesungs-verzeichnis: Sommersemester 1995. Göttingen, Vandenhoeck \& Ruprecht, 1995.

GOMES, A . A . Natureza e tratamento do beribert. Rio de Janeiro, Typ. de Francisco Leonardo Gomes. 1883.

GONDIM, E. M. A novarsenotherapia no beribert. Bahia, Livraria Economica, 1921.

GONTIJO,R.M. A parceria e o café na zona da mata mineira: 1850 - 1906. Belo Horizonte, 1992. [Dissertação de Mestrado - Faculdade de Filosofia e Ciências Humanas da UFMG]

GRANDE Enciclopédia Portuguesa e Brasileira. Lisboa; Rio de Janeiro, Editorial Enciclopédia Ltda, 1954. v.14.

GROLIER MULTIMEDIA ENC. Danbury, CT, Grolier Eletronic Publishing, Inc, 1996: Funk, Casimir. [CD-ROM].

GROLIER Mult. Enc. Op. cit.: Bulbonic Plague.

GROLIER Mult. Enc. Op. cit.: Eijkaman, C.

GROLIER Mult. Enc. Op. cit.: Magendie, François.

GROLIER Mult. Enc. Op. cit. : Göttingen

GROLIER Mult. Enc. Op. cit. : Henle, Friedrich.

GROLIER Mult. Enc. Op. cit. : Wroclaw.

GROLIER Mult. Enc. Op. cit. : European Universities, Germany. 
GUSTAFSON, M. Vila Rica, Ouro Preto, verdade e lenda. 4a. ed. Belo Horizonte, Una Graphos Impressora, 1983.

HARDMAN, F. F. Trem fantasma: a modernidade na selva. São Paulo, Companhia das Letras, 1988.

HARRISON, S. Notes on the vitamins. The j. of trop. med. and hygiene, $26(17): 281-2,1923$.

HAUCK, J. F. et al. História da igreja no Brastl - segunda época: A igreja no Brasil no século XIX. tomo II/2. 3a. ed. Petrópolis, Ed. Paulinas, 1992.

HÉBRARD. Béribéri. In: GRALL \& CLARAC. Traité de pathologie exotique. Paris, Libraire J D Balliere, 1911.

HEINE, H. O Rabi de Bacherach. São Paulo, Hucitec, 1992.

HINDEN, H. Deutsche und Deutscher Handel in Rio de Janetro: Ein hundertjähriges Kulturbild. Zur Zentenar Feir der Gesellchaft "Germania". Rio de Janeiro, Hoepfner \& Co, 1921.

HOLANDA, S. B. de. (Org.) Histórla geral da civilização brasileira: $\boldsymbol{I}$. O Brasil monárquico: 3. Reaçð̇es e transaçóes. São Paulo, Difel, 1967.

HOLDERLIN, F. Poemas [trad. e introdução de José P. Paes]. São Paulo, Companhia das Letras, 1991.

HOLLYDAY. F. B. M. Otto von Btsmarck. Grolier Mult. Enc. Op. Cit.

IGLÉSIAS, F. Política econômica do governo provincial minetro (1835-1889). Rio de Janeiro, MEC/INL, 1958.

IHDE, A. J. \& JANSSEN, J. F. Early american studies on respiration and calorimetry. Mol. Cell. Btochem., 5 (1-2): 11-6, 1974.

INOUYE, K. \& KATSURA, E. Etiology and pathology of beribert. Vitamin B research committee of Japan, Tokyo, 1965.

INSTITUTO EVANDRO CHAGAS. 50 anos de contribuição às ciências biológicas e à medicina tropical. Belèm, Fundação Serviços de Saúde Publica, 1986. 
KARASCH, M. C. Slave life in Rio de Janeiro: 1808-1850. Princeton, Princeton University Pres, 1987.

KATSURA, E. \& OISO, T. Beriberi. In. BEATON, G. H. \& BENGOA, J. M., ed. Nutrition in preventive medicine. Geneva, World Health Organization, 1976. (Monograph series, 62).

KaUffman, G. B. Pelletier. Grolier Enc. Mult. Op. Cit.

KEINHENZ, C. Boccaccio. In: Grolier Multimedia Enc. Op. cit.

KIERKEGAARD, S.A. Obras escolhidas. São Paulo, Abril Cultural, 1984. (Coleção ‘Os Pensadores').

KIKUCHI, T. Autocuraterapia. Prática global do tratamento preventivo. São Paulo, Musso Publicações, 1981.

KLEE, G. A. Java. In: Grolier Multimedia Enc. Op. Cit.

KNOWLTON, C. S. Sírlos e libaneses. São Paulo, Ed. Gráfica Piratininga, 1960.

KOMISSAROV, B. Expedição Langsdorff: Acervo e fontes históricas.

São Paulo : Editora Unesp, Brasilia : Edições Langsdorff, 1994.

KOSTER, H. Viagens ao nordeste do Brasil. 2a. ed. Recife, Secretaria de Educação e Cultura ;Governo do Estado de Pernambuco ;Departamento de Cultura, 1978.

KRAEHE, E. E. Frederick William IV, King of Prussia. Grolier Mult. Enc. Op. cit.

LACAZ, C. S. et al. Introdução à geografia médica do Brasil. São Paulo, Edgard Blücher Ltda. : Edusp, 1972.

LACERDA, J. B. de. Contributions l'etude de la cause do beriberi, 1907 [ Microfilme. Biblioteca Nacional, RJ].

LACERDA, J. B. O micróbito do berlbért. 1887 [ Microfilme. Biblioteca Nacional, RJ ].

LACERDA, L. B. Fastos do Museu Nacional do Rio de Janetro. Rio de Janeiro, Imprensa Nacional, 1905. 
LANGGAARD, T. J. H. Diccionario de medicina domestica e popular. v.3. Rio de Janeiro, Laemmert, 1873.

LE GOFF, J. As plantas que curam. In. Le GOFF, J. (Apres.) Op. Cit.

LE ROBERT Dictionnaire Illustré des Noms Propres. Paris, Le Robert, 1993.

LEIBBRAND, W. Robert Koch. In: Die Grossen Deutchen: Deutsche Biographie. v.4, Berlin, 1957.

LIMA JR., A . O Colégio do Caraça. Rev. do Inst. Hist. e Geog. de Minas Gerais, $9:$ 21-32, 1962.

LIMA JR., A. A capitania das Minas Gerais. Belo horizonte : Itatiaia, São Paulo : Edusp, 1978.

LIMA JR., A. de. Vila Rica do Ouro Preto: Sintese histórica e descritiva. Belo Horizonte, Edição do autor, 1957.

LIMA, A. A. A voz de Minas. Rio de Janeiro, Ed. Agir, 1946.

LIMA, J. F. da S. Ensaio sobre o beribert no Brasil. Salvador, Typographia de J. G. Tourinho, 1872. p. II.

LIMA, J. F. de S. Ensaio sobre o beriberi no Brazil. Salvador, Typ. J. G. Tourinho, 1872.

LIVRO DO SEMINARISTA, O. 3a. ed. São Paulo, Editora "Ave Maria” Ltda, 1959.

LOVELACE, C. O beriberi na Madeira-Mamoré. Brasil Medico. Rio de Janeiro, 1912.

LUKÁCS, G. El asalto a la razón. Barcelona, Ediciones Grijalbo S.A., 1978 .

LUKÁCS, G. Existencialismo ou marxismo P. São Paulo, Livraria Editora Ciências Humanas Ltda., 1979. p. 15-16.

LUZ, F. A . F. da. Da Nutriçào. Rio de Janeiro, Typographia Cinco de Março, 1876. 
LUZ, M. T. Medicina e ordem politica brasileira: Políticas e instituições de saúde (1850-1930). Rio de Janeiro, Ed. Graal, 1982.

Machado de Assis. A Semana, vol. III, p. 772. Ed. coligida por Mário de Andrade, 1910.

MACHADO, $R$ et al. Danação da norma - Medicina social e constituição da psiquiatria no Brasil. Rio de Janeiro, Ed. Graal, 1978.

MAIA, T \& MAIA, J. R. C. O folclore das tropas, tropeiros e cargueiros no Vale do Paraíba. Rio de Janeiro, MEC - SEC :FUNARTE: Instituto Nacional do Folclore ; São Paulo : Secretaria de Estado da Cultura : Universidade de Taubaté, 1981.

MARC-BONNET, H. Histoire des ordes religieux. Paris, Press Universitaires de France, 1949.

MARTINHO, L. M. \& GORENSTEIN, R. Negociantes e calxeiros na soctedade da independência. Rio de Janeiro: Secretaria Municipal de Cultura, Turismo e Esportes; Departamento Geral de Documentação e Informação Cultural: Divisão de Editoração, 1993.

MARX, K \& ENGELS, F. Sobre literatura e arte. São Paulo, Edições Mandacaru Ltda., 1989.

MARX, K. \& ENGELS, F. Obras escolhidas. 3 v. São Paulo, Alfa-Omega Ltda., srd.

MASTERS, W. E. Essentials of Tropical Medicine. New York, William Wood \& CO., 1920.

MATOS. R. J. da C. Corografia histórica da provincia de Minas Gerais (1837). Belo Horizonte : Itatiaia ; São Paulo : Edusp, 1981. v.2.

MATTOS, A . O sábio Dr. Lund e os estudos sobre a pré-história brasileira. Belo Horizonte, edições Apollo, 1935. p.297.

MAZZILLI, R. N. Contribuição da química na origem da ciēncia da Nutrição. Faculdade de Higiene e Saúde Pública. s.r.d [mimeo.]

McCONNELL, V. F. Liebig. Grolier Mult. Enc. Op. cit. 
McCOLLUM, E. $\mathrm{V}$ et al. Os novos conhecimentos da nutrição. Rio de Janeiro, Ed. Guanabara Waissman-Koogan Ltda., 1943.

MEGAW, J. W. D. The beriberi and epidemic dropsy problem. The indian med. gax., $58(5): 282,1923$.

MELLO, E. M. H. de. Bertbert. Rio de Janeiro, Typographia Carioca, 1877.

MENDONÇA, S. de S. Berlbert . Bahia, Imprensa Official do Estado, 1919.

MENEZES, R. Dicionário literário brasileiro, 2a. ed. Rio de Janeiro, Livros Técnicos e Científicos, 1978.

MENSE, C. Handbuch der Tropenskrankheiten. 3a ed. Leipzig, J. A . Barth, 1924. v. 3,

MESNARD, P. Klerkegaard. Lisboa, Edições 70, 1986.

MEYERS Enziklopädisches Lexikon. Mannheim, Klambt-Druck GmbH, 1974. v.10.

MINISTÉRIO DA JUSTIÇA E NEGOCCIOS INTERIORES. Arquivo Nacional. Registro de estrangeiros: 1808-1842. Rio de Janeiro, 19601964. $4 \mathrm{v}$.

MINISTÉRIO DA SAÚDE. Boletim Informativo da D. O . H. Ano II, n. 18, Junho, 1966.

MONDIN, B. Curso de filosofia: os filósofos do ocidente. 3a. ed. São Paulo, Ediçōes Paulinas, 1983. 3 V. p. 33.

MONIN, E. L'Hygiene de l'estomac: Guide pratique de l'alimentation. Paris, Octave Doin éditeur, 1888.

N. Tulp (593-1674): www. mc. Vanderbilt .edu / biolib / hc / nh1.html.

NERY, I. S. R. Analogias entre o berlbéri e a malárla. Typografia Montenegro, Rio de Janeiro, 1899.

NETTO, A. R. O caminho para formação do serviço sanitário de São Paulo de 1579 a 1891. Arquitvos de Higiene e Saúde Pública, 7(14) : 734, 1943. p. 23. 
NICOLÁO, A . J. Beriberi. Rio de Janeiro, Typographia Carioca, 1877.

NOVAES, R. L. A saúde e os conceitos. São Paulo, 1976. [Dissertação de mestrado apresentada à Faculdade de Medicina da USP].

NOVAES, R. L. O tempo e a ordem: sobre a homeopatia. São Paulo, Cortez/Abrasco, 1989.

NOVO Conhecer Brasil. v. 1. São Paulo, Abril S.A Cultural e Industrial, 1977.

NOVO Dicionário básico da língua portuguesa. Rio de Janeiro, Ed. Nova Fronteira, 1988.

NUNES, E. D. \& BEVILAQUA, L. D. P. Transformações sócio-econômicas e perfis de mortalidade no municipio de Campinas: 1900-1930. Universidade Estadual de Campinas, 1991 (Relatório final).

NUNES, E. D. Medicina social: origens e desenvolvimentos. Revista Cultura Vozes, (84): 5-20.

NUNES, E. D. Sobre la historia de la salud pública en el Brasil: revisando algunos estudios. [ Presentado en el I encuentro de la salud publica, La Habana, Cuba, 1994].

OBERACKER Jr. , C. H. A contributção teuta à formação da nação brastleira. 2a. ed. Rio de Janeiro, Presença, 1985.

OLIVEIRA, C. R. Medicina e Estado: origem e desenvolvimento da medicina social no Brasil - Bahia: 1866 - 1896. Rio de Janeiro, 1982. [Dissertação de mestrado - Instituto de Medicina Social da UERJ].

OLIVEIRA, J. D. de. Vitaminas e aminoácidos. São Paulo, Mario M. Ponzini \& Cia, 1941.

OTTONI, D.B. Beribert. Rio de Janeiro, Imprensa Industrial, 1880.

PAULA, H. de. A medicina dos médicos \& a outra ... . Belo Horizonte, Imprensa Universitária, 1982.

PEIXOTO, A . Higiene. 5a ed. Rio de Janeiro, Liv. Francisco Alves, 1930. v. I : Higiene Geral. 
PEIXOTO, A . Higiene. 5a ed. Rio de Janeiro, Liv. Francisco Alves, 1931. v. II : Medicina Preventiva.

PEREGALLI, E. Escravidảo no Brasil. São Paulo, Global, 1988. p. 67.

PEREIRA, F. B. Beribert no Braztl. Bahia, Litho-typographia de João Gonçalves Tourinho, , 1881.

PIÑERO, J. M. L. Medicina, Histórla, Sociedad. 3a ed. Barcelona, Editorial Ariel, 1973.

PLESSIS, A. Napoléon III: Un Empereur "socialiste"?. L'Histoire, no 195, Janeiro, 1996.

POMER, L. A guerra do Paragual: a grande tragédia rioplatense. 2a. ed. São Paulo, Global, 1981.

POMPÉIA, R. O Ateneu. São Paulo, Círculo do Livro, srd

PORTO, A . \& HOFFMANN, A . Moinhos: Na roda do tempo. Globo Rural, (dez.): 10-110, 1994.

PORTOCARRERO, V. Foucault: A história do saber e das práticas.

In.: PORTOCARRERO, $\mathrm{V}$ (Org.). Filosofia, história e soctologia das ctênctas. Rio de Janeiro, Ed. Fiocruz, 1994.

PREFEITURA MUNICIPAL DE PETROPOLIS. Centenário de Petrópolis. Petrópolis, 1943. v.3: Os fundadores.

PROUS, A. Arqueologia brastletra. Brasilia, Ed. UnB, 1992.

RANDOLPH,B. Congregation of priests of the mission. In: Herbermann,C.G et al., ed. The catholic encyclopedia: An international work of reference on the constituition, doctrine, discipline, and history of the catholic church. Albany, The Encyclopedia Press Inc, 1913. v.10.

REGO, J. P. Apontamentos sobre a mortalldade da cidade do Rto de Janetro particularmente das crianças ... Rio de Janeiro, Typographia Nacional, 1878. 
REGO, J. P. Esboço histórico das epidemias que têm grassado na cidade do Rio de Janeiro de 1830 a 1870 . Rio de Janeiro, 1872.

REGO, J. P. Memoria historica das epidemias da febre amarella e cholera-morbo que têm reinado no Brasil. Rio de Janeiro, Typographia Nacional, 1873.

REIS, A. A. de S. A história da medicina no Brasil (Notícia Synthetica). In: Diccionario histórico, geographico e ethnografico do Brasil.

REIS, A. A. de S. História da medicina no Brasil (Notícia synthetica). In: DICCIONARIO HISTORICO, GEOGRAPHICO E ETHNOGRAPHICO DO BRASIL. v. 1, Rio de Janeiro, Imprensa Nacional, 1922.

REIS, J. J. A morte é uma festa: ritos fúnebres e revolta popular no Brasil do século XIX. São Paulo, Companhia das Letras, 1991.

RESENDE, A . de L. Memórias. 2 v. Belo Horizonte, Ed. do autor, 1970.

Revista do Arquivo Público Mineiro. Belo horizonte, Paulinas, 1983. 3 V. p. 33.

REYNES, V. Précts d'épidémiologie et prophylaxie des grandes endeméles tropicales. Paris, Masson \& Cie, Éditeurs, 1955.

RIBEIRO, B. A . Principios da alimentação do homem normal. Boletim do Instituto de Higlene de São Paulo, (63), 1938.

Robert R. Williams. http:// www.invent.org/ book/ book.text /109.htm

RODRIGUES, A . P. O valor alimentar dos produtos vegetais brasileiros. Arq. Bras. Nut., 4 (1) : 6, 1945.

ROSEN, G. Uma história da saúde pública. Hucitec: Unesp : São Paulo, Abrasco : Rio de Janeiro, 1994.

ROWEN, H. H. Dutch West India Company. In: Grolier Multimedia Enc. Op. cit.

SAINT-HILAIRE, A. Viagem pelas provincias do Rto de Janeiro e Minas Gerais. Belo Horizonte, Itatiaia ; São Paulo, Edusp, 1975. 
SAINT-ROMAIN, A. de. Pasteur: As verdadeiras razões de uma glória, p. 89. In.: As doenças tem história, s.r.a., Terramar, s.r.d.

SALGADO, J. A. Os meios de vida, as infecçōes e o destino do homem. In.: TONELLI, E. Doenças infecciosas na infância. Rio de Janeiro, Medsi, 1987.

SALLES, J. de. Se não me falha a memória..., Instituto Moreira Salles : Ed. Giordano, São Paulo, 1993.

SALLES, P. História da medicina no Brasil. Belo Horizonte, G. Holman Ltda, 1971.

SALLES, R. Guerra do Paraguai: escravidão e cidadania na formação do exército. Rio de Janeiro, Paz e Terra, 1990.

SANDWITH, F. M. A historical note on beri-beri and rice from the writings of dr. Bontius. Transactions of the ...., $\boldsymbol{I}(7,8): 257-259,1909$.

SANTOS FILHO, L. de C. A Febre Amarela em Campinas: 1889-1900. Campinas, Área de Publicações CMU/UNICAMP, 1996.

SANTOS, A . F. dos. Formulário para o hospital da Santa Casa da Misericórdia do Rio de Janetro. Rio de Janeiro, Almeida Marques, 1879.

SANTOS, A. F. Beriberi na provincia de Minas. In: AZEVEDO, A . C. de M. Beribert. Rio de Janeiro, Typ. Acadêmica, 1875.

SANTOS, A. F. dos. Hypoemia intertropical. Rio de Janeiro, 1862. [Tese de doutoramento - Faculdade de Medicina do Rio de Janeiro].

SANTOS, J. F. dos. Memórlas do distrito diamantino. Belo Horizonte : Itatiaia, São Paulo : Edusp, 1976.

SANTOS, K. M. O dos. O Desenvolvimento histórico da clência da nutrição em relação ao de outras ciências. Campinas: UNICAMP, Centro de Lógica, Epistemologia e História da Ciência, 1989 (Coleção CLE, v.5).

SANTOS, N. C. O Naturalista. Belo Horizonte, Imprensa Oficial, 1923. 
SANTOS, O . P. \& NOGUEIRA, C. C. Fósforo total em nossos alimentos. O hospital, $17(2): 207,1940$.

SANTOS, O . P. Determinação dos sais de cálcio dos nossos alimentos. An. Fac. Med. USP, $12(10):$ 401, 1936.

SARTRE, J-P. Obras escolhidas. São Paulo, Abril Cultural, 1984. (Coleção "Os Pensadores").

SCHELLING, F. W. J. Obras escolhidas. São Paulo, Abril Cultural, 1984. (Coleção "Os Pensadores").

SCHEUBE, B. Die Beriberikrankheit. Jena, Gustav Fischer, 1894,

SCHMIDT, C. B. O milho e o monjolo: aspectos da civitização do milho. Técnicas, utensilios e maquinaria tradicionats. Rio de Janeiro, Ministério da Agricultura : Serviço de Informação Agrícola, 1967.

SCOTT. H.H. A history of tropical medicine . Baltimore, William Wood Book, 1939.

SECRETARIA DA AGRICULTURA DO ESTADO DE MINAS GERAIS. A agropecuária mineira - sua historia, sua evolução. Belo Horizonte, 1978.

SEYN, E. DE. Dictionnaire historique et geographique des communes belges. Bruxelles, A . Bieleveld, Éditeur, 1924.

SFEZ, L. La santé parfalte: critlque d'une nouvelle utople. Paris, Éditions du Seuil, 1995.

SHATTUCK, G. C. The relation of beri-beri to polyneuritis from other causes. The Amer. J. of trop. med., 3 (6), 540-3.

SHIMAZONO, N. \& KATSURA, E., ed. Beribert and thiamine. Vitamin B research committee of Japan, Tokyo, 1965.

SILVA, F. B. da. Consult. Sob o beribert. Fortaleza, 1874.

SILVA, F. Caraça, apontamentos históricos e notas biográficas. Revista do Archivo Publico Minetro, ano XII: 5-205, 1907. 
SILVEIRA, A . da. Floras e Serras Mineiras. Belo Horizonte, Imprensa Oficial, 1908.

SOARES, S. F. Notas estatisticas sobre a produção agricola $e$ carestia dos gêneros alimenticios no império do Brasil. Rio de Janeiro, IPEA/INPES, 1977.

SOURNIA, J-C. \& RUFFIE, J. As eptdemias na história do homem. Lisboa, Edições 70, 1984.

SOUZA, B. F. de. Beribéri e Cardiopatia. Belém, 1952. [Tese de Livre Docència - Faculdade de Medicina e Cirurgia do Pará].

SOUZA, G. H. de P. \& WANDERLEY, L. A . Ensaios de calorimetria alimentar. Boletim do Instituto de Hygiene, 6 , 1921.

SOUZA, J. M. de. Ctdade: momentos e processos. São Paulo, ANPOCS: Marco Zero, 1993.

SPIX, J. B. von \& MARTIUS, C. F. P. von. Reise in Brastlien in den Jahren 1817-1820. Stuttgart, Brockhaus, 1967.

SPIX, J. B. von \& MARTIUS, C. F. P. von. Viagem pelo Brasil. Rio de Janeiro, Imprensa Nacional, 1938.

STANGERUP, H. Lagoa Santa, vidas e ossadas. Rio de Janeiro, Nórdica Ltda., 1983.

STANLEY, A . The nature of beri-beri. The Journal of Hygiene, II: 369$81,1902$.

STEINBRÜCK, P. Robert Koch. A saúde do mundo. Janeiro, 1982.

STITT, A . B. The diagnostics and treatment of tropical diseases. Philadelphia, P. Blakiston's Son \& CO, 1922.

TAUNAY, A.d'E. A retirada da Laguna. 13a. ed. São Paulo, Melhoramentos, 1952.

TELAROLLI JR., R. Epidemias no Brastl: uma abordagem biológica e social. São Paulo, Ed. Moderna, 1995.

TELAROLLI JR., R. PODER E SAÚDE: A república, a febre amarela e a formação dos serviços sanitários no estado de São Paulo. 2 v. 1 
Tese de doutoramento apresentada à Faculdade de medicina da UNICAMP ]. Campinas, 1993.

TELLES, F. E. da F. Um grande nome nacional: Paula Souza. Anhembi, $48(144)$ : 474-80, 1962.

THE ETIOLOGY of beriberi. Lancet, II : 842, 1911.

TODHUNTER, N. Development of knowledge in Nutrition. J. American Dietetic Association, 41: 335:340, 1962.

TOLEDO, R. P. de. À sombra da escravidão. Veja, ano 29, n. 20: 52-65, 1996.

TORNERO, N. Caminhos da cólera. São Paulo, Moderna, 1995.

TORT, P. Lund, Peter Wilhelm (1801 - 1888). In: TORT, P. (Org.). Dictionnaire du darwinisme et de l'evolution. 3 v. Paris, Presses Universitaires de France, 1996. v.2.

TRUZZI, O. M. S. Patrícios - Sírios e libaneses em São Paulo. [Tese de doutoramento apresentado ao Instituto de Filosofia e Ciencias Humanas - UNICAMP]. Campinas, 1993.

VALLERY-RADOT, R. A vida de Pasteur. 3a. ed. Rio de Janeiro, Vecchi Editor, s.r.d.

VANNUCHI, $\mathrm{H}$ et alli., ed. Aplicaçðes das recomendaçðes nutricionats adaptadas à população brastleira. Ribeirão Preto, Legis Suma Ltda, 1990. (Cadernos de Nutrição, v.2).

VEIGA, J .P. X. da. Ephemerides minetras (1664-1897). Ouro Preto, Imprensa Oficial do Estado de Minas, 1897.

VIEIRA, P. E. G. História de doenças: ponto de encontros e de dispersões. 2 v. [ Tese de doutoramento apresentada à Escola Nacional de Saúde Pública / Fundação Oswaldo Cruz ]. Rio de Janeiro, 1995.

WALKER, M. E. M. Pioneers of public health. New York, The Macmillan Company, 1930.

WELLINGTON, A . R. Notes on beri-beri. Trans. soc. trop. and hig., $\boldsymbol{I}$ (5,6): 226-243, 1909. 
WEREBE, M. J. G. A educação. In: HOLANDA, S. B. de (Org.). Históría geral da civilização brasileira. II: O Brasil monárquico; 4. Declínio e queda do Império. 4ª. ed. São Paulo, Difel, 1985.

WHITE, H. A Questão da narrativa na teoria contemporânea da história. RH - Revista de história, (2-3) : 63-3. 1991.

WILlEMS, E. A aculturação dos alemães no Brasil. São Paulo, Companhia Editora Nacional, 1946.

WINAU, R. Robert Koch und seine Zeit. http://www.rz.charite.huberlin.de /ch_koch. html.

WUCHERER, O. Anchylostomos duodenaes. Gazeta Medica da Bahia. n. 37, p.150, 15 de janeiro 1868.

ZARUR, D. Uma velha e nova história da Santa Casa. 2a. ed. Rio de janeiro, Binus Artes Gráficas Ltda., 1985.

ZEMELLA, M. P. O Abastecimento da capitania das Minas Gerais no século XVII. 2. ed. São Paulo, Hucitec/Edusp. 1990.

ZICO, J, T. Caraça: peregrinação, cultura, turismo. 5a. ed. Belo Horizonte, Ed. Littera Maciel, 1988.

ZICO, J. T. Caraça e a familla imperial. Belo Horizonte, Editora O Lutador, 1991.

ZICO, J. T. Caraça: Ex-alunos e visitantes. Belo Horizonte, Editora São Vicente, 1979.

\section{Documentos diversos:}

Carta do Pe. J. T. Zico, CM, de 24 de julho de 1995.

Congregados no Caraça: 1820-1952 . Manuscrito de autoria do Padre Pedro Sarnel. Arquivo do Caraça.

Documento 8(2)CM/5 , CR-118 ; Doc. $13(1) \mathrm{CM} / 12$, HI-2 ; Doc. 1(1) $\mathrm{CC} / 10$, HI-37, Arquivo geral da Casa Central da Congregação da Missão (CCCM), Rio de Janeiro.

Documento 13(1)CM/1 , SA-1: Arquivo geral da Casa Central da Cor gregação da Missão (CCCM), Rio de Janeiro. 
Documento 8 (2); CM/5; CR - 178, Carta de 20/9/1910. Arquivo geral da Casa Central da Congregação da Missão (CCCM), Rio de Janeiro.

Documento 8 (2); CM/5; CR - 198, s.d.; Documento 8 (2); CM/6; CR 200, Carta de 07/10/1910. Arquivo geral da Casa Central da Congregação da Missão (CCCM), Rio de Janeiro.

Documento 8 (2); CM/6; ED - 111. Arquivo geral da Casa Central da Congregação da Missão (CCCM), Rio de Janeiro.

Livro da Botica, 1874-84. Manuscrito, Arquivo do Caraça.

Livro de matriculas, de 1856 a 1910 - Manuscrito, Arquivo do Caraça.

Livro de Óbitos do Colégio Caraça. Manuscrito, Arquivo do Caraça.

\section{Jornais e Prospecto:}

“Diário de Minas”, Anno I, n. 155-7 de 30-10-1873.

"Diário official". Novo Regulamento da Directoria Geral de Saude Publica. 21-4-914.

“Jornal do Commercio”, n. 227, 15/8/1852.

"O Jequitinhonha" ( Maio de 1863, Janeiro a Agosto de 1869, Abril de 1870, Novembro de 1871, Junho de 1872). Arquivo Público Mineiro: J.A 08 e J.A 26.

Dom Antônio Ferreira Viçoso (13-05-1787 - 07-07-1875): prospecto elaborado pela "Vice-postulação e secretariado da beatificação de D. Antōnio F. Viçoso". Mariana, 07 de julho de 1984. Arquidiocese de Mariana, MG.

\section{Depoimentos e Fllme:}

ALMEIDA, F. T. de. Depoimento, Rio Janeiro, novembro de 1996.

BACK. S. ( produtor e diretor). A guerra do Paraguai. Longa metragem, com depoimentos e imagens.,

História da Guerra do Paraguai. Depoimento anōnimo, Campinas, 1996. 
Relatos pessoais de agricultores das regiões mineiras de Barão de Cocais e Francisco Sá.

ZICO, J. T. Depoimentos, Caraça, julho de 1996. 